UNIVERSIDADE DE SÃO PAULO

FACULDADE DE EDUCAÇÃO

THAIS SURIAN

“Sou imenso, quando escrevo.” Práticas da escrita literária de professores: entre saraus e concursos literários 


\section{THAIS SURIAN}

"Sou imenso, quando escrevo." Práticas da escrita literária de professores: entre saraus e concursos literários

\section{Versão Corrigida}

Tese apresentada ao Programa de Pós-graduação em Educação da Faculdade de Educação da Universidade de São Paulo como exigência parcial para a obtenção do título de Doutora em Educação.

Área de Concentração: Didática, Teorias de Ensino e Práticas Escolares.

Orientação: Profa. Dra. Dislane Zerbinatti Moraes.

\section{São Paulo}


AUTORIZO A REPRODUÇÃO E DIVULGAÇÃO TOTAL OU PARCIAL DESTE TRABALHO, POR QUALQUER MEIO CONVENCIONAL OU ELETRÔNICO, PARA FINS DE ESTUDO E PESQUISA, DESDE QUE CITADA A FONTE.

Catalogação na Publicação

Serviço de Biblioteca e Documentação

Faculdade de Educação da Universidade de São Paulo

$371.17 \quad$ Surian, Thais

S961s "Sou imenso, quando escrevo." Práticas da escrita literária de professores: entre saraus e concursos literários / Thais Surian; orientação Dislane Zerbinatti Moraes. São Paulo: s.n., 2019.

394 p. ils.; tabs.; anexos; apêndice

Tese (Doutorado - Programa de Pós-Graduação em Educação. Área de Concentração: Didática, Teorias de Ensino e Práticas Escolares) - - Faculdade de Educação da Universidade de São Paulo.

1. Práticas da escrita 2. Professores 3. Cultura escrita 4. Literatura I. Moraes, Dislane Zerbinatti, orient.

Elaborado por Nicolly Leite - CRB-8/8204 
SURIAN, Thais. "Sou imenso, quando escrevo." Práticas da escrita literária de professores: entre saraus e concursos literários, tese de doutorado, Faculdade de Educação da Universidade de São Paulo, 2019.

Aprovada em:

\section{Banca Examinadora}

Profa. Dra. Dislane Zerbinatti Moraes (Orientadora)

Instituição: Faculdade de Educação da USP

Assinatura:

Profa. Dra. Denice Barbara Catani

Instituição: Faculdade de Educação da USP

Assinatura:

Profa. Dra. Maria Rosa Rodrigues Martins de Camargo

Instituição: Universidade Estadual Paulista

Assinatura:

Prof. Dr. Elizeu Clementino de Souza

Instituição: Universidade do Estado da Bahia

Assinatura:

Prof. Dr. Silvio Pereira da Silva

Instituição: Universidade Metodista de São Paulo

Assinatura: 
Mesmo quando tudo pede

Um pouco mais de calma Até quando o corpo pede Um pouco mais de alma Eu sei, a vida não para [...]

A vida é tão rara

Tão rara...

(Lenine)

Dedico esta tese à minha amada mãe, Maria Sueli, que tão incansavelmente me acompanhou em todos os momentos, mas como um momento raro da vida nos deixou... 


\section{AGRADECIMENTOS}

Com a finalização desse intenso processo de formação, que culminou nesta pesquisa, é preciso agradecer a todos que me acompanharam e contribuíram de alguma forma em minha trajetória acadêmica e pessoal.

À Profa. Dra. Dislane Zerbinatti Moraes, minha orientadora, que me acolheu na Faculdade de Educação, a quem admiro, agradeço pelos momentos de discussão sobre a pesquisa durante as reuniões de orientação, na disciplina cursada e nos encontros do grupo de estudos, pelas indicações preciosas de leitura e pela compreensão que teve comigo em momentos difíceis vividos nesse processo.

À Profa. Dra. Denice Barbara Catani agradeço pelo acolhimento cuidadoso no exame de qualificação, pelas contribuições discutidas posteriormente e pela participação na banca de defesa.

À Profa. Dra. Maria da Graça Jacintho Setton agradeço pelas contribuições feitas durante o exame de qualificação e nas aulas da disciplina sobre projeto de pesquisa que muito contribuíram na construção do trabalho.

À Profa. Maria Rosa Rodrigues Martins de Camargo, que me acompanha desde a graduação na UNESP, agradeço por ter sido minha orientadora na graduação e no mestrado, pelo compartilhamento de experiências literárias e acadêmicas que me inseriram neste universo de pesquisa, pelas contribuições realizadas no exame de qualificação, pela disposição em dialogar comigo em diversos momentos. Agradeço por fazer parte do exame de defesa da pesquisa que se apresenta.

Ao Prof. Dr. Elizeu Clementino de Souza, agradeço por participar da banca de defesa e pelas contribuições à pesquisa realizada.

Ao Prof. Dr. Silvio Pereira da Silva, agradeço pela participação na banca de defesa e pelas contribuições feitas à pesquisa.

Ao Prof. Dr. Antonio Castillo Gómez, agradeço por ter me recebido na Universidad de Alcalá - Espanha, e muito gentilmente ter me inserido nas atividades de seu grupo de pesquisa, pelas indicações de leitura e discussões teóricas sobre cultura escrita, que ampliaram minha perspectiva sobre o campo. 
Agradeço às Professoras Verónica Sierra Blas e María del Val González de la Peña pelas discussões teóricas sobre minha pesquisa e por permitirem que eu acompanhasse as disciplinas que ministravam na Universidad de Alcalá - Espanha sobre cultura escrita, enriquecendo ainda mais a minha formação acadêmica.

À Profa. María del Mar del Pozo Andrés agradeço pelas discussões sobre o meu objeto de estudo e por ter me colocado em contato com professores espanhóis o que possibilitou conhecer um pouco mais da prática docente no país.

Ao Instituto Federal de Educação, Ciência e Tecnologia de São Paulo, agradeço pela possibilidade de me afastar de minhas atividades profissionais, com vistas a dedicar-me ao desenvolvimento desta pesquisa. Agradeço também à equipe de trabalho e chefias que permitiram o afastamento.

Aos funcionários da FEUSP, da Secretaria de pós-graduação, da Biblioteca e Centro de Memória pela celeridade, cuidado e colaboração nas informações concedidas.

Agradeço à Secretaria Municipal de Educação de São Paulo por possibilitar o acesso aos documentos do Concurso Literário Valeu, Professor. Aos funcionários da Biblioteca Pedagógica e Memória Técnica Documental da Secretaria Municipal de Educação, agradeço a atenção e disponibilidade em me atender em diversos momentos de consulta ao arquivo. Agradeço especialmente à servidora Patrícia Martins da Silva Rede pela dedicação com a qual sempre me recebeu, bem como pelos entusiasmados diálogos estabelecidos sobre o concurso literário.

Aos professores escritores e professoras escritoras, agradeço imensamente pela colaboração, disponibilidade em compartilhar seus textos literários e pelos intensos relatos fornecidos durante as entrevistas que atribuíram valores muito significativos ao trabalho. Sem vocês esta pesquisa não teria sido possível.

Ao Grupo de Pesquisa Literatura, História e Educação: faces do ensino e da pesquisa sobre formação e profissão docente, agradeço pelas leituras e discussões que ajudaram a construir o objeto de pesquisa. E aos amigos e colegas do Grupo - Jaqueline, Gabriel, Marta, Arlete, Fernando Henrique, Patrícia, Fernando Jorge e Silmara - agradeço pelo acolhimento, apoio e parcerias.

A Arlete Oliveira um agradecimento especial, sobretudo pela preciosa colaboração que me levou aos materiais do Concurso Literário Valeu, Professor, muito obrigada. 
Às amigas que me acompanham desde a graduação na UNESP - Juliana de Souza Silva e Eliane Ap. Bacocina -, agradeço pelas parcerias, conversas sobre a pesquisa, apoio em todas as fases da vida pessoal e acadêmica.

Às amigas que encontrei no percurso profissional em São Paulo - Maria, Lilian, Viviane, Raíssa, Tatiane, Daiane, Nathane, Michelli, Solange (in memorian) e aos amigos Alex, Daniel e Edmundo -, agradeço todo o apoio, conversas descontraídas e carinho que colaboraram para aliviar a tensão da vida.

Aos amigos que encontrei na FEUSP - Patrícia Ap. do Amparo, Fernando Jorge Farias e Roseane Farias -, agradeço por todos os momentos compartilhados, especialmente pelas conversas sobre as nossas pesquisas que, embora informais, colaboraram para o desenvolvimento e aprofundamento das discussões desta tese.

Aos meus amados pais, Rogério e Sueli (in memorian), agradeço por sempre estarem comigo, pela paciência, amor, carinho e por terem me ensinando a persistir.

Às minhas irmãs, Thalita e Thatiane, agradeço todo amor e cuidado.

Ao meu companheiro Marcelo, agradeço pela parceria de todos os momentos, principalmente pela paciência, pelo cuidado, enfim, pelo amor a mim dedicado.

Aos meus familiares que sempre me acompanham, agradeço pelo apoio e torcida. 


\section{RESUMO}

SURIAN, Thais. "Sou imenso quando escrevo." Práticas da escrita literária de professores: entre saraus e concursos literários, tese de doutorado, Faculdade de Educação da Universidade de São Paulo, 2019.

A presente pesquisa teve como objetivo identificar e analisar práticas da escrita literária realizadas por professores, buscando compreender a relação que estabelecem com a escrita em seus respectivos contextos sociais. Assim, buscamos identificar que práticas da escrita são essas, em quais espaços, que tipo de material escrito é produzido e que usos fazem de tais materiais. A pesquisa é de abordagem qualitativa visando, segundo Bogdan e Biklen (1994), a descrição do objeto, a fundamentação teórica e o estudo das percepções. Os referenciais teóricos estão fundamentados em autores da História Cultural que compreendem a escrita como práticas culturais, históricas e cotidianas - Roger Chartier (1990) e Michel de Certeau (2014) -, no referencial teórico da História da Cultura Escrita representado por Antonio Castillo Gómez e Antonio Viñao Frago, e em Bourdieu (1996), com o conceito de campo literário. A pesquisa de campo compreendeu a identificação das práticas da escrita e coleta dos materiais escritos e realização de entrevistas com os professores. Os materiais produzidos pelos professores foram identificados a partir de dois espaços: o Concurso Literário Valeu, Professor e saraus que ocorrem em São Paulo, assim, as fontes documentais compreendem textos literários publicados em livros pelo Concurso Literário Valeu, Professor, e textos literários publicados em suporte impresso e digital dos professores participantes de saraus. Desse modo, a análise das fontes documentais em conjunto com as entrevistas possibilitou a construção das seguintes categorias de análise, a saber: práticas e usos da escrita, modos de produção e materialidades, o compartilhamento de experiências literárias, distinção a busca por reconhecimento, interlocução com a realidade no âmbito da crítica, da denúncia e da representação. Com isso, depreendemos que a prática da escrita literária efetivada por esse grupo de professores compreende modos diversos de produzir, evidenciando as representações de seus respectivos contextos sociais, bem como fazer a crítica e a denúncia de uma sociedade desigual. Para além disso, deve-se mencionar que os professores ocupam determinadas posições no campo literário e educacional que estão em disputa na busca por um certo reconhecimento.

Palavras-chave: práticas da escrita, professores, cultura escrita, literatura. 


\begin{abstract}
SURIAN, Thais. "I AM IMMENSE WHEN I WRITE." TEACHERS' LITERARY WRITING PRACTICES: IN-BETWEEN SOIREES AND LITERARY CONTESTS, doctorate thesis, FEUSP, 2019.
\end{abstract}

This research aimed to identify and to analyze literary writing practices carried out by teachers, trying to understand the relation they establish with writing in their respective social contexts. Thus, we sought to understand which writing practices are these, in which spaces, which type of written material is produced, and which uses these materials have. The approach of this research is qualitative, aiming, according to Bogdan and Biklen (1994), the description of the object, the theoretical foundation, and the study of perceptions. The theoretical references are grounded in authors of the Cultural History who understand writing as cultural, historical, and daily practices - Roger Chartier (1990) and Michel de Certeau (2014) -, in the theoretical reference of the History of the Written Culture represented by Antonio Castillo Gómez and Antonio Viñao Frago, and in Bourdieu (1996) with the concept of literary field. The field research covered the identification of writing practices and the collection of written materials and interviews with the teachers. The materials produced by the teachers were identified from two spaces: the Literary Contest Valeu, Professor ("Thanks, Teacher") and soirees that take place in São Paulo, so the documentary sources are literary texts published in books by the Literary Contest Valeu, Professor ("Thanks, Teacher") and literary texts published in the print and digital media of the teachers who participated in the soirees. Therefore, the analysis of documentary sources and the interviews enabled the construction of the following analysis categories: writing practices and uses, production modes and materialities, sharing literary experiences, distinction - the search for recognition, dialogue with reality in the field of criticism, denunciation, and representation. Thus, we inferred that the literary writing practices carried out by this group of teachers cover different production modes seeking to present their representations of their respective social contexts, as well as criticizing and denouncing an unequal society. Furthermore, teachers occupy certain positions in the literary and educational field that are in dispute in the search for a certain recognition.

Key-words: writing practices, teachers, written culture, literature. 


\section{LISTA DE ILUSTRAÇÕES}

IMAGEM 1: Cédula de votação da ilustração do concurso literário de 2010.

IMAGEM 2: Cédula de votação da ilustração do concurso literário de 2011.

IMAGEM 3: Cédula de votação da ilustração do concurso literário de 2012.

IMAGEM 4: Capa e contracapa do livro do concurso literário publicado em 2010.

IMAGEM 5: Capa e contracapa do livro do concurso literário publicado em 2011.

IMAGEM 6: Capa e contracapa do livro do concurso literário publicado em 2012.

IMAGEM 7: Fotografia do Sarau do Mercado.

IMAGEM 8: Fotografia do Sarau Quinta Poética.

IMAGEM 9: Fotografias do Sarau Café com poesia.

IMAGEM 10: Cartaz de divulgação do Sarau Roda da Palavra.

IMAGEM 11: Fotografias do Sarau Roda da Palavra.

IMAGEM 12: Fotografias do Sarau do PI.

IMAGEM 13: Fotografias do Sarau Amigos do Parque Pinheirinho D’água.

IMAGEM 14: Fotografias do Sarau do Grajaú.

IMAGEM 15: Fotografias do Sarau Sobrenome Liberdade.

IMAGEM 16: Fotografias do Sarau da Cooperifa.

IMAGEM 17: Fotografias do Sarau na Galeria.

IMAGEM 18: Fotografias do Sarau Lapada Poética.

IMAGEM 19: Mapa com a localização dos saraus.

IMAGEM 20: Capa e contracapa do fanzine Linguística.

IMAGEM 21: Capa e contracapa do fanzine Fôlego.

IMAGEM 22: Capa e contracapa do fanzine In versus.

IMAGEM 23: Capa e contracapa do livreto (des) caminhos.

IMAGEM 24: Folha de rosto do livreto (des) caminhos.

IMAGEM 25: Dados do exemplar do livreto (des) caminhos.

IMAGEM 26: Capa e folha de rosto do livreto pedaços.

IMAGEM 27: Última página do livreto pedaços.

IMAGEM 28: Capa e contracapa do livreto Deve ser isso.

IMAGEM 29: Folha de rosto do livreto Deve ser isso.

IMAGEM 30: Última página do livreto Deve ser isso.

IMAGEM 31: Capa e contracapa da revista Poesia sem Medo.

IMAGEM 32: Capa e contracapa do livro Cantos e desencantos de um Guerreiro. 
IMAGEM 33: Capa e contracapa do livro Pétalas e Pedradas.

IMAGEM 34: Capa e contracapa do livro Uma vez poetas ambulantes...

IMAGEM 35: Capa e contracapa do livro Toda via, .

IMAGEM 36: Capa e contracapa do livro Falo.

IMAGEM 37: Capa e contracapa do livro Caçando Estrelas.

IMAGEM 38: Capa e contracapa do livro Elas.

IMAGEM 39: Capa e contracapa do livro $A$ vida em três tempos.

IMAGEM 40: Capa e contracapa do livro 21 Gramas.

IMAGEM 41: Página inicial do blog Girassol Poético.

IMAGEM 42: Página de publicação do blog Girassol Poético.

IMAGEM 43: Página inicial do blog Palavrinhas, palavras, palavrões! 


\section{LISTA DE TABELAS}

QUADRO 1: Professores do concurso literário por ano e sexo.

QUADRO 2: Professores vencedores do concurso literário por DRE.

QUADRO 3: Formação dos professores vencedores do concurso literário de 2010.

QUADRO 4: Formação dos professores vencedores do concurso literário de 2011.

QUADRO 5: Formação dos professores vencedores do concurso literário de 2012.

QUADRO 6: Classificação dos textos publicados no concurso literário 2010.

QUADRO 7: Professor autor por categoria do concurso e sexo.

QUADRO 8: Classificação dos textos publicados no concurso literário 2011.

QUADRO 9: Classificação dos textos publicados no concurso literário 2012.

QUADRO 10: Professor autor por categoria do concurso e sexo. 
SME: Secretaria Municipal de Educação

DO: Diário Oficial da Cidade de São Paulo

DOT: Diretoria de Orientação Técnica

CEUs: Centros Educacionais Unificados

DRE: Diretoria Regional de Educação

EJA: Educação de Jovens e Adultos 


\section{SUMÁRIO}

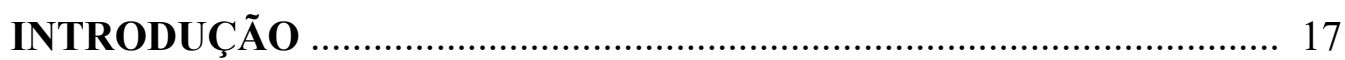

1. PERCURSO METODOLÓGICO DA PESQUISA ….................................. 20

1.1 Delimitações da pesquisa e do objeto de estudo ..................................... 20

1.2 Diálogo com as pesquisas sobre escrita de professores ........................... 26

1.3 Percursos da pesquisa de campo ....................................................... 34

2. CULTURA ESCRITA, PRÁTICAS DA ESCRITA E LITERATURA ..... 44

2.1 Cultura escrita: o campo e a prática da escrita ........................................ 44

2.2 Definindo os tipos de escrita: ordinária, popular, profissional, literária ... 54

2.3 Literatura: algumas definições ................................................................ 57

2.4 Literatura Marginal e Periférica ............................................................ 63

\section{VALEU, PROFESSOR: UM CONCURSO LITERÁRIO PARA} PROFESSORES

3.1 Contexto de criação do concurso literário ...................................................6 69

3.2 Valeu, Professor: ocorrência do concurso literário .................................. 76

3.3 Os textos inscritos no concurso literário: dados gerais ............................. 94

3.4 Professores participantes do concurso literário ....................................... 96

3.5 Imagens veiculadas pela imprensa oficial e a percepção dos professores .. 102

3.6 Antologias do Concurso Literário Valeu, Professor: fontes materiais da pesquisa

4. SARAUS NA CIDADE DE SÃO PAULO …......................................... 120

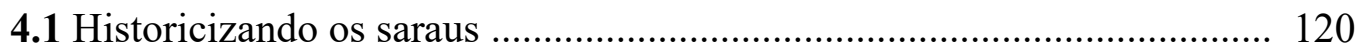

4.2 Afinal, como são os saraus atuais? .................................................... 123

4.3 Os saraus e os professores: desencontros, encontros na cidade ................ 139

5. PROFESSORES ESCRITORES ….................................................... 144

5.1 Origem social dos professores entrevistados ....................................... 144

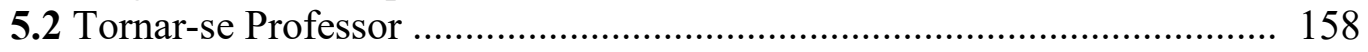

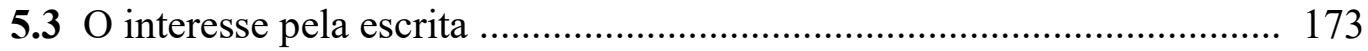

6. TEXTOS LITERÁRIOS: USOS, MATERIALIDADES, SUPORTES E TEMAS DA ESCRITA ….............................................................. 178

6.1. Práticas e usos da escrita: diversidade de sentidos e de práticas ...... 179

6.1.1 A escrita autobiográfica ou "do eu".................................................... 179

6.1.2 A Escrita induzida - o Concurso Literário Valeu, Professor .................. 185

6.1.3 A escrita poética .............................................................................. 193

6.1.4 Compartilhar experiências literárias - difundir, educar, formar pela

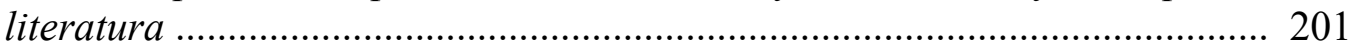

6.2. Modos de produção dos escritos: instrumentos usados na produção, suportes e materialidades..................................................................... 207

6.2.1 Materialidades dos escritos ................................................................. 215

6.3. Distinção: busca por reconhecimento ............................................. 237

6.4. Interlocução com a realidade: crítica, denúncia e representações ..... 244

6.4.1 Representações sobre a profissão docente e o contexto escolar ........... 245

6.4.2 A constituição de uma outra ideia de periferia ................................... 253

6.4.3 Cotidiano em São Paulo ......................................................................... 265 
6.4.4 Escrever do "ponto de vista" feminino .................................................... 268

6.4.5 Escrever em tempo de internet ........................................................ 274

7. CONSIDERAÇÕES FINAIS. Ser professor, ser escritor: duas facetas

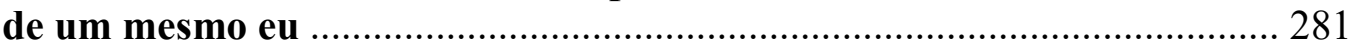

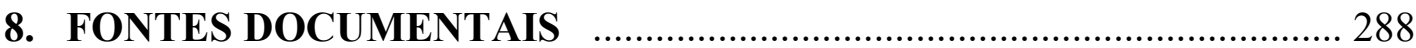

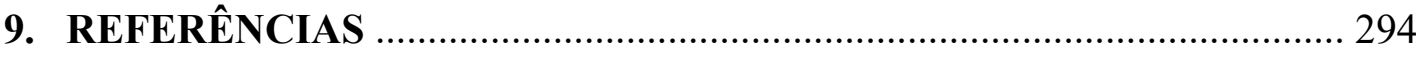

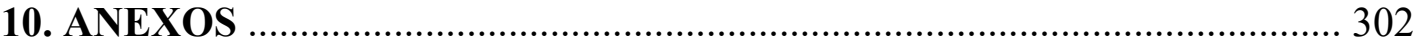

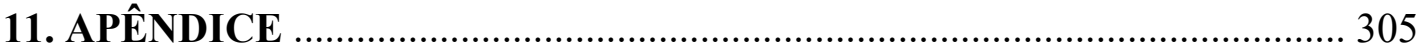




\section{INTRODUÇÃO}

A presente pesquisa desenvolvida no Programa de Pós-graduação em Educação da Universidade de São Paulo, no âmbito da linha de pesquisa Didática, teorias de ensino e práticas escolares, buscou investigar as práticas da escrita literária efetivadas por professores atuantes na educação básica. A escrita - práticas, usos e materialidades configurou-se como tema e objeto de estudo desde os primeiros passos na trajetória pessoal de formação e investigação quando, ainda na graduação em Pedagogia, optou-se por estudar práticas da escrita realizada por mulheres que, nos escritos produzidos, relataram a condição feminina ${ }^{1}$; em seguida, no Mestrado, delineou-se como objeto de estudo a escrita realizada por mulheres em salas de Educação de Jovens e Adultos no município de Rio Claro, identificando as práticas realizadas por esse grupo, os materiais produzidos e que relações mantinham com os escritos pessoais produzidos ${ }^{2}$. Tais estudos possibilitaram refletir sobre as relações que as pessoas "comuns", leia-se mulheres, possuem com a escrita - mesmo no caso de pessoas em processo de escolarização que, talvez, pudessem levar a identificar uma relação com a escrita mais voltada às atividades cotidianas. Ao contrário do que se supunha, foram observadas práticas da escrita íntima e pessoal, em que predomina uma relação que excede a comunicação com o outro, isto é, um diálogo com a primeira pessoa discursiva, com o "eu", indicando, assim, a existência de escritas poéticas e confessionais.

Partindo dessas experiências de pesquisa, delineou-se como possibilidade de investigação estudar os professores e suas práticas da escrita, tornando-se importante refletir sobre como os professores se relacionam com a prática da escrita e com o ato de escrever - inseridos que estão no universo da cultura letrada. Ressalta-se, com isso, que

\footnotetext{
1 SURIAN, T. Mulheres escritoras relatam sua condição de mulher enquanto escrevem. 2006. $52 \mathrm{f}$. Trabalho de Conclusão de Curso (Graduação em Pedagogia) - Instituto de Biociências, Universidade Estadual Paulista, Rio Claro, 2006.

2 SURIAN, T. Um estudo das práticas da escrita de mulheres (escritoras ou não). 2009. 154f. Dissertação (Mestrado em Educação) - Instituto de Biociências, Universidade Estadual Paulista, Rio Claro, 2009. Ambos estudos foram realizados sob a orientação da Profa. Dra. Maria Rosa Rodrigues Martins de Camargo.
} 
a delimitação do objeto deste estudo constituiu-se a partir da pesquisa de campo, já que inicialmente as análises centravam-se nas práticas da escrita de professores que incluíam escritos profissionais, pessoais, literários e/ou jornalísticos, de modo que antecipadamente ao início da pesquisa de campo não foi preestabelecido um tipo de prática da escrita, porque objetivou-se fazer uma incursão no campo de investigação em busca de fontes produzidas por professores de modo a identificar variadas práticas. No entanto, durante este processo identificou-se materiais literários que caracterizavam um certo tipo de prática da escrita, o que permitiu a redefiniçao do objeto de estudo e consequente redirecionamento da pesquisa de campo, como relatado adiante. Dessa forma, a pesquisa estabeleceu a prática da escrita de textos literários, compreendendo literário de modo amplo, em consonância com as discussões propostas pelo crítico Antonio Candido (2004), o qual considera que o literário refere-se a todo texto poético, dramático ou ficcional produzido em uma sociedade. Sendo assim, esses textos requerem um trabalho específico com a linguagem, bem como a adoção de forma, estilo e léxico compatíveis com este universo - assim como a fabulação que, a depender do professor escritor, apresenta maior ou menor grau de proximidade com o real.

A pesquisa embasou-se nos estudos de Chartier (1990) que compreende a prática da escrita como histórica e cultural, na qual os agentes sociais imprimem as percepções e representações do mundo social em que estão imersos. Considerando o campo da cultura escrita, recorreu-se às pesquisas desenvolvidas por Viñao (2000) e Castillo Gómez (2010) em que tratam da escrita como objeto privilegiado de estudo. Por outra parte, recorre-se a Bourdieu (1996) na compreensão e articulação do conceito de campo literário.

Para identificar e compor o contexto de produção do material, as fontes foram coletadas a partir de dois "espaços", a saber: o Concurso Literário Valeu, Professor e os saraus realizados em São Paulo - espaços nos quais foi possível encontrar diversos materiais escritos por professores. O corpus utilizado para a análise privilegiou as entrevistas realizadas com os professores e os textos literários produzidos por eles, isto é, materiais que foram publicados de modo impresso ou digital. As entrevistas foram realizadas com dezessete professores: nove participantes do concurso literário e oito dos saraus. Além destas, realizou-se uma entrevista com um membro da comissão organizadora do concurso literário. Partindo dessas fontes, estabeleceu-se categorias de análise (BOGDAN; BIKLEN, 2010), que compreendem: práticas e usos da escrita, os modos de produção e materialidades, a busca por reconhecimento e a interlocução com a realidade, sendo esta última, uma categoria de análise temática dos textos. 
Em síntese, esta tese estrutura-se da seguinte forma: em primeiro lugar consta a Introdução, que apresenta a trajetória pessoal da pesquisadora, o objeto de estudo, as bases teóricas e metodológicas da pesquisa, bem como as categorias de análise elaboradas a partir das fontes documentais e das entrevistas. A seguir, no primeiro capítulo, apresenta-se a delimitação do estudo, os objetivos propostos e a inserção na fundamentação teórica, além do detalhamento da pesquisa de campo. No segundo capítulo, desenvolve-se a fundamentação teórica sobre cultura escrita, práticas da escrita e literatura estabelecendo diferenciações destas práticas. Já no terceiro capítulo, reconstrói-se a história do Concurso Literário Valeu, Professor e seu contexto de ocorrência, a partir de fontes documentais institucionais - cedidas pela Secretaria Municipal de Educação de São Paulo - e de entrevistas aos professores participantes. No quarto capítulo realiza-se uma breve historicização e caracterização dos diferentes grupos de saraus observados, propondo diálogos com suas identidades geográficas (espaciais). No quinto capítulo, cujo núcleo são as entrevistas realizadas, evidencia-se a trajetória de formação dos professores, suas origens e o interesse inicial pela escrita. No sexto capítulo, e num primeiro momento, analisa-se as práticas da escrita dos professores utilizando as entrevistas e os textos, de modo a evidenciar os usos que fazem de suas práticas; no segundo momento, privilegia-se os materiais - enquanto objetos de produção-, e descreve-se os modos de escrita para, em seguida, realizar-se a análise dos textos propriamente ditos, considerando que os temas da escrita aparecem de modo imbricado nas relações estabelecidas com o "eu", com a identidade, e o universo social dos professores e outros textos que possuem elementos predominantemente ficcionais. Nas Considerações Finais, retoma-se os principais pontos discutidos e analisados na tese. Por fim, apresenta-se os anexos e apêndices, que incluem tabelas elaboradas a partir de documentos identificados na Secretaria Municipal de Educação de São Paulo, além de roteiro e transcrição das entrevistas.

Se como dizia o professor Márcio Vidal Marinho em um de seus poemas: "Sou imenso, quando escrevo", este verso é utilizado não somente para intitular esta pesquisa, como também para deixar em evidência os múltiplos sentidos da escrita produzida pelos vários protagonistas aqui reunidos. 


\section{PERCURSO METODOLÓGICO DA PESQUISA}

Neste capítulo abordaremos ${ }^{3}$ a tessitura envolvida no processo de pesquisa, tratando da definição do objeto de estudo, a delimitação das discussões, o diálogo estabelecido com os estudos realizados sobre a produção escrita de professores que contribuíram para a reflexão sobre o objeto em questão e, ao final, o percurso realizado para identificar as fontes materiais e os professores escritores.

\subsection{Delimitações da pesquisa e do objeto de estudo}

O principal núcleo deste estudo são os professores e suas práticas da escrita literária. A partir deste objeto, buscamos identificar as práticas realizadas e compreendêlas no âmbito das práticas culturais. A prática da escrita, enquanto práxis cultural, está fundamentada nos estudos de autores da História Cultural, como Roger Chartier e Michel de Certeau, os quais entendem a escrita e a leitura como práticas culturais, históricas e cotidianas. Nesta perspectiva, a história cultural busca " [...] identificar o modo como em diferentes lugares e momentos uma determinada realidade social é construída, pensada, dada a ler" (CHARTIER, 1990, p. 16).

Diante disso, delimitamos como elemento de leitura e análise o seguinte questionamento: Que tipos de relações os professores possuem com a prática da escrita literária no contexto atual?

Com base na questão supracitada, definimos o objetivo geral desta tese: identificar e analisar as práticas da escrita literária realizadas por professores, na tentativa de compreender a relação que estes estabelecem tanto com a respectiva prática quanto com a cultura escrita na atualidade. No que se refere aos objetivos específicos ressaltamos a necessidade de: realizar um levantamento das práticas da escrita desenvolvidas por

\footnotetext{
${ }^{3}$ A partir deste ponto, o texto se apresenta escrito na terceira pessoa do plural por uma opção gramatical e por compreender que esta pesquisa foi construída em diálogo com a Profa. Dislane Zerbinatti Moraes, orientadora deste trabalho.
} 
professores; construir (coletar) um corpus de fontes para análise composto por materiais escritos por professores - textos que foram publicados ou que pertencem ao arquivo pessoal dos docentes; identificar que práticas são essas, quais as condições de produção (como e quando são realizadas) e se existe a circulação desses materiais; analisar as práticas da escrita identificadas a partir das fontes coletadas, detectando as possíveis relações do professor com o ato de escrita.

A metodologia está embasada na pesquisa qualitativa que, segundo Bogdan e Biklen, "é uma metodologia de investigação que enfatiza a descrição, a indução, a teoria fundamentada e o estudo das percepções pessoais" (1994, p. 11).

A pesquisa de campo compreendeu a compilação de materiais coletados basicamente em dois espaços: tanto nos arquivos da Secretaria Municipal de Educação de São Paulo (SME - SP) quanto nos saraus realizados na mesma cidade e na região metropolitana. Vale mencionar que a opção por tais fontes se justifica pela especificidade destas práticas, as quais apresentam materiais diversos, bem como permitem visualizar as relações que, atualmente, os professores estabelecem com a escrita. Desses espaços, constituiu-se o corpus de fontes documentais que compreendem: textos literários, identificados a partir do Concurso Literário Valeu, Professor realizado pela SME de São Paulo; textos literários impressos e publicados por professores frequentadores de saraus e materiais publicados em ambientes virtuais, compartilhados por professores atuantes em saraus.

Pesquisando as práticas da escrita e das fontes documentais, optamos, incialmente, por coletar o maior número possível de materiais disponibilizados, para organizar o corpus e, a partir daí, refletirmos acerca da possibilidade de realizar entrevistas com os professores. Durante a leitura, organização e classificação das fontes, observamos que os materiais compilados ofereciam uma dimensão específica de análise das práticas - tendo em vista os suportes, materialidades, formas, conteúdos e discursos -, cujas nuances só poderiam ser resgatadas por meio de entrevistas com os autores de tais textos. Por conta disso, a segunda etapa da pesquisa de campo esteve pautada na realização de entrevistas com os professores identificados em ambos espaços, que foram convidados a participar de uma entrevista semiestruturada (gravada e transcrita). Isso porque, como sabemos, a realização das entrevistas na pesquisa qualitativa é de fundamental importância, pois “[...] é utilizada para recolher dados descritivos na linguagem do próprio sujeito, permitindo ao investigador desenvolver intuitivamente uma ideia sobre a maneira como os sujeitos 
interpretam aspectos do mundo" e se relacionam com a escrita. (BOGDAN; BIKLEN, 1994, p. 134)

A prática da escrita é uma prática cultural histórica que traz a marca de quem escreve, possibilitando que diferentes tipos de registros - cotidianos, confessionais, profissionais e/ou literários - demonstrem aspectos da vida em sociedade, nos mais distintos contextos. No processo da escrita, acreditamos existir um movimento "do eu", do indivíduo, em relação intrínseca com a própria "necessidade" de escrever - muito embora, e desde uma perspectiva diacrônica, a escrita tenha sido incorporada de modo paulatino no cotidiano das sociedades.

Castillo Gómez em seus estudos sobre a História da Cultura Escrita, quando se refere à Idade Média na Europa, século XIV, afirma que houve um processo lento para que a população comum tivesse acesso à escrita como língua incorporada às atividades cotidianas, administrativas e literárias. Antes, o uso da escrita era encontrado apenas em alguns espaços determinados:

Antes de esto, los testimonios más antiguos de escritura en vulgar los hallamos en textos tan diferentes como documentos jurídicos y administrativos, sermones, vidas de santos, glosas, adivinanzas, etc., en muchos casos aprovechando los espacios en blanco dejados en algunos folios de pergamino o en el verso de los mismos, lo que dice bastante de la función subsidiaria que tenían muchos de esos ejercicios, como si no fueran más que circunstanciales ensayos de lenguas en estado de prueba. (2010, p. 184).

Roger Chartier, a partir de um estudo sobre as assinaturas de documentos notariais, judiciais, fiscais e de paróquias entre os séculos XVI e XVIII, que indiciavam o contato com a escrita em determinadas sociedades, apontou que na Europa as assinaturas de homens eram em maior número que as de mulheres indicando que estas não participavam do aprendizado da escrita na mesma proporção que os homens. Entretanto, isso não indicava que as mulheres não eram leitoras, como afirma o autor:

$\mathrm{Na}$ Europa, as porcentagens de assinaturas mostram uma série de diferenças. A primeira, entre homens e mulheres. Por toda parte, os homens sempre assinam mais que as mulheres e muitas vezes com uma vantagem que pode chegar a $25 \%$ ou $30 \%$. Se esta diferença atesta claramente que as mulheres participam menos do mundo da escrita, não devemos porém tomá-la como a medida exata de uma desigual capacidade de leitura. De fato, nas sociedades antigas a educação das meninas inclui a aprendizagem da leitura, mas não a da escrita, inútil e perigosa para o sexo feminino. Mais ainda que para os homens, as taxas de assinaturas de mulheres não podem indicar, portanto, a porcentagem de "leitoras" do Antigo Regime, pois muitas nunca aprenderam a escrever - e isso não se restringe aos meios populares. (1991, p. 117). 
No contexto histórico apresentado pelos autores, o uso dos materiais escritos é ampliado, de modo que atinge outros grupos da sociedade e possibilita o acesso de textos para a leitura das mulheres da elite e classes populares - ainda que em condições desiguais. Segundo Chartier, as práticas podem ser muitas, inumeráveis, realizadas cotidianamente pelas pessoas em diversos espaços públicos e privados, sendo bastante complexa a interpretação desses dados. No caso da leitura, o autor apresenta um modo de interpretação dessa prática:

Para uma história da leitura, por exemplo, é necessário organizar modelos de leitura que correspondam a uma dada configuração histórica em uma comunidade particular de interpretação. Não se consegue reconstruir a leitura, mas descrever as condições compartilhadas que a definem, e a partir das quais o leitor pode produzir a criação de sentido sempre presente em cada leitura. (CHARTIER, 2001, p. $32-33)$.

Assim como a leitura, nota-se que a escrita se configura em consonância com determinados contextos nos quais buscamos atribuir sentidos, bem como compreender os processos de escrita praticados pelos professores.

O campo da cultura escrita constitui-se com base nas práticas de escrita e leitura, nos objetos materiais produzidos, nos usos cotidianos, nas apropriações e representações identificadas a partir de diferentes fontes documentais, em contextos sociais e históricos diversos. As práticas efetivas da escritura e da leitura, presentes na vida cotidiana dos sujeitos - neste caso professores (homens e mulheres) -, podem assumir formas específicas. Em vista disso, nos interessamos por modos de escrever que podem configurar novas histórias de escrita.

Para pensarmos essas práticas, recorremos a Michel de Certeau, o qual afirma que dessas práticas é necessário reter os instrumentos, produtos e esquemas descritivos para se compreender a "historicidade cotidiana, indissociável da Existência dos sujeitos que são os atores e autores de operações conjunturais" (1994, p. 82, grifos do autor).

Castillo Gómez (2012) indica que a História da Cultura Escrita como campo de estudo busca compreender as relações estabelecidas entre a escrita - sistema, forma, produção - e a sociedade que a utiliza em determinado momento histórico. Este campo de estudos vem dialogando com a História da Educação em pesquisas cujos objetos de interesse são, basicamente, produções escolares de períodos passados, a exemplo os cadernos escolares, que reconstroem a história da escola e da educação, assim como 
expõem usos escolares da escrita. O campo teórico da História da Cultura Escrita fornece aporte para compreendermos o objeto de estudo, a fim de compreendermos a relação do professor com a prática da escrita.

O professor é o profissional que, independente da modalidade de ensino em que atue e da área em que lecione, está imerso na cultura escrita, seja elaborando plano de aula e de ensino, preparando os materiais, alfabetizando crianças e adultos, seja incentivando a leitura, desenvolvendo com os alunos a escrita - o que inclui desde ensinar a registrar os conteúdos da aula a produzir os diferentes tipos de textos que compõem o currículo escolar -, ensinando os conceitos das diferentes áreas do conhecimento e aprimorando a capacidade leitora e escritora dos alunos. Por outro lado, a leitura e a escrita, além de instrumentos de trabalho, fazem parte da formação do professor. Na realização da leitura - de textos acadêmicos, informativos e/ou literários - e na produção escrita - escritos profissionais, pessoais, literários e/ou outros - estão presentes processos de formação do indivíduo, que são indissociáveis da pessoa do professor, ou seja, todo o conhecimento acumulado em sua trajetória o acompanha no exercício do magistério.

Kramer e Souza apresentam a problemática envolvendo a formação de professores e alunos, indicando que o professor para tornar seus alunos leitores e escritores precisa, antes, ser ele mesmo um leitor e escritor.

\footnotetext{
Entendemos, assim, sua formação permanente como direito irrestrito e inalienável. A fim de concretizar esse direito no processo de construção de sua cidadania, é urgente que conquistem sua palavra, recuperem o significado de sua profissão, se apropriem da leitura e (re)descubram a paixão pela escrita. Tornem-se ou descubram-se autores. (KRAMER; SOUZA, 2003, p. $09-10)$.
}

Verifica-se que a escrita e a leitura se constituem como aspectos inerentes à formação do professor e, segundo Kramer (1999), esta é uma questão que deve ser entendida como integrante de políticas públicas de formação dos docentes.

Dito isto, apresentamos as seguintes hipóteses de tese: a) considerando os diversos campos de conhecimento que formam professores para atuar no magistério e a realidade da profissão docente advinda do processo de profissionalização ao longo da história e da crise da profissão (NÓVOA, 1999; 2007), acreditamos na existência de diferentes relações dos professores com a prática da escrita literária e, por conseguinte, com a cultura escrita, entendendo que possam evidenciar práticas mais representativas da profissão, outras ligadas à vida cotidiana e/ou pessoais, e outras, ainda, propriamente ficcionais; b) 
ao produzirem textos literários, talvez, os professores busquem serem reconhecidos como escritores no campo (BOURDIEU, 1996).

Diante dessas hipóteses, questionamos: como identificar práticas da escrita entre professores? O que os professores escrevem no século XXI? Com qual objetivo? Quais as condições de produção? Quais são os suportes desses escritos na atualidade? Quais usos fazem do material escrito produzido?

A escrita produzida por pessoas anônimas tem importância por mostrar os contextos histórico, social e cultural nos quais eles estão inseridos e os usos que fazem da escrita. $\mathrm{Na}$ sociedade, os professores são pessoas que apresentam um grupo de características decorrentes da atuação profissional e da formação, aspectos que serão diferentes a depender do contexto social dos grupos: lugar de atuação, formação acadêmica e continuada, origem, entre outras. Considerando esses aspectos, para se estudar esse grupo é necessário considerar o contexto profissional no qual estão inseridos. Assim, Chartier (1990), afirma que o "mundo social" constitui-se de uma construção histórica elaborada pelas práticas políticas, sociais e discursivas nas quais é possível identificar as representações de uma determinada realidade.

As estruturas do mundo social não são um dado objectivo, tal como o não são as categorias intelectuais e psicológicas: todas elas são historicamente produzidas pelas práticas articuladas (políticas, sociais, discursivas) que as modelam, que constituem o objecto de uma história cultural levada a repensar completamente a relação tradicionalmente postulada entre o social, identificado com um real bem real, existindo por si próprio, e as representações, supostas como reflectindo-o ou dele se desviando. (CHARTIER, 1990, p. 27).

Com o objetivo de fundamentar e contextualizar quem são os professores na atualidade, como um grupo social, os estudos de António Nóvoa $(1999,2007)$ são imprescindíveis ao tratar da profissionalização docente e das representações de ser professor construídas historicamente.

Dessa forma, a pesquisa justifica-se por buscar compreensão sobre as escritas literárias produzidas por professores e, ao identificar as práticas da escrita realizadas por esse grupo, organizar um corpus de fontes documentais com os materiais disponibilizados, apresentando os modos de escrever, os tipos de texto, os usos dos materiais e a contextualização da produção dos professores escritores contribuindo para a reflexão da relação que estes possuem com a escrita para além do âmbito escolar. $\mathrm{Na}$ busca pela compreensão das práticas da escrita de professores, a construção teórica fundamenta-se em Chartier nos conceitos de prática, representação e apropriação; em 
Castillo Gómez e Viñao Frago no que corresponde ao campo História da Cultura Escrita; em Nóvoa e Catani no que cabe ao campo da história da profissão docente e o processo de profissionalização que culminou na forma profissional atual de professor; e nas proposições de Bourdieu sobre o campo literário para compreender a posição dos agentes - os professores - no espaço social.

\subsection{Diálogo com as pesquisas sobre escrita de professores}

Neste momento pretendemos apresentar algumas pesquisas do campo educacional brasileiro que, fazendo uso dos escritos de professores como objetos e/ou fontes, indiciam possíveis relações do professor com a cultura escrita. Tais pesquisas foram identificadas a partir de publicações que tiveram como objetivo tratar da memória docente ${ }^{4}$ e de escritos autobiográficos $^{5}$ de professores; outras foram identificadas a partir de levantamento bibliográfico realizado em revistas científicas conceituadas na área da Educação ${ }^{6}$, a saber: Educação e Pesquisa, Cadernos de Pesquisa e Revista Brasileira de Educação, compreendendo o período de 2006 a 2016, fazendo uso das palavras-chave "escrita de professores", "escrita de si" e "escrita literária de professores”. Além disso, realizamos a leitura dos sumários e resumos quando a busca por termos não foi efetiva. Durante o levantamento nas referidas revistas, identificamos doze artigos que abordam o tema da escrita e escritos produzidos por professores, sendo que a maioria visam discutir a formação dos professores e os aspectos profissionais a partir do material produzido, embora apresentem fundamentações teóricas e metodológicas distintas ${ }^{7}$. Corazza et. $a l .^{8}$ (2014), apresenta um projeto intitulado Escrileituras, que articula formação de professores e ensino da escrita por meio de oficinas, as quais têm por objetivo desenvolver as competências de leitura e escrita entre os participantes, valendo-se da "perspectiva do

\footnotetext{
${ }^{4}$ MIGNOT, A. C. V. et. al. (orgs.) Práticas de memória docente. São Paulo: Cortez, 2003; BASTOS, M. H. C. et. al. (orgs.) Destinos das letras: história, educação e escrita epistolar. Passo Fundo: UPF, 2002.

5 MIGNOT, A. C. V.; et. al. (orgs.) Refúgios do eu: educação, história e escrita autobiográfica. Florianópolis: Mulheres, 2000.

${ }^{6}$ As revistas selecionadas estão vinculadas à universidades da região sudeste e, por isso, possibilitam olhar para a produção veiculada nesse território do país. Assim, é importante pontuar que o levantamento realizado a partir de revistas em outras regiões possa indicar diferentes pesquisas neste campo. Os artigos identificados no levantamento bibliográfico encontram-se listados no apêndice.

${ }^{7} \mathrm{O}$ artigo de Gago (2015) trata do contexto espanhol e, por esse motivo, não está descrito entre as pesquisas desenvolvidas no país.

8 CORAZZA, Sandra Mara et al. Escrileituras: um modo de ler-escrever em meio à vida. Educ. Pesqui., São Paulo, v. 40, n. 4, p. 1029-1043, dez. 2014.
} 
pensamento da diferença em educação"; e com base nas discussões teóricas propostas por Gilles Deleuze e Félix Guatarri, utiliza a "didática-artística da tradução e o método cartográfico". As oficinas buscam promover o pensamento crítico e a busca pelo novo, aliados às práticas de escrita e leitura dos alunos da educação básica e dos estudantes de graduação em formação.

Adotando a perspectiva do ensino da escrita, Gomes-Santos ${ }^{9}$ (2010) investiga como a escrita se converte em objeto a ser ensinado pelos professores e, para isso, estabelece o seguinte corpus de análise: gravações em áudio e vídeo dos momentos de ensino em uma sala dos anos iniciais do ensino fundamental e em uma sala da Educação de Jovens e Adultos. A análise dos materiais revelou o predomínio de práticas dialógicas nas quais o ensino da escrita se constitui a partir do diálogo instituído entre os participantes - professor e alunos -, assim como com os autores dos materiais em uso, texto e livro didático.

O estudo apresentado por Freitas et. al. ${ }^{10}$ (2008) privilegiou a formação de professores em uma disciplina no curso de graduação em Matemática. A disciplina Geometria Plana e Desenho Geométrico foi escolhida por considerar o ensino da escrita discursiva como aspecto necessário à formação dos futuros professores. A autora da pesquisa enfatiza que a escrita tem um potencial formativo, entretanto, afirma que os estudantes de graduação em Matemática apresentam dificuldades em se expressarem textualmente, o que para ela evidencia que os cursos pouco enfatizam a dimensão escrita na formação dos professores desta área.

Rosa et. $a l^{11}$ (2008) realizou uma pesquisa com estudantes de licenciatura sobre memórias acionadas a partir dos odores sentidos nas escolas em que foram estagiar. Com isso, os estudantes foram orientados a, durante este período, escrever textos narrativos relacionando os odores percebidos às suas memórias. Nos relatos dos futuros professores, apareceram tanto a lembrança afetiva de determinados professores, como a escola que, enquanto espaço institucional, permitiu a socialização e constituição de amizades. Para a autora, essa perspectiva formativa possibilita um novo encontro do estudante com a escola e, também, consigo mesmo, pois a partir da experiência escolar é que se escolheu ser

\footnotetext{
${ }^{9}$ GOMES-SANTOS, Sandoval Nonato. A escrita nas formas do trabalho docente. Educ. Pesqui., São Paulo, v. 36, n. 2, p. $445-458$, ago. 2010.

10 FREITAS, Maria Teresa Menezes; FIORENTINI, Dario. Desafios e potencialidades da escrita na formação docente em matemática. Rev. Bras. Educ., Rio de Janeiro, v. 13, n. 37, p. 138- 149, abr. 2008.

${ }^{11}$ ROSA, Maria Inês Petrucci; RAMOS, Tacita Ansanello. Memórias e odores: experiências curriculares na formação docente. Rev. Bras. Educ., Rio de Janeiro, v. 13, n. 39, p. 565- 575, dez. 2008.
} 
professor. Ainda nessa perspectiva da formação de futuros professores, Charréu et. al. ${ }^{12}$ (2015) apresenta um estudo em que toma os diários de aula e portfólios confeccionados por licenciandos durante a prática do estágio. A escrita dos diários de aula, que é o objeto do nosso interesse, visa formar o professor a partir de uma prática pedagógica reflexiva. Assim, o estudante em formação elabora seu relato acerca das experiências de estágio, partindo de observações práticas. Com esse material, o estudante pode, então, dialogar com seus pares, no ambiente universitário. De modos distintos, os cinco estudos relatados se debruçaram sobre a prática da escrita no ambiente escolar e/ou acadêmico, objetivando desenvolver, juntamente com os professores, as habilidades de leitura e escrita. Para, a partir desta última, formar professores capazes de refletir não somente sobre o próprio processo de formação, mas também a propósito das práticas pedagógicas que levam a cabo.

Teresa Rego ${ }^{13}$ (2014) estudou os memoriais de concurso para os cargos de livredocência e titular na carreira universitária de professores vinculados ao campo educacional, enfocando nestes a trajetória de formação, a constituição da identidade docente, a educação, e a relação com a escrita autobiográfica. Para a autora, a prática da escrita de memoriais e a análise dessas narrativas foram ainda pouco exploradas e possuem potencial de pesquisa sobre a profissão docente e as práticas escolares considerando que os professores narram suas trajetórias de formação ao longo da vida em tais relatos. Além disso, se apresenta como um material importante para a compreensão de como se elabora a identidade do professor universitário. Zilma Oliveira ${ }^{14}$ (2006) também estudou memoriais, neste caso, foram produzidos por educadores da educação infantil que produziram seus memoriais como Trabalhos de Conclusão do Curso Normal, de nível médio, realizado em serviço no Programa ADI-Magistério. A pesquisadora enfatiza a importância deste tipo de relato autobiográfico para a compreensão das identidades sociais que constituem esses sujeitos educadores, pois na elaboração da escrita sobre a trajetória formativa emergem os pensamentos, conflitos e as posições sociais de cada educador, sendo possível compreender como a identidade docente se constitui em cada relato individual, assim como as semelhanças e distâncias que

\footnotetext{
${ }^{12}$ CHARRÉU, Leonardo Verde; OLIVEIRA, Marilda Oliveira de. Diários de aula e portfólios como instrumentos metodológicos da prática educativa em artes visuais. Cadernos de Pesquisa, São Paulo, v. 45, n. 156, p. $410-425$, abr./jun. 2015.

${ }^{13}$ REGO, Teresa Cristina. Trajetória intelectual de pesquisadores da educação: a fecundidade do estudo dos memoriais acadêmicos. Rev. Bras. Educ., Rio de Janeiro, v. 19, n. 58, p. 779 - 800, set. 2014.

${ }^{14}$ OLIVEIRA, Zilma de Moraes Ramos et al. Construção da identidade docente: relatos de educadores de educação infantil. Cadernos de Pesquisa, São Paulo, v. 36, n. 129, p. 547- 571, 2006.
} 
compõem tal grupo. Em contextos diversos, os relatos autobiográficos de professores nos aproximam da dimensão da pessoa do professor e da sua trajetória de formação para se constituir um professor, seja na educação básica ou no ensino superior, e isso possibilita a realização de estudos para se compreender cada vez mais as nuances dos profissionais que atuam no campo educacional.

Marin et. al. ${ }^{15}$ (2007) analisou os estudantes concluintes do Curso Normal Superior de uma instituição privada em relação à aptidão de leitura e escrita deles para atuarem nos anos iniciais do ensino fundamental e identificou que estes estudantes apresentam dificuldades na expressão escrita, na compreensão do texto lido e na utilização de argumentos, conhecimentos esses necessários ao exercício da profíssão. Portanto, para a autora, esses futuros professores apresentam lacunas significativas em suas formações em relação à comunicação e ao "acesso ao universo simbólico da cultura ocidental" (MARIN et. al., 2007, p. 38). Este estudo se aproxima do desenvolvido por Kramer e Souza (2003), que abordaremos adiante, o qual trata da importância dos professores serem leitores e escritores para que possam desenvolver tais habilidades em seus alunos.

O artigo de Bueno et. al. $(2006)^{16}$ compreende uma revisão de trabalhos no campo educacional sobre as histórias de vida e estudos autobiográficos de professores no país, considerando o aspecto metodológico de pesquisa, no período de 1985 a 2003, a partir de teses, dissertações, revistas científicas e livros. O tema privilegiado desta revisão feita pelas pesquisadoras compreendeu a formação de professores e a profissão docente. Assim, este artigo contribui para a reflexão da nossa pesquisa na medida em que nos aproxima de alguns trabalhos realizados no período anterior ao levantamento que realizamos e nos mostra que os trabalhos identificados utilizaram os relatos orais (histórias de vida, memórias, lembranças) e escritos em estudos no campo da história da educação e outros como fontes para a compreensão das trajetórias de formação e vida profissional dos professores, sendo este último o interesse das pesquisadoras envolvidas na revisão. Chamou-nos a atenção a recorrência da temática identitária de professores presentes nas pesquisas apresentadas na revisão, o que indica segundo Bueno,

uma tendência que vem se acentuando há mais de uma década em outros países, sobretudo nos contextos francófonos, nos quais a noção

\footnotetext{
15 MARIN, Alda Junqueira; GIOVANNI, Luciana Maria. Expressão escrita de concluintes de curso universitário para formar professores. Cadernos de Pesquisa, São Paulo, v. 37, n. 130, p. 15- 41, Abr., 2007.

${ }^{16}$ BUENO, Belmira Oliveira et al. Histórias de vida e autobiografias na formação de professores e profissão docente (Brasil, 1985-2003). Educ. Pesqui., São Paulo, v. 32, n. 2, p. 385-410, ago. 2006.
} 
de identidade tem sido adotada por aqueles que desejam compreender, no campo da Educação e da Formação, como as mudanças individuais e coletivas se processam. (BUENO et. al., 2006, p. 404).

De algum modo, a questão da identidade nos remete ao nosso objeto de estudo, pois quando um professor opta por escrever um texto literário trazendo aspectos da profissão docente, ele está elaborando uma narrativa ficcional a partir da sua identidade profissional, seja se aproximando da realidade, seja construindo uma outra, talvez menos transparente e com menor grau de intimidade com o real.

$\mathrm{O}$ artigo de Aquino ${ }^{17}$ tece considerações sobre a escrita escolar a partir das reflexões elaboradas por Michel Foucault sobre a escrita de si, assim, o autor afirma que a "[...] escrita e seus afazeres despontam como um campo empírico de lutas críticas em favor da potencialização dos modos de existência aí em causa." (AQUINO, 2011, p. 647), portanto, a escrita no universo escolar, pedagógico, é disciplinada por uma série de normas pertencentes a este campo, e o que escapa às normas é compreendido como literário, metafórico, segundo o autor. No entanto, Aquino enfatiza a importância de que a negação da escrita escolar, pedagógica que disciplina é a adoção de um "norte éticopolítico" e, que pode possibilitar a constituição de uma escrita da experiência. De outro ponto, o autor afirma que as pessoas escrevem a partir da vida, pela "potência de existir". Nesse sentido, o artigo nos leva a refletir sobre o que move a escrita literária dos professores, já que esta é uma produção elaborada para além do ambiente escolar e que, como veremos adiante, algumas estão imbricadas ao contexto escolar e profissional, e outras totalmente distantes.

A pesquisa desenvolvida por Wiara Alcântara ${ }^{18}$ (2012) estudou a carreira do magistério em São Paulo, no período de 1920 a 1950, a partir dos escritos literários contos, romances e autobiografias - produzidos pela professora Botyra Camorim. Utilizados como fontes primárias, estes materiais foram confrontados com a legislação, textos de outros educadores e outras pesquisas, permitindo evidenciar do ponto de vista de uma trajetória individual as formas de constituição da carreira docente no referido período. Em relação ao nosso objeto de pesquisa, a professora Botyra Camorim ao escrever textos literários, escolhe narrar a sua profissão apresentando ao leitor as tensões e desafios presentes no cotidiano profissional aproximando-se, assim, de alguns

\footnotetext{
${ }^{17}$ AQUINO, Julio Groppa. A escrita como modo de vida: conexões e desdobramentos educacionais. Educ. Pesqui., São Paulo, v. 37, n. 3, p. 641 - 656, dez. 2011.

${ }^{18}$ ALCÂNTARA, Wiara Rosa Rios. A sala de aula foi o meu mundo: a carreira do magistério em São Paulo (1920-1950). Educ. Pesqui., São Paulo, v. 38, n. 2, p. 289 - 305, jun. 2012.
} 
professores identificados nesta pesquisa, permitindo-nos vislumbrar as diversas finalidades da produção escrita do professor e como em cada época e lugar os professores (pelo menos os que optam por fazer relatos sobre o magistério) compreendem a sua profissão.

Apontamos a relevância do trabalho de Dislane Zerbinatti Moraes (1996) que desenvolveu uma pesquisa sobre escritos literários de professores analisando quatro romances, do período de 1920 a 1935, produzidos por professores paulistas: O professor Jeremias, O calvário de uma professora, Alegrias, Agruras e Tristezas de um Professor e O professor Policarpo: páginas de bom humor. Neste estudo, os romances são analisados em seus discursos e contextos de produção com o objetivo de identificar as representações que os professores elaboraram sobre a profissão, a formação, a escola de atuação e os órgãos de direção. Esta pesquisa se aproxima do presente estudo considerando que a investigação é feita a partir de escritos literários de professores, ou seja, pelas fontes privilegiadas para o estudo, porém se distancia no tempo histórico delimitado e se diferencia em relação ao gênero literário, pois a pesquisa reuniu romances para a análise. Assim, o estudo contribui para a reflexão sobre as escolhas teóricometodológicas possíveis ao analisar materiais escritos por professores. No estudo de Moraes, os professores autores dos romances traziam suas necessidades políticas ao defenderem a posição do professor naquele contexto histórico, aconselhavam os professores-leitores a lutar contra os problemas vivenciados e elogiavam a prática docente e, ao fazerem isso, acabavam muitas vezes trazendo ao texto um tom de denúncia sobre as condições de trabalho vivenciadas por eles no Brasil nas décadas de 20 e 30. Nesse sentido, encontramos semelhanças em relação às fontes aqui estudadas, porque os professores apresentam em alguns de seus textos certa crítica da realidade, aproximandose do tom de denúncia apresentado por Moraes (1996).

Outro estudo a ser apresentado sobre escritos de professores, desenvolvido por Maria Teresa Santos Cunha pesquisou diários íntimos de duas professoras catarinenses, escritos entre 1964 e 1974, quando eram normalistas e iniciaram na carreira do magistério. A partir da perspectiva teórica de Roger Chartier, a pesquisadora analisa os diários das professoras sob dois eixos norteadores: "o trabalho e as práticas e experiências pessoais das professoras em questão" (2000, p. 163), buscando como foi representado no diário o início da vida profissional, os desafios, as inquietações, entre outros aspectos. A relação do professor com a escrita, neste caso, se configura pela prática da escrita íntima, confessional, na qual as jovens professoras narram cotidianamente os desafios 
enfrentados como estudantes e ingressantes na carreira " $[$... ] anunciando, cada qual a seu modo, as variadas práticas que atravessam e constituem as representações sociais desse fazer feminino de professora. [...]" (p. 178).

Ana Chrystina Venancio Mignot estudou as cartas recebidas por Edgar Sussekind de Mendonça, na prisão política de 1935 a 1936. Edgar era professor e atuou em outras atividades, como diretor de escola, escritor, tradutor, editor e fundou a Associação Brasileira de Educação (ABE), em 1924. No ano de 1932, foi signatário do Manifesto dos Pioneiros da Educação Nova. A sua prisão ocorreu em decorrência de acusação sobre a sua participação no levante comunista de 1935. Estando preso, Edgar recorre à leitura e a escrita de cartas para "aliviar tensões e suprir suas carências mais profundas" (2002, p. 117), trocando cartas com a sua família, amigos, colegas de trabalho e alunas. Para Mignot, estudar as cartas trocadas entre Edgar e seus correspondentes inclui examinar os suportes, os temas tratados, a frequência da correspondência, o período histórico, considerando que a escrita epistolar tem características próprias, além disso, permite "[...] entrever sua trajetória e ampliar a compreensão a respeito da história política do país e, em particular, sobre o papel desempenhado por alguns dos educadores que estavam mais fortemente comprometidos com um projeto de transformação da sociedade brasileira no qual a escola laica, gratuita e universal seria peça fundamental” (p. 116).

Em outro estudo realizado por Maria Teresa Santos Cunha (2002) sobre professores, o objeto delimitado agora são cartas trocadas entre duas amigas professoras, uma residente em Santa Catarina e outra no Paraná, no período entre $1^{\circ}$ de agosto de 1967 e 19 de junho de 1968. As professoras atuavam no magistério primário e estavam em formação, uma em Pedagogia e a outra concluindo o curso na Escola Normal. Na troca de correspondências, elas compartilham as experiências vividas, incluindo as da profissão, comentam leituras, questionam normas e valores da época, além de evidenciar as representações construídas no convívio social. Fundamentando-se em Chartier e nos estudos do campo da cultura escrita, a pesquisadora analisa “[...] as cartas em uma tensão que as contemple tanto como uma prática cultural (regras, rituais do ato de escrever, locais da escrita, recepção, periodicidade) como um conjunto de documentos históricos que elabora representações sobre um dado capital de vivências da época e, dessa forma, se faz portador/produtor de sentidos para a história" (2002, p. 184, grifo do autor).

A pesquisadora Francisca Izabel Pereira Maciel desenvolveu um estudo a partir do arquivo pessoal da professora Lúcia Casasanta, no qual elaborou a biografia intelectual da professora e teve contato com um acervo de cartas recebidas por ela entre as décadas 
de 30 e 80, cujos remetentes foram seus familiares, amigos, intelectuais, políticos de Minas Gerais, editores, professores, alunos e ex-alunas. Para analisá-las foram criados três grupos de cartas: pessoais, oficiais e pedagógicas. As cartas pedagógicas são correspondências de professoras do ensino primário e de escolas normais e alunos. Neste estudo, Maciel privilegia as cartas escritas por professoras para Lucia Casasanta abrangendo três décadas do século XX, sendo de 1950 a 1984 -, com o intuito de compreender os motivos que levaram as professoras a lhe escreverem cartas. Os conteúdos de tais cartas revelavam o cotidiano da escola e as angústias das professoras que se preocupavam com o fracasso escolar dos alunos. Desse modo,

[...] As professoras, ao mesmo tempo em que pediam orientações metodológicas, solicitavam de Lúcia Casasanta posicionamentos sobre determinados procedimentos metodológicos. Podemos inferir que as professoras estavam, de certo modo, questionando, reavaliando as suas práticas. As cartas traziam também pedidos de indicação bibliográfica, livros que poderiam ler para se capacitar, o que indica a importância que teve Lúcia Casasanta como mentora intelectual [...]. (MACIEL, 2002, p. 212).

Solange Jobim e Souza e Sônia Kramer desenvolveram na Faculdade de Educação da UERJ, na década de 90, a pesquisa Cultura, modernidade, linguagem: o que narram, leem e escrevem os professores. Partindo da teoria crítica da cultura e da modernidade, as pesquisadoras objetivaram conhecer a trajetória de leitura e escrita de professores da pré-escola e das primeiras séries do primeiro grau da escola pública, com a finalidade de fornecer subsídios para políticas públicas de formação e acesso à escrita. Adotando a metodologia "história de vida" (FERRAROTTI, 1983) convidaram professores a relatar "suas trajetórias com a leitura/escrita" (2003, p. 27) compreendendo as entrevistas/relatos em sentido dialógico (BAKHTIN, 1982).

Nas entrevistas com os professores é comum aparecerem relatos sobre o gosto pela leitura e pela escrita em suas trajetórias de vida. Porém, ainda mais regular, é que estas narrativas revelam a obrigatoriedade da leitura exigida pela escola, bem como a vergonha de escrever, já que a escrita é criticada de forma negativa na escola. Com base nisto, as pesquisadoras assinalam que

[...] a escola, mais do que formar o leitor, parece exercer um papel crucial na formação do não-leitor. Muitos são os depoimentos que registram o abandono da prática de leitura e de escrita, no momento em que os livros se tornam obrigatórios, únicos (um livro para toda a turma e um tipo de livro para cada série) [...]". (SOUZA; KRAMER, 2003, p. $38)$. 
Em uma perspectiva diversa da trazida por este estudo, Kramer e Souza buscam compreender como se dá a trajetória de leitura e escrita de professores que atuam com crianças que iniciam sua vida escolar e, consequentemente, o aprendizado da leitura e da escrita. Diante do resultado que apresentam, são identificados uma série de desafios no tocante a formação de professores, bem como para o ensino brasileiro.

No Brasil, os estudos que tratam dos escritos de professores evidenciam as diferentes abordagens teóricas e metodológicas utilizadas, assim como a constituição de perspectivas de pesquisa a partir de fontes escritas por professores e narrativas localizadas em diferentes espaços e tempos históricos. Este aspecto permite-nos visualizar a história da educação e da cultura escrita no país considerando práticas determinadas, assim como possibilita compreender e investigar - a partir de trajetórias individuais e de pequenos grupos -, como se constitui a identidade docente. Neste sentido, podemos afirmar que as práticas da escrita de professores viabilizam uma multiplicidade de pesquisas no campo educacional, ao mesmo tempo em que estão imbricadas em outros campos do conhecimento - conforme enfatizado nos trabalhos anteriormente descritos. Com essa diversidade, compreendemos que há múltiplas formas desde as quais podemos olhar para as fontes que subsidiam o presente estudo.

\subsection{Percursos da pesquisa de campo}

Ao considerar pesquisas que pretendem estudar o cotidiano, os fazeres e as práticas de pessoas comuns, refletimos sobre o que significa a seleção de fontes documentais, orientados, sobretudo, pelas seguintes questões: onde buscar escritos produzidos por pessoas comuns e o que os arquivos públicos conservam em relação a este tipo de documento da população? Assim, aproximando-nos do pensamento de Hobsbawm (1990) quando trata do problema técnico de estudar e pesquisar sobre a história do povo, ou seja, a história "menor", o autor afirma não haver um conjunto de materiais/fontes prontos sobre a história do povo que se quer estudar. Nesse sentido, o objeto de estudo definido pelo investigador pode ter uma dimensão desconhecida do passado ou, ainda, ser um tema pouco explorado.

O pesquisador que tem por objetivo estudar a história “menor" necessita garimpar diferentes espaços na busca de suas fontes, procurando responder a determinadas perguntas da pesquisa - desse modo, os materiais serão revelados à medida que o 
investigador realizar certos questionamentos. Isso pressupõe olhar para o arquivo e para as fontes em busca de respostas ou indícios que levem a uma interpretação.

Nessa busca dos materiais, o pesquisador assume uma posição teórica e metodológica que configura a organização do arquivo, a classificação dos dados levantados e o modelo interpretativo adotado - neste último serão apresentados os resultados da pesquisa a partir do percurso escolhido. Tal interpretação revelará dimensões contidas em uma história mais ampla e que, a princípio, não tinham sido reveladas.

No decorrer do levantamento de práticas e materiais produzidos por professores, nos deparamos com uma informação de um concurso literário realizado pela Prefeitura de São Paulo. Ao buscar informações mais detalhadas, verificamos que o concurso literário intitulado Valeu, Professor foi uma ação realizada pela Secretaria Municipal de Educação de São Paulo para professores da rede. A partir da ocorrência do concurso literário nos anos 2010, 2011 e 2012 três livros foram publicados, um por ano, com os textos literários vencedores. Com vistas a compreender essa prática cultural da escrita no contexto da Rede Municipal de Educação de São Paulo é necessário acessar os arquivos desse concurso para além do manuseio dos livros publicados e buscar na totalidade da documentação a forma de conduzir o processo do concurso, as escolhas feitas, a manufatura de cada etapa e seus agentes.

À vista disso, a Secretaria Municipal de Educação de São Paulo possui um Núcleo de Documentação que é composto pela Memória Técnica Documental onde ficam arquivados os documentos técnicos e pedagógicos produzidos pela secretaria, com o objetivo de construir a memória da educação do município, além de possibilitar consultas e pesquisas por meio da Biblioteca Pedagógica Profa. Alaíde Bueno Rodrigues, que é especializada em Educação e atende os profissionais da SME e o público geral; e pelo Memorial do Ensino Municipal - um museu da educação paulistana que preserva objetos e documentos que podem ser vistos em exposições e/ou consultados em pesquisas específicas.

No primeiro contato realizado com a SME, a Memória Técnica Documental foi o lugar indicado para iniciar a busca das fontes. Utilizando o catálogo do acervo da Memória Técnica Documental foram realizadas buscas de palavras-chave "Valeu Professor" localizando sete arquivos. Essa ferramenta de busca não permite a visualização do documento, sendo necessário solicitar cópia dos arquivos e aguardar a separação do material para análise. $\mathrm{Na}$ consulta aos documentos, os materiais são disponibilizados 
digitalmente, muito embora alguns estivessem na forma impressa, como no caso dos três livros publicados no concurso. Como havia excedente dos livros, um exemplar de cada edição do concurso foi doado para a pesquisa. Além disso, por conta da visita ao arquivo uma profissional da Biblioteca Pedagógica foi indicada como conhecedora do concurso literário e se disponibilizou a colaborar com o fornecimento da documentação necessária para a realização do trabalho.

O manuseio dos documentos cedidos possibilitou identificar que nos arquivos da Memória Técnica Documental constavam documentos internos da SME e notícias publicadas em boletins informativos, intitulados Nossa Escola - Boletim oficial da Secretaria Municipal de Educação de São Paulo sobre o Valeu, Professor. Ademais, todas as informações sobre o concurso e o evento Valeu, Professor publicadas no Diário Oficial da Cidade de São Paulo e acessadas por meio do DO online que, desde $2005^{19}$, publica suas edições também neste formato. Desse modo, não eram todos documentos do concurso literário que estavam sob a tutela da Memória Técnica Documental, outros se encontravam guardados na Biblioteca Pedagógica, na forma impressa, organizados de acordo com o formato em que foram manuseados pelos membros da comissão organizadora do concurso literário. Acreditamos que isso se deve ao fato de ter neste espaço um profissional que atuou na comissão do concurso em todas as edições.

Considerando que a SME tem um setor responsável por preservar os documentos históricos e pedagógicos da educação no município, refletimos sobre a lógica de organização do arquivo, pois os documentos de confecção do concurso literário não passaram pelo mesmo processo de classificação e catalogação que os outros recebidos pela Memória Técnica Documental.

As fontes documentais do Concurso Literário Valeu, Professor apresentam uma parte da história da SME e dos professores que atuaram e/ou atuam na rede municipal de ensino, ainda que não pertençam ao grupo de documentos organizados e classificados nos arquivos institucionais. Nesse sentido, para tratar dessa questão da guarda dos documentos nas instituições recorremos às autoras Nunes e Carvalho (1993):

Sob esse ponto de vista, a concepção corrente nas mais diversas instituições, ainda hoje, em suas diferentes instâncias, é a valorização enfática dos documentos enquanto objetos de caráter comprobatório. Ou seja, mantém-se uma concepção construída nos séculos anteriores. $\mathrm{O}$ valor informativo, que se refere ao uso do documento do ponto de vista científico e cultural, raramente é considerado [...]. (p. 33).

\footnotetext{
19 A ferramenta de busca das edições do Diário Oficial da Cidade de São Paulo está disponível em: http://www.docidadesp.imprensaoficial.com.br/.
} 
Assim, atentando para os documentos de caráter comprobatório, no que cabe ao arquivo relacionado ao concurso literário, está na guarda da Memória Técnica Documental os documentos internos à SME que tratam da criação do evento Valeu, Professor e do concurso literário, e as notícias publicadas no boletim informativo Nossa Escola. Além destes, os exemplares dos livros também constavam no arquivo, já os regulamentos, comunicados, portarias e outros documentos oficiais ficam nos arquivos no Diário Oficial da Cidade de São Paulo por terem sido publicados neste veículo de comunicação. Todos os demais documentos referentes ao concurso literário permanecem armazenados na Biblioteca Pedagógica, em arquivo restrito à consulta, sem classificação e catalogação, o que nos leva a refletir se a instituição compreende que estes documentos não só confirmam uma prática cultural, como também conformam a história de um grupo de profissionais, além de conter parte da história da profissão docente em São Paulo em um determinado contexto, possuindo, portanto, valores científicos e culturais específicos.

Dessa forma, essas fontes documentais podem reconstruir e recompor a história da educação desse lugar a partir do momento em que o pesquisador se debruça sobre tais arquivos, valendo-se de questionamentos e buscando nos arquivos as respostas imprescindíveis às suas indagações. Vale assinalar que, ainda que distintos pesquisadores se dediquem às mesmas fontes, múltiplas interpretações podem decorrer, especialmente pelos conceitos adotados e tratamento analítico dado ao material.

Para acessar os arquivos que estavam na Biblioteca Pedagógica e que não eram públicos, isto é, que não tinham sido publicados, tampouco classificados para fins de pesquisa, procedemos à solicitação formal junto ao Secretário de Educação, que em resposta nos informou que o acesso para fins de pesquisa seria possível, mas que não poderíamos fazer cópia dos documentos, nem citação dos textos inscrito, em função dos direitos autorais dos participantes que não tiveram seus textos publicados e que poderiam fazê-lo em outro momento. Com isso, tivemos acesso a todos os documentos a e passamos a agendar consultas ao arquivo, com o objetivo de ler e registrar os dados necessários para compreender o concurso literário, levando em consideração seu contexto de criação e a ocorrência das edições. Vale destacar que todos os textos inscritos no concurso literário compõem as fontes da pesquisa desta tese, com vistas a estabelecer certas dimensões bem como caracterizar o referido concurso, porém, deve-se mencionar que, diante da restrição colocada pelo Secretário de Educação, os textos não publicados não foram, aqui, analisados. 
Durante o ano de 2016, já com acesso aos documentos do arquivo, fundamentalmente formado por textos literários, fichas de inscrição, ilustrações, cédulas de votação das ilustrações e documentos da comissão organizadora, percebemos a riqueza de dados presente na totalidade destes e consideramos ser necessário obter autorização dos autores para incluir os textos não publicados nas fontes da pesquisa. Desse modo, em conversa com a profissional da Biblioteca Pedagógica, optamos por enviar e-mail aos professores inscritos com uma carta convidando-os a participar da pesquisa e autorizando a utilização de tais textos. Para isso, a Biblioteca Pedagógica, representada por essa profissional, enviou e-mail institucional a todos os professores inscritos, mas as respostas recebidas autorizando a utilização dos textos na pesquisa foi em número bem reduzido.

Passado um tempo havíamos compreendido que, para entender determinados aspectos das práticas da escrita de professores, seria de fundamental importância conversar com esses indivíduos praticantes, ou seja, realizar entrevistas com os professores. Neste sentido, avaliando o pequeno quantitativo de respostas que tivemos na tentativa de contato por meio da SME, decidimos por enviar e-mail diretamente aos professores com a mesma carta de apresentação da pesquisa, explicando a necessidade de autorização para uso dos textos não publicados e convidando os interessados a realizar uma entrevista. Tivemos mais respostas com o contato direto, o que viabilizou a obtenção de algumas autorizações para usar os textos e entrevistar alguns professores. Além dos documentos do Valeu, Professor, outros ainda compõem as fontes desta pesquisa, como é caso dos textos produzidos por professores que participam de saraus em São Paulo.

Consideramos importante esclarecer como chegamos aos saraus, já que eles não possuem uma relação direta com o concurso literário realizado pela SME. Nossa busca por materiais escritos por professores se constitui numa etapa da pesquisa de campo e não sabíamos ao certo onde encontrar tais materiais. Para isso, era imprescindível que adentrássemos distintos territórios. Assim, circulando um pouco pelo cenário cultural de São Paulo, nos chamou a atenção a quantidade e diversidade de divulgações de saraus em bibliotecas públicas e casas de cultura, de modo que essa prática cultural nos mobilizou a conhecer a dinâmica de um sarau atual, assim como seus agentes produtores e frequentadores. Sendo assim, iniciamos a busca pelos saraus em diversas regiões na cidade. Inicialmente, realizamos uma pesquisa na página eletrônica da prefeitura de São Paulo, na qual são divulgadas as atrações culturais da cidade, incluindo os saraus que acontecem em espaços públicos. 
Como ponto de partida, interessou-nos conhecer os saraus localizados na região central da cidade, os quais assistíamos e, em momentos oportunos, nos apresentávamos aos organizadores e perguntávamos sobre a participação de professores, assim como esclarecíamos outras dúvidas que surgiam naquele momento. Com isso, fomos formando uma rede de contatos e mesmo que em determinado sarau não houvesse um professor, a pessoa responsável sempre fazia a indicação de um outro grupo de sarau para conhecermos. A partir de então, fomos ampliando os diálogos com os grupos de saraus e conhecendo cada vez mais as características presentes em cada $u^{20}$. A medida que fazíamos esses contatos, fomos nos distanciando da região central da cidade e conhecendo saraus localizados tanto em bairros considerados periféricos ${ }^{21}$ quanto na região metropolitana de São Paulo.

Nos saraus em que encontrávamos professores participantes e/ou organizadores, explicávamos a pesquisa, falávamos sobre a compilação dos materiais escritos pelos professores e convidávamos os interessados para uma entrevista. Desse modo, mantivemos contato com os professores de forma que conseguíamos acompanhar a agenda dos saraus e saber sobre os materiais que publicavam, além de recebermos indicações de outros professores vinculados a saraus com os quais poderíamos entrar em contato.

Dessa forma, sublinhamos que os saraus que acontecem em São Paulo foram espaços que possibilitaram identificar professores escritores. Para isso, foi necessário conhecer diferentes saraus nos anos 2015, 2016 e 2017, tais como: Sarau Sobrenome Liberdade, Sarau do Grajaú, Sarau Amigos do Parque Pinheirinho D'Água, Sarau do PI, Sarau do Mercado, Sarau das Artes, Quinta Poética, Sarau Café com Poesia, Sarau Roda da Palavra e Cooperifa. Os materiais produzidos e disponibilizados por esses

\footnotetext{
${ }^{20}$ Optamos por inserir a caracterização dos saraus mais adiante no texto.

${ }^{21}$ Raquel Rolnik, ao tratar da questão territorial na cidade de São Paulo, aponta para a forma em que foi constituída a cidade e nos fez refletir sobre questões que envolvem a periferia - conforme assinalado no excerto a seguir: "Ao mesmo tempo que configuram os territórios da riqueza, a concentração de investimentos em "melhoramentos" e a legislação também definem aqueles lugares onde deverá se instalar a pobreza. O movimento, desde seu nascimento, é centrífugo, ou seja, delimita as bordas da zona urbana ou mesmo a zona rural como local destinado aos mais pobres. Diga-se de passagem, que a lógica de destinar as lonjuras para os pobres atravessou, incólume, o século XX, adentrando o século XXI. Começa com a proibição da instalação de cortiços na zona central, definida pelos códigos de posturas e sanitários a partir de 1886, que também permitem que vilas operárias "higiênicas" sejam construídas fora da aglomeração urbana. E continua com a delimitação do chamado perímetro urbano, demarcação de áreas que deveriam obrigatoriamente receber serviços de infraestrutura, excluindo bairros operários já inteiramente habitados na época, como Vila Prudente, Tatuapé, Canindé. Dessa maneira, demarcava-se uma área "regulada" da cidade, onde a habitação popular - na época, o cortiço e outras formas de moradia de aluguel - não poderia acontecer, ao mesmo tempo que se configurava, fora do perímetro urbano, uma zona de obscuridade sobre a qual o olhar do poder municipal não vigoraria.” (ROLNIK, 2017, p. 26)
} 
professores possuem suportes diferentes, a saber: textos impressos publicados em formato de livro e fanzines, além de textos divulgados em ambientes digitais.

Assim, os professores identificados nos saraus foram: Jefferson, Michele, Cecilia, Virginia, Márcio e Janaína. À medida que mantínhamos contato com esses professores, passamos a receber indicações de outros saraus e professores, com os quais fizemos contato. No entanto, dentre os indicados, apenas dois professores aceitaram participar da pesquisa, são eles: José Vandeí e Letícia ${ }^{22}$.

Realizar buscas em museus e arquivos públicos também foi uma possibilidade pensada para encontrar materiais de professores. Por conta disso, contatamos o Museu da Pessoa $^{23}$ em São Paulo, tendo em vista que a página eletrônica do Museu aponta a existência de coleções sobre professores. Contudo, em nosso contato, soubemos que toda a coleção é constituída por documentos de áudio e vídeo, não recebendo nenhum tipo de documento escrito - o que nos levou a desprezar esta possibilidade, uma vez que nosso estudo não considera o tipo de material fornecido.

No segundo semestre de 2016, consultamos o Centro de Memória da Educação ${ }^{24}$ da Faculdade de Educação da USP, que mantém arquivos da Escola da Aplicação da USP, além de outros acervos de professores e que receberam doações, tais como: cadernos de alunos e de professores, materiais didáticos, registros da profissão elaborados pelos professores, entre outros. Além desses materiais, identificamos alguns textos que, conforme observado, foram elaborados por professores para as suas respectivas disciplinas, também encontramos indícios de um concurso literário para alunos, realizado provavelmente em 1980, e uma caixa intitulada "Caixa Antologia", sem data, na qual havia textos literários e sequências didáticas, muito provavelmente produzidos pelos professores da época para utilizar em sala de aula. Mesmo sendo materiais de grande riqueza em relação às práticas de escrita de professores no âmbito escolar, optamos por não dar continuidade às buscas neste arquivo, considerando que foram produzidos no contexto da Escola de Aplicação e em período histórico anterior ao que já havíamos coletado.

Outra forma de recolher materiais produzidos por professores ocorreu por meio de redes de contato, divulgando a pesquisa e convidando professores escritores a

\footnotetext{
${ }^{22}$ Os nomes Cecilia e Virginia são ficcionais por opção das professoras, mesmo estando os seus respectivos textos publicados.

23 Informações sobre o Museu da Pessoa podem ser obtidas por meio da página eletrônica: https://www.museudapessoa.net/pt/home

${ }^{24}$ Página eletrônica do Centro de Memória da Educação: http://www.cme.fe.usp.br/
} 
participar. A divulgação se deu por meio de publicação de uma carta na rede social Facebook pedindo que a mensagem fosse compartilhada e que os professores interessados entrassem em contato. Foi desse modo que um professor, residente no município de Rio Claro, disponibilizou-nos catorze cadernos contendo os seus registros de aula no ensino fundamental da rede pública de ensino dos municípios de Rio Claro, Santa Gertrudes e Ipeúna - todos localizados no interior de São Paulo. Os cadernos desse professor são nomeados na rede municipal como "Semanários". Os "Semanários” são, essencialmente, cadernos nos quais são registrados tanto os conteúdos da aula lecionada pelo professor polivalente, quanto observações mais pontuais e reflexivas relacionadas à própria prática e ao aprendizado dos alunos. Ressaltamos que estes cadernos configuram uma prática de escrita profissional e que, dada a diferença da natureza desta produção em relação às outras fontes coletadas, os cadernos do professor não serão analisados no interior desta pesquisa $^{25}$.

Como descrito, diversos espaços foram visitados em busca de materiais escritos por professores e, neste sentido, podemos dizer que tivemos acesso a uma considerável diversidade de materiais: desde textos literários e materiais didáticos a registros de aula, narrativas de áudio e vídeos. Porém, era preciso fazer uma escolha e fizemos. Optamos por selecionar apenas os materiais literários por serem de mesma natureza e por vislumbrar variedade de práticas e riqueza de contextos e temas nos diferentes grupos. As principais fontes documentais das práticas da escrita de professores elencadas para esta pesquisa são os textos literários produzidos para o Concurso Literário Valeu, Professor e os dos professores vinculados aos saraus.

Depois de ter um primeiro contato com os diversos materiais dos professores, entendemos que os textos nos possibilitam uma dimensão da análise das práticas, no entanto, para compreendermos as motivações da escrita e conhecermos as trajetórias dos professores que escolhem escrever e publicar textos literários, seria preciso conversar com cada um deles e, para isso, julgamos que o uso do instrumento entrevista seria a maneira mais adequada. Realizamos entrevistas individuais e com um roteiro semiestruturado $^{26}$, no qual elaboramos grupos específicos de perguntas: as que seriam apresentadas a todos os entrevistados; outras, mais específicas, destinadas àqueles que

\footnotetext{
${ }^{25}$ A decisão pela exclusão dos materiais de registro profissional se deu após o exame de qualificação, de acordo com as considerações feitas pela banca examinadora.

${ }^{26} \mathrm{O}$ roteiro utilizado para a realização das entrevistas encontra-se no apêndice.
} 
participaram do concurso literário; e, por fim, teríamos aquelas direcionadas aos participantes dos saraus.

Dessa maneira, contatamos os professores que conhecemos nos saraus e fizemos o convite para uma entrevista. Com relação aos professores do concurso literário, fizemos o convite por e-mail, assim como relatado anteriormente, porém, nem todos os professores que responderam ao e-mail se dispuseram a participar da entrevista. Alguns, inclusive, queriam responder as perguntas como um questionário. Entretanto, compreendíamos que esta prática não corresponderia à metodologia adotada, tampouco cumpriria o objetivo a que se propunha, de modo que realizamos as entrevistas apenas com os professores que aceitaram participar presencialmente.

As entrevistas foram combinadas com cada professor participante de forma individual e em data e local mais adequado, sugerido pelo próprio professor. Para o dia da entrevista também pedimos ao professor que levasse seus materiais, sobretudo aqueles que desconhecíamos - isto nos permitiu incorporar textos e livros disponibilizados ao corpus de fontes documentais.

A etapa da realização das entrevistas teve início no segundo semestre de 2017 e finalizada no primeiro semestre de 2018 totalizando dezessete (17) entrevistas com professores, sendo nove (9) professores participantes do Concurso Literário Valeu, Professor e oito (8) professores vinculados aos saraus. O roteiro da entrevista foi utilizado como diretriz para a conversa - não havendo a necessidade de ser cumprido integral e rigidamente. Dessa forma, as entrevistas foram conduzidas de modo a enfatizar os relatos produzidos por cada um dos entrevistados - acrescentando ou eliminando questões quando necessário, principalmente no caso de questões sobre os quais o entrevistado já havia se posicionado. Em todas as entrevistas utilizamos gravador de voz mediante a autorização dos entrevistados, as quais foram transcritas posteriormente, gerando um arquivo sobre esse grupo ${ }^{27}$.

Em conjunto com os textos literários, as entrevistas representam as principais fontes para a compreensão das práticas da escrita de professores que nos permitiram conhecer as trajetórias de formação, as experiências profissionais e os caminhos percorridos por cada um para produzirem narrativas literárias.

\footnotetext{
${ }^{27}$ As entrevistas realizadas geraram transcrições extensas e em função do volume de material, optamos por disponibilizar duas transcrições dos professores que estão no apêndice, sendo uma referente ao participante do concurso literário e uma do professor atuante nos saraus.
} 
Outras fontes documentais compõem esta pesquisa de modo secundário, a saber: os documentos institucionais do concurso literário - regulamentos, comunicados, entre outros -, notícias veiculadas na imprensa oficial e interna da SME, e documentos da comissão organizadora do concurso. Em relação ao concurso literário, realizamos uma entrevista com um membro da comissão organizadora, cujo objetivo era o de conhecer, mais detalhadamente, o processo de criação e condução do mesmo, do ponto de vista de quem colaborou na efetivação deste na SME. Essa entrevista também foi gravada e transcrita, todavia a identidade do entrevistado será mantida em sigilo ${ }^{28}$.

\footnotetext{
${ }^{28}$ A transcrição da entrevista encontra-se no apêndice.
} 


\section{CULTURA ESCRITA, PRÁTICAS DA ESCRITA E LITERATURA}

Neste capítulo apresentaremos os aspectos teóricos adotados para compreender nosso objeto de estudo - práticas da escrita literária de professores -, o qual será tratado a partir do campo da cultura escrita e fundamentado nos estudos realizados por Castillo Gómez e Viñao Frago, assim como estudos desenvolvidos no Brasil no campo da História da Cultura Escrita, a fim de compreender o conceito prática da escrita embasado em Roger Chartier.

Considerando os tipos de textos (literários) escritos pelos professores, explicitar que concepção de literatura alberga esta pesquisa é de fundamental importância. Neste sentido, iremos recorrer aos debates apresentados tanto por Pierre Bourdieu quanto por Antonio Candido, de modo a conceituar e discutir, respectivamente, literatura e campo literário.

\subsection{Cultura escrita: o campo e a prática da escrita}

A fim de estabelecer o campo de estudos da História da Cultura Escrita nos aprofundamos nas considerações apresentadas por Galvão e Frade (2016) - considerando, obviamente, o caso específico do Brasil. Antes, porém, vale mencionar que os estudos que tratam da cultura escrita guardam relações com determinadas áreas da pesquisa, tais como: a história da educação, da alfabetização, do livro e da leitura. No Brasil, diversos estudos são desenvolvidos nesta direção, entretanto, deve-se enfatizar o fato de que a "[...] cultura escrita é capaz de abarcar um conjunto mais amplo de objetos e abordagens. [...]" (p. 208). Em alguns países este campo já se apresenta consolidado. No Brasil, entretanto- 
e considerando que este campo passa por um processo de construção muito específico ${ }^{29}$ são observadas importantes contribuições, especialmente de trabalhos desenvolvidos por pesquisadores como Antonio Castillo Gómez, Armando Petrucci, Roger Chartier, Jean Hébrard e Anne-Marie Chartier.

Galvão e Frade compreendem a "[...] cultura escrita como o lugar simbólico e material que o escrito ocupa em determinados grupos sociais, comunidades e sociedades, em épocas distintas [...]" (2016, p. 207). Com base nesta definição, as possibilidades de estudo no campo são variadas, a saber: "as instâncias ou instituições que ensinam ou possibilitam a circulação do escrito; os objetos que lhe dão suporte; os próprios suportes nos quais o escrito é difundido e ensinado; os sujeitos que o utilizam (ou não); os seus meios de produção e transmissão.” (2016, p. 207 - 208) Ressaltamos, além disso, a importância de contemplar a historicidade dos problemas de investigação sobre cultura escrita, tendo em vista que a relação que uma sociedade ou alguns grupos possuem com o escrito - independentemente do aspecto a ser pesquisado -, carece de contexto histórico para sua compreensão.

Clarice Nunes (1998), anos antes, realizou um balanço das comunicações brasileiras do I Congresso Luso-Brasileiro de História da Educação que aconteceu no ano de 1996, em Lisboa-Portugal, o qual teve como tema Leitura e escrita em Portugal e no Brasil (1500-1970). Os 140 trabalhos analisados representavam várias regiões do país. No entanto, havia uma concentração da produção na região sudeste, seguida da sul. Acompanhando a tendência internacional de pesquisas na última década, a percepção sobre os objetos de estudos foram ampliadas incorporando novas fontes para o campo de pesquisas no Brasil. Nunes chamava a atenção para a falta de fontes como os cadernos escolares e provas, além de destacar a relevância desses materiais para a história da educação. Dentre as temáticas sobre leitura e escrita abordadas nos trabalhos, a pesquisadora percebeu que, de um lado, prevalece a dispersão de temas; e, de outro, a concentração em dois aspectos: práticas de leitura e escrita e instituições escolares. No que se refere às práticas de leitura e escrita, os trabalhos enfatizam os dispositivos impressos, a análise de um tipo de escrita, formas de leitura e escrita em instituições, leituras de textos específicos, representação tanto do leitor quanto daqueles que estão

\footnotetext{
${ }^{29}$ Com o objetivo de contribuir com o campo de estudos História da Cultura Escrita no Brasil, a Revista Brasileira de História da Educação publicou no ano de 2016 o Dossiê: História da Cultura Escrita trazendo pesquisas desenvolvidas tanto em âmbito nacional quanto internacional, que, sem dúvida, vem colaborando para a consolidação do campo.
} 
excluídos do universo letrado, tradições orais e problemas de leitura e escrita. No que diz respeito às pesquisas sobre professores, verifica-se a centralidade na "revisão do papel do educador e pedagógico de certas ordens religiosas (os jesuítas ainda polarizam a nossa atenção), do que para a análise de trajetórias de vida de professores alfabetizadores [...]" (NUNES, 1998, p. 23). A autora, vale dizer, insiste na importância em estudar as trajetórias dos professores com o objetivo de resgatar as memórias da formação, da atividade profissional e da participação em organizações docentes. Como vimos no levantamento realizado em revistas científicas, essa lacuna vem sendo superada pelos estudos sobre as histórias de vida e trajetórias docentes.

Retomando a história da escrita, Antonio Viñao Frago (1996) em seu artigo "Por una Historia de la Cultura Escrita: observaciones y reflexiones" apresenta aspectos da transição de uma sociedade que utiliza a oralidade como forma de comunicação e de se relacionar para uma que passa a ter a escrita inserida em seu contexto. A transição da oralidade para a escrita revela-se como um processo lento, cujos grupos sociais passaram a usar a escrita e seus diferentes suportes cotidianamente, ampliando e aperfeiçoando seus usos até o momento de sua total incorporação às formas de comunicação, pensamento, registro e atividades profissionais.

La difusión, en una sociedad dada, de esta mentalidad letrada corre pareja, en el contexto del proceso de transición desde la oralidad "mixta" a la oralidad "segunda", con el progresivo desplazamiento de lo oral por lo escrito en el seno y en el funcionamiento de las distintas organizaciones sociales. Examinar este desplazamiento o sustitución en una sociedad determinada significa, en último término, analizar el proceso de difusión y configuración, en dicha sociedad, de aquellos supuestos, rasgos y efectos que caracterizan a la cultura escrita. (VIÑAO FRAGO, 1996, p. 50 -51).

Segundo Viñao, a oralidade mixta ocorre quando em uma determinada sociedade a influência do escrito é parcial e externa e o grupo continua tendo modos de expressão e de pensamento fundados na cultura oral. Na oralidade segunda, a cultura escrita torna-se mais predominante na vida social gerando uma desvalorização dos modos de expressão e pensamento da oralidade. A transição da cultura oral para a escrita provocou muitas mudanças na sociedade, não somente nos usos, mas também nas técnicas e tecnologias desenvolvidas, e tais mudanças geraram a ampliação da alfabetização, a invenção das copiadoras, mudanças nas formas de comunicação e de expressão, assim como nas formas de pensamento. 
Diferentemente da oralidade, o escrito tem o poder de registrar num determinado contexto, espaço e tempo uma dada realidade, uma interpretação desta efetuada por quem faz o registro escrito. Considerando o poder do registro, Viñao Frago (1996) afirma que a escrita teve uma importante função na formação dos Estados Modernos justamente por possibilitar registrar e arquivar as informações sobre a população e as práticas realizadas por quem governava, ou seja, por registrar a forma de organização adotada. Além disso, a escrita foi utilizada como forma de propaganda, divulgação das ideias e realizações do Estado com o fim de influenciar a opinião pública e, também, por outro lado, para deixar registrado os direitos do Estado frente a outros, como ao poder religioso e à sociedade. Para o autor, o poder do escrito está no registro realizado de uma determinada realidade que, por sua característica de permanência, o conteúdo do texto é uma interpretação do real e não um espelho do real, e justifica que se por algum motivo a pessoa que escreve se esquecer de registrar algum dado existente daquele momento, este será ausente e não haverá como comprová-lo naquela situação, por outro lado, se houver um acréscimo de informação por um erro, esta será dada futuramente como existente naquela realidade. Assim, o texto escrito interpreta e transforma a realidade remetendo sempre a um contexto de produção e a uma dada realidade.

[...] el lenguaje es una convención, algo producido y utilizado por seres humanos en situaciones de interacción. Y lo escrito es solo una de las modalidades del lenguaje. Una modalidad que ejerce su imperio frente a otras por su capacidad para fosilizar en el espacio y en el tiempo, en forma de huella, como la fotografía, la realidad a la que siempre remite. (VIÑAO FRAGO, 1996, p. 54).

A capacidade da escrita de fixar, fossilizar o registro produzido é uma característica que permanece. No entanto, as formas de fazê-lo foram sendo transformadas pelas novas técnicas e tecnologias do escrito. Considerando o tempo histórico da Idade Média até a atualidade, muitas mudanças ocorreram em relação aos materiais usados para escrever, aos suportes que guardam os escritos, as formas que usuários utilizam para realizá-la, as formas de edição, impressão e divulgação e, ainda, de leitura.

De acordo com Castillo Gómez (2010), a restrição da alfabetização que existia na Alta Idade Média está relacionada com a característica sagrada atribuída ao escrito, ainda ligada a outras de ordem política e social que determinavam a inacessibilidade ao material escrito, assim como ao conhecimento deste, existindo os profissionais da escrita incumbidos de administrar e cuidar dos escritos da época. Contrariamente, na Baixa Idade 
Média, a circulação de um escrito de conteúdo laico e profano colabora para a compreensão dos diferentes usos e sentidos atribuídos à escrita. Assim, a história da escrita demonstra marcas da divisão social e de gênero, presentes em determinadas épocas históricas, indiciadas por quem acessava o conhecimento e as técnicas do escrito. Se na Alta Idade Média os alfabetizados se restringem a determinados grupos, na Baixa Idade Média iniciam na aprendizagem da leitura e escritura os comerciantes e artesãos que vivem nos grupos urbanos desse período e percebem a necessidade de inserção no universo do escrito que está se difundindo entre a população medieval.

Em relação aos instrumentos e suportes do escrito, a Idade Média abarca mudanças significativas, tendo passado pelo rolo de papiro usado sobre os joelhos e enrolado conforme seguiam as colunas do texto, usado até o século VII, a pele de pergaminho ou a folha de papel com a forma quadrada ou retangular era usada dobrada ao meio, em quatro, em oito ou dezesseis para formar o caderno de quatro, oito ou dezesseis páginas, o codex que reuniam os cadernos, e a invenção da Prensa de Gutenberg a qual marca uma etapa importante na difusão do escrito. Segundo Castillo Gómez (2010), a prensa não significou uma ruptura em relação aos usos dos manuscritos, as primeiras reproduções feitas usando a prensa foram de escritos de séculos anteriores e, também, pouco houve de mudança no catálogo de livros da época. Ocorreu, sim, uma adaptação aos gostos e ao mercado de cada lugar. Em relação ao manuscrito, o impresso implicava a uniformidade do texto e a fixação de uma obra modelo que poderia sofrer anotações e comentários no momento da leitura, entretanto, no processo de elaboração de uma obra modelo poderia acontecer um erro de tipografia e o escrito ser alterado, sendo esse aspecto uma preocupação da época.

A escrita pessoal é difundida a partir do século XVI e enfrenta problemas em relação ao suporte, porque neste momento as folhas eram adquiridas individualmente e necessitava de um encadernador para organizá-las em função do uso, o que poderia ocorrer antes ou depois de efetuado o registro. Segundo Hébrard (2000), a maioria das representações de homens escrevendo na pintura apresenta o escritor com a folha e isso “[...] se deve talvez à pregnância da imagem dos copistas e dos notários medievais, que sempre preferiram trabalhar com folhas separadas a escrever em cadernos ou registros já encadernados." (p. 32) No entanto, a escrita do diário necessita da continuidade textual, seja ordenando as folhas escritas com o auxílio de um encadernador, seja com um suporte ordenado antecipadamente, pela paginação das folhas ou ainda por meio dos registros de datas. 
A prensa colabora para a reorganização do universo dos profissionais da escrita que não se restringem mais às chancelarias e ateliês de cópia, pois os negociantes criam uma nova ordem nos processos de escrita que ficam mais rápidos e usam línguas vernáculas para a contabilidade e a correspondência. No curso deste século há o desenvolvimento dos poderes judiciários que criam os escriturários para a realização dos atos jurídicos e, com isso, os colégios formam jovens na habilidade da escrita, portanto,

[...] a partir do século XVI, os saberes e as técnicas de escrituração estão ordenados em torno de três polos constitutivos de culturas específicas: as administrações civis, religiosas e jurídicas; o mundo dos comerciantes; e o mundo escolar. Esses três polos, cada um por si, são suscetíveis de fornecer aos escritores ordinários os modelos de que necessitam. (HÉBRARD, 2000, p. 35).

Jean Hébrard ao tratar da escritura escolar afirma que esta conseguiu dominar os espaços da escrita organizados em códice e inseri-los em dispositivos, pois os estudantes oriundos de meios populares que frequentavam a escola aprenderam, a partir de 1850, a escrever e organizar a escrita nos cadernos de acordo com as normas, o que indica que “[...] a escola pôde ser (e ainda é) o lugar de uma aprendizagem sutil dos gestos gráficos elementares, que prepara para as mais variadas escrituras pessoais. [...]" (HÉBRARD, 2000, p. 57). O caderno passou por um processo de mecanização da produção (diminuição dos custos pela simplificação da encadernação por meio da indústria) e redução de seu custo e, por isso, foi comumente utilizado no século XIX para os registros da vida cotidiana e pode ser encontrado ainda como suporte de diferentes tipos de escrita ordinária como os diários pessoais, relatos de vida e crônicas.

Viñao Frago (2010) afirma que a evolução tecnológica da escrita manual ordinária teve como características a busca por rapidez, simplicidade e funcionalidade e, com esse objetivo, foi criada a "pluma metálica", em 1780, que ainda necessitava do tinteiro, mais tarde, a "estilográfica" e, em 1943, apareceria as primeiras canetas.

[...] A principios del siglo XIX ya era evidente que el futuro de la escritura manual no iba a depender de las necesidades planteadas por los calígrafos, sino de aquellos, cada vez más, para los que la escritura era un elemento consustancial a su oficio o tarea; es decir, de los burócratas y contables, de los estudiantes y escritores, de las oficinas y bufetes, de los comercios y universidades. [...] (VIÑAO FRAGO, 2010, p. 329).

A caneta rapidamente ganha público pela facilidade do manuseio e pelo baixo custo tornando-se, no século XX, o instrumento de escrita mais popular. Fez parte desse processo de desenvolvimento dos instrumentos a escrita mecânica, por meio da 
taquigrafia a qual possibilitava uma escrita tão rápida quanto a fala utilizando símbolos que representavam as palavras. Também surgiram as primeiras máquinas de escrever que traziam somente letras em maiúscula. Somente em 1878, a máquina de escrever incorporaria letras maiúsculas e minúsculas. Em poucas décadas e num crescente, as máquinas de escrever foram sendo usadas como instrumentos de escrita principalmente nos espaços profissionais. Com o aperfeiçoamento dos modelos da máquina, seu uso se amplia e ocupa os espaços das casas, como afirma Viñao:

[...] El papel carbón (1890) y la máquina portátil, más ligera, ayudaron a extender todavía más la escritura mecanografiada. La máquina portátil, en especial, sacó dicha escritura de las oficinas y despachos, de los que se había adueñado en los primeros años del siglo, para llevarla al ámbito doméstico y personal [...]. (VIÑAO FRAGO, 2010, p. 332).

No final da década de 70, já no século XX, surgem os primeiros computadores e processadores de texto fazendo com que a máquina de escrever fosse considerada um instrumento ultrapassado em termos tecnológicos. Logo, as empresas e escritórios passam a substituir suas máquinas elétricas pelos computadores que possuem mais velocidade nas ações e simplificam as correções. Essa mudança de instrumento gera toda uma transformação nas formas de escrever dos séculos XX e XXI considerando, também, que a apropriação dele na realização das atividades profissionais e pessoais da vida em sociedade ocorreu rapidamente.

Los escritores pasaron de la máquina de escribir a los procesadores de textos mucho más rápidamente de lo que habían pasado del manuscrito a la mecanografía las generaciones anteriores. Los ordenadores personales - incluso los portátiles - se difundieron entre los profesionales, escritores, profesores y estudiantes al mismo tiempo que lo hacían la edición electrónica y la informatización de administraciones y empresas. La mayor velocidad, la simplificación de los ajustes y correcciones - que convierten al autor en impresor de su propio texto - y las posibilidades de conservación, recuperación y reproducción que ofrecen, han generalizado, en solo dos décadas, una tecnología de la escritura que no solo ha desplazado a las máquinas de escribir, sino que también ha sustituido a la escritura en muchos ámbitos y usos. (VIÑAO FRAGO, 2010, p. 333).

De modo cada vez mais intenso, os computadores estão presentes na vida cotidiana e seu uso no âmbito pessoal e profissional permite uma nova forma de escrever, os registros não mais ocupam as folhas - de caderno, de fichário, entre outras. O suporte agora é a tela que permite uma escrita uniforme e clara, sem as características deixadas pelo manuscrito quando é possível identificar o tipo de letra usada e o traçado que é tão característico de cada indivíduo. Além disso, a escrita em processadores de textos permite 
correções e reescritas sem deixar nenhum vestígio, não há versões dos escritos produzidos a menos que o autor/escritor escolha, numa tomada de consciência, conservar os diferentes esboços confeccionados até se chegar ao texto final. Agora, se isso não é realizado, um texto que tenha passado por muitas reelaborações perderá tais marcas, prevalecendo tão somente uma única produção final, como se assim o fosse desde o seu esboço inicial.

As formas de armazenamento e conservação do escrito também se transformaram e tornar um texto elaborado no computador em um material impresso é algo que ocorre a depender do objetivo daquele que escreve, ao fim a que se destina o texto. A impressão é uma opção, contudo há outras formas de conservar o texto em arquivos digitais armazenados no próprio computador, em dispositivos móveis como o CD-Rom (disco compacto com memória somente para leitura) e o pen drive (dispositivo de armazenamento), o segundo mais usual na atualidade, sendo que já foi muito utilizado o disquete, que era um dispositivo móvel de conservação e armazenamento que foi ultrapassado por novas tecnologias para esse fim.

Ainda nessa perspectiva, o indivíduo que escreve pode ser ele mesmo o editor e impressor de seu próprio material, sem necessitar de profissionais especializados para toda e qualquer situação que desejar elaborar um material.

$\mathrm{O}$ advento do computador ocorre num momento em que a sociedade experiencia uma cultura audiovisual com o rádio, a televisão, a fotografia e o cinema. Dentre esses, a televisão ocupou e ocupa um lugar significativo na vida familiar e social servindo como meio de comunicação e entretenimento, de tal modo que se discute sobre a existência de uma oposição entre cultura escrita e televisiva. Para Viñao Frago (2010), a linguagem televisiva gera modos de pensar e de compreender a realidade opostas ao que se encontra em determinados tipos de leitura, ou seja, a televisão promove uma leitura superficial e extensiva da realidade, ao passo que a cultura tipográfica proporciona a leitura intensiva tendo como consequência a aprendizagem de modos de ler e escrever.

A difusão da internet no final do século XX e sua democratização no XXI, trouxe ainda mais transformações na cultura escrita, considerando que ela reforça as características do audiovisual por ter uma forma fragmentada de se apresentar pela tela do computador, não linear, com informações superficiais que mesclam textos, sons e imagens numa velocidade que implica mudança. Nesse suporte - isto é, a tela aliada ao dinamismo da rede de internet -, é o usuário leitor quem define a forma de ler o texto que, a depender do conteúdo, não mais necessita de linearidade. 
Viñao Frago (2010) afirma que a cultura escrita eletrônica e informatizada implica novos: suporte, espaço de leitura e relação do leitor com o escrito. O texto eletrônico revolucionou os suportes do escrito, a leitura e, também, as maneiras de escrever. Isso não significa que com o computador e a internet as formas anteriores de escrever foram extintas, pois no curso da história, algumas formas permanecem, outras deixam de existir ou são transformadas em novos modos de ler e escrever. No mesmo sentido, Chartier (2002) afirma que novas técnicas não eliminam antigos usos do escrito e que a era do texto eletrônico será, ainda, a era do manuscrito e do impresso.

Apesar das permanências em relação ao escrito, Chartier (2002), indica que o universo digital revolucionou a técnica de produção do escrito, as estruturas e formas mais fundamentais dos suportes da cultura escrita e a percepção das entidades textuais. Para o ele, o texto digital provocou rupturas na ordem dos discursos estabelecidos a partir da relação com diferentes objetos, categorias de textos e formas de leitura, na ordem das razões que são as modalidades de argumentação e critérios mobilizados pelo leitor na aceitação ou recusa, e na ordem das propriedades que fundamenta e define as características literárias dos textos.

Com estas considerações, ao se pesquisar as práticas da escrita importa conhecer, diante deste contexto onde modos coexistem, como os sujeitos realizam suas práticas da escrita e o motivo de suas escolhas. Assim, Viñao Frago indica:

[...] en lo que a la vídeo-escritura se refiere, la primera decisión a tomar por sus usuarios recae sobre qué es lo que se escribe a mano y qué es lo que se escribe con un ordenador [...]. La segunda decisión afecta a la necesidad o no de pasar lo escrito de la pantalla al papel impreso con más o menos frecuencia a fin de poder asir el texto en su globalidad y efectuar correcciones en el mismo. (2010, p.348 - 349).

Aos que escrevem na tela, segundo Viñao Frago (2010), o texto produzido em diversos dispositivos usados atualmente - tela de computadores, tablet, aparelho de celular - oferece dois perigos: o primeiro se refere ao excesso de textos produzidos e o segundo, em relação com a despreocupação, com o rigor da elaboração textual. Aliado à isso, vive-se um momento em que as pessoas não são apenas receptoras e leitoras da cultura escrita. $\mathrm{O}$ universo da rede de internet possibilitou a colaboração daqueles que são leitores, mas também facilitou o acesso a quem quer produzir um conteúdo por meio de sites, blogs e até páginas de redes sociais. Com essas novas possibilidades, escrever e publicar a própria opinião, sua história de vida, narrar fatos, entre outros, se tornou simples e não existe a figura do editor que qualifica o material para ser publicado, 
tampouco a do revisor para verificar possíveis erros na linguagem de quem escreve, isso considerando o âmbito das escritas ordinárias ampliadas com o advento da internet. Para Chartier (2002), o mundo da comunicação eletrônica tem "superabundância textual" que ultrapassa a capacidade que os leitores possuem de apropriação.

A partir dessas considerações do campo da cultura escrita no qual estão ancorados os autores aqui mencionados, reflete-se ser fundamental identificar quais os modos de escrever adotados pelos professores, em quais suportes realizam as escritas, com quais instrumentos e/ou dispositivos, que materialidades são produzidas a partir de tais práticas, que conteúdos apresentam os materiais e, por fim, que relações foram construídas com a cultura escrita na atualidade levando em conta as permanências e transformações do escrito na sociedade.

Tomando a perspectiva de prática de Roger Chartier (1990), a percepção do indivíduo em relação ao mundo social gera práticas e estratégias que são sociais, políticas e escolares, buscando a imposição de uma autoridade que possa justificar as escolhas realizadas. Assim, as representações do social estão em disputa e são importantes “[...] para compreender os mecanismos pelos quais um grupo impõe, ou tenta impor, a sua concepção do mundo social, os valores que são os seus, e o seu domínio" (p. 17) As representações podem ser articuladas em três aspectos em relação ao mundo social, pelo

[...] trabalho de classificação e de recorte que produz configurações intelectuais múltiplas pelas quais a realidade é contraditoriamente construída pelos diferentes grupos que compõem uma sociedade; em seguida, as práticas que visam a fazer reconhecer uma identidade social, a exibir uma maneira própria de ser no mundo, a significar simbolicamente um estatuto e uma posição; enfim, as formas institucionalizadas e objetivadas em virtude das quais "representantes" (instâncias coletivas ou indivíduos singulares) marcam de modo visível e perpétuo a existência do grupo, da comunidade ou da classe. (CHARTIER, 1999, p. 12).

A materialidade dos objetos culturais -suportes, meios de produção e circulaçãoé fundamental para a compreensão das práticas, porque para Chartier, a produção de sentido se dá incluindo os aspectos materiais que ordenam os textos, assim como a textualidade presente neles. Dessa forma, "[...] a significação do texto não pode ser dissociada da matéria que organiza a forma da sua percepção nas apropriações" (CARVALHO; HANSEN, 1996, p. 10).

Chartier (1999, p. 09) entende que as apropriações estão presentes nas práticas e objetivam "uma história social dos usos e das interpretações" que devem olhar "para as 
condições e os processos que, muito concretamente, sustentam as operações de produção do sentido" e que não estão dissociadas dos indivíduos que as realizam.

\subsection{Definindo os tipos de escrita: ordinária, popular, profissional, literária}

No campo de estudos da cultura escrita nos deparamos com alguns conceitos que definem a variedade de tipos de escrita, os quais são identificados considerando os indivíduos, a classe social a que pertencem e os usos que realizam. Assim, é fundamental explicitar os tipos de escrita e a compreensão de cada um no campo, a saber: escrita popular, escrita ordinária, escrita profissional ou institucionalizada e escrita literária.

De acordo com Castillo Gómez (2002), as escritas populares são assim chamadas por se tratar dos usos da escrita efetivados por pessoas oriundas das classes populares ou "subalternas". São indivíduos com pouca escolarização, que exercem trabalhos que não necessitam de formação acadêmica, geralmente pertencentes às classes baixa e médiabaixa, e que utilizam a escrita como uma atividade para comunicar e não como uma função. Compartilham uma proximidade social e estão na condição de dominados em relação ao controle dos meios de produção, ou seja, são trabalhadores operários, da indústria ou mesmo das atividades informais da sociedade, entre outras. De fato, não são profissionais da escrita, mas sim indivíduos “[...] que se aproximan al mundo de lo escrito por otras razones estrictamente personales" (p. 25).

Em relação aos tipos de textos produzidos por este grupo estão as cartas, os diários, cadernos de registros variados como de viagem, de contas etc., livros de família e de memórias, cadernos da escola e canções populares. O conteúdo desses materiais é muito variado e depende de cada situação de produção. A linguagem utilizada se aproxima mais da língua falada, tendo pouca ou nenhuma preocupação com as normas da língua escrita, porém quando se estuda este tipo de material, a atenção se volta para o que desejam expressar esses indivíduos e os fins para os quais utilizam o escrito, pois já é sabido que possuem uma competência gráfica parcial. Para Castillo Gómez, esses indivíduos

[...] Evidencian una necesidad de escribir que rompe las coordinadas diseñadas para interpretar otras actividades más institucionales o letradas. Sus autores se mueven en una franja imprecisa entre la oralidad y la escritura, entre el alfabetismo y el semialfabetismo, es 
decir, en ese punto en el que se verifica el primer contacto con el escrito y sus complejidades, reglas, límites y misterios; pero teniendo claro que esto no significa que debamos considerar dichos textos como una simple transposición de lo hablado [...]. (2002, p. 27).

Segundo Castillo Gómez (2002), a escrita ordinária se caracteriza pela apropriação e uso da competência gráfica, ou seja, do conhecimento da escrita, fora dos âmbitos institucionalizados como a escola que a ensina ou os espaços nos quais esta se faz necessária aos profissionais, como em um cartório, por exemplo, porque nesses ambientes a produção escrita é controlada e limitada às práticas e formas definidas pelas instituições. Portanto, para o autor, “[...] Conviene recordar que escrituras ordinarias son igualmente los diarios, agendas, cuadernos y epistolarios de qualquier aristócrata, y, obviamente, a nadie se le ocurriría considerar a dichas personas como exponentes de las clases subalternas [...]” (CASTILLO GÓMEZ, 2002, p. 24). Desse modo, a diferença existente entre a escrita ordinária e a popular reside no conhecimento da língua escrita pelo sujeito que a pratica e não na tipologia dos textos produzidos.

Castillo Gómez atenta para a riqueza de detalhes presente nas escritas ordinárias consideradas pessoais e autobiográficas:

[...] En el campo de las ordinarias, las personales y autobiográficas representan verdaderos actos de memoria, desencadenados, en general, por la intensidad de las experiencias vividas y por la voluntad de no arrojarlas al silencio: es el caso de los epistolarios y diarios escritos desde y en el frente, en una cárcel, durante el exilio o desde la emigración. (2002, p. 37).

Agora, os escritos populares considerados memórias possuem característica híbrida, pois apresentam uma mescla de anotações de contas, informações sobre a vida pessoal e familiar, assim como acontecimentos vividos.

A escrita profissional se caracteriza pela especificidade de variadas profissões que necessitam de uma linguagem específica própria da área, atendimento a normas e formas características para a produção de documentos escritos, atendimento a determinados requisitos quanto ao conteúdo do texto, ou seja, é uma produção com limites e padrões definidos pela instituição à qual representa.

A profissão de professor, neste sentido, exige a realização de uma escrita profissional utilizando a linguagem pedagógica, característica da área educacional. Sendo assim, são variados os documentos que o professor escreve e depende também da modalidade de ensino em que atua, por exemplo, um documento comum a todos os professores da educação básica é a produção do diário de classe, que é um documento de 
registro no qual os professores registram a frequência dos estudantes, os conteúdos ensinados, a forma de avaliação, o resultado das avaliações realizadas, assim como outras informações que julgarem ser importante para o conhecimento da equipe gestora da escola. O diário de classe se constitui em um documento da instituição de ensino, devendo permanecer nesta e a sua produção ocorre no mesmo espaço, sendo limitado em relação à sua forma de produção que deve seguir um padrão adotado pela rede de ensino, um único diário deve conter todo o registro de um ano letivo completo de uma determinada turma de estudantes, ou seja, o espaço para a descrição também é reduzido e deve se apresentar uma descrição concisa. Além disso, este é um documento que a equipe gestora acompanha, isto é, analisa a cada determinado período se a escrita do mesmo vem ocorrendo seguindo as orientações dadas e, caso haja algum desvio da norma, o professor deve refazê-lo.

Diferentemente do diário de classe, em algumas etapas da educação básica, como no ensino fundamental I, por exemplo, os professores são orientados a produzir cadernos de registro das aulas. Este tipo de escrita profissional se caracteriza pela construção de uma descrição do cotidiano das aulas com o objetivo de acompanhar o trabalho desenvolvido com os estudantes. Sendo assim, a elaboração do caderno precisa abarcar aspectos da aula que possibilite ver o conteúdo curricular, a metodologia de ensino adotada, os materiais utilizados, a forma de avaliação, entre outros. A reflexão é parte constituinte deste tipo de caderno e da prática profissional docente, mas nem sempre é uma obrigatoriedade que conste no registro. Assim, como o diário de classe, os cadernos são lidos pela coordenadora pedagógica das escolas que, em geral, acompanha com mais proximidade o trabalho docente. O que o diferencia do documento anterior é que os cadernos são de propriedade dos professores, constituem uma demanda institucional, mas a partir de uma perspectiva teórica sobre a necessidade de se registrar com mais detalhes o cotidiano escolar e refletir a partir dele, assim, os cadernos ficam com os professores durante todo o ano letivo e quando este finaliza, não são arquivados na escola, são dos professores.

Nesse sentido, Zabalza (1994) afirma que o fato de o diário atender a uma solicitação que objetive a avaliação do professor, pode afetar a sua produção, ou seja, nem todo o registro pode ser fidedigno, pode ocorrer situações no ambiente escolar que o professor decida ocultar do diário.

Por fim, a escrita literária é um tipo de escrita que exige o conhecimento da norma culta da língua, assim como das formas e características empregadas em cada gênero 
literário. A produção da escrita literária não é descritiva da realidade, é uma construção ficcional que pode partir da realidade de quem o produz e, desse ponto de vista, tem maior liberdade na criação do sentido do texto e na adoção de linguagem estética e não prescritiva. No ponto que segue trataremos mais especificamente da literatura e das características de sua produção.

\subsection{Literatura: algumas definições}

Neste ponto discutiremos a noção de literatura que adotamos para considerar os materiais produzidos pelos professores em diferentes circunstâncias como textos literários, para isso, nos valeremos principalmente das reflexões de Antonio Candido e Pierre Bourdieu.

De início, consideramos fundamental trazer uma discussão de Antonio Candido (2004) sobre o direito à literatura como um direito fundamental ao indivíduo, assim como a alimentação, a moradia, a educação, entre outros. Essa reflexão surge como uma proposta confiada ao autor para escrever sobre direitos humanos e literatura. Candido nos conduz a pensar que aquilo que é indispensável a nós, também o é para o outro e, dessa forma, questiona quais são os bens incompressíveis, ou seja, aqueles "que não podem ser negados a ninguém" (2004, p.173) e cita os que obviamente são assim considerados como a comida, a roupa, a moradia, no entanto, o que é considerado indispensável ao indivíduo se altera de acordo com a época e a sociedade, e está relacionado à divisão social em classes. Nesse sentido, o autor questiona se os indivíduos de classe mais privilegiada pensam no direito que as classes mais baixas teriam de ler um clássico da literatura como Dostoiévski e, com isso, afirma que:

[...] são bens incompressíveis não apenas os que asseguram a sobrevivência física em níveis decentes, mas os que garantem a integridade espiritual. São incompressíveis certamente a alimentação, a moradia, o vestuário, a instrução, a saúde, a liberdade individual, o amparo da justiça pública, a resistência à opressão etc.; e também o direito à crença, à opinião, ao lazer e, por que não, à arte e à literatura. (2004, p. 174).

Considerando a literatura de modo amplo, Candido afirma que o indivíduo não passa um dia sequer, seja em sonho ou em vigília, sem momentos de "fabulação", porque este universo está presente no cotidiano da vida em sociedade em diversas modalidades e níveis como nas canções, nas novelas, nos noticiários, nas histórias contadas, entre 
outras formas, todas possuem alguma espécie de criação, de fabulação. Desse modo, o autor chama de literatura: “[...] todas as criações de toque poético, ficcional ou dramático em todos os níveis de uma sociedade, em todos os tipos de cultura, desde o que chamamos folclore, lenda, chiste, até as formas mais complexas e difíceis da produção escrita das grandes civilizações" (CANDIDO, 2004, p. 174). Deste ponto de vista, a literatura é uma necessidade e, portanto, um direito, sendo que cada sociedade elabora as suas manifestações literárias de acordo com as suas necessidades, convicções e normas. Assim, para Candido, nas sociedades

[...] a literatura tem sido um instrumento poderoso de instrução e educação, entrando nos currículos, sendo proposta a cada um como equipamento intelectual e afetivo. Os valores que a sociedade preconiza, ou os que considera prejudiciais, estão presentes nas diversas manifestações da ficção, da poesia e da ação dramática. A literatura confirma e nega, propõe e denuncia, apoia e combate, fornecendo a possibilidade de vivermos dialeticamente os problemas. Por isso é indispensável tanto a literatura sancionada quanto a literatura proscrita; a que os poderes sugerem e a que nasce dos movimentos de negação do estado de coisas predominante. (2004, p. 175).

A literatura além de ser um instrumento de formação, tem uma função humanizadora que se caracteriza pela elaboração de uma estrutura pelo escritor que, ao organizar a palavra de um modo coerente, possibilita que organizemos os nossos pensamentos e sentimentos. De acordo com Candido, “[...] A produção literária tira as palavras do nada e as dispõe como todo articulado. Este é o primeiro nível humanizador, ao contrário do que geralmente se pensa. A organização da palavra comunica-se ao nosso espírito e o leva, primeiro, a se organizar; em seguida, a organizar o mundo [...]” (2004, p. 177).

Embasando-nos nas reflexões de Candido, compreendemos que a literatura exige um trabalho com a linguagem, numa ordenação da palavra (matéria) para formar uma estrutura coerente, além disso, esse trabalho desenvolvido pelo escritor tem uma perspectiva estética, sensível. Bourdieu (1996) ao analisar A educação Sentimental de Flaubert, faz uma diferenciação entre a escrita literária e científica:

Não há melhor atestado de tudo que separa a escrita literária da escrita científica do que essa capacidade, que ela possui exclusivamente, de concentrar e de condensar na singularidade concreta de uma figura sensível e de uma aventura individual, funcionando ao mesmo tempo como metáfora e metonímia, toda a complexidade de uma estrutura e de uma história que a análise científica precisa desdobrar e estender laboriosamente [...] (p. 39). 
O que Bourdieu aponta, no excerto acima, que caracteriza a escrita literária é a perspectiva sensível e o trabalho com a linguagem a partir de uma estrutura para narrar uma história. No caso da obra de Flaubert analisada por Bourdieu, existe uma complexidade e densidade características deste autor, no entanto, os textos literários têm diferentes níveis de complexidade e densidade e, de acordo com a qualidade que apresentam, são consideradas obras de maior ou menor valor no campo literário.

Segundo Candido, todas as obras compõem o movimento literário, independente do seu valor, como afirma:

Isso não quer dizer que só serve a obra perfeita. A obra de menor qualidade também atua, e em geral um movimento literário é constituído por textos de qualidade alta e textos de qualidade modesta, formando no conjunto uma massa de significados que influi em nosso conhecimento e nos nossos sentimentos. (2004, p. 182).

Terry Eagleton (1983) em uma discussão da teoria literária indica alguns possíveis sentidos atribuídos à literatura: a escrita ficcional, imaginada, sem compromisso com a veracidade de fatos reais; outra definição se dá através do uso da "linguagem de forma peculiar" distanciando-a da linguagem utilizada no cotidiano; como um "discurso não pragmático" que visa mais o modo de falar do que a realidade da qual trata; e que a definição de literatura pode ser dada por quem lê e não pela origem do texto, pois nem todo texto considerado literatura foi considerado como tal por quem o escreveu. Deste ponto, o autor afirma que não há uma definição objetiva e fixa para o que é literatura, mas que esta depende dos valores e crenças considerados por determinadas sociedades:

[...] os juízos de valor que a constituem são historicamente variáveis, mas que esses juízos têm, eles próprios, uma estreita relação com as ideologias sociais. Eles se referem, em última análise, não apenas ao gosto particular, mas aos pressupostos pelos quais certos grupos sociais exercem e mantêm o poder sobre outros [...]. (EAGLETON, 1983, p. 17).

Um outro autor do campo da teoria literária que aborda as compreensões sobre literatura, Jonathan Culler (1999), afirma que textos literários e não-literários podem ser estudados de maneiras semelhantes, pois as obras teóricas apresentam de modo análogo elementos em seus discursos que são literários, mesmo não sendo uma obra literária. Um exemplo citado pelo autor é o discurso histórico que se vale da narrativa literária para compor os fatos e descrever determinado período do passado. Para o autor, os textos literários são mais amplos que os informativos, e importam aos leitores não pela 
informação, mas sim pela "narratividade" que possuem na maneira de comunicar, de contar uma história. Nesse sentido, o que diferencia os textos literários dos não-literários é o contexto que os identifica como literatura e o tipo de atenção que provoca no leitor, uma vez que um texto literário não exige uma compreensão imediata assim como outros tipos de textos.

Esse contexto apontado por Culler (1999) é similar às instâncias que avaliam os textos e colocam um valor nas obras - o que Bourdieu (1996) chama de instâncias de legitimação. Portanto, para que uma obra seja reconhecida como literária no campo, esta deve ser analisada por profissionais especializados que lhe atribuirão um valor tendo em vista sua qualidade. Assim, Culler indica algumas formas de legitimar uma obra:

[...] O que diferencia as obras literárias dos outros textos de demonstração narrativa é que eles passaram por um processo de seleção: foram publicados, resenhados e reimpressos, para que os leitores se aproximassem deles com a certeza de que outros os haviam considerado bem construídos e "de valor" [...]. A "Literatura" é uma etiqueta institucional que nos dá motivo para esperar que os resultados de nossos esforços de leitura "valham a pena". E muitos dos traços da literatura advêm da disposição dos leitores de prestar atenção, de explorar incertezas e não perguntar de imediato "o que você quer dizer com isso?". (CULLER, 1999, p. 33).

A obra de arte, assim como a literária, define-se por meio de instâncias de legitimação que elaboram os critérios que determinam o que é ou não considerado uma obra de arte. Essas instâncias constituem o campo no qual as obras são ou não legitimadas, neste caso, tratamos de campo literário, e este para se constituir como tal precisa dos agentes em ação que vão estabelecer as regras determinantes do campo. Os agentes são indivíduos especializados em determinado aspecto da arte e, com o seu trabalho de análise das obras, afirmam se uma obra pertence ou não ao campo. Para que isso ocorra, a obra deve expressar qualidade. No âmbito literário, os agentes que constituem o campo são os críticos, os editores, os avaliadores de prêmios de literatura, entre outros. Para Bourdieu (1996), a existência da instituição não está somente nas coisas, mas também nos cérebros dos indivíduos, como afirma:

[...] Nas coisas, sob a forma de um campo artístico, universo social relativamente autônomo que é o produto de um lento processo de emergência; nos cérebros, sob a forma de disposições que se inventaram no próprio movimento pelo qual se inventava o campo a que estão ajustadas [...]. (BOURDIEU, 1996, p. 323). 
Dessa forma, para que a obra de arte seja constituída de sentido e de valor, segundo Bourdieu (1996), é preciso uma relação entre o "habitus cultivado e o campo artístico", pois para que exista a obra de arte se faz necessário indivíduos com disposições suficientes para apreendê-la. As instituições, que são as instâncias de legitimação do campo, é que definem o valor atribuído ao artista/ao escritor e aos produtos oriundos de sua arte. Tais instituições, de acordo com Bourdieu (1996), são os espaços de exposição, como museus; Prêmios como o Nobel e as Academias de Letras e de Artes são instâncias de consagração; as instâncias de reprodução são as escolas de artes, por exemplo; e os agentes especializados são os críticos, colecionadores etc. que possuem as disposições necessárias para apreciar e perceber as obras. O campo não define somente o valor da obra e do artista, uma vez que também elabora as regras para o seu funcionamento construindo uma linguagem específica que considera o modo de falar do artista e da obra, bem como trata da remuneração do trabalho artístico e a maneira de nomear o profissional artista. O artista é também uma construção do campo, ou seja, é um produto dessas instâncias que outorgam valor à obra e ao seu criador, como afirma Bourdieu (1996):

Não vêem que a interrogação ritual sobre o lugar e o momento do aparecimento da personagem do artista (oposto ao artesão) reduz-se de fato à questão das condições econômicas e sociais da constituição progressiva de um campo artístico capaz de fundar a crença nos poderes quase mágicos que são reconhecidos no artista. (p. 325 - 326).

Portanto, o que Bourdieu (1996) nos mostra é que existem mecanismos sociais nos quais tanto se produz a ideia de artista como criador de uma obra de arte quanto se constitui o campo artístico. Sendo este o espaço de produção do valor do artista e da sua obra, é nesse espaço também onde se mantém a crença desse valor. Considerando que o campo artístico é responsável pelo valor atribuído às obras e aos artistas, este possui forças em seu interior que determinam as medidas de cada um e, por isso, o artista não tem autonomia absoluta, assim como o campo não se apresenta plenamente autônomo, pois funciona de acordo com as exigências impostas. Dessa forma, existem vários responsáveis pela elaboração do valor do artista e da obra, assim como pela desvalorização de outros, situação essa que coloca em luta no campo os produtores da arte e suas criações, como afirma o autor:

Assim, à medida que o campo se constitui como tal, a produção da obra de arte, de seu valor, mas também de seu sentido, reduz-se cada vez menos exclusivamente ao trabalho de um artista que, paradoxalmente, concentra cada vez mais os olhares; ela põe em jogo todos os produtores de obras classificadas como artísticas, grandes ou pequenas, célebres, ou seja celebradas, ou desconhecidas, os críticos, eles próprios 
constituídos em campo, os colecionadores, os intermediários, os conservadores, em suma, todos aqueles que têm ligação com a arte e, vivendo para a arte e da arte, opõem-se em lutas de concorrência que têm como aposta a definição do sentido e do valor da obra de arte, portanto, a delimitação do mundo da arte e dos (verdadeiros) artistas, e colaboram, por essas próprias lutas, na produção do valor da arte e do artista. (BOURDIEU, 1996, p. 330).

Culler (1999) corrobora com essa discussão quando afirma que a literatura é uma “instituição paradoxal”, porque para criá-la se faz necessário atender às normas, no entanto, também transcendê-las, e em relação ao sentido, a literatura pode ser a maneira de apresentar uma ideologia e o meio de contestá-la.

Dessa forma, a literatura não tem um fim específico, tampouco fixo, ela pode ser criada para afirmar, para criticar ou para contestar algo, sendo importante pontuar que a escrita literária não tem compromisso com a realidade, é um tipo de produção que apresenta diferentes níveis de relação com o real, podendo se caracterizar por um nível maior ou menor de proximidade com o real.

Apesar do distanciamento que mantém com a realidade, a obra é sempre construída a partir de uma realidade social onde se posiciona o artista/ o escritor, ou seja, mesmo produzindo um texto ficcional, o escritor parte de uma realidade dada, a dele, e apresenta em sua obra a percepção que tem do universo social em que está inserido. É, então, nesse sentido que Bourdieu afirma: “[...] O verdadeiro assunto da obra de arte não é nada mais que a maneira propriamente artística de apreender o mundo, isto é, o próprio artista, sua maneira e seu estilo, marcas infalíveis do domínio que tem de sua arte. [...]" (BOURDIEU, 1996, p. 334)

Antonio Candido (1965) em sua obra Literatura e Sociedade afirma que o escritor exerce uma função social, tem uma posição diante do seu grupo e atende as expectativas dos seus receptores (leitores). Para o autor, a obra depende parcialmente da relação do escritor com o meio no qual está inserido. "[...]A matéria e a forma da sua obra dependerão em parte da tensão entre as veleidades profundas e a consonância ao meio, caracterizando um diálogo mais ou menos vivo entre criador e público." (CANDIDO, 1965, p. 88).

Assim, a literatura necessita de um público com o qual as obras agem, além de agirem umas sobre as outras, mantendo-se vivas pela interação entre o autor, obra e público gerando sentidos diversos para o que é lido e interpretado, isto é, o público leitor não é passivo em relação à obra literária, nem as leituras produzem apenas um sentido. 
De acordo com Candido, "A literatura é, pois, um sistema vivo de obras, agindo umas sôbre as outras e sôbre os leitores [...]" (1965, p. 88).

O público leitor não se constitui como um grupo coeso, diferentes indivíduos interessados em um tema ou autor ou, ainda, uma história é que vão formar o público de determinada obra. Candido (1965) afirma que esse público se configura a partir dos meios de comunicação, pela opinião literária e pelas elites que definem o gosto ${ }^{30}$. Desse modo, para que o escritor tenha a sua posição reconhecida, este depende que o público aceite a sua obra e, nesse sentido, acreditamos que se inclui nesse público o leitor especializado.

\subsection{Literatura Marginal e Periférica}

Discutiremos neste momento a concepção das expressões "literatura marginal" e "literatura periférica" para ampliar a compreensão do contexto no qual acontecem os saraus na cidade de São Paulo e onde identificamos alguns dos professores escritores participantes da pesquisa.

"Literatura marginal” é um termo usado para nomear as produções literárias que se encontravam à margem do campo literário (Bourdieu, 1996) estabelecido e do mercado editorial e, também, os escritores que estavam em condição de marginalidade em relação a determinado aspecto da sociedade e, ainda, as obras que não cumpriam os requisitos estéticos literários.

Os “poetas e escritores marginais" do período da ditadura, nos anos 60 e 70, assim foram chamados por produzirem um material literário não institucionalizado, subversivo para a época e que poderia criticar de forma direta ou indireta o governo ou, ainda, como críticos das regras editoriais e, por isso, essa produção literária circulava fora do mercado editorial, com os próprios autores produzindo diferentes cópias de seus textos e distribuindo-os pela cidade. Segundo Mei Hua Soares (2008), o termo "marginal" surgiu

\footnotetext{
${ }^{30}$ Setton (2009) afirma, a partir dos estudos de Bourdieu, que o gosto considerado legítimo é aquele mais próximo aos grupos dominantes na sociedade e o gosto considerado ilegítimo é mais próximo das classes populares. De acordo com a autora, "Na luta pela produção de uma visão legítima de um gosto, pela imposição de uma concepção estética ou de uma opção a outra prática de cultura, o que se verifica também é uma disputa pela autoridade de um poder simbólico no mundo social” (SETTON, 2009, p. 84).
} 
a partir da resistência cultural de grupos artísticos dessa época, sendo que na literatura havia um grupo de concretistas nomeados de "escritores da geração mimeógrafo"31.

Uma narrativa que foi considerada como marginal, respeitando o fato de a autora não ser uma pessoa letrada, ou seja, não possuir escolarização, viver nas bordas da cidade, na favela do Canindé em São Paulo, e escrever sobre sua condição de excluída socialmente é a da Carolina Maria de Jesus, com a publicação do seu diário intitulado Quarto de despejo: o diário de uma favelada ${ }^{32}$.

Diferentemente dos "poetas e escritores marginais" da época ditatorial, a "literatura marginal" passa por uma ressignificação a partir dos anos 90, período em que é possível identificar de acordo com Lucía Tennina “[...] uma coincidente articulação de práticas vinculadas à cultura escrita por parte de uma série de jovens de trajetória não letrada, habitantes de diversas regiões da chamada "periferia” de São Paulo" (2017, p. 24). Nas publicações dos jovens, já se evidenciava a presença dos elementos dos bairros em que viviam, como uma espécie de vinculação com a origem social. É nesse contexto que, em 1988, Sérgio Vaz, morador de um bairro na região de Santo Amaro, publica Subindo a ladeira mora a noite junto com Adriane Mucciolo, de maneira independente. Pouco tempo depois, Sérgio Vaz publica A margem do vento (1991) com a colaboração da empresa em que trabalhava e realizando ele mesmo a divulgação e venda da obra; já em 1994, consegue publicar Pensamentos vadios também com o apoio de uma empresa.

No mesmo período, Reginaldo Ferreira da Silva, o Ferréz, era um jovem que vivia no Capão Redondo, bairro no extremo sul de São Paulo, escritor, que em 1997 conseguiu publicar seu primeiro livro de modo independente, Fortaleza da desilusão - que reunia poesias de sua autoria. Com a publicação do romance Capão pecado, em 2000, pela editora Labortexto, Ferréz busca maior distribuição de sua obra e a legitimação de seu lugar de autor, de acordo com Tennina (2017). Tendo alcançado reconhecimento no

\footnotetext{
31 "Os escritores da "geração mimeógrafo" ficaram conhecidos por veicularem seus textos mediante cópias mimeografadas e vendidas em portas de bares e restaurantes. Recusavam a divulgação mercadológica formal, mas também viam suas obras rechaçadas pelo próprio mercado, uma vez que os poemas, contos e romances que escreviam eram considerados de teor subversivo ou não passavam pelo critério de qualidade literária dos editores" (SOARES, 2008, p. 86).

${ }^{32}$ A obra Quarto de despejo foi escrita por Carolina em cadernos e folhas recolhidas do lixo por ela, que era catadora de materiais para reciclagem, seu meio de subsistência, e em tais ela contava a sua rotina na favela do Canindé como uma mulher sem trabalho formal, mãe solteira e tendo que sustentar seus três filhos. Seus escritos se tornaram livro com a colaboração do jornalista Audálio Dantas que conheceu Carolina durante uma reportagem na favela e depois de ler os cadernos decidiu buscar recursos para viabilizar a publicação dos mesmos. O livro foi lançado em 1960 e logo o conteúdo repercutiu na imprensa, assim como questionamentos sobre a autoria do material dada a escolarização incompleta da autora.
} 
campo com tal publicação, Ferréz foi convidado a contribuir com a revista Caros Amigos que era produzida pela editora Casa Amarela desde 1997.

É na Caros Amigos que, em 2001, Ferréz desenvolve uma edição especial da revista com textos de escritores independentes de regiões distantes de São Paulo e dois cariocas moradores da favela Cidade de Deus (Edson Veóca e Paulo Lins). A essa publicação, deu o nome de Literatura Marginal. A cultura da periferia. Segundo Tennina, "Tanto os críticos literários como os próprios escritores coincidem em apontar esses números especiais da revista Caros Amigos como o início de uma nova fase em relação à literatura dos setores de trajetória não letrada" (2017, p. 27).

Outro escritor que aparece nesse cenário é o Binho Padial, também pertencente à zona sul, e que decide escrever suas poesias nos versos de cartazes publicitários de campanhas políticas que encontrava nos postes na região do Campo Limpo, nomeando essa intervenção de Postesia. Depois de escrever suas poesias nos versos dos cartazes, Binho colocava-os de volta nos postes escondendo as propagandas políticas.

Esses três escritores que circulavam pela zona sul de São Paulo divulgando e vendendo seus materiais, a partir da circulação de suas obras e do reconhecimento que foram adquirindo, mostraram um movimento cultural que estava crescendo nas regiões distantes da cidade.

Ferréz teve uma importante atuação quando idealizou as edições especiais da revista Caros Amigos sobre literatura marginal, pois como afirma Tennina, tais edições “[...] visibilizaram naquele momento uma cena literária dispersa e desconhecida inclusive dos próprios colaboradores, dando-lhe um nome que permitia identificá-la" (2017, p. 28). As edições sobre literatura marginal foram organizadas em três atos, Ato I (2001), Ato II (2002) e Ato III (2004) trazendo um manifesto na abertura, com o objetivo de caracterizar o que estava sendo chamado de literatura marginal. No manifesto da primeira edição, Ferréz explicita algumas das características dessa literatura: "A Caros Amigos Literatura Marginal vem para representar a cultura autêntica de um povo composto de minorias, mas em seu todo maioria. E temos muito a proteger e a mostrar, temos nosso próprio vocabulário que é muito precioso [...]” (CAROS AMIGOS, Literatura marginal. A cultura da periferia. Ato I, 2001, p. 03).

Tennina (2017), ao estudar o movimento de saraus em São Paulo, pontua que essa "literatura marginal", ressignificada por essas pessoas, apresenta uma originalidade característica de um escritor que vive a realidade da periferia, não é um escritor observador de um contexto social, mas, antes, um sujeito, um agente deste contexto, de 
modo que "[...] A proposta desse grupo de escritores passa pela elaboração de uma estética das favelas diferente daquela que foi se afirmando nas formulações imagéticodiscursivas dos espaços de consenso [...]" (TENNINA, 2017, p. 29).

No mesmo período em que Ferréz organizava a primeira edição da revista, Sérgio Vaz criava o Sarau da Cooperifa ${ }^{33}$, em 2001, se tornando mais tarde uma referência e o mais conhecido sarau da cidade.

O termo "literatura periférica" foi cunhado por Allan da Rosa quando publicou seu primeiro livro de poesias, em 2005, chamado Vão pela Edições Toró. Na mesma ocasião do lançamento do livro, Allan da Rosa organizou em parceria com a ONG Ação Educativa o Primeiro Encontro de Literatura Periférica, fato que marcou o surgimento do termo. Para Lucía Tennina (2017), o uso do termo "periférica” tem relação com um “espaço determinado" que são as periferias das metrópoles, além de conter os elementos da "literatura marginal", dessa forma, a autora afirma:

\begin{abstract}
A literatura marginal da periferia ${ }^{34}$ não é um conjunto homogêneo do qual se pode derivar uma representação unitária, mas sim algo que se define a partir de sua mobilidade como um processo performativo de posicionamento do sujeito que escreve em relação à certa ideia de "marginalidade" a partir da qual toma a palavra em determinado espaço, momento, série literária ou circunstância. (TENNINA, 2017, p. 33).
\end{abstract}

No artigo elaborado por Antonio Leite sobre a literatura periférica em São Paulo ${ }^{35}$, o autor apresenta dois contextos que caracterizam o uso dos termos "literatura marginal" e "literatura periférica", sendo o primeiro uma influência do movimento Hip Hop a partir da década de 90 e o segundo uma relação estreita com os saraus que surgem nos bairros distantes da cidade, como afirma:

\begin{abstract}
A literatura de Ferréz, bem como a escrita de muitos dos autores por ele lançados, filia-se esteticamente ao movimento hip hop, tendo no RAP uma influência fundamental, remetendo assim as origens da literatura periférica à década de 1990 onde o Movimento Hip Hop se consolidou impulsionado pelo sucesso do grupo Racionais MC's. Esse período liderado por Ferréz é chamado de Literatura Marginal, pois assim, ele o denominou, imprimindo esta marca aos produtos literários que empreendeu. Já a produção literária vinculada aos saraus expande o arco de influências, incorporando uma escrita vinculada à negritude (algo presente no Rap também), à música popular brasileira, aos cânones da literatura brasileira, além do próprio Hip Hop, adensando uma produção literária que adquiriu forma de livro a partir de diversas
\end{abstract}

\footnotetext{
${ }^{33}$ Optamos por não detalhar as características do Sarau da Cooperifa neste momento, pois trataremos deste sarau mais adiante.

${ }^{34}$ Lucía Tennina adota em sua pesquisa o termo "literatura marginal da periferia".

35 Artigo Marcos Fundamentais da Literatura Periférica em São Paulo publicado na Revista de Estudos Culturais 1, Dossiê sobre Cultura Popular Urbana.
} 
coletâneas publicadas com o apoio de editais públicos, notadamente do Valorização de Iniciativas Culturais (VAI) [...]. Esse período é marcado pela emergência do termo Literatura Periférica. (LEITE, [s./d.], p. 05).

Lucía Tennina (2017) aponta que a opção em adotar um ou outro termo entre os acadêmicos não é um consenso e cita que Paulo Roberto Tonani do Patrocínio prefere usar "literatura marginal" considerando que estes escritores escrevem sobre o que está à margem. Outro exemplo é Heloisa Buarque de Hollanda que sugere o uso de "Literatura Hip-Hop" considerando a relação que estas produções escritas possuem com o movimento Hip Hop. Alejandro Reyes, por seu turno, prefere "Literatura Periférica" por entender que os autores são originários de populações marginalizadas. Assim, Tennina adotou em seu estudo a forma de "literatura marginal da periferia" por compreender que essa forma "[...] dá conta da marginalidade no campo literário dessas produções e de sua relação com um território e uma origem social determinada” (TENNINA, 2017, p. 33).

Ao estudar as obras de quatro escritore ${ }^{36}$ oriundos de periferias da cidade de São Paulo que conseguiram reconhecimento por meio da publicação de seus textos, Mei Hua Soares compreende que esse tipo de produção escrita não se elabora apenas por sujeitos que estão nas margens da cultura letrada e do processo de escolarização, realizando-se, também, por quem adentrou o universo letrado e acadêmico, como afirma no trecho que segue:

Considerando estas informações, podemos depreender que a posição social dos autores, o lugar que lhes cabe, não se encontra integralmente às margens de uma cultura dominante, na medida em que dos quatro, três apropriaram-se do saber acadêmico e todos desenvolvem atividades formais não sem prestígio dentro da sociedade; embora ainda moradores da periferia, já foram em grande parte aceitos em seus papéis sociais. Ainda assim, suas obras permanecem fiéis à vertente marginalperiférica, o que ratifica a idéia de que se trata também de um projeto estético e não de obra produzida para denunciar uma condição de vida apenas. Oriundos de periferia e, mesmo inserindo-se nos meios legitimados de poder cultural (academias, escolas, mídia, mercado editorial), ao continuarem se reportando às comunidades de origem e escrevendo em meio a elas e para elas - e não somente delas ou em nome delas - constituem um movimento literário de valor sóciocultural relevante. (SOARES, 2008, p. $99-100$ ).

Assim, como aponta Soares (2008) sobre os escritores estudados por ela, alguns professores identificados nesta pesquisa por meio dos saraus se vinculam a esse

\footnotetext{
36 Mei Hua Soares (2008) estudou as seguintes obras: Capão Pecado do Ferréz, Graduado em
} marginalidade do Sacolinha, Vão de Allan da Rosa e Te pego lá fora do Rodrigo Ciríaco. 
movimento da literatura periférica, escrevendo sobre e para a periferia de modo independente, tendo formação escolar e acadêmica, além de estarem inseridos profissionalmente no magistério. 


\section{VALEU, PROFESSOR: UM CONCURSO LITERÁRIO PARA PROFESSORES}

Neste capítulo será apresentado o Concurso Literário Valeu, Professor considerando o seu contexto de criação no âmbito da Secretaria Municipal de EducaçãoSME, a periodicidade e forma de organização do mesmo, os dados dos professores participantes que puderam ser levantados a partir das fichas de inscrição e que apresentam informações substanciais para uma primeira leitura sobre as escritas produzidas por eles, um esquadrinhamento dos textos inscritos no concurso e que não foram publicados, e uma descrição dos livros, das antologias nas quais estão os textos selecionados nas respectivas edições do concurso literário. Para isso, utilizaremos como fontes documentais os três livros publicados com textos vencedores, textos inscritos no concurso e que não foram selecionados para a publicação, fichas de inscrição, documentos da comissão organizadora, documentos publicados no Diário Oficial da cidade de São Paulo nos respectivos anos e os recolhidos no arquivo da Memória Técnica Documental que incluem o Nossa Escola - Boletim oficial da Secretaria Municipal de Educação de São Paulo e outros documentos da SME sobre o concurso.

\subsection{Contexto de criação do concurso literário}

Tomando como fontes os materiais do Concurso Literário Valeu, Professor, fazse necessário reconstruir a história deste concurso literário realizado pela Secretaria Municipal de Educação de São Paulo, para professores da educação básica da rede de ensino nos anos de 2010, 2011 e 2012, com o intuito de compreender em qual contexto educacional as escritas foram fomentadas e apresentadas ao concurso.

O Concurso Literário Valeu, Professor se constitui como uma fonte para a pesquisa por apresentar e ser um espaço de uma prática da escrita realizada por 
professores, neste caso, a escrita literária. Sabemos que esta não é uma prática livre da escrita, pois está condicionada às regras de um concurso e, também, porque existe a intencionalidade de quem promove tal ação e realiza um julgamento sobre a totalidade dos materiais apresentados gerando a eleição de alguns e a exclusão de outros. Desse modo, para compreender a história do concurso literário é necessário contextualizá-lo no âmbito da Secretaria Municipal de Educação e das ações que esta vinha realizando para os professores no âmbito da gestão da rede de ensino.

No início de 2009, inicia-se na Prefeitura de São Paulo a segunda gestão do prefeito eleito Gilberto Kassab. Com ele, continua na gestão da Secretaria Municipal de Educação o Alexandre Alves Schneider que assumiu a SME em 2006 e nela permaneceu até 2012, quando pediu exoneração do cargo para candidatar-se a vice-prefeito de José Serra nas eleições municipais do mesmo ano. Alexandre Schneider formou-se em Administração de Empresas e Mestrado em Administração Pública e Governo ambos pela Fundação Getúlio Vargas. Antes de atuar na SME ocupou o cargo de Secretário Adjunto de Governo na Prefeitura de São Paulo durante os anos de 2005 e parcialmente em $2006^{37}$.

Em 2005, na primeira gestão de Gilberto Kassab, o Secretário de Educação era José Aristodemo Pinotti, e a SME criou o Programa São Paulo é uma escola, instituído pelo Decreto 46.017/05 e regido pelo Decreto 46.210 de 15 de agosto de 2005, que tem como objetivo ampliar o tempo de permanência dos estudantes na escola oferecendo atividades diversificadas nas áreas de esporte, cultura, educação e social. Outro Programa implantado pela SME, instituído pela Portaria 6.328 de 23 de setembro de 2005, é o Programa Ler e escrever - prioridade na Escola Municipal "[...] com o objetivo de desenvolver Projetos que visam a reverter o quadro de fracasso escolar ocasionado pelo analfabetismo e pela alfabetização precária dos alunos do Ensino Fundamental e Médio da Rede Municipal de Ensino" (SÃO PAULO, 2005), iniciado em 2006. Esses programas vão se estabelecer durante a gestão do Secretário Alexandre Schneider que assume o cargo na referida secretaria em 2006. Segundo Aguiar (2011), que estudou as propostas educacionais da prefeitura de São Paulo, esses dois programas embasaram as ações da Secretaria Municipal de Educação na gestão do prefeito Kassab, que para ela foram impostas sem discussão ampla com a comunidade de professores que compõem a rede municipal.

\footnotetext{
${ }^{37}$ Informações coletadas no currículo Lattes: http://lattes.cnpq.br/9545072153797848
} 
O Programa Ler e escrever - prioridade na Escola Municipal era composto de alguns projetos que focavam o ensino e aperfeiçoamento da leitura e escrita durante os anos iniciais da educação básica. Um desses projetos é o Toda Força ao $1^{\circ}$ ano que inseriu para atuar junto com o professor de $1^{\circ}$ ano, do Ensino Fundamental I, um estagiário estudante de Pedagogia que faria a função de professor auxiliar. Além disso, a Diretoria de Orientação Técnica - DOT desenvolveu cadernos de orientação ao trabalho docente sendo o Guia para o Planejamento do Professor Alfabetizador dividido em três volumes. Nesse guia fica exposto o foco da SME no desenvolvimento da competência leitora e escritora de seus estudantes propondo-se a meta de alfabetizar todos no fim do primeiro ano do ciclo I.

Como decorrência do Projeto Toda Força ao $1^{\circ}$ ano, a SME organizou uma publicação com os registros de alguns professores e estagiários participantes deste. $\mathrm{O}$ livro Aprender... com quem? Um diálogo em construção ${ }^{38}$, publicado em 2011, apresenta relatos de experiência dos profissionais envolvidos nesse processo: os professores de $1^{\circ}$ ano do Ensino Fundamental I, os formadores das Diretorias Regionais de Ensino, os orientadores das instituições universitárias parceiras, os estagiários e os coordenadores pedagógicos das escolas. Na apresentação do livro, o Secretário Alexandre Schneider afirma que "[...] esta publicação documenta - ao mesmo tempo em que propõe - que novas relações podem ser estabelecidas entre quem aprende e quem ensina, permitindo novas formas de organização do ensino e da aprendizagem [...]” (SÃO PAULO, 2011, p. 05).

Nessa mesma direção, a SME criou em 2005 um projeto intitulado Professores Autores com o fim de divulgar as obras acadêmicas e literárias dos professores da rede municipal de ensino. A divulgação é feita por meio da página eletrônica ${ }^{39}$ da Biblioteca Pedagógica na qual existe um índice de autores e em cada registro consta uma imagem da capa do livro, os dados bibliográficos como nomes dos autores, editora e ano de publicação para livros e outros dados quando é um texto de revista ou outra modalidade, seguida de um resumo da publicação, além disso, as obras impressas ficam expostas durante um período numa estante do projeto na biblioteca acima citada. Para isso, os

\footnotetext{
38 Tomamos conhecimento dessa publicação em uma visita à Biblioteca Pedagógica quando nos foi apresentada uma professora do DOT, que colaborou com o concurso literário e participou do projeto Toda Força ao $1^{\circ}$ Ano tendo acompanhando o processo de confecção desta obra.

39 Página eletrônica do Projeto Professores http://portal.sme.prefeitura.sp.gov.br//Main/Noticia/Visualizar/PortalSMESP/Projeto-Educadores-Autores
} 
professores interessados em divulgar suas obras precisam entrar em contato com a biblioteca e enviar um exemplar da publicação.

Essas ações descritas que foram realizadas pela SME, iniciadas em período anterior ao início do concurso literário, são interpretadas como um esforço da secretaria em promover ações de incentivo ao professor leitor e escritor na gestão em questão. São diferentes ações identificadas que podem levar os professores participantes a refletirem sobre a importância de serem leitores e escritores efetivos para que desse modo, a formação e a experiência que adquirem nesse processo possam levar a práticas pedagógicas que contribuam para a formação de estudantes leitores e escritores. Nesse sentido, Kramer e Souza (2003) indicam a necessidade de políticas públicas de formação de professores que visem formar professores leitores e escritores, pois somente desse modo, eles conseguirão atuar na formação dos estudantes.

Com a identificação dessas ações da SME, inferimos que o concurso literário não se apresenta como uma prática isolada no âmbito da gestão da rede de ensino, ele integra um grupo de práticas que a SME vinha realizando em diversos espaços que à ela compete, visando, a nosso ver, o incentivo, a reflexão e a formação do professor como leitor e escritor. Apontamos neste momento que quando discorremos sobre a formação do professor como escritor tratamos de uma relação mais efetiva com a produção da escrita em diferentes aspectos, seja a profissional, a de foro íntimo, a informativa e/ou a literária.

Nesse contexto, em 2009, a SME criou o Valeu, Professor ${ }^{40}$ como uma ação para homenagear os professores no mês de outubro, o mês no qual se comemora o dia do Professor e que aparece nomeado nos documentos oficiais como Mês da Educação e, também, como valorização ${ }^{41}$ do professor pelo trabalho prestado à educação do município. A primeira notícia sobre as atividades do Valeu, Professor foi publicada no Diário Oficial da cidade de São Paulo, em 4 de setembro de 2009, informando sobre o lançamento do Cartão do Educador e oferecendo $20 \%$ de desconto na compra de livros nas livrarias cadastradas no programa - ação que foi considerada como a abertura das comemorações do Valeu, Professor. A notícia ainda informava que todos os professores da rede municipal, ativos e aposentados, receberiam o cartão em suas respectivas residências até 15 de outubro, dia do Professor.

O Valeu, Professor, neste ano de 2009, configurou-se como um evento ocorrido nos dias 2 e 3 de outubro com uma série de apresentações culturais, esportivas,

\footnotetext{
${ }^{40}$ Memória Técnica Documental, documento de código E4.1/72 e E4.1/72b.

${ }^{41}$ Perspectiva da gestão da Secretaria Municipal de Educação.
} 
gastronômicas e recreativas durante 24 horas ininterruptas em diversos locais da cidade, a saber: Mercadão, Cine Olido, Casa das Rosas, Parque da Luz, Pinacoteca, Museu da Língua Portuguesa, Centros Educacionais Unificados (CEUs), PlayCenter, livrarias, cinemas e teatros. Além de assistir e participar das atividades, os professores ainda poderiam ser protagonistas em artes plásticas, música e literatura. Nas palavras do Secretário de Educação sobre o evento:

Temos de valorizar esse que é o personagem central da melhoria da educação em São Paulo. Todos estes eventos são gratuitos. E nossos professores também serão protagonistas. Aqueles que forem músicos poderão tocar e fazer shows. Os poetas poderão ir à Casa das Rosas. É o reconhecimento dos professores por parte da Cidade [...]. (SÃO PAULO, 2009).

Dessa forma, os professores poderiam realizar inscrições para expor trabalhos artísticos nas categorias pintura, gravura e desenho. As obras escolhidas foram expostas de 2 a 15 de outubro no saguão da Prefeitura de São Paulo e depois participaram de exposição itinerante nos CEUs e outros locais. Os professores músicos precisavam fazer inscrição e escolher uma unidade do CEU onde gostariam de realizar a apresentação, poderia ser sozinho ou em grupo, com inscrição de até oito músicas. A participação dos inscritos foi confirmada por e-mail e uma comissão foi responsável por escolher o repertório e a quantidade de músicas a ser apresentada por cada inscrito.

Em relação ao professor poeta que é citado pelo Secretário de Educação na primeira notícia publicada, não há nenhuma notícia sobre inscrição para esse grupo, o que identificamos nos documentos é um convite datado de 17 de setembro de 2009, para que os professores autores divulguem suas obras no Valeu, Professor e, para isso, os interessados deveriam contatar a Biblioteca Pedagógica. Segundo um membro da comissão organizadora, os professores autores realizaram uma conversa sobre suas obras publicadas durante o evento, conforme relata em entrevista:

O Valeu, Professor, ele foi criado antes, o concurso literário aconteceu no ano seguinte, no ano anterior não houve o concurso, mas houve a apresentação dos professores autores, que o Projeto Professores Autores aqui da biblioteca existe desde 2005, se não me falha a memória, e aí então teve essa ideia, professor autor, ele escreve, vamos valorizar esse professor, vamos fazer, assim, um bate papo com ele, nos CEUs, num lugar que eles escolhessem. A gente deu uma relação de lugares, normalmente eram nas bibliotecas dos CEUs que os professores iam, nos CEUs mais próximos das suas casas. E aí eles conversavam, então tinha lá o público do $\mathrm{CEU}$, da biblioteca, que eles conversavam como era escrever um livro, como era essa experiência, como era ser professor da rede e esses professores que se apresentaram nos CEUs, todos eles tinham livros aqui que faziam parte do Projeto 
Professores Autores, que é a divulgação, a exposição do livro e a informação dessa publicação no portal, na página da biblioteca. (Entrevista com membro da comissão do concurso, 2016) ${ }^{42}$.

Nesse sentido, localizamos um documento de divulgação da programação das atividades no qual consta uma atividade intitulada Professor Autor, que consiste em uma conversa sobre a experiência de ser professor autor, como segue a transcrição do cartaz: "PROFESSOR AUTOR (02/10, das 18h às 19h) - Educadores com livros de literatura publicados e cadastrados na Biblioteca Pedagógica de SME, compartilharão suas experiências como professores/autores" (Memória Técnica Documental, E4.1/72b, 2009).

Além disso, as comemorações pelo mês do professor ainda incluíam uma grande festa realizada em 07 de outubro na qual se premiava o professor Emérito e os professores Destaques do ano, seguido de um show de encerramento que, no referido ano, foi do músico Milton Nascimento.

Em 6 de outubro, o Diário Oficial da cidade de São Paulo publica uma notícia resumindo o evento e afirma que houve a participação de mais de 15 mil professores em cem atrações oferecidas. Dos professores artistas que inscreveram trabalhos, 26 obras foram expostas. A exposição contou com a presença de 400 pessoas aproximadamente na abertura, mas nada foi mencionado em relação aos professores músicos inscritos. Outra informação que consta nesta notícia é que dez bailes aconteceram durante a noite, realizados pelas DREs ${ }^{43}$. Este documento termina com a fala de um professor do CEU Vila Atlântica sobre o evento: “[...] Iniciativas como esta são fundamentais para nós, educadores, termos acesso a várias formas de cultura e isso ajuda também em sala de aula [...]” (SÃO PAULO, 2009).

Essa fala do professor tem relação com a afirmação feita pelo prefeito, publicada na primeira notícia do Diário Oficial da Cidade, que diz “[...] Esse é um reconhecimento que mostra a preocupação da Cidade de estar ao lado deles, criando condições para que eles possam se capacitar e se tornarem professores cada vez melhores [...]" (SÃO PAULO, 2009).

\footnotetext{
${ }^{42}$ De acordo com as normas do Comitê de Ética, e seguindo a opção da pessoa entrevistada, manteremos o nome do membro em sigilo.

${ }^{43}$ A Secretaria Municipal de Educação de São Paulo possui treze (13) Diretorias Regionais de Educação (DRE). Essas diretorias realizam a gestão da rede de escolas agrupadas por cada região da cidade e possuem certa autonomia nas ações desenvolvidas, a saber: DRE Pirituba, Freguesia/Brasilândia, Jaçanã/Tremenbé, Penha, São Miguel, Guaianazes, Itaquera, São Mateus, Ipiranga, Butantã, Campo Limpo, Santo Amaro, Capela do Socorro.
} 
Em 2010, ao iniciar o ano, a Secretaria Municipal de Educação insere o Valeu, Professor no seu calendário oficial de atividades prevendo a data de 22 a 24 de outubro para este, como consta na Portaria $n^{\circ} 653$ de 19 de janeiro, passando, portanto, a ser um evento oficial contínuo. A publicação seguinte ocorre em 02 de março no Nossa Escola ${ }^{44}$ Boletim oficial da Secretaria Municipal de Educação de São Paulo com uma nota divulgando que haverá a segunda edição do evento em outubro, como segue a transcrição: "Neste ano, ocorrerá a 2a . Edição do Valeu, Professor!, evento realizado pela Secretaria Municipal de Educação com atividades culturais, artísticas e de entretenimento na cidade. Será em outubro, não perca!” (SÃO PAULO, 2010)

Na publicação seguinte, em 08 de maio, a SME estabelece o concurso literário como parte do Valeu, Professor. O concurso literário foi instituído pela Portaria SME $n^{\circ}$ 2.718 de 07 de maio de 2010, publicada no Diário Oficial da cidade de São Paulo em 08 de maio juntamente com o regulamento do mesmo. Nesta portaria, o Secretário de Educação cria o concurso literário considerando a segunda edição do evento Valeu, Professor com o objetivo de "[...] estimular a produção de textos literários, incentivar e divulgar novos talentos na área da literatura" (SÃO PAULO, 2010, p. 12).

O concurso literário passa, portanto, a integrar o evento Valeu, Professor promovido pela SME com o objetivo de homenagear os educadores da cidade de São Paulo. Segundo o Secretário Municipal de Educação, Alexandre Schneider, o evento foi "[...] criado para valorizar os profissionais da Rede Municipal de Ensino e para agradecêlos pelo serviço inestimável que prestam à nossa sociedade" ${ } 46$.

De acordo com o contexto no qual foi criado o concurso literário, entendemos que existe um incentivo às práticas da escrita dos professores e, também, a outras práticas de cultura como a dança, a música, o teatro e as artes visuais, valorizando assim aquele indivíduo que desenvolveu uma habilidade artística e possibilitando que as atividades artísticas sejam apreciadas por espectadores que incluem outros professores, alunos e comunidades das escolas nas quais muitas vezes estes professores atuam. Portanto, considerando a diversidade de ações implantadas pela SME envolvendo um investimento em leitura e escrita, compreendemos que a secretaria assumiu uma política de valorização das habilidades desenvolvidas pelos professores para além das que envolvem a profissão

\footnotetext{
${ }^{44}$ No decorrer do texto, este documento será chamado de Boletim Nossa Escola.

${ }^{45}$ Memória Técnica Documental, SME-67.

46 Trecho extraído do texto de apresentação do Secretário de Educação publicado na antologia intitulada Eu me lembro: crônicas, contos e poesias em 2010.
} 
docente diretamente, assim como incentivou e assumiu a produção intelectual dos professores atuantes na rede de ensino.

\subsection{Valeu, Professor: ocorrência do concurso literário}

O Concurso Literário Valeu, Professor ocorreu nos anos 2010, 2011 e 2012, tendo surgido de uma iniciativa do Secretário Municipal de Educação Alexandre Schneider em parceria com profissionais da secretaria. O concurso destinava-se a professores, coordenadores pedagógicos, assistentes de direção, diretores de escola e supervisores escolares (ativos e aposentados) da rede municipal de educação de São Paulo.

Em cada ano, o concurso teve um tema definido previamente: Eu me lembro... em 2010, Sob o céu da cidade em 2011 e Sem remetente.com em 2012. Os temas eram escolhidos pelo Secretário de Educação e publicados no regulamento, de acordo com informações recolhidas em entrevista:

Olha, o secretário que dava o tema, o Alexandre Schneider. Tanto que é assim, a gente, num primeiro momento, nós pensamos em deixar o tema livre, mas era muito difícil um tema livre para a gente depois fazer a comissão julgadora, então, foi levado ao secretário, e o secretário deu esse tema, e o primeiro foi Eu me lembro que era bem amplo também, mas os três temas foram escolhidos pelo secretário. (Entrevista com membro da comissão do concurso, 2016).

No Artigo $1^{\circ}$ da Portaria $n^{\circ} 2.718$, consta que o concurso literário compreende quatro categorias: poesia, conto, crônica e ilustração. Do mesmo modo, essa informação aparece no regulamento publicado em anexo à portaria. Os professores poderiam inscrever apenas um trabalho em cada categoria, podendo participar em mais de uma. Para efetivar a inscrição, os professores precisavam no período de 24 de maio a 18 de junho preencher a ficha de inscrição ${ }^{47}$ disponível na página eletrônica da SME e enviar por correio ou entregar pessoalmente juntamente com duas cópias impressas do texto e/ou ilustração e uma cópia do material em CD para a Biblioteca Pedagógica. A categoria ilustração foi pensada para gerar a capa do livro que seria publicado com os textos vencedores.

\footnotetext{
47 Modelo da ficha de inscrição em anexo.
} 
Em todas as edições do concurso havia uma comissão julgadora responsável por selecionar os textos e ilustrações, assim como organizar o livro a ser publicado, além disso, alguns membros ainda atuaram na organização e desenvolvimento das etapas do concurso, como recebimento e ordenamento das inscrições, divulgação na rede de ensino, entre outras. A nomeação dos membros era publicada no Diário Oficial da cidade de São Paulo e a distribuição se deu da seguinte forma: representantes da Secretaria Municipal de Educação e especialistas da área gráfica e editorial indicados por instituições parceiras, que em 2010 foram Eduardo Yasuda (representante da área editorial, atuou como Presidente da Associação Nacional de Livrarias - ANL - em duas gestões (1994 - 2003, e 2005-2007) ${ }^{48}$; Ione Aparecida Cardoso Oliveira (professora em atuação na SME); Karine Gonçalves Pansa (representante da área editorial, foi Presidente da Câmara Brasileira do Livro - CBL - de 2011 a 2015 e diretoria da Girassol Brasil) ${ }^{49}$; Patrícia Martins da Silva Rede (professora em atuação na SME); Silvana Moura Riguengo (professora) e Toni Brandão (escritor, autor de publicações de literatura infantojuvenil). Em entrevista, um membro relata:

A comissão julgadora era composta por seis pessoas, a gente achava que esse era um número bom, então três de SME e três de fora. [...] E a outra pessoa era o seu Yasuda que era de fora, então, porque era um super parceiro, aí no primeiro ano foi o Toni Brandão, um escritor, e teve também a Karine, que era de uma editora. Mas as pessoas de fora, era o seu Yasuda que trazia, porque como presidente da CBL imagina a quantidade de pessoas que ele conhece. (Entrevista com membro da comissão do concurso, 2016).

O critério de avaliação usado pela comissão julgadora consta no regulamento publicado e contempla os seguintes itens: “[...] a presença de aspectos próprios da categoria textual, aspectos gerais de gramática e ortografia, relação com o tema proposto e originalidade" (SÃO PAULO, 2010, p. 12). Na avaliação, os textos eram lidos por três membros que atribuíram conceitos de A a E. Ao final, os que receberam conceitos maiores foram os selecionados para compor o livro, considerando a quantidade de páginas disponíveis para a edição. Em entrevista, o membro da comissão julgadora nos relata como as avaliações foram efetivadas:

[...] todo o texto era lido por três pessoas, então a comissão era de seis pessoas, então três leituras para cada texto. Então [...] sempre era pra ser uma pessoa de SME, ou duas, e sempre um de fora, então, nunca três, as três de SME leram o mesmo texto, isso era um critério também

\footnotetext{
48 Informação extraída da página eletrônica da Associação Nacional de Livrarias, disponível em: http://anl.org.br/web/quemsomos-presidentes.php

49 Informação extraída da página eletrônica da Câmara Brasileira do Livro, disponível em: http://cbl.org.br/a-cbl/a-associacao/presidentes
} 
que era usado. Então, a gente fazia uma distribuição de acordo com as pessoas que estavam lá mesmo e não deixando que três pessoas de SME lessem o mesmo texto e nenhuma de fora. Então, a gente dava conceitos $\mathrm{A}, \mathrm{B}, \mathrm{C}, \mathrm{D}$ e E, igualzinho o da escola mesmo, o A para melhor texto, o $\mathrm{B}$ mais ou menos e quando era $\mathrm{E}$ a gente até desconsiderava, então se você olhar os textos, que você acompanhou, que você vê, muitos têm conceitos, todos têm conceitos. Agora, quando tinha já dois Es, a gente já nem usava a terceira leitura, porque sabia que o texto era muito ruim mesmo. Agora, tinha casos, por exemplo, que um dava A e o outro dava $\mathrm{D}$, aí às vezes a gente até ia para uma terceira, até pra uma quarta leitura, então muitas vezes aquele texto eram quatro pessoas que avaliavam [...], eu acho que os critérios [...] funcionaram e a gente acabou usando os mesmos critérios para as três edições [...]. (Entrevista com membro da comissão do concurso, 2016).

Em 2010, as ilustrações inscritas foram em número pequeno, apenas quatro, por isso, a comissão julgadora fez cópias em forma de cartaz, em tamanho ampliado, e as expôs na $21^{\mathrm{a}}$ Bienal Internacional do Livro de São Paulo, no estande da SME, para que o público visitante conhecesse os trabalhos artísticos e votasse em um deles para gerar a capa do livro, como relata o membro entrevistado:

[...] no primeiro ano só recebemos quatro ilustrações, então nós fizemos num tamanho grande as quatro ilustrações para as pessoas olharem, e pegavam as cédulas que tinham os desenhos das ilustrações e assinalarem e colocarem na urna, aí nós fizemos a... [...] contagem, fizemos a contagem, a apuração, aí deu a capa vencedora e conseguimos publicar o livro. (Entrevista com membro da comissão do concurso, 2016).

A comissão criou uma cédula de votação com as ilustrações para que o público votasse durante a Bienal. A imagem a seguir mostra a cédula com as quatro ilustrações inscritas:

Imagem 1: Cédula de votação da ilustração do concurso literário de 2010. 


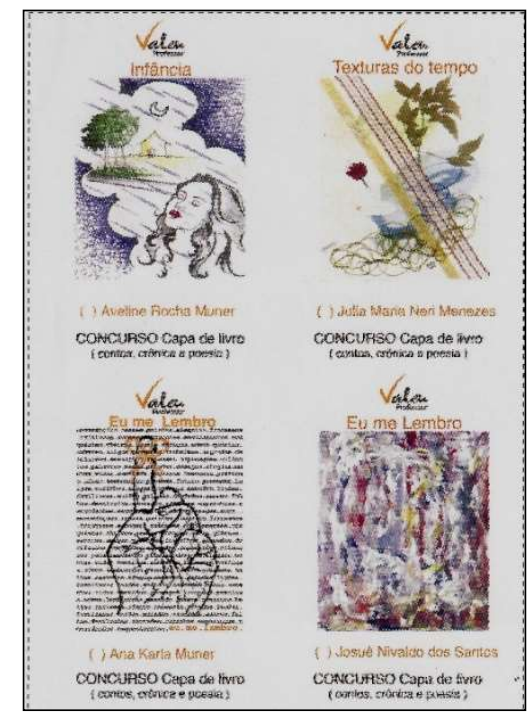

Fonte: Arquivo da Biblioteca Pedagógica (2010).

Ao final da votação, totalizaram 5.111 votos, tendo a ilustração vencedora 40,66\% destes votos, como publicado no Diário Oficial da cidade de São Paulo em 24 de agosto e no Boletim Nossa Escola n ${ }^{\circ} 34$.

O resultado do concurso, nas categorias textos literários, foi anunciado durante a Bienal Internacional do Livro. No Boletim Nossa Escola $\mathrm{n}^{\circ} 33$, publicou-se que o resultado do concurso literário foi anunciado no dia 12 de agosto durante a abertura da $21^{\mathrm{a}}$. Bienal do Livro com a presença dos professores participantes. Durante a entrevista, o membro da comissão descreveu aspectos desse momento:

[...] em 2010 como a divulgação do vencedores já foi no primeiro dia da bienal, que também foi uma coisa que a gente viu que não deu certo, porque nós fizemos assim, nós pedimos pra todos os professores que participaram, mandassem a foto e a gente não falava o porquê, aí no dia de dizer quem foram os vencedores, a gente chamou todos os professores pra um auditório, com a presença do prefeito, o Kassab foi nesse dia, e o Walcir Carrasco, ele que foi meio que o padrinho daquele dia, então era a abertura da bienal, não estava nem aberto para o público, era aquela abertura solene que depois ia abrir para o público, então estava vazio, estava super tranquilo, fizemos isso, foi legal porque as pessoas puderam conhecer Walcir Carrasco, que é... Muitos professores, que são principalmente de sala de leitura, utilizam muitos livros dele, só que foi muito chato, porque teve muito professor que estava lá que não tinha sido selecionado, então... daí mostrou as fotos dos vencedores [...] então, teve gente que saiu triste, isso foi até umas respostas que as pessoas deram do concurso, porque as pessoas ficaram chateadas, até tenho alguns e-mails desses guardados, e elas, porque elas depois mandaram o e-mail, reclamando... adoramos tudo, mas aconteceu isso, isso e isso, não foi legal, tudo, então, no ano seguinte a gente... Não pedimos mais as fotos e publicamos os nomes no Diário Oficial, nessa página especial [...]. (Entrevista com membro da comissão do concurso, 2016). 
O primeiro livro decorrente do concurso foi produzido com a colaboração da Câmara Brasileira do Livro, as editoras Editorama e Paulus, e a empresa Fibria ${ }^{50}$. De acordo com informações de um dos membros da comissão, as empresas colaboradoras foram responsáveis pela produção do livro, sem geração de custos para a SME: “[...] no primeiro ano, nós tivemos duas editoras que participaram, na verdade, tivemos a Editorama que fez a editoração e a Paulus que fez a impressão. No segundo e no terceiro, já foi a Moderna que fez a editoração e a impressão [...]" (Entrevista com membro da comissão do concurso, 2016). Foram produzidos seis mil exemplares para distribuição gratuita. As escolas municipais receberam exemplares do livro para compor o acervo de suas bibliotecas, assim como cada professor autor, vencedor do concurso, recebeu dez exemplares $^{51}$.

O lançamento do livro aconteceu na abertura das atividades do evento Valeu, Professor, no dia 22 de outubro, no prédio da Prefeitura de São Paulo, organizada de tal maneira que os professores receberam seus exemplares e se puseram na condição de autores para autografar e presentear as pessoas com os livros recebidos, segundo o relato que segue:

[...] Professor Artista, ele aconteceu em todas as edições, mesmo antes do concurso literário teve o Professor Artista e sempre tinha a vernissage que era no evento do Valeu, Professor, geralmente na sextafeira à noite e, então, tinha abertura da exposição que ficava dez, quinze dias lá no gabinete do prefeito, então já tinha acontecido isso no ano anterior e, no ano seguinte, que era o primeiro do concurso literário, teve também o lançamento do livro, a noite de autógrafos, então foi lá, [...] separadinho... os professores ganharam os livros, bonitinho. (Entrevista com membro da comissão do concurso, 2016).

O Valeu, Professor em 2010, teve ainda três outras formas de participação destinadas ao mesmo público do concurso literário. O Concurso Professor Artista, criado pela Portaria $\mathrm{n}^{\circ} 2.858$ de 17 de maio, compreende as categorias pintura, desenho, gravura, escultura e fotografia. Para se inscrever, o professor tinha que comparecer no Memorial do Ensino Municipal para entregar a ficha de inscrição e a obra artística. As obras

\footnotetext{
${ }^{50}$ Fibria é uma empresa produtora de papel que colaborou com a produção dos livros da primeira edição do concurso literário e recebeu os professores vencedores na fábrica de papel para uma visita, em Piracicaba, interior de São Paulo. No Diário Oficial da cidade de São Paulo, na Portaria no 4.922 de 14 de setembro de 2010 consta que os professores estarão dispensados de suas atividades em 16 de setembro para a participação na visita. São cinquenta e um nomes na referida portaria.

${ }^{51}$ Esses dados foram identificados nos documentos da comissão julgadora no arquivo da Biblioteca Pedagógica (documentos não catalogados).
} 
selecionadas ficaram expostas no saguão da Prefeitura de 22 de outubro a 06 de novembro. O Professor Músico teve seu regulamento publicado pelo Comunicado $\mathrm{n}^{\circ}$ 1.116 de 20 de julho o qual indicava que os professores interessados em realizar apresentações musicais sozinho ou em grupo, com até oito músicas, precisavam efetivar inscrição na DRE correspondente à região de interesse para a apresentação. A Comissão julgadora era a responsável por selecionar os inscritos, assim como definir a quantidade de músicas a serem apresentadas. O Professor de Expressão Corporal compreende as categorias dança e teatro, publicado por meio do Comunicado $\mathrm{n}^{\circ} 1.117$ de 20 de julho. Nesta modalidade, os professores precisavam entregar junto com a ficha de inscrição um material de imagem (foto ou vídeo) contendo a proposta de apresentação e indicar uma das dezesseis unidades do CEU para fazer a exibição. De acordo com o Comunicado não há seleção dos trabalhos, estes serão distribuídos conforme a disponibilidade dos CEUs, no entanto, existem restrições quanto a "[...] apresentações de cunho político-partidário ou religioso e que atentem contra a moral, bons costumes, grupos de pessoas, etnias ou segmentos da sociedade" (SÃO PAULO, 2010, p. 30). Acreditamos que a SME não recebeu um número significativo de inscrições nas categorias música e expressão corporal, pois em 21 de setembro publicou os Comunicados $n^{\circ} 1.496$ e $n^{\circ} 1.497$ reabrindo as inscrições dessas modalidades até 30 de setembro ${ }^{52}$ e, também, publicou uma notícia no Boletim Nossa Escola ${ }^{\circ} 39$.

Em 26 de outubro, a SME publica no Boletim Nossa Escola ${ }^{\circ} 43$ que a segunda edição do Valeu, Professor contou com mais de 350 atividades distribuídas pela cidade e voltadas para os professores e que no show de encerramento com o músico Almir Sater havia mais de duas mil pessoas.

No ano seguinte, 2011, o Boletim Nossa Escola $\mathrm{n}^{\circ}$ 58, de 14 de abril, publicou uma nota informativa intitulada "Lembrete" anunciando que a $3^{\text {a }}$. edição do Valeu, Professor já tinha data definida e que ocorreria entre 7 e 9 de outubro mantendo a atividade no calendário oficial da SME.

Como forma de divulgar a terceira edição do evento e os concursos destinados aos professores, a SME publica no Boletim Nossa Escola $\mathrm{n}^{\circ}$ 62, de 25 de maio, uma notícia descrevendo as atividades que serão oferecidas no ano e informando as categorias de participação. Em relação a isso ocorreu uma mudança, as apresentações de dança, teatro

\footnotetext{
${ }^{52}$ Diário Oficial da cidade de São Paulo de 21 de setembro de 2010.
} 
e música foram agrupadas e nomeadas como Professor em Cena, mantendo o Professor Artista e o Concurso Literário, como se pode observar no excerto da notícia a seguir.

O Valeu, que chega a sua terceira edição, conta com um diferencial: durante os três dias a cidade abre espaço para que os educadores, principais protagonistas da Educação, mostrem seus talentos e exponham suas artes. Professores músicos, atores e dançarinos ocuparão o Mercadão e a Praça do Patriarca. Pinturas, desenhos, gravuras, fotografias e esculturas de educadores vão compor uma exposição no hall do Edifício Matarazzo. E, para completar, obras escolhidas em um concurso literário vão compor um livro de crônicas, com textos inéditos e ilustração de capa produzidos por profissionais da Rede Municipal de Ensino. (SÃO PAULO, 2011) ${ }^{53}$.

O concurso literário foi divulgado através do Comunicado $n^{\circ} 686$ de 13 de maio de 2011, no Diário Oficial da cidade de São Paulo de 14 de maio. Com o tema Sob o céu da cidade, o concurso compreendia apenas duas categorias: crônicas e ilustrações. Observa-se que neste regulamento há uma informação inexistente anteriormente sobre as categorias do concurso, que é uma descrição que explica brevemente o que é crônica e ilustração, como demonstra o trecho a seguir:

O Concurso compreende duas categorias, a saber: - Crônica: gênero literário que tem como finalidade refletir sobre um acontecimento; sua estrutura apresenta uma introdução, um desenvolvimento e uma conclusão; seu discurso se move entre a reportagem e a literatura, entre o oral e o literário, entre a narração impessoal dos acontecimentos e a força da imaginação. Geralmente é um texto curto, breve, simples, de interlocução direta com o leitor, com marcas bem típicas da oralidade; quando predominantemente narrativa, possui trama quase sempre pouco definida, sem conflitos densos e personagens de pouca densidade psicológica, sendo os motivos extraídos do cotidiano imediato; o estilo deve dar a impressão de naturalidade e a língua escrita aproximar-se da fala. Essa liberdade discursiva privilegia o efeito de aproximação do enunciador em relação ao leitor, uma expressão jornalístico-literária, o que é feito pelo uso frequente de discurso indireto livre. - Ilustração: imagem ou figura de qualquer natureza que acompanha, explica, interpreta, acrescenta informação, sintetiza ou elucida o texto do livro. (SÃO PAULO, 2011, p. 40).

Considerando o regulamento anterior, refletimos sobre os motivos que levaram a comissão a publicar uma nota explicativa de cada categoria do concurso no regulamento e este fato associado a algumas anotações identificadas nos textos de 2010, realizadas pela comissão julgadora, nos faz inferir que alguns textos atenderam à temática do concurso, no entanto, não possuíam a forma literária da categoria à qual o texto foi inscrito. Corrobora para essa hipótese o fato de que uma parcela dos textos apresentados

\footnotetext{
${ }^{53}$ Nossa Escola Boletim Oficial da Secretaria Municipal de Educação, no 62, 2011.
} 
ao concurso em 2010 tratavam de vivências, lembranças dos professores e, em alguns casos, não foram produzidos como contos e crônicas, atendendo ao estilo de cada gênero, mas sim como narrativas memorialísticas em primeira pessoa. Nestes casos, observamos que a comissão julgadora escrevia notas nos textos indicando que eram memórias e, em alguns, essas anotações vinham seguidas de uma interrogação, pois o leitor julgador não estava seguro se o texto era uma narrativa memorialística ou conto/crônica.

Em entrevista com um dos membros da comissão julgadora, quando perguntamos sobre a opção de realizar um concurso apenas com o gênero crônica, este relata um pouco sobre os textos que não possuíam as características literárias na qual estava inscrito:

O segundo foi a crônica, porque eu imagino que era um gênero que estava sendo trabalhado na rede, então estava tendo formações para explicar o que era crônica, então, para estimular o professor a escrever crônica optou-se nesse ano de 2011. [...] Ah, eu imagino que da própria [nome de outro membro da comissão do concurso], como ela fez parte da formação, eu acho que ela deu a sugestão, inclusive explicando, mais para frente você até pergunta por quê que descreve no regulamento, mas até dando uma explicação, esta necessidade de explicar o que era crônica veio justamente no concurso de 2011, porque muita gente no concurso de 2010, que foi o primeiro, confundia um pouco conto, crônica, principalmente conto e crônica, porque poesia é mais tranquilo, mas a pessoa descrevia o texto dela como crônica e era um conto, ou contrário [...] em 2011, acho até pelo fato de ter sido trabalhado mais isso na rede, [...] se optou pela crônica somente, descrevendo o quê que era crônica e, assim, o secretário também autorizou, tudo, tudo passava pelo gabinete, a gente não fazia nada sem o aval do secretário, porque aí mostra a cara da secretaria. E aí acabou dando certo e a gente achou que mesmo as pessoas ainda confundindo um pouco crônica com conto, nós tivemos umas crônicas bem interessantes em 2011 que era $S o b o$ céu da cidade, que também já é um tema que é fácil você escrever umas histórias pitorescas sobre a cidade de São Paulo principalmente, apesar que tinha gente que até escreveu coisas de outros estados, das suas terras, porque aqui em São Paulo a gente tem gente do Brasil inteiro [...]. (Entrevista com membro da comissão do concurso, 2016).

Outro aspecto alterado no regulamento de 2011 se refere à assinatura nos materiais inscritos. No ano anterior, 2010, o autor poderia escolher se assinava usando seu nome ou pseudônimo, no entanto, em 2011 os textos e ilustrações deveriam ser assinados usando o pseudônimo adotado pelo autor e não o nome, como relatado em entrevista: “devia ter só o pseudônimo pra evitar conhecer a pessoa. Então, colocava o pseudônimo no texto [...] gostando daquele texto a gente pegava a ficha de inscrição para entrar em contato com o professor" (Entrevista com membro da comissão do concurso, 2016). Além disso, nesta edição os participantes poderiam inscrever até dois trabalhos em cada categoria. 
Os membros da comissão julgadora de 2011 foram nomeados na Portaria SME ${ }^{\circ}$ $3.480^{54}$, de 8 de julho, sendo representantes dos mesmos segmentos, da Secretaria Municipal de Educação e da área editorial, e os critérios de avaliação se mantiveram em relação ao ano anterior. Tal comissão foi composta por Eduardo Yasuda, Ione Aparecida Cardoso Oliveira, Patrícia Martins da Silva Rede e Silvana Moura Riguengo que participaram da edição anterior, os novos membros são Avelino Aparecido Alves ${ }^{55}$ e Lucia Jurema Figueirôa ${ }^{56}$ (representantes da área editorial). Para o trabalho de editoração, impressão e acabamento, a SME fez parceria com a Editora Moderna, além disso, a Câmara Brasileira do Livro também colaborou com o concurso.

A comissão escolheu 27 textos para compor o livro e divulgou a lista dos professores que tiveram seus textos selecionados na página eletrônica da SME, conforme notícia no Boletim Nossa Escola $\mathrm{n}^{\circ} 73$ de 22 de agosto; no Diário Oficial da cidade de São Paulo de 17 de agosto, foi publicada a lista de autores vencedores e os respectivos títulos dos textos, assim como a ilustração vencedora.

As ilustrações inscritas, treze no total, passaram por uma seleção prévia da comissão julgadora e as quatro escolhidas foram colocadas em votação na página eletrônica da SME e, também, era possível votar presencialmente na Biblioteca Pedagógica durante onze dias. O entrevistado nos conta sobre essa forma de votar a capa:

[...] a gente fez uma urna aqui na biblioteca e as pessoas puderam votar pelo site, pelo portal. Não foi nem pelo site do Valeu, acho que foi pelo portal da Educação mesmo, e aí foi legal, foi diferente, nós fizemos a votação física também com a urna aqui, então teve os votos no papel e teve os votos da internet [...] foi legal, a gente gostou também dessa experiência. [...] a votação pela internet [...] era com $\mathrm{RF}^{57}$, então, a pessoa tinha que votar e [...] ela votava uma vez só, então o número de pessoas que votaram não foi muito grande, mas era uma votação correta, porque às vezes aparece lá cinquenta mil votos, mas daí a pessoa votou cinco vezes, então, pelo menos assim..., e podia qualquer pessoa com RF votar, então teve gente de outra secretaria também que votou, isso foi legal, só que ficou limitado aos funcionários da prefeitura, quem era de fora que quisesse votar, podia votar no papel. (Entrevista com membro da comissão do concurso, 2016).

Na comissão julgadora não havia um membro da área de artes, por isso, os membros convidaram de modo informal uma pessoa da SME com essa formação para ajudar na seleção das obras para a votação, conforme pode ser observado a seguir: “[...]

\footnotetext{
54 Diário Oficial da cidade de São Paulo de 09 de julho de 2011.

55 Jornalista na Secretaria Municipal de Educação. No concurso literário representou a área editorial.

${ }^{56}$ Diretora Editora na Câmara Brasileira do Livro e Gerente de Relações Institucionais na Editora Moderna.

${ }^{57}$ RF - Sigla para Registro Funcional.
} 
no dia da seleção a gente até levava alguém também da área de arte, que nós temos aqui pessoas, ela não entrava na comissão julgadora, mas ela nos ajudava a selecionar as quatro que iriam pra votação" (Entrevista com membro da comissão do concurso, 2016). Abaixo, na cédula de votação estão as ilustrações selecionadas pela comissão para serem votadas pelo público.

Imagem 2. Cédula de votação da ilustração do concurso literário de 2011.

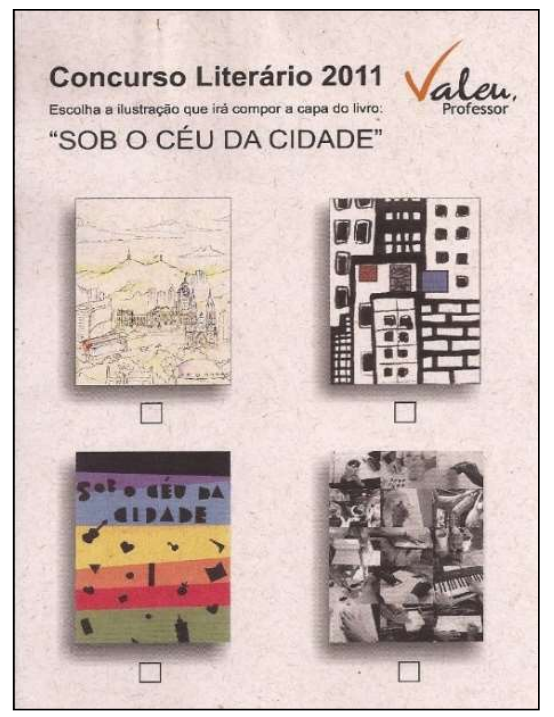

Fonte: Arquivo da Biblioteca Pedagógica (2011).

Como é possível observar na imagem da cédula de votação, as ilustrações foram impressas sem nenhuma identificação de autoria e título, diferente do que ocorreu no ano anterior, na qual constava os autores das imagens.

Após a votação foram contabilizados 337.523 votos no total e a ilustração vencedora recebeu 210.756 votos, resultado esse divulgado no Boletim Nossa Escola $\mathrm{n}^{\circ}$ 73 e no Diário Oficial da cidade de São Paulo. Acreditamos que esse quantitativo de votos se deve pela votação eletrônica que possibilita amplo acesso das pessoas interessadas em participar.

As ilustrações inscritas ${ }^{58}$ - e que não foram selecionadas para a publicação trazem representações sobre a cidade. As descreveremos de modo breve com o objetivo de mostrar o que não foi publicado. A primeira apresenta paisagens da cidade como as marginais Pinheiros e Tietê, a Ponte Estaiada e uma cena de um bairro periférico com pequenas casas e natureza ao redor. A segunda ilustra os edifícios verticalizados

\footnotetext{
58 As ilustrações inscritas não podem ser mostradas em função dos direitos autorais, de acordo com orientações recebidas da Secretaria Municipal de Educação.
} 
apresentando no rodapé da imagem o efeito de colagem que demonstra o lixo presente nas áreas urbanas da cidade. A terceira compreende várias fotografias de mãos de diferentes pessoas realizando atividades como vender grãos, ler, escrever, desenhar, as fotografias usadas para montagem da ilustração são coloridas; é da mesma autoria da ilustração que consta na cédula de votação em preto e branco. A quarta, produzida em preto e branco, representa, num primeiro plano, duas pessoas - um homem e uma mulher - em uma chamada telefônica. Supõe-se pela expressão fácil que se trata de um casal que está distante, ao fundo aparece uma pequena cidade rural onde provavelmente vive um deles. A quinta representa a primavera e é uma colagem abstrata com folhas de árvores e diferentes tipos de papéis. A sexta foi produzida com papéis coloridos e revistas, a composição mostra uma pequena escola, um jovem caminhando com uma mochila pesada, onde aparecem livros didáticos, como se tivesse acabado de sair da escola indo de volta para casa, um menino jogando basquete e uma menina que parece estar segurando um objeto eletrônico e ambos estão sendo observados pelo personagem Visconde de Sabugoza ${ }^{59}$, no canto inferior direito aparece o desenho do rosto de uma criança e na parte superior está escrito, com letras recortadas de revistas, "Valeu Professor". A sétima é um desenho em cores de um entardecer, no qual o sol e a lua se encontram e sob eles uma grande avenida com carros na qual do lado esquerdo existem edifícios e do direto muitas árvores. A oitava, de mesma autoria da anterior, é um desenho de uma grande avenida com carros, margeada pelo rio de um lado e por edifícios à esquerda; e natureza à direita. No plano central do desenho está o rosto de um palhaço que chora sobre a parte industrializada da cidade. A nona é um desenho em preto e branco com edifícios verticais e casas residenciais, cuja frente das construções possui um campo com uma quadra de futebol. As ilustrações que representam cenários da cidade nem sempre demonstram o que a cidade tem de melhor, antes, marcam problemas vividos cotidianamente por seus moradores como o excesso de lixo produzido e a poluição proveniente dos automóveis que em grande quantidade circulam todos os dias pela cidade.

Neste ano, o lançamento do livro ocorreu na Biblioteca Mário de Andrade com a presença dos professores para sessão de autógrafos, de acordo com o relato:

No segundo ano, calhou de ser a reabertura da Mário de Andrade que fazia três anos que estava fechada pra reforma, e a Mário de Andrade ficou fantástica, aí eu consegui uns contatos, porque eu conheci uma bibliotecária lá da Mário de Andrade, [...] aí ela me indicou o supervisor

\footnotetext{
${ }^{59}$ Visconde de Sabugoza é um dos personagens do clássico livro de literatura infantil Sítio do Picapau Amarelo de Monteiro Lobato.
} 
de ação cultural, eu expliquei o quê que era e vi a possibilidade de fazer o lançamento do livro lá no auditório da Mário de Andrade no ano que ela reabriu. Foi um show! O auditório lotado, os professores amaram, teve uma professora que fez um monólogo, também, então nesse dia foi só o coquetel de lançamento, teve coquetel mesmo, os autógrafos foram no hall onde tem aquela estátua da leitura que é maravilhosa, foi fantástico! [...] (Entrevista com membro da comissão do concurso, 2016).

O Valeu, Professor de 2012 manteve as três formas de participação do professor como protagonista das atividades culturais: o Concurso Literário, o Professor Artista e o Professor em Cena, mantendo, dessa forma, as ações que envolvem este evento no calendário oficial da SME.

O Professor Artista foi divulgado no Boletim Nossa Escola ${ }^{\circ} 99$ de 03 de maio informando as categorias de participação - pintura, desenho, gravura, escultura e fotografia - e a forma de inscrição. O regulamento deste concurso foi publicado pelo Comunicado ${ }^{\circ} 683$ no Diário Oficial da cidade de São Paulo de 20 de abril. Para efetivar a inscrição, os professores deveriam entregar a obra no Memorial do Ensino Municipal juntamente com a ficha de inscrição e poderiam inscrever apenas uma obra por categoria. As obras selecionadas foram expostas na Galeria Prestes Maia de 21 de setembro a 04 de outubro.

O Boletim Nossa Escola $\mathrm{n}^{\circ} 103$ publicou notícia sobre a inscrição para Professor em Cena em 28 de maio mantendo as três categorias: dança, música e teatro podendo ser uma apresentação solo ou em grupo, sendo que os integrantes do grupo poderiam ser externos à SME, mas o responsável deveria ser um professor da rede de ensino, limitando o grupo a 6 integrantes para música e 10 para teatro e dança. A inscrição deveria ser realizada do mesmo modo que no ano anterior apresentando um material em vídeo ou fotografia da proposta a ser apresentada. As apresentações eram de apenas 30 minutos para música e teatro, e 15 minutos para dança.

Neste ano, trazendo o tema Sem remetente.com, o concurso literário foi publicado no Diário Oficial da cidade de São Paulo pelo Comunicado ${ }^{\circ} 627$ de 12 de abril e as categorias definidas foram: poesia, conto e ilustração. Em relação à definição da categoria, o membro entrevistado relata que a escolha se deu com o objetivo de alternar os gêneros literários já que no ano anterior o concurso optou apenas pela crônica, como relata: “[...] como já tinha sido crônica em 2011, acabou colocando contos e poesias para 2012, para assim variar um pouco mais, então com isso, a gente acabou ficando com três gêneros, mas concentrados três no primeiro ano, somente um no segundo e os outros dois 
no terceiro" (Entrevista com membro da comissão do concurso, 2016). Da mesma maneira que no ano anterior, o regulamento apresentou uma descrição de cada categoria:

O Concurso compreende três categorias, a saber: - Conto: narrativa curta, com número reduzido de personagens, apresentando uma ou poucas ações e que tem sua origem na cultura oral. - Poesia: composição poética em versos. - Ilustração: imagem ou figura de qualquer natureza que acompanha, explica, interpreta, acrescenta informação, sintetiza ou elucida o texto do livro. (SÃO PAULO, 2012, p. 34).

Os participantes poderiam inscrever apenas um trabalho em cada categoria, assim como constava no regulamento de 2010. Para a inscrição, era necessário o preenchimento da ficha com os dados pessoais e informações sobre o material que seria entregue junto com o texto através de correspondência ou pessoalmente na Biblioteca Pedagógica, no período de 16 de abril a 11 de maio de 2012. O texto deveria conter apenas o pseudônimo do autor e estar em envelope separado da ficha de inscrição.

Em 16 de abril, o Boletim Nossa Escola n $^{\circ} 97$ publica informações sobre o concurso literário, comunicando que ele faz parte da $4^{\text {a }}$. edição do Valeu, Professor que acontecerá no mês de setembro, entre os dias 20 e 22. Ao apresentar a temática proposta, a notícia traz uma nota explicativa sobre o tema: “[...] A ideia é que os interessados discutam sobre as relações no meio digital, garantidas, muitas vezes, pelo anonimato, além das formas de expressão por meio do uso de ferramentas tecnológicas [...]" (Nossa Escola Boletim Oficial da Secretaria Municipal de Educação, 2012). Na entrevista que realizamos, o membro da comissão julgadora comenta a percepção que teve sobre o tema e os textos apresentados nesta edição:

[...] Eu me lembro é um tema muito aberto, Sob o céu da cidade também, o que fechou mais mesmo é o Sem Remetente.com, que aí a gente percebeu que houve um pouco mais de dificuldade, tanto que eu acho que foi o ano que teve menos... Menos inscrições, é. As pessoas, elas não se identificaram muito com o tema e, não sei, eu achei que foi mais complicado mesmo e, talvez, o que a qualidade dos textos seja pior, não sei... [...] (Entrevista com membro da comissão do concurso, 2016).

Seguindo os mesmos critérios de composição, a comissão julgadora foi constituída pela Portaria ${ }^{60} \mathrm{SME} \mathrm{n}^{\circ} 3.212$ de 22 de maio de 2012 e teve a participação de Avelino Aparecido Alves, Eduardo Yasuda, Ione Aparecida Cardoso Oliveira, Lucia Jurema Figueirôa, Patrícia Martins da Silva Rede e Silvana Moura Riguengo que foram

\footnotetext{
${ }^{60}$ Publicada no Diário Oficial da cidade de São Paulo em 23 de maio de 2012, p. 13.
} 
membros de edições anteriores, já a Lenice Bueno da Silva ${ }^{61}$ (representante da área editorial) passa neste ano a integrar a comissão. Os critérios de avaliação não foram alterados.

Para a escolha da ilustração, a comissão julgadora selecionou quatro obras, dentre as dez inscritas, que passaram por votação durante a Bienal Internacional do Livro de São Paulo e, para isso, a comissão elaborou a seguinte cédula:

Imagem 3. Cédula de votação da ilustração do concurso literário de 2012.

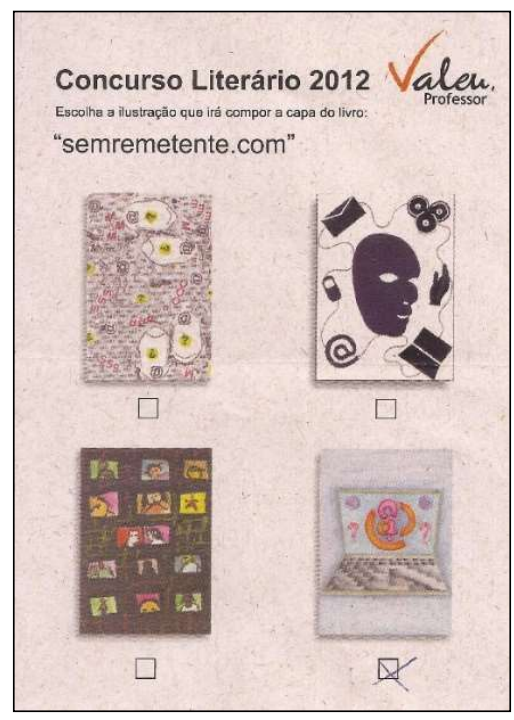

Fonte: Arquivo da Biblioteca Pedagógica (2012).

Durante a entrevista com membro da comissão do concurso, soubemos que a votação da ilustração para a capa do livro ocorreu somente na Bienal do Livro, como relata:

Só na Bienal, foi só na cédula mesmo. [...] Isso, exatamente, tanto que ela começava na Bienal e os votos eram apurados na Bienal, então, a decisão da capa ficava na Bienal. [...] na edição de 2012, a gente recebeu umas doze ou quinze ilustrações, foi bastante, mas a gente achava que quatro era um número bom pra por pra votação, porque mais que isso, às vezes acaba dando muito pouquinho votos pra algumas e acaba até atrapalhando. Então, também foram escolhidas as quatro e foi na bienal de 2012, do mesmo jeito, colocava as quatro nas cédulas, só que em $2012 \ldots$....], aí eu vou precisar lembrar como que foi... porque foi um pouquinho... porque os estandes eram diferente, os estandes da secretaria, em 2012, só teve um pedacinho lá pra isso [...]. (Entrevista com membro da comissão do concurso, 2016).

\footnotetext{
${ }^{61}$ Gerente editorial da Editora Moderna.
} 
A parceria com a editora Moderna para a confecção do livro foi mantida e, também, com a Câmara Brasileira do Livro.

O lançamento do livro Sem remetente.com ocorreu junto com a abertura da exposição Professor Artista, em 21 de setembro de 2012, na Galeria Prestes Maia durante o evento Valeu, Professor e teve a presença de vinte e cinco professores autores do total de 44 que tiveram seus textos e ilustração selecionados. O pequeno número de presentes pode ser compreendido pelo relato do membro da comissão do concurso quando nos fala sobre o lançamento no referido ano:

[...] em 2012, era fim de gestão [...] então, já foi um pouco mais difícil porque não podia sair "logo" das coisas porque teve eleição e, então, para evitar muito..., foi uma coisa bem mais simples, e o Professor Artista continuou sendo no gabinete do prefeito, mas em 2012 como tinha eleição, ficaram com um pouco de medo de fazer no gabinete do prefeito que era bem na época da eleição, outubro, então acabaram fazendo na praça [...] Prestes Maia, é isso, a galeria Prestes Maia, exatamente, foi na escada, então teve umas apresentações. A exposição do Professor Artista, então, foi lá e a gente aproveitou pra fazer o lançamento do livro lá também. Foi até legal, porque aquele espaço, ele é bonito, um espaço diferente, a gente tinha os bistrôs com os livros, com o... acho que eu até te mostrei, as plaquinhas de identificação dos professores... tudo, mas foi o ano que teve mais falta, o primeiro ano, sim, acho que a gente teve umas duas ou três faltas, no segundo, acho que por ser na Mário de Andrade, aí o pessoal só não foi mesmo quem estava doente, mas tivemos pouquíssimas faltas, mas nesse outro ano, foi bem grande o número de faltas, até porque teve também uma chuva torrencial, acho que ninguém conseguiu chegar, então, era até triste ver, sabe, muitos bistrôs vazios, sem ninguém, os livros todos lá com a sinalização... (Entrevista com membro da comissão do concurso, 2016).

De modo geral, as ilustrações inscritas neste ano trazem uma representação do universo virtual por meio de desenhos de computadores numa relação de anonimato com o outro e, nesse sentido, em alguns desenhos as pessoas não possuem rostos definidos. Assim, descreverei brevemente cada ilustração: a primeira é o desenho de um computador portátil em preto e branco e, ao redor dele, saem balões com desenhos de outros suportes de comunicação utilizados pela sociedade a saber, aparelho de celular, máquina de escrever, televisão, envelope indicando a carta, manuscrito representado por uma folha escrita e uma caneta, e rádio, na tela do computador está escrito o tema do concurso e no aparelho consta o nome da SME, abaixo do desenho está escrito "Concurso Literário Valeu, Professor", e no canto inferior direito o ano, com exceção do nome da secretaria, todos os outros aparecem na cor azul. A segunda é um desenho em cores, de um homem de costas sentado diante de um computador de mesa, parece estar concentrado realizando 
alguma atividade, ele está envolto por uma gaiola como se estivesse preso. A terceira mostra um computador portátil desenhado com lápis grafite, na tela aparece um olho e em seu interior o globo terrestre, diante do computador um rosto em perfil de uma pessoa que não possui olhos, está preenchida por linhas quadriculadas em preto e vermelho, entre o computador e a pessoa está o "mouse" representado pela forma de um relógio antigo e um anel circular, em seu interior há um rato, animal, correndo no anel demostrando a passagem do tempo. A quarta ilustração é um desenho em preto e branco de um espaço, podemos dizer de uma sala, onde aparece no centro um menino usando fones de ouvido e boné sentando diante de uma mesa com um computador portátil e em seus pés como apoio, pisando, aparece três livros que indicam na lombada Matemática, Português e Ciências, no lado direito e com uma mão apoiada na mesa e caída no chão aparece uma mulher de mais idade usando óculos, atrás dela aparece uma mulher mais jovem com os braços estendidos ao alto e em sua frente um homem com capuz, portando e apontando uma arma de fogo para ela, no canto esquerdo ao fundo está um homem adulto em cima de uma escada tentando arrumar o forro do teto que possui aberturas e por isso chove dentro da sala, na frente dele há um cachorro em cima de uma pequena mesa mordendo uma carteira e deixando cair o dinheiro que havia nela, ao fundo da sala há uma grande janela que mostra a chuva, no chão aparece muita água que está escorrendo pelo teto e molhando todo o espaço, mesmo diante de tal cenário, o menino se mantem concentrado em seu computador com uma xícara equilibrada em sua cabeça na qual goteja a água da chuva. A quinta é um desenho em preto e branco um menino sorridente que é parte humano, parte máquina, sentado em uma cadeira diante de um computador que está interligado a outras três crianças que aparecem detrás de seus computadores com expressões faciais distintas que se replicam nas telas de seus respectivos computadores. A sexta, um desenho em preto e branco de um homem que se assusta ao ligar o computador e ver que tem 1980 mensagens, a ilustração mostra um homem com a cadeira inclinada, caindo, diante do computador que possui um ponto de interrogação na tela e os envelopes representando mensagens que possuem somente um ponto de interrogação escrito nelas e se espalham pelo ambiente, na base do desenho aparece escrito muitas vezes, em muitas linhas, o tema do concurso, no canto superior esquerdo aparece um envelope aberto e parte de uma folha escrita e ao lado a mensagem "You have 1980 news messages".

Observamos que algumas ilustrações simplesmente representam o computador e seus ícones, no entanto, outros fazem a crítica em relação aos usos que a sociedade faz 
desse meio de comunicação e de informação identificada pela representação do isolamento que provoca e às vezes, de modo simbólico, numa forma de prisão. Há também a ideia de alienação ao contexto, desconsiderando os acontecimentos e voltando o interesse apenas para o universo virtual, além da representação da noção de excesso seja de informações, seja de mensagens que essas novas formas de comunicação em rede impõem ao indivíduo usuário.

Do mesmo modo que nos anos anteriores, os professores receberam dez exemplares e as DREs receberam unidades para distribuírem nas salas de leitura das escolas municipais.

Nos documentos da comissão julgadora identificamos uma troca de e-mails ${ }^{62}$ na qual o Canal Futura de Televisão convida os professores selecionados da edição de 2012 para concederem depoimentos que seriam gravados e exibidos no Espaço Professor na Bienal Internacional do Livro de São Paulo ${ }^{63}$.

Em todos os regulamentos consta a informação de que o concurso não oferece qualquer tipo de remuneração e não pode ser utilizado para evolução funcional. De acordo com informações de um membro da comissão julgadora, essa informação se fazia importante para desvincular a participação no concurso das atividades que geram ganhos e/ou benefícios na carreira, sendo esta de fato, na visão da SME, uma ação de valorização do professor em suas práticas culturais. O material enviado ao concurso, em todas as edições, deveria ser original e nunca ter sido publicado.

A ficha de inscrição também sofreu alterações durante as edições do concurso, pois em 2010 existia na ficha um campo para que o professor descrevesse sobre a motivação que o levou à criação do texto ou ilustração, já nos anos seguintes essa descrição é suprimida, permanecendo somente os dados pessoais e da obra, bem como uma pequena biografia do professor e uma declaração de cessão de direitos autorais elaborada pela comissão.

Nesse percurso histórico das edições do concurso literário é possível perceber que há permanências e mudanças na organização e execução deste, indicando, talvez, que as mudanças são tentativas de aperfeiçoamento do processo diante de ações que não tiveram êxito em anos anteriores.

Os textos selecionados para a publicação atendiam os critérios estabelecidos nos regulamentos, principalmente quanto à adequação do texto apresentado à categoria

\footnotetext{
${ }^{62}$ Documento não catalogado.

${ }^{63}$ Não identificamos outras informações sobre essa atividade externa à SME.
} 
escolhida para a inscrição. No entanto, no manuseio dos arquivos onde estão todos os textos inscritos, identifica-se que há textos que não correspondem à categoria escolhida pelo autor no momento da inscrição. Acreditamos, assim, que por receber textos incompatíveis com o gênero literário do concurso, optou-se por descrever no regulamento quais as características principais de cada gênero nos respectivos anos. Esse esclarecimento em relação aos gêneros literários feito pela comissão nos regulamentos, nos levar a supor que uma parcela dos professores participantes não tinha clareza quanto à forma dos gêneros conto e crônica. Sabemos que os professores possuem formações diversas, no entanto, se não dominam o gênero literário ao qual se apresentaram para o concurso, podemos supor que esses professores não possuem efetiva prática da escrita literária e, talvez, tenham se aventurado a escrever textos literários somente para se apresentar ao concurso e tentar uma forma de reconhecimento neste campo.

Portanto, percebemos ao manusear os documentos e realizar entrevista com membro da comissão, que o concurso literário estava inserido num grupo de ações da Secretaria Municipal de Educação que visavam o incentivo à leitura e a escrita entre os professores, assim como a formação de alunos leitores e escritores. A SME percebia o Valeu, Professor e os concursos nele inseridos como uma ação de valorização do profissional, mesmo que os professores participantes dos concursos, sendo selecionados ou não, estavam impedidos de contabilizar pontos desta atividade para as suas carreiras no município, segundo os regulamentos das três edições, como mostramos no excerto a seguir: "O Concurso Literário e sua divulgação têm cunho exclusivamente cultural e a participação nele não acarretará premiação e/ou pagamento em hipótese alguma. Os trabalhos publicados não terão efeito para fins de promoção e/ou evolução funcional" (SÃO PAULO, 2010, p. 12) ${ }^{64}$. O fato de a participação no concurso não gerar nenhuma pontuação para a carreira docente foi um aspecto que esteve presente na fala de alguns professores entrevistados, que entendiam que a valorização passava por considerar tal atividade como pontos para a carreira no magistério municipal.

Em relação a isso, compreendemos que não são todos os professores que desenvolveram uma habilidade artística, dessa forma, criar uma pontuação no interior da carreira para os possuidores de tal habilidade seria gerar um privilégio em relação aos que não o possuem, pois haveria sempre professores que não alcançariam pontos neste aspecto e, consequentemente, as carreiras não seriam equânimes.

\footnotetext{
${ }^{64}$ Portaria SME $n^{\circ} 2718$.
} 


\subsection{Os textos inscritos no concurso literário: dados gerais}

O concurso literário recebeu em 2010 um total de 155 textos inscritos, sendo 82 na categoria poesia, 37 na categoria crônica e 36 na categoria conto. Considerando que os professores poderiam se inscrever em mais de uma categoria, de acordo com os dados da comissão organizadora, 104 professores da rede municipal de educação de São Paulo realizaram inscrição no concurso. Desse total de textos inscritos, 53 foram publicados em livro, 87 não foram publicados e 15 foram desclassificados por não cumprirem o regulamento. Em relação ao descumprimento das normas, os problemas encontrados foram: inscrição fora do prazo estabelecido, envio de texto manuscrito quando este deveria ser um impresso, ausência de ficha de inscrição e dois textos inscritos numa mesma categoria o que não era permitido.

Este concurso recebeu muitos textos que trouxeram como tema as memórias: da infância, dos tempos de escola, dos professores, familiares e entre outras. Acredita-se que o tema definido para o ano tenha motivado os participantes a escreverem sobre suas lembranças, apesar disso, em relação aos textos inscritos no concurso e que não foram publicados, identificamos diferentes temáticas nas três categorias propostas.

Portanto, nos textos inscritos e não publicados nas três categorias 40 deles trazem como tema lembranças e memórias, sendo este um número significativo. Independente do gênero, os temas tratados nos textos foram agrupados como segue: lembranças/memórias da infância, dos familiares, da vida escolar e da profissão docente; histórias com elementos de fantasia/realismo fantástico (vampiros, lobisomem, viajante do tempo, e outros); morte; vida/existência; imigração; relação professor e aluno; ato de escrever; "do eu"65 (sentimentos - saudade, decepção, amor, indiferença, tristeza); cotidiano; e ensino/escola/educação. Nesse grupo, de modo geral, os textos que apresentam uma relação com a docência, a escola e a educação somam 23.

O concurso literário de 2011 recebeu 98 textos inscritos no total, sendo que 27 textos foram classificados para publicação, 62 não foram classificados, 9 desclassificados por não atender ao regulamento e 13 ilustrações. A desclassificação de alguns textos

\footnotetext{
65 “Do eu" - muitos textos, principalmente as poesias, tratam dos sentimentos e percepções do sujeito que escreve, assim, optou-se por reunir esses textos sob o título Do "eu". Esse termo foi pensado como forma de agrupar e classificar os textos a partir da publicação de Ana Chrystina Venancio Mignot intitulada Refúgios do eu: educação, história e escrita autobiográfica (2000).
} 
ocorreu por não atendimento da forma textual da crônica, ausência de ficha de inscrição e por haver inscrição de servidores técnicos da SME, mas eles não poderiam se inscrever.

Entre os textos não publicados, os temas identificados foram: o cotidiano na cidade nos seguintes aspectos - o trânsito, as diferenças sociais na cidade, a diversidade de pessoas e de atividades econômicas e culturais -; envelhecer; mudanças na paisagem da cidade; lembranças da infância e juventude; relação entre as pessoas; migração; suicídio; profissão docente; escola e sala de aula. Em relação aos textos que abordam aspectos do universo do professor - sendo a profissão, a escola, e os alunos -, estes somam 25 crônicas que não fazem parte do livro publicado.

O concurso literário de 2012 recebeu um total de 116 textos inscritos, sendo 66 poesias e 50 de contos. Desse universo de textos inscritos, 45 foram classificados para a publicação, 70 não foram classificados e apenas 1 texto (poesia) foi desclassificado por não atender ao regulamento. Neste caso, acreditamos que a postagem foi realizada após o período de inscrição do concurso e, por isso, o material não foi aceito pela comissão organizadora.

Em relação aos temas dos textos não publicados identificamos os seguintes: formas de comunicação através da internet, relações entre as pessoas antes e depois da internet, solidão e isolamento gerado pelas comunicações à distância, crítica ao tempo excessivo de uso das redes, diversidade de aplicativos e programas, comportamento das pessoas a partir da internet e relações afetivas pela internet.

O quantitativo total dos textos inscritos nos demonstra que o ano em que houve menos inscritos foi em 2011 e não 2012, como havia mencionado em entrevista o membro da comissão organizadora. Comparando o quantitativo dos textos, percebemos que a crônica é o gênero literário de menor inscrição, o que podemos inferir uma maior dificuldade do professor em escrever este tipo de narrativa literária. Esse pouco domínio do gênero pode ser decorrente das opções de leitura desses profissionais que, supomos, não abrange a crônica. De outro ponto, a poesia é o gênero literário que mais recebeu inscrições e, assim, sugerimos a hipótese de que este seja um gênero mais lido, principalmente, para os que atuam no ensino fundamental I e infantil, pois nesses anos de escolarização os professores trabalham de modo intenso com poesias infantis, músicas, cantigas, parlendas que são textos produzidos em verso. Essa inferência não significa que a poesia seja um gênero mais fácil que os demais, mas que o trabalho com determinados gêneros possibilita maior conhecimento do mesmo. Além disso, a poesia permite apresentar questões subjetivas dos indivíduos, o que chamamos de textos do "eu”, porque 
trazem aspectos sentidos e questões existenciais por meio de um eu lírico que não é um personagem de ficção, tampouco é autobiográfico em sentido estrito.

Os contos, por sua vez, são os textos em que percebemos elementos do realismo mágico conferindo o seu caráter ficcional, de criação literária, mas é também nesta modalidade em que há muitas histórias sobre a escola e a docência, transitando entre o ficcional com elementos de realidade.

\subsection{Professores participantes do Concurso Literário}

Com o objetivo de detalhar e compreender quem são os professores participantes das edições do Concurso Literário Valeu, Professor apresentaremos os dados dos professores ${ }^{66}$ utilizando, para isso, as informações das fichas de inscrição e a breve biografia dos selecionados que estão publicadas na última parte dos livros. Desse modo, escolhemos apresentar os dados separados por edição para assim identificar mudanças e continuidades dentre os participantes ${ }^{67}$.

Portanto, apresentaremos os seguintes dados: formação, DRE em que atua, sexo, condição de ativo ou aposentado e a produção escrita que foi identificada por meio das breves biografias elaboradas na ficha de inscrição. Ressaltamos que esses dados são de grande importância para configurar o grupo participante, no entanto, as informações postas nas fichas não são as mesmas, pois alguns dados que identificamos e entendemos como necessário nesta descrição não constituía um aspecto definido pela ficha, mas sim as escolhas dos professores de apresentarem determinado item, por exemplo, a formação e a modalidade de ensino não consta em todas ${ }^{68}$.

\section{$\underline{\text { Situação funcional dos professores }}$}

As edições do concurso literário possibilitaram que todos os professores em atividade nas escolas municipais e os aposentados participassem e, nesse sentido,

\footnotetext{
${ }^{66}$ Os professores inscritos na categoria ilustração estarão incluídos nestes dados.

${ }^{67}$ Optamos por apresentar os dados dos professores selecionados (vencedores) pelo concurso literário, considerando que os professores entrevistados fazem parte deste universo, assim como os textos que abordaremos adiante.

${ }^{68}$ A ficha de inscrição solicitava os seguintes dados pessoais: nome, pseudônimo, número dos documentos pessoais ( $\mathrm{RG}, \mathrm{CPF}$ ), registro funcional $(\mathrm{RF})$, endereço, telefones, e-mail, unidade educacional e diretoria de ensino.
} 
identificamos que há professores aposentados em número extremamente reduzido dentre os textos publicados.

Em 2010 são quarenta e nove (49) professores autores no total. Desses, apenas três (3) são aposentados, os outros, incluindo a autora da ilustração ${ }^{69}$, estão exercendo a profissão. No ano de 2011 não há textos publicados de professores aposentados, todos estão na condição de ativos de um total de vinte e sete (27), porém há uma professora que se aposentou de cargo de diretoria e ingressou novamente na rede de ensino como professora. Em 2012 também identificamos uma professora que está aposentada, mas que continua exercendo a profissão na rede municipal de ensino aparecendo, neste caso, como ativa; são quarenta e quatro (44) professores no total neste ano, incluindo o autor da ilustração. Desse modo, os professores aposentados são minoria nos livros do concurso literário.

\section{Classificação por sexo}

Retomaremos neste ponto a classificação por sexo, agora em relação ao número de professores e não sob a perspectiva dos textos como apresentado anteriormente.

O quadro que segue mostra que as professoras são maioria em todos os livros publicados, numa proporção mínima de o dobro em relação aos professores homens. Esse pode ser um indício do processo de feminização pela qual passou a profissão docente e que também se reflete nos dados do concurso literário.

\begin{tabular}{|c|c|c|c|}
\hline \multicolumn{4}{|c|}{ Professores por ano e sexo (vencedores) } \\
\hline & Feminino & Masculino & Total por ano \\
\hline 2010 & 33 & 17 & 50 \\
\hline 2011 & 19 & 8 & 27 \\
\hline 2012 & 35 & 9 & 44 \\
\hline Total por sexo & 87 & 34 & \\
\hline
\end{tabular}

$\underline{\text { Região de atuação na cidade }}$

\footnotetext{
${ }^{69}$ Incluindo a autora da ilustração vencedora somam-se cinquenta (50) professores.
} 
As escolas municipais de São Paulo estão agrupadas em treze Diretorias Regionais de Educação de acordo com a localização geográfica das unidades, por isso, apresentaremos as regiões de atuação dos professores seguindo a alocação da escola nas diferentes diretorias.

Ao observar o quadro que segue, percebemos que nenhum professor atuante na DRE Guaianazes aparece nos livros e as DREs Itaquera, São Mateus, Capela do Socorro e Butantã possuem o menor número de professores, sendo as duas primeiras citadas juntamente com Guaianazes pertencentes à zona leste da cidade, sendo regiões consideravelmente afastadas em relação a área central. De outro ponto, reconhecemos que os professores das DREs Santo Amaro e Pirituba/Jaraguá são em maior número, sendo estas regiões opostas na cidade, a primeira na zona sul e a segunda na zona norte ocupando uma grande área considerada extremo norte.

\begin{tabular}{|l|l|l|l|}
\hline \multicolumn{4}{|c|}{ Professores vencedores por Diretoria Regional de Educação } \\
\hline Diretoria/ Ano & $\mathbf{2 0 1 0}^{\mathbf{7 0}}$ & $\mathbf{2 0 1 1}^{\mathbf{7 1}}$ & $\mathbf{2 0 1 2}^{\mathbf{7 2}}$ \\
\hline Butantã & 3 & 1 & 1 \\
\hline Campo Limpo & 5 & 3 & 4 \\
\hline Capela do Socorro & 0 & 1 & 2 \\
\hline Freguesia/Brasilândia & 3 & 2 & 5 \\
\hline Guaianazes & 0 & 0 & 0 \\
\hline Ipiranga & 3 & 5 & 6 \\
\hline Itaquera & 1 & 1 & 1 \\
\hline Jaçanã/Tremembé & 6 & 0 & 3 \\
\hline Penha & 6 & 6 & 2 \\
\hline Pirituba/Jaraguá & 10 & 4 & 6 \\
\hline Santo Amaro & 7 & 4 & 10 \\
\hline São Mateus & 3 & 0 & 2 \\
\hline São Miguel & 4 & 1 & 3 \\
\hline
\end{tabular}

\footnotetext{
${ }^{70}$ Um professor atua em escolas de diferentes Diretorias Regionais de Educação (DRE) - Butantã e Pirituba/Jaraguá.

${ }^{71}$ Um professor atua em escolas pertencentes as DREs Ipiranga e Santo Amaro.

72 Professor atuando em escolas das DREs Ipiranga e Santo Amaro.
} 


\section{Etapas da Educação Básica}

Os professores participantes lecionam em distintas etapas da Educação Básica e alguns atuam em duas delas. No ano de 2010, verificamos que a maioria atua no Ensino Fundamental (31), seguido da Educação Infantil (9) e Educação de Jovens e Adultos (1). Em atuação em duas etapas identificamos no Ensino Fundamental e EJA (1), na Educação Infantil e Ensino Fundamental (1) e no Ensino Fundamental e Médio (1). Detectamos, ainda, os professores que exercem outro cargo no interior da carreira do magistério, a saber: coordenador pedagógico (1), supervisor escolar (2), gestor de unidade educacional (1) e assistente de direção (1). Não foi possível localizar informações acerca de um professor, de modo que desconhecemos a etapa em que atua e o nome da escola.

Em 2011, detectamos que a maior parte dos professores lecionam no Ensino Fundamental (22), na Educação Infantil são apenas três (3) e os que exercem outros cargos somam apenas dois (2), realizando atividades na coordenação de Ação Educacional e coordenação pedagógica. Neste grupo não identificamos professores atuantes em mais de uma etapa da educação básica.

No ano de 2012, do universo de quarenta e quatro professores, constatamos que a maioria atua no Ensino Fundamental (24), seis (6) na Educação Infantil e um (1) na Educação de Jovens e Adultos. Neste grupo há professores lecionando em mais de uma etapa, na Educação Infantil e Ensino Fundamental (2), no Ensino Fundamental e Médio (3). Os professores que desenvolvem atividades em outros cargos da carreira são em maior número nesta edição somando oito (8), sendo co-gestor de Merenda Escolar na DRE (1), coordenação pedagógica (2), ATE1 (2), gestor de unidade educacional (1) e supervisor (2).

\section{Formação dos Professores}

Conhecer a formação dos professores participantes se faz de extrema importância para compreendermos quem são os professores escritores que participaram do concurso literário, no entanto, este aspecto será apresentado de modo parcial em função da ausência desta informação em todas as fichas de inscrição.

Em 2010, do total de cinquenta professores vencedores do concurso, não identificamos a formação de onze (11) deles. De modo geral, esses professores realizaram cursos de graduação na área de humanidades e em minoria nas áreas de ciências exatas e 
biológicas, sendo que nove (9) deles realizaram dois cursos de graduação e apenas três (3) afirmaram ter cursado magistério.

O quadro a seguir mostra os cursos de graduação realizados e o quantitativo referente a cada curso:

\begin{tabular}{|l|l|}
\hline \multicolumn{2}{|c|}{ Formação dos Professores Vencedores de 2010 } \\
\hline Cursos de Graduação & Quantitativo \\
\hline Pedagogia & 14 \\
\hline Letras & 12 \\
\hline Artes/Educação Artística & 1 \\
\hline História & 2 \\
\hline Geografia & 1 \\
\hline Biologia & 1 \\
\hline Letras e Comunicação Social & 2 \\
\hline Pedagogia e História & 1 \\
\hline Matemática e Administração de Empresas & 1 \\
\hline Pedagogia e Letras & 2 \\
\hline Pedagogia e Ciências Sociais & 1 \\
\hline Pedagogia e Educação Artística & 1 \\
\hline
\end{tabular}

No ano de 2011, dos vinte e sete (27) professores selecionados, não identificamos a formação de seis (6). Novamente, verifica-se o predomínio dos cursos na área de humanidades, sendo que apenas dois professores concluíram cursos em outras áreas, a saber: Biologia e Licenciatura em Ciências. Os que realizaram mais de um curso de graduação aparecem em pequeno número, apenas três (3) professores. O quadro a seguir mostra os cursos e seus respectivos quantitativos.

\begin{tabular}{|l|l|}
\hline \multicolumn{2}{|c|}{ Formação dos Professores Vencedores de 2011 } \\
\hline Cursos de Graduação & Quantitativo \\
\hline Pedagogia & 7 \\
\hline Letras & 7 \\
\hline Artes Plásticas & 1 \\
\hline
\end{tabular}




\begin{tabular}{|l|l|}
\hline História & 1 \\
\hline Geografia & 1 \\
\hline $\begin{array}{l}\text { Licenciatura em Ciências (habilitação em } \\
\text { Matemática }\end{array}$ & 1 \\
\hline Pedagogia e História & 1 \\
\hline Letras e Bacharel em Estudos Linguísticos & 1 \\
\hline Biologia, Pedagogia, Direito & 1 \\
\hline
\end{tabular}

Em 2012 não identificamos a formação de oito (8) professores dentre os quarenta e quatro (44) selecionados, predominando os cursos na área de humanidades, tendo apenas dois (2) professores formados na área das ciências exatas, em Química e Matemática. Além disso, neste grupo existe apenas cinco (5) professores formados em dois ou mais cursos de graduação.

\begin{tabular}{|l|l|}
\hline \multicolumn{2}{|c|}{ Formação dos Professores Vencedores de 2012 } \\
\hline Cursos de Graduação & Quantitativo \\
\hline Pedagogia & 9 \\
\hline Letras & 14 \\
\hline Artes Plásticas/ Educação Artística & 2 \\
\hline História & 3 \\
\hline Matemática & 1 \\
\hline Pedagogia e Artes/Educação Artística & 1 \\
\hline Pedagogia e Química & 1 \\
\hline Pedagogia e Letras & 3 \\
\hline $\begin{array}{l}\text { Pedagogia, Letras e Comunicação Social } \\
\text { (Jornalismo) }\end{array}$ & 1 \\
\hline Comunicação Social (Jornalismo) & \\
\hline
\end{tabular}

Outras práticas da escrita

$\mathrm{Na}$ breve biografia elaborada a critério de cada professor, detectamos indícios de outras práticas da escrita efetivadas por eles variando da escrita pessoal à publicação de

\footnotetext{
${ }^{73}$ Este professor explicitou que cursou Jornalismo, mas não informou o curso de licenciatura realizado.
} 
livros, da escrita manuscrita às escritas digitais, ou seja, essas declarações que fazem os professores de suas práticas abarcam variados modos de se relacionar com a escrita e, também, a produção de diferentes suportes para o escrito.

Desse modo, em 2010 são dezenove (19) professores que afirmam em sua biografia a produção de algum tipo de material escrito, constatando-se a produção de escrita pessoal como cadernos de poesias, sentimentos e pensamentos, e diários, outros são poesias publicadas em revistas, jornais e antologias, livros de literatura infantil, crônicas e ainda peça de teatro. Em 2011, são dez (10) professores que registram na biografia outras práticas da escrita. Identificamos neste grupo, distinto do anterior, a escrita para blogs e a participação em outros concursos literários - embora nenhum deles indique que escreva diários ou cadernos de escrita íntima. No ano de 2012, reconhecemos que vinte e três (23) professores escrevem para além do concurso literário Valeu, Professor evidenciando escritas pessoais, participação em outros concursos literários, publicação em antologias, crônicas, poesias em suporte impresso e digital. Diferentemente dos anteriores, neste grupo há um professor que escreve histórias em quadrinhos e outro que publicou um livro sobre métodos de ensino.

Com esses dados extraídos apenas dos livros das três edições do concurso, podemos afirmar que uma parcela dos professores participantes possui uma prática da escrita pessoal e literária que independe da ação do concurso, ou seja, não possuem uma escrita apenas voltada ao concurso, mantendo uma produção escrita com intencionalidades diversas. Por outra parte, podemos supor que os professores que não apresentam em suas biografias informações sobre outras práticas da escrita são aqueles que produzem somente pela indução do concurso, ou seja, apenas escrevem para apresentar ao concurso e, talvez, com isso ter algum tipo de reconhecimento no interior da instituição. Nesse sentido, não foram contabilizados os professores que informaram em sua biografia a participação em outras edições do Valeu, Professor sem mencionar outras escritas realizadas.

\subsection{Imagens veiculadas pela imprensa oficial e a percepção dos professores}

O Diário Oficial da cidade de São Paulo e o Nossa Escola Boletim Oficial da Secretaria Municipal de Educação de São Paulo foram meios de comunicação usados para divulgar as ações do Concurso Literário Valeu, Professor visando alcançar a 
comunidade de profissionais da rede municipal de ensino. O Diário Oficial da cidade de São Paulo é a imprensa oficial na qual se publica todos os documentos expedidos pela prefeitura, no entanto, no período de ocorrência do concurso este veículo trazia na página inicial uma notícia acerca das ações da prefeitura tendo o mesmo formato que de um jornal. O Nossa Escola Boletim Oficial da Secretaria Municipal de Educação de São Paulo é uma impressa pedagógica restrita à SME, no formato de boletim informativo curto, destinada aos profissionais da educação.

O Nossa Escola foi um boletim produzido entre 2009 e 2012 trazendo informações da SME para os profissionais da rede de ensino, dessa forma, identificamos notícias sobre a carreira docente, concursos de acesso à determinados cargos na carreira, divulgação e convite para a participação em concursos na área da cultura e artes destinados a professores ou alunos, projetos desenvolvidos em escolas, ações pedagógicas e administrativas da SME, divulgação sobre a oferta de formação continuada para professores, entre outras. A periodicidade não é regular, no primeiro ano o boletim teve onze edições, nos anos de 2010 e 2011 são quarenta edições por ano indicando a periodicidade semanal, já em 2012 observamos que a periodicidade se mantém no primeiro semestre, mas ocorreu uma redução no segundo semestre fazendo com que as edições totalizassem vinte e uma.

No início do ano letivo de 2011, o Nossa Escola apresenta uma pequena nota informando a comunidade que ocorrerá o Valeu, Professor já com as datas das principais atividades como forma de chamar a atenção para essa ação institucional e convidar à participação antecipadamente, como mostra o excerto: "Lembrete! A $3^{\mathrm{a}}$. edição do Valeu, Professor! Já tem data marcada. Será nos dias 7, 8 e 9 de outubro, em vários pontos da cidade. Fiquem atentos e acompanhem as novidades!"74

O Nossa Escola é utilizado como forma de comunicar a existência dos concursos, instigar a participação e indicar aonde podem ser encontradas as informações detalhadas. Assim, extraímos dois excertos de notícias publicadas no boletim como forma de divulgar as edições do evento e os concursos destinados aos professores nos quais descrevem as atividades que serão oferecidas e as categorias de participação:

A $2^{\mathrm{a}}$. edição do Valeu, Professor será ainda melhor neste ano, com três dias de atividades culturais, artísticas e lúdicas. O evento, que acontece nos dias 22, 23 e 24 de outubro, é uma homenagem aos educadores da cidade de São Paulo e já tem inscrições abertas para o Professor Artista

\footnotetext{
${ }^{74}$ Nossa Escola Boletim Oficial da Secretaria Municipal de Educação de São Paulo, no 58, 14 de abril de 2011 .
} 
e para um inédito Concurso Literário. Confira os regulamentos no Portal da Educação e participe! (SÃO PAULO, 2010) ${ }^{75}$.

O Valeu, que chega a sua terceira edição, conta com um diferencial: durante os três dias a cidade abre espaço para que os educadores, principais protagonistas da Educação, mostrem seus talentos e exponham suas artes. [...] E, para completar, obras escolhidas em um concurso literário vão compor um livro de crônicas, com textos inéditos e ilustração de capa produzidos por profissionais da Rede Municipal de Ensino [...]. (SÃO PAULO, 2011) $)^{76}$.

No Diário Oficial da cidade de São Paulo constam os regulamentos das edições do concurso literário, a nomeação das comissões e comunicados que normatizam o concurso publicados na seção correspondente à SME e sem destaque. Com objetivo de enfatizar a ação institucional de realizar um concurso literário para professores, identificamos notícias na capa desta imprensa oficial apresentando uma linguagem narrativa, como usada nas reportagens jornalísticas, assim como consta também no boletim Nossa Escola e que é distinta da que aparece nos documentos oficiais como as portarias, regulamentos e afins.

A notícia principal da capa do Diário Oficial da cidade de São Paulo, n ${ }^{\circ}$ 143, sob o título "Público pode escolher, até o dia 12, capa de livro escrito por professores" informa que a capa do livro gerado a partir do concurso literário será escolhida pelo público da cidade e faz um convite para a votação das ilustrações finalistas criadas por professores. No entanto, o texto marca as motivações do concurso e, de modo mais amplo, o do Valeu, Professor, como modo, talvez, de mostrar à população que a gestão municipal valoriza os profisssionais da educação pública. A seguir o excerto da notícia: "Promovido pela SME com o intuito de incentivar, revelar e divulgar os talentos literários dos profissionais que atuam na rede, o concurso deu início às atividades da terceira edição do Valeu, Professor, uma homenagem da Cidade a seus educadores $[\ldots]^{p, 77}$.

Além disso, a imprensa oficial e pedagógica comunicava os resultados das três edições do concurso literário e o lançamento dos livros utilizando, para isso, o discurso do êxito nas ações realizadas e afirmando o alcance de um grande número de profissionais da educação e de público, como mostram os trechos a seguir:

\footnotetext{
${ }^{75}$ Nossa Escola Boletim Oficial da Secretaria Municipal de Educação de São Paulo, nº 23, 26 de maio de 2010.

${ }^{76}$ Nossa Escola Boletim Oficial da Secretaria Municipal de Educação de São Paulo, no 62, 25 de maio DE 2011.

${ }^{77}$ ANCHESCHI, Bruna. "Público pode escolher, até o dia 12, capa de livro escrito por professores". Diário Oficial da cidade de São Paulo, no 143, 02 de agosto de 2011, p. 01.
} 
Os ganhadores do Concurso Literário Valeu, Professor 2010 foram conhecidos na última quinta-feira, 12, na abertura da Bienal do Livro. Cinquenta e três obras irão compor o livro Eu me lembro: Crônicas, contos e poesia [...]. (SÃO PAULO, 2010) ${ }^{78}$.

No último dia da Bienal do Livro, a Secretaria Municipal de Educação divulgou a ilustração vencedora do Concurso Literário Valeu, Professor 2010. [...] A publicação conterá textos produzidos por outros 40 educadores e será lançada em outubro. A escolha foi feita pelo voto direto do público no estande que a Secretaria montou na Bienal. Ao todo, foram computados 5.111 votos. (SÃO PAULO, 2010) ${ }^{79}$.

A expressão "protagonista" empregada em diversos documentos da imprensa oficial e pedagógica indica um discurso no qual o professor tem importância central nas ações institucionais e corrobora com essa ideia os documentos e notícias oficiais nos quais o discurso está construído usando os termos "homenagear", "valorizar" e "incentivar". A concepção do concurso literário e do Valeu, Professor aparece desde a primeira edição, em 2010 e 2009 respectivamente, nos documentos como uma ação institucional de valorização do professor que atua na educação pública. A fim de comparar o que foi veiculado na imprensa oficial, identificamos dois trechos das entrevistas concedidas para a pesquisa por professores participantes do concurso e que tiveram seus textos selecionados para a publicação. Perguntamos aos professores sobre a percepção que tiveram do Concurso Literário Valeu, Professor e, com base neste questionamento, apresentamos os trechos que seguem:

$\mathrm{Eu}$ achei bem interessante, como eu te disse, porque ele tinha um tema, porque participaram professores de toda a rede, porque os textos selecionados, se a gente for olhar, a grande maioria tem uma qualidade muito boa, são textos interessantes, são textos que, às vezes, você até consegue trabalhar em sala de aula dependendo da faixa etária que você trabalha com os alunos. [...] Então, eu acho que a ideia do concurso foi muito boa, e ele promoveu isso, uma integração entre os professores, a gente conhecer, eu estou na Diretoria de Ensino do Ipiranga, aí conhecer uma professora que está na Diretoria de Ensino de Pirituba e que também tem esse gosto por escrever [...], então, foi muito legal. E até saber como é o trabalho de outros professores. (Entrevista pessoal professora Esther, 2018).

[...] não há nenhum incentivo para literatura dentro, eu não acho que há incentivo para literatura dentro da prefeitura, aí ele faz um concurso... [...] não tem nenhum tipo de incentivo porque você escreve, você não é incentivada toda vez que você vai para um evento de literatura, pode ser em faculdade, em qualquer lugar, você não é dispensada ou sai mais

\footnotetext{
${ }^{78}$ Nossa Escola Boletim Oficial da Secretaria Municipal de Educação de São Paulo, no 33, 17 de agosto de 2010.

${ }^{79}$ Nossa Escola Boletim Oficial da Secretaria Municipal de Educação de São Paulo, nº 34, 24 de agosto de 2010.
} 
cedo para ir participar, porque é alguma coisa que vale a pena. É nesse sentido que me desmotivei até a participar de outros. [...] Colocando no Portal parece que há um incentivo, mas na verdade não há. Não acho que há um incentivo, tudo bem, foi legal eles terem feito, mas foi só o que eles fizeram, não teve mais nada além que conectou o projeto também, foi um concurso só. (Entrevista pessoal professora Márcia, 2018).

Observamos no relato concedido pelos professores que a percepção deles sobre o concurso literário é distinta daquela veiculada na imprensa oficial. A primeira professora indica aspectos considerados positivos em relação ao concurso literário e enfatiza que este promoveu a integração entre os profissionais da rede, o que se justifica por ser a rede municipal de educação muito grande e com muitos profissionais, além de o livro publicado ser um material que pode ser utilizado em sala de aula. No segundo relato, a professora afirma que o concurso foi uma ação isolada e que não identifica no interior da carreira municipal ações de incentivo ao professor que escreve e, nesse sentido, nem ações que permitam maior participação destes no campo da literatura. Portanto, em nenhum desses relatos as professores perceberam o concurso como uma ação de valorização do profissional e da carreira docente, mesmo que compreendam que este tenha aspectos positivos.

Neste momento consideramos importante pontuar um aspecto que colabora para que a professora Márcia tenha compreendido o concurso literário como uma ação isolada. Durante a entrevista, a professora relatou que, por duas vezes, recebeu convite para participar de atividades literárias em outro país, lançando um de seus livros e divulgando seu trabalho artístico em um evento literário. Convites esses que foram aceitos, mas quando buscou o apoio institucional para justificar a ausência nos dias letivos considerando que existe um documento oficial que permite um tipo de afastamento para participação em atividades da área do professor, não encontrou respaldo, como relata no trecho da entrevista a seguir:

[...]eu sabia que eu tinha direito de um tipo de afastamento e ninguém sabia como fazia para eu ir até Alemanha e fazer o lançamento do livro, e eu não estava pedindo nada. Se você olhar no documento, se é algo que tem a ver com a sua..., com o que você leciona, você pode ganhar até a acomodação [...]. Eu pedi dez dias de afastamento, que era o que eu tinha direito é pedir o afastamento, dez dias, isso tá desde março indo e voltando porque eles consideram que dez dias é muito tempo para eu ir para Alemanha e voltar para lançar um livro [...]. E dias letivos foram cinco, na verdade, que eu perdi, que eu perdi foram cinco dias letivos, o resto era sábado, domingo e feriado [...]. Uma vez eu fui também participar em Portugal, mas não era numa publicação, era um evento que tinha em Portugal [...] um português que vive aqui no Brasil [...] faz 
várias coisas sobre poesia [...], e ele me chamou, aí eu fui, só que ninguém sabia me falar, sabia que tinha direito a algum tipo de afastamento, mas não sabia me explicar, nem na escola, nem em lugar nenhum, então, eu acabei indo e fiquei com dez faltas também [...], quer dizer, é umas coisas que você não tem..., ou seja, eles não consideram, eu falei, o problema é que eles não consideram literatura. [...] quando eu fui reclamar na Diretoria de Ensino, o quê que uma das funcionárias [...] que trata desses assuntos, não sei exatamente o que ela faz, ela falou, "Ah, mas pode ser que tenha... esteja sendo considerado que como você foi lançar o livro, seja algo pessoal, que você foi como algo pessoal." Nossa, algo pessoal, se eu sou de Língua Portuguesa, sou professora de Língua Portuguesa é algo pessoal? [...] Fora a portaria que tem lá, tem nesse decreto, tem falando sobre coisas artísticas, está dentro, $[\ldots]$ mas a própria pessoa que está tratando disso acha que literatura não é algo... tipo, importante. (Entrevista pessoal professora Márcia, 2018).

Fazendo o contraponto, percebemos que o concurso literário não se configurou uma ação isolada da SME, ele estava conectado a uma série de outras atividades distribuídas nas diferentes DREs, como apontamos anteriormente, no entanto, o Valeu, Professor em suas diversas modalidades tomou grande proporção no âmbito da secretaria e se tornou mais visível do que outras ações que eram mais localizadas como, por exemplo, o Programa Ler e escrever - prioridade na Escola Municipal que era destinado aos anos iniciais do Ensino Fundamental. Assim sendo, o professor atuante no Ensino Médio, EJA e Ensino Fundamental II, talvez, não tomasse conhecimento deste projeto.

Retomamos um aspecto presente nos regulamentos do concurso literário que gerou incômodo a um dos professores durante a entrevista: "O Concurso Literário e sua divulgação têm cunho exclusivamente cultural e a participação nele não acarretará premiação e/ou pagamento em hipótese alguma. Os trabalhos publicados não terão efeito para fins de promoção e/ou evolução funcional" (SÃO PAULO, 2010, p. 12) ( $^{80}$. De acordo com o trecho transcrito do regulamento do concurso, os participantes não poderiam utilizar a participação em tal como uma atividade a ser contabilizada para a carreira. Este aspecto se coloca contraditório para professores que compreendem que a valorização do profissional deveria passar por este aspecto, considerando que os professores efetivos na educação pública devem todos os anos participar de algumas atividades formativas e de outra natureza para ascenderem na carreira do magistério a cada ano e/ou período.

Desse modo, observamos que a noção de valorização está muito ligada à carreira no sentido da ascensão e da remuneração, por isso, quando as atividades do Valeu,

\footnotetext{
${ }^{80}$ Portaria SME no 2718,2010 , p. 12.
} 
Professor não pontuam para fins da carreira no magistério, esta não é considerada pelos professores uma ação de valorização.

Esses aspectos discutidos demonstram que as ações divulgadas na imprensa oficial por meio do Diário Oficial da cidade de São Paulo e pelo Nossa Escola Boletim Oficial da Secretaria Municipal de Educação de São Paulo trazendo além dos regulamentos, portarias e comunicados que envolveram o concurso, também noticiaram as etapas do mesmo sempre veiculando a imagem de uma ação institucional realizada com êxito e com participação da comunidade de profissionais da educação e, em alguns casos, com a comunidade externa objetivando "valorizar" e "homenagear" os professores da cidade, entretanto, esse ponto de vista da SME é concorrente com a de alguns professores que não possuem a mesma percepção.

\subsection{Antologias do Concurso Literário Valeu, Professor: fontes materiais da pesquisa}

\section{Eu me lembro: crônicas, contos e poesias}

Nas três edições do Concurso Literário Valeu, Professor os textos vencedores foram organizados em uma antologia que teve como título o tema do concurso. A capa do livro foi elaborada a partir da ilustração vencedora. Na edição de 2010, a ilustração vencedora foi criada pela professora Ana Karla Chaves Muner, que atua como professora de informática educativa na educação infantil e é, também, artista plástica. Na contracapa da edição consta primeiro o realizador do concurso, em seguida o título do livro, abaixo o nome do concurso acompanhado do seu logotipo e as empresas colaboradoras no final da página. 
Imagem 4. Capa e contracapa do livro do concurso literário publicado em 2010.

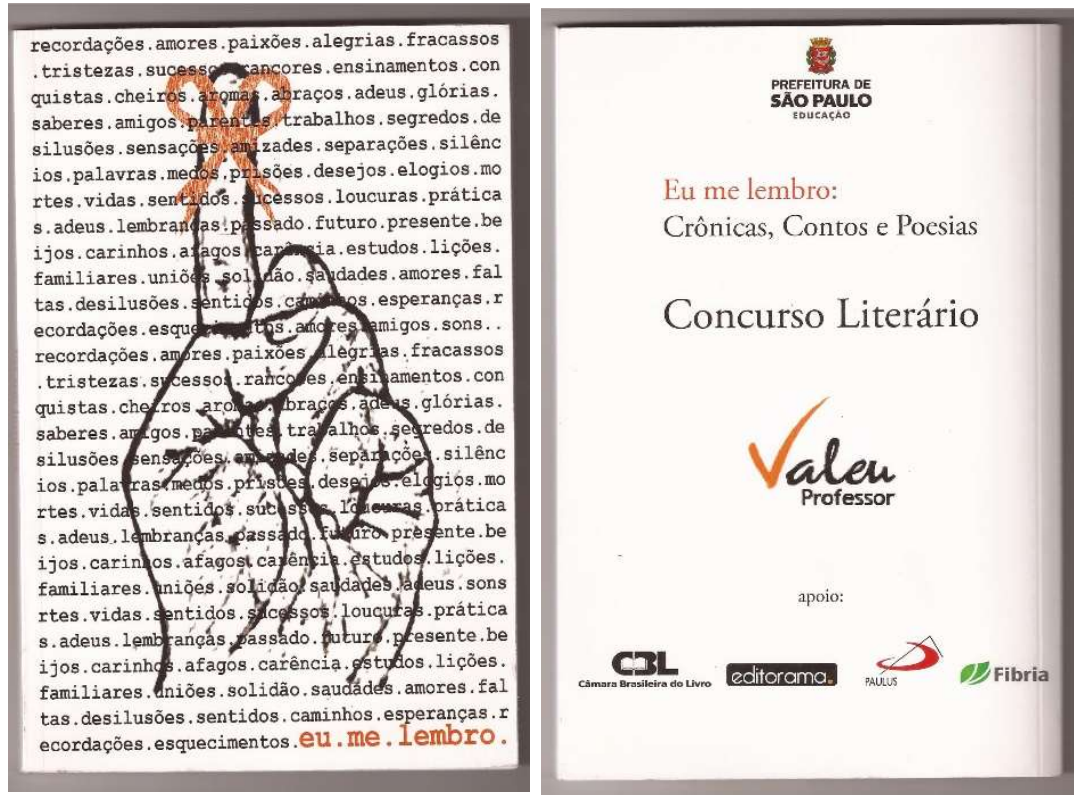

O livro é uma edição de 144 páginas composta pela folha de rosto, verso da folha de rosto contendo informações sobre os participantes no processo de produção do livro e da gestão da SME, ficha catalográfica, agradecimentos, carta de apresentação assinada pelo Secretário Municipal de Educação, sumário, apresentação elaborada pela comissão julgadora, os textos - miolo do livro -, informações sobre os autores incluindo a ilustradora e, ao final, um texto produzido pela empresa Fibria sobre as florestas no Brasil e a produção de papel. O número de páginas do livro - 144 - foi decido pelos parceiros que custearam a produção, assim, não havia no regulamento um quantitativo de textos que seriam selecionados para a publicação.

$\mathrm{Na}$ antologia Eu me lembro: crônicas, contos e poesias, os textos que compõem o livro são oito crônicas (8), cinco contos (5) e quarenta poesias (40). De acordo com informações da comissão julgadora, essa diferença na quantidade dos gêneros literários publicados ocorreu porque houve mais inscrições de poesias do que de contos e crônicas.

Considerando a temática do concurso em 2010, percebe-se ao ler os textos grande diversidade de temas/assuntos tratados e, para classificá-los, foram usadas palavras-chave que definiam de algum modo o assunto trazido no texto, bem como realizou-se agrupamentos dos assuntos afins. Quando a pesquisa abarca diferentes tipos de fontes é necessário realizar uma classificação para melhor compreensão das mesmas. Em relação às fontes, Viñao afirma: “[...] Qualquer que seja o critério de classificação ou distinção 
empregado, sempre surgem textos que se movem em terra de ninguém ou em mais de um espaço textual" (2004, p. 340), ou seja, qualquer classificação definida não abarcará a complexidade da realidade que se apresenta nos textos. Realizar uma classificação temática dos textos é uma forma adotada com objetivo de detalhar esses materiais, como indica Viñao, para elucidar se a informação trazida pelo texto responde ao que busca a pesquisa. Assim, a classificação apresentada será dos temas identificados nos textos por categoria do concurso.

No gênero crônica, os textos abordaram a vida cotidiana (3), o cotidiano da escola (1), a infância (2), a escrita de discurso político (1), sobre alunos e ser professor (1). Em relação aos contos, são cinco publicados nesta edição que trazem como temas aspectos da vida escolar (3), jogos e a infância (1), e vida conjugal (1). As poesias, em maior número neste livro, somam quarenta textos. Muitas possuem o mesmo título que o tema do concurso (7) e os assuntos abordados nas poesias são: lembranças da infầncia (9), sentimentos (9), reflexões sobre a vida/existência (8), a escola, professores e alunos (9), vida cotidiana (1), humanidade (1), sobre cidade (2), história da escrita (1).

O quadro que segue apresenta a classificação temática textos:

\begin{tabular}{|l|l|l|l|}
\hline \multicolumn{3}{|c|}{ Eu me lembro: Crônicas, Contos e Poesias - 2010 } \\
\hline Título & Gênero & Tema & $\begin{array}{l}\text { Relação com a } \\
\text { profissão docente }\end{array}$ \\
\hline Dona Sílvia & Crônica & vida cotidiana & Sim \\
\hline A Velha Alva e o Cão Sarnento & Crônica & vida cotidiana & Não \\
\hline No Ritmo do Pop & Crônica & vida cotidiana/Michael Jackson & Não \\
\hline Fuxico no Estacionamento & Crônica & cotidiano da escola & Sim \\
\hline & & & $\begin{array}{l}\text { menção ao menino } \\
\text { erudito influenciado } \\
\text { pelos pais professores }\end{array}$ \\
\hline Eu Me Lembro, Fui à Lua em 1969 & Crônica & infância & Sim \\
\hline Lista de Chamada & Crônica & alunos e ser professor & Não \\
\hline Nó na Gravata & Crônica & lembranças da infância & Não \\
\hline Autóctone na Política & Crônica & escrita de discurso político & Sim \\
\hline Moon Walker & Conto & o professor e seu aluno & o cenário do conto é a \\
\hline & escola \\
\hline Cheiro de terra, sabor de saudade & Conto & momentos da infância na escola & Não \\
\hline O Caso 162 & Conto & jogos de investigação - crianças & Não \\
\hline Lágrimas de Cebola & Conto & vida conjugal & $\begin{array}{l}\text { aluno que imaginava ser uma } \\
\text { baleia }\end{array}$ \\
\hline Pedro Baleia & Conto & Nim \\
\hline Mero Acaso & Poesia & amor/sentimentos & Não \\
\hline Dízima Periódica & Poesia & sentimentos & Não \\
\hline Eu Me Lembro & Poesia & vida, existência & $\begin{array}{l}\text { menção à escola e ao } \\
\text { aprendizado da escrita }\end{array}$ \\
\hline Lua Africana na Escola, no Trem... & Poesia & menina que inicia na escola & Não \\
\hline Cabe o Mundo & Poesia & vida, existência & \\
\hline
\end{tabular}




\begin{tabular}{|c|c|c|c|}
\hline Brincadeira & Poesia & Vida & Não \\
\hline Lembrar De Não Esquecer & Poesia & escola e suas mudanças & menção à escola \\
\hline Podes Voltar & Poesia & lembranças da infância/dor & Não \\
\hline Os Telhados & Poesia & composição da cidade & Não \\
\hline Momento num Ônibus & Poesia & $\begin{array}{l}\text { vida cotidiana no transporte } \\
\text { público }\end{array}$ & Não \\
\hline Lembro e Amo a Terra em que Nasci & Poesia & $\begin{array}{l}\text { lembranças da cidade } \\
\text { natal/natureza }\end{array}$ & Não \\
\hline Manhãs em Migalhas & Poesia & existência & Não \\
\hline Eu Me Lembro... & Poesia & vida, existência & Não \\
\hline Lembranças e Heranças & Poesia & lembranças da infância & Não \\
\hline Liberdade de Pés Descalços & Poesia & lembranças da infância & Não \\
\hline Gira - Gira & Poesia & lembranças da infância & Não \\
\hline $\begin{array}{l}\text { Lettera (ou Eu me lembro: uma breve } \\
\text { história da escrita) }\end{array}$ & Poesia & sobre a história da escrita & Não \\
\hline No Tempo & Poesia & sobre a mãe/sentimento & Não \\
\hline Sol e Garoa & Poesia & & Não \\
\hline Valeu Mestre & Poesia & sobre ser professor & Sim \\
\hline Idas / Vindas & Poesia & lembranças de ser professor & Sim \\
\hline Tempo de Ser Criança & Poesia & lembranças da infância & Não \\
\hline Eu (não) Me Lembro... & Poesia & lembranças da escola & Sim \\
\hline Quero Ser para Você & Poesia & sentimentos & Não \\
\hline Desencanto & Poesia & existência & Não \\
\hline Profissão Educador & Poesia & ser professor & Sim \\
\hline Lembro & Poesia & lembrança da infância & Não \\
\hline Tristeza & Poesia & sentimentos & Não \\
\hline Memórias Presentes & Poesia & existência & Não \\
\hline Sedução & Poesia & sentimentos & Não \\
\hline Lembranças... & Poesia & lembranças da infância & Não \\
\hline A Educação em Septilha & Poesia & sobre ser professor & Sim \\
\hline Um Beijo Eterno & Poesia & sentimentos & Não \\
\hline Eu Me Lembro... & Poesia & lembranças da infância & Não \\
\hline O Vaso & Poesia & humanidade & Não \\
\hline Maria Cocota Canhota & Poesia & escola/aluna/práticas & Sim \\
\hline Eu Me Lembro & Poesia & lembranças da infância & Não \\
\hline Eu Me Lembro - Minhas Séries Iniciais & Poesia & lembranças da escola & Não \\
\hline Eu Me Lembro... & Poesia & sobre a mãe/sentimento & Não \\
\hline Eu Me Lembro & Poesia & sobre a mãe/sentimento & Não \\
\hline
\end{tabular}

Nesta edição é possível identificar que muitos textos possuem o mesmo título do concurso, por esse motivo, nos regulamentos dos anos posteriores estava exposto que o título dos textos não poderiam ser os mesmos que o do concurso.

Outro aspecto observado no material desta edição é se os textos apresentam referências sobre a profissão docente seja no tema tratado, na personagem ou no narrador. Considerando estes elementos, identificamos que onze (11) textos apresentam relação com a identidade docente e outros quatro (4) que, de algum modo, tratam da/sobre escola.

Sobre os autores professores, observou-se que há trinta e quatro (34) mulheres e dezenove (19) homens, havendo uma concentração do sexo feminino na autoria de 
poesias. O quadro abaixo mostra dentre os professores vencedores do concurso, a separação por sexo e categoria do texto inscrito na qual se observa o dobro de mulheres autoras de poesias em relação aos homens:

\begin{tabular}{|l|l|l|}
\hline \multicolumn{3}{|c|}{ Professor autor por categoria do concurso e sexo } \\
\hline Gênero & Autoria Feminina & Autoria Masculina \\
\hline Crônica & 5 & 3 \\
\hline Conto & 2 & 3 \\
\hline Poesia & 27 & 13 \\
\hline
\end{tabular}

No final do livro há uma breve descrição de cada autor contemplando seu nome, pseudônimo, título do texto seguido do gênero, escola de atuação e outras informações fornecidas pelo professor. Essas informações que aparecem ao final do livro constam na ficha de inscrição na qual há um campo para que o professor se apresente e é com esse breve texto que a comissão organizou as informações dos autores no final do livro. Com isso, conhecemos de modo breve quem são os professores vencedores do concurso por meio de informações como escola de atuação, formação e/ou disciplina que atua, e informações pessoais que alguns escolheram divulgar. Observou-se, ainda, que alguns professores escrevem para meios de comunicação, revistas literárias, escritas pessoais, além de terem outras obras publicadas - aspecto que torna possível localizar outras práticas da escrita realizada por professores.

\section{$\underline{\text { Sob o céu da cidade }}$}

Na edição de 2011, Sob o céu da cidade, a publicação apresenta apenas o gênero crônica, são vinte e sete (27) textos. Há uma poesia nesta publicação, pois a edição da mesma estava incorreta na antologia de 2010 e como correção foi publicada novamente com as devidas alterações acompanhada de uma nota explicativa sobre o fato.

O livro possui a mesma estrutura da edição anterior: folha de rosto, verso da folha de rosto com a ficha catalográfica e nomes das pessoas que atuaram na elaboração do livro, agradecimentos, carta do Secretário Municipal de Educação para a edição de 2011, sumário, apresentação da comissão julgadora, os textos - miolo do livro - e informações sobre os autores e ilustrador. No total são 144 páginas. 
A ilustração que venceu o concurso e compôs a capa do livro é do professor de Artes Sandro da Silva Braga. Na parte superior da capa consta o logotipo do evento seguido da indicação do nome do concurso e abaixo da ilustração aparece o nome da SME; na contracapa consta os logotipos das instituições colaboradoras e o da Prefeitura de São Paulo.

Imagem 5. Capa e contracapa do livro do concurso literário publicado em 2011.
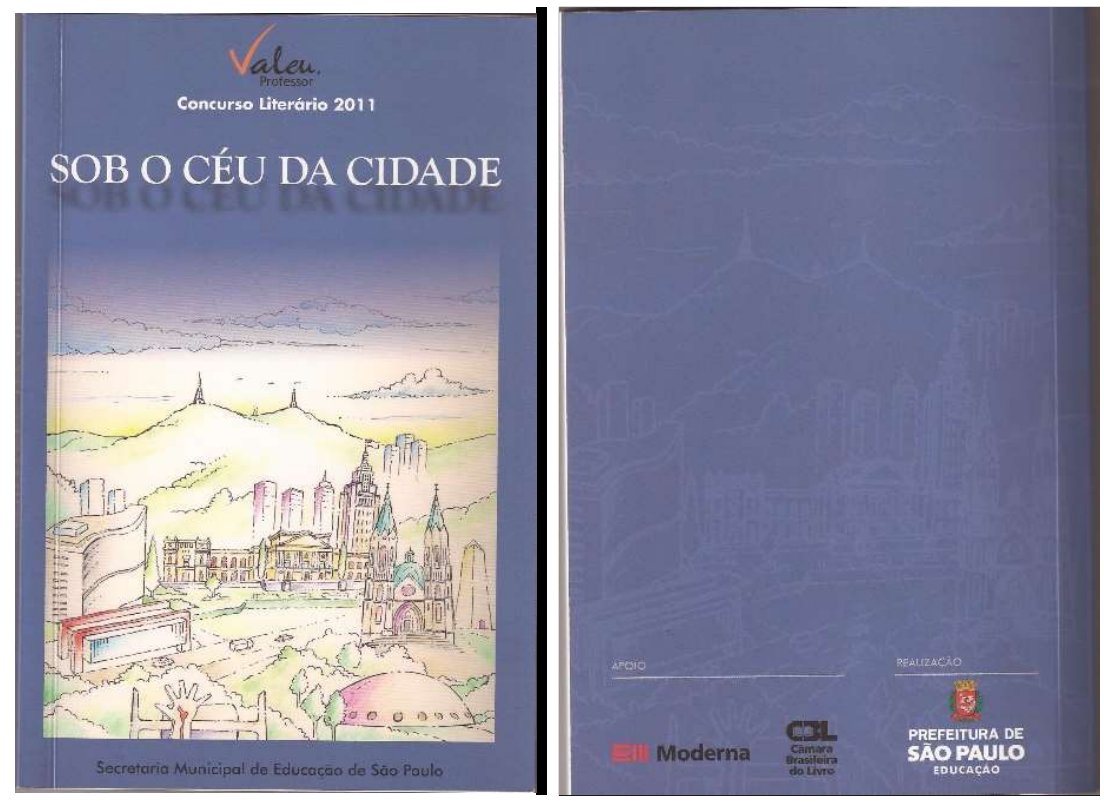

O conjunto de crônicas que compõem este livro traz diversidade de temas baseados na vida em São Paulo. São textos inspirados em fatos da realidade que compostos de elementos de fíç̧ão, crítica e fantasias tornaram-se crônicas. Os textos trazem os seguintes temas: infância (4), paisagem da cidade de São Paulo (3), sobre envelhecer (2), problema social (2), migração (1), sobre a vida/existência (2), cotidiano em São Paulo (8), suicídio (1), consumismo (1), professor (2), mudança nas relações sociais (1); os assuntos tratados nas crônicas foram agrupados sob esses temas apresentados acima.

Das 27 crônicas selecionadas para este livro, seis (6) apresentam relação com a profissão docente seja pelo tema, personagem e/ou narrador, e duas (2) apenas indicam de modo breve uma relação com a escola e o trabalho intelectual.

As crônicas são de autoria feminina em dezoito (18) e de autoria masculina em nove (9) mantendo a predominância de mulheres entre os materiais publicados.

No quadro a seguir está a classificação temática dos textos publicados nesta edição do concurso. 


\begin{tabular}{|c|c|c|c|}
\hline \multicolumn{4}{|c|}{ Sob o céu da cidade - 2011} \\
\hline Título & Gênero & Tema & \begin{tabular}{|l|} 
Relação com \\
a profissão \\
docente
\end{tabular} \\
\hline A consciência e o céu & Crônica & $\begin{array}{l}\text { Vida/existência - aluna com câncer que } \\
\text { provoca reflexões no professor }\end{array}$ & Sim \\
\hline A cor da cidade & Crônica & Suicídio - descreve um suicídio em SP & Não \\
\hline Amigo errante & Crônica & $\begin{array}{l}\text { Problema social - história de um morador de } \\
\text { rua }\end{array}$ & Não \\
\hline Aquele dia... & Crônica & Cotidiano na cidade de SP & Não \\
\hline Arco-íris & Crônica & $\begin{array}{l}\text { Professor - cotidiano de uma professora em } \\
\text { atuação na educação infantil }\end{array}$ & Sim \\
\hline Carícias verbais & Crônica & $\begin{array}{l}\text { Cotidiano na cidade - formas de tratamento } \\
\text { afetivo ouvidas em espaços públicos }\end{array}$ & Não \\
\hline Carpe diem & Crônica & Cotidiano na cidade de SP & Não \\
\hline Céus de SP & Crônica & $\begin{array}{l}\text { Migração - migrantes na cidade de SP e a } \\
\text { invisibilidade desses sujeitos }\end{array}$ & Não \\
\hline Do breve caos à brisa & Crônica & $\begin{array}{l}\text { Vida/existência-reflexões de uma mulher } \\
\text { adulta sobre a vida }\end{array}$ & Não \\
\hline $\begin{array}{l}\text { E a cidade precisa ser mais } \\
\text { atenciosa }\end{array}$ & Crônica & $\begin{array}{l}\text { Infância - homem/criança - breves relatos } \\
\text { da infância que todo adulto traz consigo }\end{array}$ & Não \\
\hline E o menino era eu! & Crônica & $\begin{array}{l}\text { Infância - desaparecimento de um menino } \\
\text { de } 8 \text { anos em SP }\end{array}$ & Não \\
\hline Entre reflexões e guarda-chuvas & Crônica & $\begin{array}{l}\text { Envelhecer - Reflexões de uma mulher } \\
\text { idosa }\end{array}$ & Não \\
\hline Eternizando Matilde & Crônica & $\begin{array}{l}\text { Problema social - sobre Matilde, uma } \\
\text { moradora de rua }\end{array}$ & Não \\
\hline Guardando um olhar & Crônica & $\begin{array}{l}\text { Cotidiano na cidade - momento de paquera } \\
\text { entre pessoas adultas no espaço público }\end{array}$ & Não \\
\hline Irresistível desejo & Crônica & $\begin{array}{l}\text { Consumismo - sobre o desejo de compra de } \\
\text { uma mulher }\end{array}$ & Não \\
\hline Janelas metropolitanas & Crônica & $\begin{array}{l}\text { Paisagem da cidade - sobre o céu da cidade } \\
\text { de SP }\end{array}$ & \begin{tabular}{|l|} 
Indica que \\
trabalha em \\
uma escola
\end{tabular} \\
\hline Metamorfose & Crônica & $\begin{array}{l}\text { Mudanças nas relações sociais, faz um apelo } \\
\text { ao respeito e à diferença }\end{array}$ & Não \\
\hline Minha querida São Paulo & Crônica & $\begin{array}{l}\text { Paisagem da cidade - conhecer/apreciar a } \\
\text { beleza da cidade de SP }\end{array}$ & Não \\
\hline O amor de ser educador & Crônica & Professor - sobre ser professor & Sim \\
\hline O céu era azul & Crônica & $\begin{array}{l}\text { Infância - recordações da infância sobre o } \\
\text { aniversário de SP em } 1954\end{array}$ & Não \\
\hline O cronista da cidade & Crônica & $\begin{array}{l}\text { Cotidiano na cidade - sobre a cidade de SP, } \\
\text { do que acontece cotidianamente nas ruas }\end{array}$ & Não \\
\hline $\mathrm{O}$ raio verde & Crônica & $\begin{array}{l}\text { Cotidiano na cidade - momento de paquera } \\
\text { entre pessoas adultas }\end{array}$ & Não \\
\hline Olhares e passadas pela cidade & Crônica & $\begin{array}{l}\text { Paisagem da cidade - sobre andar pela } \\
\text { cidade, descrição do que observa }\end{array}$ & $\begin{array}{l}\text { Indica que } \\
\text { desenvolve } \\
\text { um trabalho } \\
\text { intelectual }\end{array}$ \\
\hline Poema de menino & Crônica & $\begin{array}{l}\text { Infância - menino que vende doces nas ruas } \\
\text { relatando cenas da escola }\end{array}$ & Sim \\
\hline
\end{tabular}




\begin{tabular}{|l|l|l|l|}
\hline Rita não descia do trem & Crônica & $\begin{array}{l}\text { Cotidiano na cidade - percurso de Rita até } \\
\text { seu trabalho }\end{array}$ & Sim \\
\hline Seu Manoel & Crônica & Envelhecer & Não \\
\hline Surto no metrô & Crônica & $\begin{array}{l}\text { Cotidiano na cidade - relato de um homem } \\
\text { que tem um surto psiquiátrico na estação de } \\
\text { metrô }\end{array}$ & Sim \\
\hline
\end{tabular}

Neste livro percebemos uma quantidade menor de textos relacionados com a profissão docente, sendo escolhidos - em maior quantidade - os textos que tratam da cidade de São Paulo, de suas paisagens e acontecimentos, sublinhando a intenção quando se criou o tema.

\section{$\underline{\text { Sem Remetente.com }}$}

Na edição de 2012, intitulada Sem remetente.com, há quarenta e seis (46) textos, sendo 21 contos e 25 poesias. A categoria crônica não constava no regulamento deste ano em função de ter sido privilegiada anteriormente.

Esta antologia mantém a estrutura das edições anteriores sendo composta pela folha de rosto, verso da folha de rosto com a ficha catalográfica e nomes dos que atuaram na elaboração do livro e compunham a gestão da SME, agradecimentos, carta da Secretária Municipal de Educação, sumário, apresentação da comissão julgadora, os textos - miolo do livro - e informações sobre os autores. Diferentemente das edições passadas, este livro teve 183 páginas. Neste ano, a gestão da Secretaria Municipal de Educação mudou e Célia Regina Guidon Falótico assumiu o cargo de Secretária da Educação, e é ela quem assina a carta de apresentação do livro.

Sobre a escolha do tema deste concurso, a comissão julgadora escreveu na apresentação do livro:

Novas realidades emergem da cultura "cyber", diferentes relações se estabelecem num mundo permeado pelas novas tecnologias. É esse tempo de mutação que nos desafia a preservar o inesgotável poder construtor/ordenador da palavra (o mundo letrado, o livro). [...] Com o intuito de jogar luz sobre esse momento e de resgatar o poder da palavra como fator-chave para a construção de uma nova educação, surgiu a ideia do tema do Concurso Literário Valeu, Professor 2012: Sem remetente.com. (SÃO PAULO, 2012, p. 09, grifo do autor).

A vencedora da categoria ilustração foi Susana Rosalba Lourenço que é professora de Artes na rede municipal de educação. 
Imagem 6. Capa e contracapa do livro do concurso literário publicado em 2012.
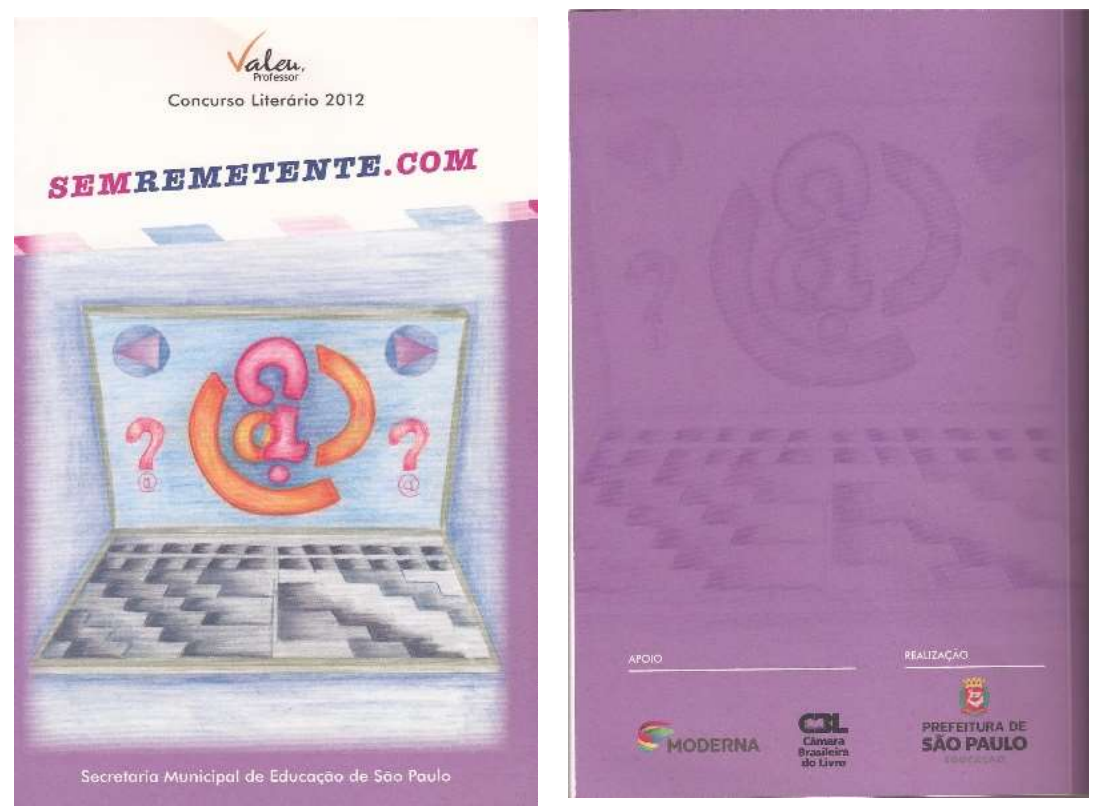

Com a temática que remete ao uso da internet e à era digital, os contos que compõem este livro trazem assuntos variados que permeiam a vida e as gerações circulando entre a tradição e a modernidade, passado-presente-futuro, o velho e o novo. Os contos mostram novas formas de comunicar, de se relacionar, de fazer amigos presentes na vida cotidiana de quem se aventura pela internet. Assim, os temas trazidos nos contos desta edição foram assim agrupados: comunicação e encontros através da internet (6), solidão (3), internet e vício (2), idoso e a internet (2), desencontros na comunicação digital (1), relaciona a escrita manuscrita com a da internet (1), civilização futurista (2), sobre escrever em blog (1), intuição feminina (1), exposição da vida na internet (1), releitura da Branca de Neve (1).

As poesias publicadas no livro apresentam ao leitor, de modo geral, reflexões e situações de como o universo virtual tem mudado a vida das pessoas, assim os temas das poesias foram agrupados em: relacionamentos amorosos e de amizade usando a internet (5), comunicação pela internet (5), sentimentos (5), solidão e internet (3), a relação das pessoas com o mundo virtual (3), mentiras e o mundo virtual (2), vida e experiências (1), relação do homem com a tecnologia (1).

O quadro a seguir mostra a classificação temática dos textos publicados nesta edição: 


\begin{tabular}{|c|c|c|c|}
\hline \multicolumn{4}{|c|}{ Sem remetente.com - 2012} \\
\hline Título & Gênero & Tema & $\begin{array}{l}\text { Relação com a } \\
\text { profissão docente }\end{array}$ \\
\hline A assinatura & Conto & $\begin{array}{l}\text { Relaciona a escrita manuscrita com a da } \\
\text { internet }\end{array}$ & Não \\
\hline A mulher virtuosa & Conto & Desencontros na comunicação digital & Não \\
\hline A quem possa interessar & Conto & Solidão/comunicação & Não \\
\hline Alguém.com.solidão? & Conto & Encontros através da internet & Não \\
\hline Amor virtual & Conto & $\begin{array}{l}\text { Encontros através da } \\
\text { internet/relacionamento amoroso por } \\
\text { meio da internet }\end{array}$ & Não \\
\hline Branca de Neve nos tempos atuais & Conto & $\begin{array}{l}\text { Releitura da Branca de Neve na era da } \\
\text { informática }\end{array}$ & Não \\
\hline Clemência & Conto & $\begin{array}{l}\text { Conto futurista de uma civilização } \\
\text { controlada por robôs e sem contato } \\
\text { físico entre as pessoas }\end{array}$ & Não \\
\hline Compartilhamento de vida moderna & Conto & $\begin{array}{l}\text { Necessidade/vício de contatos/amizades } \\
\text { pela internet }\end{array}$ & Não \\
\hline Divã & Conto & Vício de estar conectado o tempo todo & Não \\
\hline $\begin{array}{l}\text { E agora que o teto de vidro está cheio } \\
\text { de neve? }\end{array}$ & Conto & Solidão/comunicação pela internet & Não \\
\hline $\begin{array}{l}\text { Em busca de uma vida menos } \\
\text { ordinária }\end{array}$ & Conto & Encontros através da internet & $\begin{array}{l}\text { Sim, a personagem } \\
\text { é professora }\end{array}$ \\
\hline Esse tal de Feijuca & Conto & $\begin{array}{l}\text { Comunicação pela internet e a falta de } \\
\text { contato presencial }\end{array}$ & Não \\
\hline $\begin{array}{l}\text { Marcos que amava Lúcia...que } \\
\text { amaria Marcos, que amava cartas... }\end{array}$ & Conto & Amizades e a internet & Não \\
\hline Meu intruso favorito & Conto & Exposição da vida na internet & Não \\
\hline $\mathrm{Na}$ época do planeta Poluição & Conto & $\begin{array}{l}\text { Civilização futurista criada depois da } \\
\text { destruição do planeta }\end{array}$ & Não \\
\hline Notifica.com & Conto & $\begin{array}{l}\text { Comunicação pela internet e a falta de } \\
\text { contato presencial }\end{array}$ & Não \\
\hline Ponte para Asgard & Conto & $\begin{array}{l}\text { Escrita digital - história de José que } \\
\text { escreve em seu blog }\end{array}$ & Não \\
\hline Sábado e intuição feminina & Conto & Desencontros na comunicação digital & Não \\
\hline Suicídio.com & Conto & Solidão/comunicação pela internet & Não \\
\hline Um velho lobo do mar & Conto & $\begin{array}{l}\text { Idosos e internet - história de um avô } \\
\text { que descobre a internet através de seu } \\
\text { neto }\end{array}$ & Não \\
\hline Vovô é "vintage" & Conto & $\begin{array}{l}\text { Idosos e internet - história de um avô } \\
\text { que descobre a internet através das } \\
\text { netas }\end{array}$ & Não \\
\hline Anonimato & Poesia & Relacionamentos amorosos na internet & Não \\
\hline Anônimo divino? & Poesia & Relação do homem com a tecnologia & Não \\
\hline Aperte Esc & Poesia & $\begin{array}{l}\text { Comunicação pela internet e a falta de } \\
\text { contato presencial }\end{array}$ & Não \\
\hline Arquivos da mente & Poesia & $\begin{array}{l}\text { Comunicação pela internet e a falta de } \\
\text { contato presencial }\end{array}$ & Não \\
\hline Classificados da Internet & Poesia & $\begin{array}{l}\text { Comunicação - Desencontros na } \\
\text { comunicação pela internet }\end{array}$ & Não \\
\hline Conexão & Poesia & Sentimentos & Não \\
\hline
\end{tabular}




\begin{tabular}{|c|c|c|c|}
\hline De tudo que sou & Poesia & Solidão/ amizades pela internet & Não \\
\hline Deletando & Poesia & Comunicação pela internet/redes sociais & Não \\
\hline Deste outro lado & Poesia & Relacionamentos amorosos na internet & Não \\
\hline Destinatário.com & Poesia & Relacionamentos amorosos na internet & Não \\
\hline Enigmático & Poesia & Relacionamentos amorosos na internet & Não \\
\hline Face a Facebook & Poesia & Encontros/amizades pela internet & Não \\
\hline Fantasias e mentiras & Poesia & Mentiras e o mundo virtual & Não \\
\hline Gato na tuba & Poesia & Mentiras e o mundo virtual & Não \\
\hline Mensageiro virtual & Poesia & Comunicação pela internet & Não \\
\hline Mista conexão & Poesia & Relação das pessoas com mundo virtual & Não \\
\hline Necessidade urgente & Poesia & Sentimentos & Não \\
\hline Novo endereço.recomeço & Poesia & Sentimentos/recomeço/mudança & Sim \\
\hline Pensamentos plugados & Poesia & Vida/experiências & Não \\
\hline Quando cai a chuva & Poesia & $\begin{array}{l}\text { Solidão/relacionamentos amorosos na } \\
\text { internet }\end{array}$ & Não \\
\hline Quisera & Poesia & Relação das pessoas com mundo virtual & Não \\
\hline Ser & Poesia & Sentimentos & Não \\
\hline Soneto ao internauta & Poesia & Solidão/amizades pela internet & \\
\hline Teus 5 anos & Poesia & Sentimentos & Não \\
\hline Voo sem asas & Poesia & Relação das pessoas com mundo virtual & Não \\
\hline
\end{tabular}

Observamos dentre os contos e poesias publicados neste livro que apenas dois (2) apresentam aspectos da profissão docente, a saber o conto Em busca de uma vida menos ordinária, no qual a personagem é professora, e a poesia Novo endereço.recomeço que apresenta elementos presentes na carreira docente. Todos os outros textos não apresentam informações, personagens e/ou narradores que remetam à escola e à docência.

Sobre os autores, a maioria desta edição são mulheres, 35 textos de autoria feminina e apenas 11 de autoria masculina. O quadro abaixo apresenta o quantitativo de autores pelas categorias do concurso.

\begin{tabular}{|l|l|l|}
\hline \multicolumn{3}{|c|}{ Professor autor por categoria do concurso e sexo } \\
\hline Gênero & Autoria Feminina & Autoria Masculina \\
\hline Conto & 16 & 5 \\
\hline Poesia & 19 & 6 \\
\hline
\end{tabular}

Do mesmo modo que nas edições anteriores, existe a predominância de professoras autoras nos livros, no entanto, deve-se observar se esse dado necessita ser 
comparado com o universo de inscritos, além de verificar se as mulheres também são a maioria. 


\section{SARAUS NA CIDADE DE SÃO PAULO}

Neste capítulo iremos narrar como são os saraus que acontecem em São Paulo com o objetivo de demonstrar as características de diferentes tipos de saraus visitados e, a partir disso, especificar os saraus periféricos onde atuam os professores participantes da pesquisa. Antes de descrever os saraus identificados na pesquisa, apresentaremos de modo breve uma historicização das reuniões literárias brasileiras a partir dos estudos de Simone Silva (2008), Lúcia Tennina (2017) e Antonio Eleison Leite (s.d.).

\subsection{Historicizando os saraus}

As reuniões literárias promovidas por membros da alta sociedade aconteciam desde o século XIX e eram restritas a convidados específicos, ocorrendo em espaços fechados, como nas livrarias e residências de quem as proporcionava. Tais encontros possibilitavam a sociabilidade entre as pessoas da alta sociedade e os artistas e escritores que apresentavam suas obras nesses ambientes. Muito conhecida na literatura por meio das descrições dos salões das elites europeias, esse tipo de reunião literária foi trazido para o Brasil pelos imigrantes portugueses, como relata Tennina: "No caso do Brasil, por exemplo, o Palácio Imperial, em Petrópolis, era conhecido pelos saraus promovidos por D. Pedro II. Por conta da vida cultural que gira em torno da família real, a cidade de Petrópolis se tornaria uma referência nesse sentido”. (2017, p. 113)

Simone Silva (2008), em seu estudo sobre as "rodas literárias" nas décadas de 20 e 30, afirma que até a década 1920, no Brasil, os artistas eram financiados por meio de mecenas que eram, em maioria, os produtores paulistas de café. Os livros eram produzidos em pequenas quantidades e com distribuição reduzida, já que não havia muitas livrarias em São Paulo nesse período. Por isso, além dos espaços das livrarias, os escritores contavam com os salões da elite paulista para divulgar seus trabalhos. 
Desde o final do século XIX, São Paulo, por exemplo, o centro de produção brasileira, dispunha de melhores condições, mas contava com poucas livrarias, tais como a Casa Eclética, a Empresa Literária Fluminense, a Paulista, e a famosa Casa Garraux, além dos salões organizados pela elite paulista. Estes, por sua vez, geralmente constituído por uma pessoa economicamente influente, funcionavam como lugar de encontro para a oligarquia e os artistas desprovidos de recursos financeiros. O mais famoso e importante dos salões em São Paulo era o da Vila Kyrial, ao que se sabe berço de "nascimento" da Semana de 22. Pertencente ao gaúcho José de Freitas Valle, que foi para São Paulo estudar Direito, o salão da Vila Kyrial era, no início do século, o ponto de encontro de muitos artistas, políticos, jornalistas e escritores que frequentemente aí se reuniam para participar de saraus literários, audições musicais, banquetes e ciclos de conferências. (SILVA, 2008, p. 187-188).

Como relata Simone Silva no excerto acima, os salões paulistas, como o da Vila Kyrial, eram promovidos pela elite e seus frequentadores faziam parte desse universo social e intelectual - restrito a um pequeno grupo detentor de capital social e cultural para acessar os espaços da cultura letrada. De acordo com Silva (2008), na década 30 o financiamento dos artistas passa a ser estatal provocando mudanças na relação entre o artista e o mecenas:

[...] os salões e os mecenas tiveram seus papéis de "promotores" artísticos alterados após o progressivo percurso de autonomização do espaço cultural. De fato, o mecenato não havia deixado a cena cultural brasileira, mas ele tinha sofrido modificações - passou a ser "estatal" na década de 1930. (SILVA, 2008, p. 188).

A partir de meados de 1930, os artistas passam a contar com programas do governo para financiar e apoiar a arte nacional e é nesse cenário que se altera a dependência em relação aos membros da elite econômica. Com base neste contex to é que Simone Silva enfatiza a importância das "rodas literárias" como produtoras culturais, como aponta no trecho a seguir.

As "rodas" passaram a ser o meio através do qual os artistas produziam e faziam circular suas obras. No tempo das rodas, eram elas as responsáveis pelo julgamento, pela crítica e pela divulgação do produtor artístico. No caso do mundo do livro, por exemplo, evidenciase a importância que as "rodas" passaram a ter no processo fundamental de promoção do escritor ${ }^{81}$ - a publicação dos livros, que segue um largo trajeto até chegar ao editor por meio de um integrante da "roda". (SILVA, 2008, p. 189).

\footnotetext{
${ }^{81}$ Simone Silva apresenta neste artigo a articulação das "rodas literárias" na produção das obras de Mário de Andrade e José Lins do Rêgo.
} 
Como indica Simone Silva (2008), as "rodas literárias" tinham como objetivo constituir um grupo que possibilitava a publicação de obras dos escritores nelas inseridos. Nesse sentido, o manuscrito era lido por membros da roda, esta enviava a um editor conhecido que publicava a obra, em seguida havia a elaboração de uma crítica literária por um profissional e, por fim, a roda fazia críticas sobre a obra. Desse modo, essa "roda literária" conseguia percorrer caminhos para que uma obra fosse lançada, porém constituindo-se de modo diverso daquela dos salões paulistas como os da Vila Kyrial.

Com o transcorrer do século XX e as mudanças na sociedade, os saraus e rodas literárias foram sumindo desse universo elitista das grandes cidades, entretanto, no século XXI, não restrito aos grupos favorecidos economicamente, os saraus reaparecem já deslocados dos centros produtores de cultura, instalando-se em regiões distantes da capital paulista, as chamadas periferias, como um movimento novo, demonstrado no fragmento a seguir.

[...] Este tipo de reunião artística muito disseminada nos salões das elites parisienses no Século XIX foi trazido para o Brasil num desses processos de macaqueação ao qual se refere Schwarz. Fora de moda há muitos anos, o sarau ressurgiu num boteco de quebrada na periferia da Zona Sul de São Paulo com os poetas da Cooperifa em 2001. Nos recitais da Belle Époque francesa e brasileira se declamavam poesia das arcádias, do romantismo, versos parnasianos. Parece uma ideia fora do lugar se pensado no ambiente de um bar em bairro popular. Desses estilos literários, porém, o que se ouve na Cooperifa é apenas Castro Alves (Navio Negreiro), recitado por um poeta negro (Helber Ladslau) em grande performance. No mais, são poesias de autoria dos próprios frequentadores do sarau, letras de canções e muitos RAPs em composições que abordam a realidade local numa representação lírica das vivências dos poetas que fazem uso desse recurso estético para se expressarem. (LEITE, [s./d.], p. 03).

A Cooperifa que surgiu em 2001, mesmo ano em que foi publicada a primeira edição da Revista Caros Amigos sobre Literatura Marginal, é considerada o primeiro sarau periférico de São Paulo que ficou muito conhecido pela atuação de Sérgio Vaz e motivou o surgimento de outros grupos de sarau nos mesmos moldes pela cidade, como afirma Lucía Tennina:

[...] o sarau se tornou uma prática replicada em muitos outros bares de muitos bairros da periferia de São Paulo, repetindo o esquema proposto pela Cooperifa, no qual se afirmou uma série de fórmulas e modus operandi que se converteriam em regras incorporadas por todos os frequentadores e poetas de todos os saraus que foram surgindo. Desde 2001, ano após ano o número de saraus se multiplica, enchendo o calendário semanal e salpicando o mapa da cidade a tal ponto que é 
possível pensar a periferia já não apenas como um espaço delimitado a partir de valores econômicos e socioestruturais, mas como um mapa afetivo traçado a partir do circuito de saraus. (TENNINA, 2017, p. 30).

Os saraus da periferia de São Paulo com esse modus operandi como apontado por Tennina (2017) é apenas um tipo de sarau que ocorre atualmente pela cidade, outros saraus acontecem, em diversas localidades, que possuem dinâmicas distintas e pensadas a partir da proposta, dos objetivos e do público a que se destina. Nesse sentido, iremos relatar a seguir os saraus com os quais tivemos contato durante a pesquisa.

\subsection{Afinal, como são os saraus atuais?}

Os saraus que acontecem atualmente pela cidade de São Paulo e região metropolitana são reuniões literárias abertas onde as pessoas se reúnem para ler, declamar e ouvir literatura. A literatura é a arte central desses encontros, mas também é possível se deparar com apresentações musicais e de dança. Os locais de ocorrência são variados, podendo ser em bibliotecas públicas, bares, praças, escolas, centros culturais e outros espaços, a depender do grupo que os organiza.

Na cidade de São Paulo acontecem muitos saraus organizados em bibliotecas públicas e divulgados por meio da Secretaria de Cultura do município, outros são organizados por grupos independentes, associações ou coletivos, que utilizam espaços como bares, praças e/ou parques da cidade, ou ainda centros culturais para realizarem os encontros. Existem, ainda, os saraus que ocorrem em escolas públicas realizados por professores por meio de projetos extracurriculares. A periodicidade dos encontros é, em geral, uma vez ao mês.

Esses saraus foram espaços que possibilitaram identificar professores escritores. Para isso, foi necessário conhecer diferentes saraus buscando por participantes professores. Os saraus visitados de 2015 a 2018 foram: Sarau Sobrenome Liberdade, Sarau do Grajaú, Sarau Amigos do Parque Pinheirinho D'Água, Sarau do PI, Sarau do Mercado, Sarau das Artes, Sarau Roda da Palavra, Quinta Poética, Sarau Café com Poesia e Cooperifa. Esses saraus que conhecemos acontecem em diferentes regiões da cidade, com intencionalidades distintas e formas variadas, a depender dos organizadores e do público participante. Além disso, os professores foram identificados em alguns deles 
apenas. Sendo assim, descreveremos de modo breve os saraus, demonstrando semelhanças e diferenças presentes nessas reuniões literárias.

O Sarau do Mercado acontece na Casa de Cultura Santo Amaro, região da zona sul da cidade, com periodicidade mensal e na segunda terça-feira do mês, no período noturno, na sala principal da casa de cultura. Mavot Sirc é o organizador deste sarau que o realiza de forma muito simples, ordenando cadeiras em forma de círculo no espaço e conduzindo as apresentações que podem ocorrer com o leitor ou declamante sentado ou em pé. Geralmente, os participantes levam os textos que apresentarão. Percebemos que as pessoas declamam e/ou leem textos de autores consagrados da literatura e, também, textos autorais, além de cantarem. As apresentações são de livre escolha de cada participante e o organizador não tem conhecimento do que será lido ou declamado. Das pessoas que presenciamos, a leitura de textos autorais, alguns haviam publicado e estavam com o livro para divulgar no sarau, outros estavam com o caderno no qual registram os poemas, e um grupo possuía os textos organizados em uma publicação como o modelo do folheto de cordel, o grupo do Sarau da Serra. Em geral, os participantes escolhem ler poesias nesses espaços. Observamos que organizadores e participantes de determinados saraus frequentam as reuniões de outros grupos como forma de compartilhar e prestigiar a reunião do outro, bem como divulgar o próprio sarau. Nesse sentido, identificamos neste sarau os organizadores do Sarau do Grajaú, representantes do Sarau da Serra e uma representante do Sarau Poemas à Flor da Pele.

Imagem 7. Fotografia do Sarau do Mercado.

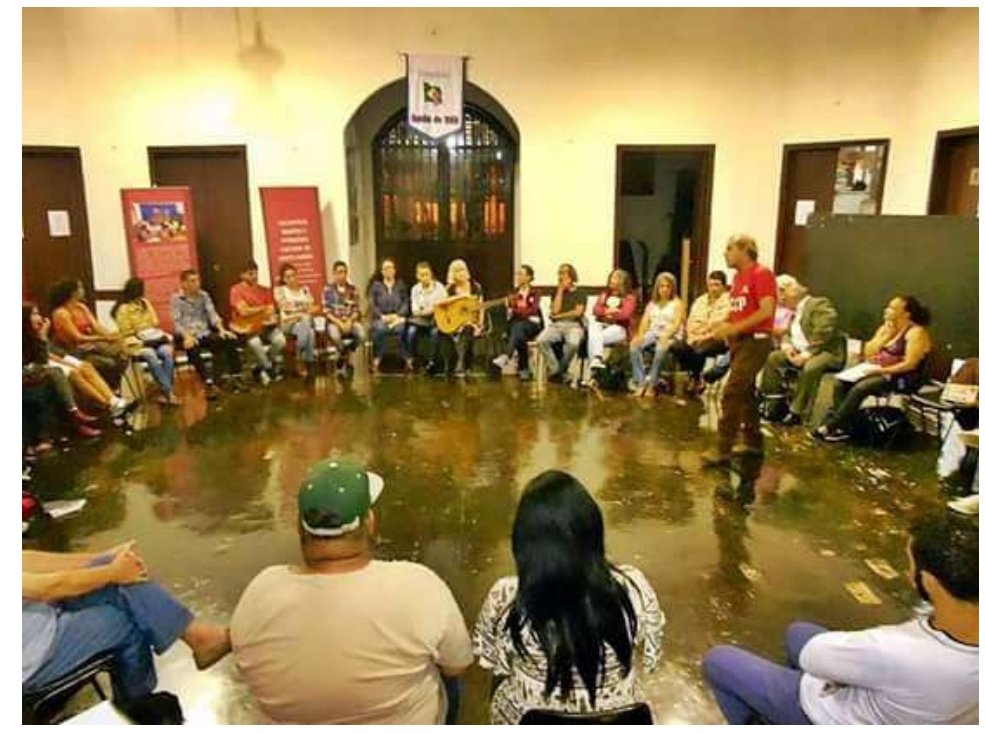

Fonte: Página do Facebook do sarau. ${ }^{82}$

\footnotetext{
${ }^{82}$ Fonte da imagem: https://www.facebook.com/pg/segundastercasdomessaraudomercado/
} 
Este sarau não consta na programação divulgada pela prefeitura de São Paulo, no entanto, identificamos que o organizador Mavot Sirc é Agente Comunitário de Cultura contemplado pelo Edital Programa Agente Comunitário de Cultura. ${ }^{83}$ A divulgação do sarau ocorre por meio da rede social Facebook Sarau do Mercado.

O Sarau das Artes faz parte da programação da Biblioteca Infantojuvenil Monteiro Lobato, com frequência semanal, ocorre toda sexta-feira no período tarde e é organizado por Maria Zélia Wolf para um público assíduo de idosos, em sua maioria mulheres. Os encontros acontecem no anfiteatro da biblioteca e possuem temas definidos e, a partir disso, são organizadas apresentações de dança, música e literatura para os frequentadores que assistem às atividades. Este é um sarau em que as pessoas frequentadoras são espectadoras e é, provavelmente, um ambiente de socialização entre os idosos da região, que não desenvolvem nenhum tipo de participação nas apresentações que ocorrem no sarau. A biblioteca está localizada na Vila Buarque, região central da cidade.

O Sarau Quinta Poética acontece na Casa das Rosas, importante casa de cultura da cidade, situada na Avenida Paulista, também região central, com frequência mensal, na quinta-feira, no período noturno. O organizador é Raimundo Gadelha, atuante na área editorial e cada encontro tem uma curadoria, que acaba sendo responsável por criar o tema do encontro e convidar as pessoas que farão as apresentações. A divulgação do sarau ocorre por meio da página eletrônica da Casa das Rosas e da Editora Escrituras e, também, consta no impresso da programação da casa de cultura. O público presente neste sarau apenas assiste às apresentações, não há espaço livre para que as pessoas leiam ou declamem. Os convidados são, de modo geral, poetas, escritores, músicos e dançarinos, mas também identificamos neste sarau convidados que atuam com outros tipos de artes como designers. As apresentações são intercaladas entre os convidados e as distintas artes selecionadas para o dia e acontecem numa das salas do andar térreo da Casa das Rosas, onde são colocadas cadeiras para os espectadores e organizado um espaço diante do público com microfone para as apresentações.

\footnotetext{
${ }^{83}$ Este Edital teve sua $1^{\text {a }}$. Edição em 2014, com encerramento previsto para agosto de 2015.Informações podem ser consultadas na página eletrônica: http://spcultura.prefeitura.sp.gov.br/projeto/152/. Informações sobre o projeto do Sarau do Mercado podem ser encontradas em: http://spcultura.prefeitura.sp.gov.br/projeto/435/\#tab=sobre
} 
Imagem 8. Fotografia do Sarau Quinta Poética.

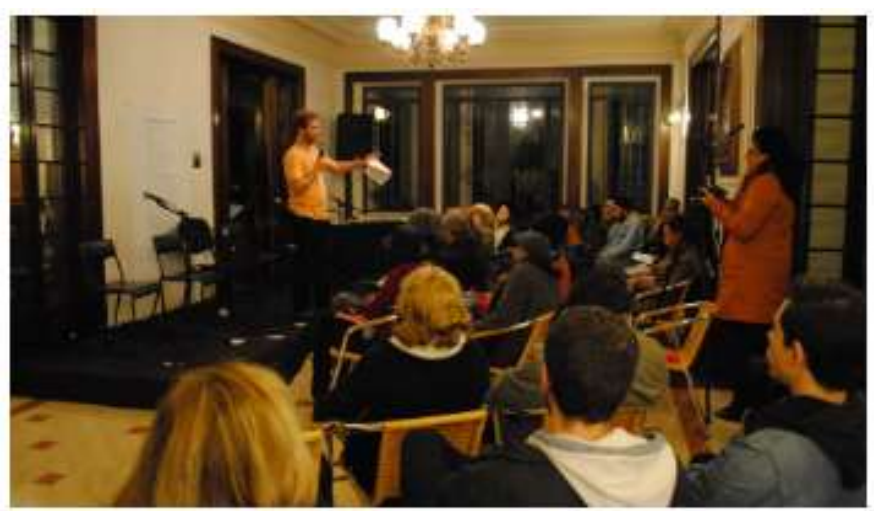

Fonte: Página eletrônica da Casa das Rosas. ${ }^{84}$

O Sarau Café com Poesia ocorre no anfiteatro da Biblioteca Municipal Hans Christian Andersen, mensalmente, aos sábados no período vespertino, sob a organização de Wilson de Oliveira Jasa e seu filho Alexandre Jazara de Oliveira Jasa. O sarau se organiza com a chegada dos participantes que são inscritos - obedecendo uma ordem para ler ou declamar poesias, cantar ou tocar um instrumento musical. Wilson organiza a lista de pessoas que irão se apresentar e a ordem de cada um, enquanto Alexandre é o apresentador formal do sarau. Como atividade de abertura cantam o Hino Nacional diante da bandeira do Brasil, exposta no centro do palco que permanece no mesmo local durante todo o evento. Preparam também, de modo coletivo, uma mesa com café e comidas para todos os participantes que podem servir-se durante o sarau que tem a duração de quatro horas aproximadamente. Os participantes são de diferentes idades, havendo crianças que acompanham os pais e, por isso, decidiram realizar em um espaço separado a atividade de contar histórias para eles, embora também ocorra a apresentação das crianças no sarau. Alguns participantes apresentam seus próprios poemas, outros leem textos de autores reconhecidos no campo literário. O evento é filmado integralmente, editado e, em seguida, disponibilizado na página eletrônica ${ }^{85}$ do sarau. Além da divulgação ser realizada em página eletrônica própria, este sarau consta na página eletrônica da prefeitura de São Paulo, na agenda impressa das bibliotecas municipais e no impresso confeccionado pelos organizadores.

Este grupo reúne os textos que produzem e publicam em antologias periodicamente. Durante o sarau são expostos alguns livros publicados por eles para venda e divulgação, porém não são apenas das pessoas que participam do Sarau Café com

\footnotetext{
${ }^{84}$ Fonte da imagem: http://www.casadasrosas.org.br/agenda/quinta-poetica

${ }^{85}$ Página eletrônica www.cafecompoesia.com.br e facebook.com/ocafecompoesia.
} 
Poesia, são também de outros dois saraus que realizam: Varal de Poesias e o Sarau da Casa do Poeta de São Paulo. Os livros são vendidos durante os encontros.

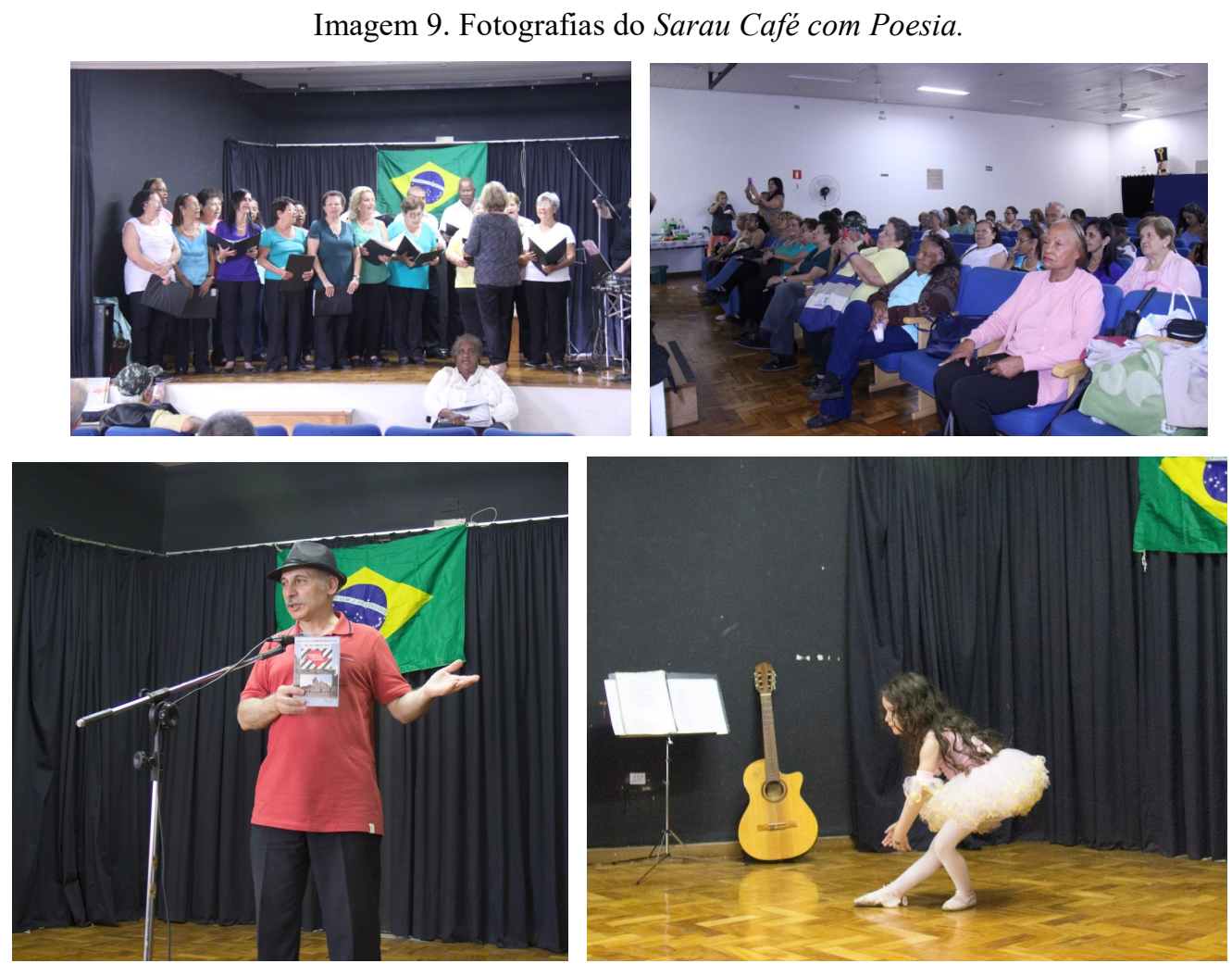

Fonte: Página eletrônica do Sarau Café com Poesia. ${ }^{86}$

O Sarau Roda da Palavra acontece na Biblioteca Pública Municipal Anne Frank, localizada no bairro Itaim Bibi, área nobre da cidade. A periodicidade é mensal, todas as segundas-feiras, no período da tarde. A responsável pelo encontro é Joyce Neia e o objetivo do sarau é divulgar a literatura e música consagradas e, também, os escritos dos próprios participantes. Neste sarau, escritores são convidados a participar para contar de suas obras e dos gêneros com os quais trabalham, assim como outros artistas. Mesmo tendo a apresentação de um convidado, os participantes podem em momento apropriado lerem e/ou declamarem. A seguir, mostraremos o cartaz de uma edição sobre o cordel.

\footnotetext{
${ }^{86}$ As fotos são feitas por membros da organização do sarau em todas as edições e estão divulgadas na página eletrônica: https://cafecompoesia.com.br/os-encontros, da qual extraímos as imagens aqui apresentadas.
} 
Imagem 10. Cartaz de divulgação do Sarau Roda da Palavra.

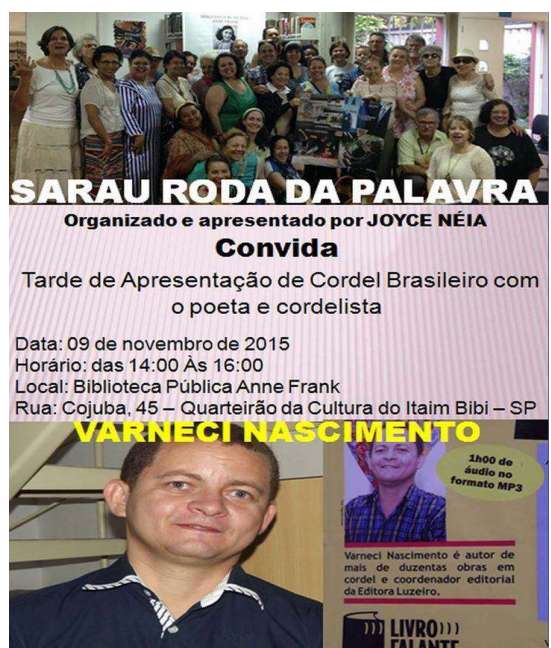

Fonte: Página eletrônica da Biblioteca Anne Frank. ${ }^{87}$

Imagem 11: Fotografias do Sarau Roda da Palavra.
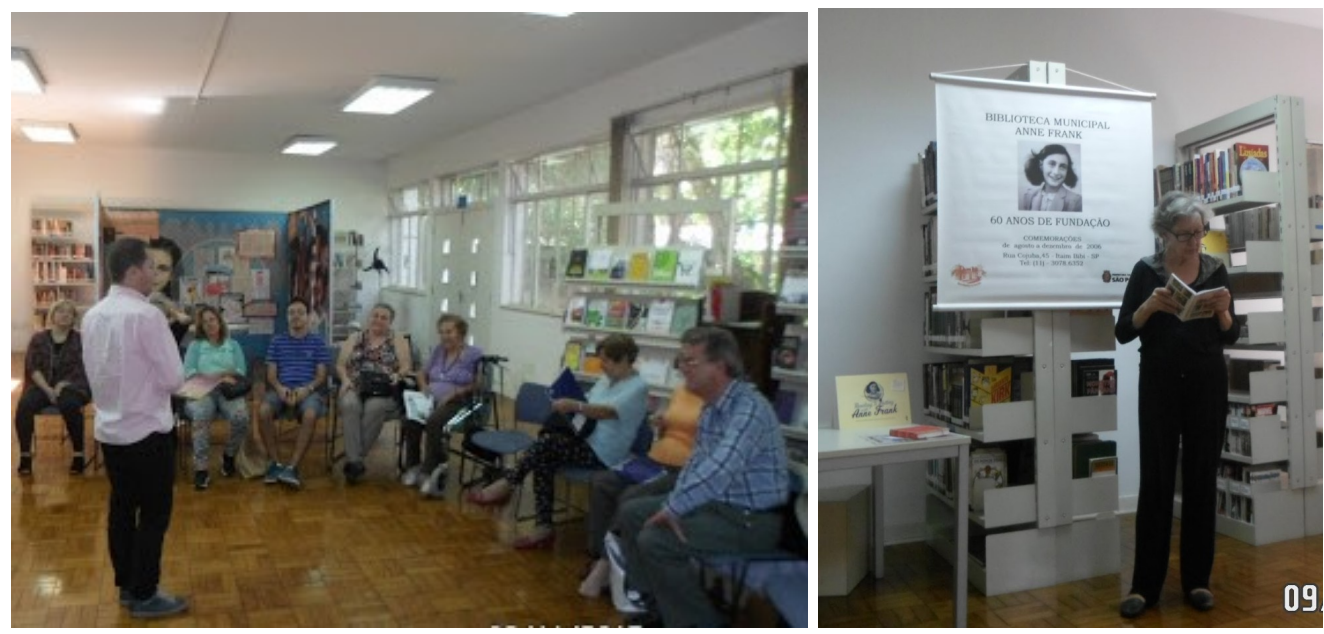

Fonte: Blog do poeta e cordelista Varneci. ${ }^{88}$

O sarau acontece no interior da biblioteca onde são dispostas algumas cadeiras para acomodar os participantes. As pessoas que se apresentam ficam em pé diante dos presentes. A programação dos encontros é divulgada por meio da rede social $^{89}$ da biblioteca e o sarau faz parte da programação que a Secretaria de Cultura ${ }^{90}$ da prefeitura de São Paulo divulga em sua página eletrônica e de forma impressa.

\footnotetext{
${ }^{87}$ Fonte da imagem: https://www.facebook.com/pg/bibliotecaannefrank/photos/?ref=page internal

${ }^{88}$ Fonte das imagens: http://varnecicordel.blogspot.com/2015/11/sarau-roda-da-palavra.html

${ }^{89}$ Página eletrônica da biblioteca: https://www.facebook.com/bibliotecaannefrank/
90 Página
eletrônica
da
Secretaria
Municipal
de
Cultura:

http://spcultura.prefeitura.sp.gov.br/evento/15139/\#tab=sobre
} 
O Sarau do PI é uma realização do Coletivo PI - um grupo que realizava intervenções urbanas explorando diferentes linguagens sob a perspectiva do feminino. $\mathrm{O}$ Coletivo PI venceu o Edital de Sarau proposto pela Casa das Rosas e, por isso, realizou durante o ano de 2015 uma série de saraus neste local, com periodicidade mensal, aos sábados no período noturno. É uma reunião aberta, mas com quantidade limitada de participantes e, por isso, distribuem senhas uma hora antes do início. Este sarau promove uma mesa de debate com convidadas que estudam ou atuam sob a perspectiva do feminino e, em seguida, realizam performances artísticas seguindo o mesmo tema proposto para o dia que incluem a declamação de trechos de obras literárias, cenas curtas de teatro, música, exibição de curta metragem. Os participantes podem falar ou fazer perguntas em momentos determinados, depois das diferentes apresentações, mas o protagonismo é das pessoas convidadas. Os frequentadores são espectadores que podem intervir no sentido de esclarecer alguma dúvida, curiosidade ou ainda comentar algo que contribua para a reflexão do tema. Neste sarau identificamos que uma das convidadas para a mesa de debate é uma professora vinculada ao Sarau Sobrenome Liberdade. A divulgação deste sarau ocorreu no caderno de programação impresso e página eletrônica da Casa das Rosas e na página eletrônica do Coletivo do PI.

Imagem 12. Fotografias do Sarau do PI.
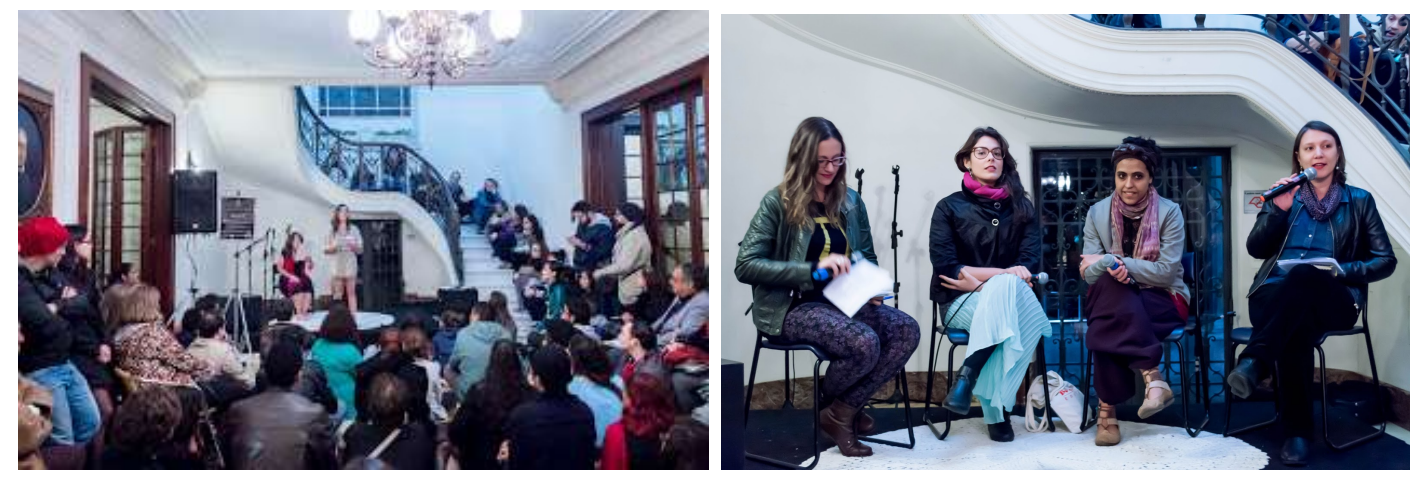

Fonte: Página eletrônica do Coletivo PI. (Crédito das fotos: Roni Adame) $)^{91}$

O Sarau Amigos do Parque Pinheirinho D'água acontece no parque de mesmo nome, mensalmente, no terceiro domingo do mês, no período da tarde. É organizado pela comunidade que reside nas proximidades do parque, localizado entre os bairros Parque Panamericano, City Jaraguá e Jardim Rincão, sendo esta uma área administrada pela subprefeitura de Pirituba. Deste sarau participam os moradores dos arredores que vão com

\footnotetext{
${ }^{91}$ Fonte das imagens: $\underline{\text { https://coletivopi.blogspot.com/2015/. }}$
} 
suas famílias, adultos e crianças. A organização é muito simples: as pessoas se reúnem em semicírculo sentadas em cadeiras diante do microfone e no centro colocam um tecido no chão com diversos livros que podem escolher um trecho para ler. Os livros são levados pelos organizadores, moradores da comunidade, e alguns são doações que recebem para o sarau. Há também participantes que levam seus livros, seus cadernos com trechos anotados de livros e ainda com pequenos textos autorais. Os que não preparam algo para compartilhar podem eleger dentre os livros à disposição. As leituras e/ou declamações são ordenadas por meio de uma lista em que as pessoas se inscrevem e a atividade ocorre ao ar livre ou numa grande sala que há no parque. Presenciamos a leitura de livros infantis realizadas por crianças se alternando entre os adultos participantes. A divulgação das atividades se dá por meio do blog do sarau ${ }^{92}$. Neste sarau há a participação de alguns professores $^{93}$ que moram e trabalham nas escolas públicas da região. Esses docentes compartilham suas opções de leituras nos saraus e os que escrevem, algumas vezes, leem suas produções.

Ao conhecer este sarau, soubemos que o Parque Pinheirinho D’água foi uma reivindicação da comunidade ao redor para que tivessem um espaço de lazer, já que essa região está muito afastada do centro da cidade. Desde sua inauguração, a comunidade se organiza para realizar atividades nesse espaço, assim como as escolas desenvolvem atividades pedagógicas no local. Nesse sentido, o sarau se constitui como uma dessas atividades de uso coletivo do parque.

Consideramos importante ressaltar que no sarau que acompanhamos, presenciamos discursos de moradores sobre a ausência de atividades culturais promovidas pela prefeitura na região, de modo que são eles que organizam as próprias atividades culturais. O sarau, neste sentido, é uma delas.

${ }_{92}$ O Sarau Amigos do Parque Pinheirinho D'água desenvolveu um blog para divulgar as ações desenvolvidas no parque: http://pinheirinhodagua.blogspot.com.br/

${ }^{93}$ Dentre os professores identificados neste sarau, uma professora aceitou participar da pesquisa. 
Imagem 13. Fotografias do Sarau Amigos do Parque Pinheirinho D'água
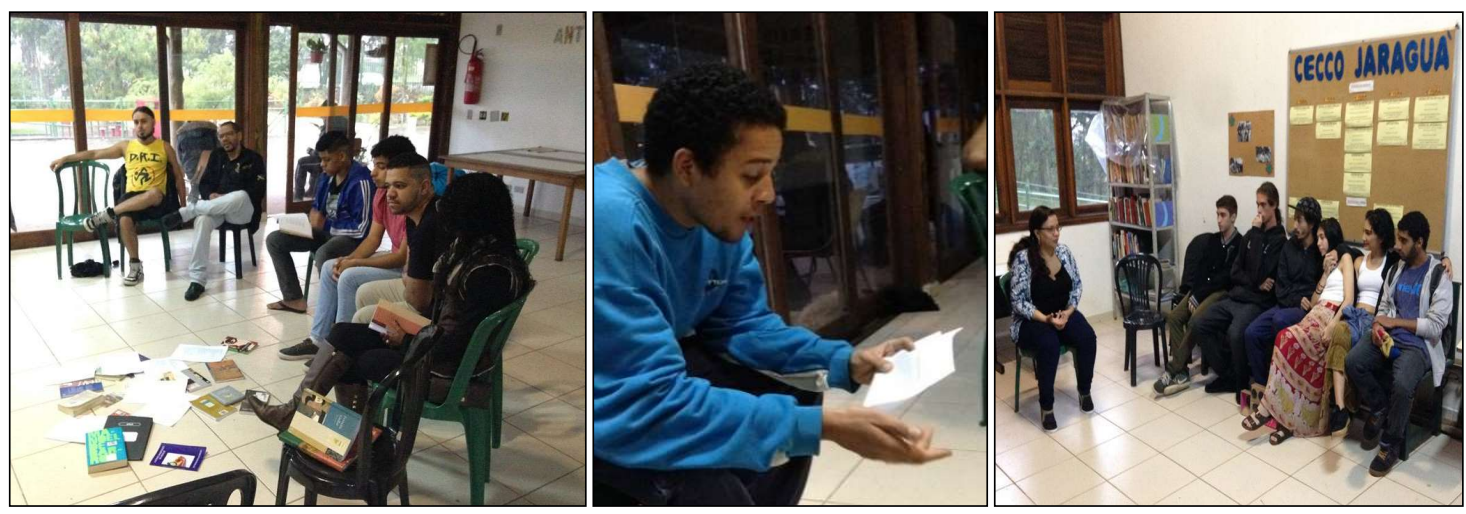

Fonte: Página eletrônica do sarau. ${ }^{94}$

O Sarau do Grajaú acontece no último sábado do mês, no período da noite, no Bar da Tia Nilde, no Parque Cocaia, zona sul de São Paulo. É organizado por moradores da comunidade e acontece desde 2014. Para o dia do sarau, o espaço do bar é reordenado de forma a criar uma área como se fosse um palco onde se instala o equipamento de som e microfone, tendo ao fundo um cartaz do sarau. Os frequentadores se acomodam em cadeiras arrumadas de modo linear, uma atrás da outra, pois o espaço é pequeno. Todos podem ler, declamar e/ou cantar e precisam se inscrever com um dos organizadores que elabora uma lista com os nomes. No canto direito do bar, há uma estante com livros que podem ser usados no momento do sarau, além de ficarem à disposição da comunidade diariamente. O sarau se inicia com a fala dos organizadores que no transcorrer da noite leem ou declamam seguindo a ordem da lista. Algumas pessoas levam seus cadernos com anotações dos trechos que irão ler, outros levam livros, aparelhos de celulares com os trechos já selecionados de uma obra e ainda há aqueles que leem versos autorais. Em algumas edições, o sarau promove o lançamento de livros independentes, que podem ser adquiridos no local e curtas apresentações musicais chamadas de "Pocket Show". Neste sarau identificamos a professora Cecilia ${ }^{95}$ que participa da organização do mesmo e há outros professores que frequentam as reuniões. Em entrevista, a professora relatou como ela e o companheiro decidiram começar este sarau no Grajaú:

Quando o [nome do companheiro] veio para cá, a gente..., a gente ainda frequentava, mas era longe, né, pra você sair daqui e ir lá pro Ademar e voltar..., e aí as meninas, eles deram uma parada, né, por n problemas

\footnotetext{
${ }^{94}$ Fonte das imagens: https://www.facebook.com/pg/sarauparquepinheirinho/photos/?ref=page internal

${ }^{95}$ A professora Cecilia (nome fictício) aceitou participar da pesquisa.
} 
do grupo e, aí, eu lembro que o [nome do companheiro] chamou a Sil e falou, "Sil, vamos retomar", eu falei, "olha, eu já...", teve todo esse processo de faculdade e tal, "terminei a faculdade, agora já estou mais tranquila, o [nome do companheiro] também, a gente pode...", aí, ela falou, "ah, não está rolando, a gente está fazendo outro projeto, tem uma revista que é o Fala Guerreira, tem um projeto para crianças, eu acho que não vai rolar" e ela ainda brincou, "faz um aí e me convida", aí o [nome do companheiro] falou, "eu acho que vou fazer mesmo, vamos fazer?" Eu falei, "ah, não..., não vou fazer, não" [risos], não, porque é uma responsabilidade, né, você começa e aquilo demanda energia, demanda tempo, não adianta eu fazer meu sarau e ficar aqui quietinha com ele [...] e, aí, eu relutei um pouquinho, eu falei, "mas como assim nós dois vamos fazer um sarau? O outro grupo tinha doze, vinte pessoas lá no começo e acabou, imagina a gente sozinho, não vai dar certo.” Aí, tinha um outro amigo nosso, o [nome do amigo], que escreve também muito, muito, muito, muito, [...]e aí, não, vamos fazer, vamos fazer e tal, só que..., aí, a gente começou, vamos fazer, vamos fazer, escolhemos o bar, pensamos, aí, conhecemos a tia Nilde, né, [...] e aí a gente veio parar no bar da tia e ela, "ah, faz o que vocês quiserem, fica à vontade", daquele jeito dela, né, e a gente fez com sete, oito poetas no primeiro, mas aí a Sil que era do Ademar veio, pegamos equipamento de som emprestado dela inclusive, veio o Augusto da Cooperifa, as pessoas foram... vieram chegando, também deram essa força, né, pra começar, e uma coisa muito legal é que veio muita gente da comunidade, né, então, não é um sarau para poetas e artistas, é pra gente do bairro, as pessoas foram chegando, então... (Entrevista pessoal professora Cecilia, 2017).

O Sarau do Grajaú recebeu o incentivo do Programa VAI - Valorização de Iniciativas Culturais - da prefeitura de São Paulo e realizou o documentário Grajaú em Foco mostrando o cenário cultural presente na região do Grajaú. A divulgação do sarau é realizada por meio da rede social Facebook ${ }^{96}$.

Imagem 14. Fotografias do Sarau do Grajaú
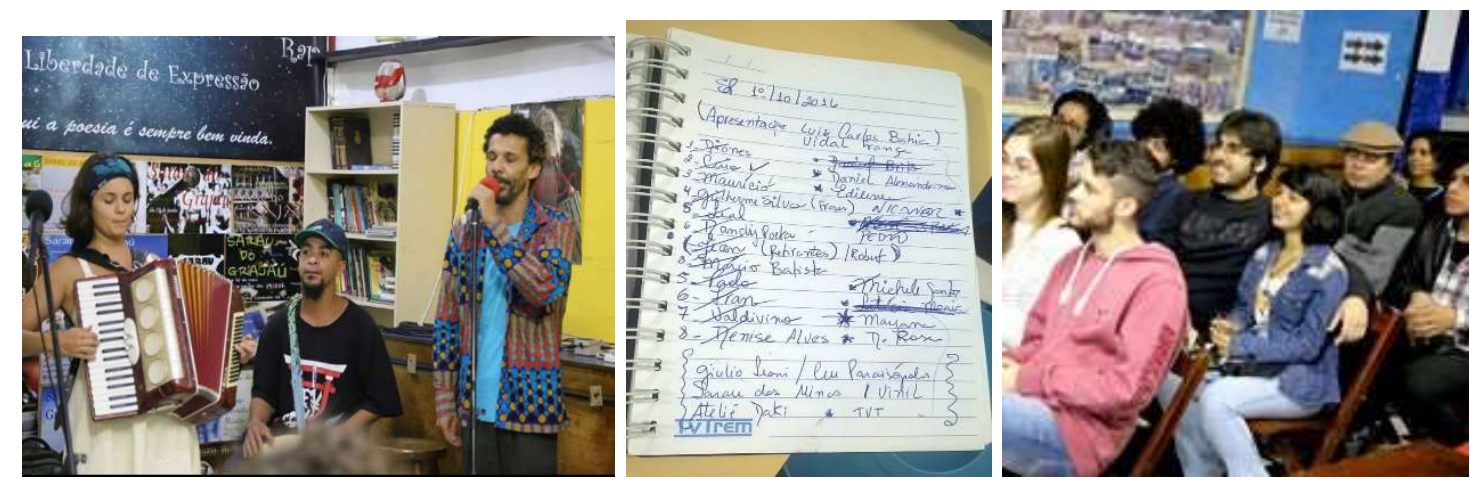

\footnotetext{
${ }^{96}$ Página de divulgação do Sarau do Grajaú na rede social Facebook: https://www.facebook.com/Sarau-doGraja\%C3\%BA-191479077716775/
} 


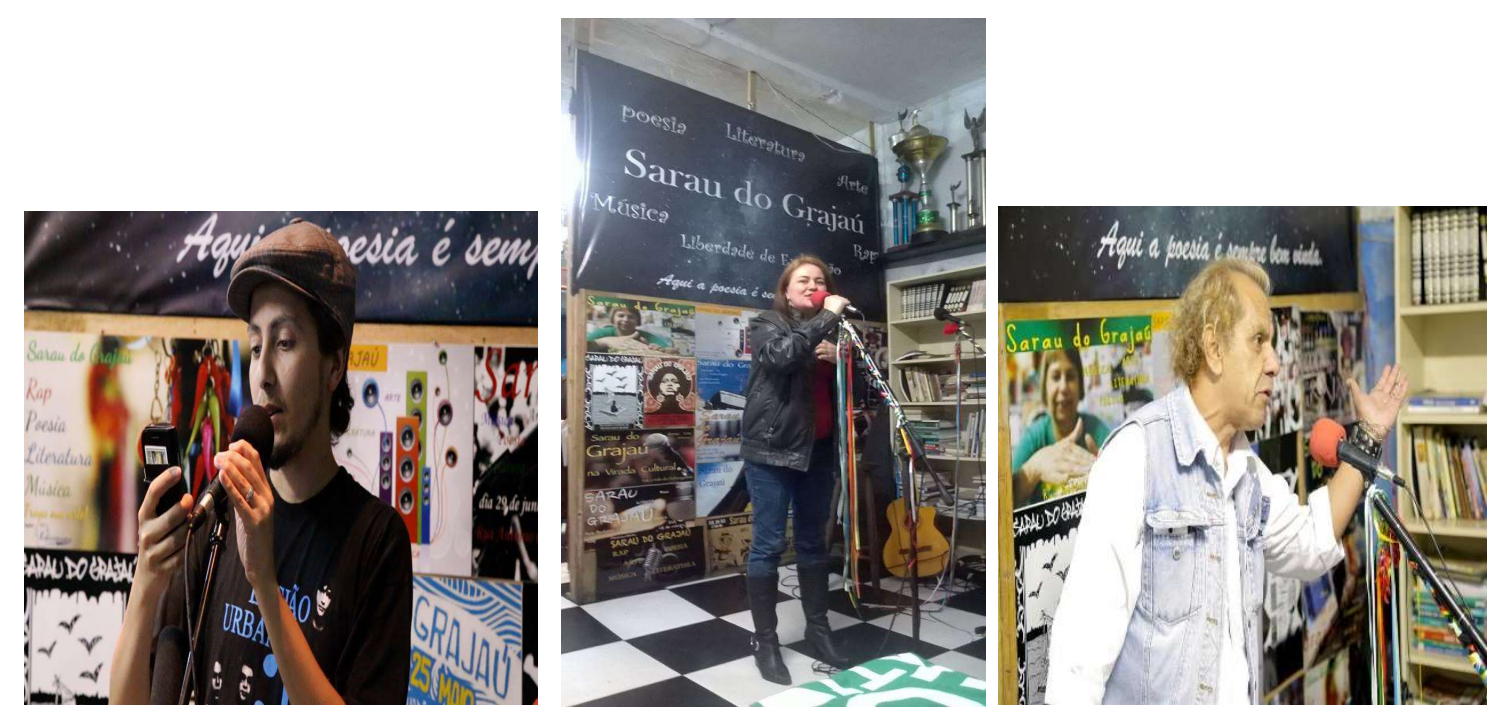

Fonte: Página eletrônica do sarau $\cdot{ }^{97}$

O Sarau Sobrenome Liberdade acontece uma vez ao mês, na primeira quinta-feira à noite, no Relicário Rock Bar, localizado no bairro Jordanópolis, zona sul de São Paulo. Organizado por um pequeno grupo de pessoas que moram e trabalham na região é composto de educadores e artistas. O sarau é aberto ao público em geral e seus frequentadores são moradores do bairro e organizadores de outros saraus. No dia do encontro literário, o bar é preparado para receber as pessoas de modo que as mesas e cadeiras são distribuídas de tal forma a deixar um espaço central vazio para circulação das pessoas, no palco ficam o equipamento de som e o microfone, o espaço é decorado com o cartaz do sarau, às vezes com fotos e frases. Logo na entrada do bar observamos uma mesa na qual se expõem os livros, folhetos, livretos em formato cordel dos autores independentes que participam dos saraus com o fim de divulgar e vender o que produzem. Todas as pessoas podem participar lendo, declamando ou cantando e, para isso, precisam se inscrever numa lista que organiza os que vão se apresentar por ordem de inscrição. Os organizadores sempre fazem uma fala inicial de apresentação e declamam um texto conjuntamente ou sozinhos. Além disso, este sarau também realiza lançamentos de publicações independentes de livros, livretos, fanzines e lançamentos de cds, também produzidos de modo independente. Quando ocorre o lançamento de cds, o músico faz uma pequena apresentação chamada de "Pocket Show". A divulgação do sarau acontece por meio da rede social Facebook ${ }^{98}$.

\footnotetext{
97 Fonte das imagens: https://www.facebook.com/pg/Sarau-do-Graja\%C3\%BA$191479077716775 /$ photos/?tab=album\&album id=195768613954488

98 Página eletrônica do Sarau Sobrenome Liberdade https://www.facebook.com/sobrenomeliberdad/
} 
Neste sarau identificamos tanto professores que atuam na organização quanto professores que são frequentadores das atividades. Tais professores escrevem textos literários e, em alguns momentos, leem seus textos nos saraus assim como publicam de modo independente, divulgam e vendem neste espaço. A professora Michele Santos atua na organização do sarau e os professores Janaína Moitinho e Jefferson Santana são frequentadores ${ }^{99}$.

Imagem 15. Fotografias do Sarau Sobrenome Liberdade.
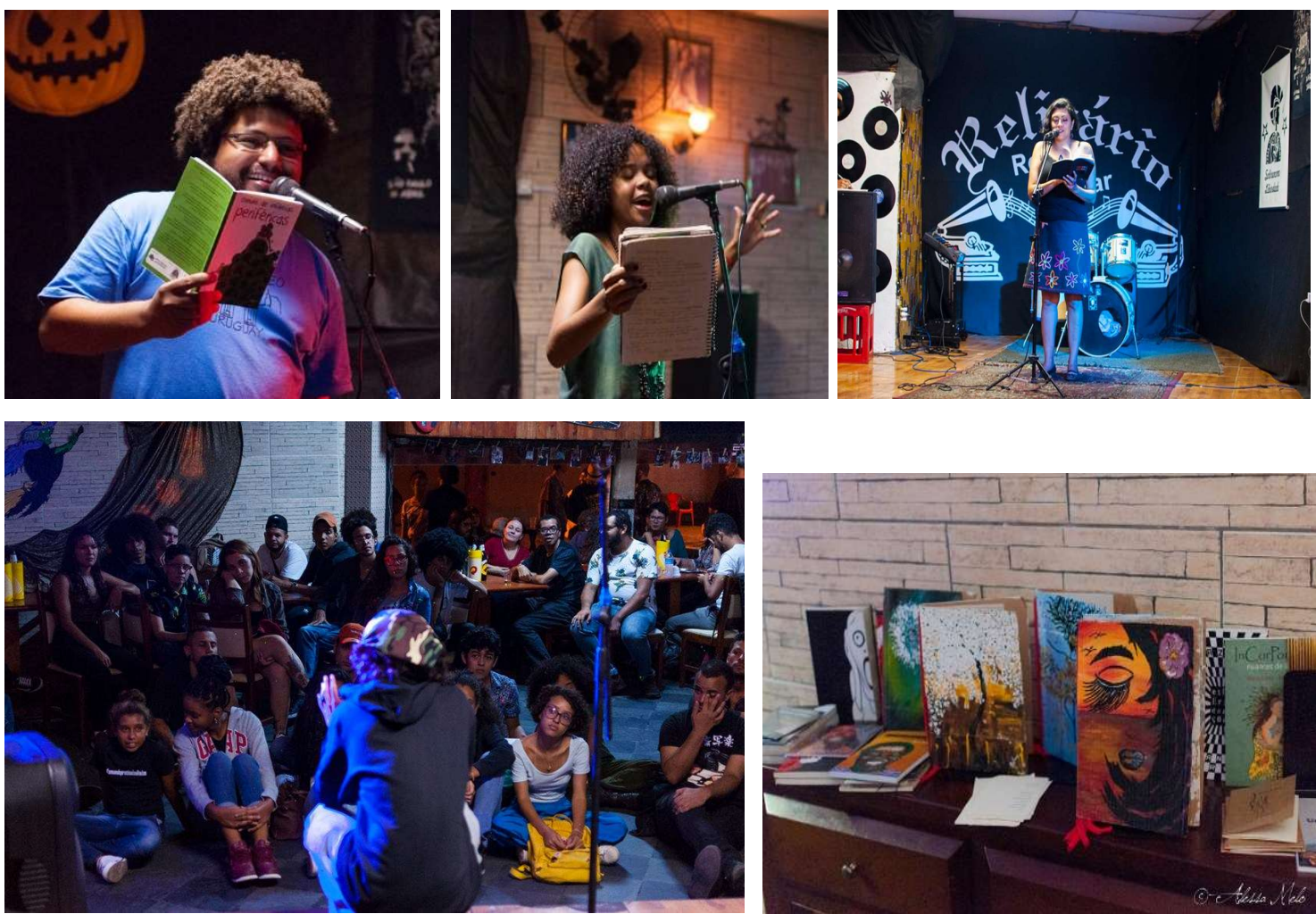

Fonte: Página eletrônica do sarau. ${ }^{100}$

A Cooperifa é um sarau realizado no Bar do Zé Batidão na zona sul de São Paulo, semanalmente, toda terça-feira no período noturno. As reuniões acontecem há 16 anos com atividades poéticas no Jardim Guarujá, periferia da cidade. Além das reuniões literárias, os organizadores desenvolvem projetos de saraus nas escolas públicas e outras ações culturais na periferia. No bar onde ocorre o sarau há uma estante de livros que podem ser lidos pela comunidade e usados durante o sarau. Microfone e equipamento de som são instalados diante das compridas mesas com bancos, sendo colocado na parede

\footnotetext{
${ }^{99}$ Os professores Michele, Janaína e Jefferson aceitaram participar da pesquisa.

${ }^{100}$ Fontes das imagens: https://www.facebook.com/pg/sobrenomeliberdad/photos/?ref=page internal
} 
ao fundo o cartaz do sarau. Todos os presentes têm espaço para ler, declamar ou cantar, mas precisam se inscrever na lista que ordena as falas de cada participante. Uma regra deste sarau é o silêncio, todos devem estar em silêncio para ouvir quem lê/declama. Este é um sarau com muitos participantes, em sua maioria moradores da comunidade e outras pessoas que se deslocam de outra região para participar. Também há lançamentos de livros e comercialização destes.

Os participantes possuem idades variadas. Identificamos, inclusive, mulheres idosas que não apenas se colocam como espectadoras, mas também levam seus cadernos com anotações para compartilhar com o grupo de presentes as suas leituras. Do mesmo modo há um considerável número de pessoas que declamam textos e cantam músicas autorais. A divulgação do sarau e das atividades que realizam ocorre por meio de página eletrônica e redes sociais ${ }^{101}$. Alguns professores ${ }^{102}$ participam frequentemente deste sarau, assim como escrevem e publicam seus textos por meio de editoras e/ou de forma independente.

Imagem 16. Fotografias do Sarau da Cooperifa.
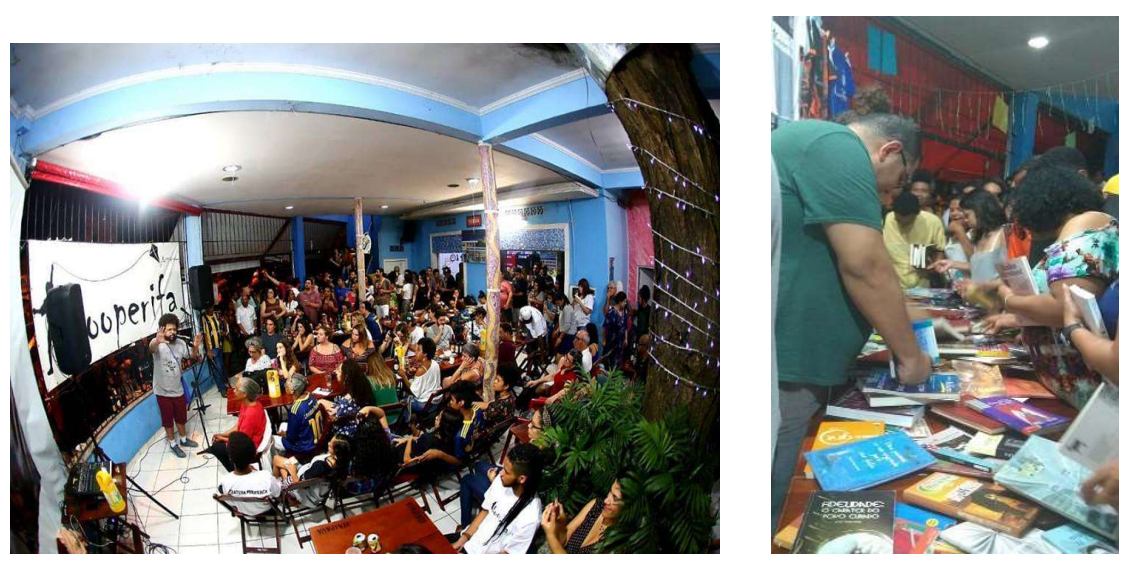

\footnotetext{
101 Página eletrônica da Cooperifa: http://cooperifa.com.br/ e Facebook https://www.facebook.com/Cooperifaoficial/

${ }^{102} \mathrm{O}$ professor Márcio aceitou participar da pesquisa.
} 

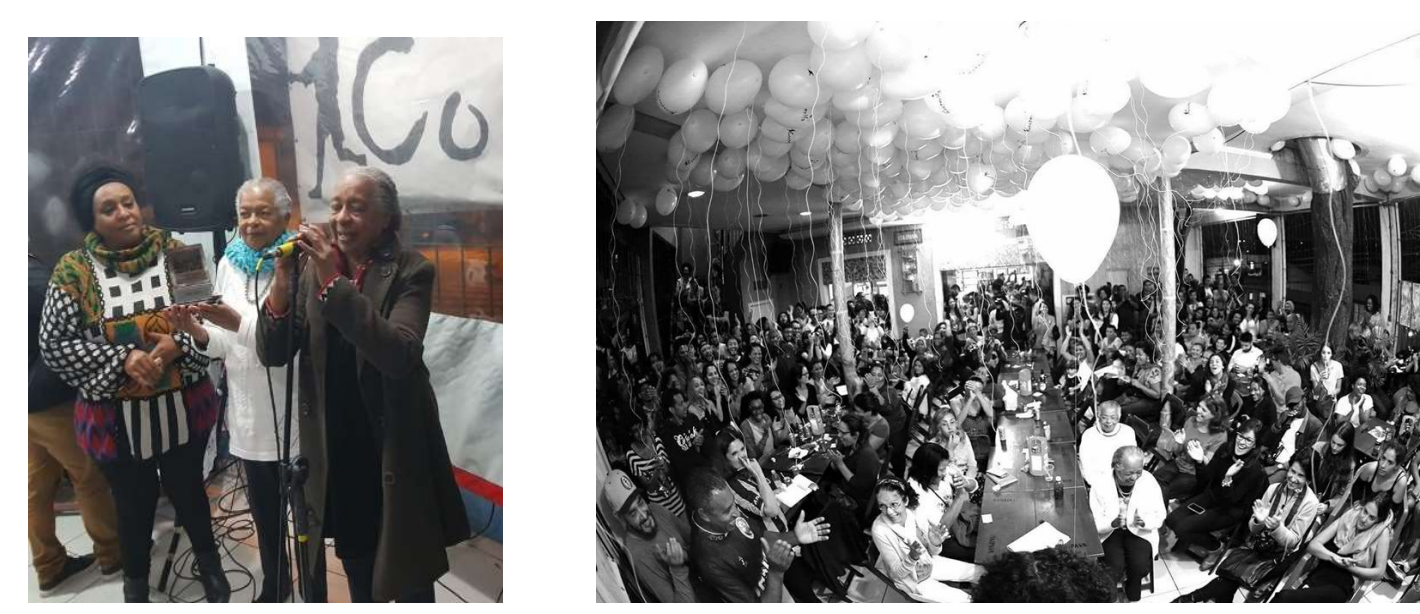

Fonte: Página eletrônica do sarau. ${ }^{103}$

O Sarau na Galeria é um sarau que acontece em Suzano, região metropolitana de São Paulo, aos sábados, mensalmente, desde 2013. Inicialmente, este sarau ocorria em um bar na região central da cidade, depois passou a ocupar o espaço de uma escola de inglês, mas o espaço não era apropriado para as atividades, foi então que os organizadores tiveram a ideia de migrar o sarau para uma escola pública localizada na região central da cidade. Com isso, atualmente o sarau acontece na Escola Estadual Geraldo Justiniano e em algumas edições é realizado em outros espaços pela cidade. É aberto a todos os interessados, com microfone aberto, o que possibilita que quem deseja possa se apresentar para ler, declamar ou cantar e também há convidados que neste espaço apresentam e divulgam seus trabalhos literários ou musicais. O professor José Vandeí que entrevistamos, relata de modo breve o início do sarau:

[...] O Sarau na Galeria ele nasceu há quatros anos atrás, rapidamente falando, numa galeria de bares que tem aqui em Suzano, no centro, eu já morava aqui, eu já conhecia as pessoas, não tinha um sarau aqui em Suzano, tinha um... Aqui em Suzano tinha o 'Literatura Nossa' que o Sacolinha organiza, mas é nos bairros, no centro não tinha. E daí, a Raquel, que é uma das precursora, a gente começou a organizar o Sarau, ela me conheceu em um evento, e ela falou: "Ah, vai lá e tal”, e eu comecei a frequentar e ele precisava sair lá do bar, foi pra uma escola de inglês, a escola de inglês não era um espaço muito adequado, e daí a gente falou: "Vamos fazer na escola, porque a escola a gente quer fazer parceria com a comunidade" já que a escola é no centro, né?! E foi um máximo, porque a gente achava que tem tudo a ver com a escola, aí já acontece há um ano e meio aqui na escola [...]. (Entrevista pessoal professor José Vandeí, 2017).

\footnotetext{
${ }^{103}$ Fonte das imagens: https://www.facebook.com/pg/Cooperifaoficial/photos/?ref=page internal
} 

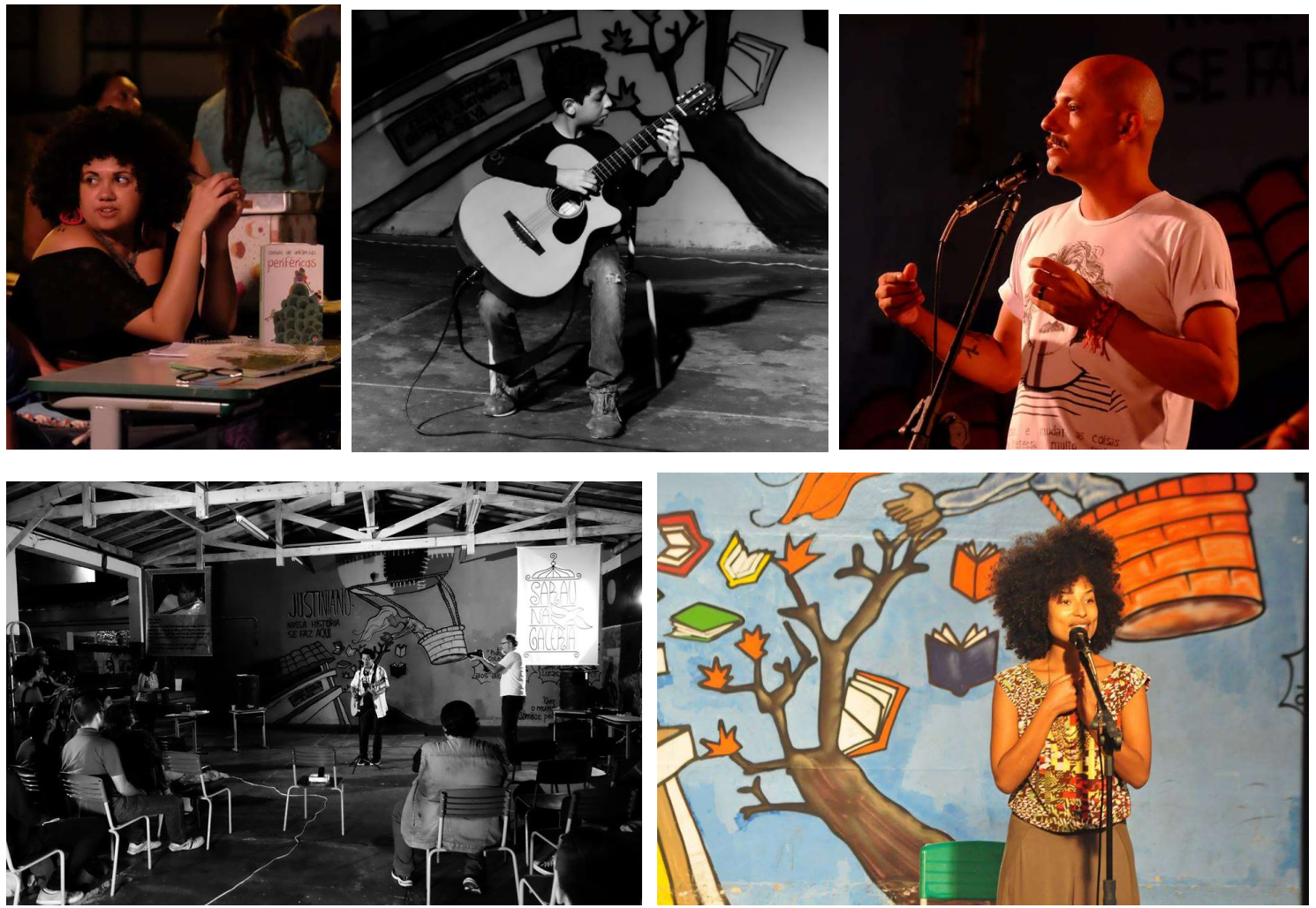

Fonte: Página eletrônica do sarau. ${ }^{104}$

Para a realização do sarau é organizado o espaço do pátio da escola que é um ambiente grande e livre, onde são arrumadas as cadeiras diante de um lindo painel pintado na parede pelos alunos, utilizado como fundo do palco, e afixado um cartaz do sarau. Este sarau também realiza lançamentos de livros independentes, além de apresentações musicais, dança e outros tipos de intervenções artísticas. A divulgação das atividades do sarau é feita por meio de redes sociais e blog ${ }^{105}$.

O Sarau Lapada Poética acontece mensalmente em São Bernardo do Campo, região metropolitana de São Paulo, no bar Ferradura, localizado no centro da cidade. A organização fica por conta do Coletivo Tantas Letras que convida escritores para participarem do sarau divulgando seus trabalhos com lançamento das obras e/ou realizando discussões sobre as próprias produções. O encontro é aberto a todos que queiram participar para assistir e/ou se apresentar, todos podem ler e declamar, mas não fazem uso de microfone. Além disso, há curtas apresentações musicais e debates. Assim

\footnotetext{
${ }^{104}$ Fonte das imagens: https://www.facebook.com/pg/saraunagaleria/photos/?ref=page internal

105 Blog do Sarau na Galeria: https://saraunagaleria.blogspot.com/p/olhares-sobre-o-sarau-nagaleria 71.html; rede social Facebook: https://www.facebook.com/saraunagaleria/
} 
como os outros saraus mencionados, este utiliza as redes sociais para divulgar a agenda de encontros. Neste sarau também há uma professora que aceitou participar da pesquisa.

Imagem 18. Fotografias do Sarau Lapada Poética
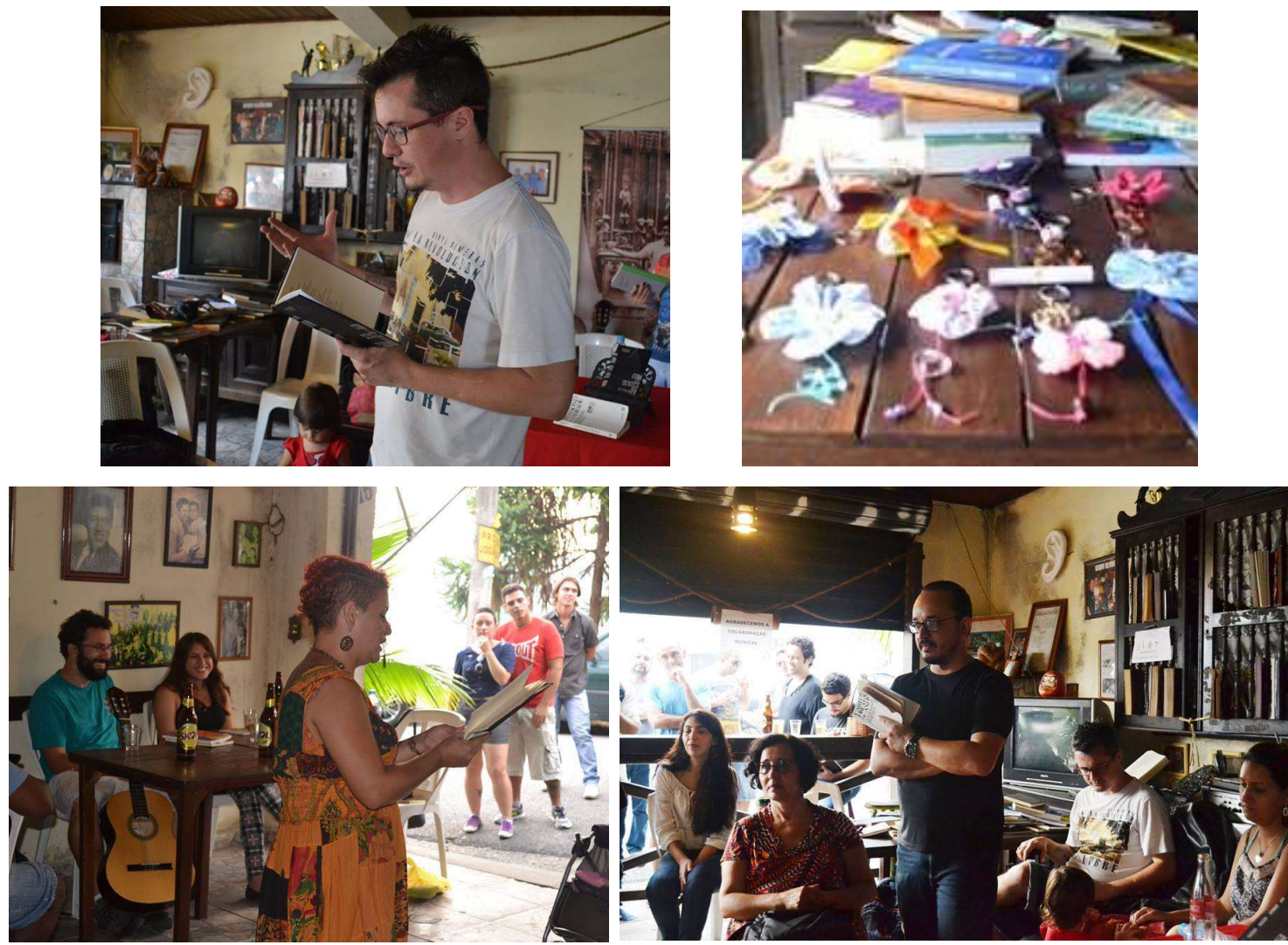

Fonte: Página eletrônica do Coletivo Tantas Letras. ${ }^{106}$

Nos saraus Cooperifa, Amigos do Parque do Pinheirinho D'água, Sobrenome Liberdade, Sarau do Grajaú e Sarau do Mercado identificamos discursos, textos autorais e leituras literárias que fazem críticas à condição social em que se encontra a população brasileira, essas críticas fazem referência às escolas e à educação pública ofertada pelos governantes, às condições não adequadas de trabalho, ausência ou insuficiência de políticas culturais para a população e políticas públicas para a juventude, e à violência sofrida pela população que vive na periferia. Portanto, foram nesses saraus que fazem estas críticas que encontramos os professores escritores e, a partir desses encontros, conseguimos localizar outros professores escritores participantes de outros saraus.

\footnotetext{
${ }^{106}$ Fonte das imagens: https://www.facebook.com/pg/letrastantas/photos/?ref=page internal
} 


\subsection{Os saraus e os professores: desencontros, encontros na cidade}

Veio com seu gingado de samba Com um jeito leve e travesso

Atravessou a rua e adentrou o bar.

Sem fita... sem pompa...

Foi logo descendo o salto, dispensando seus arautos...

Andava meio entediada De bailar pelos salões antigos, De viver eternamente de castigo Nos museus e relíquias do passado...

Ela, a flor mais bela a deusa, a musa, a mulher chamem-na como quiser: A Poesia em carne e osso!

Brincou com os copos acendeu um cigarro roubou um sorriso deu mais um trago.

Ganhou os meninos do rap do rock, do pop, do soul ganhou beijos e afagos chorou com gosto amargo gostou dos aplausos... e ficou...

E gostou de ser humana e de ouvir das bocas simples histórias dos becos e das quebradas de vilas, de maravilhas de gente apaixonada...

Desde então ela passeia sem cerimônia alguma pelas noites paulistanas.

Não tentem aprisioná-la: ela é senhora e soberana.

Não pertence a ninguém não se dobra, não se vende mas se rende faceira a todo aquele que queira sonhar com um mundo melhor.

De palavras e atitudes

De poetas e alaúdes 
De riso e choro em prol do amor...

(SANTOS, 2009) $)^{107}$

Conhecer saraus na cidade de São Paulo com o objetivo de encontrar professores escritores foi uma atividade que teve início em abril de 2015. A constante atividade dos grupos de sarau na cidade, principalmente nos bairros compreendidos como periféricos em decorrência da distância em relação ao centro e pelas características apontadas por Rolnik (2017), chama a atenção, sobretudo porque foi de maneira intuitiva que, ao constituir a proposta da pesquisa, nos questionamos sobre a possibilidade de existir professores nesses espaços. Foram dez os saraus visitados em busca de professores escritores e encontrados em alguns deles apenas. Existe grande diversidade nas formas como os saraus são conduzidos, nas discussões produzidas em seu interior, assim como do público frequentador, além dos espaços onde são realizados como mencionados acima: biblioteca pública, casa de cultura, parque e bares.

Consideramos importante pontuar que os professores escritores que identificamos nos saraus são organizadores e participantes ativos dos saraus localizados nos bairros periféricos da cidade e região metropolitana e essa característica em comum nos leva a pensar sobre o que aproxima e o que distancia esses diferentes grupos, pois estes saraus possuem um modo de operar distinto daqueles que estão ocupando os espaços das bibliotecas públicas e outros mais centrais na cidade. Assim como mencionado anteriormente, os professores que identificamos são participantes dos seguintes saraus: Sobrenome Liberdade, Sarau do Mercado, Sarau do Grajaú, Cooperifa, Sarau Lapada Poética, Sarau Amigos do Parque Pinheirinho D'Água, e Sarau na Galeria.

Dentre os saraus que acontecem na região mais central da cidade, o único que presenciamos a participação de uma professora foi o Sarau do PI que ocorreu na Casa das Rosas, e isso se deve ao fato dela ter sido convidada para compor uma mesa de discussão sobre literatura feminina, considerando que a proposta do Coletivo PI era realizar um sarau com diversas atividades e performances que levassem à discussão e reflexão da condição feminina na sociedade. Nos outros quatro saraus alocados em bairros mais centrais, como mostra o mapa a seguir, não havia professores quando participamos dos encontros.

\footnotetext{
${ }^{107}$ Bar e Poesia publicada no blog Girassol Poético.
} 


\section{Localização dos Saraus}
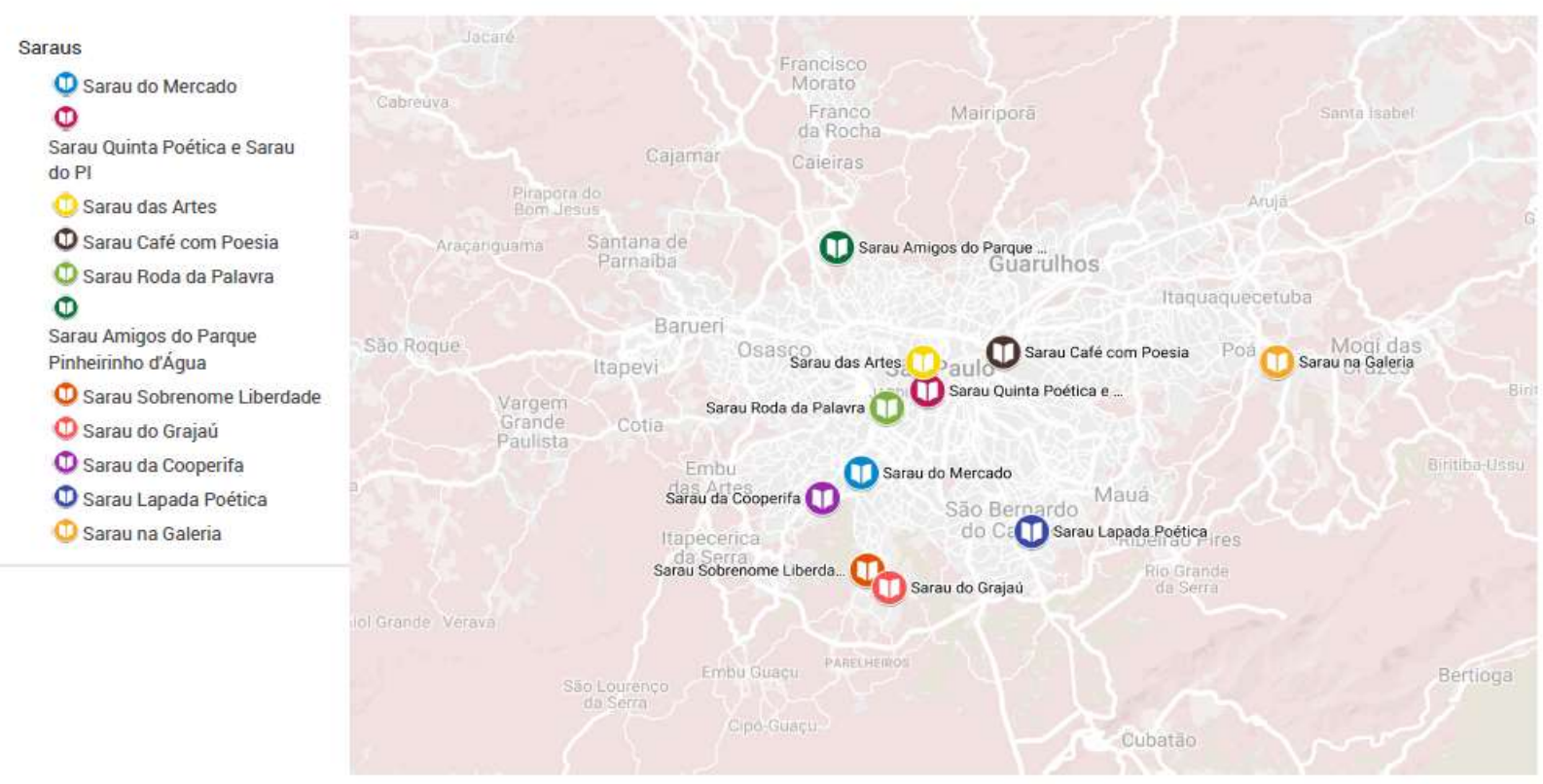

Fonte: Elaborado pela pesquisadora.

Em relação aos saraus que acontecem na Zona Sul, com exceção do Sarau do Mercado, o local em comum utilizado para as reuniões é o bar, espaço esse não pensado para uma reunião literária num primeiro momento, mas que existe em quantidade pela cidade, principalmente nos bairros mais distantes, e muito frequentado pela população ao redor - em geral homens, para momentos de lazer. Como é possível observar no mapa, os bairros do extremo sul de São Paulo onde acontecem o Sarau da Cooperifa, Sobrenome Liberdade e Sarau do Grajaú estão tão nas "bordas" do território da cidade que, ao nos deslocarmos em direção à esses bairros, vamos observando grande mudança na paisagem urbana, os altos edifícios vão diminuindo, se distanciam e encontramos áreas ocupadas por casas térreas, muitas vezes pequenas, com ruas estreitas, em alguns momentos, parecendo cidades interioranas, principalmente se o percurso margear as represas Guarapiranga e Billings. Portanto, ocupar o espaço do bar para um sarau é a possibilidade de realizar uma atividade cultural que a população tenha acesso, já que os equipamentos culturais ofertados pelo poder público não chegam a esses locais.

Em situação semelhante se encontra o Sarau Amigos do Parque Pinheirinho D’água, que está localizado no extremo norte da cidade, quase fazendo fronteira com a cidade vizinha Caieiras. No dia em que fomos neste sarau, estava acontecendo a Virada Cultural em São Paulo com uma série de atrações gratuitas, no entanto, em função das 
atividades programadas para este evento acontecerem somente na região central, todas as mais periféricas ficam excluídas da programação e é importante pontuar que neste dia, um dos participantes disse, antes de ler sua poesia, que "este sarau é um espaço de cultura organizado pela comunidade já que a Virada Cultural não chega na periferia e nem todos podem se deslocar até o centro para participar" ${ }^{108}$. Nesse sentido, Lucía Tennina afirma que:

[...] os saraus não são apenas pontos dispersos no mapa. Acabam por fazer parte de um "circuito" cultural independente e autônomo em relação àquele outro que se constituiu no chamado "Centro" de São Paulo, onde se concentra a maior parte dos recursos, equipamentos e atividades culturais da cidade, funcionando como parâmetro para os índices de qualidade, ao mesmo tempo que está circunscrito a um segmento social muito específico: a classe média urbana com escolaridade superior. (TENNINA, 2017, p. 117).

Este sarau apresenta algumas peculiaridades: primeiro, o fato de utilizar o espaço de um parque e não um bar, e isso se dá porque a ocupação do parque com o sarau é uma ação política da comunidade que reivindica espaços de lazer na periferia. A construção do parque nesse local foi uma solicitação da população ao poder público e, com a efetivação deste espaço, existe uma organização de vários grupos para o uso comum do lugar. Desse modo, o parque é um espaço simbólico da ação política deles. Outra característica são os livros levados pelos organizadores que são colocados à mostra para os participantes que queiram ler algo, mas que não se prepararam para isso. Os livros são sim manuseados até a escolha de um texto para a leitura coletiva.

A constituição de pequenas bibliotecas nos bares que ficam disponíveis à comunidade não somente em dias de sarau, mas em todos os dias, como há na Cooperifa e Sarau do Grajaú, é algo que transforma o ambiente do bar, ali passa a ser um espaço onde a cultura letrada habita, ainda que de modo tímido, mas acessível aos diversos leitores mais ou menos fluentes que coabitam o espaço. Distinto do que ocorre no sarau do parque, cujos participantes usam com frequência os livros expostos, nos saraus da zona sul observamos que a maioria das pessoas chegam com as suas leituras já selecionadas em seus cadernos e em seus aparelhos celulares.

Outra similaridade encontrada nesses saraus é a divulgação e circulação de livros, fanzines e livretos produzidos pelos próprios saraus, outros por seus autores de modo independente. Com exceção do Sarau Amigos do Parque Pinheirinho D'água, circulam

\footnotetext{
${ }^{108}$ Registro extraído do caderno de campo, por isso, não é possível dizer que é a fala literal do participante.
} 
nos saraus periféricos as obras dos escritores independentes, de forma que em diversos saraus é possível adquirir um ou vários títulos para a biblioteca pessoal. Esses títulos só podem ser encontrados nesses espaços, do mesmo modo que os lançamentos das obras acontecem nesse circuito de saraus, indicando que o sarau é fundamental para a circulação dessa produção que está às margens do círculo editorial e das livrarias, como aponta Tennina:

Os saraus são centrais na consolidação da produção da literatura marginal da periferia. [...] Neles, além da declamação, circulam publicações em formato de livro dos autores presentes. Muitos dos saraus têm hoje em dia suas próprias editoras, suas próprias estéticas, seus próprios poetas. E todos eles são elementos cruciais para a difusão das produções desses escritores, seja por meio da divulgação dos livros autorais, seja por meio das antologias que cada um dos saraus vem organizando. (TENNINA, 2017, p. 30).

Existe entre os organizadores dos saraus e escritores uma rede de contato em que um grupo não se restringe somente ao seu sarau, eles participam de outros saraus também para prestigiarem o trabalho que está sendo realizado naquela comunidade e para mostrar o próprio trabalho literário e com isso criar um público leitor.

$\mathrm{Na}$ entrevista realizada com a professora Cecilia, que participa da organização do Sarau do Grajaú, ela nos conta um pouco sobre essa parceria que é feita entre os grupos de saraus:

[...] não adianta eu fazer meu sarau e ficar aqui quietinha com ele, você falou dos outros, né, eu preciso visitar os outros, porque eu preciso também ouvir, também trocar, estar em vários espaços, trazer gente para cá, né, não é uma coisa, ah, eu fico aqui e as pessoas vem, não funciona assim, existe uma troca, uma parceria o tempo todo, né [...]. (Entrevista pessoal professora Cecilia, 2017).

Como relata brevemente a professora, os saraus realizados nas periferias, mesmo estando em diferentes zonas da cidade, organizaram uma rede na qual se apoiam na realização dos encontros, nos lançamentos de obras, na comercialização e consequente circulação dessa literatura produzida na periferia, ou seja, estes são espaços de produção cultural, no sentido dos objetos produzidos, e de práticas de cultura. 


\section{PROFESSORES ESCRITORES}

Neste capítulo iremos discutir quem são os professores participantes da pesquisa elaborando uma caracterização da origem social desse grupo num primeiro momento, em seguida tratando dos aspectos formativos, considerando a formação acadêmica e o ingresso na carreira, assim como se relacionam com a profissão no contexto atual, e por fim, como se deu o interesse pela escrita literária.

São dezessete (17) professores escritores participantes da pesquisa, sendo nove (9) do concurso literário e oito (8) vinculados aos saraus. A faixa etária é de 28 a 63 anos e suas formações acadêmicas correspondem a: Letras (7), História (2), Pedagogia (4), Artes (1), Educação Física (1) e Filosofia (1). Desse grupo, apenas 4 professores não se constituem na primeira geração de suas famílias que concluíram a formação universitária.

A seguir apresentaremos a origem social dos professores a partir das entrevistas realizadas.

\subsection{Origem social dos professores entrevistados}

O grupo de professores entrevistados é composto por dezessete professores, dos quais dez são mulheres e sete são homens de diferentes gerações, cujas idades variam entre 28 e 63 anos $^{109}$. Ainda que cada um tenha sua trajetória pessoal e de formação, quando agrupamos os relatos obtidos nas entrevistas, percebemos uma série de semelhanças entre alguns em relação aos aspectos familiares e socioeconômicos e este ponto nos possibilita refletir sobre quem são esses professores escritores. Desse modo, traçaremos um breve perfil de cada professor considerando os seguintes aspectos: o local de nascimento, formação e profissão dos pais, a instituição de formação escolar e acadêmica e outros elementos formativos relativos ao contexto familiar que constaram

${ }^{109}$ Faixa etária considerada no momento das entrevistas. 
em algumas entrevistas. Para isso, iniciaremos cada descrição com um trecho da entrevista do referido professor.

Minha mãe é... não sabe escrever, assim, ela fez na época Mobral que era $\mathrm{o}$ antigo..., era Mobral que chamava antes [...]. Bem..., é aquele bem básico que aprende o nome, mas nem, nem chega a ser anos iniciais, eu acho, aprende escrever o nome e bem basiquinho mesmo. Ela consegue ler assim, mas com bastante dificuldade. E o meu pai, é... não tenho certeza, mas acho que foi o..., o que era até quarta, quinta série, não chegou a terminar, não. (Entrevista pessoal professora Camila, 2017).

Camila nasceu na capital paulista, tem quarenta e dois anos e atua na educação infantil, em uma CEI na DRE Pirituba. Oriunda das classes populares, seus pais tiveram pouco tempo de escolarização e não concluíram o ensino fundamental, em relação ao trabalho, seu pai atuou como vigia noturno e sua mãe era do lar. A precária escolarização do pais, como demonstrado no relato, nos indicia a restrita inserção destes na cultura letrada, já que a professora relata que sua mãe lê com dificuldade e não faz referência ao pai em contato com a leitura e escrita. Camila se inseriu no mundo do trabalho bem jovem, ainda na adolescência com quinze anos, atuando no que ela chamou de "obra social" mantida por freiras que acolhia crianças de até seis anos, como nos contou durante a entrevista:

Eu trabalhei numa obra social das irmãs [...], fui convidada com 15 anos, [...] elas me conheciam da igreja, então, me convidou para trabalhar. E aí eu era nova, eu fazia de tudo, aí era tipo um grupo misto, com crianças misturadas até 6 anos na época, porque com sete ia pra escola e aí eu cuidava, dava alguma coisa para pintar e tal, [...] ainda não estava no magistério, estava estudando ainda, e aí, eu brincava com eles, eu era bem menina assim, mesmo [...] Depois que eles iam embora, eu limpava a escola [...]. (Entrevista pessoal professora Camila, 2017).

Em sua trajetória escolar, Camila foi aluna de escola pública e, influenciada por este trabalho e por uma prima, decide fazer o curso Magistério concomitante ao Ensino Médio o que a permitiria continuar trabalhando nesta instituição, mas em uma outra condição, tendo atuado na administração da instituição e, mais tarde, como coordenadora pedagógica. Ingressar no curso de Pedagogia foi algo que ocorreu anos depois em função das exigências propostas pelas políticas públicas que não mais permitiriam professores atuando sem curso superior, por isso, ela decidiu ingressar no curso de Pedagogia em uma instituição privada de ensino, concluindo a graduação em 2006. O adiamento do curso superior, no entanto, não foi simplesmente uma escolha, já que fatores determinantes não possibilitaram o ingresso e dentre eles a condição econômica, como relata: "A faculdade 
pra mim fazer era um pouco mais difícil, para pagar era mais caro, não tinha como hoje tanta possibilidade, então, eu acabei ficando como coordenadora só com o magistério [...]" (Entrevista com professora Camila, 2017). No momento da realização da entrevista, Camila estava cursando uma pós-graduação lato sensu em Gestão Escolar.

\begin{abstract}
Ah..., [...] meus pais tiveram pouca escolaridade assim, são de Pernambuco [...]. Meu pai nasceu na cidade de Arcoverde, minha mãe em Caruaru, e eram locais que não tinha praticamente escola, era muito comum as crianças irem para escola com nove, dez anos, né, então, basicamente eles tem o chamado Fund. I, né, hoje o que a gente chama de Fund. I, né, então, essa é a escolaridade deles, mas, assim, é..., minha mãe contava muita história, [...] muito dos conhecimentos deles tanto ligado ao campo, a agricultura e quanto a literatura, a literatura de cordel e tal, era muito pela tradição oral, né, que é o que se ouvia, o que você passa, que é bem interessante, mas oficialmente, formalmente era o ensino fundamental. Depois, já, a gente já adulto e tal que eles começaram a estudar, mas muito sozinhos assim, a gente ajudando pra eles poderem aprender a ler e a escrever, minha mãe lê hoje, ela lê bíblia, foi aprender a ler, porque queria ler a bíblia e tal, mas porque a gente ajudou, né, acabou ajudando de alguma forma. (Entrevista pessoal professora Cecilia, 2017).
\end{abstract}

Cecilia tem cinquenta anos, nascida em São Paulo, é filha de migrantes pernambucanos. Seus pais tiveram pouca escolarização, ainda crianças frequentaram alguns anos do que corresponde ao Ensino Fundamental I, no entanto, não ficou claro se concluíram esta etapa do processo de escolarização, pois de acordo com o relato da professora, eles voltaram a estudar muito tempo depois para aprender a ler. Em relação ao trabalho, eles foram agricultores. Aluna de escola pública, interrompeu seu processo de escolarização no Ensino Médio, pois já trabalhava e a escola que oferecia esta etapa do ensino ficava muito distante de seu local de residência, que era um bairro no extremo sul de São Paulo, como relata:

Então, eu fiz o ensino médio, na verdade eu, eu parei o ensino médio, não concluí, ah..., parei, trabalhava, estudava na época, era bem complicado, trabalhava na Vila Mariana, estudava em Santo Amaro, estudava noturno, aquelas coisas, né, uma família grande, precisava ajudar pai e mãe [...], eu morava na Pedreira, só tinha escola de segundo grau em Santo Amaro, por exemplo. Um bairro, é, então, da zona Sul que é enorme, né, mas, assim, eu precisava pegar um ônibus, levava quarenta minutos para ter acesso a uma escola de segundo grau, então era bem complicado, então eu fiz os dois anos, acabei parando, aí me casei, veio filho, vieram filhos e etc, eu fiz, depois de muito tempo, um processo que eu acho que nem existe mais que era o de eliminação de matérias [...]. Então, eu estudava sozinha, ia lá fazia as provas, eu demorei muito, principalmente porque física, química e matemática para estudar sozinha é dureza, né, e tinha que dar conta desses 
conteúdos para passar na prova, então eu fiz acho que duas vezes, um ano eliminei uma parte, no outro eliminei uma outra parte [...] e tive o meu diploma de segundo grau, de Ensino Médio (Entrevista pessoal professora Cecilia, 2017).

De acordo com o relato da Cecilia, o contexto familiar não permitia vislumbrar nem a conclusão da educação básica. Era necessário se inserir no mundo do trabalho já na adolescência e, em função dos grandes deslocamentos que precisava fazer para chegar na escola, acabou desistindo de estudar naquele momento, pois não era possível desistir do trabalho. A conclusão do Ensino Médio aconteceu por meio do processo de eliminação de matérias ${ }^{110}$ para o qual estudava sozinha e que o fez em duas partes pela dificuldade nas disciplinas das áreas de exatas. Muito embora não saibamos os motivos que não a fizeram voltar à escola para concluir o Ensino Médio, supomos que a condição feminina pode ter sido uma barreira, principalmente por ter filhos - aspecto que foi decisivo para que ela realizasse as provas de eliminação. Sobre a perspectiva de formação escolar no interior do contexto familiar, ela relata:

[...] na minha época era assim, você saiu do Fund. I, arrumava um emprego para ajudar os pais, não tinha esse acesso que a gente tem hoje, de FIES, de PROUNI, a gente não sabia nem como chegar a uma faculdade, né, faculdade era coisa pra rico, então era isso mesmo, a gente, não se tinha nem os caminhos, né, até para fazer o segundo grau era complicado [...]. (Entrevista pessoal professora Cecilia, 2017).

Para cursar uma graduação, Cecilia teve algumas dificuldades: tanto relacionadas à necessidade de trabalhar, já que ingressou no curso superior tardiamente; quanto conciliar toda a rotina familiar e de trabalho com os estudos. Desse modo, ela ingressa duas vezes no curso superior e desiste pelas dificuldades, somente no terceiro ingresso é que consegue concluir o curso de Pedagogia numa faculdade privada.

A minha mãe terminou o ensino médio, mas assim, depois de adulta, ela tinha terminado até a oitava série, [...] e meu pai também, meu pai tinha estudado até a quarta série e depois ele terminou o ciclo 2, o antigo... Até o oitavo ano, né, na época oitava série, depois também. (Entrevista pessoal professor Daniel, 2018).

Daniel tem quarenta anos, nasceu em São Paulo e seus pais tiveram acesso à escola, mas seus processos de escolarização foram interrompidos, conforme observado no trecho acima transcrito. Sua mãe conseguiu concluir o ensino fundamental e seu pai

\footnotetext{
${ }^{110} \mathrm{O}$ processo de eliminação de matérias atualmente chama-se ENCCEJA.
} 
estudou até a quarta série na idade adequada. Ambos avançaram no processo quando já adultos por meio da EJA - Educação de Jovens e Adultos, que permitiu à sua mãe que completasse o Ensino Médio e seu pai o Ensino Fundamental. Sua mãe trabalhava como auxiliar de enfermagem e seu pai como metalúrgico, atividades que exigem determinado conhecimento técnico e formação escolar mínima. Aluno da escola pública, alcançou uma vaga em uma universidade pública de prestígio no interior de São Paulo onde cursou Letras. Além da graduação em Letras, cursou Pedagogia em uma faculdade privada na modalidade EAD e Mestrado em Filosofia em uma outra universidade pública.

[...] meu pai é formado em Jornalismo e em História, e minha mãe em Educação Física. [...] Meu pai trabalhou um período como jornalista, né, mas mais em jornais católicos e a minha mãe..., mas depois assumiu aula em escola pública [...], também foi coordenador pedagógico [...] e a minha mãe sempre foi professora de Educação Física. (Entrevista pessoal professora Virginia, 2017).

Virginia nasceu em Diadema, tem 35 anos, e não faz parte da primeira geração de sua família a acessar os cursos superiores. Seu pai concluiu dois cursos superiores, História e Jornalismo, e sua mãe é formada em Educação Física, não sendo os únicos formados em cursos de nível superior nesta geração da família. Filha de professores atuantes na educação pública, Virginia sempre estudou na escola pública e optou por cursar o Ensino Médio concomitante com o técnico, concluindo o curso de Nutrição e Dietética. Além disso, teve ampla formação cultural e artística desde a infância, como relata:

[...] minha mãe sempre foi de colocar a gente em muita coisa então, assim, a gente estudava em escola municipal, mas a gente fez aula de natação no Ibirapuera, a gente fez..., estudei dos cinco até os, sei lá, dezessete, porque continuei como ex-aluna na EMIA. Que é a Escola Municipal de Iniciação Artística que fica ali na Conceição, é a única da cidade. E..., nós todas estudamos, eu fiz aula de piano, de flauta, tudo, né, dentro da rede municipal, assim. Aí eu estudei na Escola Municipal de Música, fiz as oficinas literárias lá na... eu tinha dezesseis anos mais ou menos, na oficina... Oficina da Palavra [...]. (Entrevista pessoal professora Virginia, 2017).

O ingresso no curso superior em História ocorreu depois de uma conversa com a mãe após o resultado negativo do vestibular em uma universidade pública. Sua mãe sugeriu que ela iniciasse um curso para "se ocupar" até o próximo vestibular: “[...] ela falou, "mas começa a fazer alguma coisa pra você se ocupar", [...] então, ela falou assim, 
"vai fazer História", nem tinha vestibular [...]", dessa forma, ela ingressou logo em sequência ao término do Ensino Médio no curso de História numa faculdade privada.

E aí eu comecei a fazer, enfim, não muito empolgada a princípio, né, só que depois eu comecei a me empolgar, enfim, e era o momento que minha família tinha uma crise financeira ali, né, e aí a minha mãe falou, "olha, por que que você não tenta o processo de transferência pra USP?" Aí eu pensei em prestar, só que eu já estava numa época, eu teria que retroceder muito e eu já estava entrando no mercado de trabalho lá, né, e por essas questões da vida, tal, eu falei, vou tocar aqui e vou ingressar no mercado de trabalho porque, imagina, em dois mil e..., eu ingressei, sei lá, em 2000 e em 2003 eu já estava no mercado de trabalho [...]. (Entrevista pessoal professora Virginia, 2017).

Embora realizar um curso numa faculdade particular não fosse o objetivo de Virginia, durante a graduação encontrou afinidades que a fizeram permanecer, quando ela relata que se empolgou e, aliado à isso, aparece em sua trajetória certa dificuldade financeira da família que a direciona para a possibilidade de ingresso no mercado de trabalho na área educacional. Depois de graduada, fez uma pós-graduação lato sensu em História em uma instituição privada de renome e ingressou no Mestrado em Educação na mesma instituição, estando no momento da entrevista realizando o curso de Doutorado em Educação também nesta universidade.

É fundamental, mas incompleto. [...] O meu pai era caminhoneiro, né, hoje ele é aposentado, e minha mãe sempre foi do lar. Mas, por incrível que pareça o meu pai gosta muito de leitura, aliás acho que esse meu veio literário e a minha escolha pela Língua Portuguesa veio do meu pai, é..., ele sempre gostou muito de ler, eu brinco que meu pai ia ficar míope como o Guimarães Rosa [risos], porque ele gosta muito de ler, muito, demais assim, sempre gostou muito, e o meu pai levava a gente para viajar, quando a gente era criança. (Entrevista pessoal professora Izabel, 2018).

Izabel, 38 anos, nascida na capital paulista, estudou na escola pública em todo o seu processo de formação e no Ensino Médio cursou o técnico em Contabilidade. Seus pais concluíram a primeira etapa do Ensino Fundamental, tendo a segunda etapa incompleta. Em relação ao trabalho, seu pai foi caminhoneiro e está aposentado, e sua mãe é dona de casa. Em sua entrevista, por diversas vezes, faz referência ao pai que mesmo com pouca escolarização -, sempre gostou de leitura e de "boa música". Para ela, o pai foi um incentivador da leitura para os filhos.

[...] meu pai sempre assim apresentou boa música pra gente, então, meu pai gostava de Elis Regina, meu pai gostava de Chico Buarque. E o meu pai sempre gostou muito de leitura, né, então até quando ele se aposentou, a gente ficava com muito medo, porque ele viajava muito e, 
aí, meu irmão falou assim, "a gente tem que arrumar várias atividades pro pai fazer, né, porque agora que ele vai ficar parado", e a gente começou, "ah, pai, faz isso, faz isso", aí teve um tempo que ele disse, "Ah, gente, para por favor, [...] eu me aposentei porque eu quero ler". [...] Ele falou assim, "gente, eu quero ler, porque na estrada eu não conseguia ler do jeito que eu queria". Então, assim, ele lê bastante, meu pai lê muito. (Entrevista pessoal professora Izabel, 2018).

Izabel é formada em Letras por uma instituição que foi criada pelo poder público municipal, no entanto de direito privado. Cursou duas disciplinas como aluna especial na Pós-graduação em Letras em uma universidade pública, com o objetivo de ingressar no Mestrado, mas acabou interrompendo este projeto pela dificuldade em conciliar a carga horária de trabalho com os estudos.

É, tinha muito medo de sair da minha cidade e aí eu comecei fazer um cursinho comunitário, que era bem longe da minha casa e, aí, eu ganhei a..., eu ganhei a taxa de inscrição pra fazer na [nome da universidade pública], o vestibular e, aí, eu acabei, na época eu já gostava de escrever e, aí, eu fiquei entre Letras e Psicologia, por que psicologia, eu pensei em fazer porque eu pensei, ah não, eu vou analisar várias pessoas e aí eu consigo compor melhor os personagens e, ao mesmo tempo, eu pensava fazer Letras. [...] e, aí, eu acabei prestando Letras por causa de literatura mesmo. (Entrevista pessoal professora Márcia, 2018).

Márcia tem 38 anos, nasceu em Indaiatuba, interior de São Paulo, onde viveu com seu pais. Sua mãe estudou alguns anos e não concluiu o Ensino Fundamental, trabalhou durante um curto tempo em uma tecelagem e se aposentou bem jovem por problemas de saúde, seu pai não teve escolarização e trabalhou como lavrador. Aluna de escola pública, decidiu fazer o Ensino Médio concomitante com o curso técnico em Administração para acessar um ensino de melhor qualidade, como conta em entrevista:

Eu tinha feito o técnico em administração e..., assim, eu nem tinha, eu queria fazer faculdade, mas tinha na época [nome da escola técnica] na minha cidade, mas eu não queria nada na área... tecnológica, eu acho que era mais administração, na verdade eu fiz o técnico em administração, porque para mim, também, a melhor escola que tinha era a técnica na minha cidade, era considerada melhor do que a formação normal. (Entrevista pessoal professora Márcia, 2018).

De acordo com o primeiro excerto da entrevista, Márcia ganhou a inscrição do vestibular para uma universidade pública e escolheu prestar o curso de Letras no qual foi aprovada e, para isso, foi estudar no interior de São Paulo. Na faculdade conhece seu companheiro que é da capital e para onde vão depois de formados. Estando em São Paulo, 
cursa Pedagogia em uma faculdade privada e, depois, faz o Mestrado em Filosofia em uma universidade pública.

[...] meu pai estudou até a oitava série, e minha mãe também. Na verdade é..., os dois pararam de estudar, ficaram quarenta anos sem estudar, em São Paulo, depois retomaram em São Paulo mesmo, voltaram pra oitava série, antes de virar nono ano, ensino fundamental. (Entrevista pessoal professor Márcio, 2017).

Márcio nasceu na capital paulista, tem 33 anos e seus pais são migrantes pernambucanos, cursaram o Ensino Fundamental em Pernambuco, mas não concluíram, retornando à escola já adultos, quando estavam em São Paulo para concluir esta etapa da educação na modalidade EJA. Seu pai trabalhava como metalúrgico e sua mãe como diarista. "Eu vim da escola pública. E, aí, fiz graduação em faculdade particular e o mestrado na rede pública também" (Entrevista pessoal professor Márcio, 2017). Aluno de escola pública durante toda a sua vida escolar, Márcio acessa o curso superior por meio de uma faculdade privada na qual faz o curso de Letras. Tendo o desejo de prosseguir com os estudos, começa a assistir aulas em uma universidade pública até que ingressa no Mestrado em Estudos comparados de Literatura de Língua Portuguesa concluído em 2016.

É, eu digo que foi uma coisa muito difícil, né, a gente sendo é... da periferia entrar, né, vindo de uma classe, né, tão esfolada como a nossa, entrar num curso, mesmo que seja o de Letras, né, que já é tão mal visto, né, que é a porta dos fundos, né, da [nome da universidade pública], é... foi uma coisa muito difícil, muito difícil mesmo apesar de eu ter conseguido concluir em quatro anos com muito sufoco e duas gravidez, graças à minha mãe. (Entrevista pessoal professora Arlete, 2018).

Arlete nasceu em São Paulo, tem 41 anos e sua família é de origem nordestina, do Ceará. Seus pais não concluíram o Ensino Fundamental e trabalhavam como mestre de obras, o pai, e a mãe como diarista, cozinheira e, depois, permaneceu como dona de casa. Arlete foi aluna de escola pública até a conclusão do Ensino Fundamental. No Ensino Médio fez o curso de Administração em uma instituição privada, mas para isso ingressou no estágio para custear o curso. Entre a conclusão do Ensino Médio e o ingresso no curso superior houve um intervalo, pois ela tinha como objetivo estudar em uma universidade pública e sua aprovação não aconteceu imediatamente após o término da educação básica. Portanto, Arlete ingressa no curso de Letras na universidade pública, sentindo-se 
deslocada nesse espaço em virtude das dificuldades que teve no processo de formação. A fala de Arlete chama-nos a atenção, sobretudo quando, sentindo-se excluída, se coloca como um indivíduo que ultrapassa a fronteira entre a periferia e o ambiente elitista, como no trecho a seguir:

É... foi bem complicado, a gente tem um gap muito grande, né, da formação que a gente recebe na escola pública, né, a... o próprio clima entre muitos professores, né, de lá que tem olhar assim, né, elitista, empinando o nariz, foi difícil, eu dei graças a deus quando eu terminei, eu curti mais de fazer o mestrado, né, do que a graduação, a graduação foi um processo bem... é... sufocante pra mim." (Entrevista pessoal professora Arlete, 2018).

Mesmo com as dificuldades relatadas, Arlete concluiu a graduação e cursou o Mestrado na mesma instituição e área.

“[...] o acesso à universidade, também, foi coisa nova para as camadas populares, e eu sou a primeira a me formar da minha família, da minha casa, agora meu irmão caçula se formou também, mas eu tinha sido a primeira." (Entrevista pessoal professora Janaína, 2017)

Janaína tem 32 anos, nasceu em São Paulo e seus pais tiveram acesso ao curso superior, porém ambos não concluíram. Sua mãe iniciou Filosofia em uma universidade pública e trabalha como funcionária pública, seu pai ingressou em contabilidade e, mesmo não concluindo o curso, trabalhou nessa área por muito tempo e depois com vendas. Ela começou a trabalhar em editora antes de ingressar na faculdade e nessa área ficou por um tempo até que decidiu que queria fazer o curso de Pedagogia, ingressando em uma instituição privada através do sistema de bolsas, conforme relata:

[...] E, eu fui bolsista nessa instituição, é bom constar. Como é uma instituição católica, eles faziam bolsa social, então não foi PROUNI, não teve nem... eu fiz uma prova na [nome da faculdade privada], e a partir da classificação eles chamaram, e compuseram uma sala de Pedagogia social com 70 alunos. Por exemplo, desse vestibular, fizeram a primeira sala, e lógico que vão desistindo, desistindo, até que no fim se formam 15, 20. Então, eu tive acesso, tipo, porque era bolsista, porque pagando eu não conseguiria fazer. (Entrevista pessoal professora Janaína, 2017).

Durante o curso de graduação, fez estágio remunerado e antes de concluir o curso foi aprovada em um processo seletivo de uma instituição privada para atuar com educação infantil. No momento da entrevista, estava cursando uma pós-graduação lato sensu na área de literatura em uma outra instituição privada. 
“[...] Eu estudei numa escola, que hoje ela é renomada, é uma escola de elite, só que na época, essa escola ficava na praça Roosevelt, tinha um grupo de alunos que eram bolsistas e eu fiz todo o meu aprendizado no [nome da escola] como bolsista [...]" (Entrevista pessoal professora Esther, 2018).

Esther, nascida em São Paulo, tem 52 anos e seus pais frequentaram a escola por pouco tempo e não chegaram a concluir o Ensino Fundamental I sendo que seu pai era comerciante e sua mãe costureira. Apesar de ser de classe popular, tendo pais com pouca escolarização, Esther estudou em uma escola privada considerada de elite na cidade, porém teve bolsa de estudos para isso. Na época em que realizou o Ensino Médio era possível escolher as ênfases dos cursos e ela optou pela área de exatas, como relata: “[...] eu sempre estudei lá como bolsista. Na época, o que que eu acabei fazendo, como eu era bolsista, era boa aluna, eu fiz colegial de exatas. Mas eu não queria seguir nenhuma carreira na área de exatas [...]” (Entrevista pessoal professora Esther, 2018). Sabendo que não queria seguir numa carreira na área de exatas, Esther fez vestibular para o curso de Pedagogia numa universidade pública para o qual foi aprovada. Durante sua carreira fez alguns cursos de pós-graduação lato sensu, mas o único que nos indicou foi em Educação Matemática realizado em uma faculdade privada.

\begin{abstract}
Não, era uma coisa muito minha, eu sempre li muito, né, eu sou uma pessoa que devorava livros, eu lia três livros ao mesmo tempo, então eu tinha muito isso, é engraçado, meu pai era analfabeto, mas ele simplesmente... ele comprava assim, né, na época a gente tinha aquelas enciclopédias, né, aquelas coleções e ele comprava muito pra gente. Quando eu entrei na escola, com sete anos na primeira série, eu já lia, mas eu não escrevia, mas eu lia tudo, porque meus irmãos, eu ficava muito curiosa e meus irmãos me ensinavam, minha irmã e meu irmão então, eu perguntava: “que letra é essa?" E eles falavam então, eu ia juntando e ia tentando ver que palavra que era e aí eu fui aprendendo a ler. Não sabia escrever, mas sabia ler. Aí eu pegava esses livros, via as figuras e tal, então já tinha um incentivo embora, você vê, com essa restrição toda em casa de ter o pai e a mãe que não dominavam mesmo a questão da escrita e da leitura, enfim. (Entrevista pessoal professora Regina, 2017).
\end{abstract}

Regina tem 50 anos, nasceu em São Paulo e, como afirma em seu relato que seu pai é analfabeto e sua mãe cursou o Ensino Fundamental I. Embora o pai não tivesse acesso à cultura letrada, ele compreendia de alguma forma a importância dos livros na formação dos filhos e os comprava. Aluna de escola pública, Regina fez o curso magistério e ingressou numa faculdade particular para cursar Educação Artística, mais tarde fez Pedagogia também em uma instituição privada e atua na educação infantil. 
Foi a pastelaria que pagou os meus estudos. E, bom, foi isso, eu queria ter feito outro caminho, meu sonho era fazer faculdade pública. Mas, eu sou de uma época que pra gente era impensável, acho que era um sonho dourado, garota você vai acabar o ensino médio e você vai trabalhar. Tanto que eu fui trabalhar [...]" (Entrevista pessoal professora Michele, 2017).

Michele tem 37 anos, nasceu em São Paulo e seus pais estudaram até a conclusão do Ensino Fundamental. Seu pai era metalúrgico e para isso obteve uma formação técnica e sua mãe foi dona de casa até que o pai ficou desempregado, foi quando abriram um comércio no bairro onde moram e ambos passaram a trabalhar como comerciantes. Como relata em sua entrevista, no excerto acima, a perspectiva familiar em relação aos estudos da filha era com a conclusão do Ensino Médio e posterior ingresso no mundo do trabalho. Isto, de certo modo, já representava um avanço na formação escolar em relação aos pais, embora ela quisesse estudar em uma universidade pública. Dado o contexto socioeconômico, Michele foi trabalhar com a família e depois de alguns anos que havia terminado a educação básica decide ingressar em uma faculdade privada para cursar Letras.

Eu me formei, na verdade, eu entrei tardiamente no ensino superior, com 24 anos. E aí, eu fiz [nome da faculdade privada] [...]. E foi uma época que foi aquela transição do FHC para Lula, que quando começaram as bolsas, e começou a oferta de ensino superior com preço mais acessível. E aí, eu peguei essa época, não tive bolsa, porque meio que eu decidi em cima da hora, "Não, eu vou dar um jeito em minha vida, vou estudar, enfim". E, nessa época eu trabalhava com meus pais, inclusive, vendia pastel [...] (Entrevista pessoal professora Michele, 2017).

Mesmo sem ter sido beneficiada por um programa de bolsas, a maior disponibilidade de cursos superiores após os anos 2000, com mensalidades mais acessíveis visando logicamente as classes populares que pela primeira vez estavam acessando o nível superior, possibilitou com que Michele fizesse seu curso, mas para isso teve que trabalhar durante a sua formação.

“A mãe é fundamental... incompleto e o pai é médico.” (Entrevista pessoal professor Jamir, 2018). Com essa resposta breve que Jamir, 52 anos, nascido na capital paulista, falou sobre a formação de seus pais. Sua mãe é dona de casa e seu pai é funcionário público. Seu curso superior foi em História numa universidade pública renomada, mais tarde cursou Pedagogia em uma instituição privada e fez o Mestrado em Educação na mesma instituição pública em que se graduou. Atualmente é supervisor de 
ensino na SME, mas ingressou na carreira como professor de História e foi diretor de escola por um período.

Olha, foi muito difícil. Porque assim, eu vim de escola pública, e eu me formei no Ensino Médio em 96, eu entro na universidade em 2006. Eu estive 10 anos sem estudar, porque eu não tinha condições de bancar uma faculdade, a faculdade não tinha, na época também, as políticas públicas de... de acesso, não se compara o que é hoje, né?! Então, era bem difícil, e eu tinha que trabalhar e tal [...] (Entrevista pessoal professor José Vandeí, 2017).

José Vandeí tem 40 anos, nasceu no interior do Ceará e migrou para São Paulo quando tinha treze anos com sua mãe e irmãos, como ele conta: "Eu nasci no Ceará, no Jambo Cariri, no Vale do Cariri, no Ceará, em uma cidade chamada Lavras da Mangabeira. Na verdade, Lavras da Mangabeira é uma cidade e eu nasci em um vilarejo chamado Iboripi, que é um nome indígena [...]" (Entrevista pessoal professor José Vandeí, 2017). Seus pais frequentaram a escola por um tempo, não concluíram o Ensino Fundamental I e, mesmo com pouca escolarização, sabiam ler e escrever. No Ceará, trabalharam como agricultores. Sua mãe se aposentou depois que veio para o estado de São Paulo e seu pai faleceu, quando ainda viviam no Ceará. Aluno de escola pública e que, ainda jovem, precisou se inserir no mundo do trabalho, da conclusão do Ensino Médio até o ingresso no ensino superior, José teve um intervalo de tempo de dez anos na sua formação, uma vez que em função de sua condição socioeconômica não pode ingressar na universidade.

E, em 2006, eu entrei na [nome da universidade privada] através de bolsa, fui bolsista. E aí, foi muito difícil, porque assim, a escola pública ela não me deu uma bagagem para fazer uma universidade como a [nome da universidade privada], ela não me deu uma base. Então, para eu acompanhar, assim, o ritmo das aulas, tudo, foi bem difícil, e era mais difícil porque eu trabalhava o dia inteiro, estudava a noite, e além de tudo eu não podia ter notas baixas, [...] ter falta, porque eu era bolsista. E, não era nem bolsista $100 \%$, era $75 \%$, então, tinha uma parte que eu ainda pagava. (Entrevista pessoal professor José Vandeí, 2017).

A possibilidade de fazer um curso superior se deu por um programa de bolsas de estudo e que mesmo assim ele precisava conciliar trabalho durante o dia e estudo no período noturno. Dessa forma, José concluiu o curso de Filosofia numa instituição privada de renome, posteriormente, fez o curso de Pedagogia na modalidade EAD em outra instituição privada.

“O meu pai tem o ensino médio completo, recém-concluído, minha mãe tem o fundamental incompleto" (Entrevista pessoal professor Jefferson, 2017). Jefferson tem 
28 anos, nasceu em São Paulo e sempre viveu no extremo sul da cidade, onde estudou em escolas públicas. Seu pai concluiu o Ensino Médio na modalidade EJA e trabalha como caminhoneiro mesmo sendo aposentado, e sua mãe não concluiu o Ensino Fundamental e é dona de casa.

Então, eu... eu me formei numa instituição assim, que é bem longe da minha casa, que tá num outro contexto social, né? É... por ser bolsista, né, por ser um homem, né... Traços negros, né, sou um homem negro, então, eu sofri alguns tipos de discriminações lá dentro da universidade, né? Então foi um processo bem complicado pra me adaptar, né? E... mas assim, eu fui levando as coisas, né, fui tentando ali amadurecer mesmo dentro da faculdade, porque é um retrato também do que a gente vê socialmente e, e eu consegui, eu a... eu acho que eu consegui até aproveitar bastante [...] da faculdade, né. (Entrevista pessoal professor Jefferson, 2017).

O ingresso no curso superior ocorreu através de bolsa de estudo em uma instituição privada de renome e que, de modo geral, atende um público oriundo das classes média e alta. A diferença dos contextos sociais do professor com outros universitários gerou o incômodo relatado na entrevista, porém isso não foi um impeditivo para que concluísse o curso de Letras nesta instituição.

“[...] Eu tenho uma família, que tem muitos professores. Então, desde cedo, eu sempre ouvi muito sobre a educação, preocupação sobretudo sobre a Educação Pública [...]" (Entrevista pessoal professora Leticia, 2017). Letícia tem 30 anos, nasceu em São Paulo, e não faz parte da primeira geração de sua família com acesso à formação de nível superior. Como no trecho da entrevista acima, na sua família tem vários professores e seus pais também completaram o ensino superior, sendo que o pai é engenheiro e atua nessa área e sua mãe é formada em Direito e Jornalismo, e escolheu trabalhar como advogada. Durante a sua vida escolar, Leticia frequentou a escola pública, mas no ensino superior cursou Educação Física em uma instituição privada. "[...] Resolvi fazer Educação Física, porque eu sempre tive uma relação, também, muito forte com o esporte, eu jogava futebol na minha adolescência, na minha infância, sempre gostei muito de todos os esportes [...]" (Entrevista pessoal professora Leticia, 2017).

Meu pai é japonês. [...] ele estudou no Japão um pouco, e depois estudou no Brasil, também. É isso, então eu acho que nenhum dos dois é completo. Porque, ele veio com 10 de lá, com uns 10 anos, mais ou menos. Então, até os 10 ele estudou no Japão, e depois, quando chegou no Brasil, estudou no Brasil. Então, ele sabia das coisas, mas para leitura, não era muito... e a minha mãe, também, minha mãe é nissei, então, ela já... mas, acho que não tem diploma, ela estudou primário, 
aquela escola que é no interior, então era uma escola simples, é diferente daqui [...] (Entrevista pessoal professor Osvaldo, 2018).

Osvaldo tem 63 anos, nasceu em Miracatu, interior de São Paulo, e é descendente de japoneses. Como relatou na entrevista, não sabe ao certo quanto tempo de escolarização seus pais tiveram, acredita que não completaram o ensino fundamental e que seu pai tinha dificuldade com a leitura. Na cidade onde viveu seus pais trabalharam como agricultores e comerciantes.

[...] é que eu sou descendente de japonês, o japonês quando ele cai aqui no Brasil, ele tinha um objetivo, que era voltar pro Japão. E, o japonês entende que [...] a arte faz parte da cultura no Brasil, faz parte da vida das pessoas, tanto é que no Japão eles falam que é um país que tem a cultura artística, eles falam isso. Então, é lógico que a arte não é importante pro japonês, ela faz parte, o importante é formar médico, engenheiro, principalmente estas duas coisas, médico e engenheiro, as áreas técnicas que eles dizem. Então, eu também entendia assim, que eu tinha que estudar engenharia, tanto é que a minha formação é toda voltada pra engenharia, o primeiro e segundo grau. Eu, por exemplo, nos anos 80, eu estudei na [nome da instituição pública], estudava desenho... (Entrevista pessoal professor Osvaldo, 2018).

Osvaldo relatou que ingressou em cursos voltados para áreas mais técnicas, mas que o seu desejo era fazer um curso de Artes. Num determinado momento decidiu mudar sua trajetória de formação e ingressou no curso de Educação Artística, numa instituição privada na capital - onde já vivia e trabalhava -, se formando de 1988. Anos mais tarde, fez uma pós-graduação lato sensu em uma instituição pública. Atualmente é professor de Artes.

A partir dessa caracterização a respeito da origem social dos professores entrevistados, percebemos que a maioria advém das classes populares, representando, por um lado, a primeira geração de suas famílias que teve acesso aos cursos superiores e, por outro, certa ascensão quanto à formação escolar, logo, ao capital cultural adquirido em virtude da formação escolar e acadêmica (BOURDIEU,1996).

Observamos nos diferentes relatos dos professores a importância das famílias nos seus processos formativos representado pelas memórias dos pais que contam histórias, no incentivo à leitura, nas famílias de professores que promovem discussões sobre educação no ambiente familiar, e nas famílias que, independente da formação dos pais, houve incentivo aos estudos e valorização da educação. Nesse sentido, Bourdieu (1996) contribui de modo fundamental para esta reflexão sobre origem social e formação escolar quando afirma: 
Os movimentos da bolsa de valores escolar são difíceis de antecipar e aqueles que podem se beneficiar, através da família, dos pais, irmãos ou irmãs etc., ou de suas relações, de uma informação sobre os circuitos de formação e seu rendimento diferenciado, atual e virtual, podem alocar melhor seus investimentos escolares e obter o melhor lucro de seu capital cultural. Essa é uma das mediações através das quais o sucesso escolar - e social - se vincula à origem social. (BOURDIEU, 1996, p. 42).

\subsection{Tornar-se professor}

Neste momento interessa-nos refletir acerca do processo de formação dos professores, considerando seus cursos de graduação e a área de atuação no magistério, pois compreendemos que se tornar professor é um processo que não inclui somente o curso superior, mas também o exercício do magistério e outros cursos que são realizados durante a trajetória profissional. Em paralelo a isso, discutiremos como esses professores se relacionam com a profissão, visto que em algumas entrevistas ${ }^{111}$ aspectos sobre a carreira foram abordados pelos professores - os quais compreendemos como elementos constitutivos do posicionamento desses agentes em seus respectivos espaços sociais.

Tomar a decisão de ingressar em um curso superior que forma professores, as licenciaturas, é algo que ocorre dentro de um conjunto de possibilidades no universo dos indivíduos, a depender do seu contexto social e econômico. Esta é claro uma escolha, entretanto não podemos dizer que esteja desvinculada dos determinantes sociais aos quais pertencem as diferentes classes sociais, ou seja, esta escolha se constitui a partir do espaço social $^{112}$ no qual está posicionado este agente e no universo de possibilidades que se apresenta. Dessa forma, assinalamos que escolher um curso de licenciatura e tomar a decisão de ingressar na carreira do magistério é uma decisão que muitas vezes não se estabelece com clareza.

\footnotetext{
111 Para discutir sobre a formação desses professores selecionamos excertos das entrevistas que consideramos mais expressivos em relação à escolha profissional, a formação na graduação e a relação com a carreira, de modo que os professores não se repetirão em todos os aspectos tratados.

112 "A noção de espaço contém, em si, o princípio de uma apreensão relacional do mundo social: ela afirma, de fato, que toda a "realidade" que designa reside na exterioridade mútua dos elementos que a compõem. Os seres aparentes, diretamente visíveis, quer se trate de indivíduos quer de grupos, existem e subsistem na e pela diferença, isto é, enquanto ocupam posições relativas em um espaço de relações que, ainda que invisível e sempre difícil de expressar empiricamente, é a realidade mais real [...] e o princípio real dos comportamentos dos indivíduos e dos grupos". (BOURDIEU, 1996, p. 48 - 49, grifos do autor).
} 
A professora Márcia, durante a entrevista, fez um apontamento sobre a escolha da profissão que ilustra bem esse universo que se apresenta ao indivíduo no interior de seu espaço social:

Isso que eu ia falar, é diferente, né, como a gente pensa a profissão depois que é professora. Assim, pra começar, acho que um dos motivos, né, eu acho engraçado que às vezes você está dando aula e quando você está nervosa os alunos comentam "ah, mas você é professora porque você quer", né, mas aí eu falo, eu costumo comentar com eles, "não, não é exatamente porque eu quero, porque onde eu estava, o mais próximo de eu chegar e ter vida melhor seria sendo professora", né, e aí eu acho que isso mudou um pouco ainda com as políticas públicas, PROUNI, eu acho que deu uma amenizada nisso. Mas quando você queria fazer ensino superior e era de classe muito baixa, ainda mais eu que estava em Indaiatuba que não tinha faculdade, não tinha nenhuma faculdade pública... (Entrevista pessoal professora Márcia, 2018).

No mesmo sentido, a professora Michele relatou da sua escolha pelo curso de Letras considerando, inicialmente, trabalhar com tradução, pois não desejava lecionar. No entanto, a formação que teve quando cursou as disciplinas pedagógicas a fizeram a mudar seu rumo profissional, pois proporcionaram à ela uma visão da educação desconhecida até então, como segue o relato:

Bom, pra mim, coisas que pesaram muito na minha formação humana assim, em geral, foram os livros e a arte de forma geral, assim. Eu gosto de desenhar, eu fiz a capa do livro, né?! Eu desenho, eu sempre gostei de artes visuais, manuais, de escrever e de ler, também. Isso pra mim era muito natural [...], não tinha nenhuma ligação com aspecto escolar, mesmo quando eu era mais nova, era uma coisa que eu fazia por prazer mesmo. E aí, quando eu fui procurar uma formação, eu cheguei a pensar a fazer artes, mas acho que os livros falaram mais alto, assim, a questão dos livros para mim é muito, eles têm uma voz muito grande para mim. E, mesmo quando eu estava fora da escola, eu tinha terminado e tinha essa coisa: "Ah, eu não vou continuar estudando", eu fiquei muito triste quando acabou ensino médio, porque eu sabia que ali acabou o estudo pra mim, eu gostava de estudar. E aí, eu pensei: "Ah, vou fazer Letras", mas quando eu penso em Letras. Eu já pensei nessa coisa do: "Ah, vou fazer Letras pra dar aula em escola pública. Aí, essas crianças hoje em dia?!". Então, quando eu entrei, eu entrei pensando em fazer uma coisa dentro da área de inglês, tradução, porque eu precisava de inglês, também. E eu tinha uma facilidade para aprender línguas, é meio do caminho, assim, no processo... Como o curso, ele era licenciatura, então tinha as disciplinas específicas das áreas didáticas, eu acabei me afeiçoando, assim, conheci Paulo Freire, faz toda a diferença você perceber o lado político da Educação. Então, uma coisa me encantou, talvez eu tivesse uma visão de educação, mais um Caminho Suave ${ }^{113}$, sei lá, essa coisa, sabe, da professorinha. E, quando eu vi essa questão política, dentro da Educação, começou a me encantar. E, pra mim, também, pensei: “Ah, tradução eu vou ter que investir, vou ter que fazer

${ }^{113}$ Referência à cartilha Caminho Suave que era muito utilizada no processo de alfabetização de crianças. 
outros cursos, tem muito de quem indica". Aí de repente, fazer concurso pode ser uma boa, é um caminho mais rentável. A gente, que vem, assim, como diz minha mãe: "Mais humilde", [...] a gente que vem de uma realidade financeira mais, menos favorável, a gente pensa muito nessa questão da rentabilidade financeira, não tem como, não dá para ficar saindo, pegar a mochila e sair por aí, porque não tem como se suster. E aí, foi um processo, que meio que uma coisa, levou a outra, terminei a faculdade, "E ah, agora vou fazer concurso", [...] os primeiros que eu fiz, eu já passei. Estudei bem, bastante, claro [...]. E aí, nesse meio tempo, [...] enquanto não me chamavam, [...] já entrei na rede estadual, em 2010, como... o que eles chamam hoje de categoria O, que aí é a via de acesso, todos entram por essa categoria, que é uma categoria horrorosa, você não tem direito a nada, você não tem acesso ao hospital de servidor público, enfim, sucateamento. (Entrevista pessoal professora Michele, 2017).

Além dessa identificação sentida a partir das disciplinas pedagógicas, a professora considerou como seria a sua inserção profissional se optasse por trabalhar com tradução ou se escolhesse o magistério, considerando que para atuar com tradução necessitaria de outros cursos e, talvez, até ocupar uma outra posição no espaço social, mais privilegiada, para que esta inserção fosse possível. Considerou também a necessidade imediata de trabalho, algo que se tornou viável iniciando no magistério na condição de temporária que, como ela mesma relatou, é um tipo de contrato precário em termos de carreira e que o professor tem menos direitos do que em comparação aos efetivos de concurso.

No estudo desenvolvido por Narvaes (2000), sobre as significações da profissão entre um grupo de professoras em formação no curso de Pedagogia no Rio Grande do Sul, utilizando o método das histórias de vida, a pesquisadora buscou "imagens de professor e as significações sobre a profissão" (p. 42) entre um grupo de nove estudantes que, apesar de estarem no processo de formação universitária, oito delas atuavam como professoras e estavam em diferentes momentos da carreira. Entre este grupo, a escolha da profissão foi permeada por hesitações e conflitos, não sendo, portanto, uma decisão sem questionamentos, como afirma:

Para algumas das alunas tornar-se professora foi uma questão de oportunidade. Foi a opção mais viável, seja porque a profissionalização era oferecida na região onde residiam, porque era a alternativa mais barata, seja porque oferecia oportunidade de emprego facilmente após o término do segundo grau. (NARVAES, 2000, p. 50).

Este estudo de Narvaes (2000) colabora para a discussão em relação aos relatos das professoras que expomos anteriormente, nos quais a licenciatura e a profissão do magistério estão no universo de possibilidades de acesso ao curso superior e a uma profissão mais reconhecida. O relato das professoras a seguir é um contraponto em 
relação às anteriores se considerarmos o conhecimento do universo profissional do magistério que elas já tinham quando escolheram seus cursos de licenciatura, pois são duas entrevistadas que possuem familiares professores e, assim, as questões educacionais já permeavam os seus respectivos contextos de origem.

[...] bom eu venho de uma família de professores, né, então assim, eu tenho tios professores, eu tenho um tio que é diretor do estado, mas os meus pais foram os primeiros a cursar a universidade, então, meu pai do lado da família dele e minha mãe do lado da família dela, eles não são os únicos, mas foram os primeiros, né. Então, se você pensar assim, década de 70, né, eles já na universidade era uma vitória, né, [...] quando eu falo formação de professor acho que tem esse lado também, né, assim, na minha família a gente sempre falava sobre escola, sobre... então, quando eu ingressei, na verdade, eu sabia muito de como é o universo, enfim, né. Mas a princípio, eu não ia fazer é... eu não ia optar pela formação, assim. Meu primeiro vestibular, na verdade, o vestibular que eu prestei na [nome da universidade pública], foi pra Jornalismo, foi pra comunicação, e aí foi o ano que não passei, eu não passei por um, dois pontos na primeira fase, só que tinha sido um ano muito difícil pra mim, assim, eu tinha tido síndrome do pânico, então, eu fiz um curso técnico, que agora é [nome da escola técnica], né? (Entrevista pessoal professora Virginia, 2017).

Primeiramente, eu acredito que a gente não se forma professora apenas no curso de graduação. [...] porque eu tenho tias e tios que sempre trabalharam na educação pública, e sempre tiveram a educação pública como o ideal de igualdade, de promoção de igualdade. Então, eu acredito que a minha formação enquanto professora se dá desde antes de eu fazer o curso de licenciatura. [...] E aí, eu gostava e já pensava em ser professora de Educação Física de escola pública. [...] nunca pensei em ser de escola particular, justamente por esses ideais de promoção de igualdade através da educação [...]. Na faculdade, o curso que eu fiz na [nome da universidade] foi um curso bastante fundamentado nos princípios da educação, porque era um curso muito forte a questão da licenciatura [...]. Então, eu tive várias disciplinas: didática da educação física, psicologia da educação. Foi uma formação muito interessante, eu acredito que me deu uma amplitude de visão não só sobre a educação física, mas sobre o que é o ser humano [...]. Então, eu acredito que ampliou muito a minha formação, enquanto uma pessoa que tem uma visão humana sobre a profissão e sobre as relações cotidianas. (Entrevista pessoal professora Letícia, 2017).

Os relatos das professoras Letícia e Virginia demonstram que a escolha do curso de licenciatura ocorreu tendo conhecimento da carreira do magistério em função de suas famílias, no entanto, há diferenças entre elas, enquanto Letícia opta pelo curso de Educação Física visando atuar na educação pública, com uma perspectiva de educar para a transformação social, Virginia escolhe a licenciatura em História após a não aprovação no vestibular em Jornalismo apenas para não ficar sem estudar, mas outras questões 
socioeconômicas a levaram continuar o curso e a se formar, iniciando assim, na carreira do magistério. Essa tensão da escolha profissional de Virginia nos indica que mesmo tendo conhecimento da carreira, a sua opção foi permeada de conflitos.

Narvaes (2000) também identificou que as professoras atribuem à profissão um sentido de amor e doação, característico do processo de feminização do magistério, no qual construiu-se uma ideia de docência relacionada à maternidade e, outro sentido, é o da prática social transformadora que a autora relaciona com o discurso que circula na universidade. Esse discurso da prática e da educação como transformadora da realidade $^{114}$, ou seja, a educação como um ato político também aparece nos relatos anteriormente expostos, cujas professoras enfatizam os aspectos motivadores da profissão escolhida.

Essa imagem profissional ligada ao cuidado, à doação, muito relacionada ao processo de feminização da carreira estudado por Demartini e Antunes (1993), se apresenta no relato de uma das professoras que atua na educação infantil.

Gosto, trabalhar com as crianças, assim... eu, como eu te disse, eu sempre fiquei na educação infantil, então, eu me identifico com as crianças pequenas, né. Eu tive sempre isso na minha mente, eu nunca quis ter experiência com crianças maiores, de..., de formar mesmo, não. Eu sempre me identifiquei com o trabalho na educação infantil e..., não sei, é uma coisa que para mim, eu me identifico [...], e... não sei se porque desde os 15 , é uma coisa que eu nunca consegui ver separado de mim, é como se já fosse incorporado, então, o trabalho na educação infantil pra mim é..., é parte da minha vida, é parte de mim, é gratificante por todos os lados essa troca, porque é uma troca grande, sabe, ao mesmo tempo é uma troca de carinho, né, de escuta e... de ver eles também evoluindo [...]. (Entrevista pessoal professora Camila, 2017).

A carreira do magistério foi se constituindo em diferentes momentos. Segundo Nóvoa (1999), a função docente foi desenvolvida por religiosos e leigos no interior de congregações religiosas nos séculos XVII e XVIII, como os jesuítas e oratorianos que elaboraram "um corpo de saberes e de técnicas e um conjunto de normas e valores específicos da profissão docente" (NÓVOA, 1999, p. 16). Segundo o autor, os professores

\footnotetext{
${ }^{114}$ Paulo Freire (2002) afirma que ensinar é uma forma de intervir no mundo, sendo assim, a intervenção pode ser reprodutora de uma dada realidade ou transformadora desta: "Outro saber de que não posso duvidar um momento sequer na minha prática educativo-crítica é o de que, como experiência especificamente humana, a educação é uma forma de intervenção no mundo. Intervenção que além do conhecimento dos conteúdos bem ou mal ensinados e/ou aprendidos implica tanto o esforço de reprodução da ideologia dominante quanto o seu desmascaramento. Dialética e contraditória, não poderia ser a educação só uma ou só a outra dessas coisas. Nem apenas reprodutora nem apenas desmascaradora da ideologia dominante. (FREIRE, 2002, p. 110 - 111, grifos do autor).
} 
aderiram, inicialmente, a um sistema de normas e a uma ética essencialmente religiosos, fazendo com que o modelo de professor fosse próximo ao de padre. Vale ressaltar que, mesmo com as mudanças ocasionadas pelo processo de estatização do ensino, essas motivações não desapareceram.

No Brasil colonial, segundo Demartini e Antunes (1993), as escolas e os colégios eram administrados e mantidos por jesuítas e apenas os homens podiam estudar. Nesse momento, havia uma divisão social dos papéis ${ }^{115}$ que eram definidos para homens e mulheres, e a escola não era o espaço ocupado por elas. Assim, no processo de profissionalização docente, o magistério era um trabalho para homens posto que somente eles possuíam o direito à educação, logo, ao trabalho nas escolas. Em 1827, a mulher adquire o direito à educação com a criação de escolas de primeiras letras para meninas. A partir disso, surgem as primeiras vagas para as mulheres no magistério primário, possibilitando assim a ampliação da instrução. No entanto, as autoras afirmam que, com o ingresso das mulheres no magistério, as diferenças entre homens e mulheres passaram a existir também no exercício da profissão. Os currículos eram diferentes para meninos e meninas, eles tinham mais disciplinas no currículo do que as meninas, o que implicava em diferença salarial entre os sexos, porque estes recebiam seus salários de acordo com as disciplinas que lecionavam. Ressalta-se que no currículo dos meninos havia conteúdos de matemática que foram excluídos do currículo previsto para a escola de meninas, além do que somente professores podiam lecionar esses conteúdos aos meninos.

Nóvoa (1999) afirma que a ambiguidade presente no estatuto profissional foi acentuada pelo processo de feminização do magistério que criou diferenças entre as imagens masculinas e femininas da profissão docente.

Demartini e Antunes (1993, p. 06) apresentam um trecho da Lei de 1827, que trata do currículo destinado às meninas: "Quanto ao trabalho das professoras, o Artigo $12^{\circ}$ previa o seguinte: 'As mestras, além do declarado no art. $6^{\circ}$, com exclusão das noções de geometria e limitando a instrução de arithmetica só as suas quatro operações, ensinarão também as prendas que servem à economia doméstica"”. Em 1830, com a criação das primeiras Escolas Normais, um projeto de lei determinava que nas escolas públicas as mulheres teriam preferência no magistério primário. Apesar disso, eram os homens que frequentavam as Escolas Normais. De acordo com as autoras, somente no final do Império é que as mulheres chegaram à Escola Normal. Em São Paulo, isso aconteceu em 1875

${ }^{115}$ A palavra "papéis" está sendo usada para definir algo fixo, de acordo com o que era entendido como tarefa atribuída a cada sexo. 
quando foi criada a seção feminina anexa ao Seminário das Educandas. Com a reabertura da Escola Normal de São Paulo em 1880, as classes passaram a ser compostas por homens e mulheres, mas mantinha-se o ingresso separado por sexo. "O número de matrícula geral dos alunos de $1^{\circ}$ e $2^{\circ}$ anos era 61 , dos quais 29 eram mulheres. $\mathrm{O}$ curso anexo recebeu 127 matrículas, 55 rapazes e 72 moças, sendo que no $1^{\circ}$ ano havia 24 moças para 20 rapazes" (DEMARTINI; ANTUNES, 1993, p. 06). Esses números de matrículas indicam para as autoras o início da feminização na Escola Normal de São Paulo, de modo que a feminização do magistério primário está relacionada à necessidade de professores nas escolas preliminares e, também, para "dar um destino às órfãs educandas que não se casavam" (p. 07). Para as autoras, essa iniciativa teria gerado bons resultados, no entanto o salário pago aos professores era baixo e, esse salário teria afastado os homens do magistério. Outro fator que pode ter afastado os homens da carreira é a mudança da Escola Normal em 1894 que ampliou o curso de três para quatro anos, tendo como consequência a necessidade de investir mais tempo na formação e recebendo, posteriormente, um salário não muito atrativo.

A carreira e a remuneração dos professores e professoras eram diferenciados como apresenta Demartini e Antunes (1993, p. 07) no Inquérito do Prof. Oscar Thompson, em 1914, que era diretor da Escola Normal da capital, no qual ele sugere novos critérios para os salários dos professores seguindo a ordem: "1. a localização da escola; 2. a categoria da escola; 3. a série em que o professor lecionava; 4. o sexo do professor" e justificava "É sabido que o professor tem maiores responsabilidades civis que a professora. $O$ professor é sempre o chefe de família. (...) A professora é em regra casada e com o esposo divide o peso dos encargos da família." As pesquisadoras indicam que a ideia de vocação é outro aspecto que contribuiu para a feminização da docência, entendendo que atividades que necessitassem de sentimento, paciência, dedicação e minúcia deveriam ser realizadas por mulheres, porque estas eram características inatas delas. "As chamadas diferenças "naturais" entre os sexos, somadas ao conceito de vocação, foram incorporadas ao discurso sobre a importância do trabalho feminino, que se associou ao discurso dominante sobre o não-trabalho da mulher" (1993, p. 08).

Outro elemento considerado por Demartini e Antunes para a feminização da carreira é o fato de o magistério possibilitar à mulher trabalhar e manter as atividades domésticas pela jornada de trabalho ser menor e pelo período de férias escolares. Nesse sentido, Demartini e Antunes (1993) e Vianna (2013) compreendem que o magistério se 
tornou uma profissão feminina em números, mas também, porque era a única possibilidade profissional das mulheres brancas de classe média até os anos de 1930.

Em 1997 foi realizado o primeiro Censo do Professor pelo Ministério da Educação que indicou que 85,7\% da categoria docente na Educação Básica eram mulheres e 14,1\% homens. Isso confirma a feminização da carreira do magistério, segundo Vianna (2013) que, embasando-se nos dados do Ministério da Educação divulgados em 2009, verifica que ainda é possível identificar a maioria feminina na carreira docente, no entanto com índices diferentes de acordo com a etapa do ensino. Ou seja, a maior presença feminina ocorre na Educação Infantil 97,9\% e no Ensino Fundamental 82,2\%, no Ensino Médio essa proporção diminui para $64,1 \%$ e cai ainda mais no Ensino Superior no qual as mulheres correspondem a 44,8\% dos professores. Ela afirma ainda que a Secretaria Municipal de Educação de São Paulo teve um aumento de 30\% de homens atuando na educação, entre 2005 e 2010, nas funções de educadores, professores, auxiliares técnicos e diretores de escola.

Entretanto, embora haja esse acanhado crescimento do sexo masculino, a configuração do que chamamos de feminização do magistério tem sua história e suas implicações de gênero para além da mera composição sexual da categoria docente. Uma dessas implicações diz respeito ao fato de que encontramos mais homens exatamente nos níveis e modalidades de ensino que ainda oferecem maior remuneração e usufruem mais prestígio. (VIANNA, 2013, p. 167).

Sobre as posições de maior prestígio, apenas um professor, quando falou sobre a sua formação acadêmica e em atuação, relatou que em sua carreira atuou em diferentes atividades, de professor a diretor de escola e supervisor de ensino, além de ter experiência em outras secretarias no município de São Paulo e atuação sindical, como segue o relato:

Formação.... Foi boa na História [...]. E a formação em serviço, eu sempre busquei. Então, sempre, os cursos oferecidos de enriquecimento dentro da rede eu sempre fui atrás. E tive atuação também fora [...] da sala de aula em vários momentos. No governo Erundina, no Governo Marta e, mas até em outros também, trabalhando em CEU, mas sempre tive atuação em vários campos da educação, mas formação inicial muito boa, e complementar também dentro da rede, o que era oferecido de possibilidade. (Entrevista pessoal professor Jamir, 2018).

Outros professores quando são perguntados sobre se tornar um professor, comentam sobre a importância do exercício da profissão como uma etapa dessa formação:

Então, foi realmente na prática, eu me formei na prática. Eu tinha bastante base para ensinar Artes, mas assim, a gente vai... quando você chega na escola, você percebe que você vai ensinar umas coisas bem básicas, bem básica. E, a partir daí, você vai formando as suas turmas, 
você vai aprendendo assim, você trabalha com os alunos, e eles vão acompanhando você e você vai acompanhando eles. [...] Então, isso foi muito bom, porque eu fui aprendendo do que eles precisavam e eles aprenderam comigo o que eles precisavam. [...] Então, o que acontece, isso aí que você está me perguntando, eu digo o seguinte, eu fui um professor, que foi um artista que entrou na escola. E, enquanto isso, dava aulas pros alunos [...] e eles me ensinavam como ser professor, foi mais ou menos isso, foi assim que eu fui aprendendo. [...] (Entrevista pessoal professor Osvaldo, 2018)

E nesses trinta anos, já fiz de tudo. Já dei aula pra criança em pré-escola, já dei aula pra adulto no EJA, já dei aula em faculdade, já fui coordenadora pedagógica. [...] Porque assim, formação como professora... A gente... Eu fiz uma boa faculdade, mas ela não foi suficiente para me formar professora, né? Eu acho que a gente aprende a ser professora no dia a dia da sala de aula, buscando essa formação. [...] (Entrevista pessoal professora Esther, 2018).

Aprender a ser professor na prática em sala de aula, assim como nos relatou os professores nos trechos acima transcritos, quer dizer que a prática docente é constituinte da formação do professor, porque o curso de graduação oferece os conhecimentos necessários ao exercício da profissão, mas a maneira com que cada um se apropria das teorias e as coloca em uso na sala de aula é muito própria, característica de um processo identitário como afirma Nóvoa (2007, p. 16), quando diz que o processo de construção da identidade dos professores abrange "a adesão a princípios e a valores e a adopção de projectos" relacionados aos estudantes com os quais atuam, "a acção" que implica na opção das formas de agir que envolvem decisões pessoais e profissionais, e "a autoconsciência" envolvendo a reflexão sobre a ação docente, ou seja, sobre a própria atuação. E quando nos referimos à adoção de princípios e valores na formação e na atuação docente, uma das professoras fez um relato sobre a atitude que adotou em relação à sua formação:

[...] Então, eu procurei por mim mesmo e até nas férias estudava outras coisas, e todo mundo ficava bravo: "Como assim, você pega livro pra ler nas férias, e você lê mesmo?", e eu falava: "Não, porque a educação é o tempo todo, se o professor não gosta de estudar, como que o aluno vai gostar? Se o professor não gosta de ler, como o aluno vai de ler?". Então, eu fui uma aluna bem 'nerdinha', e até hoje eu respeito muito Morin, o José Pacheco, os principais, e o Paulo Freire, que foram os que mexeram mais na minha cabeça, ali na faculdade e atualmente, no exercício da educação [...] (Entrevista pessoal professora Janaína, 2017).

Nesse sentido, o professor Márcio relata sobre a sua escolha profissional rememorando a sua atuação num projeto de capoeira com o qual teve contato por meio 
da escola e participou durante vinte anos. Neste relato, ele aponta a importância que a escola tem em apresentar e oferecer aos alunos o contato com atividades culturais:

Acho que tem a ver com a história da minha adolescência, com a militância. Eu fazia capoeira, e lá no meu grupo de capoeira, o mestre achava que a gente precisava saber outras coisas além da capoeira. Então ele trazia palestrantes pra poder falar do ECA, da saúde sexual, e nisso ele nos envolveu no movimento de adolescentes brasileiros. Então, nós passamos a fazer essas discussões não só nas aulas de capoeira, mas com outro grupo, de teatro, dança, escolas particulares, e essa troca foi se dando, não só aqui na capital, mas circulando pelo Brasil. Nós ficamos nesse movimento uns 10 anos, circulando o Brasil, discutindo bastante, e aí sempre tinha essa coisa de... você está no movimento, você deixa de ser um adolescente e vira um adulto. Tivemos essa formação para ser um educador dentro dessa história toda. Eu acho que essa transição de ser educador me fez permanecer [...] Ah, várias motivações, claro. Mas uma outra motivação é... tem a ver... Tudo está ligado, enfim, não tem uma só, embora os caminhos possam ter outras vielas. Porque durante minha vida escolar, eu só assisti a uma apresentação cultural dentro da escola, uma única, durante todos anos, onze, doze anos que fiquei na escola, foi justamente uma única apresentação de capoeira, que foi deste grupo no qual fiquei vinte anos e, depois, comecei a analisar que se a escola tivesse me oferecido outras coisas, talvez eu tivesse conhecido outras coisas também. E aí eu quis, né, proporcionar isso à escola. Aí quando vem as aulas, eu tento proporcionar um monte de coisa... (Entrevista pessoal professor Márcio, 2017).

Para o professor Márcio, adotar esse posicionamento de proporcionar atividades culturais para que os alunos conheçam outros universos culturais se configura em uma das formas de se tornar professor.

Entender a profissão e os processos que a constituíram tal como é hoje se faz importante para compreender as representações da docência elaborada e percebida por cada um desses professores, do mesmo modo compreender que "o professor é uma pessoa", como afirmou Ada Abraham, e que sua forma de se relacionar com a profissão está entrelaçada pelo modo como ele se constitui enquanto indivíduo. Nóvoa (2007) indica que a separação entre o profissional e o indivíduo no século XX provocou uma crise identitária entre os professores e "[...] A transposição desta atitude do plano científico para o plano institucional contribuiu para intensificar o controlo sobre os professores, favorecendo o seu processo de desprofissionalização" (p. 15). É sobre o aspecto do controle profissional que a professora Regina indica para o desapontamento sentido em relação à profisssão, em decorrência das sucessivas mudanças que ocorrem a cada troca de governo e o quanto isso afeta diretamente o trabalho em sala de aula:

[...] e cada governo que muda, muda o olhar, né, que é aquilo que a gente estava fazendo, então eu fui me decepcionando, mas, ainda assim, 
eu ainda gosto muito das coisas e das possibilidades que ela dá e das dificuldades também de exercer essas possibilidades então, esse desafio é interessante na educação. (Entrevista pessoal professora Regina, 2017).

O professor Jefferson nos relatou que sua formação acadêmica forneceu os subsídios teóricos para o exercício profissional, mas não o preparou para a realidade em que atua na escola pública, lembrando que esse professor se graduou em uma instituição particular que, em geral, oferece cursos para um público detentor de um capital econômico maior.

[...] Lógico que ela não me preparou, eu acho ela não me preparou pra realidade que eu, que eu estou. Que eu estou numa escola de periferia com todas as questões da periferia e isso eu fui aprendendo nos saraus mesmo, né? No... Nos eventos culturais, porque eu já era do sarau antes de entrar na faculdade, né?... Não, eu entrei na faculdade na mesma época do sarau, mas eu já conhecia os movimentos da região, né, já tinha participado de outros eventos, então conhecia toda essa movimentação. Então eu acho que a faculdade, ela me deu um pouquinho a parte acadêmica, mas o que eu aprendi mesmo eu acho que foi dentro desse movimento aí. (Entrevista pessoal professor Jefferson, 2017).

Essa realidade da periferia a que se refere o professor Jefferson, com questões sociais diversas que afetam o cotidiano da escola, provavelmente não era uma questão a ser tratada naquele ambiente acadêmico dado que o público que ali se forma, talvez, busque por campos de atuação mais alinhados com as suas posições no espaço social. Do mesmo modo, apresentamos o relato da professora Arlete que se sentiu deslocada ao cursar a graduação em uma universidade pública, no entanto, quando ela inicia a carreira no magistério não sente aquele estranhamento tão comum nos primeiros anos de ser professor:

Oh, eu acho que foi mais tranquilo do que estar na universidade, né, porque eu vim dar aula, a primeira escola que eu lecionei, foi na escola onde eu estudei, né, aí é um retorno, né. E aí você tem uma..., uma identidade, né, com o lugar, com as pessoas, né, então foi muito tranquilo. E eu trabalhei muito naquela região, né, é perto da minha casa e eu ia a pé, conhecia todos os alunos, então, era outra relação, né, não é aquele professor intruso que chega e todo mundo quer testar, eles sabiam quem eu era, né, então, foi bem tranquilo. (Entrevista pessoal professora Arlete, 2018).

Em seus estudos sobre o ciclo de vida profissional dos professores Huberman (2007) aponta dois aspectos comuns no início da carreira, a saber: o "choque do real" ou "sobrevivência" e o aspecto da "descoberta". A "sobrevivência" ou "choque do real" se 
constitui no impacto inicial produzido ao se confrontar com o exercício do magistério e isso pode se dar de diversas formas, como na relação pedagógica, nas condições da escola, distância entre a realidade e os ideais, entre outros. E o aspecto da "descoberta" é a experimentação da atuação profisssional, o entusiasmo. É frequente encontrar nas pesquisas a indicação do choque com a realidade no momento inicial da carreira, no entanto, Huberman (2007, p.39) afirma que "[...] a literatura empírica indica que os dois aspectos, o da sobrevivência e o da descoberta, são vividos em paralelo e é o segundo aspecto que permite aguentar o primeiro".

Assim como a professora Arlete que não se sentiu impactada com o início na profissão, o professor José, que já havia trabalhado como educador social antes de se formar, após concluída a graduação, inicia sua carreira na mesma região onde vivia, na periferia da zona leste e, apesar dos problemas sociais que ele já conhecia, relata sua identificação com o lugar, conforme observado a seguir:

Então, quando eu entrei na faculdade, eu já levava essa bagagem de educador popular, porque desde a minha adolescência eu já trabalhava com grupos de jovens, na comunidade onde eu morava, que foi na Ermelino Matarazzo, na zona leste. Então, eu já tinha experiência de trabalhar com grupos. Então, a Educação Popular pra mim já era uma... já tinha uma experiência, aí quando eu passei, quando eu comecei a fazer Filosofia e comecei a fazer a licenciatura, eu me apaixonei pela escola. É o que eu quero, e daí eu fui conhecendo mais um pouco da teoria. Mas aí, paralelo a isso, eu comecei a fazer, trabalhar como educador social, também. Então, eu fui... eu acho que a minha prática ajudou muito, porque eu fui fazendo a universidade, conhecendo a teoria mesmo, e já trabalhando na prática. Então, um tempo sem experiência teórica, eu lembro que quando eu entrei na escola, assim, pra mim foi... não tive nenhum choque, não tive grandes dificuldades, porque eu já trabalhava com os meninos em situação de vulnerabilidade em Heliópolis, eu trabalhei em São Miguel, trabalhei em Guaianazes. Então, enfim, trabalhar na escola pública pra mim, não foi nenhum trabalho assim. E, então, a minha formação foi assim, foi uma prática aliada a teoria, eu estava ali na universidade, eu tinha um outro... no começo eu trabalhava com uma produtora, assim, com publicidade, e eu fui largando aos poucos para ir entrando na Educação, e em $2010 \mathrm{eu}$ assumo de vez. (Entrevista pessoal professor José Vandeí, 2017).

Retomando os aspectos da profissionalização, no século XX, os professores possuem prestígio que está relacionado às ações realizadas pelas associações intrinsecamente ao corpo docente. Além disso, o Movimento da Educação Nova, nos anos 20 é, segundo Nóvoa (1999, p.19), consequência de “[...] uma lenta evolução cultural que impôs socialmente a ideia de escola e o produto da afirmação das 'novas' ciências sociais e humanas (nomeadamente das ciências da educação), mas representa também um forte 
contributo para a configuração do modelo do professor profissional". Assim, com a profissionalização, os professores possuem um estatuto social e econômico que possibilita o "prestígio social" e uma condição "econômica digna", fundamentais para o exercício da atividade profissional. Para Catani e Silva (2009, p. 02), a profissionalização abarca várias dimensões do magistério sendo “[...] a formação, a instituição e os saberes, o exercício concreto da atividade, as relações com o Estado, as formas de organização da categoria profissional".

Na transição dos anos 30 para 40, no século XX, ocorreu a expansão do ensino público primário, no entanto, a ampliação afetou ainda mais as condições de trabalho dos professores, considerando que foi permitida "a oficialização do magistério leigo; supressão do quinto ano, redução da duração do curso primário para dois anos, facilitação dos cursos normais, três ou mais períodos de aula, regime de quatro turnos, construção de galpões escolares de madeira e sem as mínimas condições para a atividade docente" (VIANNA, 1999, p. 85). Com essas mudanças e o ensino sob influências de novas teorias, as regras que indicavam o comportamento e a imagem coletiva das professoras passaram por modificações. Em 1950, a ampliação dos ginásios possibilitou o crescimento do ensino Normal gerando um excedente de professoras formadas que o Estado não conseguia contratar.

Catani e Vicentini afirmam que a partir dos anos 50, os professores passaram a reivindicar melhores condições de trabalho e a reclamar contra os salários que eram baixos "[...] mediante a realização de passeatas e de atos públicos, que procuravam afirmar a imagem do docente como um profissional (não mais um sacerdote) que deveria ser bem remunerado [...]" (2003, p. 151).

De acordo com Vianna (1999), na década de 70, os professores sofriam com a desvalorização dos salários e o grande número de aulas que precisavam lecionar para aumentar a renda, existindo muitos docentes atuando sem concurso, isto é, na condição de professor temporário. Segundo a autora, o processo que levou à maioria feminina no magistério nos anos 90 está relacionado “[...] ainda que indiretamente, com a dinâmica do mercado de trabalho e nela a divisão sexual do trabalho e a configuração das chamadas profissões femininas" (VIANNA, 2013, p.165).

Nóvoa (1999), ao tratar da crise da profissão, afirma que o foco da crise está na diferença entre uma "visão idealizada e a realidade concreta do ensino" (p. 22). A sociedade contemporânea entende que é necessário investimentos em educação para obter desenvolvimento, porém os profissionais da educação sentem-se insatisfeitos e 
desmotivados, é comum as ausências do trabalho e o abandono da profissão, e falta reflexão sobre a prática. Para o autor é preciso romper com a "imagem profissionalizada das escolas" e com o poder do estado sobre a educação (NÓVOA, 1999, p. 23).

Quando perguntamos aos professores se eles gostam da profissão que exercem, o questionamento leva a respostas reflexivas acerca das condições de trabalho a que são submetidos e às dificuldades encontradas na sala de aula. No relato a seguir, a professora Izabel que atua na área de Língua Portuguesa, fala sobre o desafio que se impõe cotidianamente à prática pedagógica pelos diferentes estágios de aprendizado em que se encontram alunos de uma mesma sala:

[...] E eu gosto muito de dar aula, embora seja extremamente desafiador, porque o professor, ele não pode ter só uma formação técnica, ele não pode ser bom só tecnicamente, ele não tem que ser um conhecedor só de literatura, ele não tem que ser um conhecedor só de gramática, ele tem que ser um conhecedor do mundo, né, então assim, você vai lidar com gente, então você tem que ter habilidade como gestor de sala, é... e o que eu acho, e o que é realmente um desafio, mas para mim sempre é muito instigante, é isso, a questão da educação inclusiva e a questão, assim, de como preparar sua aula, porque assim, você tem salas cada vez mais heterogêneas assim, muito, muito diversas [...] É..., você tem alunos que leem, por exemplo, você tá falando assim, "ah, gente, hoje nós vamos falar de crônica". Aí, tem um aluno que levanta a mão, "professora, Crônica de uma morte anunciada do Gabriel García Marquez, o quê que tem a ver com o gênero crônica? [...] então, você tem alunos que fazem esse tipo de pergunta, porque eles leem [...], e você tem alunos que estão ainda numa alfabetização pré-silábica, né, você tem alunos que são medianos, e aí, dependendo da aula que você prepara, esses alunos que estão avançados ficam desmotivados, esses alunos que são medianos acompanham bem a sua aula e ficam satisfeitos, e esses que são pré-silábicos acham que você está falando sobre a composição do átomo, então assim, é muito complicado, [...] esse é um desafio que a gente tem que lidar, mas, assim, eu acho que os desafios fazem a gente crescer, isso é o legal da nossa profissão. (Entrevista pessoal professora Izabel, 2018).

Neste outro relato que também é de uma professora de Língua Portuguesa, notase a reflexão a respeito do ensino de literatura para alunos da escola pública que vivem em condições extremamente precárias.

E, aí, dar aula, na verdade, acaba sendo consequência, né, assim..., porque é muito diferente do que você imagina quando você está na faculdade, porque nem sempre dentro da... até..., e eu acho que uma das coisas que é bem frustrante, é em relação à literatura que, por exemplo, você vai ensinar literatura num meio em que a literatura não tem função utilitária nenhuma, é difícil você explicar isso, né! Fazer com que os alunos apreciem a arte e, ao mesmo tempo, você assumir que realmente a arte não precisa ter nenhuma função utilitária, ela não precisa ser nada, então, essa é uma das frustrações. Pra quem já deu aula sabe que é, né, convencer os alunos é realmente uma tarefa... E aí, tem todo aquele 
negócio social que você não consegue, várias coisas você... que é a frustração do dia a dia mesmo de dar aula, né, várias coisas que você pensa e você não consegue colocar em prática, né, que às vezes você é tudo dentro da sala de aula menos professora [...]. É, mediando conflitos, escutando aluno, tem problema com a mãe, [...] choveu muito e a casa dele está alagada, às vezes o pai está desempregado, o irmão está preso, $[\ldots]$, eu tenho muitos alunos que às vezes eles vivem com pessoas que nem tem parentesco sanguíneo, $[. .$.$] a mãe não podia mais$ cuidar e entregou pra uma madrinha que também não tem... [...] Então, são coisas que é difícil você [...] achar que é importante você ensinar alguma coisa para eles de estética, por exemplo [...], que realmente pra ele, né, não faz muito sentido. (Entrevista pessoal professora Márcia, 2018).

Este relato que acabamos de apresentar está carregado de tensão e do conflito vivenciado por esta professora no cotidiano das aulas e este é um desafio enorme que se coloca a todos os professores que atuam na escola pública, pois são problemas sociais da vida desses alunos, inseparáveis deles e, em consequência, afetam o aprendizado e a prática docente.

A precarização da carreira é discutida por dois professores que atuam em regiões periféricas e pontuam que não se sentem amparados pelo sistema educacional em suas atuações ao mesmo tempo em que são cobrados por resultados.

Eu gosto, mas acho a profissão muito ingrata [risos], sabe, eu gosto, eu gosto de educar, eu gosto de alfabetizar, mas eu acho todo o sistema muito complexo, eu acho ah... extremamente desgastante, sabe, quando você se envolve mesmo, porque as pessoas falam, "ah, mas é uma profissão, não é uma vocação e tal", mas é muito difícil você lidar com o ser humano e não se envolver, né, não perceber que por trás da questão do aprendizado daquela criança está uma família com dificuldade, $n$ problemas e tal, então, é o desejo de que ele aprenda, de que evolua, né, então, nesse sentido é bem desgastante eu acho, eu acho, falta um monte de coisa, né, falta o apoio para o professor, falta o apoio para a escola, falta achar o caminho de engajar mais a família, né, mas de modo geral eu gosto, acho que é bom, acho que é bem gratificante. (Entrevista pessoal professora Cecilia, 2017).

Eu gosto da profissão, mas eu detesto a forma como nós somos tratados assim, não falo nem pela comunidade que a gente tem apoio de alguns pais, né, aqueles que conseguem, aí a gente vai dar com essas mazelas que arrebentam na escola, mas que não são problemas só da escola, são problemas sociais, né, por exemplo, famílias desestruturadas, pobreza extrema, essa epidemia de drogas e alcoolismo etc, e isso vai estourar na escola, mas de um modo geral, eu sinto que a comunidade apoia os professores, por outro lado, a maioria dos governantes deixam a desejar, sabe, assim é... a política de um modo geral, né, que procura mais mostrar do que fazer no final das contas, sabe, e aí, de um modo geral, eu acho que a gente não é valorizado tanto quanto deveria ser, por 
exemplo, eu tenho que acumular cargo, porque senão eu não consigo..., não tem luxo nenhum na minha vida, sabe, não consigo, temos uma casa, dois filhos, né, a menina terminou na escola pública, o menino está na escola particular e um carro popular, [...] mas para ter uma vida comum, eu tenho que acumular cargos e a [nome da companheira] também é professora, entendeu, para ficar a vida..., não é num [...] bairro mais caro, nada, é na periferia também, que eu trabalho onde eu moro mesmo, e se eu não acumular assim, eu não consigo dar uma estrutura que seja mediana para minha família, para os meus filhos. Então aí, você tem que fazer uma jornada de oito, dez horas, mas que a gente sabe que não é só isso, porque... na sala de aula, aí tem aquele negócio do preparar aula, de corrigir, de mexer com a parte burocrática que eu confesso para você que eu detesto. [...] você tem que trabalhar muito para algum outro profissional que tem o curso superior também, ele trabalha uma jornada de oito horas, por exemplo, entendeu, e aí a gente tem que fazer uma jornada bem maior para ganhar mais ou menos a mesma coisa tendo curso superior [...]. (Entrevista pessoal professor Daniel, 2018).

Para Nóvoa (1999), os professores precisam adquirir mais autonomia na profissão e ter uma relação mais intensa com os envolvidos no processo educacional. Para isso, é preciso romper com a ideia "funcionarizada" de professor fazendo com que o Estado tenha uma função de acompanhar e avaliar e menos burocrática e de regulação. Assim como aparece no último excerto acima, o professor enfatiza o desgosto pela forma com que é tratado pelo estado e expõe a precariedade do trabalho do docente que precisa ter duas ou mais jornadas de trabalho para conseguir sobreviver minimamente.

Portanto, tornar-se professor é um processo que se constitui na trajetória profissional, no entrelaçamento da teoria aprendida na academia com a prática em sala de aula, onde o professor vai construindo sua forma de lidar com o tempo e o espaço das aulas, com os conteúdos a serem ensinados, construindo um modo de se relacionar com os alunos e com o corpo de profissionais que atuam na escola. Esse fazer-se professor é inseparável da pessoa que ele é, ou seja, as suas referências históricas, sociais e culturais fazem parte desse modo ser. Assim para Nóvoa (2007), a identidade se constrói no espaço de lutas, tensões e conflitos no qual o professor encontra sua maneira de exercer a profissão e de ser professor.

\subsection{O interesse pela escrita}

[...] Quem fez gostar de ler, foi meu avô. [...] Porque que eu estou te dizendo que foi meu avô. Meu avô era um contador de histórias. Então eu adorava quando ele vinha e ele contava aquelas lenga-lengas de 
Portugal. Que meu avô era português, meus pais são portugueses, então ele contava umas histórias, que hoje a gente chama de lenga-lenga... [...] Histórias encadeadas e eu amava ver meu avô contar aquelas histórias. Então, antes de saber ler, eu já gostava de histórias por causa do meu avô. Aí, depois na escola, aprender a ler e escrever, tinha um incentivo desse professor, então tudo vai casando... E é claro que hoje gosto muito de ler, né? Inclusive ela é meu instrumento de trabalho, a leitura, né, de tudo. Leitura e escrita é meu instrumento de trabalho. (Entrevista pessoal professora Esther, 2018).

Ao ler este trecho contado pela professora Esther durante a entrevista, refletimos sobre como se deu o interesse dos professores pela prática do escrever e lendo os relatos coletados percebemos que para desenvolver uma prática da escrita seja ela pessoal, literária ou de outra natureza o contato com o universo da cultura escrita e da literatura teve início bem antes como, por exemplo, no contexto familiar da professora Esther em que seu avó lhe contava as histórias de Portugal que a sua família nomeava de "lengualengua". O ato de contar histórias - fábulas, contos populares ou inventadas - muito comumente praticado pelas pessoas mais velhas às crianças da família é uma forma de iniciar esse indivíduo no mundo das narrativas ficcionais. As narrativas orais, contadas, dramatizadas ou lidas são um recurso pedagógico muito utilizado nos anos iniciais do processo de escolarização para introduzir os alunos nesse universo ficcional e, assim, instigar o interesse pela leitura literária e escrita.

Não, na minha família ninguém escrevia, mas como eu disse, minha mãe contava muita história, né, e gostava muito, ela contava cordel, várias histórias, várias coisas, meu pai também, meu pai contava mais histórias dele, de vida, de fazenda, de não sei o que, que ele é apaixonado [...] pelo campo, pela natureza e tal, então as histórias do meu pai eram mais assim, com uma visão muito bonita e a minha mãe, às vezes, tinha uma visão muito dura do nordeste, das dificuldades e tal, sabe, que..., e ao mesmo tempo as histórias de cordel que ela lembrava, as histórias que a mãe dela contava, então, como eu disse, eu sempre associei muito escola e literatura, sempre, desde criança, pra mim escola está muito ligada ao livro e a essa literatura [...]. (Entrevista pessoal professora Cecilia, 2017).

Assim, percebemos que os momentos de contação de história no interior das famílias se constituíram para as professoras Esther e Cecilia como um primeiro contato com as narrativas e contribuíram para que elas se interessassem pela literatura.

A escola, neste sentido, tem fundamental importância na inserção das crianças no universo da cultura letrada, sobretudo a partir dos processos de alfabetização, letramento, bem como por meio da leitura de textos literários. Identificamos, assim, que, por meio da atuação do professor, a escola cumpriu o importante papel de possibilitar o 
aprofundamento dos saberes, a apropriação e o desenvolvimento de estratégias de leitura e escrita em relação aos professores entrevistados. E, nessa perspectiva, apresentamos o relato do professor Daniel sobre o trabalho desenvolvido com redações enquanto era aluno:

Então, o primeiro incentivo foi esse negócio da..., eu tinha uma professora na oitava série, tinha lá por uns catorze anos, ela achava assim que minhas redações se destacavam e aí ela chamava uma professora, a outra, e mostrava, né, às vezes lia na sala de aula, mas não falava quem era, eu sabia que era minha, e eu achei que eu tinha um talento pra aquilo ali. Então, é... a escrita assim com alguma ambição literária foi com dezessete pra dezoito anos, mas eu sempre fui bom em redação na escola, então, sempre as professoras elogiavam e tal, não sei muito bem por que, [...] e aí quando eu tinha lá uns dez, onze, doze anos comecei a descobrir Legião Urbana, essa coisa toda, que de alguma forma falava comigo, mas eu não entendi muito bem, sabe, e aí fui prestando atenção nas letras por trás desse rock nacional e comecei a escrever poemas também, mais treze pra catorze, assim comecei a ter os cadernos, né, escrever, não sei nem se era poema, se era diário, era tudo meio misturado, sabe, mas uma prática de escrita, e aí lá com dezessete, dezoito eu comecei a escrever mesmo contos, assim, tal, ficção mesmo. (Entrevista pessoal professor Daniel, 2018).

Para outros professores entrevistados, o incentivo e o trabalho realizado pela escola em relação à leitura literária foi um aspecto motivador, que deu início à escrita ficcional e pessoal, conforme os relatos apresentados pelos professores Márcio e Esther:

É, acho que por gostar de ler poesia, eu passei a querer escrever, assim, eu acho que... Eu ganhei um livro do Vinícius de Moraes, uma coletânea belíssima que eu tenho até hoje, e eu utilizava esses poemas claro, obviamente pra distribuir para as meninas. Só que aí, eu queria que as palavras fossem minhas, e aí eu comecei a... Acho que esse foi meu principal motivo pra começar. Porque eu, nesse processo eu descobri... Porque eu adorava as aulas de Língua Portuguesa na escola, não as de gramática, mas, sobretudo de Literatura, e quando tinha que escrever, eu criava uma história, recontar uma história, eu adorava, pegava uma história, sei lá, do leão e do rato, reescrevia, eu adorava, queria escrever, eu inventava as histórias, eu modificava completamente as histórias, na escola, foi a principal assim. (Entrevista pessoal professor Márcio, 2017).

[...] Eu já escrevia quando eu estava na escola. Sempre gostei de escrever. Pra mim o escrever é um jeito de... uma válvula de escape, me comunicar com o mundo, é uma atividade prazerosa. [...] Na verdade, eu acho que o que me motivou a escrever... Primeiro eu escrevia para guardar na gaveta. Então, eu escrevia um poema, guardava... Escrevia um texto que eu achava legal, guardava... Como eu te disse, era uma coisa que eu fazia pra mim, era uma forma até de... eu me conhecer melhor. E, assim, engraçado né? Que você pega os textos que você escreveu a trinta, quarenta anos atrás e compara com agora, ali você tem uma história de vida, né? Então assim, não tinha nenhum exemplo. Na 
escola, o que eu tive, foi muito incentivo pra leitura. Eu lembro que eu tinha um professor, que ele pedia para que a gente lesse os livros que a gente pegava na biblioteca e a gente tinha que contar o começo do livro pra ele oralmente. E não podia contar o final. Porque tinha muitos livros que ele já tinha lido, evidente. Então a gente não podia enganar, a gente não podia dizer pra ele, "olha, eu li o livro tal", só que... Falando da capa, né? Da contracapa, porque ele fazia perguntas sobre os personagens... Então eu acho que esse incentivo, de tanto gostar de ler, que também me levou a escrever. (Entrevista pessoal professora Esther, 2018).

Para as professoras Camila, Regina e Cecilia, a escrita pessoal na adolescência, na forma de um diário com os acontecimentos vivenciados no cotidiano ou ainda um tipo de escrita mais intimista sobre os próprios sentimentos, se constituiu como o início de uma prática da escrita, como relatam:

Eu acho que na adolescência...na adolescência eu escrevia bastante, eu escrevia dos amigos que eu fazia, eu escrevia dos lugares que eu ia, das situações, dos namorados, das viagens, tudo isso eu escrevia, tudo que era muito positivo eu escrevia, porque eu queria reviver de novo, ler detalhes, saber como é que era... então, isso eu fazia questão. Este momento foi bem forte, eu lembro que eu tinha assim agendas que eu adorava rever algumas viagens, algumas situações, como é que eu estava... Então, eu acho que esse foi o momento mais forte. (Entrevista pessoal professora Regina, 2017).

$\mathrm{Na}$ verdade, eu sempre gostei de escrever no sentido de [...] diário, vai, desde muito nova, assim, até encontrei meu namorado hoje, hoje fizemos tal coisa, eu sempre gostei de escrever e, depois, eu sempre gostei de escrever cartas ou bilhetes ou uma prática que eu uso até hoje, quando eu quero expor uma coisa, eu acredito que escrevendo eu consigo expressar melhor o que eu quero dizer [...]. (Entrevista pessoal professora Camila, 2017).

[...] na adolescência eu comecei a escrever, [...] acho que com 16, 17 anos, mas era muito para mim assim, sabe, era meio desabafo, eu sempre fui uma pessoa que teve muita dificuldade de falar de mim, [...] de falar dos meus problemas, embora eu pareça muito expansiva, eu sempre fui muito fechada assim, né, principalmente na escola, na escola eu era extremamente tímida, então, acho que o meu lugar de botar para fora, de me expressar era muito na escrita, mas era uma coisa meio desabafo, uma coisa de adolescente, uma coisa muito para mim assim, não tinha ideia, ah, vou escrever, vou ser escritora, não. [...]". (Entrevista pessoal professora Cecilia, 2017).

Embora a professora Izabel não tenha mencionado a relação com os conhecimentos aprendidos na escola com o início de sua prática da escrita, supomos que as aulas de Língua Portuguesa foram propulsoras desse tipo de produção escrita que ela gostava de realizar na adolescência e que são conhecimentos aprendidos na escola: 
Bom, na verdade, escrever literariamente eu comecei na adolescência, eu sempre gostei de fazer paródia, gostava de escrever poemas, é... e sempre gostei também de estruturas rimadas, muito, muito, muito. $\mathrm{Na}$ minha adolescência, inclusive, quando a gente precisava na escola ou mesmo fora dela, ou no local de trabalho quando alguém, "ah, a gente precisava tanto fazer uma paródia", o pessoal sempre me procurou, então assim, eu me lembro desses primeiros registros literários. É..., durante a época de faculdade, eu escrevi um pouco de poemas, escrevia muita crítica literária, bastante crítica literária nessa época e, depois da minha formação, aí, crônicas, mais crônicas mesmo. (Entrevista pessoal professora Izabel, 2018).

Partindo dos relatos apresentados pelos professores, compreendemos que a escola - no tocante aos conhecimentos escolares relativos à leitura e à escrita -, bem como o contexto familiar apresentam importantes contribuições para a inserção na cultura escrita. Conforme observado, a escola, em sentido estrito, cumpre sua função social no ensino dos conhecimentos específicos. Além disso, devem ser enfatizadas as relevantes contribuições que tiveram os professores dos entrevistados, principalmente na formação de novos leitores e escritores. 


\section{escrita \\ 6. TEXTOS LITERÁRIOS: usos, materialidades, suportes e temas da}

Neste capítulo apresentaremos e analisaremos as práticas da escrita efetivada pelos professores entrevistados, a fim de responder os objetivos propostos pela pesquisa, demonstrar as práticas da escrita identificadas, os usos atribuídos às diferentes práticas, as materialidades e suportes dos materiais que foram disponibilizados e os temas selecionados pelos professores para os seus textos. Para isto, elaboramos categorias de análise que nortearão a construção das possibilidades de interpretação dos materiais. Essas categorias foram pensadas considerando quatro aspectos: categorias dos usos, modos de produção, distinção e categorias temáticas.

Identificar e delimitar os usos que os professores fazem de suas práticas da escrita é fundamental para a compreensão do movimento que os leva a escrever textos literários. Dessa forma, as categorias foram construídas a partir da leitura atenta e análise dos materiais literários e das entrevistas realizadas. Em relação aos usos da escrita, estabelecemos quatro categorias que dimensionam a diversidade das práticas efetivadas pelos professores da pesquisa, a saber: o autobiográfico ou "do eu", a escrita induzida, a escrita poética, e o compartilhamento de experiências literárias. Em seguida, analisamos os modos de produção dos textos considerando os instrumentos utilizados na confecção, os suportes e as materialidades. Para isso, utilizamos as entrevistas em diálogo com os materiais - livros, fanzines, imagens dos blogs, revistas - recolhidos durante a pesquisa.

A distinção é uma categoria importante que analisa a partir do conceito de Bourdieu (1996) sobre o campo literário os indícios de busca dos professores pelo reconhecimento no campo.

Em relação às categorias temáticas, analisamos os textos considerando os conteúdos e discursos presentes, compreendendo que os textos selecionados propõem uma interlocução com a realidade social de seus respectivos autores objetivando representar, criticar ou denunciar determinados aspectos. Quanto à interlocução com a realidade, definimos subcategorias ou eixos de análise, a saber: representações sobre a 
profissão docente e o contexto escolar, a constituição de outra ideia de periferia, cotidiano em São Paulo, escrever do "ponto de vista" feminino e escrever em tempo de internet.

\subsection{Práticas e usos da escrita: diversidade de sentidos e de práticas}

Desde uma perspectiva histórica, a prática efetiva da escrita sempre apresentou diferentes formas, instrumentos e suportes, sendo que com o desenvolvimento das sociedades a escrita seus usos foram sendo cada vez mais incorporados à vida cotidiana - à medida que as pessoas começaram a ter acesso à escolarização e aprenderam a ler e a escrever. Do mesmo modo, os instrumentos, técnicas e suportes da escrita foram aperfeiçoados, provocando mudanças na forma de produzir o material escrito. Essas mudanças não significam o abandono imediato de uma forma de fazer e a adoção de outra completamente nova, uma vez que as práticas coexistem num mesmo recorte histórico, evidenciando processos de transição e de adoção de formatos mais modernos e sofisticados.

Ao analisar as práticas de escrita dos professores, identificamos que estes exploram distintos suportes e estabelecem objetivos específicos, evidenciando, assim, uma multiplicidade de práticas de escrita. Tendo em vista que a escrita literária é objeto desta pesquisa, notamos que alguns professores circulam por estas categorias de uso que elaboramos, de modo que suas produções constarão em mais de uma categoria; por outro lado, há professores que exercitam apenas usos específicos, cabendo-lhes tão somente a inclusão em uma das categorias.

\subsubsection{O autobiográfico ou "do eu”}

A escrita autobiográfica ou "do eu" se caracteriza pela prática em que o professor escritor se expõe diretamente, estabelecendo com o leitor a dimensão autobiográfica de sua criação, seja escrevendo sobre si ou expondo sua opinião sobre determinado assunto, seja quando o texto produzido trata de situações vividas.

Então, eu acho que é um pouco... não sei se eu encaixo em algum gênero, não, mas é meio autobiográfico o que eu escrevo, né, não era essa a intenção no começo do blog, sabe, eu tinha uma ideia de falar..., na verdade, são vários os assuntos que tem lá, né, porque tem política, tem não sei o que, tal, mas acabou virando uma coisa meio 
autobiográfica, então, o que eu vejo sobre determinado tema e foi se configurando assim [...] e eu fui gostando também disso, né, e... já teve texto que eu tirei, né, eu falei, não, esse tá autobiográfico demais pra uma rede, né, deixa eu tirar isso aqui, né, já teve texto que foi polêmico que eu não aguentei muito a polêmica, daí eu também tirei, né, enfim, [...] mas é isso, é autobiográfico, são pensamentos assim, [...] não enquadro em gênero nenhum." (Entrevista pessoal professora Virginia, 2017).

A prática da escrita da professora Virginia conforma textos narrativos de caráter autográfico, nos quais a autora expõe suas reflexões a partir da sua vida cotidiana - e isso inclui o trabalho, a família, sua percepção sobre o mundo, sua condição feminina na sociedade atual. A dimensão autobiográfica dos seus textos é estabelecida imediatamente na relação com o leitor do seu blog, especialmente quando escreve um texto sobre a decisão de criar um blog com o intuito de relatar as próprias experiências. Durante a entrevista, a professora escritora nos contou um pouco sobre a produção que elabora para o blog, como segue:

Acho que são assuntos, assim, da minha vida, né, tem essa coisa do trabalho, né, do que é ser professora, de como eu encaro a profissão, tal, a relação com a maternidade, né, porque a princípio eu pensei em escrever um blog que fosse voltado, minha inspiração inicial foi essa, né, um blog que fosse voltado também pra essa questão da maternidade, mas eu também não consegui escrever só sobre isso, né, então tem muito da minha relação com a maternidade lá, relação de gênero, né, então, as minhas relações pessoais na minha e... o que é ser mulher dentro de um relacionamento, né, fazendo tudo isso que a gente faz, gênero, essa questão da maternidade, essa questão da profissão e tem algumas questões políticas também, de posicionamento político, né, especialmente nesse período mais turbulento que a gente tá vivendo aqui. Acho que fica claro qual é meu posicionamento, né, nos textos. (Entrevista pessoal professora Virginia, 2017).

Este tipo de escrita desenvolvida por Virginia não se configura como uma prática da escrita estritamente pessoal, como seria um diário ${ }^{116}$, por exemplo. Sua produção pressupõe um leitor, uma edição que visa a publicação digital e, nesse sentido, existe um trabalho com a linguagem que é distinto do que ocorre quando a escrita é elaborada para

\footnotetext{
${ }^{116}$ Maria Teresa Santos Cunha ao estudar os diários de duas professoras afirma: "Praticados na intimidade, onde é possível estar emocionalmente nu e formalmente descomposto, o diário procede de um reconhecimento de si pela escrita que, efetuada em solidão, faz crer que quando alguém fala/escreve sobre si mesmo tende a ser mais sincero do que quando se dirige a outrem. Em geral, tais arquivos íntimos fazem alusões enigmáticas a fatos e pessoas; são receptáculos de impulsos, crises, confidências, que, por acompanhar o andamento do calendário, não são construções meramente retrospectivas, como as autobiografias, por exemplo. O diário pede periodicidade, e seu/sua autor/a tem o recôndito desejo de perpetuar-se e, mais do que isso, constituir sua própria identidade. [...]. Nele o/a situa-se no mundo, organiza seu cotidiano pela escrita, faz igualmente uma reorganização interna dos acontecimentos que pontuam sua vida e assim constrói um destino próprio para si. [...]" (CUNHA, 2000, p. 159 - 160).
} 
si mesmo. A dimensão autobiográfica está contida nessas narrativas construídas para um outro âmbito da leitura, que pode ser conhecido ou não, a depender da circulação do material. Desse modo, as experiências postas nas narrativas são as selecionadas pela escritora para serem compartilhadas, e compreendem um "eu" que ela quer mostrar.

Ao iniciar o blog em 2015, a professora escritora publicou um texto intitulado Começar um blog no qual relata, e ao mesmo tempo reflete, sobre a iniciativa de escrever para esse espaço digital/virtual:

Iniciei o desafio de criar o meu blog. Para mim um desafio porque embora goste muito de escrever, desde que era menina, sou um tanto desorganizada. Mas a ideia de ter um espaço meu para comunicar pensamentos, ações, reflexões, sempre me atraiu. Faltava coragem. Alguns amigos me impulsionaram [...].

[...] Fazer um blog para que? Sem grandes pretensões, pra me divertir, me comunicar, relaxar, tensionar... Com qual temática? Não quero fazer um blog de um tema específico e sim de tudo o que me der vontade. [...] Fiquei ainda um bom tempo pensando em qual nome o blog poderia ter; quando me veio à mente "Palavrinhas, Palavras e Palavrões".

Depois de ter duas lindas filhas, um dos meus temas prediletos são as coisas de gente miúda, suas percepções, invenções, questionamentos, sensações, então poderia haver um espaço para isso: PALAVRINHAS (cujo diminutivo não significa menor, nem menos importante). As PALAVRAS representariam as situações cotidianas, aquelas que enchem esse espaço chamado vida e que são imprescindíveis. E os PALAVRÕES, representariam o extraordinário, aquilo de maravilhoso ou péssimo que acontece durante a nossa existência e que por isso merece destaque.

Criei o blog e me achei extremamente original, rs. Depois ao fazer uma busca no google descobri outros blogs com o mesmo nome, [...] depois pensei que a originalidade não viria do nome do blog, mas do seu conteúdo, mas mais depois ainda, pensei que se não tenho grandes pretensões com o blog, originalidade não é pré-requisito [...]. (Virginia, 2015, grifos da autora).

Com este texto inicial do blog, depreendemos que de imediato a professora escritora acordou com o seu suposto público leitor que o material produzido seria de cunho autobiográfico. Pensando assim, refletimos quais aspectos do autobiográfico são escolhidos para compartilhar e identificamos a identidade profissional como um elemento importante dessa dimensão e a condição feminina na sociedade.

Viñao (2000) afirma que a pessoa que produz textos autobiográficos transita entre o pessoal, íntimo e o que é público, condição essa que é aceita desde que decide escrever e que o texto produzido pode ser lido por alguém. Esta escrita se configura em "refúgio" para quem escreve e pode também, pela apropriação feita pelos leitores, se tornar "refúgios" de outros ou outras. 
Para Lejeune (2008, p. 14), a autobiografia é uma "narrativa retrospectiva em prosa que uma pessoa real faz de sua própria existência, quando focaliza sua história individual, em particular a história de sua personalidade.” Além dessas características, a autobiografia implica um narrador que precisa ser identificado e que se diferencia da personagem principal na enunciação. Dessa forma, neste tipo de literatura existe uma relação de identidade entre o autor, o narrador e a personagem principal. Esses elementos diferenciam a autobiografia de outros tipos de textos que apresentam dimensões do real, como memórias, biografia, romance pessoal, diário, poema autobiográfico e ensaio.

Considerando que os textos produzidos pela professora Virginia em seu blog são independentes, ou seja, não possuem sequência cronológica, mas são retrospectivos, narrados em primeira pessoa e apresentando dimensões da sua vida pessoal, profissional, seu posicionamento político e experiências culturais, os textos reunidos não reconstroem a história individual da professora, revelando apenas fragmentos desta - o que não confirma uma autobiografia em sentido estrito, como definida por Lejeune (2008). Este tipo de material já se constitui como fragmentário se consideramos o seu suporte, a tela, arquivado digitalmente por data de publicação e sem ordenação à leitura, como acontece com o objeto livro. A partir destes apontamentos, entendemos que os textos produzidos pela professora Virginia se enquadram na definição de "autobiografias e memórias em sentido estrito" de Viñao que são textos em que os professores narram as suas vidas.

Sob um ou outra denominação - autobiografias, memórias, recordações, confissões, testemunhos, impressões etc. - nesta parte englobo todos aqueles textos nos quais os professores e mestres narram suas vidas, independentemente de que tal narração ou relato se revista de um caráter mais ou menos pessoal, íntimo, profissional ou público. (VIÑAO, 2004, p. 341).

Em um texto intitulado Balanço, publicado em janeiro de 2016, a professora Virginia escreve uma narrativa retrospectiva sobre o que viveu em 2015, contudo não é um relato de fatos, é mais do que isso, é introspectivo, no qual ela reflete sobre os sentidos de sua vida pessoal, as suas escolhas, como é possível ler no excerto abaixo:

[...] A ideia de ressignificar a vida continuava. Comecei a pensar nas coisas que tinha que mudar: passo muito tempo no trabalho. Tem amigos com quem tenho que me encontrar mais. Preciso estar mais tempo com as minhas filhas. Preciso de mais momentos exclusivos com o meu marido. Preciso ver mais filmes, frequentar mais os espaços culturais, preciso cuidar melhor da minha saúde. Preciso me alimentar melhor. Preciso, preciso, preciso. A construção mental da lista me 
deixou extenuada. Eram tantas coisas que eu precisava cumprir e que não daria conta. E isso continuava me deixando angustiada.

Passei um tempo, não intencional, mas necessário, de bloqueio às redes de comunicação. Falei com uns poucos amigos e parentes na passagem do ano. Fiquei longe de Facebook, WhatsApp, blog, telefone, etc. E percebi que estive mais tranquila nesse período, pois só o que importava era o que eu realmente vivia e sentia. Não havia qualquer necessidade de comunicar aos outros sobre nenhuma das minhas ações. E entendi, ou lembrei, que não conseguimos ser perfeitos e realizar tudo aquilo que esperam de nós e que exigimos de nós mesmos. Simplesmente não dá. Então o que conta é fazer o que for possível da melhor maneira possível. É fazer com paixão. E não importa o quanto os outros são melhores que você nisso ou naquilo. O que importa é que você fez o melhor que podia naquela situação. Estou tentando equilibrar os tempos e os papeis. Isso leva a fazer escolhas e definir prioridades. (Virginia, Balanço, 2015).

Narrado em primeira pessoa, a narradora-personagem constrói sua introspecção a partir de sua posição social de mulher, casada, com filhos, que tem amigos, que trabalha e precisa circular por todos esses espaços de sua vida pessoal de forma satisfatória o gera tensão no relato ao perceber as próprias fragilidades, tensão esta revelada por "não conseguimos ser perfeitos" ou ainda "realizar tudo aquilo que esperam de nós". Em relação à dimensão profissional, a professora escritora não explicitou sua profissão, mas expôs uma outra tensão que é o tempo destinado ao trabalho numa perspectiva idealizada do exercício profissional e não numa simples relação de remuneração, como segue o trecho:

[...] Meu trabalho consome boa parte do meu tempo, ele não pode ser simplesmente uma ação mercenária, ele tem que ser fruto de uma utopia, de um horizonte que quero alcançar individualmente e em sociedade, mas também tem que estar em equilíbrio com os demais papéis que eu desempenho [...]. (Virginia, Balanço, 2015).

Como percebemos pelos excertos apresentados, o trabalho com a linguagem construído por esta professora escritora visa narrar a si mesma, apresentando uma dimensão "do eu" que ela pretende expor - vislumbrando, talvez, que os possíveis leitores de seus textos são mulheres que, assim como ela, também se questionam acerca de suas posições sociais.

Em um outro texto, escrito dois anos depois, algumas questões antes tensionadas são retomadas de modo mais ameno, como segue:

Como vocês podem ver mudou o nome do blog. E claro, isso tem a ver com as mudanças que aconteceram comigo também. Um aforismo grego decidiu instalar-se na minha mente e desde então não se desalojou: "Conhece a ti mesmo e conhecerá o universo e os deuses". 
Imagino que todos nós ao longo dos anos temos esses momentos de reflexão sobre os rumos que tomamos na vida. [...]

$\mathrm{Eu}$ iniciei esse processo. Aos trinta e cinco anos me peguei parada, olhando para trás e mirando para frente e pensando: e agora? Como tudo o que eu vivi me transformou naquilo que sou? Eu sou o que eu gostaria de ser? [...] Que mulher quero ser daqui em diante? O que preciso fazer para ser essa mulher? Qual é meu projeto de vida?

É muito difícil parar pra pensar sobre isso. Muitas vezes ligamos no piloto automático e seguimos. Trabalho, militância, rotina: compras no supermercado, leitura das notícias diárias, academia, filhos, e tantos outros compromissos que temos que assumir (temos?). E o tempo passa. $[\ldots]$

E eu pergunto a você, qual o seu projeto de vida? O que você pensa em conhecer e realizar durante a sua existência? A vida é muito mais do que trabalhar, pagar as contas e acumular bens materiais. É um presente único. São os instantes de riso e de choro, os abraços amigos, o convívio com aqueles que amamos, os momentos de prazer, as dificuldades e superações, a realização diante de uma ação bem executada, é a luta por justiça e por aquilo que se acredita. A vida não é a hora que passa, mas tudo que pulsa dentro da gente. (Virginia, 2017).

Nesse texto, a professora escritora contando sobre seu processo de mudança pessoal, retoma preocupações que demonstram pontos de tensão desse "eu" - que é o ser mulher e as diversas atribuições assumidas, às quais ela questiona se devem ou não serem assim. Novamente a relação com o trabalho se faz presente e, talvez, se aproxime tanto dessa ação bem executada que a realiza quanto da "luta por justiça e por aquilo que se acredita".

No data em que se comemora o dia dos professores, depois de saber sobre o fechamento de escolas estaduais, Virginia decide escrever sobre ser professora, rememorando alguns momentos sua formação, início de carreira, as dificuldades, o reencontro com alunos anos mais tarde. Segue um trecho:

[...] Nossa profissão não tem glamour, não tem nada de Sidney Poitier em Ao Mestre com Carinho. Mas tem gente e gente faz toda a diferença, ou pode fazer. Fui me tornando professora aos poucos. Entre as imagens dos professores que eu gostava e daqueles que eu não queria ser, fui me constituindo, fui buscando o meu caminho, a minha forma de exercer a profissão. Comecei aos 21 anos. Já passei por muita coisa e por muita gente.

Recentemente encontrei dois alunos da época em que comecei a dar aulas. Uma foi minha aluna no Ensino Médio há dez anos, está agora com 27 anos, formada em Serviço Social, trabalha na área, foi tão carinhoso o nosso encontro, disse que uma das opções ao escolher o vestibular foi História, mas que recuou perante a desvalorização do magistério. $O$ outro foi meu aluno na mesma época, mas no fundamental, está agora com 22 anos. Passou um filme na minha cabeça. O tempo passou para mim, já não sou mais a mesma, envelheci, engordei, tive outras experiências, mas o gosto pela educação não, continua intacto. Não é exatamente pela carreira, porque o negócio as 
vezes é trash, estou falando daquela sensação de olhar no olho de um ser humano e pode ser um aluno, um pai, um colega e sentir que em contato, mediando a teoria e a realidade vivida, nos transformamos, ensinamos, aprendemos e já não somos mais os mesmos.

Estou em uma nova fase de buscas. Reencontrando caminhos: entre a dureza e a doçura, entre a teoria e a prática, entre mim e o outro, entre a esperança e a desesperança, entre tantas outras coisas mais. Mas, com a certeza de que a história se constrói a cada dia e se é possível construir o horror, também é possível buscar o amor; se existe a injustiça é possível ter justiça; se existe tudo o que existe, então outras forma de ser existirão. Outro mundo é possível e como educadora, não vejo outra opção que não seja ir em busca dele. (Virginia, Reflexões sobre ser professora, 2015, grifo nosso).

Ao rememorar como se tornou professora, Virginia indica que adotou práticas com as quais se identificou, provavelmente oriundas de professores com os quais teve contato durante a sua formação escolar e acadêmica. Nesse processo de se constituir professora, Virginia segue procurando caminhos que representam o equilíbrio, sem a adoção de opostos.

Diante do exposto, reafirmamos que a prática da escrita da professora Virginia para o blog pertence ao gênero narrativas autobiográficas nas quais as dimensões "do eu" aparecem expostas.

\subsubsection{A escrita induzida - o Concurso Literário Valeu, Professor}

A seguir analisaremos as práticas da escrita produzidas para o Concurso Literário Valeu, Professor e que definimos como escrita induzida, isso porque é uma produção realizada a partir da existência de um concurso e que visa especificamente a participação nesse processo. A fim de realizar este tipo de escrita, o professor escritor teve que atender as regras estabelecidas que incluíram adequação ao gênero literário proposto e à temática central, formatação e tamanho do texto, que não poderia ser muito extenso. Portanto, a produção do texto para a participação neste concurso não era livre, ou seja, os inscritos precisaram escrever de acordo com as regras impostas e, por isso, entendemos que esta prática se configura sob determinada demanda e, assim, a nomeamos escrita induzida ${ }^{117}$.

\footnotetext{
117 Anna Iuso no artigo Le savant en personne. Sollicitations et modèles de l'autobiographie intellectuelle en Italie au XVIIIe siècle apresenta a primeira chamada para autobiografias como se conhece hoje e demonstra que o modelo de autobiografias intelectuais do século XVIII não foram escritas de modo espontâneo. Fonte: IUSO, Anna. Le savant en personne. Sollicitations et modèles de l'autobiographie
} 
Nesta perspectiva, Antonio Viñao apresenta duas classificações para os textos produzidos por professores, que se aproximam em certa medida dos textos elaborados para o concurso literário em questão: os "textos gerados a partir da demanda efetuada em uma pesquisa específica" e "experiências e quefazer na aula ou centro docente e referências à realidade escolar vivida”. Na primeira classificação, Viñao fala de duas situações ocorridas na França em que acontecem "pesquisas-concurso" para mestres promovidas pelo ministério (1860) e outra por uma revista profissional (1911), e ainda, uma "pesquisa-debate" feita por um revista literária (1897), visando que os professores relatassem sobre a carreira e as condições para o exercício da profissão ${ }^{118}$. Viñao afirma que:

Não se conhecem pesquisas de alcance semelhante na Espanha, embora se pudessem incluir nesta epígrafe aqueles textos relativos ao quefazer ou forma de trabalhar na aula, mencionados na epígrafe seguinte, escritos em resposta a demandas ou concursos convocados por revistas pedagógicas e profissionais. (VIÑAO, 2004, p. 350).

$\mathrm{Na}$ segunda classificação apresentada (VIÑAO, 2004, p. 351), quanto as experiências de aula e realidade escolar, o autor considera os textos nos quais os professores querem mostrar “[...] a realidade material e pessoal da aula ou da instituição [...]", assim como o trabalho da sala de aula objetivando difundir suas experiências.

[...] Ainda que em algumas ocasiões esses escritos se publiquem em forma de livro ou folheto [...], o habitual é que apareçam, como artigos, em livros de autoria coletiva ou em revistas pedagógicas ou profissionais, tanto por iniciativa própria, como em resposta a algum concurso ou petição em tal sentido, ou que continuem, em muitos casos, manuscritos." (VIÑAO, 2004, p. 351).

As classificações elaboradas por Viñao são as que mais se aproximam da condição apresentada no Concurso Literário Valeu, Professor - guardadas, obviamente, as devidas diferenças temporais e sociais de cada país.

Os professores participantes do concurso literário possuem práticas da escrita distintas: há aqueles que escrevem textos literários sob determinada demanda, outros que escrevem de modo ordinário e se arriscaram em enviar para o concurso, e há aqueles que escrevem e publicam literatura frequentemente, e no momento do concurso decidiram

intellectuelle en Italie au XVIIIe siècle. In: IUSO, Anna (dir.) La face cachée de l'autobiographie. Garae Hésiode. 2011, p. 63-82.

118 Essas informações sobre os concursos na França, Viñao extraiu de um trabalho desenvolvido por Philippe Lejeune (1985), intitulado Les instituteurs du XIXe siècle racontent leur vie, publicado em Histoire de l'Éducation, n. 25. 
participar. As professoras Camila e Regina, por exemplo, escrevem a partir de demandas específicas, seja para algum concurso seja a pedido de uma solicitação específica e, essas características ficam visíveis em seus relatos - apesar de na adolescência terem escrito diários ou outros gêneros textuais. Em virtude da entrevista, concluímos que a produção de um texto tem origem em uma motivação externa. Nos trechos a seguir, observa-se que as professoras escritoras comentam aspectos referentes às práticas da escrita anteriormente citadas:

[...] Escrever poesias, poemas, na verdade, e... acho que foi mais quando eu me separei do pai da minha filha, dezesseis anos atrás, mais ou menos, eu comecei a escrever poemas de amor, assim, fui pegando algumas, alguns ganchos, assim, que tinha a ver com sentimento e eu escrevia várias coisas, [...] e eu gostava das rimas e acabava achando as palavras certas. Então, [...] comecei escrever vários poemas e..., e fui deixando isso meio que como um acervo, assim, e durante um tempo eu me senti inspirada por esse lado, né, lado do sofrimento, da paixão e, talvez, até colocava pra fora o que estava dentro de mim pela escrita, né. [...]. (Entrevista pessoal professora Camila, 2017).

Então, assim, tem aqueles que é muito autoral, né, que é essa coisa muito minha, uma descrição pessoal, não sei se é uma biografia, talvez, essas coisas que eu escrevi, essa coisa muito biográfica, porque é minha vida e... as outras coisas, mais assim contos, situações engraçadas, inusitadas que, às vezes, eu vejo e falo, nossa, daria um conto interessante, né, não tendo temática, né, porque, por exemplo, esse texto que foi publicado ele tinha um tema, então, na verdade a gente teve que pensar, eu no caso tive que pensar alguma coisa ali, né, que correspondesse aquele tema, mas, no geral, eu acho que é mais biográfico ou contos de situações cotidianas. (Entrevista pessoal professora Regina, 2017, grifo nosso).

Como observamos no relato das professoras, escrever poemas e textos autobiográficos constitui-se numa prática que ficou no passado. Por outra parte, as professoras continuam se relacionando com a escrita em diversos momentos, principalmente no âmbito profissional. No entanto, vale mencionar, a escrita literária se restringe a demandas específicas, conforme relata a professora Regina, a qual produziu um texto exclusivamente para participar do Concurso Literário Valeu, Professor.

Para a professora Camila a prática de escrita é bem particular, tendo em vista que escreve poesias com o objetivo de homenagear pessoas em momentos comemorativos: “[...] E, de vez em quando, quando precisa pra alguma coisa, dia dos Pais, homenagem pra alguma coisa, aí eu..., Natal, eu desenvolvo, assim, com um pouco de facilidade" (Entrevista pessoal professora Camila, 2017). Além disso, a professora Camila já participou de seleções e concursos promovidos pela Câmara dos Escritores, que define 
temáticas e publica antologias com os textos selecionados a um custo baixo, como ela relata:

[...] Quando eu descobri a Câmara dos Escritores $^{119}$, que tinha as coletivas, aí, como eles sugerem o tema, então, aí eu usava o tema pra poder produzir um poema, então, aí eu direcionei um pouco quando eu quis participar pra esse lado também, de seguir o título, a sugestão que vinha deles e criar em cima disso. Nesse meio tempo aconteceu o projeto também da prefeitura que também tinha um título. [...] E, assim, eu nunca tinha pensado em participar de projetos assim, e eu falei, vou mandar, quem sabe. Eu gosto do que eu escrevo então, às vezes, eu imagino que as pessoas vão gostar também, e..., também, participei desse concurso com um tema, então, eu criei em cima do tema. Então, assim, algumas vezes foram acontecendo de..., de você acabar criando em cima de um tema já voltado pra...”. (Entrevista pessoal professora Camila, 2017).

Assim como a professora Regina, Camila também escreveu o texto do concurso literário a partir da divulgação do regulamento, condicionando sua criação às regras estabelecidas. Durante a entrevista, as professoras relataram o desejo de escrever e publicar um material próprio. No caso da professora Regina, nota-se seu interesse em escrever sobre a identidade do professor que atua na educação infantil: "[...] eu tenho a vontade de voltar a escrever mais. Hoje, se eu for escrever, a minha vontade é de escrever algo que diz respeito a situação atual da educação, eu penso muito em escrever a respeito da identidade do professor de educação infantil [...]”. (Entrevista pessoal professora Regina, 2017). Já a professora Camila fala em publicar um livro de poemas infantis: “[...] e os que eu tenho guardado, talvez, futuramente, principalmente os infantis, eu pensei em fazer um livro, mas ainda tá como projeto" (Entrevista pessoal professora Camila, 2017).

O segundo grupo de professores representa aqueles que escrevem textos literários de modo ordinário e se arriscaram em enviar para o Concurso Literário Valeu, Professor, mas este não é o único motivador da escrita deles, uma vez que participar de concursos literários é um dos usos que fazem de suas práticas. Esse grupo compreende o professor Jamir e as professoras Arlete, Esther e Izabel.

Então, às vezes na escola, a gente tem alguns saraus, que a gente faz com os alunos, então, nesses saraus eu costumo produzir um poema, tal, mas assim, aí, eu escrevo e descarto, e não costumo guardar esses poemas, tanto que eu falei que essas minhas escritas que eu tinha

\footnotetext{
${ }^{119}$ Câmara Brasileira dos Jovens Escritores, fundada em 29 de dezembro de 1986, com a proposta de "[...] incentivar a produção literária de autores publicando em livro suas poesias, contos, crônicas, romances ou qualquer outra forma de expressão literária [...]" (1986) e, para isso, realiza seletivas periodicamente nas quais os autores podem submeter seus textos e, de acordo com a avaliação, conseguir a publicação do mesmo nas antologias organizadas. As informações foram extraídas da página eletrônica: http://www.camarabrasileira.com.br/ Acesso em julho de 2019.
} 
guardado eram mais de crônicas, porque os poemas, eles me remetem àquela escrita minha mais da infância, aquela escrita mais espontânea, então assim, eu escrevo para colocar os meus sentimentos [...], escrevo para o sarau com os alunos e depois jogo fora o poema [...]. Eu gosto de escrever poemas, [...] depois de adulta comecei a escrever assim, não diários, mas eu gosto de escrever reflexões de como eu me sinto, tal, mas são escritas minhas... mesmo, bem particulares. (Entrevista pessoal professora Izabel, 2018).

[...] Tenho muitos poemas, é o que eu mais gosto de escrever. Eventualmente, eu escrevo alguma crônica, algum conto, eu trabalho com produção de material didático. Então nesse momento, eu estou produzindo planos de aula de matemática. Agora, é muito engraçado, porque eu fiquei com a parte da lógica [...] para crianças. E problema de lógica, é problema com narrativa. Você tem que contar uma historinha antes de chegar na lógica. $\mathrm{E}$ até poema eu coloquei no meio dos meus planos, tá? (Entrevista pessoal professora Esther, 2018).

De acordo com os excertos acima, vemos que as professoras Izabel e Esther realizam práticas da escrita com objetivos diferentes sendo a escrita pessoal com reflexões sobre si mesma, a escrita de poesias que para Izabel é destinada a um fim pedagógico para o sarau com os alunos, mesmo afirmando gostar de escrevê-las, já para Esther a escrita de poesias é um gosto e que eventualmente pode se tornar uma publicação, quando inscreve algum de seus textos poéticos em concursos. Por outro lado, Esther escreve sob demanda quando elabora material didático. Segundo Bourdieu (1997), o gosto pela escrita como pontuado pelas autoras se constitui elemento de um habitus ${ }^{120}$ que é a disposição de cada agente em fazer escolhas de acordo com características intrínsecas que levam a um estilo de vida único, assim, diferenciando-o em suas práticas.

Em relação ao Concurso Literário Valeu, Professor, a professora Esther transitou pelos diferentes gêneros literários propostos inscrevendo textos em todos eles, tendo participado das três edições do concurso e sido selecionada para publicar nos três livros. $\mathrm{Na}$ entrevista, ela relata que elaborou os textos para o concurso como um desafio a si mesma:

Na verdade quando eu vi que ia ter o concurso literário, o que eu pensei foi “oba, que legal! Vou inscrever, quero participar." Então foi aquela

\footnotetext{
${ }^{120}$ De acordo com Setton (2009), “a noção de habitus encerra uma posição estratégica à medida que possibilita articular influências externas de socialização (posição social), portanto, influências conjunturais na composição e formação cultural dos indivíduos e a construção de suas subjetividades. O habitus surge então, como um conceito capaz de conciliar a oposição aparente entre realidade exterior e as realidades individuais, é instrumento conceitual capaz de expressar o diálogo, a troca constante recíproca entre o mundo objetivo e o mundo subjetivo das individualidades. Ele é, em tal caso, concebido como um sistema de esquemas, individual e socialmente constituído, de disposições estruturadas (no social) e estruturantes (nas mentes), adquirido na e pelas experiências práticas, (em condições específicas de socialização), constantemente orientado para funções e a ações do agir cotidiano. [...]" (SETTON, 2009, p. 77 - 78).
} 
motivação mesmo do é gostoso escrever, eu gosto de participar dos concursos literários, aí, nossa, desafio, tem um tema. O tema aqui é internet, o tema aqui é a cidade de São Paulo, tem um gênero específico. Será que eu consigo escrever um texto legal dentro desse gênero? Então foi mesmo pra me testar, também, entendeu? (Entrevista pessoal professora Esther, 2018).

No entanto, a professora Izabel que gostava de escrever crônica e que durante um período de sua vida colaborou com este gênero literário para um impresso de uma empresa, se inscreveu nas categorias em prosa apenas, a crônica em 2011, e o conto em 2012, tendo escrito os textos especificamente para as edições do concurso.

[...] eles falaram do concurso Valeu, Professor, falaram que era escrita de crônica, aí, isso já me agradou, já tinha tido uma experiência com crônica, já fazia um tempo que eu não escrevia com muita, ah... tantas coisas, mas enfim, [...] o que me assustou um pouco foi, porque o concurso, ele tinha regras bem definidas, quantidade de páginas, tal, né, mas eu encarei isso como um desafio e, aí, eu falei assim, "não, vou tentar escrever mesmo tendo essa quantidade de regras, porque talvez eu consiga" e como eu tenho o hábito de revisar os textos, pode ser que nessa revisão eu consiga me habituar, aí, acabou dando certo [...]. (Entrevista pessoal professora Izabel, 2018).

O professor Jamir pratica a escrita da poesia - eventualmente publicadas em antologias organizadas por coletivos de saraus com os quais tem contato - e, às vezes, participa dos encontros. No concurso literário da prefeitura, inscreveu poesia na primeira e na terceira edição, sendo que nesta última também apresentou um conto, e ambos foram selecionados para a publicação.

Mais em poesia. [...] até pro concurso [...] foi meio provocado, né, crônica ou conto foi... produção meio de encomenda [risos] e que até deu certo assim. Então se me propuserem, se eu for desafiado, eu escrevo, mas normalmente vai mais fluindo de uma ideia, de uma imagem, de um acontecimento, então, o conteúdo filosófico, político ou pessoal, como fonte de inspiração. (Entrevista pessoal professor Jamir, 2018).

Essa "inspiração" que ele comenta no relato é a matéria prima que compõe as poesias que escreve, o que nos indica que são as experiências vividas que move o processo de escrita poética deste professor. Assim como ele, a professora Arlete escreve a partir das percepções de seu espaço social e de suas experiências. A primeira publicação da Arlete aconteceu através do concurso literário e, depois disso, ela passou a enviar o que escreve para outros concursos, como nos conta: 
É, eu escrevia e engavetava, né, não achava que tinha a força necessária, e aí uma amiga falou, né, desse concurso, "ah, você escreve tão bem, vai escreve, manda", e aí... e aí fui premiada, né, no concurso selecionaram, aí fui no outro ano e selecionou de novo, aí falei, é... então, parece que o negócio não é tão ruim assim, não [risos]. [...] eu tenho contos, crônicas, e... poemas, e acho que são os gêneros que eu... o que eu acho que eu tenho mais, mais facilidade de escrever são contos e que um amigo falou que não são contos, que é uma mistura de contos com crônica, que tem uma coisa assim, mas que eu chamo de conto. (Entrevista pessoal professora Arlete, 2018).

Os contos que a professora Arlete inscreveu no concurso literário nos anos 2010 e 2011 eram textos literários produzidos a partir de sua realidade, foram situações vividas que ela transformou em literatura. No relato que segue, a professora fala da crônica inscrita no concurso intitulada Céus de $S P$ em que ela narra a personagem Dona Florita.

\footnotetext{
Naquele dia, né, eu voltei pra casa daquele enterro e eu falei, se não escrever a Dona Florita, quem é.... é como se ela evaporasse no ar, né, e aí a literatura tem essa pretensão, né, pretensiosa, né, como é que a gente deixa de falar, de presenciar, coisas assim tão puras, né, tão... que são propositalmente apagadas, abafadas, proibidas de dizer, né, proibidas de existir, né, e era de uma... uma pessoa de uma... bondade, de uma leveza, aí o... o conto, crônica, o que quiser chamar, nasceu dessa... desse sentimento, né, que é um sentimento de revolta, de tristeza..., de como as nossas vidas, né, morando, sendo o que a gente é, morando onde a gente mora, é propositalmente abafada e a nossa existência apagada, né, ninguém sabe que a dona Florita existiu, né, e ela era um ser humano incrível. [...] (Entrevista pessoal professora Arlete, 2018).
}

Após a publicação de seu primeiro texto, ela passou a participar de outros concursos literários e a colaborar com a Revista Cruviana e com o Blog Aspirinas e Urubus, neste último ela colaborava com uma crônica semanal.

No último grupo estão os professores que participaram do concurso, mas diferente dos anteriormente citados, estes possuem diversas obras publicadas e quando ocorreu o concurso já escreviam e publicavam literatura, são eles: a professora Márcia e os professores Daniel e Osvaldo.

Quando aconteceu a primeira edição do Concurso Literário Valeu, Professor, a professora Márcia já havia participado de concursos durante a sua graduação, escrevia para revistas literárias, para seu blog e tinha um livro publicado. Sua participação ocorreu apenas em 2010, e naquele momento ela tinha uma poesia que era possível enquadrar na temática proposta e o conto ela escreveu para participar, como relata: “[...] O poema eu já tinha e enviei, agora o conto, eu acho que eu escrevi quando saiu o concurso, eu fiquei 
pensando o tema, é, mas eu lembro que não era nada, não me lembro de ter alguma relação com escola [...]” (Entrevista pessoal professora Márcia, 2018).

A prática da escrita do professor Osvaldo se efetiva em vários gêneros literários que ele escreve objetivando a publicação:

[...] Primeiro, eu escrevo poesia, escrevo ensaio, romance, contos, é que mais? Tem mais coisa... Crônica eu tenho, mas é mais assim, é como no caso desses livros que são publicações coletivas. [...] eu tenho contos [...] e novelas também, eu escrevi novelas, [...]. As novelas eu não publiquei não, eu ia publicar... [...]. O que eu não escrevi foi peça pra teatro [...]. (Entrevista pessoal professor Osvaldo, 2018).

Como conta o professor Daniel, quando participou da primeira edição do concurso foi motivado pelo desejo de ser lido. Na ocasião, o professor colaborava com revistas literárias, já tinha publicado um romance e um livro de contos, assim como mantinha um blog. Os textos inscritos tinham sido produzidos anteriormente e somente os adaptou às normas do concurso, como relata:

[...] eu falei, vamos tentar, né, porque nessa época eu ainda estava muito com essa vontade de ser lido, né, eu precisava talvez da chancela do outro para achar que tinha valor o que eu escrevia [...]. Eu gostei também, porque era um conto sobre escola e, [...] foi no ano que eu tinha ido parar, em 2009 eu fui parar nessa escola do outro lado, eu tive que comprar uma moto, caí da moto, que eu precisava acumular com o estado aqui, e no meio desse, tinha um menino lá que chamava Maciel mesmo, né, e aquela coisa de ouvir a história dele, né, só tragédia, a gente dá aula em periferia assim e, às vezes, o moleque que mais dá trabalho e... [silêncio] você percebe que ele está sozinho no mundo, né, a situação é muito difícil e a gente... [...] É ficção, né. As bases sempre sai da vida, né, do menino que existia mesmo... [...] Era um conto que falava de escola, eu já tinha escrito ele, na verdade, só cortei, dei uma reduzida nele para caber, né, cortei umas partes e tal, e aí escrevi lá, no concurso. (Entrevista pessoal professor Daniel, 2018).

Considerando as entrevistas e as produções desses professores - Daniel, Márcia e Osvaldo -, verifica-se que a prática da escrita ficcional é a mais realizada por eles, porque existe uma intenção e um frequente exercício de escrita ficcional - alguns com mais, outros com menos elementos da realidade.

Neste sentido, confirma-se que a escrita induzida por meio de um concurso institucional com temática estabelecida e outras regras é apenas um dos usos da escrita que esses professores exploram, já que se identifica a existência de uma multiplicidade de outras práticas, às quais vão do pessoal e íntimo ao ficcional. Mesmo sendo uma produção literária a partir de determinada demanda, observamos que os professores buscaram não apenas um espaço de publicação, mas também um âmbito institucional, a 
partir do qual pudessem relatar a si mesmos, suas realidades profissionais e pessoais, assim como as próprias invenções.

\title{
6.1.3. A escrita poética
}

\author{
O poeta é um fingidor \\ Finge tão completamente \\ Que chega a fingir que é dor \\ A dor que deveras sente. \\ (Fernando Pessoa)
}

A escrita poética é uma prática muito frequente e característica dos professores identificados nos saraus e acreditamos que esse uso está muito relacionado com as possibilidades de leitura e declamação que o texto escrito em verso possibilita. Como o sarau, em geral, pede uma dinâmica de apresentação com ritmo, entonação da voz, marcações bem definidas nos textos - ritmo - para as declamações, nesse espaço, o texto poético em verso é o mais usado. Assim, consideramos nesse grupo os professores que escrevem principalmente poesia, são eles: Cecilia, Márcio, Michele, Jefferson, Letícia, José Vandeí e Janaína. Isso não significa que não produzam outros tipos de textos, mas nesses casos a poesia se sobrepõe às outras formas.

Salete Cara (1989) em um estudo sobre a poesia lírica em que trata das mudanças teóricas da concepção da lírica desde a Antiguidade, na poética de Aristóteles, até a poesia moderna, afirma que o poeta moderno percebeu que não é possível uma relação plena de sentido entre ele e a realidade, o que gerou uma crise e deslocou o olhar do poeta para os "modos possíveis" desta relação - poeta e realidade -, tendo como consequência a valorização da linguagem. Com isso, “[...] entra também em crise o conceito de lirismo como “expressão pessoal” (p. 07). Na poesia moderna, o poeta não consegue atribuir um sentido único sobre o que fala e precisa se voltar para as possibilidades da linguagem, assim, o "eu lírico" não é mais o poeta, a pessoa real que expressa suas emoções no texto poético. De acordo com Cara:

O sujeito lírico sempre existe através das escolhas de linguagem que o poema apresenta, mas na poesia moderna fica mais evidente que o sujeito lírico é o responsável por esses "atos de denominação": não pode ser confundido com o poeta em carne e osso porque sua existência brota da melodia, do canto, da sintaxe, do ritmo: o sujeito lírico é o próprio texto, e é no texto que o poeta real transforma-se em sujeito lírico. (CARA, 1989, p. 48). 
Ainda segundo Salete Cara (1989), na Lírica de herança clássica, os poemas são mais curtos, não possuem personagens bem definidos e o ritmo e a melodia são recursos usados para expressar o "eu”, "o estado da alma”, porém quando a lírica é usada de modo adjetivado, ela expressa uma qualidade que é consequência dos "traços estilísticos" de um texto que não precisa ser necessariamente poesia. Cara afirma que essa situação se aplica também à Épica e ao Drama ${ }^{121}$.

Para Cara (1898), estes gêneros tradicionais não bastam para compreender os textos poéticos que hoje se apresentam, pelo trabalho realizado com a linguagem conter características de mais de um gênero num mesmo texto e, ainda, pela inventividade presente em cada produção literária moderna.

O que ficou dessa herança foi principalmente a concepção do texto como realidade de linguagem e suas articulações com as séries histórica e literária, o que permite entender os gêneros como modos de selecionar e organizar, como linguagem, aspectos da realidade empírica ou da imaginação. Nesse sentido, os três gêneros tradicionais já são hoje insuficientes. (CARA, 1989, p. 68),

Portanto, a autora fala em lirismo como característica da linguagem usada no poema, podendo existir temas mais líricos do que outros, assim, Cara afirma: "O lirismo é uma maneira especial de recorte do mundo e de arranjo da linguagem [...]. Mas para o poeta e crítico moderno a poesia lírica vai-se concretizar, de fato, no modo como a linguagem do poema organiza os elementos sonoros, rítmicos e imagéticos [...]" (CARA, 1989, p. $07-08)$.

A partir dessas considerações sobre a escrita poética, depreendemos que os professores aqui elencados apresentam uma escrita carregada de lirismo, cuja elaboração do sujeito lírico pode trazer uma dimensão do próprio poeta, mas também pode referenciar um outro, numa relação com a realidade demarcada pela posição social desses agentes - professores escritores.

\footnotetext{
Literatura,

Meu alimento mais nutritivo,

Donde a energia é extraída

Para me fazer caminhar.
}

\section{$[\ldots]$}

\footnotetext{
121 “....] cabem na Épica os textos, em verso ou em prosa, onde um narrador conta uma história com personagens, acontecimentos e situações; cabem no Drama os textos dialogados para serem representados num palco" (CARA, 1989, p. 56, grifos da autora).
} 
Arte de fibra,

Capaz de expelir

Toda porcaria a me contaminar.

[...]

(SANTANA, Gula Literária, 2011, p. 17).

O professor Jefferson faz parte de um grupo de poetas chamado Coletivo Poetas Ambulantes, que faz intervenções poéticas mensais em transportes públicos na cidade de São Paulo como principal atividade, mas também realiza tais intervenções em praças, bibliotecas e escolas. O professor também frequenta o Sarau Sobrenome Liberdade. Sua prática da escrita poética gerou várias publicações que estão em impressos como fanzines e livretos artesanais ${ }^{122}$, antologias poéticas ${ }^{123}$ e $\operatorname{livros}^{124}$ de sua autoria. Além das publicações impressas, ele mantém dois blogs onde costumava publicar suas poesias e que, no momento, não possuem publicações novas ${ }^{125}$. Tem ainda poesias não publicadas e arrisca-se a escrever contos que estão mantidos em arquivo pessoal.

Eu acho que eu ainda estou fincado na poesia, né, eu ainda não consigo fugir da poesia. Eu tento escrever [...] na área da prosa, contos, [...] tentei estruturar um romance uma vez, mas, ainda está meio complexo na minha cabeça isso, né. Ainda estou na área da poesia, [...] no estilo dos poemas menores, nas sínteses poéticas [...], estou meio que nessa pegada influenciado por Leminski, essa galera aí dos haicais ${ }^{126}[\ldots]$. Eu acho que nesse momento eu estou vivendo um momento político muito intenso também, [...] os meus poemas [...] tem muito de amor, tem uma lírica muito forte, né, mas isso já é passado [...]. Agora eu estou meio que misturando essas coisas e eu acho que eu estou mais no tom político hoje inclusive [...]. (Entrevista pessoal professor Jefferson, 2017).

A poesia do professor Jefferson possui um lirismo que em alguns textos revela-se por meio de traços existenciais e de um sujeito apaixonado, que retrata seus sentimentos. Entretanto, em outros materiais esse lirismo vem carregado de crítica social, sobretudo

\footnotetext{
${ }^{122}$ Livreto (des) caminhos (2017); fanzine In versus e Linguística [s.d.].

${ }^{123}$ Uma Vez Poetas Ambulantes... (2013).

${ }^{124}$ Livros: Petálas e Pedradas (2014) e Cantos e desencantos de um guerreiro (2011). Outras obras nas quais tem participação, mas que não compõem essas fontes são: Poetas do Tietê, Slam do Grito e Suburbano Convicto.

${ }^{125}$ Blogs: Guerreiroperiférico.blogspot.com.br e Meusencantosedescantos.blogspot.com.br

${ }^{126}$ De acordo com Paulo Franchetti (2008), que publicou um artigo sobre o haicai no Brasil, a apropriação do haicai na literatura brasileira ocorreu com Guilherme de Almeida, nas décadas de 1930 e 1940, tendo mantido a forma dos versos e inserindo rimas, característica que não havia tradição oriental dos haicais. "Na sua adaptação do haicai, Guilherme de Almeida aproveitou basicamente duas características formais do poema japonês: a distribuição das palavras em três segmentos frasais (que ele identificou ao verso, medido à maneira portuguesa) e a composição por justaposição de duas frases, numa estrutura tópico/comentário. Mas como as 17 sílabas do original, distribuídas em três versos de medida diferente e sem rima, não produziam efeito rítmico interessante, Guilherme de Almeida inseriu no seu haicai duas rimas: uma a unir o primeiro com o terceiro verso, e outra interna ao segundo verso, ocupando a segunda e a última sílaba” (FRANCHETTI, 2008, p. 261).
} 
nos textos em que constrói uma ideia de "sujeito periférico" que expressa as mazelas percebidas na periferia da cidade de São Paulo. Nesta escrita poética sobre o "sujeito periférico", este professor escritor faz a crítica social em relação ao que falta neste território que historicamente foi sendo ocupado pela população de menor de renda, como já mencionado anteriormente, onde vive uma população negra e de migrantes nordestinos, característica essa também presente em sua escrita poética, como podemos observar no excerto do poema a seguir:

\author{
Sou pássaro na gaiola, \\ Comendo o alpiste que determinam \\ Entre o tempo contado de relógios \\ Para seguir no pio de uma longa jornada. \\ Fui capturado \\ Pela necessidade de comer. \\ Trancaram-me \\ Nesta vida minha adestrada. \\ Vidas nossas \\ Penduradas nas extremidades dos casarões, \\ Sem libertação \\ Para desfrutar do meio. \\ $[\ldots]$ \\ (SANTANA, Pássaro, 2011, p. 41).
}

“Minha posição política é de poética.” (Michele, 2015, p. 37)

A professora Michele é uma das organizadoras do Sarau Sobrenome Liberdade e sua produção escrita compreende poemas e textos em prosa. A primeira publicação de um poema ocorreu da sua participação no sarau quando o coletivo organizou a primeira Antologia do Sarau Sobrenome Liberdade em comemoração ao primeiro aniversário. Tem um conto publicado na Revista Literária Raimundo ${ }^{127}$ e relatou que está se arriscando a produzir textos em prosa que, por enquanto, não foram publicados. Michele já publicou um livro de poesias ${ }^{128}$ de modo independente e começou a produzir livretos artesanais $^{129}$.

[...] eu escrevia na minha época de 'diarinho' com toques estilísticos, eu escrevia muito como se fosse ensaio, sabe, pensamentos sobre o mundo e tudo mais, mas era uma coisa que eu nunca... nunca trouxe pra fora. Mas, era um exercício de escrita, agora para publicação literária, dentro do literário, a poesia foi quando eu comecei estruturar já pensando na ideia de publicação, mas aí, ela floresceu dentro dos universos dos saraus. Agora, recentemente, eu tenho feito algumas produções em prosa e eu estou alimentando mais, assim, o lado da

\footnotetext{
${ }^{127}$ Revista digital, conto publicado Arrocha, Edição Verão de 2016.

128 Toda via, (2015).

${ }^{129}$ Deve ser isso: poemas possíveis (2017).
} 
prosa. Então, eu estou com muita esperança de prosear mais do que poetizar. A poesia, ela tem uma coisa, que para mim ela tem um mistério muito dela, assim, ela tem um momento, [...] eu tenho gostado muito do trabalho cerebral da prosa, ele tem me puxado mais, eu não sei explicar [...]. (Entrevista pessoal professora Michele, 2017).

na minha cara agreste

duas retinas de gude

rolando chãos de terra árida

e não há lágrima que umedeça-me a pátria

no ponto desértico do mapa

: meu peito

(SANTOS, Carcará, 2015, p. 15).

A escrita poética desta professora se assemelha em certa medida ao do professor Jefferson, visto que expressa a questão periférica e o fenômeno da migração nordestina, aspectos que se fundem numa identidade - a de um sujeito lírico feminino -, e se entrelaçam na história de vida dessa professora escritora. Além disso, a discussão do feminino na sociedade perpassa a sua poética.

Que faço eu na corda bamba dos versos

Onde eu mesma me impeço

De cair na real...

Idade dos sonhos longínquos

Espécie de trapézio virtual.

Que faço eu flutuando entre os pássaros

Rebuscando palavras asteroides,

Cometas que rimam, ascendem e caem

Na estéril loucura de um poeta

Que aflito necessita de ar.

Que faço eu senão tentar...

(Cecilia, Corda Bamba, 2001, p. 83).

Cecilia é uma das organizadoras do Sarau do Grajaú e sua produção escrita contempla a poesia principalmente, tendo publicado um livro ${ }^{130} \mathrm{em} 2001$, depois de reunir diversos poemas escritos durante alguns anos da sua vida, também escreveu um livro de literatura infantil ${ }^{131}$ e relatou que tem contos escritos em seu arquivo pessoal. Além desse material, possui um blog ${ }^{132}$ e uma página em rede social destinada exclusivamente para

${ }^{130}$ Caçando estrelas (2001), publicado pela editora Nativa.

${ }^{131}$ O Saci na cidade (literatura infantil), não tivemos acesso ao livro.

${ }^{132}$ Blog Girassol Poético. 
publicar alguns de seus textos. Em relação à prática da escrita literária, Cecilia afirma que escreve pouco e que é movida por suas experiências:

Eu não me acho uma... do ponto de vista da produção escrita, eu não me acho uma grande produtora de literatura, escrevo pouco, sabe, bem pouco assim, gostaria de escrever mais, mas eu não me cobro muito, eu escrevo a medida que eu sinto desejo de escrever, à medida que eu sinto vontade, principalmente a poesia para mim é algo que não é construída, ah, falar hoje vou escrever sobre a luz, não, é algo que eu senti, que me incomodou, que me tocou e, aí, eu vou lá [...] e eu escrevo, depois, eu posso até rever, trabalhar, mas nunca é uma coisa trabalhada, sabe assim, ah, preciso escrever sobre a situação do país, não, se eu não sentir o desejo de, eu não escrevo, eu acho que isso é até ruim, porque eu poderia ter uma produção maior, né, mas eu escrevo impressões mesmo, da vida, das pessoas [...]. (Entrevista pessoal professora Cecilia, 2017).

A escrita poética de Cecilia condensa um lirismo que, explorando a primeira pessoa, expressa sentimentos e desejos de um sujeito lírico feminino, além de retratar certa tristeza e dor. Para esta professora escritora, a sua poesia traduz sua própria vida, tendo em vista que: “[...] na medida que você vai amadurecendo e vendo outras coisas, você vai colocando isso na sua escrita, vai estar refletindo ali a sua vida, o seu olhar sobre o mundo [...]" (Entrevista pessoal professora Cecilia, 2017).

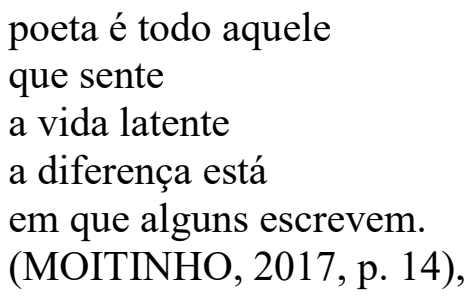

Frequentadora de diversos saraus na cidade, conhecemos a professora Janaína no Sarau Sobrenome Liberdade, no qual participa para assistir e apresentar sua poesia e divulgar seus materiais. Além disso, ela é uma das organizadoras do Slam do Grito ${ }^{133}$ que, diferentemente dos saraus, é uma competição de poesia em que os poetas declamam - em até três minutos -textos autorais, bem como são avaliados por um júri. Sua prática da escrita teve início com a produção de textos autobiográficos, passando, posteriormente,

\footnotetext{
${ }^{133}$ O Slam do Grito foi criado em 2013 e as primeiras batalhas aconteceram em bares na região do Ipiranga, depois se fixando na estação de metrô Sacomã. Os slams se configuram em competições que sucessivamente elege representantes para competições que se iniciam locais e vão se expandindo pelo estado e pelo país: Slam SP e Slam BR, respectivamente (considerado o torneio nacional de poesia falada). De cada torneio ou batalha de poesia, o júri seleciona um representante e o vencedor do torneio nacional participa da Copa do Mundo de Poesia. Durante o ano de 2015, o Slam do Grito teve o apoio do programa VAI da prefeitura de São Paulo e publicaram a antologia Marginais plácidos 2015 na qual reúne textos dos vinte e quatro finalistas das competições do referido ano.
} 
pelo universo poético. Além disso, Janaína relata a busca pelo aprendizado da escrita de textos em prosa, tais como contos e crônicas.

A maior parte das coisas é poesia, [...] textos poéticos. Quando eu comecei, eu escrevia desabafos [...] em primeira pessoa, contando coisas que eu tinha vivido, mas hoje em dia o que predomina é a poesia. E, eu estou tentando exercitar contos e crônicas de novo, numa outra perspectiva, meio auto-ficcional. Aí, eu tenho exercitado com ajuda de mestres e mestras da literatura contemporânea, fazendo oficinas mesmo [...]. (Entrevista pessoal professora Janaína, 2017).

Os textos poéticos que Janaína escreve estão publicados em antologias, em revista literária, livreto artesanal confeccionado por ela e fanzine ${ }^{134}$. Nesses textos nos deparamos com um sujeito lírico feminino, que expressa os sentimentos por meio de poemas curtos, escritos em primeira pessoa em sua maioria.

\author{
Sou poeta \\ Não porque quis ser \\ Sou poeta \\ Porque nasci. \\ (MARINHO, Poeta, 2016, p. 64).
}

O professor Márcio é integrante do Sarau da Cooperifa e foi a partir desse espaço que iniciou suas experiências de escrita, privilegiando tanto a produção de textos poéticos, quanto de textos em prosa, como relata: "Minha escrita principal é a poesia. O poema mesmo. Mas faço algumas crônicas, contos, mas não é a principal. Meu segundo livro só que tem crônicas, contos, aforismos, e outros tipos de texto, mas no geral são só poemas. [...]” (Entrevista pessoal professor Márcio, 2017).

Sua produção compreende a publicação de três livros ${ }^{135}$, sendo dois de poesias e um em que há outros tipos de textos intercalados aos poemas. Em sua poesia identificamos marcas do seu espaço social - a periferia - bem como a posição que ocupa neste lugar, já que assumiu a literatura periférica como campo de produção literária e partir deste espaço discursivo é que emite sua crítica social.

\footnotetext{
Um pouco do que sou,

Está nas minhas lembranças apagadas pelo tempo,

$\mathrm{Na}$ memória de tudo que não fiz, na contradição da vida,

Que só percebo quando revejo minha história, reviro meu baú,

E faço notas do subterrâneo
}

\footnotetext{
${ }^{134}$ Livreto Pedaços (2017); fanzine Fôlego [s.d]; Revista literária Poesia sem medo (jun. 2017); Elas Antologia Poética (2017).

${ }^{135}$ A vida em três tempos (2014); 11 gramas (2016); Receitas para amar no século XXI (2010), este último não faz parte dos materiais da pesquisa.
} 
Redescobrindo um pouco do que sou naquilo que deixei de ser [...]. (Oliveira, 2016, p. 20).

José Vandeí, um dos organizadores do Sarau na Galeria, começou a escrever nos ambientes de saraus que frequentava na cidade de São Paulo e se encantou pela poesia, gênero literário privilegiado por ele em suas práticas da escrita.

Eu escrevo poesia, eu não me arrisquei ainda na prosa, crônicas, contos, [...] eu já fiz dois minicontos, mas eu sinto que não é muito a minha praia, eu gosto mesmo da poesia, que é um estilo livre. Por muito tempo, devido ao cordel, a rima ela me prendia muito, e daí eu comecei a fazer um exercício de me livrar da rima, mas eu faço poesia que é o que eu gosto de fazer. (Entrevista pessoal professor José Vandeí, 2017).

Sua produção está publicada em antologias poéticas e em 2016 publicou seu livro de poesia Falo, cujo lirismo presente nos poemas expressa tanto a construção da identidade do sujeito lírico, quanto sua crítica à realidade social.

A professora Letícia é uma das organizadoras do Sarau Lapada Poética e a prática da escrita que utiliza para publicar e mostrar no espaço do sarau é a poesia, para a qual realiza oficinas onde busca se aperfeiçoar na produção deste gênero literário.

Bom, acho que o que eu vou responder, não vai ser surpresa, mas eu escrevo, gosto mais de escrever poemas, por conta das oficinas que eu fiz. Porque, no início eu pensava em escrever romances e contos, mas eu fui e comecei a fazer oficinas de poemas e gostei bastante, porque é um trabalho árduo, você... eu me debruçar em cima de um poema pra criar, escrever, pensar cada verso, eu gosto bastante. Então, o que eu mais escrevo são poemas, pra mostrar para os outros são poemas. Eu gosto de escrever coisas pra mim, às vezes eu deixo o dedo solto no computador e escrevo algumas coisas, mas é bem raro. E, virtualmente, aí nas redes sociais, de vez em quando, sai algum ensaio informal, como todos os que estão na rede, eu acho [...]. (Entrevista pessoal professora Letícia, 2017).

Em sua escrita poética estão presentes o feminino e o existencial, sendo que este último se revela característico do lirismo e das problemáticas vinculadas às questões sociais. Durante a entrevista a professora explicou que está preparando o material para a publicação de um livro e alguns de seus textos estão em coletâneas ${ }^{136}$. Além disso, comentou que já publicou alguns textos na página eletrônica Jornalirismo ${ }^{137}$.

\footnotetext{
${ }^{136}$ Em 2016 foi selecionada para publicar um texto no $3^{\circ}$. Concurso Lamparina Publica, promovido pela editora Lamparina Luminosa.

${ }^{137}$ Disponível em: http://www.jornalirismo.com.br/literatura/tres-pontos-e-uma-costela-2/. Acesso em: 13 set. 2019.
} 
Desse modo, a escrita poética produzida por esses professores - para além de prática cultural em sentido estrito -, nos demonstra uma série de usos, cujos textos literários demarcam posições sociais bastante específicas, a saber: apresentar e fazer crítica à realidade e consolidar uma identidade que os represente tanto individual quanto coletivamente, isto é, com a qual possam dialogar juntamente com seus pares. literatura

6.1.4. Compartilhar experiências literárias - difundir, educar, formar pela

Compartilhar experiências literárias é uma categoria de análise construída ao passo que identificamos entre os professores entrevistados que escrever literatura é uma prática cultural efetivada não restrita a si mesmo, mas sim uma prática partilhada de modos diversos, que visa atingir objetivos que, embora distintos, convergem para ações de formação, difusão e educação por meio da literatura.

Difundir literatura pela cidade de São Paulo é uma ação do professor Jefferson juntamente com outras pessoas, que se nomeiam Poetas Ambulantes. Estes poetas saem uma vez ao mês para ler e declamar poemas em transportes públicos, com o intuito de promover à população trabalhadora o contato com a poesia.

Diversas doses ventriculares de desalentos irrigaram desordenadamente meus impulsos. Restou sobreviver de marca-passos, contando as dores antes mesmo de viver as aventuras. Porém nem sempre as comportas comportam o que queremos.

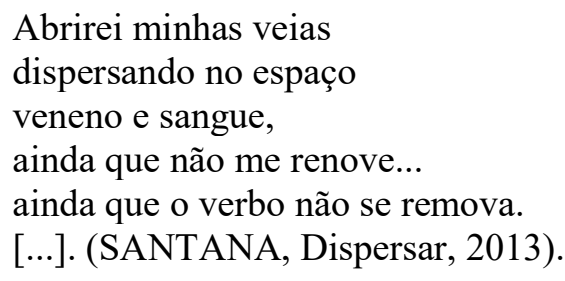

O fragmento acima transcrito, publicado na antologia do Coletivo Poetas Ambulantes, traz uma poética representando no primeiro verso, "diversas doses ventriculares de desalentos", o que significa para este sujeito lírico que compartilhar 
literatura em um espaço improvável, de modo desavisado, "dispersando no espaço/ veneno e sague" comprova que a literatura pode aliviar a desesperança da população trabalhadora, que enfrenta longos períodos de deslocamento diariamente, sendo a dispersão do veneno compreendida como a crítica que se produz contra o sistema de desigualdades produzido no interior das sociedades capitalistas. Fazer uso dos transportes públicos para difundir literatura, que não necessariamente seja a produzida pelos grupos da periferia, em um espaço onde as pessoas não estão ali com esse fim, se configura em um modo distinto de operar em relação aos saraus, visto que os saraus - apesar de ocuparem espaços abertos, democráticos, no interior de suas comunidades -, as pessoas interessadas e/ou apenas curiosas precisam realizar um movimento de deslocamento até o local de encontro para ouvir e sensibilizar-se com alguns dos textos apresentados.

Esse grupo de poetas ambulantes, especificamente, acredita na possibilidade de atingir outras sujeitos sociais, fazendo com que se interessem por poesia - pessoas essas que, muito provavelmente, não são leitoras nem letradas e para as quais a literatura é algo distante. O grupo, neste sentido, desloca a poesia, retirando-a do espaço canônico e ressignificando-a a partir das apropriações que levam a cabo, especialmente quando compartilham suas experiências com outras pessoas.

Há quem ache que a poesia feita

É somente dada por grande feito.

Mas a poesia se faz sem decreto

E em cada instante se apresenta.

[...]

Há quem feche os olhos e se esconda

diante da melodia e não dance,

não oferece permissão pra que se poetize.

Mas a poesia permanece escancarada.

[...]

Nas favelas, ainda que digam em poucas,

As flores ainda nascem plantadas e inesperadas,

[...]

Pra que os dias de poesia não se retenham em livros

guardados, empoeirados e esquecidos nas estantes,

é preciso que se abram olhos e coração para os indícios

de harmonia lírica de todos os instantes.

Se o tempo é de metralhadoras que não param de atirar, de medos manifestados, de amores não correspondidos... mais do que nunca é tempo de amar!

Pra que hoje mesmo, seja o tempo da poesia cativar.

(SANTANA, A poesia de todos os instantes, 2013, sem nº. página).

De acordo com Antonio Candido (2004), a literatura, entendida em seu sentido amplo, é um direito e uma necessidade, posto que a fabulação se faz presente na vida 
individual e coletiva das sociedades em variadas dimensões. Esta afirmação, inclusive, corrobora o relato apresentado pela professora Michele:

\begin{abstract}
“O preço do poema é a eterna falta de serventia para fins comerciais', é o que está escrito ali naquele livro, é o que eu tenho visto, que cada vez mais, isso é fato, a vida corrobora essa fala. Mas, quando a gente pensa em: "Por que escrever?", a gente sempre procura um objetivo, que esteja ligado a uma questão de utilidade, a escrita e a literatura é muito inutensílio, ela provoca toda reflexão e tal, e tudo mais. Mas, eu acho que ela preenche a necessidade do ser humano de fabular mesmo, quando é a questão do prosaico, da prosa. E, da poesia é do espantar o olhar, sair do lugar comum [...]." (Entrevista pessoal professora Michele, 2017).
\end{abstract}

Observa-se que os saraus são espaços de difusão não só da literatura canônica mas também da que é produzida na periferia, de modo que aproxima as pessoas de pouca escolarização ao universo da cultura letrada, além de promover e criar um ambiente voltado para a cultura, já que as políticas públicas, normalmente, não chegam a estes espaços. Essa ação em diversos grupos, como mostramos anteriormente, tem a presença de professores que, independentemente da formação que possuem, entendem que o acesso à cultura é um direito inalienável, assim como o é a literatura. Possibilitar o acesso aos bens culturais é promover e fomentar a formação do indivíduo, a qual pode ocorrer por meio da leitura, como quando constituem pequenas bibliotecas no bares e parques; pela oralização da literatura nos saraus; pelos debates realizados nestes espaços; através das apresentações musicais e, ainda, em virtude do incentivo à criação escrita.

Antonio Candido (2004) afirma que as sociedades elaboram as suas próprias manifestações literárias de acordo com seus impulsos, convicções, sentimentos objetivando o fortalecimento destes, sendo a literatura fundamental na formação e educação da população. Essa concepção de Candido se faz presente nos discursos e práticas dos professores entrevistados, e não somente daqueles que possuem uma estreita relação com a periferia e os saraus. Outros professores externam essa concepção nas entrevistas e nos textos literários quando propõem uma poética, uma ficção ou ainda uma escrita autobiográfica com temáticas latentes que precisam ser discutidas e refletidas, como relata a professora Letícia: "E, tem coisas que me incomodam muito na sociedade, que eu acredito que a gente tenha que jogar luz sobre, e eu acredito que a literatura é uma ótima ferramenta pra isso [...]”' (Entrevista pessoal professora Letícia, 2017). 
Detentores de um capital $_{\text {cultural }}{ }^{138}$ adquirido pela formação escolar e acadêmica, os professores escritores sabem a importância da literatura para a formação humana e escolar das crianças e jovens com os quais trabalham, principalmente os que atuam nas periferias e os que são originários delas, por reconhecerem que à medida que os alunos se apropriam das leituras literárias que realizam, progridem nos conhecimentos adquiridos em termos de linguagem - oral e escrita - ampliando, assim, a compreensão de seu mundo social, bem como rompendo ciclos de reprodução social, como a pobreza por exemplo.

Então, às vezes, você gosta muito de um conto ou um filme e você quer mostrar e os alunos não conseguem..., até porque é compreensível que, por exemplo, tem alunos que estão numa condição, numa realidade tão... difícil, que é difícil mesmo eles apreciarem, né, então, às vezes eles gostam de coisas que são mais práticas e que tem o resultado imediato, que até, às vezes, você consegue falar, não, mas se você souber se expressar bem, escrever bem, você vai ter chances maiores, que é uma forma de fazer com que eles consigam apreciar a literatura, mesmo eu não achando que essa é a função principal da literatura, não acho que tem que ter função nenhuma na verdade. É... mas aí você tenta, mas assim mesmo é muito difícil. (Entrevista pessoal professora Márcia, 2018).

O relato da professora Márcia nos mostra preocupação com ensino da literatura na escola e, mesmo que critique a noção de utilidade da literatura, ela faz uso deste artifício para que os alunos se aproximem do universo literário. Apaixonada pela literatura, como a professora Michele diz, seu trabalho formativo e de educação no interior da escola passa pelo encantamento pelos livros e pela literatura se colocando como responsável por esse processo em relação aos alunos com os quais atua:

[...] e eu acho que também é importante o fato que eu não foco só dentro da minha área, aquela questão de ser professora de Português, que ensina a gramática, blá, blá... Minha paixão, por exemplo, na literatura sempre vem com uma aula de história junto. Então, promover o encantamento [...], é a questão, também, do mediar leituras, na Sala de Leitura, eu sou uma mediadora de leitura, quando você encanta o livro para uma criança, eu acho que isso a gente não pode roubar, não pode roubar esse direito das crianças, dos mais novos, de descobrir esse encanto. [...] Então, é nesse sentido de resistência, de defender fronteiras, ali... fronteira dos sonhos, fronteira do descobrir, de ter um

\footnotetext{
${ }^{138}$ Segundo Bourdieu (1999): “O capital cultural pode existir sob três formas: no estado incorporado, ou seja, sob a forma de disposições duráveis do organismo; no estado objetivado, sob a forma de bens culturais - quadros, livros, dicionários, instrumentos, máquinas, que constituem indícios ou a realização de teorias ou de críticas dessas teorias, de problemáticas, etc.; e, enfim, no estado institucionalizado, forma de objetivação que é preciso colocar à parte porque, como se observa em relação ao certificado escolar, ela confere ao capital cultural - de que é, supostamente, a garantia - propriedades inteiramente originais." Setton (2009), afirma de maneira concisa que o capital cultural compreende "saberes e conhecimentos reconhecidos por diplomas e títulos" (p. 75).
} 
tempo como ele tem que ser, do fruir, do aprender-se, de aprender o olhar estético. (Entrevista pessoal professora Michele, 2017).

A fala da professora atribui um determinado valor ao conhecimento e à apreciação literária indicando seu capital simbólico, como afirma Bourdieu:

O capital simbólico é qualquer propriedade (de qualquer tipo de capital, físico, econômico, cultural, social) percebida pelos agentes sociais cujas categorias de percepção são tais que eles podem entendê-las (percebê-las) e reconhecê-las, atribuindo-lhes valor. [...] Mais precisamente, é a forma que todo tipo de capital assume quando é percebido através das categorias de percepção, produtos da incorporação das divisões ou das oposições inscritas na estrutura da distribuição desse tipo de capital (como forte/frágil, grande/pequeno, rico/pobre, culto/inculto etc.). (BOURDIEU, 1996, p. 107).

O relato da professora Cecilia, por sua parte, nos dá a dimensão do espaço do sarau como um espaço democrático em que qualquer pessoa sendo ou não letrado pode fazer uso da palavra compartilhando literatura e outras formas culturais sem a necessidade de, segundo Bourdieu (1996), instâncias de legitimação que confiram autorização à fala:

[...] uma outra questão que eu acho incrível nos saraus é a humanização das relações, a humanização da arte, né, eu não preciso ser um catedrático para falar, né, eu não preciso ter um diploma para ir lá, dizer, gente desculpa, eu sou uma diplomada, eu sou uma literata e eu vou falar, não, né, você pode errar, você pode esquecer, você pode ler no seu celular, ler no seu livro ou quem tem uma boa memória, declamar [...]. (Entrevista pessoal professora Cecilia, 2017).

Dessa forma, o espaço dos saraus se constitui como um lugar simbólico no qual a literatura canônica e a produzida na periferia ocupam o mesmo espaço social aproximando a população da literatura, ao mesmo tempo que permite às pessoas se desenvolverem por meio dela.

Nessas práticas coletivas, nas quais a literatura tem centralidade, os professores escritores se formam na diversidade de leituras que realizam e ouvem, canônicas e periféricas, nos debates que acontecem a partir das demandas locais e nas próprias práticas da escrita, conforme relata a professora Cecilia a seguir:

[...] após os saraus mudou muito a minha escrita, né, porque eu conheci diversos movimentos feministas, [...] então, se você pegar um poema meu, Mulher, [...] é aquela mulher é.... mística, né, é aquela mulher que não é carne e osso, aquela coisa assim, se você pegar o meu poema Justiça ${ }^{139}$, que eu escrevi depois, é totalmente feminista, né, então é um olhar diferente, né, então, as questões sociais que você vai descobrindo, né, as diferenças sociais, as questões de preconceito, tudo o que você

\footnotetext{
${ }^{139}$ Não tivemos acesso ao poema Justiça para estabelecer uma diferenciação.
} 
vai agregando aí na sua vida a partir de outras experiências você vai colocando, né, então, a minha escrita hoje tem muito disso, ela tem a questão feminista, ela tem a questão da desigualdade [...]. (Entrevista pessoal professora Cecilia, 2017).

A professora Arlete compartilha com os alunos os textos literários que escreve, com o objetivo de evidenciar que eles também podem se envolver na escrita destes tipos de textos e, com isso, incentiva a autoria:

[...] eu usei textos meus na sala de aula, né, e eu acho que isso é muito produtivo, né, então, mostrar pro aluno que eu escrevo, né, tem uma influência muito bacana e... [...] eu acho que a literatura é que potencializa os outros gêneros, que te dá possibilidade, se você não se apaixonar [...] pela escrita, você não vai conseguir [...] escrever outros [...] textos mais utilitários, né, e aí nesses desafios de escrita, eu falava, não, vocês vão escrever, mas eu também vou, eu vou trocar o texto que eu escrevi com vocês, né, e a gente fazia [...] uma roda de escrita [...] e eles gostavam muito, né, e eu sempre tive essa preocupação, porque escrever, na minha formação enquanto aluna de... tanto de Ensino Fundamental, Ensino Médio e na Universidade, era uma coisa que claramente diziam, não é pra você, escrever não é pra você, escrever é muito difícil, né, eu... eu, é uma coisa... não é um discurso declarado, mas tacitamente se reproduz isso, $[. .$.$] escrever você não precisa, você$ tem que manusear os textos utilitários, né, escrever não é pra você [...]. E aí, eu remando na contracorrente, não, eles podem produzir literatura, né, eles têm capacidade de desenvolver essa autoria, né, e é bem legal [...]. (Entrevista pessoal professora Arlete, 2018).

Portanto, como os textos e relatos demonstraram, os professores escritores encontram modos de compartilhar suas experiências literárias com um outro, tais como alunos, participantes dos saraus e até "viajantes" dos transportes públicos, com a finalidade de não apenas de difundir a literatura, mas de formar, sensibilizar e fazer pensar os que por eles passam. Nessas experiências com o outro se formam ao mesmo tempo que promovem formação operando com suas apropriações literárias e representações de mundo. 


\subsection{Modos de produção dos escritos: instrumentos usados na produção, suportes e materialidades}

Discutiremos neste momento os modos de produção dos professores entrevistados considerando os instrumentos utilizados na escrita, os suportes, os momentos de produção que são característicos de cada indivíduo, bem como a materialidade dos escritos produzidos.

Os modos de produção do material escrito é um aspecto do campo da cultura escrita que contribui para mostrarmos como os indivíduos se relacionam com as técnicas e tecnologias do escrito. Chartier (2000), afirma que as mudanças nos instrumentos e tecnologias usadas para a produção do material escrito não é algo que se convencionou rapidamente, sobretudo porque novos modos coexistem com os anteriores gerando diversas maneiras de se produzir as práticas. Um exemplo das permanências na produção do escrito apresentado por Chartier (2000) refere-se à revolução de Gutenberg, já que com a técnica dos tipos móveis foi possível produzir mais livros com custos reduzidos e aumento da tiragem - ainda que a estrutura do livro, o codex, tenha se mantido.

[...] Ambos son objetos compuestos por hojas dobladas cierta cantidad de veces, lo cual determina el formato del libro y la sucesión de cuadernillos. Estos cuadernillos se unen, se cosen uno junto al otro y se protegen mediante la encuadernación. La distribución del texto en la superficie de la página, los instrumentos que permiten establecer referencias (paginación, foliación), los diversos tipos de índices: todo esto ya existe desde la época del manuscrito [...]. (CHARTIER, 2000, p. $13-14)$.

O manuscrito revela, por assim dizer, uma escrita que tem continuidade e tradição mesmo após séculos da invenção do alemão Gutenberg - obviamente, que esta continuidade não se dá, exatamente da mesma maneira, pois há muito tempo os livros não são reproduzidos neste formato. No entanto, os professores entrevistados ainda são apreciadores deste formato da tradição escrita, como podemos observar em alguns relatos: "Eu faço manuscrito e, às vezes, eu faço alguma produção direto no computador e já coloco assim, já posto, alguma coisa que eu quero fazer naquele momento [...], mas é... eu gosto mais do manuscrito ainda" (Entrevista pessoal professora Cecilia, 2017).

“[...] Normalmente é manual, com garranchos. Que é a escrita rápida, que o pensamento não vai fugir... É uma escrita quase incompreensível [risos], aí depois vai pro 
computador. Nunca vai direto pro computador. Sempre faz um [...] rascunho mesmo [...]"

(Entrevista pessoal professor Jamir, 2018).

$[\ldots]$ Tenho caderno, $[\ldots]$ tenho folha que fica jogado, $[. .$.$] eu achei outro$ dia o rascunho, [...] do poema que eu participei do concurso, de anos atrás, está dentro de livro que eu rascunhei e ficou lá [...], normalmente eu vou escrevendo à mão [...], eu rabisco em cima dela mesmo e mudo, vou relendo, aí eu falo, não, essa palavra não combinou, aí eu penso numa outra palavra, dou uma rabiscada, escrevo do lado, eu volto sempre no mesmo papel e vou relendo, releio várias vezes até eu achar que está bom [...], mas é sempre ali no caderno, no rascunho, não tenho o hábito de escrever no computador. (Entrevista pessoal professora Camila, 2017).

Eu tenho um caderno que eu escrevo e [...] a escrita mesmo... manual, não abro mão. Essa permite correções, permite você riscar e saber que ali está intenso [risos], né, porque fica, se você rabisca a palavra e você acha que ela é inadequada, ela fica ali, no computador você deleta, então, no computador, na verdade, fica tudo muito pronto, entendeu, você tem uma escrita já finalizada, ela vai surgindo e vai finalizando, então, não tem uma interação. (Entrevista pessoal professora Regina, 2017).

Percebemos que para alguns professores o manuscrito vincula-se ao processo de elaboração do texto literário, pois é possível manter as trocas de palavras realizadas e testar possibilidades até a confecção do texto final. Por outra parte, há os professores que preferem os recursos tecnológicos para a produção dos textos, fazendo uso do papel somente em circunstâncias em que tais recursos não estão disponíveis, como é o caso dos relatos a seguir:

Então, se eu tiver numa situação assim que eu não tenha computador à minha disposição, vai caneta e papel, vou rascunhando e é assim, é um rascunho que só eu entendo, muitas vezes eu utilizo códigos e tal, é..., faço um rascunho e depois passo para o computador, e é interessante, porque os meus primeiros escritos sempre foram com papel, eu não tinha intimidade com o computador, [...] e eu acho que eu era muito mais cuidadosa, eu fazia um rascunho, desse rascunho, [...] eu [...] passava a limpo e guardava, guardava numa pasta como a gente fazia antigamente com papel de carta quando a gente era adolescente, depois eu digitava, eu guardava os arquivos, mas eu sempre guardei o escrito e sempre guardei [...] o arquivo informatizado. Mas, aí, depois, eu passei a pegar uma intimidade maior com o computador, então, eu passo a escrever diretamente no computador e foi aonde eu acabei me perdendo, porque eu já não tenho mais uma escrita inicial [...]. (Entrevista pessoal professora Izabel, 2018).

Então, eu escrevo de tudo quanto é jeito. Eu escrevo no computador, no celular [risos]. Porque o celular hoje é o que está mais à mão, né? É o que está pertinho o tempo todo. Manuscrito... [...]. Na verdade, o manuscrito é mais de rascunho. Quando o texto está pronto, a gente vai 
jogar no computador, editar, fazer a coisa bonitinha. E o celular, porque como ele está à mão, é fácil de registrar, de guardar a ideia, ele é muito usado também [risos]. (Entrevista pessoal professora Esther, 2018).

[...] acho que no começo até escrevia em papel, depois que começou a febre do computador, sempre escrevi direto no computador, porque eu acho mais fácil, acho mais rápido também. Então, se eu tenho uma ideia, eu acho que eu perco menos coisa na hora de transcrever do que se eu tivesse... [...], assim mesmo acabo usando bloco de notas do celular, por exemplo, tive uma ideia que, sei lá, que depois eu vou desenvolver, aí, eu anoto no bloco de notas e depois eu utilizo. [...] eu não tenho $[. .$.$] muito costume de [...] de escrever no papel, no papel, às$ vezes, pra revisar, [...] eu fiz um capítulo, sei lá, eu posso imprimir e, às vezes, eu acrescento alguma coisa ali a lápis, a caneta, assim. (Entrevista pessoal professora Márcia, 2018).

Entre os recursos tecnológicos utilizados existem diferenciações, pois os aparelhos móveis do tipo smartphone, tablets são suportes usados comumente para não perder uma ideia, uma proposta de texto literário quando se encontra em uma situação de trabalho, deslocamento ou outra que não seja na residência, no entanto, para a efetiva criação do texto, os computadores do tipo desktop ou portátil são os mais adotados, até porque eles mantêm os arquivos guardados para um uso futuro.

Eu escrevo no computador e eu o guardo em pastas, assim, não joguei na nuvem ${ }^{140}$ ainda, não tenho essa preocupação, mas eu guardo em pendrive e guardo no computador. Eu não tenho um caderninho, eu acho bem romântico aquilo quem tem, eu acho bem legal, eu queria ter, mas escrever à mão e tudo mais, eu não, e também no celular eu não desenvolvi essa habilidade de ficar escrevendo coisas no celular. Eu tenho umas pequenas poesias ou inspirações, mas aí eu venho pro meu notebook, eu começo a escrever, eu salvo tudo. Então, eu arquivo virtualmente, mas eu não escrevo em cadernos não. (Entrevista pessoal professor José Vandeí, 2017).

Diferentemente do papel, a produção escrita realizada no computador não possibilita a permanência das alterações no texto e esta não é uma preocupação apresentada pelos professores que fazem uso desses recursos, pois eles relataram que fazem as revisões diretamente no texto apagando as versões anteriores e salvando o produto final - dizemos final até a próxima alteração realizada antes de ser publicado, caso contrário, ele pode ser revisado inúmeras vezes. A professora Letícia relatou certo incômodo em relação ao que se perde quando se escolhe usar computador para elaborar o próprio material, já que, uma vez realizadas as mudanças, estas não podem ser desfeitas.

Eu prefiro sentar sozinha, em uma mesa, com uma caneta, um papel. Eu tenho algumas cadernetas, todas amassadas, mas eu gosto de pegar uma

${ }^{140}$ Referência ao armazenamento realizado na internet. 
caderneta, um papel, uma caneta ou um lápis, sentar, não precisa ser necessariamente em um local que esteja totalmente silencioso, porque eu consigo me concentrar bem, se eu estiver envolvida ali, eu consigo. Mas, eu preciso desse momento para parar e escrever, elaborar, cortar versos, ler, reler, cortar o que eu acho que está excessivo, pensar se precisa adicionar mais coisas, mais versos, mais imagens. Às vezes, eu até penso em versos quando eu estou em trajetos, mas eu não consigo parar para anotar, geralmente, então, eu guardo muita coisa aqui na minha cabeça e, depois, eu vou elaborar isso, sentada, sozinha. Às vezes, eu escuto música, às vezes, não. [...] Eu, caneta, papel. Ou lápis e papel. E eu preciso do papel, não gosto de escrever no computador, e eu acredito que no computador a gente perde muita coisa, porque você tem uma coisa no computador que é o backspace que no papel você não tem isso, no papel, por mais que você risque um verso, se eu quiser reler o que eu tinha escrito antes, está lá, porque muitas vezes o que eu escrevo, eu risco, tento uma outra coisa, um outro verso, outra ideia, e percebo que a primeira estava melhor. No computador, muitas coisas se perdem [...]. E, eu acho mais confortável caneta e papel. (Entrevista pessoal professora Letícia, 2017).

Apesar da variedade de editores de textos oferecidos atualmente pelos aparelhos tecnológicos portáteis, alguns professores ainda optam por escrever em papel e, para isso, utilizam cadernos nos quais produzem de modo sequencial e contínuo, para somente depois fazer uso do computador, de modo a digitar e revisar o material produzido, como segue o relato:

É à mão, a maioria à mão e no trânsito, porque que nem eu falei para você, eu acumulo cargo, né, então sempre que eu tenho um tempinho livre, eu procuro uma sala aonde ninguém vai, uma sala aonde ficam os livros velhos, teve uma escola que eu fui, que era legal, que tinha um bosquezinho com a mesa e eu ia para lá, sempre que eu tenho um tempo livre eu estou escrevendo, sabe, dando continuidade, isso às vezes é ruim, às vezes é bom, por que é ruim, porque às vezes a escrita, ela..., que nem no processo de um romance, você volta da parte de onde você parou, demora um pouquinho para engrenar de novo até se tornar..., [...] até chegar naquele ponto em que o texto escreve por si mesmo e, às vezes, quando eu chego nesse ponto, aí eu tenho que interromper pra voltar [...], mas eu escrevo em trânsito e depois eu vou digitando, aí digito, releio, mudo, corrijo, mexo, já é um processo que eu não gosto mais, muito, o processo que eu gosto mesmo é o momento de sentar e escrever, sabe, sentar e escrever, e sentir que... há muito mais coisa em mim do que..., ou o que não está em mim, mas está passando por mim, do que eu imaginava, né, que a escrita, chega um momento que ela começa a tomar os seus próprios caminhos, [...] vai saindo e as coisas tomam vida assim, sabe [...]. (Entrevista pessoal professor Daniel, 2018).

E com este relato acima, passamos dos instrumentos de escrita para os momentos de produção que, como disse o professor Daniel, são momentos curtos no interior da rotina pessoal, pois o cotidiano do professor é intenso tanto quando está na escola, quanto 
fora dela em função das atividades de planejamento de aula e correção de avaliações dos alunos. Assim, alguns professores, quando possuem intervalos entre aulas, aproveitam esse curto espaço de tempo para se dedicarem às suas criações.

\begin{abstract}
Escrevo no computador. Escrevo aqui na escola, tem horários que a gente cumpre, que chama HA, horas-atividades, que o professor tem pra estudar, pra você preparar uma aula, e aí é nesses momentos assim, que, lá na sala de leitura vazia, que a sala de leitura está vazia, que eu estou no computador, aí eu consigo escrever alguma coisa. Em casa, geralmente depois da meia-noite, que é quando eu tenho silêncio, porque é cheio de criança. Mas como eu escrevo pouco, não consigo escrever mais de um texto, o tempo de duração que eu fico escrevendo é mínimo. A menos que eu tenha que escrever outro tipo de texto, aí vão horas e horas e horas... Sei lá, um artigo, alguma coisa, porque aí leva leitura [...]. (Entrevista pessoal professor Márcio, 2017).
\end{abstract}

As formas adotadas pelos professores seja para esboçar a ideia de um texto, seja para a sua efetiva criação são bem variadas, enquanto alguns necessitam de silêncio, isolamento e um espaço específico para a escrita, outros escrevem em meio a ruídos, nos meios de transporte coletivos, na escola e em outros espaços, basta surgir uma ideia para que o processo de criação se inicie. Os relatos em sequência vão demonstrar essa variedade de espaços nos quais os professores produzem seus textos.

Eu gosto de escrever no ônibus. Eu adoro escrever no ônibus. Aí, eu tenho um bloquinho comigo, que, às vezes, eu tenho alguma emoção que eu estou trabalhando ou, às vezes, eu vejo alguma cena, e eu anoto a cena como gatilho, para tentar escrever sobre ela. E, às vezes, vem uma frase, dormindo ou tomando banho [...]. Então, quando tem essa frase que vem, eu fico exercitando ela, pra ver se eu encaixo em algum lugar, [...] quando é uma emoção minha, eu também tento de maneiras diferentes dizer a mesma coisa [...]. Mas, eu adoro pegar o ônibus, eu evito pegar metrô para pegar o ônibus, sentar na janelinha e ficar rabiscando, lendo alguma coisa, ouvindo uma música, o tempo do trajeto de uma hora e pouco, às vezes, pode escrever, às vezes não. $\mathrm{E}$, quando eu estou muito afobada, muito perturbada com alguma dor, provavelmente, paixão, aí eu escrevo várias no mesmo dia. [...] Então, eu acho que a maior parte das vezes, eu tenho uma ideia pré-existente, que eu falo que preciso desenvolver, e aí quando eu tenho tempo, que não é sempre, eu vou e me disciplino a escrever sobre aquilo. Mas, é muito menos tempo do que eu gostaria por trabalhar uma jornada de quase 10 horas, contando o horário de almoço são quase 10 , eu trabalho 9 horas na escola. (Entrevista pessoal professora Janaína, 2017).

Então, em casa eu tenho, [...] é um quartinho mesmo que [...] eu adaptei lá e ficou, tipo, uma biblioteca, que é quase fora de casa que eu uso para escrever, então, aí, eu acendo incenso, coloco a música tipo clássica para ficar mais calmo, pra sentir que estou em outro lugar, mas é sempre em casa mesmo. (Entrevista pessoal professora Márcia, 2018). 
[...] no meio da rotina difícil, não dá, você precisa dar uma parada, né. Normalmente sozinha mesmo, num horário um pouco mais tarde, quando já parou tudo, tô sozinha na sala, né, tá sossegado, não tem barulho e [...] aí já vou colocando no papel, que a mente, às vezes, já tem, já tá tudo ali meio misturado só quem tem que ser organizado [...]. preciso estar sozinha, preciso estar em silêncio. (Entrevista pessoal professora Camila, 2017).

Eu costumo mais escrever em casa, no quarto, se a gente for pensar em espaço. Então, à noite, também, eu gosto bastante, eu produzo mais à noite. Então, [...] eu tenho que estar com os meus livros, assim, olhando, porque aí eu me inspiro, eu pego um livro, pego outro, e leio, e pesquiso. [...] Eu posso até estar viajando, estar no trem e vir uma inspiração, aí eu escrevo alguma coisa e tal, mas pra finalizar, [...] eu preciso desse espaço mesmo [...]. Eu tenho o lance da inspiração, mas eu tenho o lance, também, do trabalho. Eu me inspiro, mas eu também, eu nunca, acho que não tem nenhuma poesia minha que saiu assim "Pah", saiu da inspiração e já foi pro papel. Eu quando vou ler, eu lapido bastante, de pesquisar um pouco as palavras, a métrica, o ritmo, eu gosto muito de pesquisar, aí sai, aí demora um pouquinho, mexo, mexo, mexo, até ficar pronto. (Entrevista pessoal professor José Vandé́, 2017).

[...] não tem um lugar específico, mas é assim, é sozinha, então, na minha casa, no escritório, a gente tem um escritório ou, sei lá, na sala, mas aí eu tenho que estar sozinha, é o momento em que as meninas não estão, assim, e o [nome do companheiro] não está ou ele está também, mas aí está só ele ou ele está cuidando das meninas e eu estou, né, disponível lá pra escrever o texto, mas não tem música, não, mas eu tenho que estar sozinha, assim, daí eu vou e escrevo, não escrevo e publico, né, eu leio várias vezes antes, assim, leio pra ele também, aí vou repensando até que daí eu publico. (Entrevista pessoal professora Virginia, 2017).

Alguns processos de escrita são mais curtos, como relatado anteriormente pela professora Cecilia que publica e posta no blog ou em redes sociais, pois são textos mais breves e que, em geral, são publicados na internet. Agora, quando a escrita dos textos literários exige continuidade como romances, por exemplo, e/ou textos em que o processo de criação leva um tempo maior, estabelecer a continuidade da produção em meio à rotina de trabalho é uma dificuldade, como exposto pelo professor Daniel no excerto acima. Outro professor que tratou do aspecto da continuidade na produção dos textos e fazendo justamente uma relação com o cotidiano do professor é o Osvaldo e isso se deve ao fato de ele também criar narrativas mais extensas. Além disso, a escrita para ele é uma atividade diária, como um trabalho, conforme relata:

[...] é bem diário. Não era diário, assim, antigamente não era assim não, mas hoje é bem diário mesmo, porque a minha segunda atividade [...] hoje é escrever, primeiro é da escola e depois é escrever. Já está virando um trabalho, já está virando uma profissão, um trabalho, sei lá, profissão não sei se é, mas trabalho eu sei que é. Eu escrevo no 
computador, na mão eu não escrevo mais não, é tudo no computador. [...] Eu hoje escrevo em qualquer lugar. (Entrevista pessoal professor Osvaldo, 2018).

Há ainda os casos em que os professores escolhem o suporte e instrumentos da escrita a depender da finalidade destes, por exemplo, textos produzidos para serem publicados na internet são confeccionados diretamente no computador, já a escrita de foro íntimo é mantida em caderno, assim como os registros de estudo e da profissão, como nos conta a professora Virginia:

[...] O que está no blog, está só no blog. É, e eu acho que eu recuperei, assim, tenho em arquivos separados também no Word, mas é... eu escrevo no computador, mas, às vezes, eu tenho uma ideia e escrevo no caderno, mas eu sou uma pessoa que escreve muito no cotidiano, pra você ter uma ideia [risos], eu vou te mostrar uma coisa, aqui, oh, eu tenho... só aqui, hoje, eu tenho quatro caderninhos [risos]. Então, eu tenho... esse caderno aqui, ele é novo, mas eu tinha um outro que era mais ou menos parecido que eu vou escrevendo coisas pessoais, assim, da minha vida, pensamentos, tal, né. [...] Aí eu tenho um outro, que eu gosto de caderninhos, né, não gosto de cadernões, [...] mas esse aqui é um caderno da escola, por exemplo, [...] as coisas que eu tenho que fazer na escola, tá vendo? As tarefas que eu tenho que cumprir essa semana e as próximas, né, então, aqui também. E aí, esse aqui é caderno da... do doutorado, [...] que eu tenho as questões todas das disciplinas, dessas agora que eu estou fazendo neste semestre, né, e esse aqui foi o período que a minha vida estava mais bagunçada, então, ele tem coisas assim da escola e do doutorado, entendeu? Mas não tem nada pessoal, então são quatro caderninhos e aí eu ando com todos. (Entrevista pessoal professora Virginia, 2017).

Nesses variados modos de produção, identificamos professores que escrevem suas ideias de textos literários em quaisquer espaços e momentos, fazem uma pausa e registram determinada reflexão para trabalhar nela posteriormente, conforme exposto nos trechos a seguir:

[...] é qualquer hora, então de repente surge a ideia [...] na mesa dum bar, no ônibus, em casa, [...] qualquer lugar, né, que tem a ideia, de repente é um pedacinho mesmo e ela vai ser desenvolvida, às vezes, vem inteira, acabada, tá ali. Se eu reler, talvez até modifique, mas normalmente já chega meio acabada. Algumas coisas são construídas, então, tem uma frase, uma palavra, um pensamento, uma ideia, vamos trabalhar isso daqui, então tem algo que já vem pronto e algo que vem a ser trabalhado a partir de um fragmento menor. (Entrevista pessoal professor Jamir, 2018).

Olha, é tudo muito variado, né? Uma época que eu produzi muito, foi quando eu ia de ônibus pra uma outra escola que eu dava aula. Então no ônibus iam surgindo ideias, eu ia fazendo anotações. Às vezes, até dando aula, surge uma ideia. Você vai lá, faz uma anotação. Às vezes, 
você está inquieta e aquele poema está ali brotando, germinando, e duas horas da manhã, você acorda pra escrever. Então assim, eu posso estar agora conversando com você, se me surgir a ideia, eu procuro, nem que seja uma observação breve, e escrevo. (Entrevista pessoal professora Esther, 2018).

Adentrar a madrugada escrevendo, no silêncio quase absoluto da cidade, é um momento propício para as criações de alguns professores, talvez, por ser aquele tempo em que todos dormem e não há espaço para atividades do cotidiano.

São bem aleatórios, normalmente quando eu estou sozinha, eu tenho bastante dificuldade de escrever, então, esse é um outro fator, eu tenho muita dificuldade de escrever com barulho, com um monte de gente, quando está todo mundo vendo filme e eu estou lá, eu não consigo, por isso [...], muitas das coisas que eu escrevi, eu escrevi à noite, a maior parte delas quando está silencio total assim, sabe, eu acho que a maioria dos escritores é notívago, né [...]. (Entrevista pessoal professora Cecilia, 2017).

$\mathrm{Eu}$ consigo produzir, eu acho que nos momentos mais inesperados assim. Quando eu estou indo dormir, eu não consigo dormir que estou com uma insônia, aí eu vou lá e consigo produzir aí. Quando eu estou na rua andando, aí alguma coisa me chama atenção, eu paro anoto aquilo, né, que se não até esqueço, então eu estou na produção assim inesperada. Dá um lapso, né, aí eu escrevo sobre aquilo, depois eu reflito sobre aquilo, né? Então, acho que primeiro vem essa inspiração do nada e aí depois eu vou mexer naquilo. Depois eu mexo naquilo, arrumo aquilo, aumento, diminuo, sabe? [...] Às vezes, eu estou na sala de aula acontece, eu estou ali pensando [...] no que que eu vou falar, ai vem uma construção poética na cabeça aí, tem hora que dá para anotar, tem hora que não dá para anotar... nossa, eu perco muito poema assim. [...] Mas hoje eu acho que eu utilizo todas essas plataformas, tanto a do celular, que ela é mais imediata, [...] o computador, que é o que eu mais gosto de escrever hoje [...] e os cadernos que eu acho que é o modo mais bonito, mais clássico, deixar sua letra [...]. (Entrevista pessoal professor Jefferson, 2017).

Geralmente em casa, quase sempre sozinha. Às vezes, o que a gente chama de inspiração, eu chamo de insight [...] ou a coisa do cotidiano, que alimenta e você vê e não quer esquecer aquela imagem e [...] eu costumo anotar, [...] mas dali nunca vai sair nada com traços estilísticos [...]. Agora da escrita, fatalmente, vai ser à noite e acaba sendo a maior parte das vezes final de semana, que se eu tenho um domingo, aí sei lá, a tarde, a manhã é livre, eu posso dormir até mais tarde, e aquela noite do sábado, que eu escolho pra varar [...]. Mas, é bem esse bem isso, nos periodozinhos de folga da semana e aos finais de semana, que é quando eu consigo mesmo. E, às vezes, me angustia bastante, eu sinto assim, um impulso que eu tenho vontade de sentar e escrever, aí eu olho para o notebook ou eu olho para outra coisa que eu tenho que fazer, aí dá vontade de chorar, assim, é muita agonia. Eu fiz uma oficina recentemente, com a facilitadora ela se chama Cláudia Pucci, e ela é da área de dramaturgia. E, ela tratava muito dessa questão do tempo, na vida do escritor, assim. E, ali, eu com certeza, foi onde eu elaborei essa 
decisão de tirar essa licença e me dedicar mesmo. (Entrevista pessoal professora Michele, 2017).

Os relatos dos professores nos mostram que a produção de seus textos ocorre em espaços diversos e fazendo uso dos instrumentos e suportes mais adequados à determinado momento da escrita, objetivando não perder uma ideia quando não é possível estabelecer de imediato a pausa para escrever. Entretanto, mesmo os que são adeptos dos cadernos, blocos de anotação e outros suportes em papel, fazem uso dos recursos tecnológicos para o acabamento do texto, considerando revisão do conteúdo e da forma, correção ortográfica, além da guarda em arquivos digitais seja no computador ou na internet.

\subsubsection{Materialidades dos escritos}

A materialidade dos objetos produzidos pelos professores faz parte da constituição dos modos de produção característicos de cada escritor, dando-nos pistas dos objetivos e perspectivas de cada um ao elaborar determinado material impresso ou digital. Para discutir a materialidade, separamos as produções de acordo com características comuns, independente da autoria, Desse modo, constituímos cinco grupos, a saber: fanzines ${ }^{141}$, livreto, revista, livro e blog. O corpus de fontes é composto por três fanzines, três livretos, uma revista, dez livros ${ }^{142}$ e dois blogs.

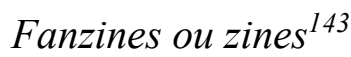

Os fanzines identificados na pesquisa são pequenos impressos medindo $10,5 \mathrm{~cm}$ por 7,5 cm, contendo oito folhas que, dobradas ao meio, correspondem a dezesseis

\footnotetext{
${ }^{141}$ De acordo com Magalhães (2012), os fanzines foram criados nos Estados Unidos por volta de 1930 como uma revista produzida por fãs de determinadas expressões artísticas tendo como objetivo divulgar os trabalhos autorais de jovens da época. O primeiro fanzine criado no Brasil, por Edson Rontani, é de 1965, contendo histórias em quadrinhos. "O caráter de "marginalidade", por serem publicações produzidas à margem do mercado, sem fins lucrativos e com forte motivação comunitária, habilita os fanzines a se inserir na categoria de folkcomunicação, pois são porta-vozes de setores e expressões artísticas menosprezadas pela grande imprensa. Os fanzines representam o pensamento de indivíduos, associações e grupos de aficionados que produzem seus próprios veículos como forma de interação, troca de informações e opiniões" (MAGALHÃES, 2012, p.102).

${ }^{142}$ Os livros do Concurso Literário Valeu, Professor não está contabilizado neste momento devido à caracterização das publicações terem sido feitas no capítulo específico do concurso literário.

${ }^{143}$ Zine é o nome adotado pelos professores para esse material impresso.
} 
páginas, incluindo a capa. São confeccionados artesanalmente, em folhas coloridas, de modo que a reunião das folhas é feita por um ou dois grampos. Na capa trazem o título do fanzine e o nome do autor, no seu interior, a primeira informação que consta no verso da capa é o contato do autor através da rede social Facebook, pela página poética ${ }^{144}$ e pelo e-mail. O fanzine Fôlego apresenta os créditos de editoração e ilustração, aspecto que não existe nos outros dois, pois acreditamos que foram confeccionados integralmente pelo autor. Na contracapa dos fanzines Linguística e In Versus, ambos de mesma autoria, o autor libera a reprodução para fins não comerciais e com a devida citação de quem os escreveu.

No interior dos fanzines constam treze poesias curtas, uma por página, acompanhadas de algumas ilustrações que dialogam com os textos. Apesar do papel do fanzine ser colorido, a impressão foi feita em preto e escala de cinza. Algumas marcas mais claras exibem falhas na confecção do material, indicando que foram fotocopiadas, talvez, como forma de redução dos custos de produção.

O fanzine Linguística apresenta uma característica peculiar, pois as poesias do impresso foram manuscritas, assim como a paginação foi realizada da mesma forma, o que contribui ainda mais para a percepção de um impresso artesanal. Na capa e contracapa, a fotografia parcial de um rosto com a língua exposta fazendo relação com o título atribuído ao material. Nele não há nenhuma ilustração em seu interior.

Imagem 20. Capa e contracapa do fanzine Linguística.
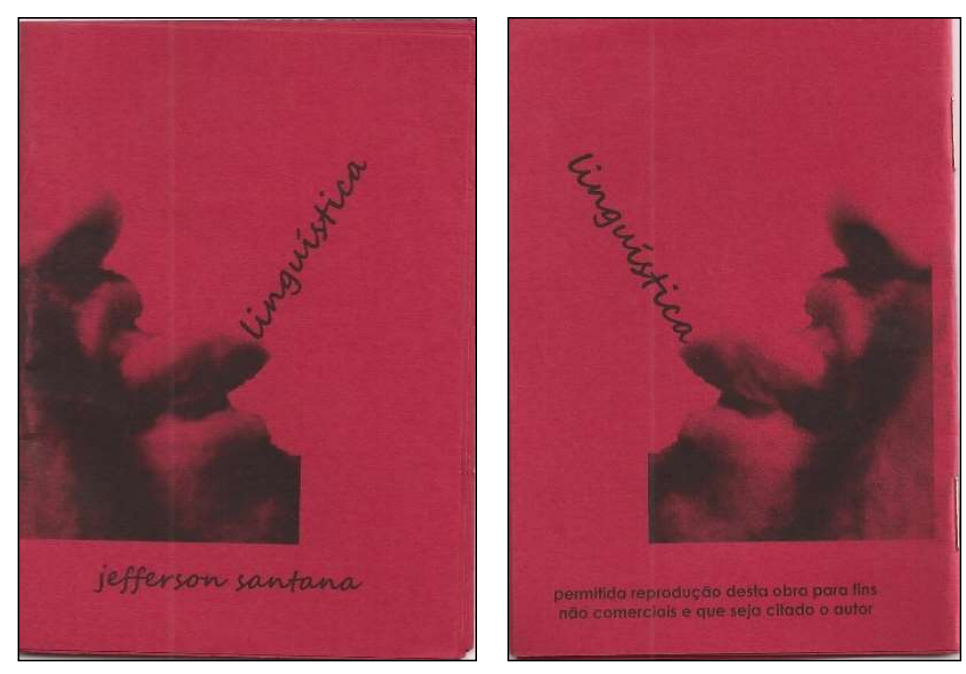

\footnotetext{
${ }^{144}$ A página poética que consta no material é uma página criada na rede social Facebook exclusivamente para divulgar e publicar os escritos do professor Jefferson.
} 
A maioria das poesias contidas nesses impressos não possuem título, além disso, os autores escolheram o uso de letras minúsculas em todos os versos, não havendo o uso de maiúsculas. A letra maiúscula foi utilizada somente na capa dos fanzines Fôlego para o título e nome da autora e no In Versus, apenas para o nome do autor, como podem ser observados nas imagens a seguir.

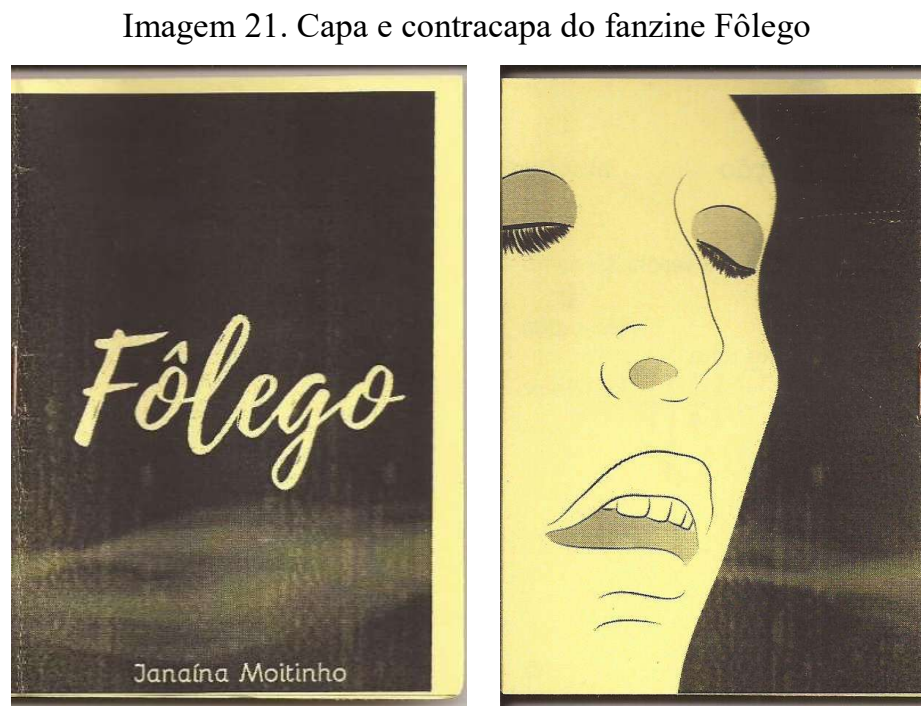

$\mathrm{Na}$ contracapa deste fanzine consta a ilustração de um rosto - provavelmente feminino -, com a boca aberta expressando relação análoga ao título. Tal ilustração representa algumas poesias no interior do impresso que tratam poeticamente a condição feminina.

O fanzine In Versus possui uma poesia na contracapa, como pode ser observado na imagem a seguir, que faz alusão à própria ideia de escrever poesia. A imagem da capa representa instrumentos da cultura escrita. 

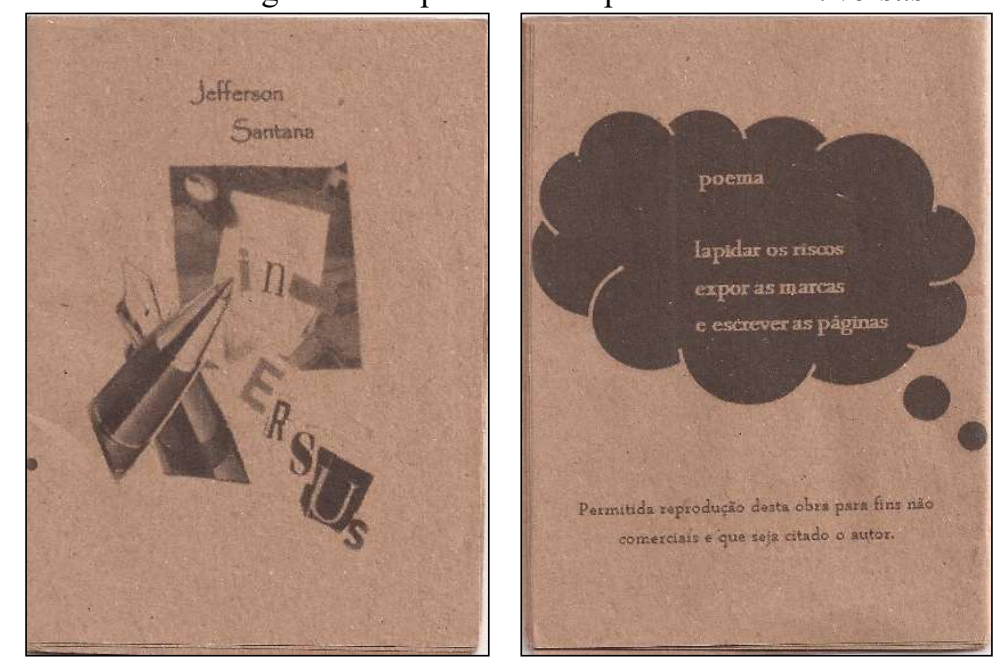

\section{Livretos artesanais}

Escolhemos chamar de livretos os materiais impressos medindo $15 \mathrm{~cm}$ por $10,5 \mathrm{~cm}$, que foram produzidos artesanalmente por seus respectivos autores. $\mathrm{O}$ formato adotado se caracteriza pelo in folio, uma folha de papel A4 com duas dobras, sendo que em uma é feito um corte e a outra é dobrada ao meio para formar o livreto. Os materiais são compostos de sete e oito folhas dobradas ao meio, dois deles contando a capa e um deles sem contar a capa, pois esta exige mais elaboração.

Ambos os livretos são de poesias curtas organizados de modo a conter uma poesia por página e sem ilustrações. Seguindo a mesma proposta editorial dos fanzines, nos livretos pedaços e (des) caminhos os miolos, onde constam as poesias, foram elaborados usando letras minúsculas apenas o que, segundo Araújo (1986), o uso deste tipo de letra favorece a estética e deixa o texto mais legível ao leitor ${ }^{145}$.

Os três impressos se caracterizam pelo uso de papel de variadas cores que oferecem contrastes ao folhear o material. Além disso, dois deles são costurados de forma manual. Ao observar os livretos, é possível inferir que os respectivos autores aprenderam técnicas específicas para a confecção desses materiais, cuja produção passou por um processo de elaboração e criação gráfica, idealizado, inclusive, pelos próprios autores.

Nesse momento, vamos tratar das características específicas de cada livreto. No livreto (des) caminhos, imagem a seguir, observamos que as ilustrações da capa e contracapa indicam trajetos em sentidos opostos, o que nos permite refletir sobre as idas e vindas e mudanças que ocorrem nas trajetórias individuais. O papel utilizado na capa é

\footnotetext{
${ }^{145}$ Araújo, Emanuel. A construção do livro.
} 
cinza cintilante com impressão em preto, o uso de maiúsculas só acontece no nome do autor e dados da obra, e esta é a segunda edição da mesma. Para a costura do livreto o autor utilizou um fio encerado preto que, além de reunir as páginas, é utilizado para fechar o material fazendo um laço ou um nó.

Imagem 23. Capa e contracapa do livreto (des) caminhos
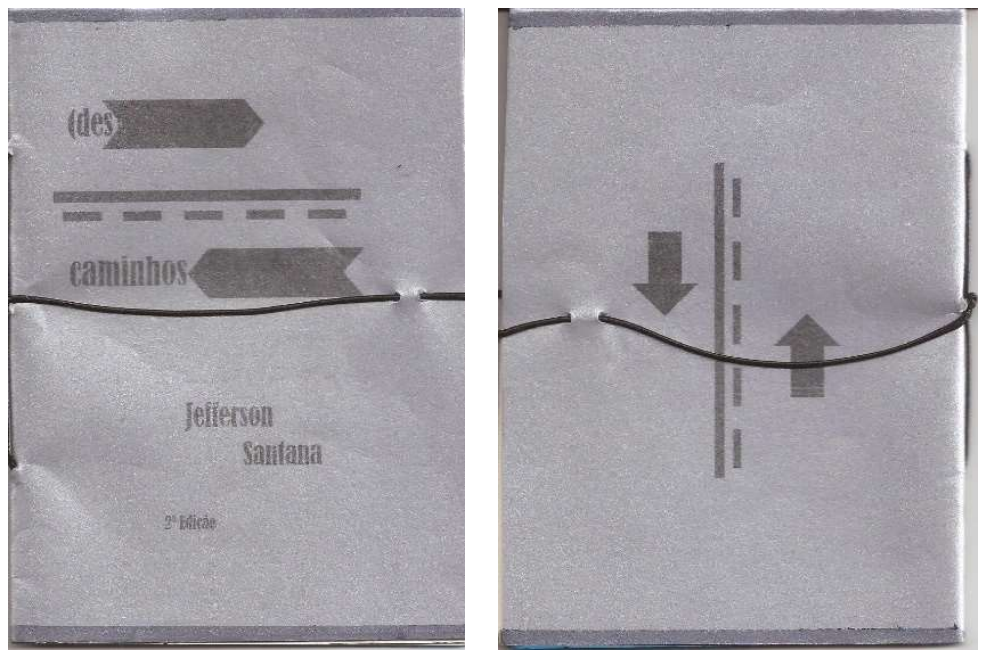

Ao abrir o livreto encontramos uma página azul que contrasta com a cor da capa e é o espaço utilizado pelo autor para fazer a dedicatória àquele que adquire um exemplar. O papel usado do miolo é de tom amarelo que propicia um conforto visual ao leitor. A informação sobre a costura adotada para a confecção é um registro importante da pessoalidade posta no material.

Imagem 24. Folha de rosto do livreto (des) caminhos.

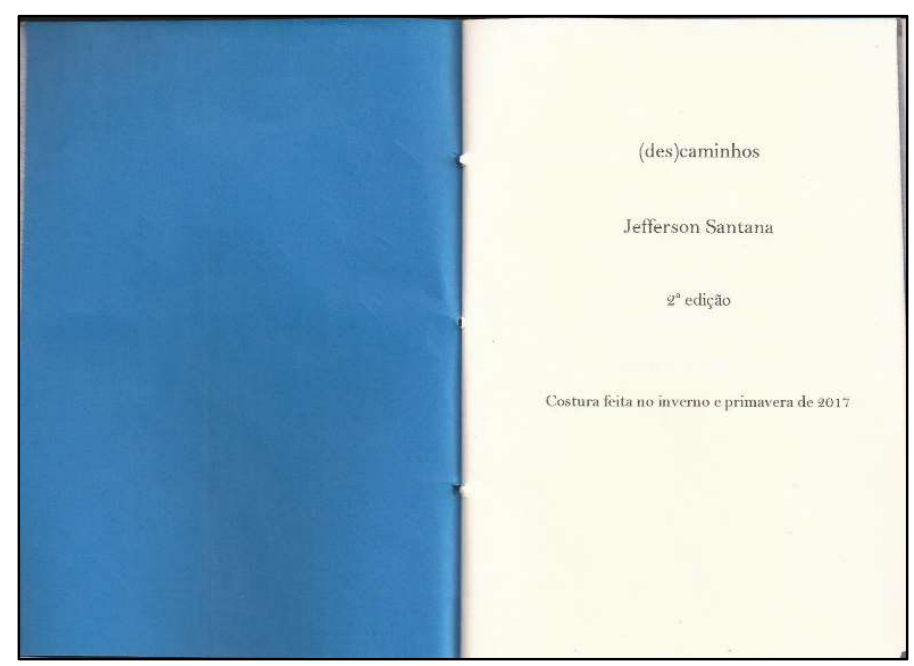


Como é possível observar na imagem a seguir, as páginas são numeradas e a diagramação posicionou os textos centralizados nas páginas. Outro aspecto importante e característico do autor é a frase de permissão para a reprodução do material, algo que identificamos somente nos materiais deste professor. Por fim, queremos enfatizar que os exemplares são numerados e a sequência numérica é feita de modo manuscrito.

Imagem 25. Dados do exemplar do livreto (des) caminhos.

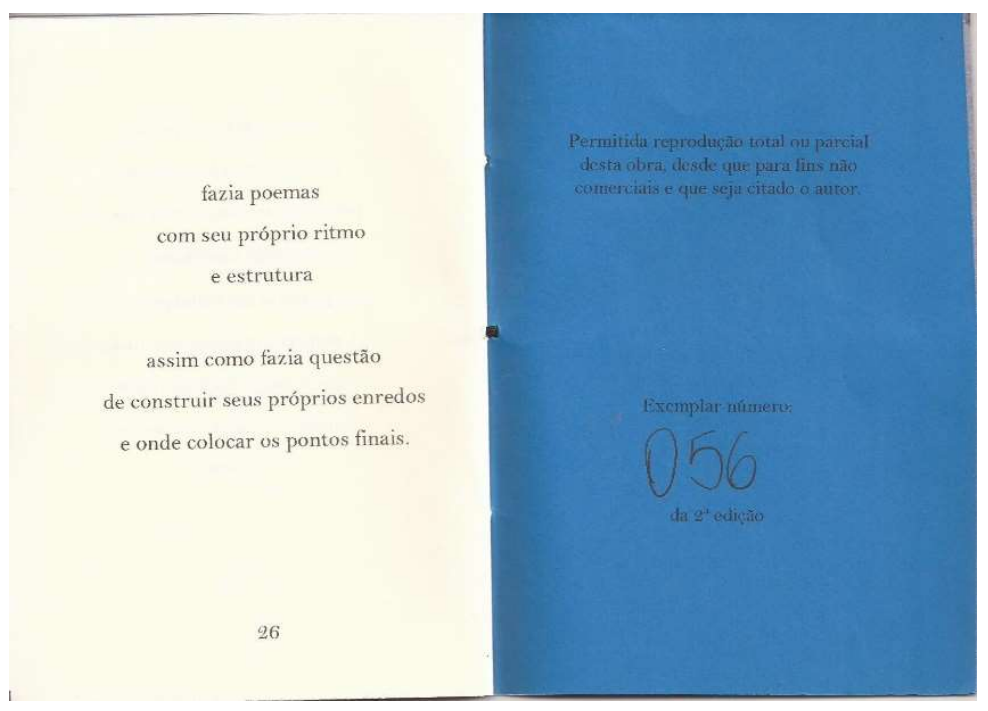

O livreto pedaços é o único desse grupo que não foi costurado. A autora fez uma dobra no meio das folhas reunidas e colocou um elástico para prender e formar o material, como é possível observar na imagem abaixo. Quando abrimos o livreto, encontramos uma folha de papel branca translúcida na qual podemos identificar os dados da obra conforme aparece na segunda imagem.

Imagem 26. Capa e folha de rosto do livreto pedaços.
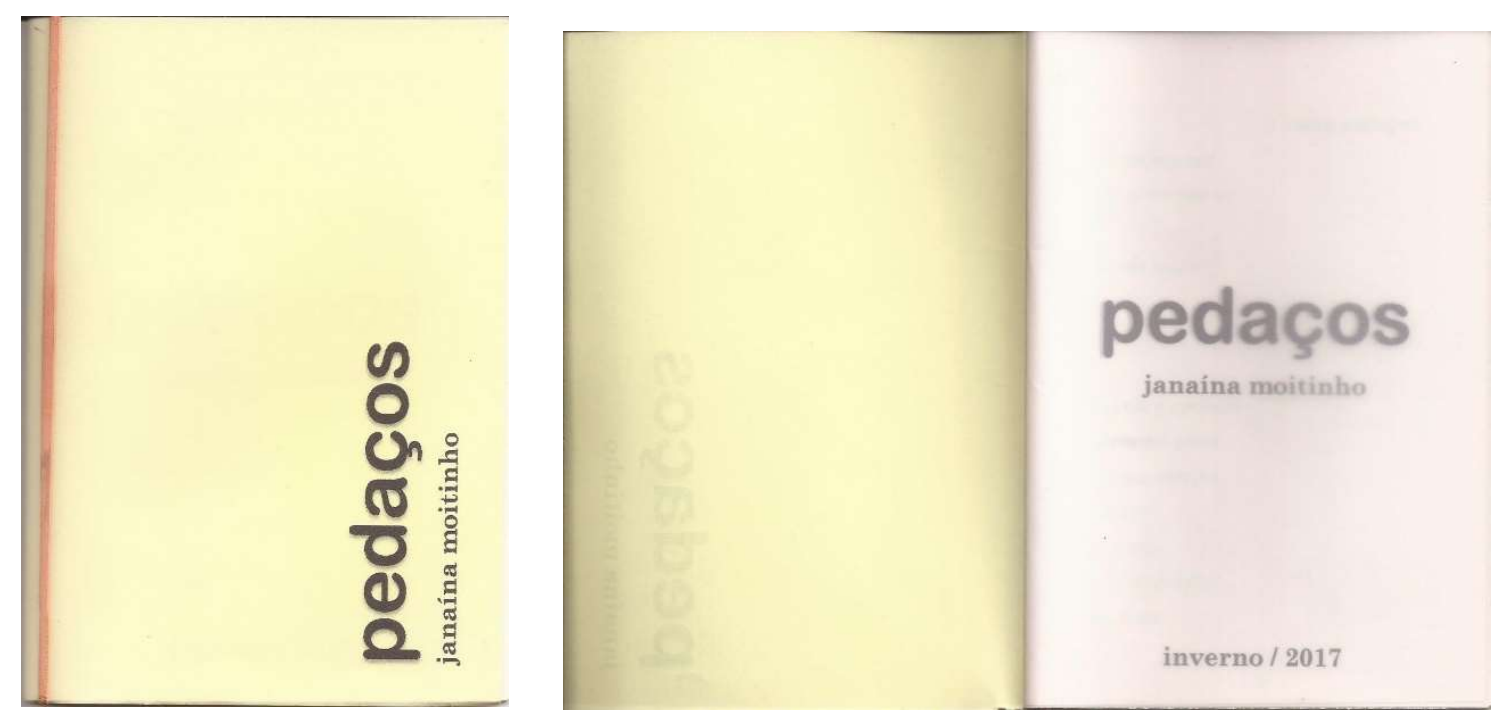
As páginas do livreto são numeradas e na última página, também em papel translúcido, a autora inseriu alguns dados biográficos, seu endereço na rede social e os créditos para o projeto gráfico e de diagramação, o qual teve a colaboração de uma outra professora escritora.

Imagem 27. Última página do livreto pedaços.

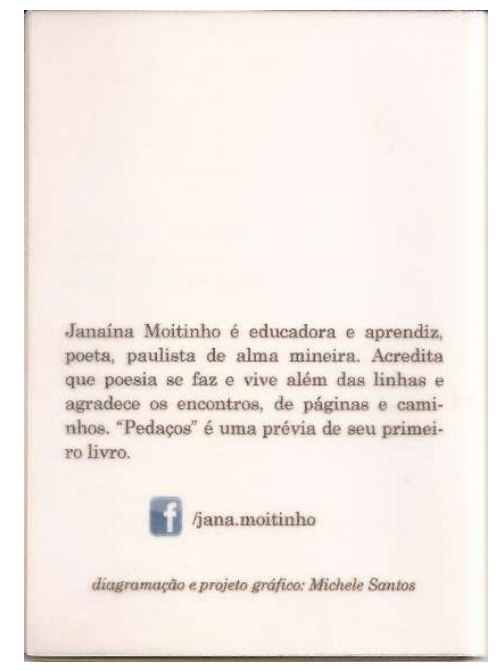

O terceiro livreto dessa série, intitulado Deve ser isso foi confeccionado usando papel cartão de maior gramatura para a capa e contracapa, envolvido em tecido de estampa floral que gerou um efeito de contraste de cores. A costura externa realizada com linha é feita de modo a deixar um fio solto excedente com três miçangas na ponta que pode ser utilizado como marcador de página. $\mathrm{O}$ título do livreto e a autoria foram inseridos por meio de um carimbo na capa. Acompanhando o livro há um marcador de página confeccionado com os mesmos materiais da capa, contendo também o título e autoria e no verso deste, os contatos da autora na rede social e endereço eletrônico, além de um verso de uma poeta chamada Matilde Campilho. 
Imagem 28. Capa e contracapa do livreto Deve ser isso.
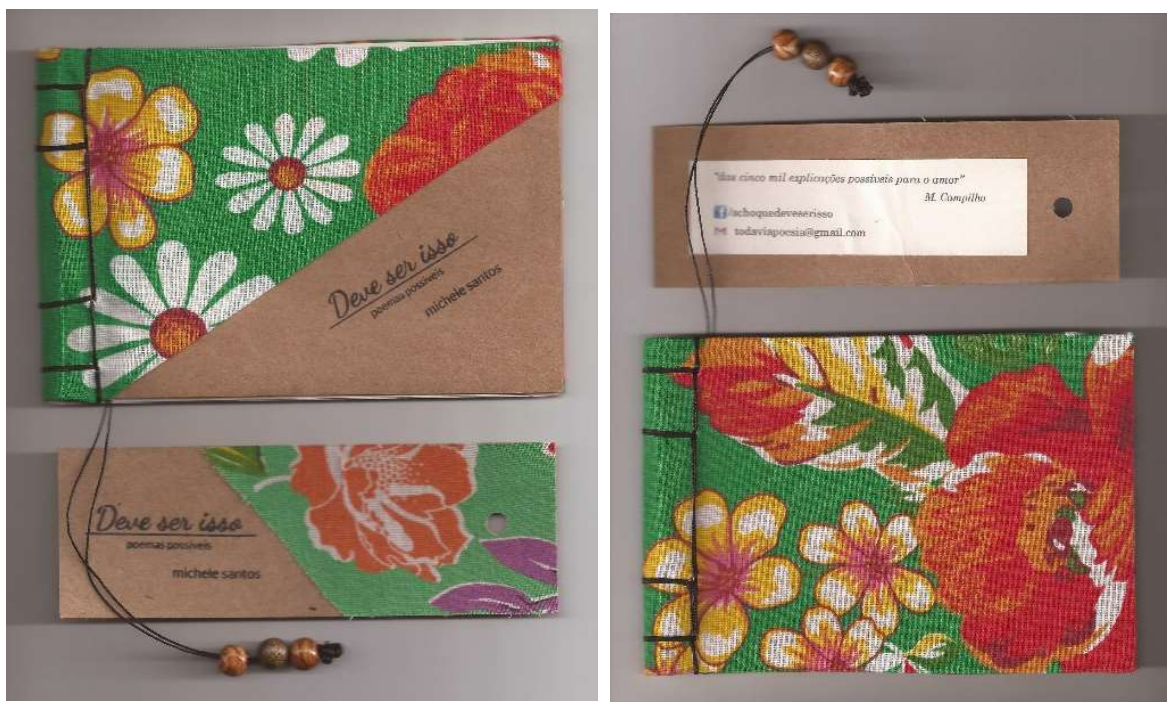

Ao abrir o livreto encontramos um papel branco translúcido com os dados da obra, ano de edição, a informação de que a edição foi realizada pela autora e, ainda, a numeração do exemplar inserida de modo manuscrito. Neste material, a autora registrou o total de exemplares confeccionados: duzentos. No miolo do livreto são usadas folhas em tom amarelo, sem paginação e contendo uma poesia por página.

Na primeira página, a autora faz uma breve explicação sobre a idealização deste livreto a partir da leitura da obra da poeta portuguesa Matilde Campilho e, no final, após a última poesia, consta um excerto do texto da escritora.

Imagem 29. Folha de rosto do livreto Deve ser isso.

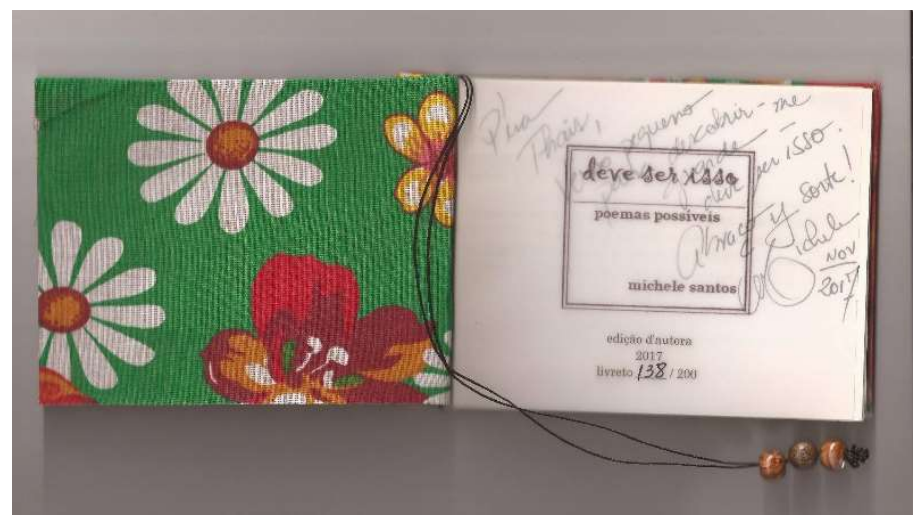

Na última página, também em papel translúcido, há a ilustração de um coração, em sequência, a informação de que a autora foi responsável por todas as etapas de produção do mesmo e o agradecimento às pessoas que fazem livros artesanais. 


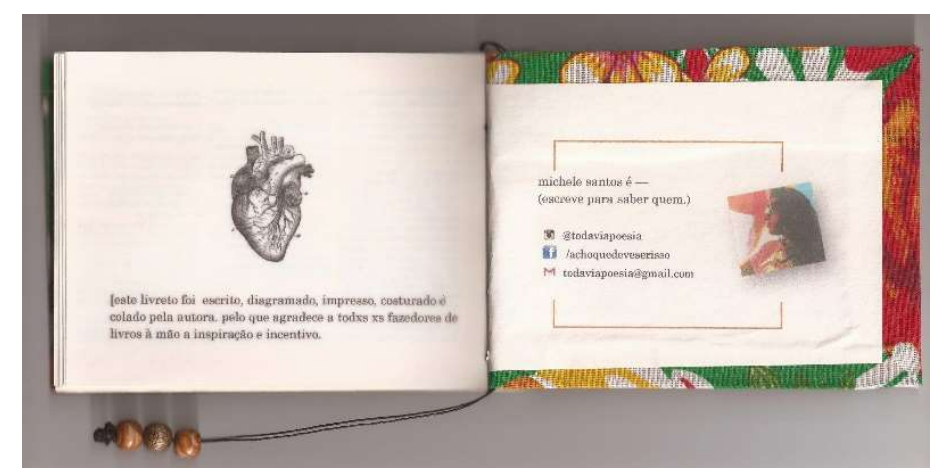

No verso da contracapa há uma fotografia da autora e algumas informações para contato. Além dos aspectos apresentados, consideramos importante dizer que a autora utilizou diversas estampas de tecido na produção deste livreto fazendo com que cada exemplar adquirido pelo leitor fosse um material único. Essa professora escritora também levou exemplares dos livretos para alguns saraus, no entanto, eles não estavam completamente acabados, de modo que o leitor poderia escolher a capa do seu exemplar para ser costurado ali no momento e, assim, observar parte do processo de confecção do material, como ela nos relatou na entrevista:

[...] Ontem mesmo, eu estava no lançamento do artesanal do Deve ser isso, e aí tinha um rapaz que ele ficou curioso, e aí [...], eu tenho levado alguns prontos já, e alguns outros eu costuro no evento, que eu acho que é uma estratégia de marketing... [Risos]. "Meu Deus, quem sou eu falando isso?" Mas, é uma coisa que, eu acho que as pessoas se interessam mais, assim, e é gostosinho, você está no sarau, ouvindo poesia e costurando. Agora que eu estou com mais prática na costura, então... [...] aí eu já levo com as guias, [...] mais ou menos coladinho. Aí tem as guias, passo o furador, aí faço o processo da costura, bato o carimbo do título." (Entrevista pessoal professora Michele, 2017).

Essa série de livretos artesanais nos demonstra um movimento de retorno aos livros produzidos manualmente, confeccionados um a um, com marcas características da pessoalidade de cada autor. Acreditamos que essa forma de produzir o material ocorra por dois motivos: pelo baixo custo, considerando que o escritor é o próprio editor e impressor do material e, desse modo, pode publicar sem a ação do mercado editorial; e por ser uma maneira de criar materiais exclusivos, que imprimem uma identidade do autor no material para além do texto, tornando cada material único tanto em sua materialidade quanto pela experiência de leitura que proporciona. 
A Revista Poesia sem Medo é uma publicação mensal de poesia produzida pelo Slam do Grito e Edições do Tietê, ambos coletivos de literatura da cidade São Paulo. O material é confeccionado em papel branco, medindo $21 \mathrm{~cm}$ x $15 \mathrm{~cm}$, impresso em preto e com dezoito páginas. Em todas as páginas há ilustrações e uma parte delas é produzida por Ligia Regina, as outras não possuem créditos, o que indica que foram extraídas a partir de banco de dados de imagens disponíveis na internet. Essa edição é de junho de 2017 e homenageia mulheres escritoras, trazendo uma pequena biografia de quatro poetas; são quarenta e duas poesias e a maioria das poesias publicadas nesse número são de autoria feminina. No verso da capa consta o editorial e o expediente, no verso da contracapa uma última poesia e a propaganda de um programa de rádio chamado Poesia é da hora.

Imagem 31. Capa e contracapa da revista Poesia sem Medo.
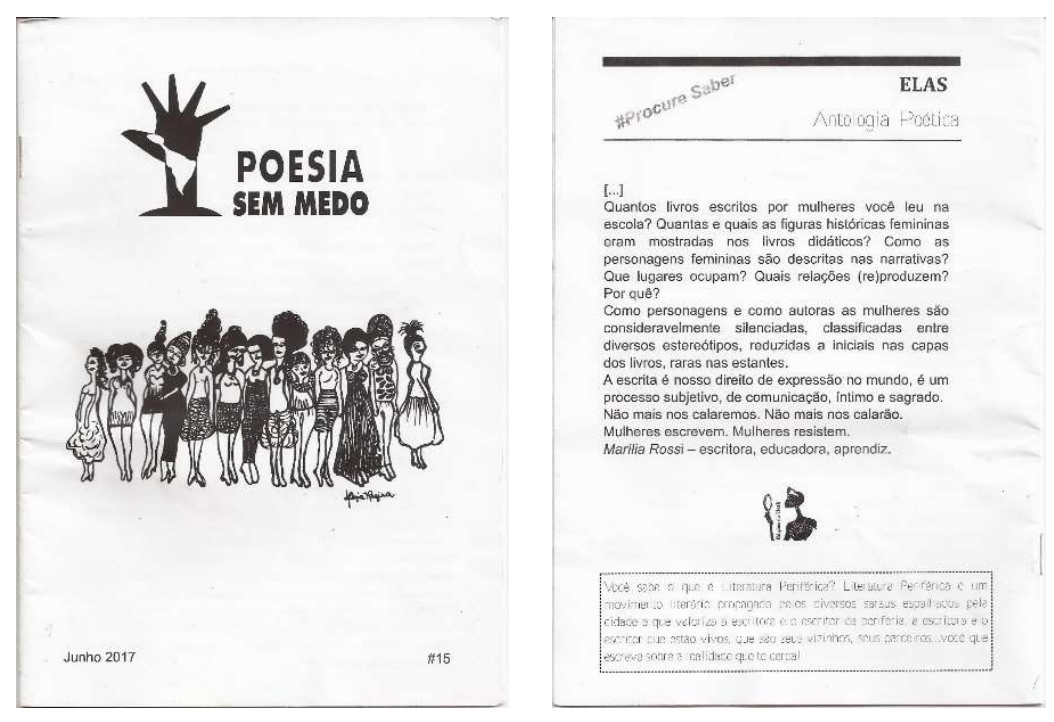

A capa traz uma ilustração dedicada às mulheres e na contracapa há a indicação de um livro de poesias escrito por mulheres-ELAS: Antologia Poética -, um texto breve sobre literatura escrita por mulheres e protagonismo feminino, no quadro final uma informação sobre Literatura Periférica.

No expediente da revista constam os softwares usados na edição e a autorização para copiar e compartilhar a revista ou parte dela indicando os créditos, além de ter um endereço eletrônico da mesma. 
Em relação ao alcance e circulação deste material, não há informações sobre a tiragem, no entanto como ela foi criada para ser distribuída gratuitamente, supomos que a quantidade produzida é pequena e que a circulação acontece por meio dos grupos que a confeccionam: o Sarau Poetas do Tietê, que detém o selo Edições do Tietê e realiza os saraus na zona norte de São Paulo; e o coletivo Slam do Grito, que desenvolve suas atividades na zona sul da cidade. Além disso, alguns dos autores identificados na publicação são participantes de saraus da zona sul.

\section{Livros}

Os livros compõem o maior grupo desses materiais recolhidos durante a pesquisa e selecionamos dez deles para apresentar as características materiais. Dentre esses livros, três são antologias, sendo um de contos e dois de poemas, outros seis livros são poemas de um único autor e, por fim, um livro que, além das poesias, possui alguns contos, crônicas e aforismos.

As publicações ocorreram no período de 2001 a 2017, sendo que três livros são publicações independentes nas quais o processo de produção do livro não passou por nenhuma editora, os outros seis livros foram produzidos por editoras. Os livros têm o tamanho de $21 \mathrm{~cm}$ por $14 \mathrm{~cm}$, sendo que um deles mede $23 \mathrm{~cm}$ por $16 \mathrm{~cm}$, contendo diversas fotografias - talvez o material seja maior em virtude da quantidade de imagens visando melhor adequação destas com os textos.

A obra Cantos e desencantos de um Guerreiro, de Jefferson Santana, foi publicada em 2011 pela Editora Scortecci e é composta de setenta e uma poesias, sendo que treze delas estão agrupadas sob o subtítulo “Aos Guerreiros distraídos pelo amor”. O livro tem uma dedicatória à mãe e à irmã do autor, consideradas guerreiras periféricas; e prefácio escrito pelo poeta Sérgio Vaz, idealizador do Sarau da Cooperifa. Para Sérgio Vaz, o autor de Cantos e desencantos de um Guerreiro "[...] chegou ao Sarau da Cooperifa com sua voz tímida, e seu jeito simples, típico de pessoas que se revelam logo de cara, e assim como a sua poesia, surpreendeu a todos nós com a sua força poética. E uma rima afiada, como uma adaga que procura corações desavisados" (p. 07).

$\mathrm{Na}$ capa uma foto do autor caminhando na plataforma de uma estação de trem, cena típica dos moradores da capital que utilizam os transportes públicos regularmente. Na contracapa uma poesia intitulada "Pássaro" representativa do conteúdo do livro, uma 
poesia sobre a condição de trabalhador explorado, este é o principal tema que permeia esta obra. A última página inclui o endereço eletrônico e blog do autor.

Imagem 32. Capa e contracapa do livro Cantos e desencantos de um Guerreiro.
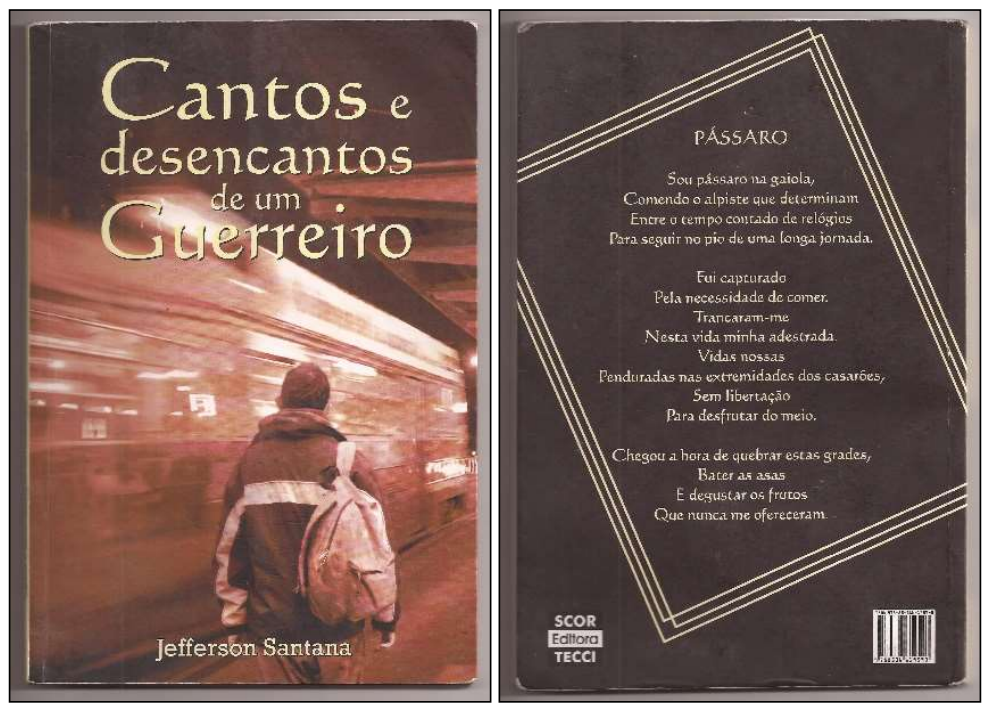

Pétalas e Pedradas, publicada em 2014, é uma obra independente do mesmo autor, já que não possui vínculo com nenhuma editora. $\mathrm{O}$ livro possui uma capa e contracapa com uma ilustração em preto e branco representativa do título da obra, elaborada por Lúcia Vitória Achê. É um livro composto por cento e trinta e quatro textos poéticos sequenciados e sem nenhum subtítulo. A apresentação elaborada por Ni Brisant, co-fundandor do Sarau Sobrenome Liberdade, intitula-se Do canto fez-se o voo e, para além de apresentar a obra ao leitor, relata de modo breve a biografia do autor e seu livro publicado anteriormente. As ilustrações presentes em algumas poesias são de Lu'z Ribeiro, membro do Coletivo Poetas Ambulantes, e de Frenesi. O selo deste coletivo está impresso no interior do livro.

Imagem 33. Capa e contracapa do livro Pétalas e Pedradas.
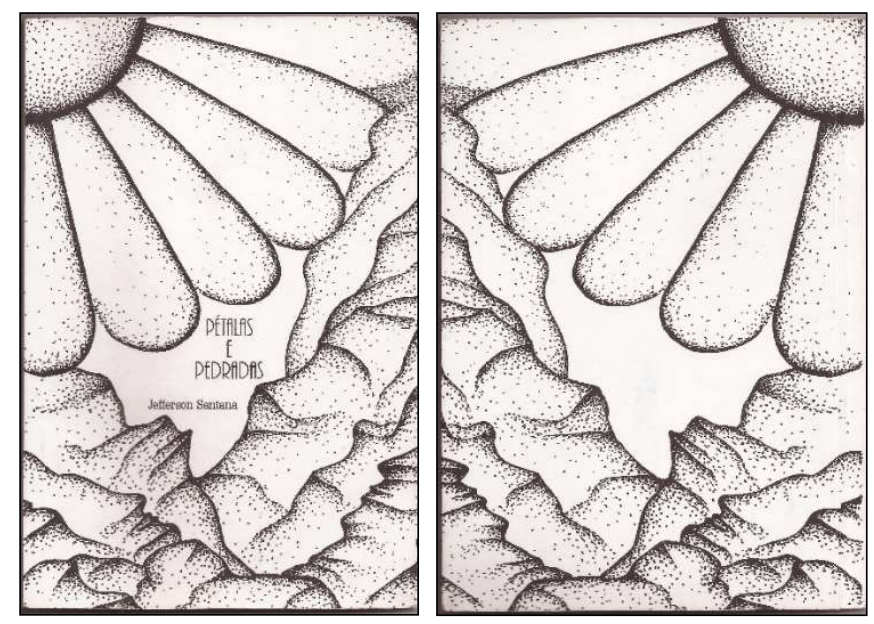
Uma vez Poetas Ambulantes... é uma publicação do Coletivo Poetas Ambulantes na qual estão reunidos poemas e fotos dos integrantes do grupo, além de relatos das intervenções realizadas em espaços públicos. Publicado pela editora Conecta Brasil, o livro tem o símbolo da Prefeitura de São Paulo e do projeto VAI - Valorização de Iniciativas Culturais. O livro está na segunda impressão, sendo que a primeira edição e impressão são de 2013. O livro é composto de três narrativas iniciais a modo de apresentação tanto da história quanto da proposta do coletivo. $\mathrm{Na}$ sequência estão os textos poéticos produzidos por 21 autores e, no final do livro, uma breve apresentação de cada autor.

Imagem 34. Capa e contracapa do livro Uma vez poetas ambulantes...
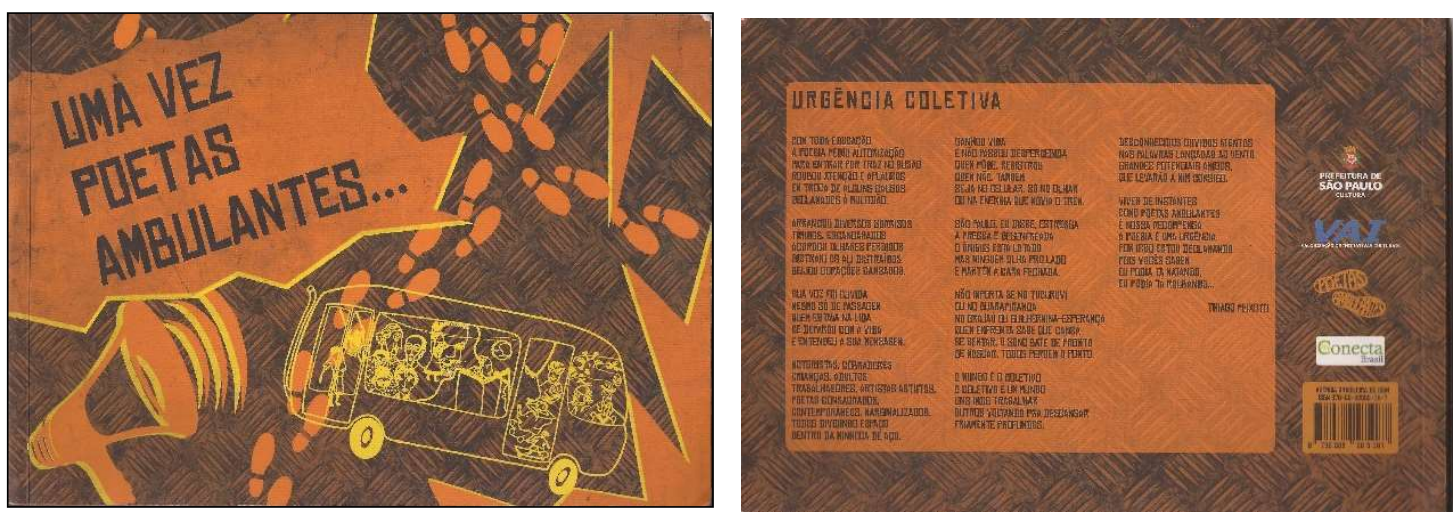

A capa foi criada com a ilustração de um transporte público com várias pessoas em seu interior e, em destaque, aparece uma pessoa com um livro, no contexto da imagem um megafone e marcas de passos. Essa imagem representa o trabalho desenvolvido por este coletivo que faz leituras e declamações de poesias em transportes públicos da cidade de São Paulo. Outros tipos de intervenções literárias também são realizados, mas a principal ação deste coletivo acontece nos transportes públicos.

$\mathrm{Na}$ contracapa uma poema de um dos poetas que narra em versos um pouco dessa história ambulante de poesia:

Com toda educação

A poesia pediu autorização

Para entrar por traz no busão

Roubou atenção e aplausos

Em troca de alguns causos

Declamados à multidão.

Arrancou diversos sorrisos 
Tímidos, escancarados

Acordou olhares perdidos

Distraiu os ali distraídos

Beijou corações cansados.

$[\ldots]$

Viver de instantes

Como poetas ambulantes

É nossa recompensa

A poesia é uma urgência

Por isso estou declamando [...].

(PEIXOTO, 2013).

No miolo do livro foi utilizado papel fotográfico e entre os textos há fotos das intervenções desenvolvidas pelo coletivo todas impressas em cores. Os textos foram impressos em preto e branco, o que gerou um contraste em relação à cor usada em diferentes páginas - branca, roxa e preta. E não possui paginação.

O livro Toda via, lançado em 2015, é uma publicação independente de poesia em que a autora foi responsável por todo o processo de organização, editoração e criação da ilustração da capa. Teve uma tiragem de mil exemplares que ela mesma divulgou e vendeu nos saraus e outros espaços literários. A apresentação foi escrita por Janaína Moitinho, que é uma professora que também participa de saraus. Os cinquenta e seis poemas que compõem o livro estão organizados da seguinte forma: Entre/tanto (singelagens e metas físicas), Con/tudo (documentos sócio-histéricos), A/pesar (hermenêutica dos amores brutos), Em/bora (punches de 1/2 libra) e Mas (...). O texto da orelha do livro diz: “- Escuta:”. Na orelha da contracapa há uma breve biografia da autora acompanhada de uma foto. Para o miolo utilizou-se papel Polen Bold em tom amarelo, impressão em preto e sem ilustrações.

Imagem 35. Capa e contracapa do livro Toda via,

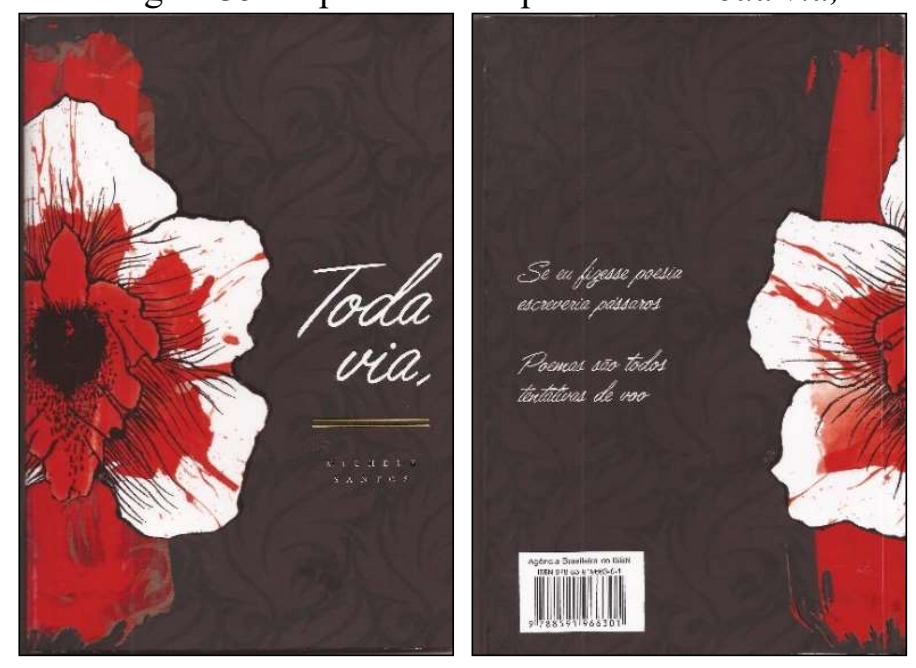


Após a última poesia há sete páginas em branco e sem paginação o que pode indicar que a autora deixou essas folhas sem texto para o que o leitor pudesse se arriscar a escrever.

O livro Falo (2016) é composto de quarenta e cinco poesias precedidas de dedicatória e agradecimento do autor, após o sumário há uma apresentação escrita pelo Sacolinha ${ }^{146}$ e no final há um posfácio elaborado por Renato Almeida e, em seguida, uma fotografia do autor e seu endereço eletrônico. No interior do livro há três ilustrações, uma delas é a reprodução em preto da imagem da capa e mais duas que dialogam com as poesias. A imagem de capa é colorida, como na imagem acima. O miolo foi impresso em preto e o papel utilizado é em tom amarelo. A Editora Espaço Idea é a responsável pela edição do material. E o texto de orelha foi produzido por uma professora que também é frequentadora de saraus.

Imagem 36. Capa e contracapa do livro Falo.
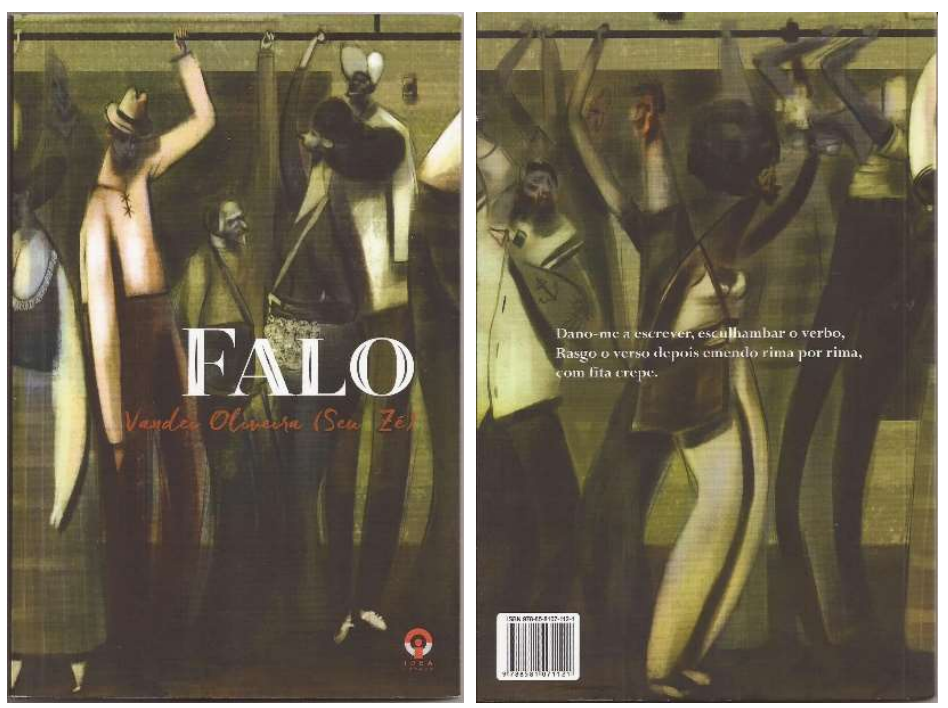

O livro Caçando Estrelas foi publicado em 2001 pela editora Nativa. É um material com uma edição simplificada, em papel branco, impressão em preto, sem orelha na capa, o texto da contracapa foi elaborado pelo editor, possui epígrafe, texto de agradecimento e uma apresentação ao leitor todas escritas pela autora. São sessenta e quatro poesias organizadas de modo sequencial e sem nenhuma separação e/ou subtítulo,

\footnotetext{
${ }^{146}$ Sacolinha é o pseudônimo de Ademiro Alves de Sousa, escritor de romances e contos.
} 
e não há dados da autora presente no material. O livro, paginado, também possui índice que antecede os poemas.

Imagem 37. Capa e contracapa do livro Caçando Estrelas.
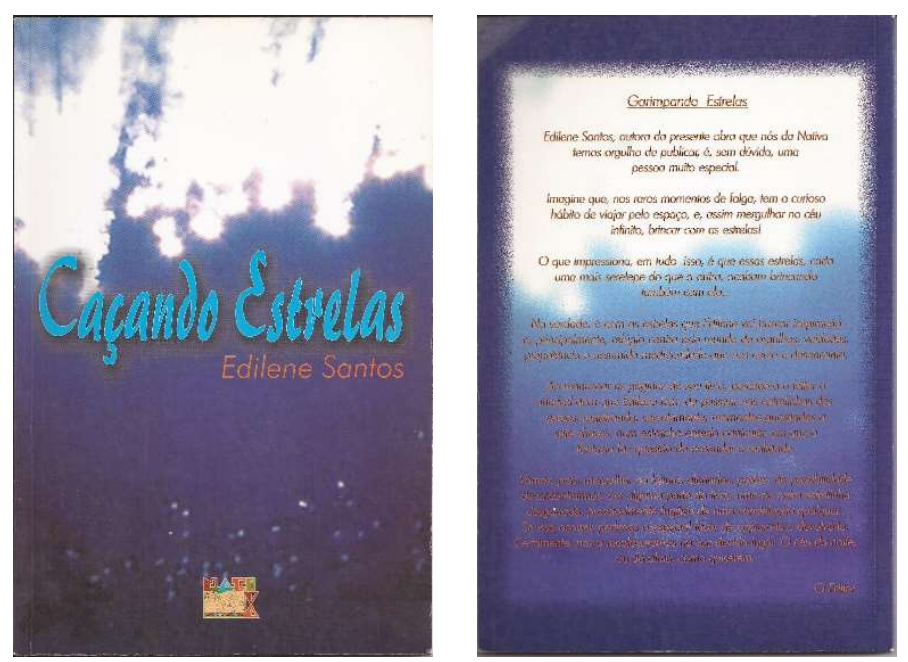

Elas Antologia Poética foi publicado em 2017 por um grupo de autoras de modo independente. Ao observar o material percebemos que todo o processo de edição foi feito por esse grupo, e que, inclusive, a ilustração e arte da capa foram desenvolvidas por mulheres. É um material de edição simplificada, com utilização de cores somente na capa, sendo o miolo impresso em preto e com papel branco.

Imagem 38. Capa e contracapa do livro Elas.
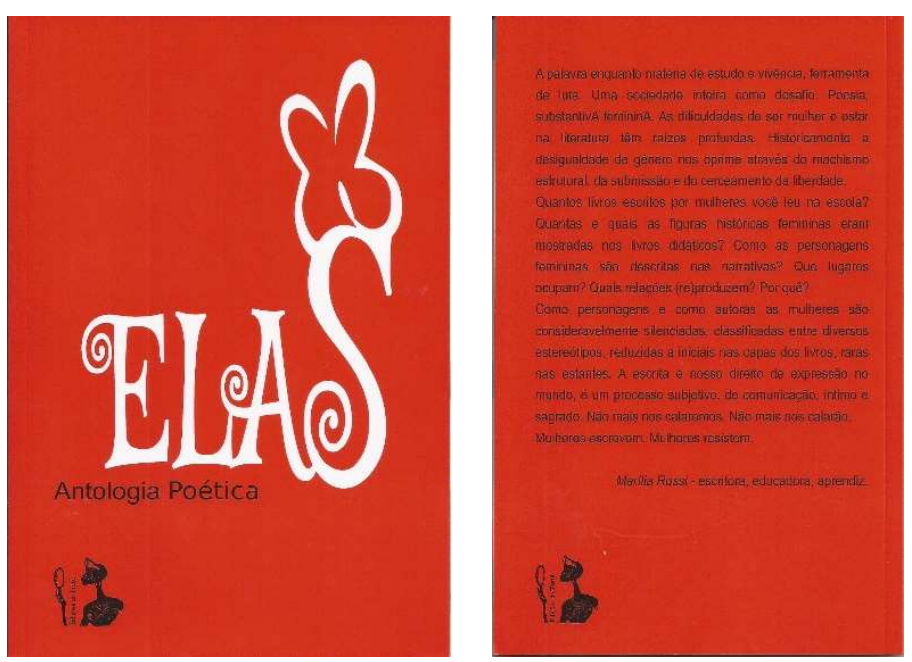
A publicação não possui registro, e sua edição se deu por meio de softwares livres. No material é possível identificar tanto uma apresentação escrita por uma das autoras, quanto ausência de índice dos poemas. Talvez a falta de índice justifique-se por ser uma publicação caracterizada por textos poéticos curtos. O texto da contracapa foi escrito por professora escritora de Minas Gerais. No final do livro há uma breve apresentação de todas as mulheres que participaram na produção do material e, sem seguida, um posfácio. O selo Edições do Tietê está impresso no material e, talvez, seja pela participação de uma ou mais autoras no sarau que detém tal selo. Uma característica interessante diz respeito à autorização para a reprodução sem fins comerciais, desde que citados os nomes das autoras.

A Vida em Três Tempos é uma publicação de 2014 produzido pela editora Ibis Libris do Rio de Janeiro. Este livro, escrito por um único autor, traz poesias, aforismos, contos e crônicas organizados sob a perspectiva do tempo, conforme o título da obra. Assim, os textos foram agrupados: Em Tempo de Guerra, Em Tempo de Trégua e Em Tempo de Paz. No miolo encontramos o sumário, a dedicatória muito breve escrita em uma frase, e os setenta e um textos.

Imagem 39. Capa e contracapa do livro $A$ vida em três tempos.
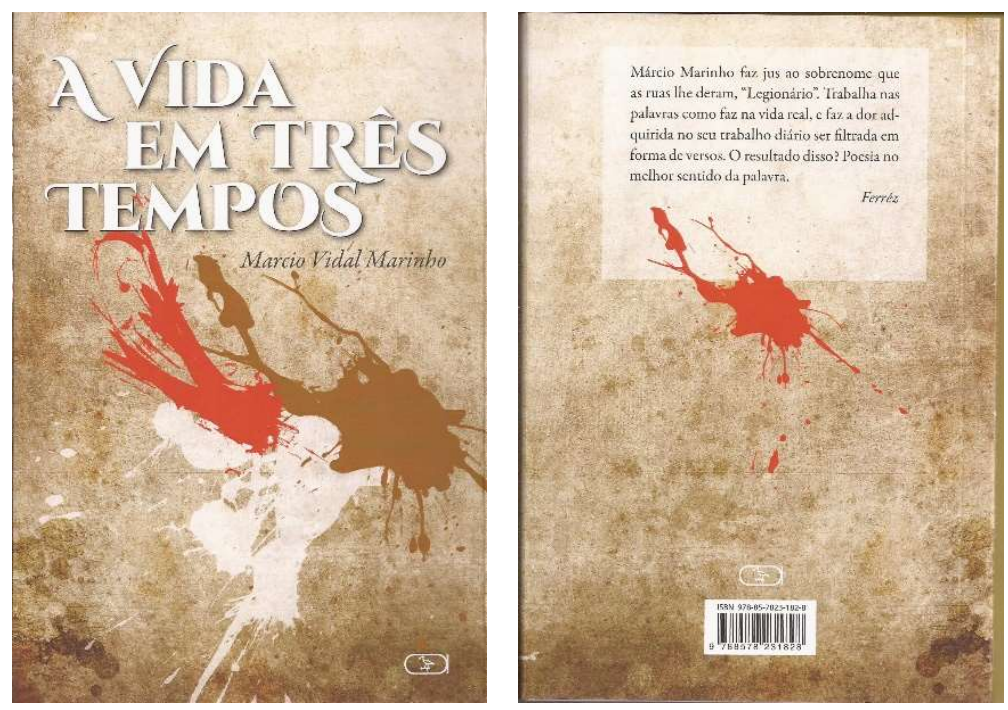

O texto da contracapa foi escrito por Ferréz que é um poeta muito conhecido da periferia de São Paulo; o texto da orelha de capa é do professor da USP Emerson da Cruz Inácio, que faz uma breve apresentação da obra; e na orelha da contracapa consta uma biografia do autor com indicação de seus livros e a relação com o Sarau da Cooperifa. 
Esta é uma edição feita com papel Polen Bold em tom amarelo e as cores são usadas apenas na capa, o interior foi impresso em preto e sem ilustrações.

O livro 21 gramas é uma publicação de poesia, produzida pela editora Ibis Libris do Rio de Janeiro em 2016, na qual constam cinquenta poesias sequenciadas. No material há um sumário com os títulos das poesias, em seguida a dedicatória do autor, o prefácio escrito por Sérgio Vaz, que é o idealizador do Sarau da Cooperifa, e uma epígrafe.

Imagem 40. Capa e contracapa do livro 21 gramas.
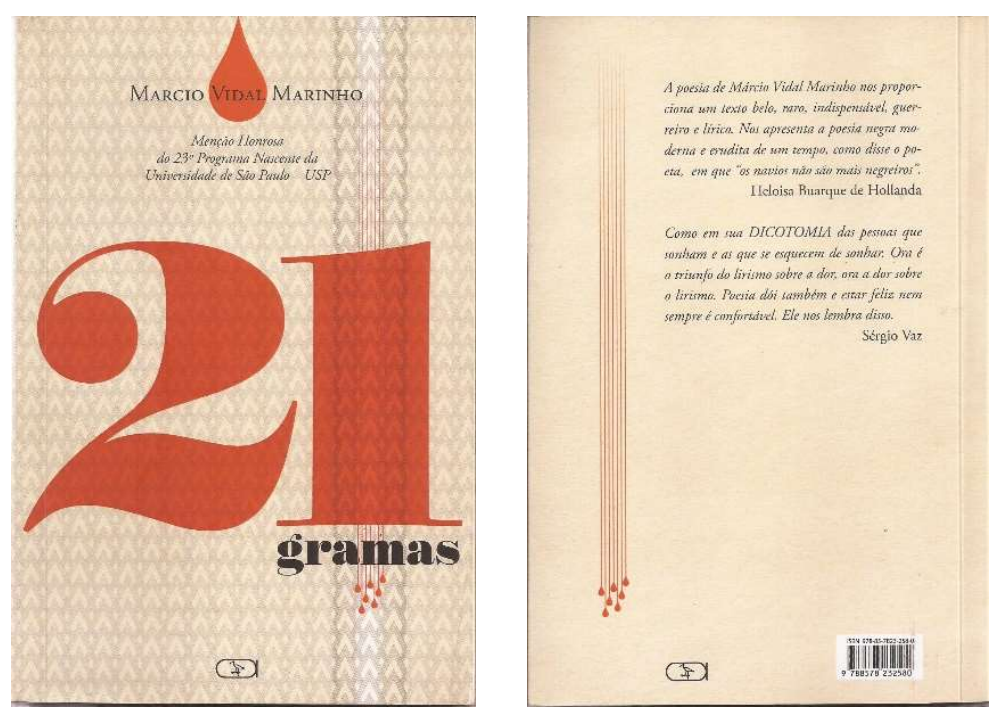

Esta publicação recebeu Menção Honrosa do $23^{\circ}$. Programa Nascente da Universidade de São Paulo (USP), dado que consta na capa do livro e que demonstra ao leitor uma avaliação feita num espaço legitimado de conhecimento que é a universidade, conferindo, assim, qualidade à obra do autor. Outra característica importante deste material é que o texto de orelha foi escrito por Heloisa Buarque de Hollanda, que apresenta o escritor e a obra ao leitor. Também há uma biografia breve na orelha da contracapa. Na contracapa do livro, o editor reproduziu trechos dos textos da Heloisa Buarque de Hollanda e do Sérgio Vaz, ato esse que traz legitimação à obra no campo literário.

\section{Blogs}

Neste momento falaremos de dois blogs que pertencem a duas professoras que publicam, principalmente, em espaços digitais: blog Girassol Poético e o blog Palavrinhas, Palavras e Palavrões! 
No blog Girassol Poético há registros sequenciais de 2009 a 2014, sendo a maioria dos textos de 2009; nos anos de 2015 e 2016 não há nenhuma publicação e a autora volta a publicar no espaço em 2017, que é a última publicação no blog. As publicações foram diminuindo com o passar dos anos, pois outras redes digitais surgiram o que fez com que a forma de publicar também passasse por mudanças. Alguns dos textos postados pela autora não são de sua autoria e estão devidamente citados.

Segue uma imagem parcial do blog:

Imagem 41. Página inicial do Blog Girassol Poético.

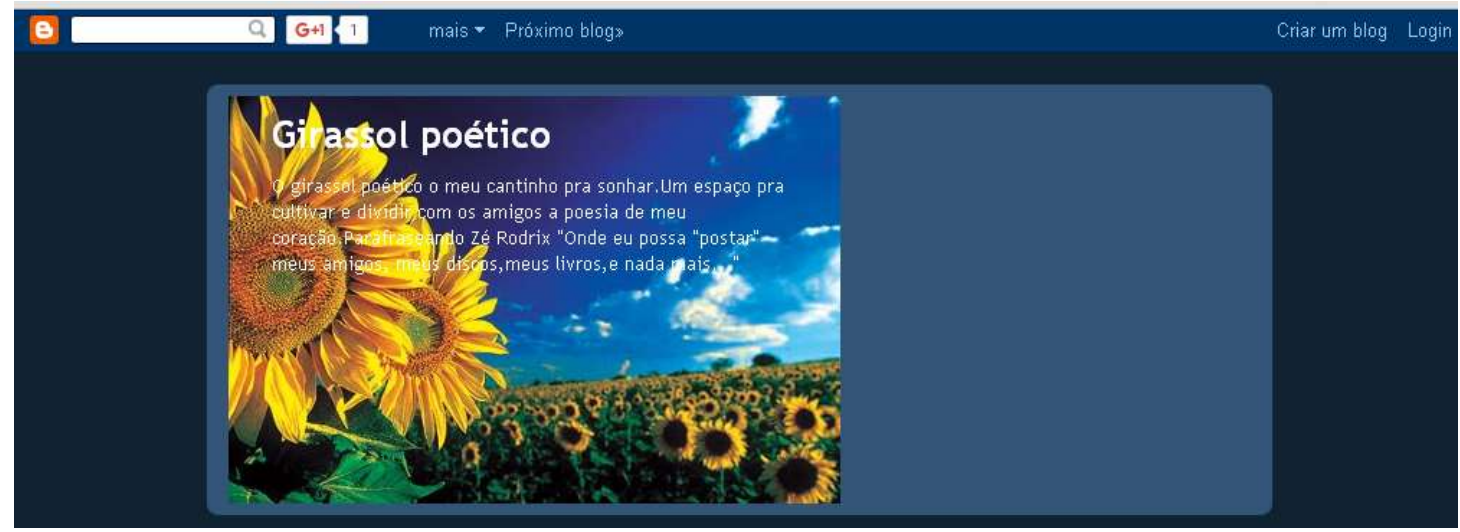

Neste blog a imagem inicial de um campo de girassóis se mantém fazendo referência ao nome da página eletrônica, os textos ficam organizados por data de publicação e podem ser lidos acessando o ano e o mês em que foram inseridos na página. Dessa forma, é possível escolher o texto a ser lido. Esse arquivo fica listado do lado direito da tela e é similar a um índice. O fundo da tela é azul, porém, no espaço em que ficam os textos, a cor é acinzentada, gerando contraste de cor em relação às letras.

$\mathrm{Na}$ imagem que segue, observamos que o texto fica centralizado na página, à direita visualizamos um quadro verde onde acessamos todos os arquivos publicados e abaixo deste há um quadro com as pessoas que acompanham o blog, os chamados "seguidores". 
Imagem 42. Página de publicação do blog Girassol Poético.

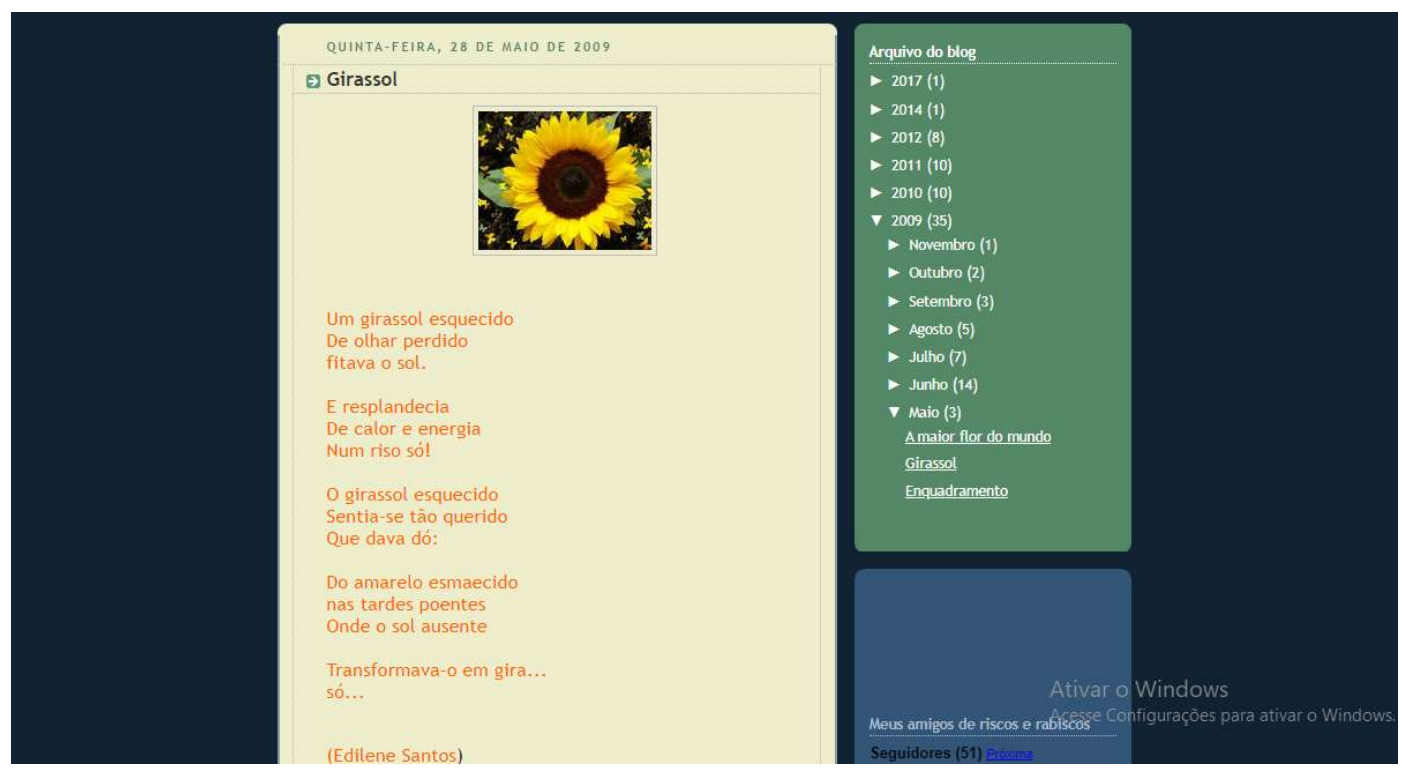

Antecedendo os textos é possível inserir imagens e é o que faz esta autora que coloca fotografias ou ilustrações que dialogam com os textos publicados. A maioria dos textos são poéticos. Apesar da autora não ter publicado textos nos últimos dois anos, este blog se mantém ativo e é o espaço no qual é possível identificar o maior número de textos da autora.

O blog Palavrinhas, Palavras e Palavrões! foi criado em abril de 2015 e tem uma formatação diferente do anterior. As publicações mais recentes estão dispostas em quadros que aparecem ao leitor já na página inicial com o título e parte do texto, como aparece na imagem abaixo. Para ler o texto completo, o leitor precisa "clicar" no texto de seu interesse para poder visualizá-lo. Assim como o blog anterior, os textos ficam arquivados de acordo com a data de publicação na página eletrônica. 
Imagem 43. Página inicial do Blog Palavrinhas, Palavras e Palavrões!

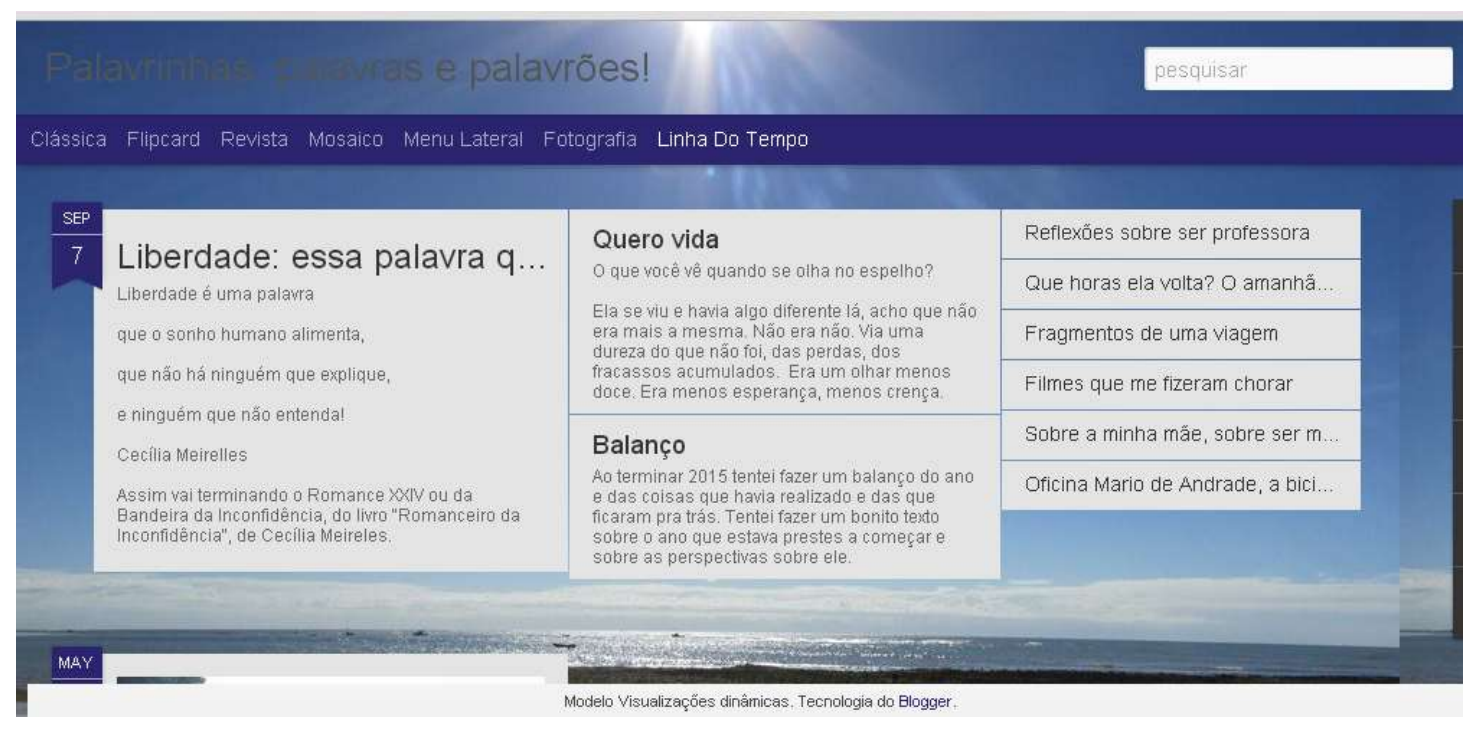

No canto direito da tela aparece uma lista com os títulos de alguns textos publicados o que pode ser também uma forma de acessá-los. Neste blog, a autora escreve textos autobiográficos sobre temas diversos relacionados ao seu cotidiano e espaço social. Dentre os temas presentes estão o exercício de criar um blog, a maternidade, ser professora, entre outros.

A página tem uma fotografia do mar que se mantém fixa na tela, as caixas onde aparecem os textos são claras e, de alguma forma, se misturam com a fotografia. Neste tipo de espaço digital é possível limitar o acesso das pessoas, ou seja, o autor pode escolher quem pode ler seu material. Nesse sentido, este blog teve um período de acesso ilimitado no qual qualquer pessoa poderia ler os textos, depois a autora decidiu limitar a leitura a um grupo de pessoas por meio de autorização ${ }^{147}$.

De acordo com as características apresentadas dos blogs, afirmamos que estas páginas funcionam como suportes digitais para os textos das professoras, os quais podem ser acessados a qualquer momento e sem a necessidade de adquirir (comprar) o material para ser lido, além de não ter custo de publicação para as autoras e permitir alterações, edições e correções a qualquer tempo. Sabemos que esse modo de publicação é completamente distinto do impresso não apenas nos modos de produção, mas também na materialidade que resulta da edição e na experiência de leitura que proporciona, como afirma Chartier:

\footnotetext{
${ }^{147}$ A professora autora do blog decidiu desativar a página, então, não é mais possível acessar o respectivo conteúdo.
} 
O novo suporte do texto permite usos, manuseios e intervenções do leitor infinitamente mais numerosos e mais livres do que qualquer uma das formas antigas do livro. No livro em rolo, como no códex, é certo, o leitor pode intervir. Sempre lhe é possível insinuar sua escrita nos espaços deixados em branco, mas permanece uma clara divisão, que se marca tanto no rolo antigo como no códex medieval e moderno, entre a autoridade do texto, oferecido pela cópia manuscrita ou pela composição tipográfica, e as intervenções do leitor, necessariamente indicadas nas margens, como um lugar periférico em relação à autoridade. Sabe-se muito bem [...] que isto não é mais verdadeiro. $\mathrm{O}$ leitor não é mais constrangido a intervir na margem, no sentido literal ou no sentido figurado. Ele pode intervir no coração, no centro [...]. (CHARTIER, 1999. p. 90 - 91).

Apontamos os blogs como suportes para os textos, pois observamos que o blog é uma forma de publicar os textos em formato eletrônico, de modo similar com que determinado texto seria publicado em suporte impresso, mudando, é claro, a ordenação imposta pelo impresso e que não há no blog, por exemplo, pois o leitor define os caminhos de leitura. Assim, o que essas autoras fazem é publicar seus textos em um suporte digital que é o blog, diferentemente de escritores que produzem literatura digital e, nesse sentido, é preciso fazer a diferenciação.

Corrêa distingue as novas propostas de literatura digital e a literatura em suportes digitais, já que existe uma diferença na literatura que é transcrita do papel para um suporte digital, como os aparelhos exclusivos para leitura de livros digitais e outras telas similares, para aquela que é concebida exclusivamente para o meio digital, ou seja, é um tipo de literatura que requer tecnologia digital em sua constituição.

[...] E aqui se faz necessário repetir a pequena distinção entre a literatura em meio digital e a literatura digitalizada. Essa última é a transposição de material publicado em papel para leitura na tela, sem qualquer outra distinção; a primeira é dependente de estruturas formais (hardware e software) que inviabilizam, em tese, sua produção em papel. Na observação do que se tem feito, muito do que se considera literatura digital se assemelha mais a um jogo e poderia ser resolvido por algo como print-on-demand (impressão sob demanda), vez que o resultado gráfico é uma individuação de leitura cuja programação decorre de combinações pré-estabelecidas [...]. (CORRÊA, 2016, p. 130).

Exemplos de literatura em meio digital citados por Corrêa (2016) são os projetos desenvolvidos por Marcelo Spalding nos quais ele experimenta formas de produção de literatura digital que necessita obrigatoriamente da interação do leitor, não é apenas a leitura do texto, é preciso fazer escolhas para acessar o que se vai ler. No projeto intitulado 
Minicontos coloridos ${ }^{148}$, o leitor escolhe a porcentagem das cores vermelho, verde e azul e clica no link "pinte seu miniconto". O resultado é uma tela colorida gerada a partir das porcentagens de cores escolhidas e os textos possuem relação com a seleção de cores, de modo que, a cada escolha de cores, é gerado um novo miniconto e o leitor tem uma nova experiência de leitura. Em outro projeto do mesmo autor, intitulado Um estudo em vermelho $^{149}$, o leitor encontra uma história com oito possibilidades de desfecho e para começar a leitura envia seu nome e endereço eletrônico, o que faz com que o leitor se transforme em um personagem da história que é lida. O leitor precisa escolher entre duas possibilidades, capazes de gerar desfechos diferentes.

Neste sentido, esclarecida a diferença entre literatura digital e literatura em suportes digitais, reafirmamos que o que as autoras de blog fazem é a publicação de literatura em suportes digitais.

\subsection{Distinção: busca por reconhecimento}

Nesse momento vamos discutir o que significa a participação dos professores em concursos e prêmios literários, tais como o Jabuti, o Prêmio São Paulo de Literatura e o Programa Nascente da USP, tendo em vista que, além do concurso literário Valeu, Professor, identificamos professores que não só participaram de outros concursos como também, três deles, estão inscritos em prêmios de literatura.

Denice Catani, em seu artigo sobre os escritos dos professores no campo educacional ${ }^{150}$, busca compreender a relação dos professores com a produção de manuais, revistas e obras memorialísticas. Delimitando três períodos que marcam movimentos no campo educacional brasileiro - décadas finais do século XIX, as décadas de 1920 e 1930, e os anos 1960 e 1970 - Catani (2008) afirma que os escritos de professores nesses momentos evidenciam disputas no campo e a busca por mais espaço nas ciências humanas para a pedagogia.

[...] Escritos de defesa da pedagogia como ciência, obra dos educadores-cientistas podem ser identificados nos períodos propostos, notadamente desde o início. Por outro lado, a tradução de

\footnotetext{
148 O projeto está disponível na seguinte página: http://www.literaturadigital.com.br/minicontoscoloridos/ 149 Projeto disponível na seguinte página: http://www.literaturadigital.com.br/estudoemvermelho/

${ }^{150}$ CATANI, D. B. Os escritos dos professores no campo educacional brasileiro (1890 - 1970). In: Actas do VII Congresso Luso-Brasileiro de História da Educação. Porto, Portugal: Faculdade de Psicologia e Ciências da Educação (universidade do Porto), jun. 2008, p. 1 - 10.
} 
conhecimentos de outras áreas (psicologia e filosofia) e também a tradução da legislação põem-se a serviço das orientações práticas que se forjam no intuito de dizer aos professores como devem proceder. Educadores-tradutores escrevem para pautar diretamente a conduta docente. Uma força mais indireta pretende ser exercida pelos escritos éticos e poéticos-literários, que quase sempre de caráter memorialista, projetam-se sobre a vida e o trabalho dos professores. Os educadoresliteratos afirmam-se, talvez, pelo recurso à modalidade artística mais prontamente disponível para eles. (CATANI, 2008, p. $1-2$, grifos da autora).

Como expresso no excerto acima, Catani supõe que os professores utilizem o recurso literário por ser uma modalidade artística mais próxima, ou seja, o trabalho com a linguagem faz parte da formação docente e do cotidiano profissional e a literatura requer o desenvolvimento dos recursos linguísticos aliada à fabulação. Essa suposição dialoga com o universo de professores participantes desta pesquisa posto que a maioria possui formação em cursos da área de ciências humanas. De outro ponto, os professores escritores desta pesquisa não se restringem a produzir textos memorialísticos e, também, não são restritos às temáticas do âmbito educacional.

Considerando os estudos desenvolvidos por Bourdieu ${ }^{151}$, o campo literário está inserido num âmbito de poder, que pode ser entendido como "o espaço das relações de força entre agentes ou instituições que tem em comum possuir o capital necessário para ocupar posições dominantes nos diferentes campos (econômico ou cultural, especialmente)" (1996, p. 244). A “ordem literária” caracteriza-se pela inversão econômica, ou seja, aos produtos culturais dos escritores são atribuídos valores que não correspondem ao seu custo de forma direta, mas ao valor simbólico atribuído à obra e que não é mensurável economicamente. A atribuição do valor é uma ação das instâncias de consagração que existem no campo literário como a Academia, as editoras, os concursos e prêmios, por exemplo.

Chartier (2005) afirma que a produção do valor inclui a produção de uma crença neste que é conferido pelos leitores que, neste caso, precisam ter adquirido as disposições necessárias para uma apreciação estética. Desse modo, é o campo literário, por meio de suas instâncias de consagração, que legitima ou não o escritor e sua obra literária.

Os professores entrevistados participaram de prêmios e concursos literários promovidos por diferentes instituições e com públicos específicos, a saber: o Concurso Literário Valeu, Professor, realizado no âmbito da Secretaria Municipal de Educação e

\footnotetext{
${ }^{151}$ Referência ao estudo desenvolvido em As regras da arte (1996).
} 
destinado somente aos seus professores e com repercussão restrita ao universo institucional; O Programa Nascente da Universidade de São Paulo, que visa o público de estudantes em diversas categorias artísticas, neste caso o professor se inscreveu na categoria Texto; o renomado Prêmio Jabuti, que contempla obras nas seguintes modalidades literárias: poesia, conto, crônica, romance, literatura infantil e juvenil, sendo que a professora participante inscreveu uma obra na categoria poesia; o Prêmio São Paulo de Literatura, realizado pela Secretaria da Cultura do Estado de São Paulo, e destinado à apreciação de romance de ficção, abrangendo duas categorias: melhor romance do ano e melhor romance do ano de estreante (destinada a escritores estreantes) - neste caso, a professora concorreu a melhor romance do ano.

Como pode ser observado, em todas as situações os professores escritores inscreveram suas obras - sendo livro completo ou texto individual -, para a participação nesses concursos, e este aspecto evidencia a busca por certo tipo de reconhecimento no campo. Todavia, podemos afirmar que existem distinções no tocante à essa busca por reconhecimento, pois os professores participantes do Concurso Literário Valeu, Professor sabem que o concurso se restringe ao âmbito institucional. De certo modo, isto nos permite inferir que os professores buscam demonstrar suas aptidões no campo educacional em que estão inseridos, isto é, vislumbram o reconhecimento de seus pares.

Quando perguntamos aos professores sobre a participação no referido concurso, obtivemos respostas variadas relacionadas à motivação e posterior desmotivação em alguns casos, como veremos a seguir: "[...] me inscrevi sem muita expectativa e mandei lá, mas é muito interessante esse negócio de participar de concurso, [...] quando você é escritor de gaveta, né, você quer testar, quer ver se... se o texto provoca alguma coisa nas pessoas, né, então foi positivo por esse lado" (Entrevista pessoal professora Arlete, 2018, grifo nosso).

[...] foi muito gratificante ter participado do projeto, e... me senti bem, eu também gostei do meu poema, da produção, e ter ido ler na Bienal, eu senti [...] super realizada, era uma produção minha, e... essa possibilidade eu achei super especial que eles deram, eu gostei muito [...] então, pra mim, assim, foi uma experiência muito boa, eu gostei muito e lamentei depois de não ter mais, porque eu não vejo, assim, esse lado aí incentivando nós professores que temos esse tipo de trabalho a publicar, [...] a gente acaba tendo meio que guardado [...]. (Entrevista pessoal professora Camila, 2017, grifo nosso).

Porque eu vejo que a gente é muito pouco valorizado em sala de aula assim, e esse concurso também, foram duas edições, depois eles mesmos pararam, sabe, pouco destaque [...], talvez um apoio da prefeitura pra que eles publicassem seus livros. [...] esse negócio de 
concurso já me deixa meio assim, mas como eu falei, [...] em 2010 assim, eu achava que ainda eu tinha que, [...] provar pra todo mundo alguma coisa, né, eu não tenho que provar mais nada pra ninguém, sabe, provar que eu escrevo, que tem valor, porque olha... sabe, porque como eu falei também, isso aí tem a ver um pouco com a família, de vir de um família que precisava... via, talvez, o estudo como um modo de ascensão social, estudar para ascender socialmente e ganhar dinheiro, e a literatura não tem essa função [...]. (Entrevista pessoal professor Daniel, 2018, grifo nosso).

Os excertos acima transcritos nos oferecem indícios que nos possibilitam compreender a participação desses professores em um concurso literário institucional: por uma parte, revela-se a busca pelo reconhecimento da própria produção, ou seja, a necessidade de que uma autoridade legitimada pelo campo apresente uma avaliação que eleve o texto da condição de uma produção individual para o âmbito literário reconhecido, conforme consta nos relatos de Arlete e Daniel. Por outra parte, no caso da professora Camila, que escreve a partir de demandas como o concurso, supomos o interesse pelo reconhecimento da qualidade do texto, sobretudo quando afirma que: "Eu gosto do que eu escrevo então, às vezes, eu imagino que as pessoas vão gostar também [...] (Entrevista pessoal professora Camila, 2017).

Os relatos apresentados expressam a noção de valor que o concurso proporcionou aos professores selecionados, muito embora eclodam posicionamentos contrastantes por parte dos concorrentes: para a professora Camila, por exemplo, a participação no concurso foi uma forma de sentir-se realizada e incentivada, ao passo que para o professor Daniel o concurso, além do pouco destaque, não teve continuidade, e isto não colabora para a efetiva valorização do professor.

No relato que segue, o professor Jamir aborda outro aspecto que é o da divulgação, isto é, o concurso como um espaço para divulgar o que produzem os professores, assim, entendemos que é uma busca por ser reconhecido no espaço social em que se localizam.

Eu me inscrevi porque apareceu, as divulgações da prefeitura, mas eu era também um divulgador. [...] Que é um estímulo à produção, né. Que a gente está estimulando a criança, você estimula o educador também pra poder gerar um, uma sinergia de pensamento e de ideia. [...] Eu acho que pra todo mundo que participou [...] é uma mobilização interessante. Então, um canal [...] de divulgação, de mostra, de dizer, "oh, eu, a rede produz". Tem coisas boas e coisas ruins, né, estava até relendo... [...]. (Entrevista pessoal professor Jamir, 2018).

$\mathrm{O}$ relato que segue manifesta o descontentamento da professora que tinha expectativas em relação ao concurso no âmbito institucional, acreditando que essa ação 
fosse o início de uma sequência de outras que levassem à valorização das aptidões dos professores em relação à escrita:

[...] eu participei mesmo, porque qualquer coisa que tem de literatura, na época, eu era..., [...] não aconteceu nada e eu achei que acontecesse, achei que esse seria o primeiro passo para uma valorização do professor escritor, por exemplo, do professor que escrevesse, [...] mas não houve [...], teve o concurso, mas não teve por exemplo, que nem essa ideia de fazer uma revista voltada [...] pra artes em geral, eu nem tinha falado de literatura, mas de artes mesmo, até coisas de artigos científicos, que tem vários professores que estão na rede e estudam ainda, ou mestrado, ou doutorado, ou especialização, ou que escreve mesmo e gosta de escrever [...]. Também [...] porque se você falar, o professor escritor, não quer dizer que ele seja escritor de escrita de Literatura Infantil ou que seja escrita sobre a escola, né, que a escrita é algo mais, ainda mais coletivo do que é escola, eu acho. Nesse sentido, também, meio que desanimei, porque eu achei que [...] sempre que houvesse o concurso haveria essa filtragem de [...] temática do professor-aluno, dessa relação, mas foi não só por isso, mas foi pelo que eu te falei também, que eu acho que não há mesmo uma política de incentivo à literatura em geral [...]. (Entrevista pessoal professora Márcia, 2018, grifo nosso).

De todo modo, este relato nos leva a refletir que circula nos discursos dos professores participantes do concurso uma pauta, um apelo pela valorização dos produtos culturais produzidos pelos professores que, para terem um valor atribuído, precisam de instâncias de consagração. O Concurso Literário Valeu, Professor se constituiu nessa instância quando fez o público, ainda que restrito à instituição, conhecer um grupo de professores que escrevem literatura, garantindo, assim, a publicação dos textos. Nesse sentido, Bourdieu afirma ao tratar da ação do "comerciante de arte", neste caso, a instituição, que: "Ele contribui para fazer o valor do autor que defende apenas pelo fato de o levar à existência conhecida e reconhecida, de assegurar-lhe a publicação (sob sua capa [...]), oferecendo-lhe como garantia todo o capital simbólico que acumulou, e de o fazer entrar, assim, no ciclo de consagração [...]” (1996, p. 193).

Em outra posição estão os professores que participam dos saraus periféricos e que no campo da literatura periférica já são reconhecidos como poetas pelo público frequentador. Em relação a esse campo, Tennina (2017) nos apresenta uma interpretação fundamental para compreender a noção de poeta utilizada nos saraus periféricos para nomear todos aqueles que apresentam seus textos autorais e que não precisam ser pessoas letradas: "A noção de poeta com que trabalham Vaz e muitos outros poetas dos saraus da periferia está associada diretamente à persona, entendida no mesmo sentido de prósopon, termo grego que conserva um significado ligado ao que está atrás da máscara, a 
intimidade de uma pessoa"(TENNINA, 2017, p. 52, grifos da autora). Assim, o poeta é aquele expressa sua própria linguagem ao estilo do texto, inclui as diversas expressões artísticas. Portanto, mesmo os professores que se afirmam como produtores de literatura periférica, pois inscritos territorialmente e dentro de temáticas sociais características desse campo, sendo reconhecidos em seus espaços sociais como escritores/poetas, buscam extrapolar o universo literário periférico onde já são reconhecidos e vislumbram, ainda, o reconhecimento em âmbito maior, em instituições que reconhecidamente tem o poder de legitimar um artista - que são os chamados Prêmios nos casos que aqui trataremos.

O relato abaixo é da professora Michele que inscreveu seu livro, Todavia, uma produção independente, no Prêmio Jabuti em 2016, na categoria poesia:

[...] Ah, pra mim o livro é de 2015! É o livro, cara, se ele for um bom livro, ele vai ter uma sobrevida boa. Às vezes, as pessoas pensam por causa de concursos, eu, por exemplo, eu sou muito louca, mandei pro Jabuti, né?! Mandei, [...] esperei, paguei. É um rim, paguei quatrocentos reais. Mas, era aquela coisa, eu tinha isso em mente já. Ele não é um livro que eu estou trabalhando, trabalhando só pelo livro. Então, esse livro também vai custear outras coisas. Por exemplo, o Jabuti custeou pela venda do livro. [...] E, aí, existe toda essa questão, que é discutida hoje em dia, que os homens ganham mais prêmios, que existe todo um QI dentro desses concursos. Mas, gente, eu não quero deixar de ser essa romântica, abestada, cheia das cobiças, eu vou ser e vou continuar sendo. Porque, se eu não mandasse, eu ia ficar: "E se, e se, e se?", eu odeio o "E, se?", mesmo... quebrei a cara! Tá, mas eu não vou morrer com essa dúvida, eu sei que não foi. (Entrevista pessoal professora Michele, 2017).

De acordo com o relato, a professora não foi selecionada para o prêmio que abrange todo o território nacional e, por isso, recebe muitos inscritos. Nesse excerto, a professora fala de um "QI", uma expressão usada popularmente para referir-se a indicações, de modo que o ponto de vista apresentado pela professora representa, em certa medida, a constituição do campo literário que não é isento de tensões. Assim, um agente, um escritor já reconhecido ou que foi publicado por um editora de maior capital simbólico, provavelmente terá mais chances de receber um prêmio como este, posto que já passou pelo processo de reconhecimento e ocupa, por consequência, uma posição mais privilegiada no campo.

O relato seguinte é do professor Márcio, que submeteu seu livro 21 gramas, antes mesmo de ser publicado no $23^{\circ}$. Programa Nascente da USP, tendo recebido pelo texto uma Menção Honrosa: 
É, porque, por exemplo, o 21 gramas antes de publicar, eu coloquei em concurso, e no concurso teve resultados muito positivos, por exemplo, lá no Nascente, da USP, eu ganhei menção honrosa... É, então, eu ganhei a menção honrosa no Nascente e aí depois, conversando com os, por acaso encontrando os julgadores lá do concurso, eles me deram alguns toques, na verdade me falaram que só não ganhei porque não existe segundo lugar, que eles ficaram entre meu texto e o de outro cara, e o outro cara estava há dez anos lá na USP tentando o mesmo texto, e aí ele ganhou. Ele foi preparando tanto esse texto que chegou uma hora que eles falaram, "não, agora tá bom". [...] Foi inédito, e tal, ter recebido essa menção honrosa. [...] é que foi o primeiro texto da literatura periférica a receber. (Entrevista pessoal professor Márcio, 2017).

Ao submeter seu texto poético ao prêmio, no interior da Academia, o professor Márcio foi em busca de uma avaliação especializada da sua produção e, ao receber a menção honrosa, algo inédito no programa, acabou não só legitimando o escritor/poeta de literatura periférica, como também rompendo o território da periferia na difusão de sua prática. Após o prêmio, o professor fez as alterações recomendadas pelos especialistas para publicar o livro e, nesse processo, alcançou outra marca de legitimação, já que o texto de orelha do livro foi escrito por Heloisa Buarque de Hollanda, uma acadêmica do campo literário.

A professora Márcia, citada anteriormente por participar do concurso literário Valeu, Professor, participou no ano de 2018 do Prêmio São Paulo de Literatura, ficando classificada entre os dez finalistas ${ }^{152}$ na categoria romance ${ }^{153}$. Apesar deste fato ter ocorrido após a nossa pesquisa de campo, consideramos relevante para essa discussão citar a ação da professora em se inscrever neste prêmio, bem como o resultado obtido. $\mathrm{O}$ fato dela não ter sido a vencedora da melhor obra do ano, não diminui o prestígio alcançado, visto que passou pela avaliação dos especialistas do prêmio e foi classificada. Essa classificação assegura, como na citação de Bourdieu (1996) indicada anteriormente, que a obra e a escritora estejam inseridas no "ciclo de consagração" vinculado ao referido prêmio, permitindo que a professora seja considerada uma escritora legítima e, com isso, ingresse em espaços cada vez mais prestigiados.

Portanto, depreendemos que os professores que se inscrevem em prêmios e concursos buscam um reconhecimento no campo, no entanto, não podemos afirmar que todos buscam o mesmo tipo de reconhecimento, pois como vimos nos relatos e nos tipos de prêmios e concursos que se inscrevem, podemos afirmar por correlação que há

\footnotetext{
152 Lista das obras finalistas do prêmio em 2018 disponível em: https://premiosaopaulodeliteratura.org.br/blog/finalista-2018/

${ }^{153}$ A obra finalista é $O$ enterro do lobo branco, publicada pela editora Patuá em 2017.
} 
diferenciações entre um prêmio já consagrado de literatura e outro de âmbito mais restrito. Dessa forma, entendemos que os professores participantes do concurso literário Valeu, Professor e de outros concursos literários de menor abrangência buscam, primeiro, um reconhecimento de suas aptidões no âmbito profissional e, depois, procuram conferir legitimidade ao texto produzido.

Em relação aos professores que participaram dos prêmios de maior abrangência, inferimos que eles objetivam se legitimar enquanto escritores no campo literário e sabem que, para isso, precisam ser consagrados por alguma instância conceituada no campo.

A marca da consagração denota uma distinção daquele professor escritor em relação a outro, este outro pode ser um outro professor no campo educacional ou um outro escritor no campo literário (considerando que estamos nos referindo a posições diferentes nos campos a despeito dos prêmios e concursos referidos), uma característica de diferenciação, segundo Bourdieu:

[...] o que comumente chamamos de distinção, uma certa qualidade, mais frequentemente considerada como inata (fala-se de "distinção natural"), de porte e de maneiras, é de fato diferença, separação, traço distintivo, resumindo, propriedade relacional que só existe em relação a outras propriedades. (1997, p. 18).

\subsection{Interlocução com a realidade: crítica, denúncia e representações}

Neste momento vamos analisar as temáticas presentes nos textos que fazem interlocução com a realidade seja para representar uma determinada realidade, uma percepção do mundo social, seja para criticar ou denunciar questões latentes do universo social desses professores escritores, que buscam por meio de seus escritos ficcionais retratar certa dimensão de suas experiências e percepções de mundo. Para tanto, elencamos as seguintes categorias temáticas extraídas a partir de leituras atentas dos materiais: representações sobre a profissão docente e o contexto escolar no qual os professores narram de modo fíccionalizado aspectos da escola pública e da profissão; a constituição de uma outra de ideia de periferia apresenta textos marcados pela questões territorial e social; o cotidiano em São Paulo evidencia textos que tratam da cidade; escrever do "ponto de vista" feminino traz a autoria feminina e os aspectos que as professores escolhem transformar em ficção; e escrever em tempo de internet aborda 
alguns textos que nos dão pistas de como os professores escritores percebem a cultura escrita na revolução digital.

\subsubsection{Representações sobre a profissão docente e o contexto escolar}

Os textos do Concurso Literário Valeu, Professor são materiais que possibilitaram identificar uma prática de escrita literária entre os professores da educação básica e, para além, encontramos em tais fontes aspectos da profissão docente registrados pelos profissionais, os quais indicam formas de ser e estar na profissão, a relação com os alunos, a valoração do profissional em atuação na educação e as condições de trabalho. São narrativas literárias que nos mostram como esses professores se percebem no interior da profissão e quais conflitos atravessam o contexto escolar e as práticas docentes, ou seja, por meio destes textos conhecemos aspectos do mundo social desses professores e as práticas representadas.

Considerando a perspectiva de prática de Roger Chartier (1990), a percepção do indivíduo em relação ao mundo social gera práticas e estratégias que são sociais e políticas, buscando a imposição de uma autoridade que possa justificar as escolhas realizadas. Assim, as representações do social estão em disputa e são importantes “[...] para compreender os mecanismos pelos quais um grupo impõe, ou tenta impor, a sua concepção do mundo social, os valores que são os seus, e o seu domínio" (CHARTIER, 1990, p. 17).

Portanto, a partir de uma ação institucionalizada da prefeitura em criar um concurso literário com temas amplos que podem ou não remeter ao universo educacional, alguns professores decidem narrar o contexto escolar e suas práticas profissionais nos demonstrando quais são as percepções desse universo social construídas por eles. Esses relatos sobre a profissão foram identificados nos textos publicados nos livros e, também, nos textos inscritos não selecionados para a publicação.

\section{$\underline{\text { Pedro Baleia }}$}

No conto intitulado Pedro Baleia, a professora, narradora-personagem, relata a história do menino Pedro na educação infantil para o qual lecionou durante um ano. 
Naquele início de ano, a professora propôs estudar os animais aquáticos e ao exibir um filme sobre as baleias para as crianças, percebeu que Pedro encantado com as baleias mudou seu comportamento. "[...] Nunca em seus poucos anos de vida ele havia visto um animal tão interessante! Tudo ele queria saber, sua curiosidade não tinha fim: - Que tamanho é a baleia?/ - O que ela come?/ - A baleia é brava? [...]" (SÃO PAULO, 2010, p. 61), e tantas outras perguntas que fazia à professora em classe e, quando estava em casa, era aos pais que questionava. A mãe estava preocupada com o pequeno Pedro, pois ele passou a imitar os hábitos das baleias, queria comer apenas peixe e dizia que não precisava escovar os dentes e, por isso, a mãe procurou a professora para uma conversa e esta relata:

Procurei orientar o melhor possível explicando que poderia ser apenas uma fase, para que ela se acalmasse, que isso é comum e que poderíamos tentar desviar o interesse por outras coisas. / Foi inútil! Nem valentes leões, gigantescos dinossauros ou bravos super-heróis ganhavam das baleias. / Já no dia seguinte, percebi sua transformação! Ele não entrou na sala andando ou correndo como as outras crianças: entrou nadando! (SÃO PAULO, 2010, p. 62).

E a professora segue narrando as estratégias utilizadas na sala de aula para mostrar ao Pedro outros conteúdos que também poderiam ser interessantes:

Ao desenhar só fazia baleias. Pintura, só de baleias. Modelagem: baleias. Escreva seu nome: Baleia. [...] Durante o ano inteiro procurei outros assuntos que o interessassem, mas nada deu certo! Pedia um desenho, mas não podia ser baleia... Ele desenhava o mar e dizia que a baleia estava atrás! Fazia baleia de todo tipo: enormes, pequeninas, baleia mãe, baleia pai, baleia filhinho, baleia dançarina, baleia assassina... (SÃO PAULO, 2010, p. 62).

A narradora-personagem vai nos apresentando dimensões do contexto escolar na educação infantil por meio da descrição das cenas literárias em que desenvolve sua atuação docente. $\mathrm{O}$ ano letivo terminou e o Pedro em sua nova turma, tinha também outra professora. Mas, curiosa, a narradora busca conversar com a professora do Pedro.

Um dia desses encontrei sua nova professora. Não resisti e perguntei:

- E o Pedro, como vai? Ainda é uma baleia?

Ela me olhou, sorriu disse apenas:

- Não. Agora ele é um tubarão!

(SÃO PAULO, 2010, p. 62-63). 
Neste conto ficcional, a professora escritora fez uso dos recursos presentes na literatura fantástica ${ }^{154}$. Inicialmente, a autora estabelece, por meio de diálogo com o leitor, um de pacto de verdade: "Esta é uma história que aconteceu comigo. Eu sei que é verdadeira porque eu conheci o Pedro Baleia. Fui sua professora durante um ano". Depois, ao construir a narrativa, vai criando uma atmosfera de suspense em relação ao comportamento da personagem Pedro, como podemos perceber no seguinte excerto: "Coloquei aquele desenho do "Pinóquio" onde ele é engolido por uma baleia, ele assistiu várias vezes e, agora, a coisa piorou: ele virou uma baleia!”. A atmosfera de suspense vem seguida de outra estratégia, que é a surpresa, recurso usado quando ela narra "entrou nadando!” e "Agora ele é um tubarão!”.

Desse modo, compreendemos que a professora escritora adotou recursos da literatura fantástica para compor essa ficção sobre a escola e a prática pedagógica com efeitos de surpresa tornando o conto Pedro Baleia uma leitura divertida.

\section{Moon Walker}

O conto Moon Walker apresenta um relato cheio de vida e de intensos conflitos de um professor, narrador-personagem, na relação construída com o estudante Maciel no contexto escolar. Antes de apresentar trechos deste conto, pontuamos que a personagem professor não tem nome, é simplesmente professor. E, assim, demarca já no primeiro parágrafo suas condições de trabalho:

[...] Eu estava passando por dias difíceis naquele ano. Tinha ido parar numa escola que ficava há mais de sessenta quilômetros de casa. Além disso, tinha de conciliar os horários com mais outras duas escolas. Foi numa tarde em que o calor estava torrando nossos miolos que ele chegou, todo malandro, negro, cheio de desenhos no corte de cabelo, franzino, com um par de tênis que devia caber uns dois pés dele dentro, querendo puxar assunto pra não fazer a lição, eu andava esperto com todas essas malandragens: / - O senhor tem uma moto, né professor? É meio feia a moto do senhor, mas dá pro gasto. Meu tio tem uma Hornet, por que o senhor não compra uma Hornet? / - Não tenho dinheiro. O que é que seu tio faz? / - Meu tio é ladrão [...]. (SÃO PAULO, 2010, p. 41).

Observamos que, logo no início do conto, o narrador-personagem marca um aspecto da profissão docente: a condição de trabalho. Se considerarmos o território

\footnotetext{
${ }^{154}$ Antologia da literatura fantástica, organizada em 1965 por Jorge Luis Borges, Adolfo Bioy Casares e Silvina Ocampo, apresenta uma reunião de contos fantásticos nos quais diversos recursos podem ser observados. A editora Cosac Naify traduziu a obra original para a Língua Portuguesa e publicou em 2013.
} 
urbanizado das cidades brasileiras, sessenta quilômetros entre uma escola e outra parece algo fictício, no entanto, para uma cidade como São Paulo, este tipo de trajeto convertese em uma distância real, comumente enfrentada pelos professores que possuem jornada dupla. Outro elemento inerente à condição de trabalho refere-se à carga horária diária que, às vezes, é distribuída em até três escolas diferentes. Dito isto, é importante observar que estes fenômenos revelam os baixos salários recebidos pelos professores, os quais necessitam conciliar uma série de fatores, a fim de complementar a renda mensal e, assim, suprir suas necessidades essenciais. Estes aspectos marcados numa narrativa literária representam questões da crise da profissão docente (NÓVOA, 1999) que em seu processo histórico passou por mudanças nas imagens construídas de professores e nas reivindicações por melhores condições de trabalho. Catani e Vicentini (2003), afirmam que a partir dos anos 50, os professores passaram a reivindicar melhores condições de trabalho e reclamar contra os salários que eram baixos "[...] mediante a realização de passeatas e de atos públicos, que procuravam afirmar a imagem do docente como um profissional (não mais um sacerdote) que deveria ser bem remunerado [...]” (2003, p. 151). Anos mais tarde, já na década de 70, Vianna (1999) afirma que os professores sofriam com a desvalorização dos salários e grande número de aulas que precisavam lecionar para aumentar a renda, existindo muitos professores atuando sem concurso, trabalhando na condição de temporário.

Seguindo com o conto Moon Walker, o professor, personagem desta história, tece a narrativa nos apresentando seu aluno Maciel, um menino cuidado pela avó, órfão de pai e com uma mãe alcoólatra. Conhecendo um pouco o contexto social de Maciel, compreende a falta de interesse nas aulas e a não realização das atividades escolares pelo estudante, como descreve: “[...] - E a lição, Maciel?/ - Foi mau professor, não fiz não, mas é que essa lição é muito chata. - Eu sabia que a lição era chata mesmo. A escola era um saco pra todo mundo" (SÃO PAULO, 2010, p. 42).

Para Nóvoa (1999), os professores precisam adquirir mais autonomia na profissão e ter uma relação mais intensa com os envolvidos no processo educacional e, para isso, é preciso romper com a ideia "funcionarizada" de professor, fazendo com que o Estado tenha uma função de acompanhar e avaliar, sendo menos burocrática e de regulação.

Numa tentativa de compreender melhor o universo daquele aluno, o professor buscou seus colegas de profissão que relataram as imagens construídas do estudante Maciel: 
Durante o intervalo, na sala dos professores, perguntei aos outros sobre o Maciel. / - É um vagabundo. - Disse um. / - Parece que a família é toda desestruturada. Deu um trabalho danado no ano passado, quando o pai morreu. [...] / - Nunca veio ninguém na reunião. - Disse o professor que chamara o Maciel de vagabundo. (SÃO PAULO, 2010, p. 42)

Contrapondo à percepção dos professores da escola, em um outro dia, Maciel se aproxima do professor:

Quando voltei à sala do Maciel, ele mal esperou que eu terminasse de fazer a chamada. Pegou suas coisas, sua cadeira e foi se sentar junto de mim. / - Ei professor, hoje vou fazer a lição. Pode encher a lousa inteirinha. / [...] Estávamos lendo Emília no País da Gramática, quero dizer, estávamos tentando. A maioria abria o livro e começava a conversar. Mas o Maciel quis ler neste dia e quis ler em voz alta. E leu... E bem. Daí em diante o moleque mudou na minha aula. Não que ficasse quieto, porque isso ele não conseguia mesmo. Mas fazia todas as atividades e terminava primeiro que todo mundo [...]. (SÃO PAULO, 2010, p. 42).

No trecho acima mencionado, o professor constrói um outro relato sobre Maciel - diverso daquele apresentado por seus colegas de profissão -, evidenciando a mudança do aluno, que passa a ser um estudante interessado e disposto a realizar as atividades. As nuances são ressaltadas, principalmente, quando o professor compara a dedicação de Maciel à postura empreendida pelos demais estudantes, os quais abriam seus livros, mas não realizavam o proposto em aula. Também merece destaque a expressão usada pelo docente quando se refere à leitura do livro em sala com os estudantes: "estávamos tentando", cuja fala traz à baila uma prática pouco exitosa. A afirmação apresentada encontra ressonâncias no conto anterior, especialmente quando a professora afirma: "mas nada deu certo" e reflete acerca das tentativas de mostrar outros assuntos ao estudante que protagoniza a narrativa.

Depois um ano de trabalho na escola e em contato com Maciel, o professor relata:

[...] O fim do ano se aproximava e numa tarde de novembro o menino chegou com ar de preocupado na minha mesa. /- Fala Maciel. /- Queria saber se no ano que vem o senhor vai dar aula aqui? / Respirei fundo. Êta pergunta danada de difícil de responder. [...] Tinha de dizer a verdade. - Já pedi a remoção, Maciel, ano que vem vou trabalhar noutra escola.../ - Hã... tá bom. - Ele disse e eu pude ver o brilho das lágrimas umedecendo seus olhos, contudo não chorou. Estava calejado, o Maciel. Era só um menino, mas já tinha aprendido a agir como o mais duro dos homens. Eu, por meu lado, me sentia um traidor, um tremendo mau caráter [...]. (SÃO PAULO, 2010, p. 44).

Supomos que pela distância entre a escola e sua casa, o professor decide pedir remoção para trabalhar numa unidade mais próxima de sua residência, no entanto, esta 
decisão carrega uma tensão, representada no excerto acima, quando é questionado pelo aluno Maciel e se vê obrigado, por uma questão ética, a revelar sua ida para outra escola. Ademais, percebemos o conflito sentido pelo professor que necessita conciliar o tempo de suas jornadas laborais com a sua vida pessoal e, ao mesmo tempo, se sente traindo a confiança do estudante. Por último, é possível observar o professor num momento de introspecção, oferecendo-nos, desse modo, outras pistas sobre a relação mantida com a profissão:

No caminho da outra escola, chovia. Eu tinha escolhido esta profissão, porque já tinha sido menino. Diabo, eu não era bom com o tal do Adeus. E eu sentia uma coisa ruim por dentro. [...] E me preocupava com o que o futuro e o mundo guardavam pro Maciel. Mas tinha de fechar as médias da outra escola. É a vida. É o mundo. É a burocracia. É um resto de toco... (SÃO PAULO, 2010, p. 45).

Percebemos com este conto que o professor estabelece uma relação de afeto com Maciel que, de algum modo, propicia a este estudante maior proximidade aos conhecimentos ensinados na escola. Por outro lado, a burocracia, imposta à profissão e cobrada rigidamente dos professores, obriga o professor do Maciel a seguir sua rotina em direção à outra escola, sua segunda jornada de trabalho, sem pausas para a reflexão, porque deve atender às exigências administrativas. Assim, o aspecto emocional presente na relação estudante-professor e o caráter rígido inerente à burocracia revelam-se como representações conflitantes no interior da profissão docente.

\section{$\underline{\text { O Amor de Ser Educador }}$}

O texto intitulado $O$ Amor de Ser Educador está publicado no livro do concurso literário de 2011 que recebeu inscrições apenas de crônicas. Apesar de ter sido inscrito neste gênero e ter sido publicado como crônica, este texto se aproxima mais de um relato memorialístico que, narrado em primeira pessoa, a narradora-personagem em um momento de introspecção reflete sobre si enquanto professora. No início do relato, a autora já indica ao leitor que o texto trará uma dimensão "do eu", como pode ser observado no parágrafo inicial: "Muitas vezes me pego perdida em meus pensamentos e me surpreendo com o mundo de informações que eles revelam. Um verdadeiro mergulho num mar de reflexões." (SÃO PAULO, 2011, p. 87). 
A partir dessa introdução, a narradora se posiciona como professora rememorando quantos alunos formou, assim como quanto aprendeu com cada um deles, como observamos no excerto a seguir: "Por minhas mãos já se passaram muitos seres em formação. Por quantas vidas já passei e quantas já passaram pela minha. Fico imaginando, quantas marcas consegui deixar e quantas ainda carrego comigo. São tantas histórias, tantas lembranças, tantos sentimentos." (SÃO PAULO, 2011, p. 87).

No momento seguinte, a narradora-personagem continua sua reflexão sobre ser professora apresentando a escolha profissional como vocação: "Abracei minha vocação como uma missão. A missão sublime de mudar o mundo, ou ao menos de torná-lo melhor." (SÃO PAULO, 2011, p. 87). E a professora personagem dessa crônica continua sua reflexão fazendo diversos questionamentos retóricos sobre o exercício profissional, perguntas essas que não são respondidas no texto, mas a personagem em seu processo reflexivo encontra uma explicação. No excerto a seguir, podemos observar o questionamento e o desfecho da narradora:

Como exercer tal missão sem perder o brilho nos olhos diante de tantos percalços? [...]

Como manter acesa a chama do saber, quando em muitos momentos chego a pensar que nada sei? [...]

Uma única palavra torna-se causa e consequência de tudo.

"AMOR"

Por este amor aceito fazer parte deste jogo. Por amor continuo independente dos obstáculos impostos.

Por amor ainda acredito ser possível transformar o mundo e por este mesmo amor ando por tantos caminhos sem me importar onde eles vão dar. [...] (SÃO PAULO, 2011, p. 87 - 88).

Como observado no trecho transcrito acima, a explicação encontrada pela professora nesse relato para se manter na profissão durante a sua vida, mesmo diante de dificuldades e conflitos que ela expõe quando faz as perguntas para si mesma, está embasada na ideia de vocação, representação essa ainda presente em função da profissão docente ter sido desenvolvida por congregações religiosas nos séculos XVII e XVIII, de acordo com o Nóvoa (1999), e aliado à essa imagem profissional existe o processo de feminização do magistério que relacionou o exercício do magistério aos cuidados, como estudado Demartini e Antunes(1993). Dessa forma, compreendemos este texto como um relato memorialístico da professora que no seu processo de introspecção reflete sobre ser professora e, com isso, expõe a sua representação do magistério, do ser professora. 
Com o Concurso Literário Valeu, Professor identificamos um tipo de prática da escrita realizada por professores em atuação na educação básica que, ainda que através de uma ação institucionalizada, apresentaram seus textos literários e, dentro um universo de possibilidades de criação temática, escolheram retratar o contexto profissional. A escrita, foi, neste sentido, a maneira que esses professores encontraram para narrar suas percepções sobre a profissão docente, a fim de evidenciar as estruturas sociais nas quais professores e estudantes estão inseridos, bem como o contexto de tensão existente nas relações presentes na escola.

No estudo desenvolvido por Catani (2008), os educadores-literatos escolhem registrar experiências que muitas vezes consideram modelares e, a partir de tais, elaboram poemas, romances, memórias e autobiografias por apresentarem disposição artística para a literatura ou por "cumprir a missão de registrar" as vivências profissionais. Assim, Catani afirma a importância dessa produção para conhecermos a relação dos professores com o seu trabalho, com a profissão e com seu universo social.

Reconhecem as análises que tais materiais podem, como fonte, permitir que se reconheçam dimensões da vida e experiência do grupo profissional as quais, de outro modo, não se teria acesso. Decerto os traços que se obtém desses escritos são fragmentários e parciais, obras do trabalho e rememoração para as quais não se põe a questão de discernir níveis de objetividade nas narrativas, mas sim de chegar a compreender os modos de relação dos indivíduos professores, com seu mundo, sua cultura e se trabalho. É dessa forma que, por sua análise se pode aceder à visão que os educadores-literatos tinham de si mesmos, como pessoas e profissionais ou quais as lembranças que suas experiências lhes legaram. (CATANI, 2008, p. 08, grifos da autora)

Para Sevcenko (1983), a linguagem é fundamental a toda atividade humana, sendo gerada pelo jogo de relações entre o homem e a realidade, ela é, também, um elemento modelador dessas relações. Assim, a literatura é uma produção discursiva e, segundo o autor, é o espaço onde o discurso se apresenta inteiramente, inclusive com as tensões de uma dada estrutura social. À vista disso, podemos afirmar que os professores autores de textos literários escrevem motivados especialmente por seus contextos sociais, relatandonos tanto as representações que possuem acerca destes universos, quanto as dificuldades enfrentadas no exercício da profissão. 


\subsubsection{A constituição de uma outra ideia de periferia}

A questão da territorialidade perpassa diversos textos dos professores escritores que tratam de problemas sociais, ausência de políticas públicas nas regiões mais periféricas da cidade de São Paulo e elaboram através de seus textos representações dos sujeitos que residem e/ou trabalham nestes locais. Raquel Rolnik (1997) explica que no processo da segunda fundação da cidade São Paulo, quando ocorreram mudanças que transformaram a cidade - antes um "entreposto comercial escravagista" -, para a sede financeira do café, acontece significativo crescimento populacional ${ }^{155}$, inclusive, com a chegada de muitos imigrantes, fazendo com que a cidade passasse por transformações territoriais. Conforme sinalizado por Rolnik: “[...] A emergência da segregação como elemento estruturador da cidade foi uma das principais mudanças que ocorreram no período. A partir daí, a segregação urbana seria determinante para a fixação de valores no mercado imobiliário e para a expressão política da disputa do espaço pelos grupos sociais" (1997, p. 28) A partir desse processo, fixando valores altos para as moradias nas áreas centrais e com a proibição de $\operatorname{cortiços}^{156}$, a população de baixa renda deslocou-se das regiões onde vivia, instalando-se em áreas menos valorizadas economicamente e na zona rural.

Ao mesmo tempo em que a lei alinhavou os territórios da riqueza, delimitou também aqueles onde deveria se instalar a pobreza. $\mathrm{O}$ movimento, desde seu nascimento é centrífugo, ou seja, delimita as bordas da zona urbana, ou mesmo a zona rural como local onde esta deveria se alojar. Diga-se de passagem que a lógica de destinar as lonjuras para os pobres, assim como a de proteger os bairros exclusivos dos ricos, atravessou, incólume, nosso século. (ROLNIK, 1997, p. 47).

Dessa forma, desde sua origem a periferia é compreendida como um espaço de segregação, cujas políticas públicas são extemporâneas, e a violência comumente retratada.

o velho físico explica com olhos vítreos

a revolução de Copérnico

pra dizer que não, não eram circulares

eram elípticas as voltas dos astros

\footnotetext{
${ }^{155}$ Segundo Rolnik (1997), em 1873 a cidade tinha por volta de 30 mil habitantes, em 1893, vinte anos depois, a população correspondia a 120.775 habitantes.

156 "A constituição de um mercado imobiliário dual, no qual os pobres estavam alocados na periferia, começou com a proibição de instalar cortiços na zona central definida pelas posturas de 1886 e reiterada pelo Código Sanitário de 1894, que proibia terminantemente a construção de cortiços e permitia a construção de vilas operárias higiênicas fora da aglomeração urbana." (ROLNIK, 1997, p. 47)
} 
considere,

as teorias caem

as teorias são substituíveis

as teorias não servem de nada

enquanto a astrofísica descreve a dança dos corpos celestes

[no infinito

a gente aqui parado nestes três bairros de separação geográfica

esperando um ano-luz.

(Michele Santos, “Gira Sol”, In: Toda via, 2015, p. 11).

No poema "Gira Sol”, a professora escritora faz a crítica usando metáforas físicas, que simbolizam a passagem do tempo, a eterna espera dos que residem em "três bairros de separação geográfica", os quais não sabemos exatamente quais são, muito embora o sarau que a professora Michele organiza está na região do Grajaú - um território que é banhado pela represa Billings à sua direta, pela represa Guarapiranga, à esquerda, Nessa região existem vários bairros que estão localizados no extremo sul da cidade, território considerado periférico em relação ao centro da cidade e, assim, supomos que essa espera é por políticas públicas que representem melhorias de fato para a população ali residente.

Referindo-se à população, Raquel Rolnik (2017) afirma que a cidade de São Paulo se constituiu a partir da migração de diferentes grupos nacionais e imigrantes de diversos países. A capital recebeu um grande contingente de nordestinos atraídos pelas possibilidades de trabalho, principalmente a partir de 1940, o que fez da cidade de São Paulo "a maior cidade nordestina do Brasil". Esses migrantes nordestinos se estabeleceram e formaram suas famílias na cidade, configurando também um grupo de descendentes. No poema Eu Paulistano, a origem regional dos antecedentes do professor Jefferson se apresenta com intensidade para demarcar sua identidade de paulistano, mas também do entrelaçamento cultural de seus pais:

Eu sou um paulistano

De mãe brasileira do canto nordestino

E pai brasileiro do canto sulista.

Nascido e criado na capital paulista.

Convivi como suburbano

$\mathrm{Na}$ vida que me serviu de ensino,

Só não entendo a incógnita

Da grande capital que se limita.

No meu canto da periferia

Vou montando poesia,

Entre os prédios e as favelas, 
Eu ando por avenidas e vielas

Onde os milhões transitam

$\mathrm{E}$ as desigualdades se encontram.

$[\ldots]$

Para cá vieram as migrações

Trazendo suas tradições.

As famílias foram aumentando,

Assim dos povos nasci misturado.

$[\ldots]$

De São Paulo residente.

Com licença, sem engano

Também sou paulistano.

(SANTANA, Eu Paulistano, 2011, p. 20 - 21).

Neste poema, o sujeito lírico afirma a sua origem e de seus pais migrantes que vieram de regiões opostas do país e, nos chama a atenção, o seguinte verso: "Com licença, sem engano", em que o este sujeito lírico pede licença para afirmar a própria identidade. Rolnik (2017) nos permite refletir sobre a questão, principalmente quando trata da maior cidade nordestina do país e que recebeu imigrantes dos mais variados países e regiões. A autora afirma que, no imaginário da cidade, os nordestinos pobres e sem escolarização “invadiram" a capital, representação esta que não condiz com a realidade dos fluxos migratórios, tampouco revela a contribuição que os diferentes grupos propiciaram à construção da cidade.

As representações mais comuns constroem a ideia de uma cidade marcada positivamente pela presença europeia (as ondas migratórias predominantes do século XIX e início do século XX) e "invadida" por nordestinos pobres e analfabetos na segunda metade do século passado. Esse imaginário não tem correspondência com a realidade: por um lado, grande parte dos imigrantes europeus chegou analfabeta e em estado de absoluta miséria à cidade; por outro, a migração nordestina é muito mais heterogênea do ponto de vista econômico do que o preconceito nos permite ver. (ROLNIK, 2017, p. 128).

No poema a seguir, a professora escritora trata dos poetas que habitam a periferia, que representam as "caras sertanejas" e que fazem parte da identidade desta professora e de tantos outros no território da periferia.

Entre xenófobos e lobos bobos

a ingenuidade dos utópicos

não vai salvar florestas

as ruas dos esquecidos nos trópicos 
parindo poetas,

você viu?

não dá uma coluna de jornal

em que caiba

o espelho da gente gourmet que não reflete as caras sertanejas

em que me enxergo

[e os poetas do asfalto não serão resenhados por

Antonio Candido

Literadura

'é feia, mas é uma flor'

muitos maus poemas

inda são melhores

que poesia alguma

perceba

o intento é o alento dos incautos

para o que os salvam

[inclusive de si

E os professores da língua

Portuguesa do Brasil

ainda pensam que ensinam

o emprego dos porquês

(SANTOS, "Sociedade dos poetas vivos", In: Toda via, 2015, p. 33).

Como pode ser observado, o sujeito lírico contrapõe-se ao campo acadêmico representado por Antonio Candido, já que ao invés do termo literatura cria o trocadilho "literadura", com o objetivo de afirmar que a poesia feita por quem está neste espaço social não ocupa os espaços de prestígios, por onde, normalmente, transita a literatura canônica. Por fim, nota-se que o eu poético critica o ensino da Língua Portuguesa nas escolas que, desde seu ponto de vista, é extremamente orientado por regras e normativas gramaticais.

O poema Mais um Silva, por seu turno, contribui para a discussão de uma identidade dos sujeitos trabalhadores que habitam a cidade e a região metropolitana:

Meu sobrenome, Silva

Sobrevivente na selva

mestiço,

negação de colonizador.

Quiseram apagar minha cor,

digitalizar.

Anular meu sexo,

androginizar

Sumir com meu sotaque,

carnavalizar. 
Meu sobrenome?

Construtor de cidades,

da garoa, maravilhas e satélites.

Anderson, Benedita, Luiz Inácio, Bezerra e Chica

Da Silva.

Meu sobrenome?

Comedores de marmitas frias

Primeiro lugar da lista telefônica e do Bolsa família

Escravizados, catequizados e batizados

Da Silva.

Meu sobrenome?

Catadores de poesia entre os detritos.

$[\ldots]$

O bicho, meu Deus,

era um Silva.

(OLIVEIRA, Mais um Silva, p. 49).

Neste poema, narrado em primeira pessoa, o professor José Vandeí chama a atenção para o lugar a que são relegados os sujeitos nomeados como "Silva", nome atribuído a escravos que ao país chegaram, cujos descendentes, anos mais tarde, começaram a representar o grande número de trabalhadores que continuam sendo explorados e, de acordo com o eu poético, são tratados como "bichos".

A temática da identidade cultural brasileira constituída pela miscigenação dos povos perpassa a poética de alguns professores escritores que entrevistamos. Foi no âmbito dessa temática que o professor Márcio escreveu o poema épico "Velho Canto Brasileiro", no qual narra e questiona em oito cantos, compostos de catorze estrofes, o primeiro canto, e de três o último, o que é o negro. O excerto que segue compõe o primeiro canto:

Sob a negra noite

Deusa dos sonhos

Não saberei cantar a vida

Que é breve.

No estalo do açoite

Medonho

Na luta aguerrida

Do espírito leve.

Olhai por nós

Oh, África!

Teus filhos sedentos

No século XXI

Travam guerras

Sob o engatilhar

De uma doze. 
Quem sou,

Oh, minha uwar?

Contai minha história

Dizei tudo sobre meu sangue.

Amei, nessa terra invadida.

Sonhei com as raízes esquecidas

Vigiei para não perde-la de vista

Ofereci a vida

Para mantê-la viva.

$[\ldots]$

Sou o marinheiro,

O pescador,

$\mathrm{O}$ agricultor,

O sapateiro,

O professor.

Meu barco

Está sem rumo

E teme o destino

Bruto dos homens.

O café é servido

Falta o pão

O pai, a mãe,

Somente a solidão.

[...]

Terra preta, pele preta

Alma preta,

Orgulho preto,

Orgulho preto,

Orgulho preto,

O navio não é mais negreiro.

[...]. (MARINHO, 2016, p.13-15)

Na primeira parte do poema, o narrador, um homem negro, se situa no século XXI, sob uma guerra urbana, e questiona a própria identidade por meio de um interlocutor, "uwar" (que significa mãe na língua do povo africano Hausa). Numa referência às diversas profissões alcançadas, o homem negro sente-se orgulhoso de suas origens e de suas conquistas, mas esse sentimento não apaga o medo que ainda sente em consequência de viver em uma sociedade racista. Nos cantos que seguem, o narrador conta os horrores da história dos africanos transportados em navios acorrentados e sem humanidade, a comercialização dos homens e mulheres como objetos. 
[...]

Esse navio enlouquece a todos

Há meses no mar

Sem saber o destino

Sob o açoite

Dos homens

Dos mortos.

[...]

A lenda da pele clara

Que raptam homens

Fala sobre civilização.

Só pode ser pior do que isso.

[...]

Paramos

As correntes são puxadas [...]

Estamos num lugar desconhecido

Vejo pretos como eu

Todos amarrados.

Jogam água sobre meu corpo

Passam uma espuma

Cujo sabor me arrebentou o estômago.

[...]

Para onde estão me levando?

O que fiz para tanto? [...]

Estou algemado

Mãos e pés

Sem poder mexer

Há dois dias assim.

[...]

Sigo de mãos atadas

São ferros e correntes

Impossíveis de destruir

Meu espírito guerreiro grita

E não compreendo...

A única palavra que ouço

Mas não entendo

É negro,

Negro, negro...

O que será um negro, meu Zaci?

Deve ser o que nos espera à frente

Deve ser a morte

O ódio

O que é um negro, Zaci?

[...]

Ainda não compreendo essa língua.

Estou louco para entender

O que será um negro?

Negro?

Percebi que assim se referem a mim

Meu nome é Akins,

Mas aqui me chamam de Silva. 
Onde é aqui?

Outros iguais a mim não me compreendem

Uns falam Bantu, outros Nagô,

Eu, Hausa.

Não sou daqui, nem eles.

De onde são?

Ontem tentei fugir

Não sabia para onde ir

Fiquei desesperado na mata

Encontraram-me pelo sangue

Pelo rastro que deixei.

Hoje...

Dois dedos foram cortados

Perante aos meus iguais.

Dois dedos do pé

Meu equilíbrio não é mais o mesmo

Penso em uwar

Que deve estar desconsolada

Saí para pescar e não voltei mais.

[...]. (MARINHO, 2016, p. 17 - 27).

No canto oitavo, a história da personagem Akins termina tragicamente como a de muitos negros trazidos para serem escravizados no país. A pergunta que a personagem repete diversas vezes no poema “o que é um negro?” vai ressoando na reconstrução desse passado brasileiro por meio da leitura deste texto ao mesmo tempo em que ressoa no presente, quando atentamos para os dados da população negra morta de forma violenta no país ${ }^{157}$. A violência tematizou o poema da professora escritora Letícia que se valendo do modelo de um poema de Drummond, No meio do caminho ${ }^{158}$ (1930), escreveu o poema que intitulou Alguma releitura para o século XXI, no qual denuncia as ações violentas dos agentes de segurança pública contra os jovens negros utilizando a mesma estrutura da primeira estrofe do poema original e reescrevendo a segunda estrofe:

\footnotetext{
${ }^{157}$ De acordo com a Nota Técnica do IPEA Vidas perdidas e racismo no Brasil (2013), "[...] enquanto a taxa de homicídios de negros no Brasil é de 36 mortes por 100 mil negros, a mesma medida para os "não negros" é de 15,2. Essa razão de 2,4 negros para cada indivíduo de outra cor morto é muito mais ampla quando se analisa a vitimização por Unidades Federativas". Os dados do documento informam que no estado de São Paulo a proporção é de 16,2 negros para 12 não-negro. No Atlas da violência (2019) que utilizou dados coletados de 2007 a 2017, o índice de homicídios da população negra é de 43,1 contra 16 da população não negra para cada grupo de 100 mil habitantes. Quando observamos os dados por unidade federativa, vemos que São Paulo apresentou o menor índice de 12,6 para cada grupo de 100 mil habitantes. ${ }^{158}$ Poema de Drummond: No meio do caminho tinha uma pedra/ tinha uma pedra no meio do caminho/ tinha uma pedra/ no meio do caminho tinha uma pedra. Nunca me esquecerei desse acontecimento/ na vida de minhas retinas tão fatigadas/ Nunca me esquecerei que no meio do caminho/ tinha uma pedra/ tinha uma pedra no meio do caminho/ no meio do caminho tinha uma pedra. Publicada em Alguma Poesia, Editora Pindorama, 1930.
} 
No meio do caminho tinha um corpo

tinha um corpo no meio do caminho

tinha um corpo

tinha um corpo no meio do caminho

Impossível esquecer estas cenas

corpos pretos pequenos

corpos furados por fardas

no meio da viela tinha um corpo

mais um corpo!

mais um corpo subtraído de seu caminho

(MENDONÇA, 2015) ${ }^{159}$.

Sérgio Buarque de Holanda, na obra Raízes do Brasil, afirma que os negros e seus descendentes eram submetidos a trabalhos considerados de "baixa reputação", mesmo existindo de modo geral um convívio entre os brancos portugueses e os negros, como afirma:

O escravo das plantações e das minas não eram simples manancial de energia, um carvão humano à espera de que a época industrial o substituísse pelo combustível. Com frequência as suas relações com os donos oscilavam da situação de dependente para a de protegido, e até de solidário e afim. Sua influência penetrava sinuosamente o recesso doméstico, agindo como dissolvente de qualquer idéia de separação de castas ou raças, de qualquer disciplina fundada em tal separação. Era essa a regra geral: não impedia que tenham existido casos particulares de esforços tendentes a coibir a influência excessiva do homem de cor na vida da colônia [...]. (HOLANDA, 1995, p.55).

De acordo com o autor, os portugueses se caracterizavam por não terem um "orgulho de raça", como os povos europeus do norte, e isso se deve ao fato de já serem um povo de mestiços à época da colônia. Mesmo assim, o negro ainda vivia na condição de escravo e a submissão à condição de inferior em relação aos outros estava posta, como podemos observar no excerto a seguir:

[...] Os pretos e descendentes de pretos, esses continuavam relegados, ao menos em certos textos oficiais, a trabalhos de baixa reputação, [...] que tanto degradam o indivíduo que os exerce, como sua geração. Assim é que, em portaria de 06 de agosto de 1771, o vice-rei do Brasil mandou dar baixa do posto de capitão-mor a um índio, porque "se mostrara de tão baixos sentimentos que casou com uma preta, manchando o seu sangue com esta aliança, e tornando-se assim indigno de exercer o referido posto". (HOLANDA, 1995, p. 56).

$\mathrm{Na}$ formação da sociedade brasileira está posta uma complexidade de relações envolvendo os colonizadores, os colonizados e os escravizados que constituíram a sociedade atual a partir da exploração e da condição servil dos negros escravos. A marca

\footnotetext{
159 Poema publicado na página eletrônica Jornalirismo. Disponível em: http://www.jornalirismo.com.br/literatura/alguma-releitura-para-o-seculo-xxi/
} 
da violência física e simbólica contra a população negra e seus descentes remonta aos dias atuais e de modo extremamente intenso, que os professores escritores evidenciam essas marcas em seus poemas.

A poética produzida na periferia e a partir dela também representa uma população de trabalhadores que cotidianamente se deslocam por enormes distâncias para trabalhar no centro da cidade, como descreve o professor Jefferson no poema:

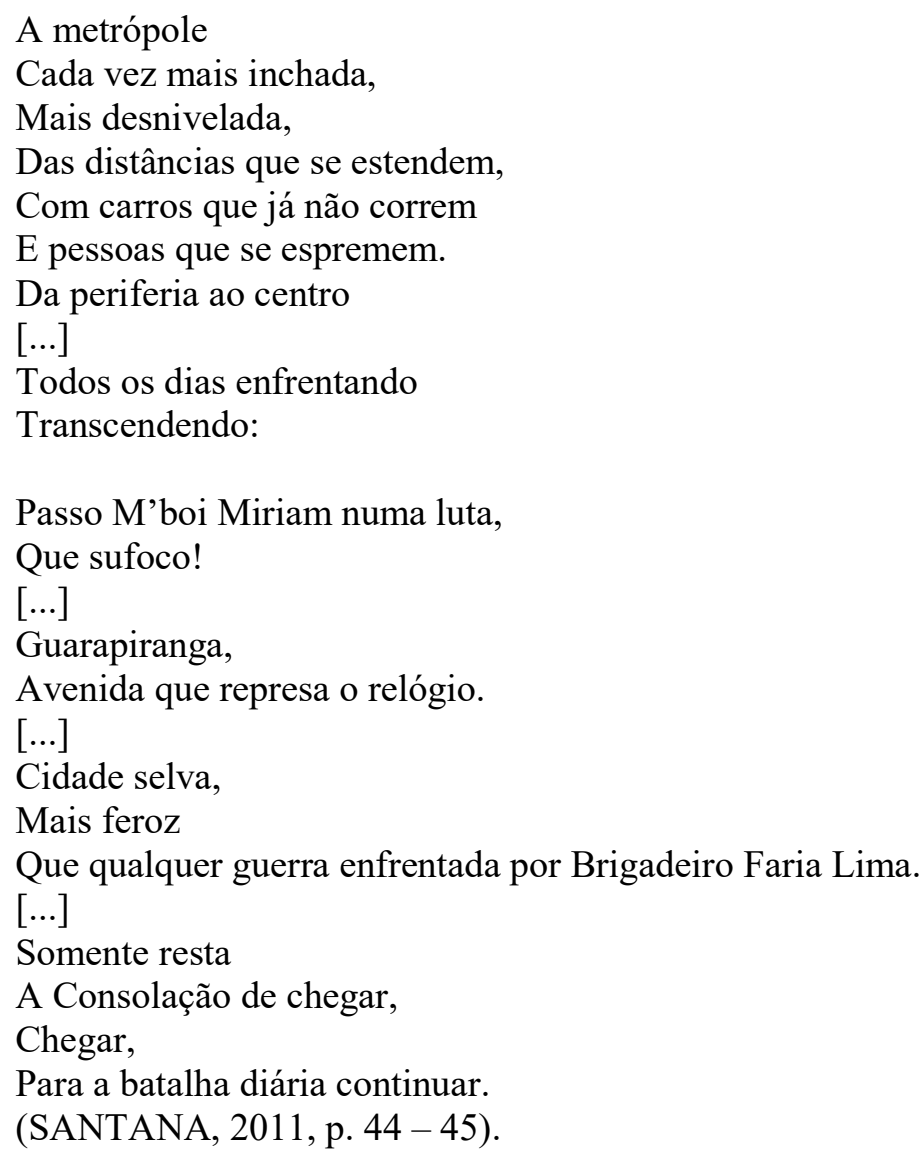

O cotidiano vivenciado pelos sujeitos que habitam áreas periféricas é representando pelo professor escritor Jefferson como uma "batalha" constante, dadas as dificuldades enfrentadas por esses agentes em suas posições sociais de dominados no campo econômico. Segundo Bourdieu (1997), cada agente é um ponto no espaço social e esta posição possibilita um ponto de vista do contexto em que se insere permitindo, assim, elaborar uma perspectiva a partir da posição assumida. O professor Jefferson constrói em seus poemas a posição de um sujeito periférico entendido e nomeado como um "guerreiro" que enfrenta as "batalhas" diárias em lutas por sobrevivência. Assim, usando o modelo de um texto religioso, o professor escritor cria um poema intitulado Oração do Guerreiro:

$[\ldots]$

Pai nosso, eu te pergunto: 
Se somos todos seus filhos

Por que nossas condições são diferentes?

Tenho fome e sede de resolver,

Porém do conhecimento

Poucas partes me apresentaram.

E não pude reter

Valor de significado suficiente

Que pudesse me deixar sossegado.

[...]. (SANTANA, 2011, p. 15).

No excerto que apresentamos, o sujeito lírico em primeira pessoa questiona o seu interlocutor representado por "Pai nosso", em alusão à crença religiosa em uma entidade superior, acerca das diferenças sociais impostas aos grupos e, nesse diálogo, ele pontua a ausência de escolarização, indicada pelas "poucas partes" de conhecimento a que teve acesso. Essa ausência de escolarização compreende um grupo de adultos que não teve acesso à escola, pois desde muito jovem precisou trabalhar para sobreviver, como aconteceu com a maioria dos pais dos professores entrevistados nesta pesquisa.

Em relação às diferenças sociais da população que vive na periferia, a crônica a seguir nos apresenta uma dimensão desses sujeitos periféricos entendidos como guerreiros em seus cotidianos e ao mesmo tempo invisíveis em suas singularidades e potencialidades pela classe dominante economicamente.

\section{Céus de SP}

A crônica Céus de $S P^{160}$ foi escrita a partir de um fato cotidiano, um ritual de sepultamento. A narradora conta esta história como quem observa o cenário, não se restringindo à narração do fato, pois descreve as personagens presentes e fala da personagem principal, Dona Florita, como quem a conhecia.

Iniciada com dois versos, em epígrafe, extraídos de uma música religiosa, a crônica começa descrevendo as personagens presentes: "Lá estavam as duas irmãs crentes de mãos dadas. A Socorro sem braço enxugava os olhos com o vazio da manga da blusa, onde outrora havia um braço agora era só a manga. Sem nada. [...] Sob o sol todos estavam.” Após descrever os presentes - Guru, Conceição, Salviano, D. Leriana e sua filha - indicando algumas breves características destes, a narradora apresenta a personagem principal que estava sendo sepultada:

D. Florita vivera seus poucos 60 anos para servir. Era copeira. Muito mais pela profissão, quase não ousava dizer. Quando falava era

${ }^{160}$ Referência do texto: São Paulo, 2011, p. 43 - 45. 
apressada e certeira para não incomodar ninguém. O sotaque ela não perdera, apesar dos quase 40 anos vividos em SP, manteve-o como lembrança do que era. Cansanção. Bahia. (SÃO PAULO, 2011, p. 43 44).

$\mathrm{Na}$ definição da personagem principal, características importantes são evidenciadas: o sotaque que demarca a origem nordestina e o trabalho relacionado com o servir, marca essa dos migrantes que saíram do nordeste e vieram trabalhar em São Paulo. Tendo pouca ou nenhuma escolarização. Essas pessoas conseguiam trabalhos de menor remuneração e com isso foram viver em regiões distantes do centro urbano, as chamadas periferias. A narradora continua nos dando indícios das condições sociais desse grupo:

Amontoados em casas pobres. Impelidos ao mesmo sonho: sobreviver. Aqui era a carestia, a exploração, a indiferença, a saudade e o maldito preconceito que tinham de enfrentar. (...) Formavam uma pequena nação de servidores. Empregadas, pedreiros, serventes, copeiras, diaristas. E para aqueles que tinham o luxo da carteira registrada: auxiliar de serviços gerais. Aos poucos esses desbravadores povoaram aquela rua das partes mais periféricas da periferia da grande SP. (...). (SÃO PAULO, 2011, p. 44).

Ao descrever D. Florita, que era viúva e sozinha cuidava da filha, pistas da situação de mulheres que sustentam suas famílias: "D. Florita era uma dessas personagens incógnitas que tece o mundo sorrateiramente. Atarracadinha e muito amável. Sabia servir como ninguém. Perdera o marido ainda jovem. Nunca mais quisera saber de homem. Era só ela e a filha [...]".

Uma pausa na narração para questionar as condições de vida que se apresentam: "Valeu tanta luta? Valeu tanta labuta? D. Florita, e agora?" No ritual de sepultamento, os presentes caminham e, nesse momento, a narradora representa as pessoas que ali seguem o cortejo da seguinte forma: "Caminhava ali uma pequena nação. Marchavam sob suas existências abafadas. Invisíveis". Outra pausa na narração, a música religiosa cantada pelos presentes é retomada. A crônica termina com o fím do sepultamento:

Agora todos tinham em suas faces o semblante amável e a quietude de D. Florita. Ali, por fim, jazia um pedaço daquela rua, um pedaço daquele povo sem braço, sem cor, sem voz, sem-terra. Silenciosamente D. Florita construiu uma cidade que não a viu nem a ouviu. Mas hoje, D. Florita, todo esse céu é seu. [...] (SÃO PAULO, 2011, 45)

Arrebatador, este texto mescla elementos da crônica, baseados em um fato ou situação da realidade, com o conto, que visa narrar uma história ficcional curta, com personagens e um narrador, neste caso em terceira pessoa. 
A realidade nua e crua da cidade de São Paulo está muito presente nesta crônica em que a professora escritora, fazendo uso do recurso literário, conta a história da D. Florita, bem como denuncia a situação de invisibilidade vivida pelas pessoas na periferia.

Com essas produções literárias, portanto, acreditamos que os professores escritores visam constituir uma outra ideia de periferia, diversa no sentido da pluralidade de sujeitos que a habitam, representando as dificuldades e, também, a potência que existe em seu interior.

\subsubsection{Cotidiano em São Paulo}

O cotidiano na cidade de São Paulo foi objeto de grande interesse, principalmente, na edição de 2011 do concurso literário Valeu, Professor, cuja crônica foi o gênero proposto para retratar a cidade. Diferentemente dos textos apresentados anteriormente, em que a crítica e a denúncia se fazem presentes, nas duas crônicas escolhidas para compor esta categoria temática observamos a representação de um cotidiano mais circunstancial, narrado a partir de um observador direto da realidade. Como afirma Jorge de Sá, a crônica trata da circunstância no

[...] sentido específico de pequeno acontecimento do dia-a-dia, que poderia passar despercebido ou relegado à marginalidade por ser considerado insignificante. Com o seu toque de lirismo reflexivo, o cronista capta esse instante brevíssimo que também faz parte da condição humana e lhe confere (ou lhe devolve) a dignidade de um núcleo estruturante de outros núcleos, transformando a simples situação no diálogo sobre a complexidade das nossas dores e alegrias [...]. (SÁ, 1999, p. 11).

Antonio Candido concorda com essa ideia de crônica enquanto texto literário que se vale de uma linguagem que se aproxima da oralidade, tratando de temas cotidianos, na "simplicidade" literária característica do gênero, não deixa de apresentar questões para reflexão em profundidade: “[...] É curioso como elas mantêm o ar despreocupado, de quem está falando coisas sem maior consequência; e, no entanto, não apenas entram fundo no significado dos atos e sentimentos do homem, mas podem levar longe a crítica social" (CANDIDO, 2003). 


\section{$\underline{\text { Janelas Metropolitanas }}$}

A crônica Janelas Metropolitanas ${ }^{161}$, escrita para o concurso literário Valeu, Professor de 2011, narra o percurso que um homem faz para chegar no trabalho por meio do transporte público, ônibus, em um dia de chuva na cidade. O narrador-personagem, em primeira pessoa, não tem nome e inicia o texto pelo trajeto que faz até o ponto de ônibus.

Indo na direção do ponto de ônibus debaixo de uma chuva frí́ssima, olhei pela janela metropolitana para o céu acima e foi um quadro cinzento com contornos escuros e sombrios que eu notei. Queria amaldiçoar a chuva gélida que batia no meu guarda-chuva comprado numa loja da Cunha Gago por sete reais. (SÃO PAULO, 2011, p. 77).

Durante a narração do percurso, o narrador-personagem descreve como se sente por ter se molhado até entrar no ônibus: "Eu me sentia molhado na poltrona desconfortável deste ônibus sacolejante". No tempo que leva de sua casa ao seu trabalho, o narrador-personagem ao olhar pela janela do ônibus e observar a cidade, começa a rememorar momentos de sua vida: "Lembrei-me do final dos anos oitenta do século passado. Lembro-me que ao olhar para aquela janela metropolitana dos anos oitenta via um quadro cor de ferrugem para um rosado com pontilhados escuros. Era visualmente belo, mas a sensação era de sufocamento." Neste excerto, a memória relatada pela personagem refere-se provavelmente à sua chegada na metrópole, também realizada por meio do transporte público que poderia ser o trem que ligava a capital a várias cidades naquela época ou, ainda, o ônibus, descrevendo a sensação sentida imediatamente ao olhar pela janela. E o relato das memórias segue durante o trajeto até que a personagem percebe que chegou ao seu destino:

Felizmente ou infelizmente (depende do ponto de vista) no início deste século tive que voltar para esta grande metrópole de janelas metropolitanas e deixar o céu maravilhoso do Vale do Ribeira querido. Embora não haja qualquer arrependimento nesta volta a minha metrópole preferida, todas estas lembranças fizeram com que eu me esquecesse da chuva, dos guarda-chuvas, dos pés úmidos, da água na calçada, dos tênis molhados. Desci do ônibus e fui com o meu pequeno guarda-chuva aberto para o meu trabalho na escola. (São Paulo, 2011, p. 79).

\footnotetext{
${ }^{161}$ Referência do texto: São Paulo, 2011, p. $77-80$.
} 
Ao longo da trama o narrador-personagem continua descrevendo seu percurso, sempre observando da janela do transporte o céu da cidade e, ao avistar um céu azul e sem nuvens, rememora a sensação que sentia ao observar o céu claro do interior:

E qual não foi a minha surpresa ao ver pela janela metropolitana um céu de um azul tão intenso e tão límpido que me trouxe imediatamente à memória meu céu interiorano abobadado dos dias mais frios. Assim de repente naquele momento me senti reconfortado, conectado e integrado nesta grande cidade paulistana, pois nada mais me faltava. (São Paulo, 2011, p. $79-80)$.

Este texto ficcional do professor inscrito como crônica, apresenta características de um relato memorialístico autobiográfico, considerando que alguns elementos inseridos na narrativa fazem parte da história de vida do professor escritor da crônica. Primeiro, o fato do deslocamento de uma cidade para outra visando um "projeto de vida" diferente do que tinha onde vivia - o interior -, depois o retorno para o Vale do Ribeira, região natal do professor e, por consequência, referência à cidade de origem. Segundo, o trabalho na escola, ainda que não mencione que tipo de atividade era desempenhada, de modo que a alusão à instituição representa outro ponto convergente entre as figuras do professor e do narrador-personagem.

Compreendemos que este é um texto literário ficcional, no entanto, alguns dos elementos constitutivos do narrador-personagem foram extraídos da vida do professor escritor, enfatizando que o texto ficcional dialoga com o real.

\section{Carícias verbais...}

A crônica Carícias verbais... ${ }^{162}$ publicada na edição de 2011 do concurso literário tem como ponto de partida um fato circunstancial. A narradora do texto cronístico resgata uma cena ocorrida dentro de um transporte público, orientando-se pela forma com a qual uma mulher, que está ao telefone, se dirige ao seu companheiro. Partindo deste episódio, a narradora inicia o texto se dirigindo ao leitor: "Logo de início, já vou explicar, para que você não me julgue erroneamente". A narradora quer se explicar, porque ouviu uma conversa de outra pessoa, mas se justifica quanto a isso: "Nunca tive por hábito "pescar" conversa alheia, mas, nos tempos atuais, tem sido quase impossível; graças ao advento do celular, à indefinição do que é público ou privado e às aglomerações, cada vez maiores,

\footnotetext{
162 Referência do texto: São Paulo, 2011, p. 35 - 37.
} 
nas filas, ônibus e metrôs". Desse momento em diante, a narradora afirma que os paulistanos se expressam de modo afetivo no tratamento a pessoa amada e passa a reproduzir essas formas de tratamento: “Algumas carícias são clássicas e nunca saem de moda: - Oi, amor!/ - Alô! Querida?/ - Meu bem...", e ela segue com uma variedade de modos usados apresentando uma série de adjetivos ou palavras adjetivadas que são utilizadas como vocativos no tratamento informal e intimista entre parceiros: "Eventualmente, são usadas expressões que soam estranhas: - Isto é com você, patroa./ - Vamos dançar, boneca?/ - Olá, chuchu!”. Até que no final chega ao fato circunstancial ouvido no ônibus: "Porém, o que ouvi outro dia, de uma mulher que falava ao celular dentro de um ônibus, foi o auge da criatividade: - Ah, galheteirinho! Você é o sal da minha vida, o vinagre dos meus dias, a pimenta que me faz arder de amor...”. E termina em seguida, se direcionando ao leitor: "Sem comentários!".

Esta crônica se baseia em um fato específico para elaborar um texto sobre as formas de tratamento informais, produzindo um texto leve e divertido de ler. Supomos que a narradora é a própria autora, outra característica da crônica, que conta o fato em primeira pessoa, sem construir personagens para narrar o fato, como afirma Jorge de Sá:

[...] o cronista age de maneira mais solta, dando a impressão de que pretende apenas ficar na superfície de seus próprios comentários, sem ter sequer a preocupação de colocar-se na pele de um narrador [...]. Assim, quem narra uma crônica é o seu autor mesmo, e tudo o que ele diz parece ter acontecido de fato, como se nós, leitores, estivéssemos diante de uma reportagem. (SÁ, 1999, p. 09).

\subsubsection{Escrever do "ponto de vista" feminino}

Tomando de empréstimo o termo ponto de vista cunhado por Bourdieu (1996), trataremos nesta categoria dos textos literários produzidos pelas professoras escritoras, mulheres que escrevem a partir da perspectiva feminina em seus respectivos espaços sociais trazendo percepções "do eu", de suas identidades com a liberdade de escrever o que permite a imaginação. Fazendo referência à liberdade de escrever das mulheres, Virgínia Woolf na belíssima obra publicada em 1929, A room of one's own, publicada em Língua Portuguesa como Um teto todo seu (1985), escreve sobre as mulheres e a ficção discutindo as efetivas condições que elas tinham de ser escritoras na sociedade europeia patriarcal do início do século XX, na qual a circulação pelos espaços públicos ainda era restrita para elas: “[...] a mulher precisa ter dinheiro e um teto todo seu se pretende mesmo 
escrever ficção [...]" (WOOLF, 1985, p. 08), afirmação essa que no transcorrer do texto se resume, de modo muito geral, na necessidade das mulheres buscarem formação e obterem independência sem atenderem às recomendações masculinas do que devem ou não fazer.

[...] minha crença é que, se vivermos aproximadamente mais um século - e estou falando na vida comum que é a vida real, e não nas vidinhas à parte que vivemos individualmente - e tivermos, cada uma, quinhentas libras por ano e o próprio quarto; se tivermos o hábito da liberdade e a coragem de escrever exatamente o que pensamos; se fugirmos um pouco da sala de estar comum e virmos os seres humanos nem sempre em sua relação uns com os outros, mas em relação à realidade [...]; se encararmos o fato, pois é um fato, de que não há nenhum braço em que nos apoiarmos, mas que seguimos sozinhas e que nossa relação é para com o mundo da realidade e não apenas para com o mundo dos homens e das mulheres, então chegará a oportunidade, e o poeta morto que foi a irmã de Shakespeare assumirá o corpo que com tanta frequência deitou por terra. (WOOLF, 1985, p. 148).

Assim, Virgínia Woolf acredita que quando as mulheres assumirem as próprias vidas e passarem a escrever o que pensam, ou seja, suas percepções do mundo elaboradas ficcionalmente, aí então, as mulheres de gerações passadas que tentaram escrever e foram impedidas, viverão através das mulheres escritoras e das suas respectivas produções literárias. A ponderação de Woolf está inserida no contexto das sociedades do fim do século XIX e início do XX, período cuja vida privada era o espaço privilegiado das mulheres e o exercício da escrita produzido por elas era restrito ao foro íntimo: cartas, diários, livros de anotações da casa e outros, chamados de "arquivos privados" por Michele Perrot (2005), prática da escrita essa indicada para as mulheres do século XIX por confessores e pedagogos visando o autocontrole, como afirma a autora. Desse modo, a memória feminina no processo histórico foi reconstituída a partir de registros privados, já que os registros públicos privilegiaram os homens ${ }^{163}$.

Norma Telles (2006) diz que escrita e conhecimento relacionavam-se com poder e dominação masculinas, pois estes prescreviam as formas que deveriam ser adotadas

\footnotetext{
${ }^{163}$ Michele Perrot afirma que "os modos de registro das mulheres estão ligados à sua condição, ao seu lugar na família e na sociedade. $\mathrm{O}$ mesmo acontece com seu modo de rememoração, da encenação propriamente dita do teatro da memória. Por força das coisas, ao menos para as mulheres de outrora e para o que resta do passado nas mulheres de hoje (e que não é pouco), é uma memória do privado, voltada para a família e para o íntimo, aos quais elas estão de certa forma relegadas por convenção e posição. Cabe às mulheres conservar os traços das infầncias em que elas são governantas. Cabe a elas a transmissão das histórias de família, feita geralmente de mãe para filha, ao folhear álbuns de fotografias aos quais, juntas, elas acrescentam um nome, uma data, destinados a fixar identidades já em vias de apagamento. Cabe às mulheres o culto dos mortos $\mathrm{e}$ o cuidado com as tumbas, o que as incumbe de velar pela manutenção das sepulturas. [...] A proximidade do cemitério fixa às vezes a sua última moradia, como se ela fosse uma dependência da casa. [...]". (PERROT, 2005, p. 39)
} 
pelas mulheres nos papéis e espaços definidos para elas. Assim, para as mulheres acessarem o universo da criação, precisaram acessar a educação e lerem o que os homens haviam produzidos sobre elas nos romances, livros de moral, entre outros. A perspectiva masculina sobre a mulher era dual, apresentando uma representação feminina virtuosa, de mãe, anjo do lar ou do oposto disso, sendo de uma mulher fatal, perversa, entre outras adjetivações consideradas negativas. Segundo Telles, é a partir do século XVIII na Europa e nas Américas que as mulheres começaram a escrever e a publicar, mesmo diante de inúmeras imposições sociais. Na sociedade brasileira do século XIX, Nísia Floresta se encorajou a escrever e a reivindicar pelos direitos das mulheres publicando, em 1832, a obra Direitos das mulheres e injustiça dos homens.

Para Telles, as imagens elaboradas nos textos dos homens não são neutras, mostraram a expressão da cultura da época e, de tanto repetidas e inculcadas para e pelas mulheres, também apareceram nos textos escritos por elas posteriormente.
A mulher serviu também se espelho mágico entre o artista e o Desconhecido, tornando-se Musa inspiradora e criatura. Para poder tornar-se criadora, a mulher teria de matar o anjo do lar, a doce criatura que segura o espelho de aumento, e teria de enfrentar a sombra, o outro lado do anjo, o monstro da rebeldia ou da desobediência. O processo de matar o anjo ou o monstro refere-se à percepção das prescrições culturais e das imagens literárias que de tão ubíquas acabam também aparecendo no texto das escritoras. (TELLES, 2006, p. 408).

Observamos, a seguir, um excerto publicado pela professora escritora Cecilia em 2001, no qual a representação da mulher com características divinas e ligadas à natureza se faz presente:

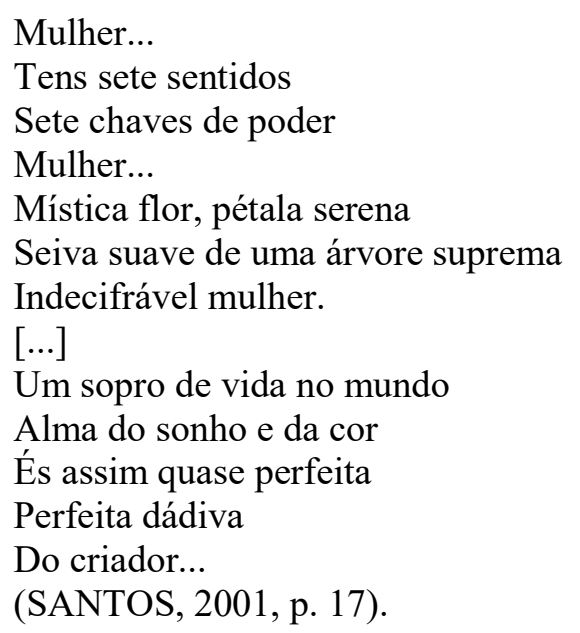

Pela utilização dos adjetivos "suave", "serena", "perfeita", "dádiva” percebemos que ainda se mantém uma percepção do feminino muito ligada às virtudes como qualidades quase que divinas, apresentada por um sujeito lírico indefinido e, por isso, 
pode representar uma visão masculina da mulher ainda muito estereotipada, como "a mulher ideal". Na sociedade atual ainda persistem traços do patriarcado ao mesmo tempo em que há movimentos de mulheres que buscam ressignificar a compreensão do que é ser mulher - os saraus, neste sentido, simbolizam importantes espaços para a reflexão acerca desta problemática. $\mathrm{O}$ excerto do poema citado anteriormente foi escrito pela professora Cecília em 2001, mais tarde, quando já fazia parte dos movimentos dos saraus, como afirmou durante a entrevista, a sua produção escrita passou por transformações decorrentes dos diálogos com outras mulheres sobre feminismo e direitos das mulheres, assim, escreve o poema que segue, publicado numa antologia apenas de mulheres:

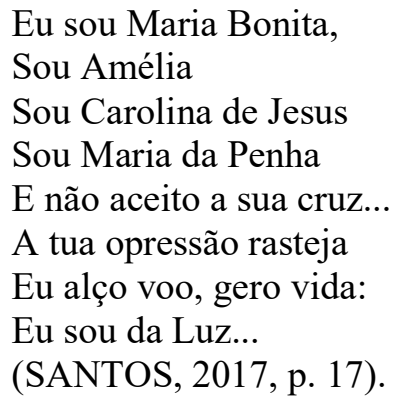

Neste poema, a professora Cecília nos apresenta uma outra representação da mulher, referenciando mulheres brasileiras que assumiram o protagonismo em suas histórias de vida, ela, autora e sujeito lírico, nega a opressão masculina, o que demonstra um reposicionamento de si na literatura que produz.

$\mathrm{O}$ excerto a seguir, escrito pela professora Virginia nos coloca a questão da liberdade de expressão alcançada pelas mulheres que, ao optarem pela escrita de textos autobiográficos, expõem questões ainda tidas como tabus, como é o caso da maternidade vista como algo natural, sem contradições e conflitos.

A maternidade não é valorizada na nossa sociedade. Nunca me senti tão controlada por pessoas que não conhecia como depois que eu virei mãe. Por um lado há a preocupação com a criança, [...] mas por outro todo mundo se sente no direito de dizer a uma mãe que ela tem que amamentar assim ou assado, que ela tem que corrigir os seus filhos dessa ou daquela forma e a lista de conselhos (determinações) é grande. Algumas mães abandonam seus filhos e isso é triste. Mas pouco se fala dos pais que os abandonam, o que é muito comum e tão triste quanto. Onde trabalho, na maior parte das vezes, o único elo de muitas crianças com o humano, é a mãe, ou uma outra mulher que faz papel de mãe, muitas crianças não tem sequer o nome do pai no registro. Continuamente ao receber essas mulheres escuto histórias de humilhação, violência doméstica, pobreza extrema. Elas precisam de políticas públicas, de proteção. As mulheres, mães, não precisam do controle do seu corpo e sim do apoio ao exercício da maternidade. (Virgínia, 2015). 
Como pode ser observado, a escrita marca um conflito muito presente na sociedade, referente ao controle do corpo feminino, assim como dos gestos e da postura. O fato da professora relatar a sua experiência como mãe e o que presencia na vida de outras mulheres, marca um posicionamento político da questão para além da crítica apresentada.

Desse modo, escrever a partir do próprio "ponto de vista", resgatando um olhar feminino que questiona o patriarcado e se coloca em diálogo com outras mulheres, é uma forma de assumir uma posição política, de luta e resistência no cenário social.

Nos poemas escritos pela professora Janaína, observamos a liberdade da exposição de um sujeito lírico feminino que expressa seus sentimentos e seus desejos, não para si mesma como acontecia no século XIX, e sim uma escrita poética para um possível leitor feminino ou masculino.

\author{
Inútil tentar brigar \\ Com roteiro \\ Na vida \\ Muito se desenha sozinho \\ Acato \\ E aguardo \\ As próximas cenas \\ $\mathrm{Na}$ trama da própria vida \\ Não dá pra ser protagonista todo dia \\ A gente faz todos os papéis \\ Tem dia de vilã \\ Outros de mocinha \\ Hoje? \\ Hoje aceito figuração \\ E me faço muitas \\ Até sozinha. \\ (MOITINHO, 2017, p.06).
}

Neste poema, a representação da mulher apresentada pelo eu poético feminino é a de uma mulher que na "trama" da vida pode ser o que desejar, podendo forjar um papel, assumir uma personagem, protagonizando a própria vida, mas quando este não for o seu desejo, estar sozinha já basta, indicando uma liberdade de escolha.

No poema a seguir, identificamos um sujeito lírico que padece, e que deste sofrimento intenso morre subitamente. Apesar de escrito em primeira pessoa, não há indícios de que o sujeito lírico seja homem ou mulher - a referência fica em suspenso, demonstrando as possibilidades da criação literária. 
Só por hoje

Rasgarei meu peito

E arrancarei flores de vidro,

Pássaros de origami e velhas mágoas

Picaretas dançam entre minhas vértebras

E eu toco calma a flauta de MAIAKÓVSKI

Nunca acreditei que gangrenas devorariam meu corpo

Pedaços de sorrisos caem desconexos da minha boca

E eu que imaginei morrer um dia de cada vez - Morte Súbita.

[...]. (BARBIERI, 2010).

A produção literária permite a fabulação, a criação de diversos personagens, cenários, narrativas e poemas com maior ou menor aproximação com o real. A partir de elementos da realidade, a professora Camila produziu um poema para o concurso literário em que trata das possibilidades fantasiar, imaginar a ser o que não se é, quando se utiliza a internet:

\author{
Numa mista conexão \\ Onde não somos ninguém \\ Onde o invisível tem coração \\ Onde tudo pode ir além. \\ Procurando entre palavras \\ Dar forma ao sentimento \\ Esperança imaginária \\ De viver neste momento. \\ Que nos faz este universo \\ Nos vestir de fantasia \\ De ser tudo ao inverso \\ Ilusão de noite e de dia. \\ A procura de identidade \\ Faz cada um sonhar \\ Que em outra realidade \\ Possa ter um lugar. \\ Onde a imaginação \\ Se mistura ao real \\ Onde a emoção \\ Flui de forma virtual. \\ (CAMILA, 2012, p. 145).
}

Embora o campo literário continue sendo, assim como a sociedade, uma arena de forças e conflitos entre homens e mulheres, cujas disputas ocorrem na busca por espaço e legitimação, observa-se que neste poema a mulher adquiriu a liberdade de se expressar seja por meio da ficção, seja através da escrita autobiográfica. Segundo Tennina (2017), o campo da literatura marginal e periférica é também um campo majoritariamente 
masculino, já que os saraus de maior visibilidade na cidade, como o da Cooperifa por exemplo, é dirigido por um homem, Sérgio Vaz. No entanto, vale enfatizar, as mulheres vêm ocupando os espaços de organização dos saraus em conjunto com outros homens e mulheres, assim como citamos anteriormente. Um exemplo apresentado por Lucia Tennina (2017), são os títulos publicados pela Edições Toró ${ }^{164}$, que de um total de quinze títulos publicados, somente três são de autoria feminina, mas que possuem homens como coautores, o que demonstra uma disputa no interior do campo literário marginal e periférico.

Regina Dalcastagnè (2018) realizou uma pesquisa sobre o perfil de escritores, personagens protagonistas e narradores no romance brasileiro, no período de 1960 a 2014 , e o resultado encontrado fornece subsídios para essa discussão sobre a autoria das mulheres professoras. De acordo com Dalcastagnè, a autoria feminina vem aumentando muito timidamente já que no intervalo de 1965 a 1979 havia 17,4\% de autoras, no período mais atual de 2005 a 2014, ela identificou apenas 29,4\% de mulheres escritoras de romances no país. É preciso pontuar que a pesquisa considerou obras publicadas por grandes editoras, o que demonstra que o campo literário brasileiro ainda privilegia os escritores. O estudo revelou, ainda, que a autoria da mulher negra é ainda mais reduzida no cenário nacional.

Para Dalcastagnè (2018), esse posicionamento do mercado editorial em relação às mulheres e outros grupos (indígenas, periféricos, negros, pobres) demonstra ao leitor que a literatura legítima é aquela produzida por homens de determinadas classes sociais, negando o que tem a dizer outros sujeitos por meio da literatura.

\subsubsection{Escrever em tempo de internet}

Nesta categoria temática elencamos três contos que, produzidos a partir do tema Sem remetente.com, nos apresentaram histórias ficcionais com elementos para uma discussão sobre a escrita na era da revolução digital. Desse modo, abordaremos os contos separadamente para, na sequência, discutirmos os elementos da cultura escrita embasando-nos em Chartier.

\footnotetext{
${ }^{164}$ Esta é a primeira editora fundada por escritor periférico (TENNINA, 2017).
} 
Em linhas gerais, o conto se caracteriza como a narrativa curta de um acontecimento, uma história inventada, isto é, sem compromisso com a realidade, cuja trama pode ser contada oralmente ou por meio da escrita. De acordo com Gotlib: "O conto, no entanto, não se refere só ao acontecido. Não tem compromisso com o evento real. Nele, realidade e ficção não tem limites precisos. [...] A esta altura, não importa averiguar se há verdade ou falsidade: o que existe é já a ficção, a arte de inventar um modo de se representar algo" (1987, p. 12). No conto há necessariamente o narrador, a voz que conta a história, e que pode assumir diferentes posições no interior deste tipo de texto literário. A elaboração de diferentes maneiras de narrar produz efeitos estéticos que são característicos do conto literário.

\section{Marcos, que amava Lúcia... que amaria Marcos, que amava cartas}

O conto "Marcos, que amava Lúcia... que amaria Marcos, que amava cartas"165, publicado na edição de 2012 do concurso literário Valeu, Professor, narra em terceira pessoa a história de Marcos, um menino que vive numa vila de pescadores e gosta de escrever cartas. As cartas que ele escreve são para sua amiga Lúcia que se mudou da vila, no entanto, ele não as envia.

Desde o dia em que Lúcia havia partido do vilarejo, Marcos passou a escrever muitas cartas... Não enviou uma sequer... Ficara com elas para si... Falavam sobre o passado, o presente e, quem sabe um dia, falariam sobre o futuro... Com Lúcia, é claro. Era com ela que dividia seus segredos... nas cartas... (SÃO PAULO, 2012, p. 67).

Marcos escreve muitas cartas para Lúcia planejando um dia encontrá-la e entregálas pessoalmente. Ele era "introvertido, romântico... E Lúcia... Lúcia era simplesmente seu mundo. Ele sairia da vila para encontrá-la... A pequena vila dos pescadores... Tão pequenina que todos conheciam exatamente cada canto daquele lugar". Passado um tempo, Marcos vai ao encontro de Lúcia e descobre que ela vive em um universo muito diverso daquele da vila de pescadores e descobre que ela tem muitos amigos, "Mais de cem", porém na vila, os amigos são poucos, porque poucos são os moradores. A personagem principal faz uma reflexão: “Como Lúcia poderia ter tantos amigos? Onde estão os amigos? Estariam por chegar?”.

\footnotetext{
${ }^{165}$ Referência do texto: São Paulo, 2012, p. $67-70$.
} 
Logo ele obtém as respostas: “Amigos virtuais... O mundo de Lúcia se abria. E seu mundo não era Marcos... Levava segundos para escrever a dezenas de pessoas... As letras surgiram rapidamente na tela... Num piscar de olhos... Lúcia achou graça na história das cartas...”.

E a carta que havia levado para Lúcia, continuava guardada: “Uma lágrima caiu... Rolou delicadamente até o envelope, que estava escondido no bolso interno da jaqueta do rapaz, manchando a letra cursiva, tão bem trabalhada no nome do destinatário: Lúcia. Cada letra feita demoradamente...”.

No enredo que conta a história de Marcos e seu encontro com Lúcia, a professora escritora inseriu a discussão sobre o que significa escrever como forma de comunicação em tempos de revolução digital, apresentando dois universos distintos através das personagens que se relacionam com o outro que está distante de formas completamente diferentes.

Seguindo com o enredo do conto:

Tudo era confuso para Marcos: postar, on-line, blog, amigos virtuais... Lúcia estava ali sozinha... E ao mesmo tempo com milhares de pessoas... numa sala... Ele não compreendia... Como se tem por amigo alguém que não se vê? [...] O que fazem quando... quando... só o olhar pode dizer... só os gestos podem explicar... só as mãos podem falar? Quando a palavra não entra em cena... (SÃO PAULO, 2012, p. 68).

Nesse momento a narradora problematiza as relações sociais que ocorrem por meio da internet e, de um modo bem sutil, critica a ausência do contato físico entre as pessoas ao mesmo tempo que questiona o que é tido como verdade na internet: "Lúcia se deslumbrava com as frases... Nos blogs... nas páginas dos amigos... Até descobrir que... Bem, algumas frases postadas não era exatamente daqueles autores citados... Nem sempre tudo era tão verdadeiro...”.

Marcos passa a usar a internet, mas não deixa de escrever cartas.

O título do conto faz referência ao poema Quadrilha de Drummond que no final é citado pela narradora de maneira irônica fazendo alusão à ideia de verdadeiro e falso ao conteúdo apresentado na internet: "Mas, pelo que se sabe, no poema de Drummond, todos eram, de fato, o próprio personagem. Não se corria o risco de João ser realmente Raimundo, ou Joaquim ser Teresa." 


\section{$\underline{\text { Ponte para Asgard }}$}

"Ponte para Asgard"166 é um conto narrado em terceira pessoa, por meio de um narrador onisciente intruso que repentinamente pausa a narrativa e se dirige ao leitor tecendo comentários. O enredo conta a história de José, um jovem que usava óculos e com acnes, que, de acordo com o narrador, era "sem graça", mas que vivia em um mundo paralelo em seu quarto: o computador. "Última geração, configurado em longo prazo com suaves prestações se seu pouco salário. Pouco, porém suficiente, já que outros gastos não tinha, por não ter uma emocionante vida no mundo número um [...]".

O universo paralelo de José se resumia ao blog: "Defronte à máquina, sentado em confortável cadeira vermelho fogo, ele podia acessar seu universo paralelo - seu blog Ponte para Asgard.” No isolamento que vivia em parte da sua rotina, José lia sobre a civilização nórdica e era sobre ela que escrevia no seu blog. "Nesse universo, José assinava seus artigos como Rainer Swardsen, e assim respondia aos visitantes mais aficionados, dentre milhares de pessoas que já haviam acessado o seu blog, e que enviavam perguntas, sugestões, críticas e elogios." Com o tempo, o seu blog passou a ser apenas uma atividade para as horas livres, até que José, sai da casa dos pais para trabalhar em um local distante. Quando chega na cidade, logo que sai do aeroporto, para em uma lan house e alguns minutos de acesso à internet:

Entra rapidamente e se dirige à moça de óculos do balcão. "Compra" dez minutos de acesso. Dez minutos. Tempo suficiente. Com a rapidez que seus conhecimentos acumulados em anos de vida solitária permitiram, retira definitivamente o blog do ar, como quem rasga uma página de livro que não será mais lida. (SÃO PAULO, 2012, p. 90 91).

\section{$\underline{\text { A quem possa interessar }}$}

"A quem possa interessar"167 é um conto narrado em primeira pessoa, apresentando uma narradora-personagem que não possui nome. É uma mulher que vive em uma cidade litorânea e que costuma se sentar na praia para observar o mar e com ele conversar.

Moro numa cidadezinha litorânea, uma península adornada pelas aguas azuis de um oceano feminino que às vezes me traz águas mansas e

\footnotetext{
${ }^{166}$ Referência do texto: SÃO PAULO, 2012, p. 87 - 91.

${ }^{167}$ Referência do texto: SÃO PAULO, 2012, p. $21-23$.
} 
brilhantes que acariciam a areia e, outras vezes, aguas turvas e opacas que escavam verdadeiros penhascos na praia. Deste cenário faço meu divã. (SÃO PAULO, 2012, p. 21).

Em um dia em que estava observando o mar, percebeu uma garrafa trazida pelas ondas e foi verificar: "[...] Chamou-me a atenção do fato de estar lacrada com uma rolha com o nítido intuito de manter conservado o seu conteúdo. [...] Percebi que, ao invés de um esperado líquido, ela continha um papel enrolado como um pergaminho que ocupava todo seu interior." O papel no interior da garrafa era uma carta, escrita em língua inglesa, como descreve a narradora:

O que ela trazia era uma carta, escrita em inglês, muito bem digitada em letras góticas, datada de mil novecentos e noventa e oito. Confesso que fiquei um tanto decepcionada. Minha imaginação, alimentada pelas histórias que compuseram a minha infância, esperava uma mensagem de algum náufrago isolado numa ilha deserta, ou um mapa do tesouro. Corri ao computador para traduzir a mensagem [...]. (SÃO PAULO, 2012, p. 22).

A mensagem era de um remetente que vivia provavelmente em Oslo, capital da Noruega, que para amenizar a solidão das noites de inverno recorria ao seu computador, como segue excerto da carta reproduzida no conto:

[...] Vivo os curtos dias intensamente, valorizando cada raio de sol e desfruto do anoitecer longo e frio na companhia de um fiel computador, que me aproxima de mundos distantes onde navego e faço amigos virtuais. Porém resolvi enviar esta mensagem de forma inusitada, usando um recurso natural e, em alusão à tecla enter, joguei a garrafa ao mar no campo enviar... [...] (SÃO PAULO, 2012, p. 22 - 23).

A narradora-personagem entendeu que era uma brincadeira do remetente e, com isso, introduziu uma reflexão como que expressão do seu pensamento, mas que também é direcionada ao leitor: "Hoje penso que estamos conectados uns aos outros, não só até onde nossos olhos podem ver, mas, mais ainda, até onde nossas palavras podem chegar. $[\ldots]^{\prime \prime}$.

$* * * *$

Nos três textos inseridos em Escrever em tempo de internet, observamos a utilização de referências materiais da cultura escrita na longa duração para a criação dos contos, nos quais os professores escritores retratam tensões atuais no uso das novas tecnologias do escrito. Para isso, fazem uso de recursos que representam o antigo e o novo da cultura escrita: pergaminho/computador, carta/tela, presença/ausência, materialidade/imaterialidade, permanência/apagamento do registro, escrita 
manuscrita/digitação, real ou verdadeiro/ falso no sentido do forjado, e um vocabulário próprio dos meios digitais.

Esses elementos que, num primeiro momento, podem parecer opostos, são representativos da cultura escrita, fazendo-nos refletir sobre o fato de que as revoluções do escrito não são uma simples modificação do suporte, já que as revoluções de Gutenberg e a digital transformaram o modo como nos relacionamos com o escrito e, por consequência, com o outro. Alguns materiais utilizados na produção do escrito já não existem nas sociedades, como o pergaminho, por exemplo. Este tipo de produção faz parte dos acervos de museus que guardam a memória da cultura escrita, no entanto, outras formas coexistem como a escrita manuscrita e a digitada, tais como o livro impresso e o digital. Para Chartier,

Insistir na importância que manteve o manuscrito após a invenção de Gutenberg é uma forma de lembrar que as novas técnicas não apagam nem brutal nem totalmente os antigos usos, e que a era do texto eletrônico será ainda, e certamente por muito tempo, uma era do manuscrito e do impresso. (CHARTIER, 2002, p. 08).

A constituição de um vocabulário característico dos meios digitais, diante do qual se viu Marcos, personagem do conto, ao se deparar com as palavras postar, on-line, blog e outras ainda que se fazem presentes nos contos seguintes, representam mais uma "língua artificial, com vocabulário e sintaxe próprios" (CHARTIER, 2002, p. 17) do que a adoção da língua inglesa como universal e elevada.

Em relação ao livro impresso e ao digital, Chartier (2002) afirma que o texto eletrônico gerou rupturas com o campo da cultura escrita, sendo que uma delas é a da "ordem dos discursos", estabelecida a partir da relação entre o objeto impresso, os tipos de textos e as formas de leitura.

É agora um único aparelho, o computador, que faz surgir diante do leitor os diversos tipos de textos tradicionalmente distribuídos entre objetos diferentes. Todos os textos, sejam eles de qualquer gênero, são lidos em um mesmo suporte (a tela do computador) e nas mesmas formas (geralmente as que são decididas pelo leitor). Cria-se assim uma continuidade que não mais diferencia os diversos discursos a partir de sua própria materialidade. (CHARTIER, 2002, p. 23).

Dessa forma, o texto eletrônico altera o suporte da cultura escrita, a percepção que o leitor tem do texto e do objeto material. Além disso, o conto "Ponte para Asgard" traz uma questão importante em relação à oposição permanência/ apagamento do registro escrito quando o narrador conta: “[...] Com a rapidez que seus conhecimentos acumulados 
em anos de vida solitária permitiram, retira definitivamente o blog do ar, como quem rasga uma página de livro que não será mais lida”. As publicações em páginas digitais, como no caso do blog, permitem a divulgação imediata sem a intermediação de um editor e sem a necessidade de uma instância de legitimação, pois este é um espaço autônomo. Além disso, da mesma maneira que o escritor decide publicar textos, pode apagá-los como fez a personagem do conto e esta é uma ação sem volta. Uma vez excluído um texto que só existia neste suporte, ele desaparece como se nunca houvesse existido. Chartier (2002) aborda a questão do medo de perder os materiais, mas como contraponto fala do excesso de materiais produzidos pela revolução digital e que, para conter tais excessos, são necessários instrumentos para classificar e hierarquizar os textos, ou seja, é preciso ter instituições de consagração das obras. No entanto, neste caso, a cultura escrita que se apresenta ordinária e pessoal, ou ainda materiais impressos ou digitais publicados de modo independente como os que mostramos nesta pesquisa, podem ser perdidos, já que não há a exigência de que passem por instâncias de legitimação, pois nestes casos esta tomada de decisão cabe ao professor escritor. Nesse sentido, consideramos ser fundamental pensar em políticas de conservação para materiais desse tipo, objetivando a preservação do patrimônio da cultura escrita na longa duração. Chartier aponta um caminho possível:

Diante desse dupla ansiedade, entre perda e excesso, a biblioteca de amanhã - ou de hoje - pode desempenhar um papel decisivo. Evidentemente, a revolução eletrônica pareceu significar seu fim. A comunicação a distância dos textos eletrônicos torna pensável, se não possível, a universal disponibilidade do patrimônio escrito, ao mesmo tempo que não impõe mais a biblioteca como o espaço de conservação e de comunicação desse patrimônio. Qualquer leitor, seja qual for o site de sua leitura, poderia receber qualquer um dos textos que constituem tal biblioteca sem paredes e mesmo sem localização, onde estariam idealmente presentes, de forma digital, todos os livros da humanidade. (CHARTIER, 2002, p. 119). 


\section{CONSIDERAÇÕES FINAIS. Ser professor, ser escritor: duas facetas de um mesmo eu}

Ser professor, ser escritor: duas facetas de um mesmo eu é o título que atribuímos às considerações finais desta pesquisa sobre as práticas da escrita literária de professores, na qual buscamos compreender as relações que possuem os professores com a prática da escrita literária no contexto atual. Para isso, objetivamos, de modo geral, identificar e analisar as práticas da escrita literária efetivadas por professores buscando a relação que estabelecem com tais. Assim, considerando os objetivos específicos a que nos propomos, identificamos as práticas da escrita literária de professores no Concurso Literário Valeu, Professor e nos saraus periféricos que acontecem em São Paulo, o que permitiu a constituição de corpus significativo de fontes documentais de práticas, composto de poemas, contos, crônicas e relatos autobiográficos, impressos ou em formato digital materializados nos seguintes suportes: livros, revistas, fanzines, revistas, livretos artesanais e blogs.

O percurso metodológico para analisar as fontes documentais - orais e textuais foi construído a partir dos professores entrevistados, pois o contato direto com o sujeito - professor - possibilitou maior aproximação entre a prática da escrita, efetivada no texto e no objeto material, e quem a realiza. As categorias de análise que construímos objetivaram responder à questão inicial da pesquisa, assim como atender aos objetivos específicos, desse modo, retomamos as categorias.

Em Práticas e usos da escrita depreendemos que as práticas realizadas pelos professores compreendem a escrita autobiográfica, na qual a professora relata suas experiências por meio de um blog, numa interlocução direta com o seu leitor, estabelecendo a dimensão de realidade do que escreve; a escrita literária induzida, na qual os textos literários foram produzidos objetivando a participação no Concurso Literário Valeu, Professor, sendo esta uma produção efetivada a partir de regras estabelecidas pela instituição; a escrita poética, na qual os professores privilegiam a escrita de poemas numa relação identitária e com a realidade em que estão inseridos e, alguns dos poemas produzidos, são usados para leitura e/ou declamação nos saraus; e o último aspecto desta categoria é o compartilhamento de experiências literárias, elaborado a partir do momento em que percebemos que o professor não objetiva escrever para si, eles e elas escrevem para compartilhar com o outro suas experiências literárias visando difundir a literatura 
que produzem e a literatura canônica, educar e formar os alunos, as pessoas da comunidade, e a si mesmos por meio da leitura e da escrita literárias.

Em relação aos saraus, eles reconstituem a forma de ler literatura na atualidade, visto que na história da leitura, segundo Chartier, a prática da leitura foi se configurando silenciosa e individualmente, entretanto nos saraus as leituras são coletivas e em voz alta, não há um só leitor, mas sim vários leitores, que reunidos em um espaço determinado compartilham suas leituras entre amigos, familiares e até desconhecidos reconstruindo assim as "sociabilidades ao redor do livro", como afirma Chartier (2002). Além disso, há a dimensão performática das leituras nos saraus, nas quais os textos são cuidadosamente escritos de modo rimado e/ou escolhidos para que a declamação seja também uma apresentação artística acompanhada de gestos, emoções e ritmo. E nesse processo, os professores que aqui entrevistamos são fundamentais, pois ao fazerem parte dos coletivos de saraus, eles compartilham as suas referências literárias que trazem de suas formações familiares e escolares, assim como as leituras cultivadas durante as formações acadêmicas e depois destas.

$\mathrm{Na}$ categoria Modos de produção dos escritos buscamos evidenciar como e quando os professores produzem seus textos, demonstrando com isso os instrumentos da cultura escrita utilizados nesses processos e, como consequência, os modos de escrever que coexistem entre antigas e novas maneiras do ato de escrita. Além disso, tratamos das materialidades dos objetos selecionados utilizando, para isso, imagens dos suportes que nos ajudam a dimensionar o trabalho de confecção de cada objeto produzido, sendo que alguns foram elaborados por editoras e outros pelos próprios professores indiciando marcas de pessoalidade no material que fazem circular e, também, ficou em evidência a existência de um espaço próprio de circulação de alguns materiais na periferia, apartado do mercado editorial, aspecto este que pode ser estudado futuramente. Em relação ao Concurso Literário Valeu, Professor, os livros circularam nas escolas e entre os autores que receberam alguns exemplares, porém, como pudemos observar nas entrevistas essas publicações não constam em todas as bibliotecas escolares, o que nos oferece pistas de que a circulação desse material foi restrita ao interior do concurso, aspecto esse que deixamos indicado para aprofundamento posterior.

Em relação à categoria Distinção, elencamos os professores e as práticas que, em nossa análise, indicaram uma busca por legitimação no campo literário e educacional por meio de concursos e prêmios de literatura. A nosso ver, três professores buscam serem reconhecidos como escritores no campo literário e, para isso, utilizam as instâncias de 
legitimação que possibilitariam tal feito, já os professores que participaram do Concurso Literário Valeu, Professor, acreditamos que buscam legitimação no interior do campo educacional em que estão inseridos, um certo reconhecimento pelos seus pares em virtude das habilidades literárias que possuem. Essa busca por reconhecimento, pela distinção, como escritores nos conduz a pensar que o campo educacional está em desprestígio e seus agentes, os professores, sentem-se igualmente desprestigiados.

Em Interlocução com a realidade: crítica, denúncia e representações privilegiamos a análise dos textos considerando as temáticas e os elementos de linguagem utilizados na composição dos textos literários, o que colocou em evidência a diversidade literária presente nas práticas realizadas pelos professores. Assim, quando tratamos das Representações sobre a profissão e o contexto escolar, apresentamos dois contos que, de modos distintos, abordam a profissão docente, um evidencia a prática pedagógica na educação infantil utilizando recursos ficcionais da literatura fantástica, o outro, é uma ficção com maior proximidade com o real, na qual o professor escritor problematiza seus conflitos profissionais ao mesmo tempo que aborda questões sociais envolvendo os alunos no interior da escola. Além desses, apresentamos uma crônica que traz um relato reflexivo de uma professora sobre o ser professora e que apesar de estar publicado como crônica, é um texto de que se aproxima do relato memorialístico. Em A constituição de uma outra ideia de periferia elencamos textos dos professores que estão vinculados aos saraus periféricos de São Paulo e que em suas produções contribuem para a representação de uma outra noção de periferia, de um território habitado por trabalhadores que buscam sobreviver cotidianamente em meio às dificuldades sociais que enfrentam. Além disso, os textos trazem as marcas identitárias de cada professor escritor, os quais são representados pela ideia do negro e seus descendentes e do migrante nordestino, marcas muito presentes e fortes de quem já se sentiu discriminado por isso. Por outra parte, notase que os saraus e as práticas da escrita ressignificam as identidades desses professores e é por meio delas que reelaboram suas representações do mundo social em que estão inseridos. O Cotidiano em São Paulo apresenta duas crônicas ficcionais em que o circunstancial presenciado no cotidiano da cidade foi retratado. Essas crônicas constroem representações da cidade nas quais os habitantes da capital paulista podem se sentir identificados. Em Escrever do "ponto de vista" feminino elencamos textos produzidos pelas professoras nos quais a perspectiva da produção escrita da mulher é redimensionada, apresentando a liberdade de expressar - de modo autobiográfico e/ou ficcional -, seus pensamentos, conflitos, representações "do eu" e dos seus respectivos contextos. E em 
Escrever em tempo de internet trazemos três contos nos quais os professores exploram a escrita fíccional, indicando não só elementos da cultura escrita, como também a coexistência entre o presente e o passado desta cultura.

Entre a escrita e o magistério é o aspecto que reservamos para a conclusão desta investigação, um estudo que não se encerra com a finalização deste texto. Sendo assim, queremos ainda estabelecer algumas correlações entre a prática da escrita efetivada pelos professores e o exercício do magistério. Ser um professor(a) escritor(a) significa para os entrevistados(as) realizar duas atividades imbricadas, porque o professor é um sujeito imerso na universo da cultura escrita pela natureza do seu trabalho e da sua formação, como mencionamos no início da tese, mas, não se resume a isso, porque o professor é uma pessoa, como já afirmava Nóvoa, e o capital cultural que possui entra em operação no exercício do magistério e na efetivação das práticas da escrita. Desse modo, não é possível dissociar o professor de sua pessoa. Com isso queremos afirmar que o ser escritor aparece no exercício do magistério e o ser professor marca a produção escrita literária dos professores. No poema a seguir, escrito em primeira pessoa, o professor Jefferson expressa a preocupação com a ausência de aulas na escola.

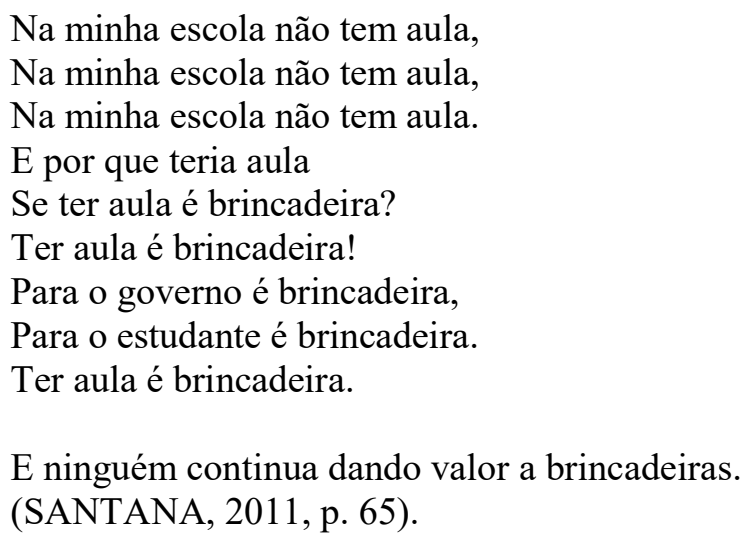

Neste poema, o professor e sujeito lírico relaciona as aulas com o vocábulo "brincadeiras", aspecto que lhe possibilita criticar de forma metafórica tanto o governo quanto a sociedade, no que se refere à ausência de seriedade na condução do sistema educacional.

$$
\begin{aligned}
& \text { O meu esporte preferido } \\
& \text { É ver criança em voo livro... }
\end{aligned}
$$

(SANTOS, 2017, p. 69). 
O poema breve da professora Cecilia expressa, por meio do jogo de palavras, a intencionalidade do professor que atua com os anos iniciais do processo de escolarização. Neste poema, verifica-se em ver a criança que aprendeu a ler, alçar voo no universo da leitura. Como podemos observar, a referência à profissão e ao contexto escolar não é direta, como vimos no conto Moon Walker, por exemplo, no entanto, esta forma sutil, consiste numa representação da professora ao seu contexto profissional.

A professora Virginia, por seu turno, afirma que o ser professora está contido nas suas escritas autobiográficas nas quais demarca a sua representação de escola e de professora a partir de um posicionamento de sujeito que compreende a educação como um ato político (FREIRE, 1996):

[...] é um terço dos textos fala sobre ser professora, o outro fala sobre ser mãe, o outro fala sobre as questões de gênero, não minto, né, tem as questões políticas que na verdade estão em todos os textos, né, no texto da maternidade, no texto das questões de gênero, no da própria escola, né, porque se você pegar, nenhum texto meu que fala sobre escola, fala sobre escola naquela perspectiva assim do professor missionário, do professor resignado, né, da docência como... enfim, é sempre numa perspectiva política, né, então, acho que tem muita influência da escola lá, né, de como eu enxergo a escola, de como eu penso a escola. (Entrevista pessoal professora Virginia, 2017).

Numa relação inversa, depreendemos a partir das entrevistas que o professor que é escritor, ou seja, que tem uma prática efetiva da escrita, "transporta" as suas referências de escritor para a escola, objetivando promover entre os alunos o interesse, o gosto, pela leitura e escrita. No excerto a seguir, o professor Márcio nos relatou o debate que promoveu entre seus alunos da escola pública com dois escritores de Cabo Verde que visitavam o Brasil:

[...] vieram dois poetas cabo-verdianos, que são uns gigantes de Cabo Verde, o Filinto Elísio e o Armênio Vieira, que ganhou o Prêmio Camões, e o próprio presidente do Cabo Verde que é um grande escritor, né. E eu os convidei, eu já tinha conhecido, porque eu os levei ao Sarau da Cooperifa em 2012, e eles estavam na USP, semana da literatura cabo-verdiana na USP, e aí nós convidamos, e eles foram, Dulcino Fortes, inclusive, um grande escritor, que faleceu, e eles foram, e aí criou um grande laço. [...] E quando ele veio eu falei "Pô, você precisa conversar com os alunos na escola" [...], Aí eles foram, nossa, e foi lindo. [...] Lá no estado, na Luís Gonzaga Pinto e Silva. Só que aí, eu os levei à Fábrica de Cultura de São Luís, porque não tinha um espaço na escola pra eu reunir só os meus alunos, porque, você trazer um escritor que pouca gente conhece, enfim, no nosso país, né, porque em Portugal, na África de língua portuguesa, eles são super famosos, e aí tem um monte de gente que nunca leu nenhum texto, e eu não dou aula pra todas as salas da escola, então eu peguei as salas que eu trabalhava, eu já estava trabalhando com as literaturas de língua 
portuguesa, né, dos países da África, e casou muito bem assim. Então os alunos foram super interessados, já tinham estudado a biografia deles, então foi uma coisa muito legal. Aí eles voltaram, né, retornaram lá pra Cabo Verde e aí eles me enviaram um e-mail, né, a editora deles lá, falando que foi uma das melhores experiências que eles tiveram no Brasil [...] então, foi muito legal. (Entrevista pessoal professor Márcio).

Por circular no campo acadêmico e no campo da literatura periférica, este professor demonstra certa rede de relações que possibilita aproximar a escola deste campo literário específico e, desse modo, propiciar aos alunos outras inserções culturais.

O professor José Vandeí nos relatou em entrevista que ser professor estabelece uma relação com a sua produção no sentido do cuidado que ele tem com o texto, com a pesquisa que desenvolve para escrever um poema e no que objetiva com a sua poesia, que é afetar o outro:

[...] interfere no sentido do cuidado que eu tenho com o acabamento da poesia, o aprofundamento teórico que tem na minha poesia, por exemplo, algumas poesias minhas, você percebe que eu tenho algumas leituras, que eu conheço determinadas teorias, determinados autores, e isso eu acho que a minha formação me trouxe. E o acabamento que eu dou nas coisas da pesquisa, tem muito a ver do que é ser professor, de ter o cuidado de fazer bem feito. Então, eu acho que interfere muito, interfere nesse sentido, não negativo. Eu acho que colabora, agrega, me ajuda. Mas, eu acho que interfere assim, não sei se a forma que eu uso a poesia, também. Pra que eu uso a poesia? Pra afetar o outro, tem muito a ver o que eu quero enquanto educador, que é afetar o outro. (Entrevista pessoal professor José Vandeí).

Afetar o outro a partir da escrita poética é comparado por este professor a afetar o outro por meio da educação, ou seja, são ações diferentes, mas que na visão deste professor possuem a mesma intencionalidade: o afetar!

Assim, concluímos este texto de investigação com um poema:

Aquele que se indaga

aponta pra si

a ponta da adaga

da dúvida

[donde a arte que me inflijo é bainha.

Escrevo porque sangro num canto

onde só a palavra estanca

escrevo pra conhecer minhas perguntas

respostas são feitas de enquantos

A palavra carrega em si o poder do encanto

mas que não se finde nela o alumbramento 
estético

o que procuro dela é o

espanto

a traduzir os lapsos do cotidiano

e perceber o milagre

das flores amarelas chorando sobre Macondo

[ao que paro

penso

peço:

que estes traços

concebidos à sombra do

caos

sejam preces a trazer

luz

pros próximos passos.

A adaga da dúvida seja enfim

lâmina

fria

cortando-me a carne

me talhe

em pedaços de

palavra \&

poesia

: vou me dar aos bifes [té não sobrar mais nada]

Irmanado meu por-dentro

pode até que fique oca. vazia,

mas consiga sentir

a tempo

que

o lamento que

verbalizo

é alimento que

compartilho

pra uma antropofagia dos sentidos.

(SANTOS, Michele, Sobre searas: saraus, 2015, p. $34-35)^{168}$.

${ }^{168}$ A forma do poema corresponde à publicação presente no livro Toda via. 


\section{FONTES DOCUMENTAIS}

\section{Textos Literários}

BARBIERI, Márcia. Manhãs em migalhas. In: SÃO PAULO (Município); Secretaria de Educação. Eu me lembro: crônicas, contos e poesias. São Paulo: SME, 2010, p. 83.

BOCCHIGLIERI, Eliane. Pedro Baleia. In: SÃO PAULO (Município); Secretaria de Educação. Eu me lembro: crônicas, contos e poesias. São Paulo: SME, 2010, p. 61-63.

ORTEGA, A. Mista conexão. In: SÃO PAULO (Município); Secretaria de Educação. Sem remetente.com. São Paulo: SME, 2012, p. 145-146.

COSTA, Arlete M. Céus de SP. In: SÃO PAULO (Município); Secretaria de Educação. Sob o céu da cidade. São Paulo: SME, 2011, p. 43-45.

QUINHÕES, J. O amor de ser educador. In: In: SÃO PAULO (Município); Secretaria de Educação. Sob o céu da cidade. São Paulo: SME, 2011, p. 87-89.

LOPES, Daniel. Moon Walker. In: SÃO PAULO (Município); Secretaria de Educação. Eu me lembro: crônicas, contos e poesias. São Paulo: SME, 2010, p. 41-45.

MARINHO, Márcio Vidal. 21 gramas. Rio de Janeiro; Ibis Libris, 2016.

. Velho canto brasileiro. In: 21 gramas. Rio de Janeiro; Ibis Libris, 2016, p. 64.

. Poeta. In: 21 gramas. Rio de Janeiro; Ibis Libris, 2016, p. 13-31.

. A vida em três tempos. Rio de Janeiro; Ibis Libris, 2014.

MARTINS, Esther M. F. Carícias verbais. In: SÃO PAULO (Município); Secretaria de Educação. Sob o céu da cidade. São Paulo: SME, 2011, p. 35-37.

MATSUDA, Osvaldo. Janelas Metropolitanas. In: SÃO PAULO (Município); Secretaria de Educação. Sob o céu da cidade. São Paulo: SME, 2011, p. 77-80. 
MENDONÇA, Letícia. Alguma releitura para o século XXI. In: Jornalirismo. Disponível em: http://www.jornalirismo.com.br/literatura/alguma-releitura-para-oseculo-xxi/. Acesso em: 09 set. 2019.

MOITINHO, Janaína. Fôlego. São Paulo: edição do autor, [s.d.]. (fanzine, folheto)

. Pedaços. São Paulo: edição do autor, 2017. (fanzine, folheto)

. O tiro. In: Pedaços. São Paulo: edição do autor, 2017, p. 05. (fanzine, folheto)

. [poema sem título]. In: Pedaços. São Paulo: edição do autor, 2017, p. 14. (fanzine, folheto)

. et.al. Poesia Sem Medo. São Paulo: Edições do Tietê; Slam do Grito. Jun., 2017. (revista, folheto)

NOGUEIRA, Jamir. Ponte para Asgard. In: SÃO PAULO (Município); Secretaria de Educação. Sem remetente.com. São Paulo: SME, 2012, p. 87-91.

OLIVEIRA, José Vandeí. Falo. Arujá, SP: Editora Espaço Idea, 2016.

Mais um Silva. In: Falo. Arujá, SP: Editora Espaço Idea, 2016, p. 49.

Notas do subterrâneo. In: Falo. Arujá, SP: Editora Espaço Idea, 2016, p. 20.

PESSOA, S. A quem possa interessar. In: SÃO PAULO (Município); Secretaria de Educação. Sem remetente.com. São Paulo: SME, 2012, p. 21-23.

PINHEIRO, Izabel. Marcos que amava Lúcia... que amaria Marcos, que amava cartas... In: SÃO PAULO (Município); Secretaria de Educação. Sem remetente.com. São Paulo: SME, 2012, p. 67-70.

SANTANA, Jefferson. Cantos e desencantos de um guerreiro. São Paulo: Scortecci, 2011.

Na minha escola não tem aula. In: Cantos e desencantos de um guerreiro. São Paulo: Scortecci, 2011, p. 65 

2011, p. 20.

Eu paulistano. In: Cantos e desencantos de um guerreiro. São Paulo: Scortecci, p. $80-81$

Trajeto. In: Cantos e desencantos de um guerreiro. São Paulo: Scortecci, 2011,

Oração do Guerreiro. In: Cantos e desencantos de um guerreiro. São Paulo: Scortecci, 2011, p. 15.

p. 41

. Pássaro. In: Cantos e desencantos de um guerreiro. São Paulo: Scortecci, 2011,

. Gula literária. In: Cantos e desencantos de um guerreiro. São Paulo: Scortecci, 2011, p. 17.

. Pétalas e pedradas. São Paulo: edição do Autor, 2014.

. (des) caminhos. São Paulo: edição do autor, . (folheto)

. Linguística. São Paulo: edição do autor, (fanzine, folheto)

In Versus. São Paulo: edição do autor, (fanzine, folheto)

et.al. Uma vez poetas ambulantes... São Paulo: Conecta Brasil, 2013.

. A poesia de todos os instantes. In: . et.al. Uma vez poetas ambulantes... São Paulo: Conecta Brasil, 2013, [s.p.].

Dispersar. In: . et.al. Uma vez poetas ambulantes... São Paulo: Conecta Brasil, 2013, [s.p.].

SANTOS, E. Caçando Estrelas. São Paulo: Editora Nativa, 2001.

Blog Girassol Poético. Disponível em: girassolpoetico.blogspot.com. Acesso em: 01 set. 2019.

Corda Bamba. In: Blog Girassol Poético; Caçando estrelas. São Paulo: Editora Nativa, 2001, p. 83. 
. Bar e poesia. In: COLETIVO CULTURAL SARAU DO ADEMAR. Primeiras

Prosas. São Paulo: edição independente, 2011, p. 22.

p. 69 .

. poesia sem título. In: Elas Antologia Poética. São Paulo: Edições do Tietê, 2017, p. 17.

poesia sem título. In: Elas Antologia Poética. São Paulo: Edições do Tietê, 2017,

. Mulher. In: Caçando Estrelas. São Paulo: Editora Nativa, 2001, p. 17.

SANTOS, Michele. Toda via,. São Paulo: Ed. do Autor, 2015.

. Gira Sol. In: Toda via,. São Paulo: Ed. do Autor, 2015, p. 11.

. Sociedade dos poetas vivos. In: Toda via,. São Paulo: Ed. do Autor, 2015, p. 33.

. Sobre searas: saraus. In: Toda via,. São Paulo: Ed. do Autor 2015, p. 34-35

. Carcará. In: Toda via,. São Paulo: Ed. do Autor 2015, p. 15.

. [poema sem título]. In: Toda via,. São Paulo: Ed. do Autor 2015, p. 37.

Deve ser isso: poemas possíveis. São Paulo: Ed. do Autor, 2017.

VÁRIOS AUTORES. Elas Antologia Poética. São Paulo: Edições do Tietê, 2017.

VIRGINIA. (nome fictício). Blog Palavrinhas, palavras e palavrões. Disponível em: http://palavrinhaspalavraspalavroes.blogspot.com.br/. Acesso em: 09 nov. 2017.

. Balanço. In: Blog Palavrinhas, palavras e palavrões. Disponível em: http://palavrinhaspalavraspalavroes.blogspot.com.br/. Acesso em: 09 nov. 2017.

Começar um blog. In: Blog Palavrinhas, palavras e palavrões. Disponível em: http://palavrinhaspalavraspalavroes.blogspot.com.br/. Acesso em: 09 nov. 2017. 
Reflexões sobre ser professora. In: Blog Palavrinhas, palavras e palavrões.

Disponível em: http://palavrinhaspalavraspalavroes.blogspot.com.br/. Acesso em: 09 nov. 2017.

As Virginias que me habitam ou conhece a ti mesmo. In: In: Blog Palavrinhas,

palavras e palavrões. Disponível em:

http://palavrinhaspalavraspalavroes.blogspot.com.br/. Acesso em: 09 nov. 2017.

SÃO PAULO (Município); Secretaria de Educação. Eu me lembro: crônicas, contos e poesias. São Paulo: SME, 2010.

SÃO PAULO (Município); Secretaria de Educação. Sob o céu da cidade. São Paulo: SME, 2011.

SÃO PAULO (Município); Secretaria de Educação. Sem remetente.com. São Paulo: SME, 2012.

\section{Documentos Oficiais da SME}

SÃO PAULO; Secretaria Municipal de Educação. Boletim Oficial da Secretaria Municipal de Educação de São Paulo Nossa Escola, 2010-2012.

SÃO PAULO (Município). Portaria SME n 2718, de 07 de maio de 2010. Diário Oficial da Cidade de São Paulo. São Paulo, 7 mai. 2010.

SÃO PAULO (Município). Portaria n 2.340 de 02 de maio de 2011. Diário Oficial da Cidade de São Paulo. São Paulo, 03 mai. 2011.

SÃO PAULO (Município). Comunicado n 685 de 13 de maio de 2011. Diário Oficial da Cidade de São Paulo. São Paulo, 14 mai. 2011.

SÃO PAULO (Município). Comunicado n 686 de 13 de maio de 2011. Diário Oficial da Cidade de São Paulo. São Paulo, 14 mai. 2011.

SÃO PAULO (Município). Comunicado n 687 de 13 de maio de 2011. Diário Oficial da Cidade de São Paulo. São Paulo, 14 mai. 2011.

SÃO PAULO (Município). Portaria n 3763 de 25 de julho de 2011. Diário Oficial da Cidade de São Paulo. São Paulo, 26 jul. 2011. 
SÃO PAULO (Município). Portaria n 3762 de 25 de julho de 2011. Diário Oficial da Cidade de São Paulo. São Paulo, 26 jul. 2011.

SÃO PAULO (Município). Comunicado $n^{\circ} 627$ de 12 de abril de 2012. Diário Oficial da Cidade de São Paulo. São Paulo, 12 abr. 2012.

SÃO PAULO (Município). Comunicado n 683 de 19 de abril de 2012. Diário Oficial da Cidade de São Paulo. São Paulo, 20 abr. 2012.

SÃO PAULO (Município). Comunicado n ${ }^{\circ} 829,11$ de maio de 2012. Diário Oficial da Cidade de São Paulo. São Paulo, 12 mai. 2012.

SÃO PAULO (Município). Portaria 3.212 de 22 de maio de 2012. Diário Oficial da Cidade de São Paulo. São Paulo, 23 mai. 2012.

SÃO PAUlO (Município). Portaria n n $^{4} .143$, de 18 de julho de 2012. Diário Oficial da Cidade de São Paulo. São Paulo, 19 jul. 2012.

SÃO PAULO (Município). Portaria $n^{\circ} 4.144,18$ de julho de 2012. Diário Oficial da Cidade de São Paulo. São Paulo, 19 jul. 2012. 


\section{REFERÊNCIAS}

AGUIAR, C.M.; CAMARGO, M.R.R.M. Entre textos, saberes e objetos: um olhar para as fontes. In: Aguiar, Carmen Maria. (Org.). Educação e Saberes: correlação com a natureza e a cultura. 1ed. Rio de Janeiro: Guanabara Koogan, 2010, v. 1, p. 109-117.

AGUIAR, D. R. da C. A proposta de política pública educacional no Município de São Paulo: a (des)construção de uma Escola pública popular, democrática e com qualidade. In: Simpósio Brasileiro de Política e Administração da Educação, 25, 2011, São Paulo. Anais... São Paulo, 2011. Disponível em: $<$ http://www.anpae.org.br/simposio2011/cdrom2011/PDFs/trabalhosCompletos/comuni cacoesRelatos/0132.pdf > . Acesso em: 08 dez. 2016.

ALCANTARA, Wiara Rosa Rios. A sala de aula foi o meu mundo: a carreira do magistério em São Paulo (1920-1950). Educ. Pesqui., São Paulo, v. 38, n. 2, p. 289305, jun. 2012. Disponível em $<$ http://www.scielo.br/scielo.php?script=sci_arttext\&pid=S151797022012000200002\&lng=pt\&nrm=iso>. Acesso em: 08 set. 2017.

AQUINO, Julio Groppa. A escrita como modo de vida: conexões e desdobramentos educacionais. Educ. Pesqui., São Paulo, v. 37, n. 3, p. 641-656, dez. 2011. Disponível em $\quad<$ http://www.scielo.br/scielo.php?script=sci_arttext\&pid=S151797022011000300013\&lng=pt\&nrm=iso >. Acesso em: 08 set. $201 \overline{7}$.

BRASIL. MEC/INEP. Censo do Professor. 2007.

BASTOS, M. H. C.; CUNHA, M. T. S.; MIGNOT, A. C. V (Orgs.). Destinos das letras: história, educação e escrita epistolar. Passo Fundo: UPF, 2002.

BOGDAN, R.; BIKLEN, S. Investigação qualitativa em educação: uma introdução à teoria e aos métodos. Portugal: Porto, 1994.

BOURDIEU, Pierre. Razões práticas: sobre a teoria da ação. Campinas, SP: Papirus, 1997.

. (coord.) A miséria do mundo. Petrópolis, RJ: Vozes, 2012.

. As Regras da Arte: gênese e estrutura do campo literário. São Paulo: Companhia das Letras, 1996.

Os três estados do capital cultural. In: Catani, A. (org.). Escritos de Educação. Petrópolis, RJ: Vozes, 1999, p. 71-79.

.; CHARTIER, R. A leitura: uma prática cultural. In: CHARTIER, Roger. (org.) Práticas da Leitura. São Paulo: Estação Liberdade, 2001, p. 231-253. 
BUENO, Belmira Oliveira et al. Histórias de vida e autobiografias na formação de professores e profissão docente (Brasil, 1985-2003). Educ. Pesqui., São Paulo, v. 32, n. 2 , p. 385-410, ago. $2006 . \quad$ Disponível em $<$ http://www.scielo.br/scielo.php?script=sci arttext\&pid $=$ S1517-

97022006000200013\&lng=pt\&nrm=iso>. Acesso em: 08 set. 2017.

CAMARGO, Maria Rosa Rodrigues Martins de. Cartas e escrita. 2000. $148 \mathrm{f}$. Tese (Doutorado em Educação) - Faculdade de Educação, Universidade Estadual de Campinas, Campinas, 2000.

CANDIDO, Antonio. O direito à Literatura. In: CANDIDO, Antonio. Vários Escritos. São Paulo: Rio de Janeiro: Duas Cidades; Ouro sobre Azul, 2004, p. 169-191.

. Literatura e sociedade: estudos de teoria e história literária. São Paulo: Companhia Editora Nacional, 1965.

. A vida ao rés-do-chão. In: Para gostar de ler: crônicas. Vol. 5, São Paulo: Ática, 2003, p. 89-99.

CARA, Salete de Almeida. A Poesia Lírica. São Paulo: Editora Ática, 1989.

CATANI, Denice Barbara. As leituras da própria vida e a escrita de experiências de formação. In: CASTILLO GÓMEZ, Antonio. (dir.); SIERRA BLAS, Verónica. (ed.). EI legado de Mnemosyne. Las escrituras del yo a través del tiempo. Gijón (Asturias): Ediciones Trea, 2007, p. $273-286$.

. Memória e Biografia: "O Poder do Relato e o Relato do Poder" na História da Educação. In: Pesquisa Histórica: Retratos da Educação no Brasil. UERJ, p. 73-80.

Os escritos dos professores no campo educacional brasileiro (1890-1970). In: Actas do VII Congresso Luso-Brasileiro de História da Educação. Porto, Portugal: Faculdade de Psicologia e Ciências da Educação (Universidade do Porto), jun. 2008, p. $1-10$.

.; VICENTINI, P. P. Minha vida daria um romance: lembranças e esquecimentos, trabalho e profissão nas autobiografias de professores. In: MIGNOT, A. C. V.;CUNHA, M. T. S. (orgs). Práticas de memória docente. São Paulo: Cortez, 2003, p. 149-166.

.; SILVA, V. B. da. Memória e História da Profissão dos Professores: As Representações sobre a Profissão Docente nos Manuais Pedagógicos. Revista Educação em Foco. 2009. Disponível em: www.ufjf.br/revistaedufoco/files/2009/10/343o-2-AnaMaria- 7 1.pdf

CASTILlO GÓMEZ, Antonio. (coord). Historia de la cultura escrita. Del Próximo Oriente Antiguo a la sociedade informatizada. Gijón (Asturias): Ediciones TREA, 2010.

Educação e cultura escrita: a propósito dos cadernos e escritos escolares. In: Educação. Porto Alegre, v. 35, n. 1, p. 66-72, jan./abr., 2012. 
(coord.) La conquista del alfabeto: escritura y clases populares. Espanha: Ediciones TREA, 2002.

CERTEAU, Michel. A invenção do cotidiano: artes de fazer. Petrópolis: Vozes, 1994. v.1.

CHARTIER, Roger. A história cultural: entre práticas e representações. Lisboa: Difel, 1990.

Las Revoluciones de la Cultura Escrita: diálogo e intervenciones. Barcelona, España: Editorial Gedisa, 2000.

A aventura do livro: do leitor ao navegador. São Paulo: Editora UNESP, 1999.

As práticas da escrita. In: (org). História da vida privada: da Renascença ao século das luzes. São Paulo: Companhia das Letras, 1991. v.3., p.113 161.

Os desafios da escrita. São Paulo: Editora Unesp, 2002.

CHARRÉU, Leonardo Verde; OLIVEIRA, Marilda Oliveira de. Diários de aula e portfólios como instrumentos metodológicos da prática educativa em artes visuais. Cadernos de Pesquisa, São Paulo, v. 45, n. 156, p. 410-425, abr./jun. 2015. Disponível em: http://publicacoes.fcc.org.br/ojs/index.php/cp/issue/view/290/ Acesso em: 10 set. 2017.

CORAZZA, Sandra Mara et al. Escrileituras: um modo de ler-escrever em meio à vida. Educ. Pesqui., São Paulo, v. 40, n. 4, p. 1029-1043, dez. 2014. Disponível em $<$ http://www.scielo.br/scielo.php?script=sci_arttext\&pid $=$ S1517-

97022014000400011\&lng=pt\&nrm=iso>. Acesso em: 09 set. 2017.

CORRÊA, Alamir Aquino. Literatura: contexto digital, hipercolonialismo e materialidades. In: Estudos de Literatura Brasileira Contemporânea, n. 47, p. 119140, jan./jun. 2016. Disponível em: http://www.scielo.br/pdf/elbc/n47/2316-4018-elbc47-00119.pdf. Acesso em: 30 ago. 2019.

CULLER, Jonathan. O que é Literatura e tem ela importância? In: Teoria Literária: uma introdução. São Paulo: Beca, 1999, p. 26-47.

CUNHA, M. T. S. Diários íntimos de professoras: letras que duram. In: MIGNOT, A. C. V.; BASTOS, M. H. C.; CUNHA, M. T. S. (Orgs.). Refúgios do eu: educação, história e escrita autobiográfica. Florianópolis: Mulheres, 2000, p. 159-180.

“Por hoje é só..." Cartas entre amigas. In: BASTOS, M. H. C.; CUNHA, M. T. S.; MIGNOT, A. C. V. (Orgs.) Destinos das letras: história, educação e escrita epistolar. Passo Fundo: UPF, 2002, p. 181-204.

MASSUELA, Amanda. Quem é e sobre o que escreve o autor brasileiro. Entrevista com Regina Dalcastagnè. In: CULT. n. 231, fev. 2018, p. 14-19. (revista) 
DEMARTINI, Z. de B. F.; ANTUNES, F. F. Magistério primário: profissão feminina, carreira masculina. Cadernos de Pesquisa, São Paulo, n.86, p.5-14, ago., 1993.

DORA LICE. O Calvário de uma Professora. São Paulo: Estabelecimento Gráfíco Irmãos Ferraz, 1928.

EAGLETON, Terry. O que é literatura? In: Teoria da Literatura: uma introdução. São Paulo: Martins Fontes, 1983, p. 01-17.

ENCREVÉ, Pierre; LAGRAVE, Rose-Marie. (coord.) Trabalhar com Bourdieu. Rio de Janeiro: Bertrand Brasil, 2005.

FRANCHETTI, Paulo. O Haicai no Brasil. Alea, Rio de Janeiro, v. 10, n. 2, p. 256269, Dez. 2008 . Disponível em: http://www.scielo.br/pdf/alea/v10n2/07.pdf. Acesso em: 14 set. 2019.

FREITAS, Maria Teresa Menezes; FIORENTINI, Dario. Desafios e potencialidades da escrita na formação docente em matemática. Rev. Bras. Educ., Rio de Janeiro, v. 13, n. 37, p. 138-149, abr. 2008. Disponível em $<$ http://www.scielo.br/scielo.php?script=sci_arttext\&pid=S1413$24782008000100012 \& \operatorname{lng}=$ pt\&nrm=iso $>$. Acesso em: 12 set. 2017.

GALVÃO, A. M. de O.; FRADE, I. C. A. da S. Dossiê: História da Cultura Escrita. In: Revista Brasileira de História da Educação. Maringá-PR, v. 16, n. 1 (40), p. 207-214, jan./abr. 2016.

GOMES-SANTOS, Sandoval Nonato. A escrita nas formas do trabalho docente. Educ. Pesqui., São Paulo, v. 36, n. 2, p. 445-458, ago. 2010. Disponível em $<$ http://www.scielo.br/scielo.php?script $=$ sci_arttext\&pid $=$ S151797022010000200002\&lng=pt\&nrm=iso>. Acesso em: 08 set. 2017.

GOTLIB, Nádia Battella. Teoria do Conto. São Paulo: Editora Ática, 1987.

HÉBRARD, J. Por uma bibliografia material das escrituras ordinárias. A escritura pessoal e seus suportes. In: MIGNOT, A. C. V.; BASTOS, M. H. C.; CUNHA, M. T. S. (Orgs.). Refúgios do eu: educação, história e escrita autobiográfica. Florianópolis: Mulheres, 2000, p. 29-61.

HOBSBAWM, E. J. A Outra História - Algumas Reflexões. In: KRANTZ, F. (Org.) A Outra História: Ideologia e protesto popular nos séculos XVII a XIX. Rio de Janeiro: Jorge Zahar Editor, 1990, p. 18-33.

HOLANDA, Sergio Buarque de. Raízes do Brasil. São Paulo: Companhia das Letras, 1995.

HUBERMAN, Michaël. O ciclo de vida profissional dos professores. In: NÓVOA, Antonio (Org.). Vidas de Professores. Porto: Porto Editora, 2007, p. 31-61.

IPEA; FBSP (orgs.). Atlas da violência 2019. Brasília: Rio de Janeiro: São Paulo: Instituto de Pesquisa Econômica Aplicada; Fórum Brasileiro de Segurança Pública, 2019. 
Disponível

em:

http://www.ipea.gov.br/portal/images/stories/PDFs/relatorio_institucional/190605 atlas da_violencia_2019.pdf. Acesso em: 21 set. 2019.

IPEA. Nota Técnica n. 10 Vidas perdidas e racismo no Brasil. Brasília: Instituto de Pesquisa Econômica Aplicada, 2013. Disponível em: http://www.ipea.gov.br/portal/images/stories/PDFs/nota tecnica/131119 notatecnicadie st10.pdf. Acesso em: 20 set. 2019.

KRAMER, Sonia. Leitura e escrita de professores em suas histórias de vida e formação. Cadernos de Pesquisa, n. 106, p. 129-157, mar., 1999.

.; SOUZA, S. J. Histórias de Professores: leitura, escrita e pesquisa em educação. São Paulo: Ática, 2003.

LYRA, Pedro. Conceito de Poesia. São Paulo: Editora Ática, 1992.

LAWN, M. Os professores e a fabricação de identidades. In: Currículo sem Fronteiras, v.1, n.2, p.117-130, jul./dez 2001.

LEITE, Antonio Eleison. Marcos fundamentais da Literatura Periférica em São Paulo. In: Revista de Estudos Culturais. Dossiê sobre Cultura Popular Urbana. [s.d.] Disponível em: http://each.uspnet.usp.br/revistaec/. Acesso em: 22 jul. 2019.

LEJEUNE, Philippe. O Pacto Autobiográfico: de Rousseau à internet. Belo Horizonte: Editora UFMG, 2008.

MACIEL, F. I. P. Cartas Pedagógicas: fragmentos de um discurso. In: BASTOS, M. H. C.; CUNHA, M. T. S.; MIGNOT, A. C. V. (Orgs.) Destinos das letras: história, educação e escrita epistolar. Passo Fundo: UPF, 2002, p.205-215.

MAGALHÃES, Henrique. Fanzine: comunicação popular e resistência cultural. In: Visualidades, v. 7, n. 1, 19 abr. 2012. Disponível em: https://www.revistas.ufg.br/VISUAL/article/view/18121. Acesso em: 05 set. 2019.

MARIN, Alda Junqueira; GIOVANNI, Luciana Maria. Expressão escrita de concluintes de curso universitário para formar professores. Cadernos de Pesquisa, São Paulo, v. 37, n. 130, p. 15-41, Abr., $2007 . \quad$ Disponível em: http://publicacoes.fcc.org.br/ojs/index.php/cp/article/view/372 Acesso em: 10 set. 2017.

MESQUISTA, Samira Nahid de. O Enredo. São Paulo: Editora Ática, 1986.

MIGNOT, A. C. V.; BASTOS, M. H. C.; CUNHA, M. T. S. (Orgs.). Refúgios do eu: educação, história e escrita autobiográfica. Florianópolis: Mulheres, 2000.

Artesãos da palavra: cartas a um prisioneiro político tecem redes de idéias e afetos. In: BASTOS, M. H. C.; CUNHA, M. T. S.; MIGNOT, A. C. V. (Orgs.) Destinos das letras: história, educação e escrita epistolar. Passo Fundo: UPF, 2002, p.115-136. 
Em busca do tempo vivido: autobiografias de professoras. In: ; et.al. (orgs.)

Práticas de memória docente. São Paulo: Cortez, 2003, p. 135-148.

MORAES, Dislane. Zerbinatti. Literatura, Memória e Ação Política: uma análise de romances escritos por professores paulistas. 1996. Dissertação (Mestrado em Educação). Universidade de São Paulo, 1996.

. Ficções, memórias e culturas da Escola: a escrita de "si", dos "outros" e da história da profissão docente. In: PASSEGGI, M. da C.; BARBOSA, T. M. N.(orgs). Narrativas de formação e saberes biográficos. Natal: RN: Ed. UFRN: São Paulo: Paulus, 2008. p. 213-229.

NARVAES, A. B. Significações da Profissão Professor. In: OLIVEIRA, V. F. de (Org.) Imagens de professor: significações do trabalho docente. Ijuí: Ed. UNIJUÍ, 2000, p. $37-$ 56.

NÓVOA, Antonio. (Org.) Profissão Professor. Porto: Porto Editora, 1999. . (Org.) Vidas de Professores. Porto: Porto Editora, 2007.

NUNES, C. I Congresso Luso-Brasileiro de História da Educação: leitura e escrita em Portugal e no Brasil (1500-1970). In: FARIA, L. M. (Org.). Modos de ler, formas de escrever: estudos de história da leitura e da escrita no Brasil. Belo Horizonte: Autêntica, 1998, p. 11-28.

NUNES, C.; CARVALHO, M. M. C. Historiografia da educação e fontes. ANPED 15 ${ }^{\text {a }}$ Reunião Anual. Caxambu, MG, 1992.

OLIVEIRA, Zilma de Moraes Ramos et al. Construção da identidade docente: relatos de educadores de educação infantil. Cadernos de Pesquisa, São Paulo, v. 36, n. 129, p. 547571, 2006. Disponível em: http://publicacoes.fcc.org.br/ojs/index.php/cp/issue/view/26 Acesso em: 10 set. 2017.

PERROT, Michelle. As mulheres ou os silêncios da história. Bauru, SP: EDUSC, 2005.

REGO, Teresa Cristina. Trajetória intelectual de pesquisadores da educação: a fecundidade do estudo dos memoriais acadêmicos. Rev. Bras. Educ., Rio de Janeiro, v. 19, n. 58, p. 779-800, set. 2014 . Disponível em $<$ http://www.scielo.br/scielo.php?script=sci_arttext\&pid=S1413$24782014000800013 \& \operatorname{lng}=$ pt\&nrm=iso $>$. Acesso em: 12 set. 2017.

ROLNIK, Raquel. A cidade e a lei: legislação, política urbana e territórios na cidade de São Paulo. São Paulo: Studio Nobel: Fapesp, 1997.

Territórios em conflito: São Paulo: espaço, história e política. São Paulo: Três Estrelas, 2017.

ROSA, Maria Inês Petrucci; RAMOS, Tacita Ansanello. Memórias e odores: experiências curriculares na formação docente. Rev. Bras. Educ., Rio de Janeiro, v. 13, n. 39, p. 565-575, dez. 2008. Disponível em 
$<$ http://www.scielo.br/scielo.php?script=sci_arttext\&pid=S1413-

$24782008000300012 \& \operatorname{lng}=$ pt\&nrm=iso $>$. Acesso em: 12 set. 2017.

SÁ, Jorge de. A Crônica. São Paulo: Editora Ática, 1999.

SETTON, Maria da Graça Jacintho. A socialização como fato social total: um ensaio sobre a teoria do habitus. Livre Docência. (Educação) - Faculdade de Educação da Universidade de São Paulo, São Paulo, 2009.

SEVCENKO, Nicolau. Literatura como missão: tensões sociais e criação cultural na Primeira República. São Paulo: Companhia das Letras, 2003.

SOARES, Mei Hua. A literatura marginal-periférica e a escola. 2008. Dissertação (Mestrado em Educação) - Faculdade de Educação da Universidade de São Paulo, São Paulo, 2008.

TELLES, Norma. Escritoras, escritas, escrituras. In: PRIORE, Mary del. (org.) História das Mulheres no Brasil. São Paulo: Contexto, 2006, p. 401-442.

TENNINA, Lucía. Cuidado com os poetas! Literatura e periferia na cidade de São Paulo. Porto Alegre, RS: Zouk, 2017.

Saraus das periferias de São Paulo: poesia entre tragos, silêncios e aplausos. Estudos de Literatura Brasileira Contemporânea. Brasília, n. 42, p. 11-28, jul./dez. 2013.

VIANNA, Cláudia. Os nós dos "nós": crise e perspectivas da ação coletiva docente em São Paulo. São Paulo: Xamã, 1999.

A produção acadêmica sobre organização docente: ação coletiva e relações de gênero. Educação \& Sociedade, ano XXII, n. 77, Dez., 2001.

O sexo e o gênero da docência. Cadernos Pagu, n.17/18, 2001/02.

. A feminização do magistério na educação básica. In: YANNOULAS, Silvia Cristina (Coord.). Trabalhadoras: análise da feminização das profissões e ocupações. Brasília: Editorial Abaré, 2013, p. 159-179.

VICENTINI, P. P. Imagens e representações de professores na História da Profissão Docente no Brasil (1933-1963). 2002. Tese (Doutorado em Educação). Universidade de São Paulo, 2002.

VIÑAO FRAGO, Antonio. Relatos e relações autobiográficas de professores e mestres. In: MENEZES, Maria Cristina (org.). Educação, Memória, História: possibilidades, leituras. Campinas, SP: Mercado de Letras, 2004, p. 333-373.

Las autobiografías, memorias y diarios como fuente histórico-educativa: tipologia

y usos. In: Revista Teias. Faculdade de Educação: UERJ, ano.1, n.1, jan./jun. 2000. 
Por una historia de la cultura escrita: observaciones y reflexiones. In: SIGNO. Revista de Historia de la Cultura Escrita 3. Universidad de Alcalá de Henares, 1996, p. 41-68.

WOOLF, Virginia. Um teto todo seu. Rio de Janeiro: Nova Fronteira, 1985.

YANNOULAS, Silvia Cristina (Coord.). Trabalhadoras: análise da feminização das profissões e ocupações. Brasília: Editorial Abaré, 2013.

ZABALZA, M. A. Diários de Aula: contributo para o estudo dos dilemas práticos dos professores. Porto: Porto Editora, 1994. 


\section{ANEXOS}

Modelo da ficha de inscrição do Concurso Literário Valeu, Professor de 2010.

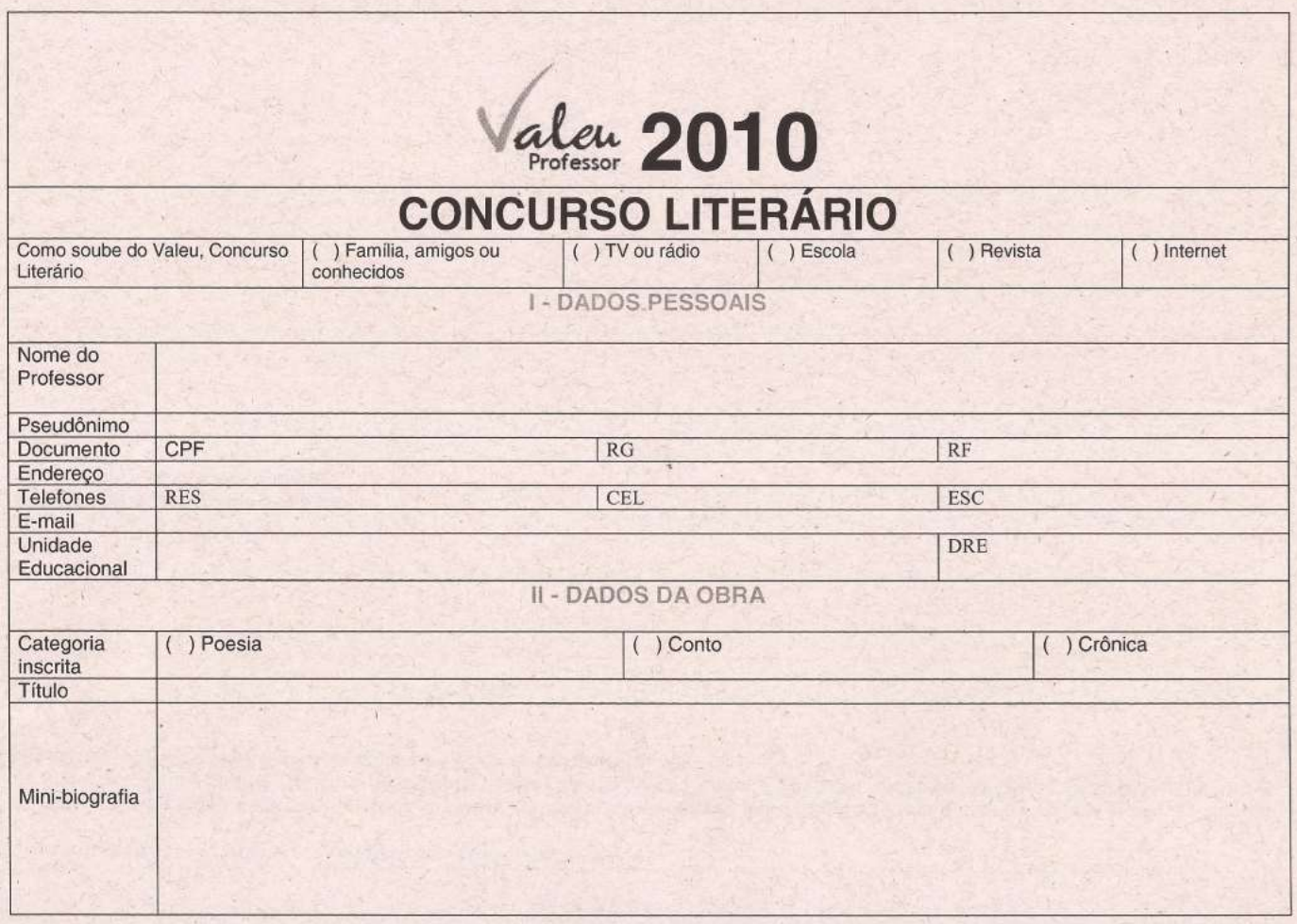

Autorizo a Realizadora a utilizar, de modo gratuito, definitivo e irrevogável, meu nome, imagem e som de voz em qualquer veículo 列 direitos autorais relativos à obra, que passará a ser de sua propriedade.

\begin{tabular}{|l|l|}
\hline DATA & Assinatura \\
\hline & \\
\hline $\begin{array}{l}\text { Breve descrição de como e em que se } \\
\text { inspirou para criar o seu trabalho }\end{array}$ & \\
& \\
\hline
\end{tabular}


Do Doc. $s / n^{0}$

Folha de Informação nº 06

$11 / 11 / 2015$

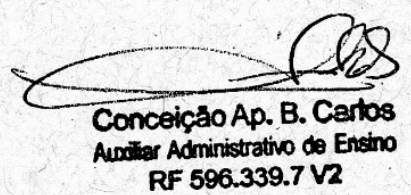

INTERESSADO: FEUSP

ASSUNTO: Acesso aos arquivos do Concurso Literário Valeu Professor

\section{SME - G}

\section{Senhor Chefe de Gabinete}

Considerando a solicitação da doutoranda Thais Surian, as informações adicionais citadas na Folha de Informação no 05 e com o intuito de esclarecer a possibilidade de acesso aos arquivos do Concurso Literário "Valeu, Professor", informo que o Centro de Multimeios Biblioteca Pedagógica disponibilizará o acesso na seguinte conformidade:

- Os livros publicados, resultado do Concurso Literário, serão doados à pesquisadora

- Documentos públicos, impressos ou que à época foram disponibilizados no Portal, tais como editais, regulamentos e modelos das fichas de inscrição, terão consulta direta no Diário Oficial ou serão enviados por e-mail;

- Fichas de inscrição preenchidas e textos inscritos e não publicados deverão ser consultados apenas no local e copiados somente com a autorização do autor;

- Outros documentos, tais como fotografias, gravações em vídeo, ilustrações e convites para o lançamento dos livros, serão consultados apenas no Centro de Multimeios Biblioteca Pedagógica e Memorial do Ensino Municipal;

- Entrevista com funcionária que participou da-organização do Concurso Literário "Valeu, Professcr" e arquivou todos os registros pertinentes ao Programa promovido por esta Secretaria em homenagem aos docentes.

Ressaltando que "a consulta aos documentos será de grande valia à pesquisa (...) e a investigação tem fins estritamente' acadêmicos e procura, em seu objetivo maior, dar 'valor à produção escrita e a iniciativas de preservação da memória da profissão de professor", a doutoranda será informada a respeito dos procedimentos para a elaboração de sua pesquisa. Desta forma, será solicitado que ela disponibilize o trabalho, forneça devolutiva aos profissionais envolvidos e envie cópia de sua tese à Biblioteca, incluindo todos os referidos créditos.

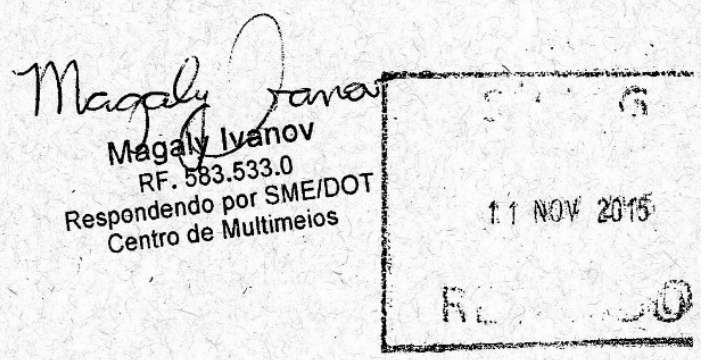




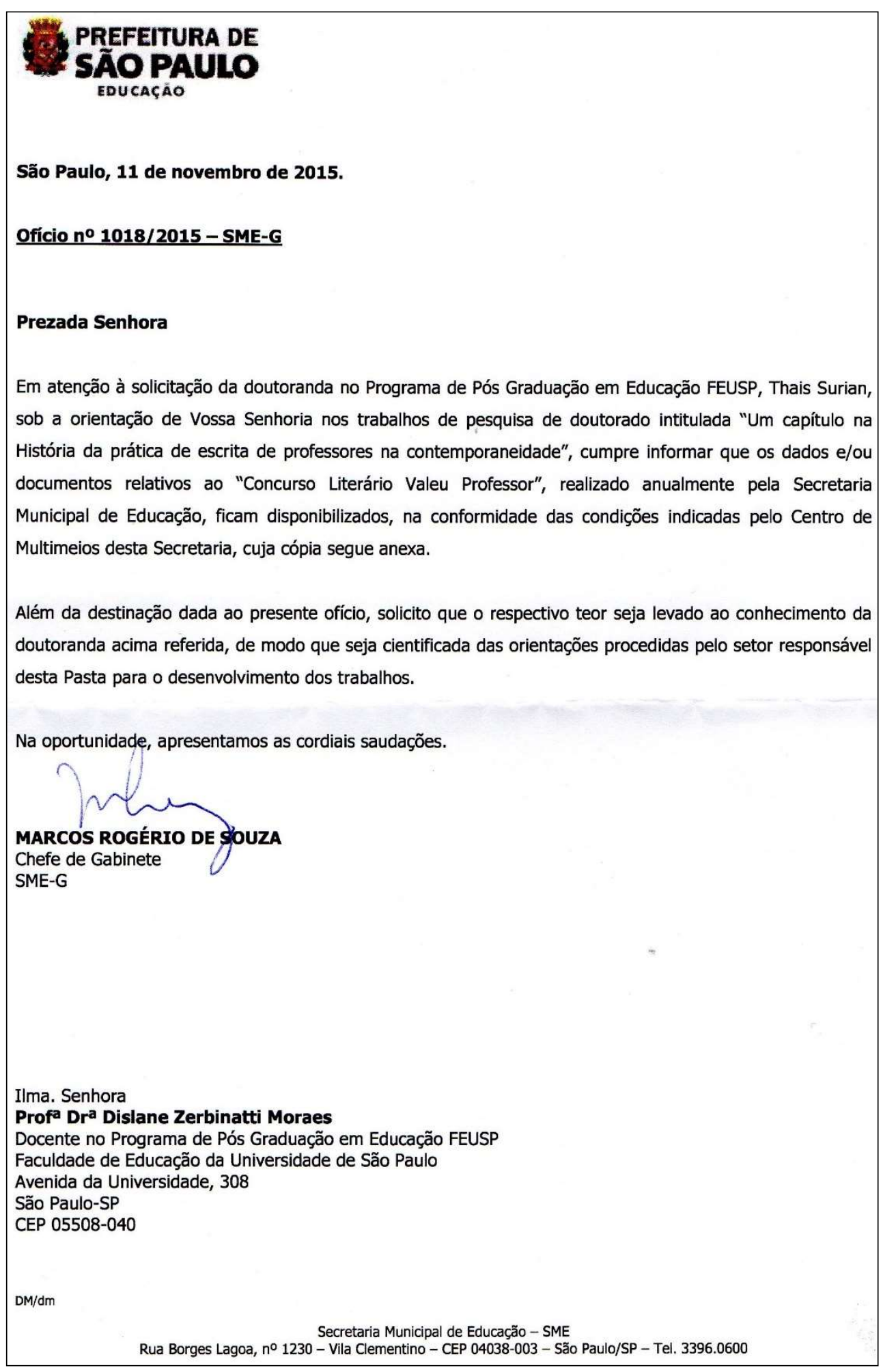




\section{APÊNDICE}

\section{Levantamento bibliográfico em revistas científicas na área da Educação}

Levantamento bibliográfico realizado nas Revistas Educação e Pesquisa, Cadernos de Pesquisa e Revista Brasileira de Educação no período de 2006 a 2016 buscando artigos que tenham estudado a produção escrita de professores. Para isso, utilizamos as seguintes palavras-chaves: escrita de professores; escrita de si; escrita literária de professores e, além disso, recorremos à leitura dos sumários das revistas citadas quando a busca não teve resultados significativos.

\section{Revista Educacão e Pesquisa - USP}

BUENO, Belmira Oliveira et al. Histórias de vida e autobiografias na formação de professores e profissão docente (Brasil, 1985-2003). Educ. Pesqui., São Paulo, v. 32, n. 2, p. 385-410, ago. 2006. Disponível em $<$ http://www.scielo.br/scielo.php?script=sci_arttext\&pid=S1517-

97022006000200013\&lng=pt\&nrm=iso >. Acesso em: 08 set. 2017.

GOMES-SANTOS, Sandoval Nonato. A escrita nas formas do trabalho docente. Educ. Pesqui., São Paulo, v. 36, n. 2, p. 445-458, ago. 2010. Disponível em $<$ http://www.scielo.br/scielo.php?script=sci_arttext\&pid=S1517-

97022010000200002\&lng=pt\&nrm=iso>. Acesso em: 08 set. 2017.

AQUINO, Julio Groppa. A escrita como modo de vida: conexões e desdobramentos educacionais. Educ. Pesqui., São Paulo, v. 37, n. 3, p. 641-656, dez. 2011. Disponível em $\quad<$ http://www.scielo.br/scielo.php?script=sci_arttext\&pid=S1517$97022011000300013 \& \operatorname{lng}=$ pt\&nrm=iso $>$. Acesso em: 08 set. $201 \overline{7}$.

ALCANTARA, Wiara Rosa Rios. A sala de aula foi o meu mundo: a carreira do magistério em São Paulo (1920-1950). Educ. Pesqui., São Paulo, v. 38, n. 2, p. 289305, jun. 2012. Disponível em $<$ http://www.scielo.br/scielo.php?script=sci_arttext\&pid=S1517-

97022012000200002\&lng=pt\&nrm=iso>. Acesso em: 08 set. 2017.

CORAZZA, Sandra Mara et al. Escrileituras: um modo de ler-escrever em meio à vida. Educ. Pesqui., São Paulo, v. 40, n. 4, p. 1029-1043, dez. 2014. Disponível em $<\mathrm{http}: / /$ www.scielo.br/scielo.php?script $=$ sci_arttext\&pid=S1517-

97022014000400011\&lng=pt\&nrm=iso>. Acesso em: 09 set. 2017.

GAGO, Sonsoles San Román. Madres sociales de la aldea: la maestra española durante el nacional-catolicismo. Educ. Pesqui., São Paulo, v. 41, n. 2, p. 359373, jun. 2015. Disponível em 
$<$ http://www.scielo.br/scielo.php?script=sci_arttext\&pid=S1517-

97022015000200359\&lng=pt\&nrm=iso>. Acesso em: 09 set. 2017.

\section{Revista Cadernos de Pesquisa - Fundacão Carlos Chagas}

OLIVEIRA, Zilma de Moraes Ramos et al. Construção da identidade docente: relatos de educadores de educação infantil. Cadernos de Pesquisa, São Paulo, v. 36, n. 129, p. 547571, 2006. Disponível em: http://publicacoes.fcc.org.br/ojs/index.php/cp/issue/view/26 Acesso em: 10 set. 2017.

MARIN, Alda Junqueira; GIOVANNI, Luciana Maria. Expressão escrita de concluintes de curso universitário para formar professores. Cadernos de Pesquisa, São Paulo, v. 37, n. 130, p. 15-41, Abr., $2007 . \quad$ Disponível em: http://publicacoes.fcc.org.br/ojs/index.php/cp/article/view/372 Acesso em: 10 set. 2017.

CHARRÉU, Leonardo Verde; OLIVEIRA, Marilda Oliveira de. Diários de aula e portfólios como instrumentos metodológicos da prática educativa em artes visuais. Cadernos de Pesquisa, São Paulo, v. 45, n. 156, p. 410-425, abr./jun. 2015. Disponível em: http://publicacoes.fcc.org.br/ojs/index.php/cp/issue/view/290/ Acesso em: 10 set. 2017.

\section{$\underline{\text { Revista Brasileira de Educacão - ANPED }}$}

FREITAS, Maria Teresa Menezes; FIORENTINI, Dario. Desafios e potencialidades da escrita na formação docente em matemática. Rev. Bras. Educ., Rio de Janeiro, v. 13, n. 37, p. 138-149, abr. 2008. Disponível em $<$ http://www.scielo.br/scielo.php?script=sci_arttext\&pid=S1413$24782008000100012 \& \operatorname{lng}=$ pt\&nrm=iso $>$. Acesso em: 12 set. 2017.

ROSA, Maria Inês Petrucci; RAMOS, Tacita Ansanello. Memórias e odores: experiências curriculares na formação docente. Rev. Bras. Educ., Rio de Janeiro, v. 13, n. 39, p. 565-575, dez. 2008. Disponível em $<$ http://www.scielo.br/scielo.php?script=sci_arttext\&pid=S1413$24782008000300012 \& \operatorname{lng}=$ pt\&nrm=iso $>$. Acesso em: 12 set. 2017.

REGO, Teresa Cristina. Trajetória intelectual de pesquisadores da educação: a fecundidade do estudo dos memoriais acadêmicos. Rev. Bras. Educ., Rio de Janeiro, v. 19, n. 58, p. 779-800, set. 2014. Disponível em $<$ http://www.scielo.br/scielo.php?script=sci_arttext\&pid=S1413-

$24782014000800013 \& \operatorname{lng}=$ pt\&nrm=iso $>$. Acesso em: 12 set. 2017. 


\section{TERMO DE CONSENTIMENTO LIVRE E ESCLARECIDO}

Concordo em participar, como voluntário/a, da pesquisa intitulada Um capítulo na história da prática de escrita de professores na contemporaneidade, que tem como pesquisadora responsável Thais Surian, estudante da Faculdade de Educação da Universidade de São Paulo, orientada pela Profa. Dra. Dislane Zerbinatti Moraes, as quais podem ser contatadas pelo e-mail thsurian@gmail.com ou telefone (19) 99603-4385.

O presente trabalho tem por objetivo identificar e analisar as práticas da escrita realizadas por professores da educação básica buscando compreender a relação que estabelecem com a escrita, assim como organizar um corpus documental de escritos de professores publicados e/ou de arquivo pessoal para análise.

$\mathrm{Na}$ condição de membro da Comissão Julgadora do Concurso Literário Valeu, Professor, minha participação consistirá em participar de entrevista que será gravada e transcrita com o objetivo de relatar como foram as edições do referido concurso. Compreendo que esse estudo possui finalidade de pesquisa, e que os dados obtidos serão divulgados seguindo as diretrizes éticas da pesquisa, assegurando, assim, minha privacidade.

Sei que posso retirar meu consentimento quando eu quiser, e que não receberei nenhum pagamento por essa participação.

Nome:

Assinatura:

Local e data: 


\section{TERMO DE CONSENTIMENTO LIVRE E ESCLARECIDO}

Concordo em participar, como voluntário/a, da pesquisa intitulada Um capítulo na história da prática de escrita de professores na contemporaneidade, que tem como pesquisadora responsável Thais Surian, estudante da Faculdade de Educação da Universidade de São Paulo, orientada pela Profa. Dra. Dislane Zerbinatti Moraes, as quais podem ser contatadas pelo e-mail thsurian@gmail.com ou telefone (19) 99603-4385.

O presente trabalho tem por objetivo identificar e analisar as práticas da escrita realizadas por professores da educação básica buscando compreender a relação que estabelecem com a escrita, assim como organizar um corpus documental de escritos de professores publicados e/ou de arquivo pessoal para análise.

Minha participação consistirá em disponibilizar o(s) texto(s) de minha autoria

\begin{tabular}{lrrrrr} 
inscrito(s) no $\quad$ Concurso & $\begin{array}{r}\text { Literário } \\
\text { com }\end{array}$ & Valeu, & Professor & no(s) & $\begin{array}{r}\text { ano(s) } \\
\text { seguinte(s) }\end{array}$ \\
\hline título(s) & & & o(s) & \\
\hline
\end{tabular}

para a pesquisa. Compreendo que esse estudo possui finalidade de pesquisa, e que os dados obtidos serão divulgados seguindo as diretrizes éticas da pesquisa, assegurando, assim, minha privacidade.

Sei que posso retirar meu consentimento quando eu quiser, e que não receberei nenhum pagamento por essa participação.

Nome:

Assinatura:

Local e data: 


\section{TERMO DE CONSENTIMENTO LIVRE E ESCLARECIDO}

Concordo em participar, como voluntário/a, da pesquisa intitulada Um capítulo na história da prática de escrita de professores na contemporaneidade, que tem como pesquisadora responsável Thais Surian, estudante da Faculdade de Educação da Universidade de São Paulo, orientada pela Profa. Dra. Dislane Zerbinatti Moraes, as quais podem ser contatadas pelo e-mail thsurian@gmail.com ou telefone (19) 99603-4385.

O presente trabalho tem por objetivo identificar e analisar as práticas da escrita realizadas por professores da educação básica buscando compreender a relação que estabelecem com a escrita, assim como organizar um corpus documental de escritos de professores publicados e/ou de arquivo pessoal para análise.

Minha participação consistirá em disponibilizar materiais de própria autoria publicados e/ou de arquivo pessoal para a pesquisa e participar de entrevista que será gravada e transcrita. Compreendo que esse estudo possui finalidade de pesquisa, e que os dados obtidos serão divulgados seguindo as diretrizes éticas da pesquisa, assegurando, assim, minha privacidade.

Sei que posso retirar meu consentimento quando eu quiser, e que não receberei nenhum pagamento por essa participação.

Nome:

Assinatura:

Local e data: 


\section{TERMO DE CONSENTIMENTO LIVRE E ESCLARECIDO}

Concordo em participar, como voluntário/a, da pesquisa intitulada Um capítulo na história da prática de escrita de professores na contemporaneidade, que tem como pesquisadora responsável Thais Surian, estudante da Faculdade de Educação da Universidade de São Paulo, orientada pela Profa. Dra. Dislane Zerbinatti Moraes, as quais podem ser contatadas pelo e-mail thsurian@gmail.com ou telefone (19) 99603-4385.

O presente trabalho tem por objetivo identificar e analisar as práticas da escrita realizadas por professores da educação básica buscando compreender a relação que estabelecem com a escrita, assim como organizar um corpus documental de escritos de professores publicados e/ou de arquivo pessoal para análise.

Minha participação consistirá em disponibilizar materiais de própria autoria publicados e/ou de arquivo pessoal para a pesquisa e participar de entrevista que será gravada e transcrita. Compreendo que esse estudo possui finalidade de pesquisa, e que os dados obtidos serão divulgados seguindo as diretrizes éticas da pesquisa, assegurando, assim, minha privacidade em relação aos escritos de arquivo pessoal. Em relação aos materiais escritos publicados na forma impressa e/ou digital, estes serão identificados.

Sei que posso retirar meu consentimento quando eu quiser, e que não receberei nenhum pagamento por essa participação.

Considerando que os materiais publicados serão identificados de acordo com a autoria, seguindo as diretrizes éticas em pesquisa, concordo que a entrevista contenha a minha identificação? O objetivo de identificar a pessoa entrevistada é a possibilidade de relacionar o autor ao texto ou livro publicado. Caso opte por não se identificar, a entrevista assegurará a privacidade da identidade.
( ) $\operatorname{Sim}$
( ) Não

Nome:

Assinatura:

Local e data: 


\begin{tabular}{|c|c|c|c|c|}
\hline \multicolumn{5}{|c|}{ Levantamento de documentos sobre as ações do Valeu, Professor nos anos 2010, 2011 e 2012} \\
\hline Data & \begin{tabular}{|l|} 
Código do \\
Arquivo \\
\end{tabular} & Título do Documento & Tipo & Resumo \\
\hline $6 / 10 / 2009$ & & $\begin{array}{l}\text { Diário Oficial da Cidade n. } \\
186 \text { - 'Valeu Professor ' atrai } \\
\text { milhares de educadores em } \\
\text { 24h de atrações } \\
\end{array}$ & Notícia & $\begin{array}{l}\text { A SME fez um resumo do que foi o evento } \\
\text { Valeu Professor. }\end{array}$ \\
\hline set./2009 & $*$ E4.1/72 & $\begin{array}{l}\text { Cartão do Educador dá } \\
\text { desconto de } 20 \% \text { na compra } \\
\text { de livros }\end{array}$ & Documento & $\begin{array}{l}\text { Criado em setembro o cartão que dá desconto } \\
\text { aos professores na compra de livros. A ação } \\
\text { antecipa a comemoração do mês da educação } \\
\text { quando acontece o Valeu Professor. }\end{array}$ \\
\hline set./2009 & $*$ E4.1/72 & $\begin{array}{l}\text { São Paulo lança o Valeu } \\
\text { Professor }\end{array}$ & Documento & $\begin{array}{l}\text { Lançamento do evento Valeu Professor que terá } \\
\text { atividades culturais e esportivas aos professores } \\
\text { em homenagem e comemoração pelo mês da } \\
\text { educação. Nesse documento consta a } \\
\text { programação do evento. }\end{array}$ \\
\hline $04 /$ set/2009 & & $\begin{array}{l}\text { Diário Oficial da Cidade } \mathrm{n} . \\
165 \text { - Cartão do Educador } \\
\text { possibilita compra de livro } \\
\text { com desconto pelo professor }\end{array}$ & Notícia & $\begin{array}{l}\text { O cartão foi lançado abrindo as atividades do } \\
\text { Valeu Professor incluindo atividades culturais } \\
\text { para serem assistidas, professores protagonistas } \\
\text { e premiação ao Prof. Emérito e Destaque. }\end{array}$ \\
\hline $09 /$ set/2009 & & $\begin{array}{l}\text { Diário Oficial da Cidade n. } \\
167 \text { - 'Valeu Professor' abre } \\
\text { inscrições para artistas } \\
\text { plásticos da rede municipal }\end{array}$ & Notícia & $\begin{array}{l}\text { Informações para professores inscrevem seus } \\
\text { trabalhos artísticos - pintura, desenho e gravura } \\
\text { - que os escolhidos seriam expostos no Saguão } \\
\text { da Prefeitura. Os profs. autores e músicos } \\
\text { também poderão divulgar suas obras. }\end{array}$ \\
\hline $15 /$ set $/ 2009$ & & $\begin{array}{l}\text { Diário Oficial da Cidade n. } \\
171 \text { - 'Valeu Professor' abre } \\
\text { inscrição para apresentação } \\
\text { de educadores músicos }\end{array}$ & Notícia & $\begin{array}{l}\text { Informações para professores músicos se } \\
\text { inscreverem para fazer apresentações nos CEUS } \\
\text { e outros locais durante o Valeu Professor. }\end{array}$ \\
\hline $17 /$ set $/ 2009$ & & $\begin{array}{l}\text { Diário Oficial da Cidade } \mathrm{n} . \\
173 \text { - Professores artistas } \\
\text { têm até amanhã para se } \\
\text { inscrever e expor seus } \\
\text { talentos }\end{array}$ & Notícia & $\begin{array}{l}\text { Prorrogação das inscrições para professores } \\
\text { artistas e músicos. }\end{array}$ \\
\hline $17 /$ set/2009 & & $\begin{array}{l}\text { Diário Oficial da Cidade n. } \\
173 \text { - Professor Autor }\end{array}$ & Calhau & $\begin{array}{l}\text { É um chamamento aos professores autores para } \\
\text { participar do Valeu, Professor. } \\
\text { Obs: Tem a forma de cartaz publicitário. }\end{array}$ \\
\hline 20/jan./2010 & & $\begin{array}{l}\text { Diário Oficial da Cidade } \mathrm{n} . \\
12 \text { - Portaria n. } 653 \text { de } 19 \text { de } \\
\text { janeiro de } 2010 \text { (página } 10 \text { ) }\end{array}$ & Portaria & $\begin{array}{l}\text { Altera o calendário de atividades e define a data } \\
\text { de } 22,23 \text { e } 24 / 10 \text { para o Valeu Professor. }\end{array}$ \\
\hline $27 /$ jan./2010 & & $\begin{array}{l}\text { Diário Oficial da Cidade n. } \\
16 \text { - Retificação da Portaria } \\
\text { n. } 653 \text { (página } 8 \text { ) }\end{array}$ & Portaria & Republicada a portaria 653 por incorreções. \\
\hline 08/mai./2010 & & $\begin{array}{l}\text { Diário Oficial da Cidade } \mathrm{n} . \\
85 \text { - Portaria SME n. } 2718 \\
\text { de } 07 \text { de maio de } 2010 \\
\text { (página 12) }\end{array}$ & Portaria & $\begin{array}{l}\text { A Portaria } 2718 \text { institui o concurso literário na } \\
\text { Rede Municipal de Ensino. }\end{array}$ \\
\hline $18 /$ mai./2010 & & $\begin{array}{l}\text { Diário Oficial da Cidade } \mathrm{n} . \\
91 \text { - Portaria SME n. } 2858 \\
\text { de } 17 \text { de maio de } 2010 \\
\text { (página } 16 \text { ) }\end{array}$ & Portaria & $\begin{array}{l}\text { A Portaria } 2858 \text { institui o concurso professor } \\
\text { artista na Rede Municipal de Ensino. }\end{array}$ \\
\hline 20/mai./2010 & & $\begin{array}{l}\text { Diário Oficial da Cidade n. } \\
93 \text { - Concurso Literário abre } \\
\text { atividades da segunda }\end{array}$ & Notícia & Divulgação da inscrição no concurso literário. \\
\hline
\end{tabular}




\begin{tabular}{|c|c|c|c|}
\hline & $\begin{array}{l}\text { edição do 'Valeu, Professor' } \\
\text { (página I) }\end{array}$ & & \\
\hline 25/mai./2010 & $\begin{array}{l}\text { Diário Oficial da Cidade n. } \\
96 \text { - Secretaria de Educação } \\
\text { abre inscrições para o } \\
\text { concurso Professor Artista } \\
\text { (página IV) }\end{array}$ & Notícia & $\begin{array}{l}\text { Divulgação da inscrição no concurso professor } \\
\text { artista. }\end{array}$ \\
\hline 25/mai./2010 & $\begin{array}{l}\text { Diário Oficial da Cidade n. } \\
96 \text { - Concurso para professor } \\
\text { artista (página I) }\end{array}$ & Chamada & $\begin{array}{l}\text { Chamada na capa para a notícia sobre o } \\
\text { concurso de professores artistas. }\end{array}$ \\
\hline $21 / \mathrm{jul} . / 2010$ & $\begin{array}{l}\text { Diário Oficial da Cidade n. } \\
134 \text { - Comunicado n. } 1116 \\
\text { de } 20 \text { de julho de } 2010 \\
\text { (página 29) }\end{array}$ & Comunicado & $\begin{array}{l}\text { Publicação do regulamento para a participação } \\
\text { de professor músico. }\end{array}$ \\
\hline $21 / \mathrm{jul} . / 2010$ & $\begin{array}{l}\text { Diário Oficial da Cidade } \mathrm{n} . \\
134 \text { - Comunicado n. } 1117 \\
\text { de } 20 \text { de julho de } 2010 \\
\text { (página 29-30) }\end{array}$ & Comunicado & $\begin{array}{l}\text { Publicação do regulamento para a participação } \\
\text { de professor de expressão corporal que } \\
\text { compreende dança e teatro. }\end{array}$ \\
\hline 07/ago./2010 & $\begin{array}{l}\text { Diário Oficial da Cidade n. } \\
147 \text { - Alunos e Professores } \\
\text { da Rede Municipal de } \\
\text { Ensino Visitam a Bienal do } \\
\text { Livro }\end{array}$ & Notícia & $\begin{array}{l}\text { Ao falar da Bienal do Livro, esta notícia } \\
\text { informa que o concurso literário para } \\
\text { professores terá votação da ilustração no evento } \\
\text { e outras informações sobre o lançamento do } \\
\text { livro. }\end{array}$ \\
\hline 13/ago./2010 & $\begin{array}{l}\text { Diário Oficial da Cidade } \mathrm{n} . \\
151 \text { - Prefeitura participa da } \\
21^{\mathrm{a}} \text { Bienal do Livro com } \\
\text { ações de incentivo à Leitura }\end{array}$ & Notícia & $\begin{array}{l}\text { Informando sobre a participação da prefeitura } \\
\text { na Bienal, esta também comunica as ações } \\
\text { presentes no estande do evento sendo uma delas } \\
\text { o concurso literário. }\end{array}$ \\
\hline 14/ago./2010 & $\begin{array}{l}\text { Diário Oficial da Cidade n. } \\
152 \text { - Os vencedores do } \\
\text { 'Valeu, Professor' }\end{array}$ & Chamada & $\begin{array}{l}\text { Chamada para a notícia sobre os vencedores do } \\
\text { concurso }\end{array}$ \\
\hline 14/ago./2010 & $\begin{array}{l}\text { Diário Oficial da Cidade n. } \\
152 \text { - Concurso Literário } \\
\text { 'Valeu Professor' divulga } \\
\text { vencedores na Bienal do } \\
\text { Livro }\end{array}$ & Notícia & $\begin{array}{l}\text { Divulgação dos nomes dos vencedores do } \\
\text { concurso literário. }\end{array}$ \\
\hline 24/ago./2010 & $\begin{array}{l}\text { Diário Oficial da Cidade } \mathrm{n} . \\
158 \text { - Público escolhe capa } \\
\text { do livro dos professores } \\
\text { autores }\end{array}$ & Notícia & Resultado da escolha da capa do livro. \\
\hline $15 /$ set./2010 & $\begin{array}{l}\text { Diário Oficial da Cidade n. } \\
172 \text { - Portaria } 4922 \text { de } 14 \text { de } \\
\text { setembro de } 2010\end{array}$ & Portaria & $\begin{array}{l}\text { Portaria dispensa do ponto os professores } \\
\text { vencedores do concurso literário que visitarão a } \\
\text { empresa Fibria. }\end{array}$ \\
\hline $21 /$ set./2010 & $\begin{array}{l}\text { Diário Oficial da Cidade n. } \\
176 \text { - Comunicado } 1496 \text { - } \\
\text { Reabertura da inscrição para } \\
\text { professor músico }\end{array}$ & comunicado & $\begin{array}{l}\text { O Comunicado divulga novo período de } \\
\text { inscrição para professor músico. }\end{array}$ \\
\hline $21 /$ set./2010 & $\begin{array}{l}\text { Diário Oficial da Cidade n. } \\
176 \text { - Comunicado } 1497 \text { - } \\
\text { Reabertura da inscrição para } \\
\text { professor de expressão } \\
\text { corporal }\end{array}$ & comunicado & $\begin{array}{l}\text { O Comunicado divulga novo período de } \\
\text { inscrição para professor de expressão corporal. }\end{array}$ \\
\hline $23 /$ set./2010 & $\begin{array}{l}\text { Diário Oficial da Cidade n. } \\
178 \text { - Professores artistas } \\
\text { ainda podem se inscrever } \\
\text { para o 'Valeu, Professor } \\
2010^{\prime}\end{array}$ & Noticia & $\begin{array}{l}\text { Informações sobre a inscrição no concurso } \\
\text { Professor Artista. }\end{array}$ \\
\hline 09/out./2010 & $\begin{array}{l}\text { Diário Oficial da Cidade n. } \\
190 \text { - Em outubro, mês da } \\
\text { Educação, eventos }\end{array}$ & Noticia & $\begin{array}{l}\text { Divulgação das atividades que acontecerão } \\
\text { durante o evento. }\end{array}$ \\
\hline
\end{tabular}




\begin{tabular}{|c|c|c|c|c|}
\hline & & $\begin{array}{l}\text { homenageiam professores } \\
\text { paulistanos }\end{array}$ & & \\
\hline 20/out./2010 & & $\begin{array}{l}\text { Diário Oficial da Cidade n. } \\
\text { 195- Prefeitura premia } \\
\text { alunos que ilustrarão as } \\
\text { capas dos cadernos escolares } \\
2011\end{array}$ & Notícia & $\begin{array}{l}\text { Na notícia sobre o concurso das capas de } \\
\text { cadernos, a SME incluiu informações sobre o } \\
\text { Valeu, Professor. }\end{array}$ \\
\hline 21/out./2010 & & $\begin{array}{l}\text { Diário Oficial da Cidade n. } \\
\text { 196- 'Valeu, Professor' } \\
\text { começa amanhã }\end{array}$ & chamada & $\begin{array}{l}\text { Chamada de capa informando que começará o } \\
\text { Valeu, Professor, notícia completa na última } \\
\text { página. }\end{array}$ \\
\hline 21/out./2010 & & $\begin{array}{l}\text { Diário Oficial da Cidade n. } \\
\text { 196- Programação especial } \\
\text { homenageia os educadores } \\
\text { no 'Valeu, Professor 2010' }\end{array}$ & Notícia & $\begin{array}{l}\text { Informações sobre o início das atividades } \\
\text { comemorativas acompanhado de programação } \\
\text { parcial. }\end{array}$ \\
\hline 22/out./2010 & & $\begin{array}{l}\text { Diário Oficial da Cidade n. } \\
197 \text { - Começa hoje o 'Valeu, } \\
\text { Professor } 2010 \text { ', com mais } \\
\text { de } 350 \text { atividades na Cidade } \\
\end{array}$ & Notícia & $\begin{array}{l}\text { Informações sobre as atividades culturais que } \\
\text { serão oferecidas aos professores. }\end{array}$ \\
\hline 22/out./2010 & & $\begin{array}{l}\text { Diário Oficial da Cidade } \mathrm{n} . \\
197 \text { - Atividades esportivas, } \\
\text { oficinas e saraus } \\
\text { homenageiam os educadores }\end{array}$ & Notícia & $\begin{array}{l}\text { Informações sobre oficinas esportivas, saraus e } \\
\text { oficinas culturais que aconteceriam no evento } \\
\text { acompanhado de programação parcial. }\end{array}$ \\
\hline 23/out./2010 & & $\begin{array}{l}\text { Diário Oficial da Cidade } \mathrm{n} . \\
198 \text { - PORTARIA No } 5.551 \\
\text { DE } 22 \text { DE OUTUBRO DE } \\
2010\end{array}$ & Portaria & $\begin{array}{l}\text { A Portaria dispõe diretrizes para o calendário de } \\
\text { atividades das unidades educacionais de } 2011 \mathrm{e} \\
\text { prevê atividades do Valeu Professor em } 7,8 \mathrm{e} \\
9 / 10 .\end{array}$ \\
\hline $27 /$ nov. $/ 2010$ & & $\begin{array}{l}\text { Diário Oficial da Cidade n. } \\
220 \text { - } 288^{\circ} \text { Sessão Solene }\end{array}$ & & $\begin{array}{l}\text { Descrição da } 288^{\circ} \text { Sessão Solene da Câmara } \\
\text { dos Vereadores em comemoração ao Dia do } \\
\text { Professor. Nessa sessão alguns professores } \\
\text { foram homenageados e, dentre esses, duas } \\
\text { professores participantes do concurso literário } \\
\text { receberam a homenagem Professor Escritor: } \\
\text { Marta dos Ramos Leitão, Jacqueline Quinhões } \\
\text { da Luz, Fernanda Batista Alves Zampieri Frias } \\
\text { Garcia. }\end{array}$ \\
\hline 02/mar./2010 & $\begin{array}{l}\text { SME } \\
67 / 2010\end{array}$ & $\begin{array}{l}\text { Boletim Nossa Escola n. } 11 \\
\text { - sem título }\end{array}$ & $\begin{array}{l}\text { Nota } \\
\text { informativa }\end{array}$ & $\begin{array}{l}\text { Nota informando que a 2a. Edição ocorrerá em } \\
\text { outubro. } \\
\text { Obs: Quadro no fim da página. }\end{array}$ \\
\hline 26/mai./2010 & $\begin{array}{l}\text { SME } \\
67 / 2010 \\
\end{array}$ & $\begin{array}{l}\text { Boletim Nossa Escola n. } 23 \\
\text { - Inscrições abertas para } \\
\text { concursos do Valeu, } \\
\text { Professor }\end{array}$ & Notícia & $\begin{array}{l}\text { Informações sobre o evento Valeu, Professor } \\
\text { divulgando o concurso Professor Artista e pela } \\
\text { primeira vez, o concurso literário. }\end{array}$ \\
\hline 20/jul./2010 & $\begin{array}{l}\text { SME } \\
67 / 2010\end{array}$ & $\begin{array}{l}\text { Boletim Nossa Escola n. } 29 \\
\text { - sem título }\end{array}$ & Mensagem & $\begin{array}{l}\text { Mensagem aos profissionais de voltas às aulas } \\
\text { informando as ações da SME para o segundo } \\
\text { semestre, dentre as ações foi citada a 2a. ed do } \\
\text { Valeu Professor }\end{array}$ \\
\hline 20/jul./2010 & \begin{tabular}{|l} 
SME \\
$67 / 2010$
\end{tabular} & $\begin{array}{l}\text { Boletim Nossa Escola n. } 29 \\
\text { - Prepare-se para aproveitar } \\
\text { o melhor da Bienal do Livro }\end{array}$ & Notícia & $\begin{array}{l}\text { Informação sobre a votação da ilustração no } \\
\text { estande da Bienal e divulgação dos vencedores } \\
\text { no local. }\end{array}$ \\
\hline 20/jul./2010 & $\begin{array}{l}\text { SME } \\
67 / 2010\end{array}$ & $\begin{array}{l}\text { Boletim Nossa Escola n. } 29 \\
\text { - Valeu Professor } 2010 \\
\text { recebe inscrições para o } \\
\text { concurso de Professor } \\
\text { Artista até o dia } 20 \text { de } \\
\text { agosto }\end{array}$ & Notícia & $\begin{array}{l}\text { Divulgação da inscrição e informações para o } \\
\text { concurso Professor Artista }\end{array}$ \\
\hline & \begin{tabular}{|l} 
SME \\
$67 / 2010$
\end{tabular} & $\begin{array}{l}\text { Boletim Nossa Escola n. } 30 \\
\text { - Inscrições abertas para o } \\
\text { Valeu, Professor }\end{array}$ & Notícia & $\begin{array}{l}\text { Informações sobre a inscrição para o concurso } \\
\text { Professor Músico e de Expressão Corporal. } \\
\text { Obs: A categoria expressão corporal inclui } \\
\text { dança, peças de teatro e esquetes. }\end{array}$ \\
\hline
\end{tabular}




\begin{tabular}{|c|c|c|c|c|}
\hline 10/ago./2010 & 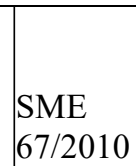 & $\begin{array}{l}\text { Boletim Nossa Escola n. } 30 \\
\text { - Estande as Secretaria terá } \\
\text { autores, oficinas e } \\
\text { discussões pedagógicas }\end{array}$ & Notícia & $\begin{array}{l}\text { Anuncia o que terá no estande da SME na } \\
\text { Bienal e cita o concurso literário, mas o nomeia } \\
\text { de Professor Escritor. }\end{array}$ \\
\hline 17/ago./2010 & $\begin{array}{l}\text { SME } \\
67 / 2010\end{array}$ & $\begin{array}{l}\text { Boletim Nossa Escola n. } 33 \\
\text { - Bienal do Livro vai até } 22 \\
\text { de agosto }\end{array}$ & Notícia & $\begin{array}{l}\text { Informa a data de término da Bienal e o que há } \\
\text { no estande da SME na Bienal. } \\
\text { Obs: A foto usada na notícia mostra a votação } \\
\text { da capa do livro do concurso literário. }\end{array}$ \\
\hline 17/ago./2010 & $\begin{array}{l}\text { SME } \\
67 / 2010\end{array}$ & $\begin{array}{l}\text { Boletim Nossa Escola n. } 33 \\
\text { - Parabéns aos vencedores } \\
\text { do Concurso Literário }\end{array}$ & Notícia & $\begin{array}{l}\text { Informa que o resultado do concurso foi } \\
\text { divulgado na abertura da Bienal do Livro e que } \\
\text { as capas estão sendo votadas. }\end{array}$ \\
\hline 17/ago./2010 & $\begin{array}{l}\text { SME } \\
67 / 2010\end{array}$ & $\begin{array}{l}\text { Boletim Nossa Escola n. } 33 \\
\text { - Venha mostrar o seu } \\
\text { talento no Valeu, Professor } \\
2010\end{array}$ & Notícia & $\begin{array}{l}\text { Informações sobre a inscrição para professores } \\
\text { músico, expressão corporal e artista. }\end{array}$ \\
\hline 17/ago./2010 & $\begin{array}{l}\text { SME } \\
67 / 2010\end{array}$ & $\begin{array}{l}\text { Boletim Nossa Escola n. } 33 \\
- \text { sem título }\end{array}$ & $\begin{array}{l}\text { Nota } \\
\text { informativa }\end{array}$ & \\
\hline 24/ago./2010 & $\begin{array}{l}\text { SME } \\
67 / 2010\end{array}$ & $\begin{array}{l}\text { Boletim Nossa Escola n. } 34 \\
\text { - Divulgada capa vencedora } \\
\text { do livro dos professores- } \\
\text { autores }\end{array}$ & Notícia & $\begin{array}{l}\text { A notícia informou o resultado da votação da } \\
\text { ilustração com a ordem decrescente de votos e a } \\
\text { imagem da capa vencedora. }\end{array}$ \\
\hline $27 /$ set./2010 & $\begin{array}{l}\text { SME } \\
67 / 2010\end{array}$ & $\begin{array}{l}\text { Boletim Nossa Escola n. } 39 \\
\text { - Inscrições abertas para } \\
\text { professores músicos, atores } \\
\text { e dançarinos }\end{array}$ & Notícia & $\begin{array}{l}\text { Informações sobre a inscrição para as categorias } \\
\text { professor músico, dançarino e ator que se } \\
\text { encerra nesta semana. }\end{array}$ \\
\hline $27 /$ set. $/ 2010$ & $\begin{array}{l}\text { SME } \\
67 / 2010\end{array}$ & $\begin{array}{l}\text { Boletim Nossa Escola n. } 39 \\
\text { - Site do Valeu, Professor } \\
2010 \text { está no ar! }\end{array}$ & Notícia & $\begin{array}{l}\text { Informações sobre a página do Valeu, Professor } \\
\text { acompanhada de imagem da mesma. }\end{array}$ \\
\hline 04/out./2010 & 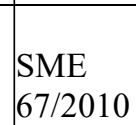 & $\begin{array}{l}\text { Boletim Nossa Escola n. } 40 \\
\text { - Inscreva-se no Valeu, } \\
\text { Professor } 2010\end{array}$ & Notícia & $\begin{array}{l}\text { Informações sobre o evento e a necessidade de } \\
\text { inscrever-se nas atividades que quer participar. }\end{array}$ \\
\hline 13/out./2010 & $\begin{array}{l}\text { SME } \\
67 / 2010\end{array}$ & $\begin{array}{l}\text { Boletim Nossa Escola n. } 41 \\
\text { - Inscrições abertas para } \\
\text { atividades do Valeu, } \\
\text { Professor } 2010\end{array}$ & Notícia & $\begin{array}{l}\text { Informações sobre o evento e a necessidade de } \\
\text { inscrever-se nas atividades que quer participar. }\end{array}$ \\
\hline 18/out./2010 & $\begin{array}{l}\text { SME } \\
67 / 2010\end{array}$ & $\begin{array}{l}\text { Boletim Nossa Escola n. } 42 \\
\text { - Chegou a hora Valeu, } \\
\text { Professor 2010! }\end{array}$ & Notícia & $\begin{array}{l}\text { SME informa que o evento Valeu, Professor } \\
\text { terá início na sexta dia } 22 \text { com atividades } \\
\text { culturais durante todo o fim de semana. } \\
\text { Programação completa no site e twitter. }\end{array}$ \\
\hline 18/out./2010 & $\begin{array}{l}\text { SME } \\
67 / 2010\end{array}$ & $\begin{array}{l}\text { Boletim Nossa Escola n. } 42 \\
\text { - Professores artistas } \\
\text { expõem suas obras no hall } \\
\text { monumental da Prefeitura }\end{array}$ & Notícia & $\begin{array}{l}\text { SME divulga a abertura da vernissage com as } \\
\text { obras escolhidas em conjunto com a sessão de } \\
\text { autógrafos dos autores vencedores do concurso } \\
\text { literário. }\end{array}$ \\
\hline 18/out./2010 & SME & $\begin{array}{l}\text { Boletim Nossa Escola n. } 42 \\
\text { - Secretaria premia seus } \\
\text { educadores }\end{array}$ & Notícia & $\begin{array}{l}\text { A Festa do Professor premiou em duas } \\
\text { categorias: Professores Eméritos e em } \\
\text { Destaque. Divulgação dos nomes dos } \\
\text { vencedores. } \\
\text { Obs: A imagem que consta na notícia tem um } \\
\text { painel de fundo com a marca do Valeu, } \\
\text { Professor, mas não fica claro se essa atividade } \\
\text { faz parte do Valeu. }\end{array}$ \\
\hline 26/out./2010 & $\begin{array}{l}\text { SME } \\
67 / 2010\end{array}$ & $\begin{array}{l}\text { Boletim Nossa Escola n. } 43 \\
\text { - Até o Valeu, Professor } \\
2011 \text { ! }\end{array}$ & Notícia & $\begin{array}{l}\text { SME fez um resumo do que foi o Valeu, } \\
\text { Professor em } 2010 \text { apresentando imagens de } \\
\text { algumas atividades e informou que a vernissage } \\
\text { continua até } 06 / 11 \text {. }\end{array}$ \\
\hline 23/dez./2010 & 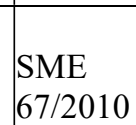 & $\begin{array}{l}\text { Boletim Nossa Escola n. } 51 \\
\text { - Muito a comemorar em } \\
2010 ! ! !\end{array}$ & Mensagem & $\begin{array}{l}\text { A SME apresenta como mensagem de fim de } \\
\text { ano um balanço das suas ações e inclui o Valeu, } \\
\text { Professor. }\end{array}$ \\
\hline
\end{tabular}




\begin{tabular}{|c|c|c|c|c|}
\hline 14/abr./2011 & \begin{tabular}{|l|l|} 
SME \\
$42 / 2011$
\end{tabular} & $\begin{array}{l}\text { Boletim Nossa Escola n. } 58 \\
\text { - Lembrete! }\end{array}$ & $\begin{array}{l}\text { Nota } \\
\text { informativa }\end{array}$ & $\begin{array}{l}\text { Nota informando que já tem data definida o } \\
\text { Valeu, Professor. }\end{array}$ \\
\hline 03/mai./2011 & & $\begin{array}{l}\text { Diário Oficial n. } 80- \\
\text { Portaria } \mathrm{n}^{\circ} 2.340 \text { de } 02 \text { de } \\
\text { maio de } 2011\end{array}$ & Portaria & $\begin{array}{l}\text { A Portaria } 2.340 \text { institui e organiza o Valeu, } \\
\text { Professor como um Programa que abarca o } \\
\text { Professor Artista, o Professor Escritor, o } \\
\text { Professor em Cena, o Professor em Destaque e } \\
\text { o Professor Emérito. } \\
\text { Obs: O concurso literário passa a ser chamado } \\
\text { de Professor Escritor. }\end{array}$ \\
\hline 14/mai./2011 & & $\begin{array}{l}\text { Diário Oficial n. } 89 \text { - } \\
\text { Comunicado } \mathrm{n}^{\circ} 685 \text { de } 13 \\
\text { de maio de } 2011\end{array}$ & Comunicado & $\begin{array}{l}\text { O Comunicado n }{ }^{\circ} 685 \text { apresenta o regulamento } \\
\text { do concurso Professor Artista. }\end{array}$ \\
\hline 14/mai./2011 & & $\begin{array}{l}\text { Diário Oficial n. } 89 \text { - } \\
\text { Comunicado } \mathrm{n}^{\circ} 686 \text { de } 13 \\
\text { de maio de } 2011\end{array}$ & Comunicado & $\begin{array}{l}\text { O Comunicado n }{ }^{\circ} 686 \text { apresenta o regulamento } \\
\text { do Concurso Literário. } \\
\text { Obs: A nomeação Professor Escritor não } \\
\text { aparece no regulamento. }\end{array}$ \\
\hline 14/mai./2011 & & \begin{tabular}{|l|} 
Diário Oficial n. 89 - \\
Comunicado $\mathrm{n}^{\circ} 687$ de 13 \\
de maio de 2011
\end{tabular} & Comunicado & $\begin{array}{l}\text { O Comunicado n } 687 \text { apresenta o regulamento } \\
\text { do Professor em Cena. }\end{array}$ \\
\hline 18/mai./2011 & & $\begin{array}{l}\text { Diário Oficial n. } 91 \text { - } \\
\text { Professores revelam talentos } \\
\text { artísticos }\end{array}$ & Chamada & $\begin{array}{l}\text { Chamada de capa do diário oficial sobre a } \\
\text { inscrição no evento. }\end{array}$ \\
\hline 18/mai./2011 & & $\begin{array}{l}\text { Diário Oficial n. } 91 \text { - } \\
\text { Secretaria de Educação abre } \\
\text { inscrições para o evento } \\
\text { 'Valeu, Professor 2011' }\end{array}$ & Notícia & $\begin{array}{l}\text { Divulgação do evento e das formas de } \\
\text { participação em que o professor pode se } \\
\text { inscrever. }\end{array}$ \\
\hline 18/mai./2011 & & $\begin{array}{l}\text { Diário Oficial n. } 91 \text { - Saguão } \\
\text { da Prefeitura terá exposição } \\
\text { com as obras do "Professor } \\
\text { Artista" }\end{array}$ & Notícia & $\begin{array}{l}\text { Informações sobre os concursos Professor } \\
\text { Artista e Concurso Literário. }\end{array}$ \\
\hline 25/mai./2011 & \begin{tabular}{|l}
$\mathrm{SME}$ \\
$42 / 2011$
\end{tabular} & $\begin{array}{l}\text { Boletim Nossa Escola n. } 62 \\
\text { - Professores podem mostrar } \\
\text { seus talentos no Valeu, } \\
\text { Professor }\end{array}$ & Notícia & $\begin{array}{l}\text { Informações sobre a 3a. Edição do evento } \\
\text { Valeu, Professor e os concursos contidos nele. }\end{array}$ \\
\hline 20/jun./2011 & $\begin{array}{l}\text { SME } \\
42 / 2011\end{array}$ & $\begin{array}{l}\text { Boletim Nossa Escola n. } 66 \\
\text { - Participe do Valeu, } \\
\text { Professor 2011! }\end{array}$ & Notícia & $\begin{array}{l}\text { Informação sobre a continuidade das inscrições } \\
\text { para os concurso Professor Artista e em Cena. }\end{array}$ \\
\hline 09/jul./2011 & & $\begin{array}{l}\text { Diário Oficial n. } 127 \text { - } \\
\text { Portaria SME n³480 de } 08 \\
\text { de julho de } 2011\end{array}$ & & $\begin{array}{l}\text { A Portaria SME n } 3480 \text { constitui a comissão } \\
\text { julgadora para a seleção dos trabalhos inscritos } \\
\text { no Concurso Literário Valeu, Professor. }\end{array}$ \\
\hline 26/jul./2011 & & $\begin{array}{l}\text { Diário Oficial n. } 138- \\
\text { Portaria } \mathrm{n}^{\circ} 3762 \text { de } 25 \text { de } \\
\text { julho de } 2011\end{array}$ & Portaria & $\begin{array}{l}\text { A Portaria } \mathrm{n}^{\circ} 3762 \text { constitui a comissão } \\
\text { julgadora do Concurso Professor em Cena nas } \\
\text { categorias música, teatro e dança. }\end{array}$ \\
\hline 26/jul./2011 & & $\begin{array}{l}\text { Diário Oficial n. } 138- \\
\text { Portaria } \mathrm{n}^{\circ} 3763 \text { de } 25 \text { de } \\
\text { julho de } 2011\end{array}$ & Portaria & $\begin{array}{l}\text { A Portaria } n^{\circ} 3763 \text { constitui a comissão } \\
\text { julgadora do Concurso Professor Artista. }\end{array}$ \\
\hline 02/ago./2011 & & $\begin{array}{l}\text { Diário Oficial n. } 143- \\
\text { Público pode escolher, até o } \\
\text { dia } 12 \text {, capa de livro escrito } \\
\text { por professores }\end{array}$ & Notícia & $\begin{array}{l}\text { A notícia informa que o público poderá votar } \\
\text { para a escolha da ilustração que será capa do } \\
\text { livro Sob o céu da cidade por meio do portal da } \\
\text { SME e presencialmente na Biblioteca } \\
\text { Pedagógica. }\end{array}$ \\
\hline 17/ago./2011 & & \begin{tabular}{|lrr} 
Diário Oficial & n. & 154 \\
Secretaria & divulga \\
vencedores do & Concurso \\
Literário Valeu, Professor
\end{tabular} & Notícia & $\begin{array}{l}\text { Notícia divulga o resultado do concurso literário } \\
\text { com a lista de textos e autores selecionados, } \\
\text { assim como a ilustração vencedora. }\end{array}$ \\
\hline
\end{tabular}




\begin{tabular}{|c|c|c|c|c|}
\hline 22/ago./2011 & $\begin{array}{l}\text { SME } \\
42 / 2011\end{array}$ & $\begin{array}{l}\text { Boletim Nossa Escola n. } 73 \\
\text { - Concurso Literário Valeu, } \\
\text { Professor } 2011 \text { divulga } \\
\text { vencedores }\end{array}$ & Notícia & $\begin{array}{l}\text { Informação sobre o resultado do concurso } \\
\text { literário que está disponível no portal da SME. } \\
\text { Obs: Apresenta a foto da ilustração vencedora. }\end{array}$ \\
\hline 30/ago./2011 & & $\begin{array}{l}\text { Diário Oficial n. 163 - } \\
\text { Professor Artista divulga } \\
\text { obras selecionadas para } \\
\text { exposição na sede da } \\
\text { Prefeitura }\end{array}$ & Notícia & $\begin{array}{l}\text { Notícia sobre o resultado das obras } \\
\text { selecionadas no concurso Professor Artista com } \\
\text { a lista de autores e obras escolhidas nas } \\
\text { categorias desenho, pintura, escultura, gravura } \\
\text { e fotografia. }\end{array}$ \\
\hline 09/set./2011 & & $\begin{array}{l}\text { Diário Oficial n. } 170 \text { - } \\
\text { Abertas as inscrições para } \\
\text { as atividades do Valeu, } \\
\text { Professor }\end{array}$ & Notícia & $\begin{array}{l}\text { Notícia informa que as inscrições para que os } \\
\text { profissionais da educação participem das } \\
\text { atividades do evento Valeu, Professor foram } \\
\text { abertas. }\end{array}$ \\
\hline 07/out./2011 & & $\begin{array}{l}\text { Diário Oficial n. } 190 \text { - } \\
\text { Começam hoje as } \\
\text { atividades do 'Valeu, } \\
\text { Professor 2011' }\end{array}$ & Notícia & $\begin{array}{l}\text { Notícia sobre o início das atividades do Valeu, } \\
\text { Professor com a divulgação parcial da } \\
\text { programação. }\end{array}$ \\
\hline 07/out./2011 & & $\begin{array}{l}\text { Diário Oficial n. } 190 \text { - } \\
\text { 'Valeu, Professor' dá } \\
\text { largada hoje }\end{array}$ & Chamada & $\begin{array}{l}\text { Chamada de capa sobre o início das atividades } \\
\text { culturais do evento Valeu, Professor. }\end{array}$ \\
\hline 15/out./2011 & & $\begin{array}{l}\text { Diário Oficial n. } 195- \\
\text { Valeu, Professor oferece } \\
\text { mais de } 230 \text { atrações em } \\
\text { três dias de festa }\end{array}$ & Notícia & $\begin{array}{l}\text { A notícia apresenta um resumo das atividades } \\
\text { ocorridas durante o Valeu, Professor nos dias } 7 \text {, } \\
8 \text { e } 9 \text { de outubro. }\end{array}$ \\
\hline 13/Abr./2012 & & $\begin{array}{l}\text { Diário Oficial N. } 70 \text { - } \\
\text { Comunicado No } 627 \text {, de } 12 \\
\text { de Abril de } 2012\end{array}$ & Comunicado & $\begin{array}{l}\text { Regulamento do Concurso Literário Valeu, } \\
\text { Professor } 2012 .\end{array}$ \\
\hline 16/Abr./2012 & & $\begin{array}{l}\text { Boletim Nossa Escola N. } 97 \\
\text { - Inscrições Para Concurso } \\
\text { Literário Valeu, Professor } \\
\end{array}$ & Notícia & $\begin{array}{l}\text { Informações sobre a inscrição do Concurso } \\
\text { Literário e a forma do texto. }\end{array}$ \\
\hline 17/Abr./2012 & & $\begin{array}{l}\text { Diário Oficial N. } 72 \text { - } \\
\text { Secretaria de Educação Abre } \\
\text { Inscrições para o Concurso } \\
\text { Valeu, Professor } 2012 .\end{array}$ & Notícia & $\begin{array}{l}\text { Abertura das inscrições para o Concurso } \\
\text { Literário. }\end{array}$ \\
\hline 20/abr./2012 & & $\begin{array}{l}\text { Diário Oficial n. } 75 \text { - } \\
\text { COMUNICADO No } 683, \\
\text { DE } 19 \text { DE ABRIL DE } 2012\end{array}$ & Comunicado & $\begin{array}{l}\text { Regulamento do Concurso "Professor Artista" } \\
\text { Valeu, Professor } 2012 .\end{array}$ \\
\hline 03/mai./2012 & & $\begin{array}{l}\text { Boletim Nossa Escola n. } 99 \\
\text { - Professor Artista do Valeu } \\
\text { 2012, inscreva-se! }\end{array}$ & Notícia & $\begin{array}{l}\text { Informações sobre a inscrição no concurso } \\
\text { Professor Artista que tem cinco categorias neste } \\
\text { ano: pintura, desenho, gravura, escultura e } \\
\text { fotografia. }\end{array}$ \\
\hline 07/mai./2012 & & $\begin{array}{l}\text { Boletim Nossa Escola n. } 100 \\
\text { - Valeu, Professor 2012: } \\
\text { inscreva-se e participe }\end{array}$ & Notícia & $\begin{array}{l}\text { Informações sobre o concurso Valeu, Professor } \\
2012 \text { para inscrição no concurso literário e } \\
\text { professor artista. }\end{array}$ \\
\hline 12/mai./2012 & & $\begin{array}{l}\text { Diário Oficial n. } 89 \text { - } \\
\text { COMUNICADO No } 829,11 \\
\text { DE MAIO DE } 2012\end{array}$ & Comunicado & $\begin{array}{l}\text { Os critérios para a participação no Valeu, } \\
\text { Professor } 2012 \text { - Professor em Cena }\end{array}$ \\
\hline 17/mai./2012 & & \begin{tabular}{|l|} 
Diário Oficial n. 92 - \\
Professor em Cena abre \\
inscrições para educador \\
mostrar seu talento artístico
\end{tabular} & Notícia & $\begin{array}{l}\text { Notícia sobre as inscrições do Professor em } \\
\text { Cena. }\end{array}$ \\
\hline
\end{tabular}




\begin{tabular}{|c|c|c|c|}
\hline 23/mai./2012 & $\begin{array}{l}\text { Diário Oficial da Cidade de } \\
\text { São Paulo - Portaria } 3.212 \\
\text { de } 22 \text { de maio de } 2012 .\end{array}$ & Portaria & $\begin{array}{l}\text { A Portaria nomeia os membros da comissão } \\
\text { julgadora do concurso literário. }\end{array}$ \\
\hline 28/mai./2012 & $\begin{array}{l}\text { Boletim Nossa Escola n. } 103 \\
\text { - Inscrições para o Professor } \\
\text { em Cena }\end{array}$ & Notícia & $\begin{array}{l}\text { Informações sobre a inscrição do professor no } \\
\text { concurso de música, dança e dramatização. }\end{array}$ \\
\hline 19/jun./2012 & \begin{tabular}{|l|} 
Diário Oficial n. 113 - \\
Concurso Literário Valeu, \\
Professor divulga a lista dos \\
vencedores deste ano
\end{tabular} & Notícia & $\begin{array}{l}\text { Divulgação dos vencedores do concurso } \\
\text { literário. }\end{array}$ \\
\hline 03/jul./2012 & $\begin{array}{l}\text { Boletim Nossa Escola n. } 106 \\
\text { - Votação para capa do livro } \\
\text { Semremetente.com }\end{array}$ & Notícia & $\begin{array}{l}\text { Informação sobre a votação da capa do livro do } \\
\text { concurso de } 2012 \text { com as imagens. }\end{array}$ \\
\hline 19/jul./2012 & $\begin{array}{l}\text { Diário Oficial n. } 134 \text { - } \\
\text { PORTARIA No 4.143, DE } \\
18 \text { DE JULHO DE } 2012 .\end{array}$ & Portaria & $\begin{array}{l}\text { Designa comissão julgadora do Professor em } \\
\text { Cena. }\end{array}$ \\
\hline 19/jul./2012 & $\begin{array}{l}\text { Diário Oficial n. } 134 \text { - } \\
\text { PORTARIA N }{ }^{\circ} 4.144,18 \\
\text { DE JULHO DE } 2012\end{array}$ & Portaria & $\begin{array}{l}\text { Designa comissão julgadora do Professor em } \\
\text { Artista. }\end{array}$ \\
\hline 17/dez./2012 & $\begin{array}{l}\text { Boletim Nossa Escola n. } 113 \\
\text { - sem título }\end{array}$ & Mensagem & $\begin{array}{l}\text { Mensagem da gestão da SME aos servidores } \\
\text { pontuando os avanços no período de } 8 \text { anos. } \\
\text { Obs: Não cita o concurso, mas indica elementos } \\
\text { do que foi a gestão. }\end{array}$ \\
\hline
\end{tabular}




\section{ROTEIRO DA ENTREVISTA COM PROFESSORES}

Data da entrevista

Local da entrevista

Nome

Local de Nascimento

Idade

Escolaridade da mãe e do pai/responsáveis

Formação e Instituição

Escolas de atuação

Tempo de magistério

1. Você poderia me contar sobre a sua formação como professora? Quais os motivos que lhe levaram a ser professora? Você gosta da profissão? Como foi o curso de graduação? Em quais escolas você lecionou? E agora, aonde leciona?

2. Quando você começou a escrever? Quais motivos lhe levaram a escrever? Alguém em sua família escrevia? Amigos? Como você descobriu que gostava de escrever? Como você descobriu o gosto pela literatura? Você gosta de ler?

3. O que você escreve - poesia, romance, comentários pessoais? Quais os gêneros? E sobre quais assuntos você escreve? Como você definiria os seus textos, os seus escritos.

4. Com qual objetivo você escreve? /Por que você escreve? O que você quer falar aos leitores?

5. Você se comunica com seus leitores? Tem contato com os leitores? O que eles acham do seu trabalho?

6. Qual é a freqüência da sua escrita? Como são os momentos da escrita - sozinha, ouvindo música, em silêncio...? O que lhe motiva a escrever, uma música, um problema, algo que vem na memória, um caso real...? Que tempo você destina à escrita?

7. Como você concilia as duas atividades: ser professora e ser escritora?

8. Você escreve a mão ou no computador? Possui cadernos, diários, folhas onde escreve ou produz seus textos no computador e assim os guarda? Poderia comentar um pouco sobre isso?

9. Quando você começou a publicar seus textos? Quem incentivou ou ajudou nesse processo?

10. Como é feita a divulgação do material publicado? 
11. O que é escrever para você?

12. SARAU: De quais saraus você participa regularmente? De quais já participou?

12.1 Que relação tem o sarau com a sua escrita?

12.2 O sarau interfere no seu modo de escrever?

12.3 Você lê seus textos no sarau?

12.4 Conte-me um pouco sobre a divulgação e venda de livros de publicação independente nos saraus.

12.5 CONCURSO LITERÁRIO: Como foi a sua participação no concurso literário "Valeu, Professor"? Em quais anos? Como você ficou sabendo do concurso? Como foi a inscrição? E a publicação dos resultados?

12.6 O que você achou do concurso e porque resolveu participar? Foi importante para você? E para os leitores, você acha que teve muitos leitores? Seus colegas souberam que você participou?

12.7 Para você, professora, como explicaria a atitude da Prefeitura em promover esse concurso?

12.8 Você tem outras publicações? Se sim, quais?

13. Em relação às publicações em espaços digitais, todos os seus textos/poesias são publicados em espaços digitais? Você poderia comentar sobre a escolha de publicar nesses ambientes?

14. O que significa escrever literatura nos dias de hoje? Você acha que ser professora interfere na sua obra literária? Se sim, de que forma? Se não, por que não interfere?

15. Como são definidos os temas dos textos que você escreve?

16. Você poderia comentar sobre suas opções de leitura? Que tipo de livro você lê? Cite alguns.

17. O que significa para você escrever literatura? 


\section{Transcrição da Entrevista realizada com Membro da Comissão Organizadora do Concurso Literário Valeu, Professor.}

Data: nov./2016

\section{Local: Biblioteca Pedagógica Professora Alaíde Bueno Rodrigues - SME}

Pesquisadora - [nome do Entrevistado], eu queria começar retomando a sua formação, você pode me falar de novo?

Entrevistado - Eu passei no concurso aqui da secretaria com o magistério, eu sou professora de educação infantil. Depois, eu fiz Biblioteconomia, depois do magistério eu fiz Biblioteconomia e depois, no finalzinho da Biblioteconomia é que eu fui fazer Pedagogia, porque era um bacharelado e não podia mudar de categoria porque eu precisava de uma licenciatura, essas coisas que tem haver com a carreira. Quando eu estava terminando a Pedagogia surgiu a oportunidade de eu vir trabalhar aqui na biblioteca. Isso foi em 1997, então, já são aí dezenove anos trabalhando aqui na Biblioteca Pedagógica.

\section{Pesquisadora - Mas você continua mantendo um cargo de professora?}

Entrevistado - Meu cargo na Educação é Professor de Educação Infantil e Ensino Fundamental e a minha lotação é numa EMEI, numa escola de educação infantil, então todo ano a gente vai lá e escolhe, eu vou e escolho a minha sala porque se de repente eu voltar para a escola, eu tenho a minha sala garantida. E aqui, a minha função é de bibliotecária, meu cargo é de professora e minha função é de bibliotecária.

Pesquisadora - Entendi, agora eu entendi.

Pesquisadora - Você poderia contar como surgiu e se desenvolveu a ideia de fazer um concurso literário para professores?

Entrevistado - A ideia do concurso literário veio depois do surgimento deste programa Valeu Professor, que era um projeto, na verdade, de incentivo, de valorização do professor, pra que ele tivesse momentos de descontração, de lazer, pra sair, fugir um pouco da sala de aula e pensar em atividades que realmente fossem de valorização dele, da pessoa dele, então tanto que tinha além do concurso literário, que teve depois, tinha o Professor Artista, que eram uns professores que pintavam, que fotografavam, que faziam esculturas, então tinha uma vernissage, tinha uma exposição desse material, tinha o Professor Músico, onde eles se apresentavam, com banda ou solo, tinha professor é.., apresentações de teatro, os professores que eram também é.. tinham, faziam peças, podiam também se apresentar em vários lugares da cidade que a secretaria fazia parcerias. O Valeu Professor, ele foi criado antes, o concurso literário aconteceu no ano seguinte, no ano anterior não houve o concurso, mas houve a apresentação dos professores autores, que o Projeto Professores Autores aqui da biblioteca existe desde 2005, se não me falha a memória, e aí então teve essa ideia, professor autor, ele escreve, vamos valorizar esse professor, vamos fazer, assim, um bate papo com ele, nos CEUS, num lugar que eles escolhessem. A gente deu uma relação de lugares, normalmente eram nas bibliotecas dos CEUS que os professores iam, nos CEUS mais próximos das suas casas. E aí eles conversavam, então tinha lá o público do CEU, da biblioteca, que eles conversavam como era escrever um livro, como era essa experiência, como era ser professor da rede e esses professores que se apresentaram nos CEUS, todos eles tinham livros aqui que faziam parte do Projeto Professores Autores, que é a divulgação, a exposição do livro e a informação dessa publicação no portal, na página da biblioteca. 
Então, o concurso literário acabou sendo uma ideia, alguém, acho que lá no gabinete da SME teve a ideia, "ah, e se a gente fizesse um concurso literário" e aí acabaram trazendo essa ideia para nós, a gente sentou com uma comissão que cuidava do Valeu mesmo, com gente do gabinete e foi se desenhando, foi se pensando como a gente poderia fazer. E aí nessa época, a gente tinha o seu YASUDA que era da CBL, que era assim um super parceiro, então ele foi um grande incentivador, ele incentivou muito a fazer esse concurso literário, e ele deu todas as condições para a gente fazer. Ele tinha um acesso muito bom com o secretário, com a secretária adjunta, então isso tudo facilitou também para a gente. E aí como foi criada a comissão que ia organizar tudo isso, eu acho que foi eu por ser bibliotecária e tinha alguém de sala de leitura e pessoas, também, do ensino fundamental e médio, do DOT na época, o próprio seu YASUDA da CBL, que também conseguiu o escritor que foi o da comissão julgadora da primeira edição, então assim, foi reunindo esse pessoal e a gente foi desenhando junto, tanto que o primeiro regulamento ele, assim, foi de fazer pesquisa mesmo, de como era o regulamento de um concurso literário, a gente fez pesquisa em vários sites, aí escrevemos, foi para apreciação, então aí foi se desenhando.

\section{Pesquisadora - E você já fazia parte da comissão do evento Valeu, Professor ou não? Essas pessoas que desenvolveram esta primeira ideia eram professores, pessoas já envolvidas com o evento Valeu, Professor?}

Entrevistado - Sim, porque como Valeu, Professor aconteceu antes do concurso literário com o Professor Autor, e eu que trabalhei com esses professores, que organizei essa atividade, essa fala deles, tanto que eu organizei da minha casa, eu não fui em nenhuma delas, eu estava lá com uma lista de professores participando, estava com um rádio, e sempre tinha alguém da secretaria que trabalhava lá, que acompanhava isso e as atividades do Valeu, porque isso acontecia num final de semana, de sexta até domingo, sempre no mês de outubro que é o mês do professor, e assim mesmo é pra dar momentos de prazer, de lazer e prazer para os professores, tanto que tinha aula de gastronomia no Mercadão, sabe, tinha visita monitorada em museus, era só se inscrever e as pessoas se inscreviam no site, então tinha um site, também, bem legalzinho que foi feito, tudo com aquela linguagem visual do loginho do Valeu, tudo era com aquela linguagem visual. Então, era bem legal, talvez até se você der uma pesquisada, você possa... é que o site deve ter saído do ar, porque tinha uma empresa contratada pra fazer o site, o site foi contratado uma empresa, mas tinha onde você podia clicar, as atividades e tudo... é que eu não imprimi nada, senão até poderia mostrar, e acho que agora não deve ter nada no ar, mas era bem legal, e era assim, também tinha um tempo determinado, ele era tipo de setembro..., não, com o concurso literário ele acabou vindo antes, porque tinha que divulgar as inscrições para os professores e tudo, mas era bem organizado. Então, eu acabei entrando porque já tinha feito esse trabalho com os professores autores, e acho que também pelo fato de ser bibliotecária, mexer com livro e muitos dos contatos com os professores autores também foi eu que fiz e, então, acabei entrando nessa primeira comissão de organização mesmo do concurso literário.

\section{Pesquisadora - Como ocorria a escolha dos temas de cada edição?}

Entrevistado - Olha, o secretário que dava o tema, o Alexandre Schneider. Tanto que é assim, a gente, num primeiro momento, nós pensamos em deixar o tema livre, mas era muito difícil um tema livre para a gente depois fazer a comissão julgadora, então, foi levado ao secretário, e o secretário deu esse tema, e o primeiro foi Eu me lembro que era bem amplo também, mas os três temas foram escolhidos pelo secretário. 
Pesquisadora - Como foi a escolha ou quem indicava a comissão julgadora, considerando que alguns membros participaram em todas as edições e outros foram trocados?

Entrevistado - A comissão julgadora era composta por seis pessoas, a gente achava que esse era um número bom, então três de SME e três de fora. Então, as três pessoas de SME sempre foram eu, a Ione e a Silvana, a Silvana trabalhava em sala de leitura na época e como ela ajudou também a fazer o regulamento, ela acabou também participando das três. E a outra pessoa era o seu YASUDA, que era de fora, então, porque era um super parceiro, aí no primeiro ano foi o Toni Brandão, um escritor e agora já não lembro se teve mais alguém, aí eu precisaria olhar.... Mas as pessoas de fora, era o seu YASUDA que trazia, porque como presidente da CBL imagina a quantidade de pessoas que ele conhece.

\section{Pesquisadora - Ah, era sempre ele que indicava os externos?}

Entrevistado - Sim, sim.

\section{Pesquisadora - Por que ele já era um parceiro para outras ações da prefeitura?}

Entrevistado - É, do Valeu basicamente.

\section{Pesquisadora - Ah, do evento Valeu, tá.}

Entrevistado - E tudo que se referisse também a parte de editora, então como tinha sala de leitura e ele conseguia muito contato com as editoras, até para a venda de livros, para facilitar, para cortesia mesmo, então ele indicava porque ele conhecia muita gente, então ele indicava um escritor e, geralmente, alguém do mercado editorial, alguma coisa assim. Então, as indicações eram sempre feitas por ele e elas mudaram. No ano seguinte o Toni Brandao não pode aí foi a Lucia Jurema que era diretora de Órgãos Governamentais, alguma coisa assim, da Editora Moderna e aí ela, no primeiro ano, nós tivemos duas editoras que participaram, na verdade, tivemos a Editorama que fez a editoração e a Paulus que fez a impressão. No segundo e no terceiro, já foi a Moderna que fez a editoração e a impressão, tanto que o layout é meio parecidinho do dois e do três, então foi a Editora Moderna que fez tudo e a Lucia Jurema que era essa pessoa, ela que inclusive conseguia os contatos da editoração, tudo, e aí num ano ela mandou a Lenice, que é uma outra pessoa também da Moderna, porque ela também não pode estar presente na data, saiu até o nome dela e o nome da Lenice na comissão julgadora, porque ela já não poderia estar presente, então... mas sempre teve gente do mercado editorial e ou escritores para poder fazer a seleção.

\section{Pesquisadora - E o que motivou as mudanças das categorias de inscrição em cada} edição do concurso?

Entrevistado - É, no primeiro ano foram três categorias, poesia, contos e crônicas. Poesia, contos e crônicas, porque a gente não tinha muita ideia, então, a gente queria ver como é que seria a vinda desses textos para nós e aí, pelo regulamento você vê que era para mandar a carta, com duas cópias do texto, mais uma versão em $\mathrm{CD}$ e a ficha de inscrição junto. Aí para os outros anos a gente foi dando uma melhorada, porque a gente viu que, primeiro, às vezes o CD não abria, então, mais importante do que ter o $\mathrm{CD}$, era ter o email para a gente pode pedir o texto depois, então a gente já descartou o CD. E aí a gente colocou o e-mail obrigatório, porque teve casos que o $\mathrm{CD}$ não abria, também não tinha um e-mail, então, não tinha nem como a gente entrar em contato com esse professor, não tinha um e-mail valido. Então, a gente obrigou, colocou o e-mail como sendo obrigatório e fez todos os contatos por e-mail, então, só pedia os textos dos selecionados, só que eles tinham que mandar só uma cópia, não precisava ser duas, porque não tinha necessidade 
de ser duas e, então, uma cópia só impressa, a ficha de inscrição separada e o e-mail tinha que constar na ficha de inscrição e aí devia ter só o pseudônimo pra evitar conhecer a pessoa. Então, colocava o pseudônimo no texto porque aí a gente lia de uma maneira bem imparcial, gostando daquele texto a gente pegava a ficha de inscrição para entrar em contato com o professor. E aí, então, isso foi no primeiro ano, foi as três categorias, sempre lembrando que tinha também a ilustração.

\section{Pesquisadora - Sim, sim.}

Entrevistado - A ilustração acompanhou todas as edições. Mas aí, então, eu vou falar só pra poder separar as categorias. O segundo foi a crônica porque eu imagino que era um gênero que estava sendo trabalhado na rede, então estava tendo formações para explicar o que era crônica, então, para estimular o professor a escrever crônica optou-se nesse ano de 2011. Em 2012, como já tinha sido crônica em 2011, acabou colocando contos e poesias para 2012, para assim variar um pouco mais, então com isso, a gente acabou ficando com três gêneros, mas concentrados três no primeiro ano, somente um no segundo e os outros dois no terceiro.

\section{Pesquisadora - Só uma questão para esclarecer, você fala que estava sendo trabalhado na rede a crônica, mas aí a ideia de colocar no concurso a crônica, ela veio de onde?}

Entrevistado - Ah, eu imagino que da própria Ione, como ela fez parte da formação, eu acho que ela deu a sugestão, inclusive explicando, mais para frente você até pergunta porque que descreve no regulamento, mas até dando uma explicação, esta necessidade de explicar o que era crônica veio justamente no concurso de 2011, porque muita gente no concurso de 2010, que foi o primeiro, confundia um pouco conto, crônica, principalmente conto e crônica, porque poesia é mais tranquilo, mas a pessoa descrevia o texto dela como crônica e era um conto, ou contrário, mas a pessoa descrevia que era uma crônica e era um conto, se é um conto e a pessoa dizer que era uma crônica era mais difícil porque ficava um pouco, acho que confuso do quê que era crônica. Aí, então, em 2011, acho até pelo fato de ter sido trabalhado mais isso na rede, isso a Ione que poderia te dar certeza, aí se optou pela crônica somente, descrevendo o quê que era crônica e, assim, o secretário também autorizou, tudo, tudo passava pelo gabinete, a gente não fazia nada sem o aval do secretário, porque aí mostra a cara da secretaria. E aí acabou dando certo e a gente achou que mesmo as pessoas ainda confundindo um pouco crônica com conto, nós tivemos umas crônicas bem interessantes em 2011 que era Sob o céu da cidade, que também já é um tema que é fácil você escrever umas histórias pitorescas sobre a cidade de São Paulo principalmente, apesar que tinha gente que até escreveu coisas de outros estados, das suas terras, porque aqui em São Paulo a gente tem gente do Brasil inteiro, então... Mas basicamente é isso.

\section{Pesquisadora - Tá. E como era realizada a avaliação dos textos pela comissão julgadora?}

Entrevistado - Desde o primeiro, a primeira edição, a gente fez de uma forma que acabou dando certo, até acho que foi um pouco ideia do seu Yasuda, porque eu acho que ele já devia estar acostumado a lidar com o mercado editorial e, então, pode ser que até tenha sido julgamentos que eles faziam mesmo, então todo o texto era lido por três pessoas, então a comissão era de seis pessoas, então três leituras para cada texto. Então, alguns textos eu li e, assim, sempre era pra ser uma pessoa de SME, ou duas, e sempre um de fora, então, nunca três, as três de SME leram o mesmo texto, isso era um critério também que era usado. Então, a gente fazia uma distribuição de acordo com as pessoas que estavam lá mesmo e não deixando que três pessoas de SME lessem o mesmo texto e 
nenhuma de fora. Então, a gente dava conceitos A, B, C, D e E, igualzinho o da escola mesmo, o A para melhor texto, o B mais ou menos e quando era $\mathrm{E}$ a gente até desconsiderava, então se você olhar os textos, que você acompanhou, que você vê, muitos tem conceitos, todos têm conceitos.

\section{Pesquisadora - Sim.}

Entrevistado - Agora, quando tinha já dois Es a gente já nem usava a terceira leitura, porque sabia que o texto era muito ruim mesmo. Agora, tinha casos, por exemplo, que um dava $\mathrm{A}$ e o outro dava $\mathrm{D}$, aí às vezes a gente até ia para uma terceira, até pra uma quarta leitura, então muitas vezes aquele texto eram quatro pessoas que avaliavam, para ver se...., então, eu acho que os critérios eles, tanto que funcionaram e a gente acabou usando os mesmos critérios para as três edições, então deu certo. No primeiro ano, o Toni Brandão, basicamente, foi mais pra colocar a sequência, que ele, como escritor, ele falou "ah, esse texto é muito legal, ele tem que ser o primeiro texto do livro", porque é aquela coisa de você pegar o livro, você lê as primeiras páginas, se você não gostar, você não para pra ler o restante. Então ele... isso foi muito legal...o que ele fez, nós não tivemos isso nas outras edições, então, nas outras edições a gente acabou colocando em ordem alfabética, se não me engano está por ordem alfabética de título.

Pesquisadora - Tá, não tinha me atentado, vou retomar.

Entrevistado - É, dá uma olhada e até você depois confirma se esta informação é isso mesmo, mas o primeiro ano você pode ter certeza que ele teve uma sequência escolhida por um escritor, a sequência que os textos aparecem no livro, aí nos outros anos, se não me falha a memória, foi por ordem alfabética por título, principalmente em relação as crônicas. E aí teve o caso que a gente precisou publicar um poema que tinha saído, na hora de editorar, ele veio, mas foi um erro também da própria professora, ele veio em coluna dupla, aí na hora que juntou o texto, ele cruzou, então veio a primeira, a segunda daqui, não foi a primeira daqui e a segunda daqui...

\section{Pesquisadora - Ah... ele intercalou os versos da poesia na edição.}

Entrevistado - Ele intercalou, exatamente, então ficou sem sentido, então teve que... daí nós republicamos, escrevemos lá uma notinha, republicamos, e depois ainda chamamos a professora para ir receber os livros, normal, como se fosse a primeira vez.

Pesquisadora - Entendi. Eu acho que você respondeu um pouco a sétima, mas eu vou retomar, caso você tenha outras informações que é: Entre os textos selecionados, como era feita a escolha para a composição do livro, e havia uma seleção de temas dos textos para a composição dos livros? E eu faço essa pergunta pensando numa questão, também, que é o seguinte, na primeira edição tem textos pré-selecionados e textos selecionados, você..., não sei se você lembra desta organização, né, e então a gente tem pré-selecionados em todas as categorias e aí depois tem os que são finalmente selecionados para compor o livro, então é um pouco pensando nessa ideia de como, porque vocês fizeram isso e como que depois foi essa escolha final para compor o livro?

Entrevistado - Então, eu vou te falar do primeiro ano e depois se precisar a gente complementa com os outros anos. Nós recebemos muitos textos no primeiro ano, foi uma adesão grande, acho que também por ser o primeiro, as pessoas ficam empolgadas, então, aqueles... os não selecionados eram realmente os que tinham os piores conceitos, os préselecionados eram aqueles que estavam no mediano, e os selecionados de cara eram os com conceitos maiores, isso numa primeira leva. Porque, o quê que aconteceu, a gente tinha cento e quarenta e quatro páginas, o livro tinha que ter cento e quarenta e quatro 
páginas, era o nosso limite, então, se passasse..., se só com os selecionados já desse as cento e quarenta e quatro, a gente nem ia para os pré-selecionados, se faltasse a gente pegava os pré-selecionados, deu para entender?

\section{Pesquisadora - Sim.}

Entrevistado - Porque quando nós fizemos a... a seleção, que o Toni Brandão foi, ele foi colocando na sequência de acordo com os melhores textos, os que estavam mais bem..., ele também ajudou, muitos ele leu, mas assim a gente fazia uma pré-leitura e mandava para ele só o que a gente julgava que eram os melhores, pra ele por na sequência, nessa sequência que foi... ela foi publicada. Só que a gente não tinha ideia se cabia nas cento e quarenta e quatro folhas..., páginas, né, isso tudo só viria depois com a editoração, então, realmente no primeiro... no primeiro boneco é..., deu para encaixar alguns préselecionados... deu pra encaixar... e aí, é..., já eram as poesias, se não me engano, ele... o Toni Brandão não... não chegou nas poesias, ele só ficou com as crônicas e com os contos, então nas poesias a gente foi encaixando mais algumas e aí pode ser que as coisas tenham saído em ordem alfabética, aí eu já também, eu já não lembro... aí..., é uma coisa para você também atentar quando você pegar os três livros e ver a...

\section{Pesquisadora - A organização.}

Entrevistado - A organização.

Pesquisadora - Tá, e assim, houve entre os que vocês classificaram como bons textos, tinha uma... uma pré-seleção de temas? É assim temas que, como comissão, queremos colocar no livro ou temas que não queremos colocar no livro? Isso teve em algum momento?

Entrevistado - Eu acho que não, a não ser que você..., ah, teve essa questão da memória, que como o primeiro foi o Eu me lembro, teve alguns professores que fizeram realmente memórias, mas aí colocaram acho que muito memórias de escola, e como não era o objetivo, nosso objetivo era mesmo um livro de lazer, um livro de prazer, uma leitura assim sem compromisso com a escola, e até foi a Ione que foi uma das pessoas que levantou essa questão, "essa aqui é muito memória, essa aqui não vai deixar o livro gostoso de ler", essa coisa de muita recordação, essa coisa meio chorosa, que fugia do tema, e fugia até das próprias categorias, porque na classificação, por exemplo, da biblioteconomia, memórias, ele não entra na categoria de nem de conto, nem de crônica. Então, ele já tem um..., ele é uma coisa diferente, então, a gente eliminava, não incluía esses textos, mas um tema, só se realmente o texto fugisse demais do tema, Eu me lembro é um tema muito aberto, Sob o céu da cidade também, o que fechou mais mesmo é o Sem Remetente.com, que aí a gente percebeu que houve um pouco mais de dificuldade, tanto que eu acho que foi o ano que teve menos...

\section{Pesquisadora - Menos Inscritos.}

Entrevistado - Menos inscrições, é. As pessoas, elas não se identificaram muito com o tema e, não sei, eu achei que foi mais complicado mesmo e, talvez, o que a qualidade dos textos seja pior, não sei..., acho... que foi a...

\section{Pesquisadora - Na terceira edição, você acha?}

Entrevistado - Eu acho que pra a gente selecionar foi mais difícil, acho que os textos também não foram assim... tão..., o que mais gostei mesmo foi Sob o céu da cidade, talvez por ser crônica que é uma categoria gostosa de ler. E porque foi diferente, a gente teve uma votação no site porque não teve bienal nesse ano, porque a votação da capa, ela ocorria na bienal. 


\section{Pesquisadora - No primeiro ano?}

Entrevistado - Isso, e no terceiro, porque em 2011 não teve, então a gente fez uma urna aqui na biblioteca e as pessoas puderam votar pelo site, pelo portal. Não foi nem pelo site do Valeu, acho que foi pelo portal da Educação mesmo, e aí foi legal, foi diferente, nós fizemos a votação física também com a urna aqui, então teve os votos no papel e teve os votos da internet, então... sei lá, foi legal, a gente gostou também dessa experiência.

\section{Pesquisadora - Só pra eu esclarecer, no primeiro ano e no terceiro a votação foi só} na bienal?

Entrevistado - Só na bienal, foi só na cédula mesmo.

\section{Pesquisadora - Ah, a urna e a cédula só lá pra quem fosse visitar o estande?}

Entrevistado - Isso, exatamente, tanto que ela começava na bienal e os votos eram apurados na bienal, então, a decisão da capa ficava na bienal.

\section{Pesquisadora - E aí a divulgação do resultado também lá, ou não?}

Entrevistado - Não, a divulgação foi no Diário Oficial e no portal, mas chegou a sair no Diário Oficial a capa escolhida, porque na época da outra gestão, antes do Diário Oficial como ele é mesmo, com os decretos, tinha uma contracapa com notícias, como se fosse de jornal mesmo, depois posso até te mostrar, pra você ver como é. E aí tinha, saíram, saiu os classificados, saiu a capa escolhida, tinha uma notícia sobre isso, era legal isso, e acho que é interessante mesmo você até olhar pra ver como é... também o faz esse diferencial da época.

Pesquisadora - Sim.

Entrevistado - E... tinha mais uma questão?

Pesquisadora - Havia seleção dos temas, que aí acho que você explicou que não tinha e.... posso fazer a oitava?

Entrevistado - Pode.

\section{Pesquisadora - Por qual motivo existe uma descrição dos gêneros literários no regulamento?}

Entrevistado - Exatamente aquilo que eu já falei, é só pra complementar, como havia essa confusão de crônica e conto no primeiro, as pessoas..., porque é o escritor que descrevia qual que era a categoria, mas havia essa confusão e no segundo foi só a crônica, então, fez essa descrição da crônica para evitar que as pessoas confundisse, mesmo assim alguns confundiram, mas... e daí no, como deu certo no 2011, em 2012 fizemos também com poesia e com o conto, e até com a ilustração, a gente até descrevia o que era ilustração também porque a pessoa também tinha que estar dentro do tema, a ilustração dela tinha que estar dentro do tema. Ah, uma coisa que eu lembrei que eu ia falar, no primeiro ano só recebemos quatro ilustrações, então nós fizemos num tamanho grande as quatro ilustrações para as pessoas olharem, e pegavam as cédulas que tinha os desenhos das ilustrações e assinalarem e colocarem na urna, aí nós fizemos a...

\section{Pesquisadora - Cédula?}

Entrevistado - A contagem, fizemos a contagem, a apuração, aí deu a capa vencedora e conseguimos publicar o livro. No segundo ano, como não teve bienal, nós fizemos aqui a urna física e foi a votação pela internet, e foi legal que era com RF, então, a pessoa tinha que votar e era..., ela votava uma vez só, então o número de pessoas que votaram não foi muito grande, mas era uma votação correta, porque às vezes aparece lá cinquenta mil 
votos, mas daí a pessoa votou cinco vezes, então, pelo menos assim..., e podia qualquer pessoa com RF votar, então teve gente de outra secretaria também que votaram, isso foi legal, só que ficou limitado aos funcionários da prefeitura, quem era de fora que quisesse votar, podia votar no papel.

\section{Pesquisadora - $\mathbf{E}$ era a comissão que fazia a escolha das quatro obras que iriam pra votação?}

Entrevistado - Sim, tanto que, no segundo ano, nós já tivemos mais, acho que talvez umas seis ou oito ilustrações, então no dia da seleção a gente até levava alguém também da área de arte, que nós temos aqui pessoas, ela não entrava na comissão julgadora, mas ela nos ajudava a selecionar as quatro que iriam pra votação, então, tudo era a comissão julgadora mesmo que fazia, e na edição de 2012, aí a gente recebeu umas doze ou quinze ilustrações, foi bastante, mas a gente achava que quatro era um número bom pra por pra votação, porque mais que isso, às vezes acaba dando muito pouquinho votos pra algumas e acaba até atrapalhando. Então, também foram escolhidas as quatro e foi na bienal de 2012, do mesmo jeito, colocava as quatro cédulas, só que em 2012... é, aí eu vou precisar lembrar como que foi... porque foi um pouquinho... porque os estandes eram diferente, os estandes da secretaria, em 2012, só teve um pedacinho lá pra isso, em 2010 como a divulgação do vencedores já foi no primeiro dia da bienal, que também foi uma coisa que a gente viu que não deu certo, porque nós fizemos assim, nós pedimos pra todos os professores que participaram, mandassem a foto e a gente não falava o por quê, aí no dia de dizer quem foram os vencedores, a gente chamou todos os professores pra um auditório, com a presença do prefeito, o Kassab foi nesse dia, e o Walcir Carrasco, ele que foi meio que o padrinho daquele dia, então era a abertura da bienal, não estava nem aberto para o público, era aquela abertura solene que depois ia abrir para o público, então estava vazio, estava super tranquilo, fizemos isso, foi legal porque as pessoas puderam conhecer Walcir Carrasco, que é... Muitos professores, que são principalmente de sala de leitura, utilizam muitos livros dele, só que foi muito chato porque teve muito professor que estava lá que não tinha sido selecionado, então... daí mostrou as fotos dos vencedores, "pô eu mandei minha foto, minha foto não está aqui", me chamaram... então, teve gente que saiu triste, isso foi até umas respostas que as pessoas deram do concurso, porque as pessoas ficaram chateadas, até tenho alguns e-mails desses guardados, e elas, porque elas depois mandaram o e-mail, reclamando... adoramos tudo, mas aconteceu isso, isso e isso, não foi legal, tudo, então, no ano seguinte a gente... Não pedimos mais as fotos e publicamos os nomes no Diário Oficial, nessa página especial, então foi legal porque... aí... mas...

\section{Pesquisadora - E no terceiro ano foi divulgado onde?}

Entrevistado - Acho que foi no Diário Oficial também, se não foi no Diário Oficial, foi no portal, mas depois saiu no Diário Oficial, aí eu já não lembro direito, mas eu me lembro que em 2011 é que teve o lançamento do livro também, em 2010 foi no gabinete do prefeito, lá no Viaduto do Chá, junto com a abertura, a vernissage do Professor Artista.

\section{Pesquisadora - Ah, do evento Valeu, Professor?}

Entrevistado - Isso, porque o professor artista, ele aconteceu em todas as edições, mesmo antes do concurso literário teve o Professor Artista e sempre tinha a vernissage que era no evento do Valeu, Professor, geralmente na sexta-feira à noite e, então, tinha abertura da exposição que ficava dez, quinze dias lá no gabinete do prefeito, então já tinha acontecido isso no ano anterior e, no ano seguinte, que era o primeiro do concurso literário, teve também o lançamento do livro, a noite de autógrafos, então foi lá, teve separadinho... os professores ganharam os livros, bonitinho. No segundo ano, calhou de ser a reabertura da Mário de Andrade que fazia três anos que estava fechada pra reforma, 
e a Mário de Andrade ficou fantástica, aí eu consegui uns contatos, porque eu conheci uma bibliotecária lá da Mário de Andrade, conheci nem me lembro se foi num evento, não me lembro quando que eu conheci a Solange, num curso, sei lá, aí ela me indicou o supervisor de ação cultural, aí eu expliquei o quê que era e vi a possibilidade de fazer o lançamento do livro lá no auditório da Mário de Andrade no ano que ela reabriu. Foi um show! O auditório lotado, os professores amaram, teve uma professora que fez um monólogo, também, então nesse dia foi só o coquetel de lançamento, teve coquetel mesmo, os autógrafos foram no hall onde tem aquela estátua da leitura que é maravilhosa, foi fantástico! E o pessoal da Mário de Andrade gostou tanto do evento em si que convidou a gente pra participar de novo quando a gente quisesse, então tiveram até outros eventos, não foi Valeu, Professor mais, tiveram até outros eventos que foi usado o auditório da Mário de Andrade. Aí, em 2012, era fimm de gestão, que essa gestão começou em 2013, então, aí já foi um pouco mais difícil porque não podia sair logo das coisas porque teve eleição e, então, para evitar muito..., foi uma coisa bem mais simples, e o Professor Artista continuou sendo no gabinete do prefeito, mas em 2012 como tinha eleição, ficaram com um pouco de medo de fazer no gabinete do prefeito que era bem na época da eleição, outubro, então acabaram fazendo na praça, como é que chama ali? É praça..., é ali no Anhangabaú, Prestes....

\section{Pesquisadora - Prestes Maia?}

Entrevistado - Prestes Maia, é isso, a galeria Prestes Maia, exatamente, foi na escada, então teve umas apresentações. A exposição do Professor Artista, então, foi lá e a gente aproveitou pra fazer o lançamento do livro lá também. Foi até legal porque aquele espaço ele é bonito, um espaço diferente a gente tinha os bistrôs com os livros, com o... acho que eu até te mostrei, as plaquinhas de identificação dos professores... tudo, mas foi o ano que teve mais falta, o primeiro ano, sim, acho que a gente teve umas duas ou três faltas, no segundo, acho que por ser na Mário de Andrade, aí o pessoal só não foi mesmo quem estava doente, mas tivemos pouquíssimas faltas, mas nesse outro ano, foi bem grande o número de faltas, até porque teve também uma chuva torrencial, acho que ninguém conseguiu chegar, então, era até triste ver, sabe, muitos bistrôs vazios, sem ninguém, os livros todos lá com a sinalização...

\section{Pesquisadora - E os livros eram doados?}

Entrevistado - Sim...

\section{Pesquisadora - Pra quem fosse no lançamento?}

Entrevistado - Então, a gente reservava dez exemplares pra cada professor, aí ele, ele levava os convidados dele e ele autografava e ele dava, para quem ele quisesse, para quem ele quisesse...

\section{Pesquisadora - Entendi, e todos os professores que participaram do concurso eram convidados para ir no lançamento ou não? Era aberto?}

Entrevistado - É a gente até convidava, mas assim os que tinham sido selecionados, os que tinham o texto publicado, eles eram quase que convocados, né, porque era noite de autógrafo, pra eles era a oportunidade deles irem, então aí já não teve coquetel, o coquetel foi só no outro ano... porque tem essa questão também do ano eleitoral.

\section{Pesquisadora - Entendi.}

Entrevistado - Mas, aqueles que não puderam ir, eles receberam os livros depois, a gente mandava por carga, então eles receberam. Depois a gente até deu mais alguns exemplares também dos livros que estavam aí, e aí mudou a gestão, foi aquela questão que eu te falei, 
com a mudança da gestão a gente ficou com um pouco de medo de colocar pra distribuir os livros, então a gente acabou ficou com uma reserva técnica grande, talvez, pra próxima a gente já consiga porque tem mais haver, uma gestão que tem mais haver com a nossa...

Pesquisadora - Ah, sim.

Entrevistado - Que que fez o concurso literário, que fez o Valeu, Professor, quem sabe a gente até consiga fazer outras edições.

Pesquisadora - Retomar?

Entrevistado - Retomar outras edições.

Pesquisadora - Entendi..., Entrevistado, acho que era isso, você quer falar de mais alguma coisa que você achou que não foi tratado, que você se lembre?

Entrevistado - É, eu acho que eu consegui falar de tudo, das ilustrações, dos dias dos lançamentos, até da distribuição dos livros, de como foi feito o regulamento, eu acho que é isso.

Pesquisadora - É isso, então, tá bom, obrigada Entrevistado, mais uma vez pela colaboração, muito obrigada.

Entrevistado - Imagina. 
Data da entrevista: $16 / 11 / 2017$

Local da entrevista: SESC Santo Amaro

Duração da entrevista: 1:28:40

Pesquisadora: Vou deixar aqui, pra facilitar... E aí assim, o começo é sempre uma, um pouco entender qual sua formação, de onde você vem, tá?... Aí queria perguntar o seu local de nascimento.

Professor: É, eu nasci, aqui, aqui em São Paulo, né, e morei sempre na mesma casa no Jardim Ângela.

Pesquisadora: São Paulo, capital...

Professor: Isso.

Pesquisadora: Jardim Ângela é aqui essa região, né?

Professor: Isso. É um pouco mais pro fundo, aqui.

Pesquisadora: De Santo Amaro.

Professor: É uns 40, 50 minutos de Santo Amaro.

Pesquisadora: Tá, e a sua idade?

Professor: Tenho 28 anos.

Pesquisadora: Qual é a escolaridade dos seus pais?

Professor: O meu pai tem o ensino médio completo, recém-concluído, minha mãe tem o fundamental incompleto.

Pesquisadora: Incompleto?

Professor: Incompleto.

Pesquisadora: E o que eles fazem como ocupação? Trabalho.

Professor: Meu pai está morando no interior e ele está trabalhando em caminhão, caminhoneiro, mas ele é aposentado, já. Minha mãe é dona de casa.

Pesquisadora: Seu pai recém-concluído, ele fez, então, educação de jovens e adultos.

Professor: Isso, é.

Pesquisadora: Agora.

Professor: Tem uns cinco, seis anos assim.

Pesquisadora: É, com, é, foi sua, você se formou quando e em que instituição?

Professor: Eu terminei a faculdade em 2012, em dezembro de 2012, é, eu fiz por sistema de bolsas, no, no Mackenzie.

Pesquisadora: No Mackenzie. Tá. E qual o seu curso. É Letras?

Professor: Letras. 
Pesquisadora: É letras...

Professor: É português e espanhol

Pesquisadora: Português e espanhol, tá... e em que escolas vocês já, você é professor desde quando?

Professor: Então, eu dei aula em 2013, um período, numa escola da, do bairro de Santana, na Zona Norte. Eu trabalhava na região central de uma outra, fazia uma outra coisa e também dava aula, era contratado de uma escola chamada Padre... Padre Antonio Vieira.

Pesquisadora: Particular?

Professor: Não. Estadual

Pesquisadora: Ah, estadual?

Professor: Isso Santa... do lado do metrô Santana. Aí eu saí, trabalhei um tempo, né? Fiquei alguns... Alguns meses, aí eu saí, aí eu esperei ser chamado num concurso, que eu já tinha feito, né, aí eu ingre..

Pesquisadora: No Estado?

Professor: Isso, aí eu ingressei em 2014.

Pesquisadora: No Estado

Professor: Aí... Isso. Aí na mesma escola em 2014 até hoje... Que é no Jardim Nakamura essa escola.

\section{Pesquisadora: Jardim Nakamura?}

Professor: Isso. É perto da minha casa.

Pesquisadora: É na...

Professor: Na região do Jardim Ângela mesmo.

Pesquisadora: Tá... Jardim Nakamura, região do Jardim Ângela. E aí você tá lá desde então. Na mesma escola.

Professor: Isso, desde 2014 lá.

Pesquisadora: E você, lá você trabalha com fundamental e médio?

Professor: Isso, sempre va... variando né? Tem...Tem ano que eu consigo trabalhar só o fundamental... Tem ano que eu consigo trabalhar os dois... esse ano eu estou com os dois.

Pesquisadora: Com... E aí que séries que você trabalha?

Professor: Esse ano sétimos, oitavos... Não, aliás, sétimos, nonos e segundos anos do ensino médio.

Pesquisadora: Segundo, dando aula de português?

Professor: Isso, mas, mas eu já transitei entre o sexto ano e o terceiro ano do ensino médio, já.

Pesquisadora: E... Aulas de espanhol não tem?

Professor: Não.

Pesquisadora: Não?

Professor: Eu passei no concurso e não fui chamado até hoje. 
Pesquisadora: Ah, então lá o seu cargo é de língua portuguesa.

Professor: Isso... É.

Pesquisadora: Tá, que é a disciplina que você leciona lá.

Professor: Isso.

\section{Pesquisadora: Tá. E... Como foi sua formação como professor?}

Professor: Então, eu... eu me formei numa instituição assim, que é bem longe da minha casa, que tá num outro contexto social, né? É... por ser bolsista, né, por ser um homem, né... Traços negros, né, sou um homem negro, então, eu sofri alguns tipos de discriminações lá dentro da universidade, né? Então foi um processo bem complicado pra me adaptar, né? E... mas assim, eu fui levando as coisas, né, fui tentando ali amadurecer mesmo dentro da faculdade, porque é um retrato também do que a gente vê socialmente e, e eu consegui, eu a... eu acho que eu consegui até aproveitar bastante, da da da... faculdade, né. Lógico que ela não me preparou, eu acho ela não me preparou pra realidade que eu, que eu estou. Que eu estou numa escola de periferia com todas as questões da periferia e isso eu fui aprendendo nos saraus mesmo, né? No... Nos eventos culturais, porque eu já era do sarau antes de entrar na faculdade, né?... Não, eu entrei na faculdade na mesma época do sarau, mas eu já conhecia os movimentos da região, né, já tinha participado de outros eventos, então conhecia toda essa movimentação. Então eu acho que a faculdade, ela me deu um pouquinho a parte acadêmica, mas o que eu aprendi mesmo eu acho que foi dentro desse movimento aí.

Pesquisadora: Do sarau...

Professor: Isso.

Pesquisadora: Tá. Você... você foi aluno de escola pública?

Professor: Fui. A vida toda.

Pesquisadora: Do estado também.

Professor: Prefeitura e estado.

Pesquisadora: Prefeitura e estado. Tá, é que acho que você pegou o estágio de transição, né?

Professor: É, eu peguei, estudei...

Pesquisadora: Tá.

Professor: Até a oitava série na prefeitura e depois eu fui pro estado.

Pesquisadora: Ah, tá. Entendi. Você é mais novo que eu...

[risos]

Pesquisadora: Tô pensando, o processo das mudanças... É.. que motivos que levaram a ser professor?

Professor: Olha.. a escola tinha, tinha alguns problemas na época que eu era aluno, mas eu sempre gostei de ajudar as pessoas, os colegas, assim, ajudar, ajudar na lição, ensinar as pessoas que tinham dificuldade né, então eu achava que tinha algum, alguma vocação pra isso, né? Lógico que o contexto hoje é muito maior, é muito mais complexo, mas eu sempre achei que eu tinha essa vocação, né, e sempre gostei de estar no meio das pessoas, né apesar de ser muito tímido, mas gostava de estar, nas, no meio das pessoas, então eu acho que eu... Eu pensei nessas questões, né? Gostar de ajudar, gostar de ensinar... né? 
Interagir... Então, eu fui procurar um curso de licenciatura e na época eu já escrevia, né, então apesar de eu gostar muito de História, acabei escolhendo Letras. Mas eu ainda tô nessa, né? De, de, de quem sabe, fazer história ou fazer uma outra área de humanas aí, ou partir para um mestrado nessa área.

\section{Pesquisadora: Mas nessa área de humanas...}

Professor: Isso.

\section{Pesquisadora: E talvez de línguas também.}

Professor: É.

\section{Pesquisadora: Tá. Você gosta da profissão?}

Professor: Olha, eu gosto da profi, da, da profissão. Eu gosto de estar junto com os jovens né, com a molecada, o que eu não gosto é da estrutura que a gente vive, né, a estrutura pra mim ela, ela, ela é massacrante e eu acho que é muito mais massacrante pra eles, inclusive, né, porque a gente tá dentro de um contexto, dentro de uma grade curricular inclusive, né, que não permite que a gente desvie muito do caminho, né, porque eu sou um poeta por natureza, então, né, aula de língua portuguesa a gente fica às vezes muito na questão da gramática, gramática, gramática... Aí tem que dá conta daquele conteúdo porque tem avaliação aqui tem avaliação ali e às vezes eu sinto falta, de, de momentos, né, mais livre, né, fora dessa grade, aí a gente acaba fazendo um evento ali outro aqui dentro da escola pra, pra dar uma amaciada, né... Tanto em mim quanto neles, né, mas apesar de gostar muito dos alunos, gosto muitos dos alunos, acho que... eu acabo aprendendo muito com eles, inclusive, eu acho que é massacrante, o dia a dia, o cotidiano ele é massacrante.

Pesquisadora: Em relação ao seu curso de graduação, é... Além dessas questões que você falou, que é do, né, do lugar social e o que você passou lá, é, em relação a sua formação, como que você considera isso?

Professor: Eu considero ela de razoável para boa, pensando no contexto que eu atuo. Foi um espaço que eu aprendi a lidar com a diversidade e a diversidade de opinião, né? E é o que eu encontro na escola de certa forma também. É um espaço onde eu aprendi, aprendi a ler determinados autores teóricos que também ajudaram a desenvolver algumas coisas também, né? Então eu acho que de razoável pra boa, assim, eu acho que eu daria uns seis ou sete pra minha formação. Lógico que se eu... Se na época eu pudesse me dedicar $100 \%$ à faculdade eu poderia ter rendido mais, se eu não precisasse ter enfrentado umas outras, outras questões, né? Acho que eu poderia ter aproveitado um pouco mais, mas eu acho que eu fui um resistente dentro da faculdade e eu acho que eu consegui aproveitar, assim, dentro do que eu podia bem.

\section{Pesquisadora: E... Você trabalhou? Ao mesmo tempo que fez a sua graduação?}

Professor: Quase todo o tempo, acho que eu fiquei, seis meses que eu fiquei desempregado. E coincidentemente fo, fo... Foi a época que eu tive as melhores notas [risos] a preocupação era só estudar, ler os textos, né? Mas todo tempo, né, eu trabalhei, eu trabalhei uma época como balconista de farmácia, caixa, é, operador de telemarketing, supervisor de telemarketing, dei aula um tempo também nesse... Não, fui dar aula depois, então assim, transitando em algumas áreas assim, né. Mas só seis meses que eu fiquei sem trabalhar.

Pesquisadora: Tá. Quando que você começou a escrever? Você consegue delimitar? 
Professor: Eu acho que escrever como... prática poética mesmo, acho que com uns 13, 14 anos. Eu a, eu a, e eu tenho uns textos guardados em casa no meio das bagunças ali, de antes, né? Mas eu acho que escrever como prática poética assim de separar, né, num caderninho, né, e falar "não, eu escrevo poesia", tal, acho que com uns 13, 14 anos, assim. Quando eu tava ali entrando no ensino médio, né, finalzinho da oitava série pro ensino médio, assim, eu acho que comecei a levar mais a sério assim, um pouquinho mais a sério.

Pesquisadora: Uhum. E... quais motivos se tem, lhe levaram a escrever?

Professor: Ah, na época eu escrevia, eu falo pras pessoas, [risos] eu gostava de conquistar as meninas com poesia. O que me motivava na, é... Naquela época...

\section{Pesquisadora: Na época.}

Professor: Era isso, né? E também, as dores, né, adolescente ali, né, vivendo vários conflitos, né, minha família estava meio se desestruturando nessa época também, porque meu pai estava saindo de casa, separando da minha mãe, mas eu acho que o que motivou mesmo ali no comecinho foi essas paixões de adolescentes aí, aí depois eu comecei a entrar muito na área social, assim, acho que com 15 anos, né, que eu comecei a circular muito dentro do bairro, eu comecei a ir para outros espaços, comecei a ver essa desigualdade, né, aí veio a, a parte social assim como um... um soco mesmo assim, sabe, e eu comecei a escrever muito sobre isso, então eu tive várias etapas aí na, na adolescência.

\section{Pesquisadora: E alguém te incentivava a escrever? Alguém na sua família ou amigos} escrevia?

Professor: Huuum, na família não. Eu lembro que tinha alguns colegas no ensino médio que eles admiravam assim, eles pegavam, né, ficava falando: "Nossa que legal, da hora". Eu tive... Tive alguns professores que também incentivaram né, mas, assim, família não. Família não tive assim esse incentivo, né, pra escrever. Gostavam, mas não...

Pesquisadora: Naquele, naquela época já, você já... Já gostava de escrever, você já tinha essa consciência, gosto de escrever.

Professor: Gosto de escrever, eu lia muito já nessa época, né? Eu... eu assim, eu demorei um pouco pra viver no meio dos livros, né, mas quando eu entrei no meio dos livros, né, quando frequentava biblioteca, assim, era... Eu lia 3, 4 livros por semana, com 14 anos, 15 anos era minha média, assim, né? Eu vinha aqui na biblioteca aqui em Santo Amaro, né, porque perto de casa não tem e... passava por baixo da catraca do ônibus, que eu não tinha dinheiro, ia na biblioteca, pegava dois livros pra levar para casa e lia um lá ainda. Aí na semana seguinte eu estava de novo, quando eu demorava mais, eu deixava dar os 15 dias lá de empréstimo, mas não passava disso não. Eu lembro que eu tinha aquelas carteirinhas de, de empréstimo de livro, eu tinha que pedir segunda, segunda via assim, porque era um ano, né? E eu ali pegando livro, pegando livro, acabava em 4, 5 meses. Era...

\section{Pesquisadora: Rápido.}

Professor: É, então, e, então, eu acho que eu gostava muito de escrever, eu gostava... Continuo gostando muito de ler, mas eu acho que hoje eu leio menos do que eu lia naquela época.

Pesquisadora: Entendi. Foi nesse momento também que você descobriu o gosto pela literatura? 
Professor: Foi... Foi a, eu vi que a literatura, ela abriu um portal pra mim né? Tipo, lia as narrativas, gostava daquela série vaga-lume lá, do, do Marcos Rei, né? E eu entrava num portal né, aí eu comecei até pegar livros até de outras áreas também fora da literatura. Mas eu acho que foi a literatura mesmo que abriu esse portal. E... aí eu me apaixonei, né? Já gostava de poesia, comecei a gostar muito mais.

\section{Pesquisadora: E [tosse] o que você... Gosta de ler hoje? Se você pode citar alguns.}

Professor: Ah, eu gosto, gosto, ainda continuo gostando de ler poesia, hoje eu gosto de ler muito as pessoas que estão nos saraus, né? Estava lendo Vitor Rodrigues esses dias, né, um livro que ele lançou... foi no fim de semana que li o Vi, o livro do... foi o último livro que eu li.

\section{Pesquisadora: É de poesia?}

Professor: É de poesia.

\section{Pesquisadora: E ele é... é de qual sarau? O Vitor?}

Professor: Ele é... ele é da zona leste, ele pertence ao Projeto Praga que é itinerante. Mas ele vai em alguns saraus ali da zona leste. Inclusive ele vai estar com a gente aí esse mês nos Poetas Ambulantes lançando esse livro. Foi o último livro que eu li. E eu gosto de ler esse autores da cena e eu gosto de ler os clássicos também, né? Então... Principalmente, eu estou num exercício de tentar ler mulheres agora, né, então eu estou voltando a ler a Cecília Meireles, estou me reencontrando de novo. Tem as mulheres que estão escrevendo na cena também, né? Tem algumas que eu não conhecia, eu comecei a conhecer tem uns dois anos, tipo a Conceição Evaristo, que eu acho ela maravilhosa, né, então são autores assim que eu tô num momento mais próximo, né? De teoria... De teoria não estou muito por dentro não, né? Eu estou tentando voltar também a ler livros de história, né? Mas eu tô... eu tô na literatura ainda.

Pesquisadora: Na literatura. E... o que você escreve? É... se você pode comentar um pouco, né? Que gêneros são... como você classifica o que você escreve hoje..., e que assuntos...

Professor: Eu acho que eu ainda estou fincado na poesia, né, eu ainda não consigo fugir da poesia. Eu tento escrever, eu já tentei escrever, é, na área da prosa, contos, né. É... tentei estruturar um romance uma vez, mas, ainda tá meio complexo na minha cabeça isso, né. Ainda estou na área da poesia, eu estou mais no estilo dos poemas menores, nas sínteses poéticas, né? Eu estou meio que nessa pegada influenciado por Leminski, essa galera aí dos haikais, aí, né, então ainda estou... Eu acho que nesse momento eu tô, eu tô nisso, mas eu também tô vivendo um momento político muito intenso também, então eu acho que eu tô, os meus poemas... Eu acho que você viu aqui, tem muito de amor, tem uma lírica muito forte, né, mas isso já é passado já, isso é de 4, 5 anos atrás. Agora eu tô meio que misturando essas coisas e eu acho que eu tô mais no tom político hoje inclusive. Né? E... Mas eu acho que eu tô ainda fincado na poesia, tentando entender a prosa um pouquinho mais, né, mas ainda tô na poesia.

\section{Pesquisadora: Tá. E... Pensando...}

Professor: Mas essas coisas se misturam, né, hoje em dia. A gente fala que escreve poesia mas às vezes você escreve um conto e tem poesia no meio, tipo Mia Couto é um desses caras que eu leio e ele está escrevendo um romance, né, um conto, né mas ali a, a... as palavras ali estão se comunicando ali de um jeito poético, então...

Pesquisadora: Para além da forma, né... 
Professor: É, então, eu acho até que é uma tendência da literatura atual, que eu falo até com os alunos quando a gente tá lendo um texto, né, que às vezes a gente tá definindo um gênero mas às vezes a gente encontra traços de outro gênero no meio, né? Então eu falo que eu escrevo poesia, porque eu acho que eu tô bem fincado na poesia, mas de vez em quando eu tento... Traçar uns personagens no meio da poesia também, então acaba se misturando.

Pesquisadora: $\mathbf{E}$, assim, os temas que você traz para poesia. Como que... você pensa neles. Como eles são definidos? Se assim posso dizer...

Professor: Ah, eu acho que eu sou muito levado ainda pelas coisas que eu sinto, sabe, então, recentemente eu passei por uns momentos muitos difíceis assim, psicologicamente falando, e eu senti que meus textos, eles retrataram isso, né? E os textos de revolta, também, revolta com a situação política, os textos mais amorosos quando eu estou meio que nessas fases também, então eu acho que eu ainda tô sendo levado pelas coisas que eu tô sentindo. Eu não consigo ainda hoje sentar e falar "hoje eu vou escrever sobre uma coisa que eu não tô sentindo", sabe? Tem gente que consegue. Eu ainda sento e quando eu paro para escrever é sobre as coisas que eu estou sentindo, então é... É isso, quando eu tô mal psicologicamente, o texto ele retrata isso, quando eu tô bem retrata isso também...

Pesquisadora: Entendi... É... Com qual objetivo você escreve? Existe um... Um, ou vários, ou porquê?

Professor: Eu acho que eu ainda escrevo para desabafar, sabe? Pra tirar um pouquinho, a gente... Às vezes eu brinco, falo assim, "gente, se eu não fosse poeta, eu acho que eu seria uma terrorista, assim, eu ia querer, queria explodir um um monte de lugar assim, apesar que eu sou bem calminho, mas você fica com vontade de fazer algumas coisas assim, né, aí eu acabo escrevendo para desabafar mesmo e é legal que, assim, você está escrevendo um texto para desabafar, as pessoas se identificam isso, acaba virando até uma mensagem, né, tem pessoa que leva aquilo até como um, "pô, esse verso aqui tá falando sobre mim", tal, mas eu acho que eu ainda não escrevo pra arrastar multidões, sabe? "Eu vou escrever um negócio aqui para arrastar uma multidão de fãs". Não, ainda não, eu acho que ainda é muito pra desabafar, sabe? Eu tenho a escrita assim, do meu lado, né, eu vivo rascunhado texto mas ainda é meio como um desabafo, né, como, organizar as ideias melhor, sabe?

Pesquisadora: $E$ nesse processo, tem algo que você, é, quer falar aos leitores? Quando você escreve, você pensa nisso? Em quem vai ler?

Professor: Apesar de eu escrever por desabafo, eu penso um pouco nos leitores. Eu penso, às vezes nas palavras que eu estou colocando ali, eu fico pensando como é que o leitor vai reagir, né? Se eu trocar a palavra x por palavra y, sabe? É... Eu acabo pensando porque como eu já estou no circuito, eu já recebi feedback de textos meus, né, então você acaba trazendo isso para sua escrita, né? Quando eu era mais jovem, que eu não tinha muitos feedback, então, né, você escreve de qualquer jeito, né? Hoje não, hoje eu já olho, né, eu penso em alguns feedbacks que eu recebi. Então, eu penso... o leitor, ele já tá dentro da, dentro da minha cabeça nesse processo.

Pesquisadora: E ...ele tá no processo mas assim, ele, é, o seu, assim, ele, ele é o seu objetivo?

Professor: Uau.

\section{Pesquisadora: Tem algo que você quer comunicar a ele?}

Professor: Às vezes sim. Quando eu tô na parte política né, eu a ... Eu acabo trazendo aquilo que eu tô sentindo mas trazer de uma forma também para ele refletir sobre o que 
ele tá pensando, né? Então quando eu tô mesmo nessa pegada política, eu penso muito nesse leitor, né, eu, tipo, eu coloco, falei: "Pô, isso vai chegar pra ele assim", pra ele refletir, né, e quem sabe mudar alguma coisa aí, né? Ou de posicionamento, né, porque a gente tá no enfrentamento, né, eu sou uma pessoa que tá em vários enfrentamentos aí, e a gente acaba trazendo essas questões. Dentro do ônibus também, então, é, não tem como não pensar, sabe? É... Então às vezes eu escrevo um texto mesmo para convencer o meu leitor sobre determinado posicionamento sabe?

\section{Pesquisadora: Uhum.}

Professor: E não, e não tenho dó de marcar isso no texto, né, mas é a forma, é uma forma que eu acho que eu tenho também de chegar nesse leitor, né, porque hoje em dia tá tudo muito restrito, né, tá tudo restrito, eu falo que a internet abriu horizontes mas tá todo mundo muito planificado dentro das suas próprias opiniões. Às vezes a poesia, ela rompe um pouco, né, a poesia, ela entra por um outro caminho e acaba atingindo a pessoa de uma outra maneira, né? Eu lembro de ações dos Poetas Ambulantes que a gente pegava um tema polêmico e ia fazer ações falando desse tema, sabe? E esse tema mesmo polêmico consegue atingir as pessoas para mudarem de opinião, pensarem melhor sobre aquilo, sabe? E geralmente nesses textos mais políticos eu, o leitor ele tá assim ali, ó. De cara ali...

\section{Pesquisadora: Entendi. Ãããnnn... Ia perguntar se você se comunica com os leitores, você se comunica nos saraus, né? Que é o que você...}

Professor: É, nos saraus, nos ônibus, nas redes sociais de vez em quando eu recebo um ou outro feedback, né, mas a minha forma de comunicação, assim, geralmente ela é mais direta, não é... Porque como eu tô no meio dos leitores, né, a maioria das pessoas que me leem são pessoas que tão comigo, tirando umas que eu nunca vi na vida mas tem meu livro, tem gente lá em Belém do Pará que eu nunca vi na vida que tem o meu livro, gente lá em Fortaleza que tem meu livro, que eu nunca vi, né, mas geralmente eu acho que, vai, uns $80 \%$ são pessoas que tão ali comigo.

\section{Pesquisadora: Tá. É... Em geral esse leitores que você tem contato...É, o que que eles acham do seu trabalho?}

Professor: A maioria dos feedbacks que eu recebi foram positivos do ponto de vista de elogios, né? Algumas críticas também, que eu acho que são muito importantes, inclusive, é... Mas normalmente eles gostam, né. Esses textos, geralmente os mais líricos, né, amorosos, provocam nesses leitores, né, algumas reações assim bem interessantes, né, fala: "Nossa, o cara mora no Jardim Ângela, não sei o que, vê bala, conviveu com bala, com tiro, o cara consegue escrever de amor", então... É possível a gente amar, né? Às vezes eu, eu recebo uns feedback assim, né: "Ah, eu lendo o seu texto eu percebi que é possível amar mesmo nos tempos de ódio, de guerra". Eu fico muito feliz por isso, gente... [riso] Ma, mas boa parte dos feedback são nessa linha assim, né.

\section{Pesquisadora: Dos elogi...}

Professor: E eu fico feliz, né, mas a, as críticas são importantes também, né, que eu recebi algumas também de, da pessoa não entender direito o estilo que escreve né, de... Fazer alguns apontamentos, a gente também leva, né, a gente leva, fala: "Não, de repente é isso mesmo", né? Pensar melhor como coloca aquela palavra.

\section{Pesquisadora: E... qual é a frequência da sua escrita?}

Professor: Olha eu... Eu venho escrevendo pouco ultimamente. Esse ano é um ano assim que eu estou dando assim muito aula. Estou muito atarefado com questões dos Poetas 
Ambulantes, né? E eu acho que eu estou escrevendo pouco. Eu acho que eu estou assim, eu pego o caderno... Eu não, eu não... Não sei precisar assim...

\section{Pesquisadora: Uhum...}

Professor: Mas eu ando com um caderno, com um bloco de notas do celular, mas assim, às vezes eu consigo rascunhar um verso num dia, depois dois dias eu rascunho outro, tem dia que eu consigo sentar, eu rascunho dois, três, sabe? Mas eu tenho tido pouco tempo inclusive para organizar tudo isso, né. Então não tenho nem noção assim quantos poemas eu estou conseguindo escrever por semana, ou por mês, sabe? Mas a frequência, eu acho que hoje ele é bem menor do que dessa época aí. Com 15, 16, anos eu... Nossa eu escrevia 4, 5 poemas por dia, assim. Era um negócio... muito louco assim, sabe? E na época eu frequentei os saraus no comecinho ali também era, sabe, 2,3 , né, às vezes estava ali na faculdade também, enquanto estava estudando, estava escrevendo poema, né, agora tem sido menos frequente, né? Agora eu tenho diário de classe, tem atividade do aluno pra pensar, tenho não sei o que e eu acho que isso, eu até brinco, eu falo: "Meu, a escola pública tem me tirado a poesia em vários momentos assim, sabe?" De eu não conseguir no domingo ter calma para sentar ali e escrever. De eu ficar pensando na, eu ficar pensando: "Meu, como é que eu vou chegar na segunda-feira pra dar aquela aula que eu estava imaginando, se meu aluno não entendeu nem a outra aula"? Aí fíca com esses quebra-cabeça e no final eu não consigo escrever nada, nada. Então, é... Eu acho que eu estou escrevendo muito pouco. O que eu posso dizer é que eu gostaria de hoje estar escrevendo muito mais e, eu espero, que daqui há algum tempo eu consiga voltar a ter, mas eu, os meus... Eu acho que meus textos hoje eles são bem melhores, ainda bem, que o de, de anos anteriores, né? Então eu acho que eu também, eu sou mais exigente com o meu texto. Também tem essa, tem a questão do tempo e tem a questão da exigência, né? Que você fica mais exigente. Não é mais aquela coisa que você escreve no papel direto e sai soltando assim, sabe? Não, hoje você para, deixa ali guardadinho né? Quando você não se sente preparado, você não encara...

\section{Pesquisadora: Não mostra.}

Professor: Não mostra, não é? Apesar que com a rede social hoje, tem coisa que você escreve, que eu escrevo e posto, né? Mas também não é com essa frequência que eu sou mais exigente.

Pesquisadora: Você falou um pouco já, mas assim, é, esses momentos de escrita, eles podem ser, é, dentro do seu contexto, assim, ele pode ser em lugares que você está, você sempre está com um caderninho, mas, é, em geral como que você produz? Produz em casa, é.... Consegue contar pra mim como é essa produção?

Professor: Eu consigo produzir, eu acho que nos momentos mais inesperados assim. Quando eu estou indo dormir, eu não consigo dormir que estou com uma insônia, aí eu vou lá e consigo produzir aí. Quando eu estou na rua andando, aí alguma coisa me chama atenção, eu paro anoto aquilo, né, que se não até esqueço, então eu estou na produção assim inesperada. Dá um lapso, né, aí eu escrevo sobre aquilo, depois eu reflito sobre aquilo, né? Então, acho que primeiro vem essa inspiração do nada e aí depois eu vou mexer naquilo. Depois eu mexo naquilo, arrumo aquilo, aumento, diminuo, sabe? Mas aparece muito nesses momentos, quando eu tô com insônia, sei lá, vou tomar banho, quando eu tô com a água caindo na cabeça, dá vontade de escrever um poema. Aí eu fíco muito bravo, né? Que não tem como escrever naquele momento [risos] mas a ... às vezes acontece assim muito inesperado. Às vezes eu tô na sala de aula acontece, eu to ali pensando ali no que que eu vou falar, ai vem uma construção poética na cabeça aí, tem 
hora que dá para anotar, tem hora que não dá para anotar... nossa eu perco muito poema assim.

\section{Pesquisadora: Nesses momentos.}

Professor: Porque tem 40 alunos ali, oh... pedindo atenção, de repente eu tô ali tentando memorizar esse lapso de poesia mas aí aparece uma dúvida aqui, algum problema ali pra resolver, o aluno que brigou com fulano de tal aí...

\section{Pesquisadora: Perdeu...}

Professor: Perdi...

\section{Pesquisadora: É... Nesse processo tem algo que motiva? Que motiva?}

Professor: Eu acho que, é, pra se libertar das dores mesmo sabe? É um negócio assim, é meio pra... Se bem que eu tenho um poema, né, que fala que a poesia, ela acaba eternizando tudo aquilo que a gente sente, né? Tem os dois lados, eu falo, mesmo tempo que eu tô descarregando aquilo que eu tô sentindo, eu também tô eternizando né? Então eu acho que a minha motivação é, meu, porque eu gosto de escrever e porque eu preciso desabafar aquilo de alguma forma, e a forma que eu encontro é através da poesia porque eu, eu amo literatura, eu amo escrever, brincar com as palavras, brincar com as ideias, né? Jogar com as palavras, né, então, é... Eu acho que é esse desafio, né? E sempre esse desafio de escrever sempre um poema, né... As pessoas falam: "Ah, qual que é seu melhor poema?". Meu, melhor poema é o próximo gente, sabe? É o próximo que eu vou escrever [risos] é isso. O que acaba motivando é você querer escrever melhor, sabe?

\section{Pesquisadora: Aham.}

Professor: Desabafo e a questão de você querer melhorar naquilo.

Pesquisadora: Eu ia fazer uma pergunta do tempo mas acho que você cravou a ideia do tempo, né? Na relação do trabalho professor com o trabalho escrita e essa questão do tempo, né?

Professor: Elas acabam se misturando, uma às vezes sobrepõe a outra... acontece também dos momentos, vai... Esse foi um ano que a gente, dos Poetas Ambulantes com bastante atividade né? Aí às vezes eu tenho que faltar na escola pra conseguir cumprir aquela atividade dos Poetas Ambulantes. Tá certo que isso acaba voltando também, para sala de aula né? Porque a experiência a gente sempre leva, né? Mas tem isso, mesmo, acho, muito mais, né, o trabalho atrapalha na poesia mas às vezes a poesia também tira um pouquinho ali do trabalho, que é muito bom também.

Pesquisadora: E... Próxima pergunta tem a ver com isso, que é como você concilia as duas atividades que é o ser professor e o ser escritor.

Professor: É então...

[risos]

Professor: Eu acho que não é nem conciliar, é imposição memo. Tem que trabalhar, pagar as contas, né? E... como eu falei, eu gosto de tá em contato mas não gosto da rotina escolar, né, mas é ela que paga os meu boletos ali no final do mês, porque às vezes na poesia sai um VAI, mas não dá para pagar os boletos com o VAI. Sai uma atividade no Sesc, né, que paga bem mas é esporádico sabe, é, aparece uma, duas, três vezes no ano. Não dá para depender disso, né, então, assim, na verdade é imposição, porque eu gostaria de ter muito mais tempo de sentar e escrever um texto com calma, de poder mandar trabalhos para vários Sesc aí do Brasil inteiro e de repente viajar levando minha arte, 
interagindo, aprendendo também, né? Então, assim, eu acho que não é nem conciliação, é isso, eu tenho que trabalhar, pagar as contas, eu consigo aproveitar alguma coisa também do trabalho, porque como eu te falei, cê aprende com os alunos também, mas a rotina escolar é uma imposição e é isso, tem que encarar isso, né. Ano que vem eu pretendo pegar menos aulas, aí eu vou ver, né, como é que, como é que eu vou sair nisso e vamos assim.

Pesquisadora: Hoje, é... esse ano, né? Você trabalha com quantas aulas? Quantas aulas você leciona?

Professor: 32, 32 aulas semanais, aí tem os ATPCs, contando tudo dá umas 40 horas semanais, né? Que é uma jornada comum de qualquer trabalhador, né, mas é aquilo que eu falo, quando você é professor, você, não é só o tempo que você tá ali na sala de aula, é o tempo todo, gente. Tipo, eu tô aqui, eu tô aqui agora falando contigo, eu já tô pensando no sarau, que eu tenho uma reunião amanhã cedo fora do meu horário de aula, inclusive, né, com alguns alunos e eu tô pensando, é, na divisão de tarefas, né? Porque eles tão organizando o sarau junto comigo, o que que a gente vai trazer de novo amanhã, que o evento já é na semana que vem, então, assim, é, eu tô aqui fazendo uma coisa fora do meu horário, mas eu tô pensando na escola, então eu acho que você, eu estou ali umas 80 horas por, por semana pensando na escola, né, se eu tenho 40 ali na escola, pelo menos umas 80 ao todo eu tô pensando nela.

Pesquisadora: E trabalhando para ela.

Professor: É trabalhando para ela, né?

Pesquisadora: Tá. É... Como que é sua escrita, ela... Pensando em como que você escreve, você tem cadernos, você escreve diretamente no computador, é... Folhas, diários, mantém diário, é, guarda os cadernos, né, as folhas que você escreve manuscrito, ou não. Como é isso?

Professor: É, os poemas que eu consigo salvar são aqueles que eu escrevo no notebook e no celular. Em cadernos eu costumo guardar, né, mas às vezes eu pego uma folhinha ali escrevo e acabo perdendo, né, acontece muito até. Mas hoje eu acho que eu utilizo todas essas plataformas, tanto a do celular, que ela é mais imediata, porque o celular tá a todo momento ali na mão, né, então, já aproveito, já deixo ali no bloco de notas, o computador, que o que eu mais gosto de escrever hoje é no, no, no computador, que eu acho que é onde eu sento, né, e consigo ali organizar na pasta já, deixar, né, mais ou menos ali de stand-by o que tem ficar de stand-by e usar o que tem que usar, né, e os cadernos que eu acho que é o modo mais bonito, mais clássico, deixar sua letra, mas o caderno nem sempre tá na minha mão, né? Então, o que eu mais gosto hoje é no computador, confesso, mas o que eu mais uso é o celular e às vezes o caderninho também.

Pesquisadora: E... Você falou que reescreve, né?

Professor: Muitas vezes eu reescrevo, mudo, tem poema que começa dum jeito, quando eu vou publicar ele já tá de outro jeito.

Pesquisadora: Mas aí quando, nesse processo de escrita no computador, por exemplo, você tem as versões ou você já faz e a versão anterior, ela se perdeu?

Professor: Não ela se perde.

Pesquisadora: Ela se perde.

Professor: Ela se perde.

Pesquisadora: Mudou e, já muda e já fica pronto. 
Professor: É, que é, o mal do, o mal do, do, do computador é esse né, que você vai mudando o Word já vai salvando, né. Você muda ali o Word já salva automaticamente, quando você vai ver, você já... E você não lembra de voltar né, dá o control $z$ lá pra voltar. No, no caderninho você ainda tem esse registro, né, de você escrever dum jeito, aí você não gostou muito, você escreve do outro. Se você não jogar fora, você vai ter ali o registro né? No computador não, no computador vai se perdendo. Então, é, eu tenho muito disso. Então, poemas que foram escritos de um jeito, que foram modificados nunca mais serão vistos. [risos].

\section{Pesquisadora: [risos] Que pena.}

Professor: A gente que é professor de língua portuguesa, a gente ainda é pedante em algumas coisas, né, que a gente fica com esse negócio da palavra, né? Aí você fíca ali falando: "Meu, essa palavra aqui não tá legal", aí você quer mudar aquela palavra de qualquer jeito, aí você vai, você muda toda a estrutura do verso às vezes.

\section{Pesquisadora: E... Quando que você começou a publicar seus textos e se teve alguém que incentivou a publicação.}

Professor: A primeira vez que eu coloquei um texto meu assim em público para várias pessoas verem, foi no primeiro ano do ensino médio quando a professora de português montou um concurso de poesia. Ela montou um concurso, colocou meu poema lá mas não colocou a autoria para não influenciar, né, até porque eu nem ganharia porque eu nem era tão popular no primeiro ano. Mas eu acabei até ganhando esse concurso aí. Mas foi o primeiro momento ali, quando eu tinha... 14? 15, 15 anos. Foi o primeiro momento ali que eu tive um poema meu público. Foi de... de resto eu deixava tudo muito guardadinho, mostrava pra uma ou outra pessoa, ali, sabe? Mas efetivamente foram os saraus que desengavetaram né, as coisas. 2009 quando eu comecei ali, de fato, com a Cooperifa, que desengavetou, desengavetou aí o livro que eu queria escrever já, virou assim uma obsessão: "Não, vou publicar um livro". Que foi inclusive esse daqui, é... Então eu acho, eu... Foi os saraus... Foram os saraus mesmo que que jogaram pro mundo a minha poesia, né, porque de resto era tudo muito, uma vez ali uma vez acolá, eram um... Foi o sarau mesmo que abriu a gaveta com os meus escritos.

\section{Pesquisadora: Que de alguma forma te incentivou a publicar o, o primeiro livro que é do... Guerreiro.}

Professor: É, então, e, e é... Muito interessante porque, assim, eu sempre tive vontade de escrever um livro. A partir do momento que eu comecei a colocar em caderno, eu já pensava já eu escrevendo um livro. Eu ia na biblioteca olhava: "Ô, já pensou aqui, um livro com meu nome", tal... Já pensava nisso, mas quando eu cheguei no sarau, eu vi que aquilo era possível mesmo. Porque eu via pessoas da quebrada com livro publicado. Aí eu falei: "gente, isso aí não é uma realidade tão distante não", né, eu vou correr um pouquinho, eu vou fazer, mas...

\section{Pesquisadora: E isso você tinha quantos anos?}

Professor: Do... Do livro?

\section{Pesquisadora: É quando você começou a frequentar a Cooperifa e...}

Professor: Eu estava com 20 anos quando eu comecei, eu já conhecia a Coope...

\section{Pesquisadora: Você já estava na universidade, não?}

Professor: Tinha acabado de entrar na faculdade. Acabado de entrar, foi no mesmo ano, na mesma época. Eu já conhecia a Cooperifa de outros rolês que eu já fazia ali, né, eu 
tinha feito... Já tinha participado de ONG ali, já tinha feito uns cursos ali na região, e Cooperifa sempre estava no nosso... Nas nossas conversas, mas eu não frequentava a Cooperifa. Eu frequentei, de fato, quando eu entrei na... É engraçado né, quando eu entrei na Faculdade, eu encontrei uma pessoa da Zona Leste dentro Mackenzie, que aí gente trocando ideia, ai ele falou: "Nossa, você mora perto da Cooperifa, tal, você já foi lá? Como assim você nunca foi lá?". Aí eu comecei a ir, né, e fiquei. Dali eu comecei a ir para outros lugares, entrei em outros coletivos...

Pesquisadora: Entendi [pausa]. É, você pode falar um pouco da divulgação do material publicado, seu. Tô pensando na divulgação do impresso agora. Né, porque você tem esses, que você publicou há um tempo, tem os zines, e agora tem esse daqui, né? Que é o Descaminhos. Como que é essa divulgação?

Professor: Eu tô meio que partindo agora para esse caminho meio que artesanal, que eu comecei a achar muito interessante a ideia de você colocar a mão na massa também na produção, sabe? Nada contra os editores independentes, até porque eu também acho que sou também um editor independente, mas eu gostei muito desse lance de poder botar a mão na massa e fazer do meu jeito também, além do texto ali escrito também a forma, né? O detalhe, o jeito de editar... Eu comecei a gostar muito disso. E eu penso, eu penso assim em breve ter uma publicação maior, né, um livro mesmo, né, costurado à mão. Eu tô amadurecendo essa ideia, na cabeça,e isso aqui são meio que experimentações, né?

\section{Pesquisadora: Uhum.}

Professor: Então eu peguei, esse aqui...

Pesquisadora: Esse então, é o terceiro, né? Que você publica...

Professor: É.

\section{Pesquisadora: Contando com esses, né?}

Professor: É. Esse aqui eu fiz uma oficina. Eu já queria, eu já tava de olho nessas publicações artesanais, de cadernos, fiz uma oficina com um grupo aí, que era especializado nisso, né? Aí eu aprendi a fazer algumas costuras para experimentar, né? Aí determinado dia, eu reuni alguns textos e falei vou publicar, isso aqui, né? Vou publicar isso daqui. Aí hoje às vezes, eu me vejo indo em alguma papelaria, né? Ai na, ai eu já penso olha, eu preciso comprar material para esse livreto mas de repente eu quero fazer mais uma coisa, vou comprar esse material aqui, vou experimentar para ver como fica, então hoje eu acho que eu tô na linha editorial, também, além de ser um poeta, eu tô pensando já como editor, né? Editor do meu trabalhos sim, mas um editor. Editor da parte artesanal. Que eu acho isso muito bonito isso, né, que eu falo que a poesia tá na linha de produção também.

\section{Pesquisadora: Também [risos]. Estético né?}

Professor: É, então, tá a minha cara, né? Pelo menos a minha ideia tá aí, né?

Pesquisadora: Ah, e ai... A divulgação, ela, ela acontece nos saraus?

Professor: Isso.

\section{Pesquisadora: Também né?}

Professor: Quando eu consigo ir nos saraus [risos], é nos saraus, ou no ônibus.

Pesquisadora: Aí é você mesmo quem leva?

Professor: Eu levo... 
Pesquisadora: Ah, você...

Professor: Aí deixo, aí deixo uma mesinha ali ou às vezes, tem uma mesinha ali disponível, eu peço pra colocar, ou a pessoa mesmo oferece, aí eu deixo, tá exposto.

\section{Pesquisadora: E... Na, nas intervenções dos poetas ambulantes, você também leva?}

Professor: Levo. Não costumo divulgar muito nas intervenções porque geralmente nas intervenções a gente tá levando um autor, né, um outro autor pra lançar, né? A gente tá mais preocupado com o lance de, de fazer interação ali para que os passageiros participem, né? Então eu acabo não divulgando muito, mas alguns integrantes vendem também.

\section{Pesquisadora: Ah, eles levam?}

Professor: Levam, aí não na saída, mas em outros momentos, eles...

\section{Pesquisadora: Aham.}

Professor: Fazem esses, esses, esses rolês esses passeios para vender esses trabalhos também. Que é uma coisa que eu ainda não faço. Eu faço mais nos saraus. Ou quando eu encontro alguém na rua que eu conheço aí eu também já...

\section{Pesquisadora: Aí você também já divulga.}

Professor: É. Já divulgo.

\section{Pesquisadora: Tá.}

Professor: E as redes sociais, né? Eu acho que as redes sociais hoje também tão... Cê solta um texto lá, solta que cê tá fazendo tal coisa, e acaba criando uma rede ali.

Pesquisadora: Dê, interessados, né?

Professor: É uma rede de interessados, uma rede ali de contato... Então acabo divulgando muito pelas rede social também.

\section{Pesquisadora: E... O que é escrever pra você?}

Professor: Ah, é um... É uma missão de vida mesmo sabe? Eu falo tanto de desabafar mas é uma missão também, eu acho que é um negócio que nasceu comigo de alguma forma, né? Que eu demorei até determinada idade pra começar e eu acho que é um negócio que eu acho que eu tenho que fazer para o resto da vida. Escrever pra mim é isso. Eu acho que se eu parar de escrever, eu acabo morrendo de alguma forma.

Pesquisadora: É... Em relação ao saraus. É, de quais saraus você participa regularmente?

Professor: A gente tava falando do Sarau lá no Grajaú, né? É um sarau assim dos saraus mensais é o que eu mais tenho frequentado ultimamente. A Cooperifa, eu frequentava muito mais, né? Pelo fato dela ser semanal, né? Eu frequento pouco, eu acho, hoje a Cooperifa, eu devo ir lá uma vez a cada dois meses, uma vez por mês, quando eu consigo, né? Eu acho que dentro da média ali de acontecimentos, o Sarau do Grajaú tá ali. O Sarau do Vinil, que é hoje inclusive, mas que eu não vou conseguir ir.

\section{Pesquisadora: O Sarau do Vinil é onde?}

Professor: É... Na Vila Joanisa.

\section{Pesquisadora: Também na...}

Professor: Perto da Avenida Interlagos ali. 


\section{Pesquisadora: Na região do Grajaú também, né? Não.}

Professor: Não.

\section{Pesquisadora: É Antes?}

Professor: É antes. Perto do shopping, ali, da um 10, 10, 15 minutos do Shopping Interlagos. O Grajaú tá mais pro fundão e... Eu tenho ido, eu ido a Saraus que não são assim muito divulgados, né? Me chamaram pra lançar num sarau lá na Cidade Ademar também, eu fui. Às vezes eu vou em Sarau do outro lado da cidade. Mas eu acho que os que eu mais tenho frequentado assim é o Sarau do Grajaú e o Sarau do Vinil atualmente. São ambientes que eu me sinto bem, me sinto bem acolhido. Me sinto à vontade ali, sabe?

\section{Pesquisadora: Uhum.}

Professor: Então eu, eu tenho ido, eu tenho ido, quando eu tenho tempo e onde eu me sinto mais acolhido [risos].

Pesquisadora: Entendi. É... Você já participou de algum, de outros, assim, com exceção desses?

Professor: É o Sobrenome Liberdade eu fui integrante, né? Também é um sarau que eu continuo frequentando, mas assim, às vezes passo três meses sem ir, aí eu vou dois meses seguidos, sabe? Então o Sobrenome Liberdade era um Sarau assim que eu era, né, além de tá na organização, mesmo quando eu saí, continuei indo, né, e... meu, o Poetas, né, que é a atividade que eu tô realizando, mas eu acho que hoje em dia são esses que eu tô conseguindo ir.

\section{Pesquisadora: Que relação tem o sarau com a sua escrita?}

Professor: É. Eu lembro que quando eu comecei a ir no sarau, eu me senti mais motivado para escrever mais, né, porque o sarau... Ia na Cooperifa toda quarta-feira na época, né? Então, toda semana cê quer apresentar um texto novo, né? Então, assim, apesar de desengavetar vários textos antigos, tem coisa que cê fala assim: "Ah, já não tô com a cara desse textos". Então vou escrever uma coisa nova, então, eu lembro que no comecinho ali, o sarau, ele me incentivava a escrever texto novo toda hora. Toda hora tinha que tá com texto novo, eu lembro de uma época que eu não repetia texto na Cooperifa, aí começou a época de repetir os textos, né, porque o tempo vai diminuindo né, os saraus vão aumentando também, mas eu acho que o sarau é o primeiro contato público, né, depois do Facebook, mas o contato direto, né, que cê vê de fato a reação e ele continua a me motivar a querer continuar escrevendo. Continua... Fala: "Não, tem alguém que tá me ouvindo, né? Tem alguém que tá me vendo, então continua, né? Continua me mantendo vivo para escrever.

\section{Pesquisadora: O sarau, ele interfere no seu modo de escrever?}

Professor: Sim. Sim. Acho que não tem como, né? Porque quando você vê a reação das pessoas, de alguma forma, tipo ó, o jeito como eu falei aquilo, né, de repente, se isso entrar em algum outro texto, né? Então interfere sim, interfere, porque a, você acaba pensando nesse leitor também do sarau. Não que ele determina exatamente, "ah, vou escrever essa ideia porque todo mundo gosta de escutar isso". Num, comigo não é assim. Mas funciona da forma assim: "Ah, de repente eu posso colocar tal coisa no poema". Sabe? Colocar a palavra dessa maneira, né? Dentro do sarau vai ficar melhor para ser compreendido, né? Que é um ambiente ali que é, é, é direto, cê fala, a pessoa escuta e ela vai reagir ali automaticamente né? Num é que nem o livro que cê pega, cê lê, depois você relê de novo, né? Então acaba influenciando, então você também se preocupa com essas 
ideias mais diretas que você coloca, né, os posicionamentos. A época que tava frequentando mais slam também, o slam tava também influenciando um pouco. Mas aí eu saí um pouquinho dos, dos slams assim. Porque o slam eu ainda acho que é mais, né, porque o slam tem a questão da competição, né? As pessoas ainda ficam mais tentadas a falar o que as pessoas gostam né? Então é isso [risos].

\section{Pesquisadora: Você competia no slams também?}

Professor: Competi pouco. Mas algumas vezes eu competi. Eu nunca gostei muito. Apesar de ser capricorniano, eu não gosto de competição, não, eu acho que... Eu respeito a história do slam, acho o slam superimportante, a molecada, tem uma molecada muito boa chegando na poesia, por causa dos slams, né, mas eu não gosto muito dessa coisa de competir, porque isso é meio... Eu vejo algumas pessoas colocando isso como prioridade, né? E acaba sendo uma reprodução meio capitalista, que é uma coisa que eu abomino, sabe? Eu gosto da coisa comunitária, sabe, a gente se articular, se ajudar, né? Eu gosto do slam quando ele tá naquele clima assim, tá... Da hora, mandou um poema legal, dez. Que o outro venha também mande um poema da hora, sabe? Não aquela coisa de torcida, "ah, eu escolhi essa pessoa para torcer e, e essa pessoa tem que ser melhor que os outros". Sabe? O, o slam, eu sinto que ele tá muito carregado dessa questão da competição. E a gente que ter cuidado, não que o sarau seja uma coisa pura que o sarau também... Apesar de não ter a competição, tem o ego, né? Então, ah, aquele poeta, que chega aqui, que ela faz mais sucesso, que recebe mais aplauso, né? Tem essa questão do ego também, né? Então é, é um outro, é uma outra versão de uma competição também, né? A gente tem que ter cuidado nessas... Onde a gente vai, que tipo de, de, que tipo de reação a gente tem nesses lugares, né? Que tipo de postura, que eu acho que assim, é, nós somos seres humanos, né? Erramos, né, não somos perfeitos, fazemos muita merda, mas a gente tem que ter muito cuidado com a nossa postura nesses ambientes, né? Evitar, sabe, reproduzir algumas coisas que a gente tanto fala no texto, que a gente abomina, mas que ali no dia a dia a gente tá fazendo igual. Então eu, eu competi pouco no slam, quando eu me sentia muito na obrigação de competir, "ah porque o Professor Santana, tal", então eu falava, "não, gente, não quero". Às vezes eu ia lá só para assistir e... A última, eu competi num slam tem uns três meses, que foi quando eu lancei esse livreto no, no, no Slam do 13, que é aqui no terminal Santo Amaro, mas a... Tô lançando, vou competir, né? Mas nem... Mas... A questão não era nem competir, era tá ali, né? Era... Seria mais fácil pra falar do meu trabalho, né? [risos].

Pesquisadora: E... Bom, a pergunta, a seguinte era se você lê seus textos no sarau. Se você lê. Né, você diz...

Professor: Eu leio menos hoje em dia.

\section{Pesquisadora: Lê menos?}

Professor: Eu leio mais textos de outras pessoas hoje em dia, você acredita?

\section{Pesquisadora: Ah é? De outros que são também poetas independentes ou de clássicos?}

Professor: Poetas indepen... Os dois, as duas coisas. Eu acho que isso é influência do Poetas Ambulantes. Porque no Poetas Ambulantes, a gente coloca também os nossos textos individuais. Mas a gente acaba pegando outros, né, para aumentar repertório, né? Então eu acabo levando isso também. Então, ah, tem vezes que eu vou no sarau, eu não quero declamar texto meu, quero declamar texto do Emerson Alcaldi, né? Quero declamar um outro texto, né? Então acontece muito de eu declamar texto de outras pessoas e algumas pessoas até acharem que são meus esses textos. Aí eu falo: "Não, gente". É que 
você se acostuma, pega a ideia daquele texto, você pega a essência daquele texto, aí você incorpora, né? Mas eu declamo muitos textos de outras pessoas também. Eu acho até legal isso.

Pesquisadora: E... Eu tinha. Olha, eu tinha colocado um pergunta que é sobre a divulgação e a venda de livros de publicação independente nos saraus, mas você já... Professor: É.

Pesquisadora: Já falou, né?

Professor: É, quando eu chego num sarau que tem uma mesinha disponível ali, às vezes eu peço pra colocar, expor, ou às vezes a própria pessoa vem procura e, e, pra colocar, né? Então, é, eu faço a divulgação e a venda geralmente nesses espaços, né?

Pesquisadora: E esses, esses que você tem? Esse aqui você lançou quando você estava na Cooperifa e foi...

Professor: Comecinho.

Pesquisadora: Foi divulgado lá, na época?

Professor: Isso, isso.

Pesquisadora: E esse daqui, que é o...Pétalas e Pedradas?

Professor: Esse eu já estava dentro do, de outro saraus, já, né? Inclusive o primeiro lançamento dele foi no Sobrenome Liberdade e eu já estava em outros espaços nessa época, né, eu já estava no Poetas Ambulantes, então eu acho que eu circulei muito mais com esse daqui, muito mais mesmo.

\section{Pesquisadora: Do que com o Desencantos... Cantos e Desencantos.}

Professor: Isso.

Pesquisadora: Tá. É... Eu queria que você falasse um pouco de publicação em espaços digitais. Que você faz uso, né, de publicações nesses espaços, como que é a escolha dos textos que vão ser publicados ali.

Professor: Legal essa pergunta, porque assim... Hoje em dia a publicação digital, ela tá muito dentro do Facebook, eu acho, Facebook como é uma ferramenta que tá todo mundo acessando ao mesmo tempo, né? É onde você tem ali, vai, na curtida ou no comentário, o Feedback mais rápido, né? Então o Facebook, ele acaba sendo a principal ferramenta hoje mas também a mais perigosa porque o Facebook, às vezes poema que você publica ali, pra você procurar depois, né... Ou às vezes as pessoas não entendem direito, ou você não entende direito o comentário, a reação, né? Então por ser muito imediato, né, esse mundo imediato, né, é perigoso, né? O mundo digital, ele é bom, porque ele facilita, facilita o contato mas ele também é tudo muito imediato, sabe? E às vezes você num... Você num tem tempo de parar para refletir sobre aquilo, né? Eu tinha uma época que eu usava muito blog. Eu gostava muito de usar o blog. O blog hoje é uma coisa quase extinta, né? Eu não alimento blog, que eu alimentava assim toda semana tem uns dois, três anos, sabe? Desde 2015 acho que eu num posto texto lá no blog. Que era uma, era, era um lugar assim que eu gostava porque é... Tinha leitores que eu iam lá, né? O blog era outra coisa, tinha que digitar, então a pessoa ia lá para ler o seus textos, né? Não era uma rede que caía lá e passava enquanto você estava jogando, né, as outras publicações. É um espaço que eu gostava muito, mas foi extinto, né, porque hoje a questão é imediata né, imediatismo, então, o Facebook acaba sendo essa, a ferramenta principal hoje, penso eu, 
que pra mim hoje é a principal, é a, é a, do ponto de vista digital, é o primeiro espaço que eu acabo divulgando.

Pesquisadora: Então, vou fazer, um comentário, né? Porque eu tinha colocado uma pergunta pra você sobre o blog, porque você tem o, os, os blogs, né, mesmo que, eles tão ativos.

Professor: É eles tão lá...

Pesquisadora: Ativos mas não tá sendo alimentado

Professor: É eu não exclui tá lá

Pesquisadora: Tá lá. É... Então assim, você, Professor, prefere a, o formato blog, né? Mas em relação a como, vamos pensar assim, o público hoje, ele tem uma relação mais direta com o Facebook, você opta pelo Facebook, é isso?

Professor: Sim, e acabei me acostumando com o Facebook, né, você acaba, você vai se acostumando, né, porque você joga: “Ah, eu publiquei no meu blog”, aí você divulga, aí as pessoas não leem, não entram, aí no Facebook você joga lá na linha do tempo, aparece, aparece.

Pesquisadora: Obrigatoriamente a pessoa vai ver, ela pode não ler mas...

Professor: Ela pode passar lá, mas também ela pode parar, né? Muito mais fácil.

Pesquisadora: E aí nesse, você tem mais retorno? Mais feedback pelo Facebook?

Professor: Sim. Sim. Eu tenho mais feedback pelo Facebook. Faz um tempinho que eu não recebo nada pelo blog, inclusive. Mas é porque como você, como eu não alimento, né? Que se eu alimentasse, talvez eu recebesse mais...

Pesquisadora: Tá.

Professor: Mas Facebook é o..

Pesquisadora: Agora, o, os textos que você coloca no Facebook, pensando que você tá alimentando agora, eles são os textos que já foram publicados anteriormente em materialmente, impresso, ou não?

Professor: As duas coisas, eu, eu coloco tanto coisas que já foram publicadas em livro tanto em coisas que eu ainda não publiquei. Coloco as duas coisas, então às vezes eu tô com....

Pesquisadora: Textos novos que você lança lá.

Professor: Isso. Às vezes eu tô com um texto ali pra parado, eu falo: "Não, tá bom de ser pro público". Aí eu coloco ali no Facebook.

Pesquisadora: Tendi. E... o que significa pra você escrever literatura hoje?

Professor: É um desafio muito grande literatura porque ela não é uma arte, acho muito atrativa do ponto de vista do que a gente tem hoje, vai, com a mídia, a mídia digital mesmo com imagem, né, com, com acesso a, a Netflix, a Youtube, né, e tem autor que já descobrindo isso que tá fazendo poema em vídeo do youtube, né? A Luiza Romão acho tá nesse caminho já, tá entendendo né, então é uma extensão da literatura. Mas eu acho que é uma grande desafio assim, escrever literatura hoje é um exercício de resistência mesmo porque eu não vejo assim tão atrativo como, como era antes que você não tinha tantos equipamentos digitais, era, de acesso quando era só a televisão, sabe? Que aí, né, tá certo que também é, os livros para quem é da periferia também não é acessível, mas eu 
acho que pelo as pessoas liam com mais cuidado, tinham... Respeitavam mais o que o autor... Respeitavam eu não sei se é a palavra certa é respeitar. Mas eu acho que tinham mais apreço pelos, pelos autores, né, os autores aí da literatura. Hoje tá tudo muito... Tá muito expandido né, e eu acho que a gente acaba tendo que entender outras mídias pra poder chegar nessas pessoas, né, então eu acho que hoje, a literatura só no livro hoje ela muito difícil de se sustentar, assim eu acho. A gente vende porque a gente tá vivo, a gente mostra, né, eu vou vender o livro, eu leio um poema aqui, a pessoa gosta, tal, mas ela não é atrativa acho que assim para as pessoas adquirirem hoje não. Quando você faz um trabalho artesanal, se torna interessante, então você vai criando mecanismos. Mas a literatura ela, eu falo que ela é o patinho feio das artes [risos] que ela acaba sendo bonita mas ela é, ninguém quer saber da literatura num primeiro momento, né, e ela tá num processo de se adaptar a essas novas ferramentas, né. Então ela acaba indo para o Facebook, ela acaba indo para o Youtube, né? Então escrever literatura e publicar, divulgar literatura hoje é... Resistência. Então tem que ter muito... Assim como tem que ter criatividade para escrever, tem que ter criatividade para divulgar. Porque não é só chegar lá e jogar, tem que saber o que você tá colocando, né? Tudo isso. Tem que pensar em tudo isso.

\section{Pesquisadora: E, você acha que ser professor interfere na sua obra literária?}

Professor: Sim. Sim. Principalmente pra professor de português, né?

\section{Pesquisadora: Você pode comentar um pouco?}

Professor: Tem que, é, tem algumas vezes que eu pego, eu pego alguns temas e fico ali rascunhando, "não, eu posso escrever sobre isso", né? Sobre essa, esse assunto aqui né, então acaba puxando. E... Eu acho que do mesmo jeito que toma o tempo também às vezes também dá uma inspiração. Tem poemas que, como eu te falei, eu estou ali na aula, dando a aula, aí eu tô pensando na, naquela, até naquela regra gramatical aí eu falo: "Gente, dá pra colocar um poema em cima disso daqui", sabe? Então, é, você, a gente extrai poesia de tudo, né? E acho que professor não é, sendo professor de língua portuguesa, principalmente, eu, eu consigo extrair alguma coisa assim, pra poesia.

\section{Pesquisadora: E... Eu quero fazer uma pergunta inversa. Ser escritor interfere no seu trabalho como professor?}

Professor: Sim. Interfere. Gostaria que interferisse até mais, viu? Gostaria inclusive de ser ali, nem ser professor assim desse negócio de professar, impor um conhecimento, né? Ser uma coisa assim mais democrática mesmo, sabe? Da gente jogar um texto na roda e cada um tirar a sua conclusão e é isso. Né? Como professor a gente tem que ficar direcionando, né, tem que ficar aqui, que tem que chegar num lugar x, né? Mas influencia sim, porque sendo escritor eu, eu acabo selecionando mais os textos que eu vou levar pros alunos, né? Então, esse cuidado com a literatura é muito maior, né, o modo como eu vou passar isso pros alunos é muito maior e eu acabo trazendo coisas do dia a dia também né, porque como eu tô no sarau eu tô no dia a dia, tem coisa nova ali né? Hoje mesmo, eu estava na aula a gente tá produzindo fanzines pro sarau, aí eu...

\section{Pesquisadora: Com os alunos?}

Professor: Isso, aí eu fui numa sala de vídeo lá que tem na escola e eu comecei a puxar poemas de, de, puxei poemas da Luz, da Mel, né, que tratam de questões do dia a dia, né? Eu acho que se eu não fosse escritor e desse meio, isso não teria na aula. Eu ficaria ali com Machado de Assis, que eu adoro, com Drummond, que eu amo, e fica, mas ficaria nisso. Não traria essas referências atuais, né? E eu tenho aluno que é super fã da Mel Duarte da Luz Ribeiro, né, de poetas atuais, assim. 
Pesquisadora: Que estão nesse cenário dos saraus, né?

Professor: Isso.

Pesquisadora: E você desenvolve um projeto de sarau, é isso? É um projeto ou são atividades...

Professor: É um projeto.

Pesquisadora: É um projeto.

Professor: É. Por enquanto eu tô conseguindo realizar duas vezes por ano, esse sarau, né?

Pesquisadora: Com os alunos lá da escola?

Professor: Isso. Aí eu monto uma equipe. E eles, e eles dividem as tarefas comigo.

\section{Pesquisadora: Aí organiza...}

Professor: Isso.

\section{Pesquisadora: Tudo. Faz tudo. E esse momento do sarau na escola, como é?}

Professor: É bem diferente, né? Porque eu, porque eu tô trabalhando né? Então eu sou responsável de fato pelo que tá acontecendo ali, né? Então quando acontece alguma coisa ali que o diretor não vê com bons olhos, sou eu que escuto, né? É diferente do sarau, que a gente também tem essa questão do público, mas a gente tá muito mais livre, né, pra experimentar as coisas, né, então, eu posso do nada, sei lá, tô numa cena dos Ambulantes eu posso inventar um trocadilho $\mathrm{x}$, para eu inventar uma ação $\mathrm{x}$, na escola tem que ter mais cuidado, né, porque tem alguns olhares ali me avaliando também, né, a escola tem essa estrutura, eu costuma dar bastante liberdade para os alunos falarem o que eles querem. Não sou de ficar restringindo. Se ele quiser falar um poema com palavrão, comigo ele pode falar, gente, mas é aquilo que eu falo, dependendo da ideia que você vai colocar, eu vou aceitar, mas o outro ali não vai aceitar, sabe? Então a... Eu acabo sendo muito mais cauteloso dentro da escola pra fazer algumas coisas, né? [pausa] No sarau eu me sinto mais liberto.

Pesquisadora: Entendi. E... [pausa] Tem uma pergunta, ela, ela retoma, mas eu queria... Vou fazer, aí você pensa se tem algo diferente pra me dizer, que é o que significa pra você escrever literatura.

Professor: Eu falei dessa questão da... Hoje é um ato de resistência, né? Por conta de tudo que tá posto em nosso cotidiano, só que eu acho que escrever literatura especificamente é você ir a fundo no significado, no, no poder das palavras, sabe? Porque a nossa, a nossa, a nossa ferramenta é a palavra, a do pintor são as cores, os traços, a nossa ferramenta é a palavra, então é a gente ir a fundo no potencial dessa palavra, dessas palavras, é você ir a fundo no, no, no que você mostra pro outro através de seu discurso, sabe? Através do seu texto, do seu poema. Então eu acho que escrever literatura é você ir a fundo, né? É aquele poema: "Penetra surdamente no universo das palavras", então você vai ali mesmo, você como escritor, né? Escrever literatura é você ir a fundo no poder daquilo, né? E você sabe que é um poder monstruoso, a palavra é, apesar da, apesar de tudo que eu falei, das, de outras mídias serem atrativas, a palavra ainda bem colocada, ela muda, muita coisa. Ela convence, ela desconvence, ela impacta muita gente, então eu acho que escrever literatura é você mergulhar nesse universo, né, e você entender esse universo.

Pesquisadora: Tá. É... Em relação aos Poetas Ambulantes. Hoje, é, como que acontece o projeto de vocês? É um coletivo, né? É, vocês... saem toda semana, como que é isso? 
Professor: A nossa saída...

\section{Pesquisadora: Se você puder contar como do, de como é.}

Professor: A nossa saída, ela continua sendo mensal, né, mas a gente tem outras atividades. Por exemplo, ensaio pra mudança de repertório, pra, a gente tá numa pegada de preparar novos espetáculos, né? Pequenos espetáculos temáticos pra levar pro Sesc, inclusive, quando chamarem, a gente tem o documentário, que tá sendo gravado, né? Então às vezes a gente tira um dia ou outro pra gravar com alguém. Mas as saídas, elas continuam sendo mensais, e algumas atividades nas escolas que, a escola chamou, a gente vai.

\section{Pesquisadora: São escolas públicas?}

Professor: É, particulares também a gente vai. Mas a gente dá preferência sempre às escolas públicas, que são as que não têm nada, né?

\section{Pesquisadora: E aí são escolas da região? Da Zona Sul? Não.}

Professor: Não. Qualquer região.

\section{Pesquisadora: Qualquer escola.}

Professor: A maioria é da Zona Sul porque a gente conhece mais gente da Zona Sul, consequentemente conhecemos mais professores da Zona Sul, né? Mas a gente já foi em escola da Zona Leste, de outras cidades...

\section{Pesquisadora: As escolas chamam e vocês fazem uma intervenção lá.}

Professor: Isso. Às vezes a gente faz uns 20, 30 minutos de intervenção...

\section{Pesquisadora: Entendi.}

Professor: É, mas assim, as atividades continuam sendo mensais dentro do ônibus, então a gente... Mês sim, mês não escolhe um autor da cena, pra lançar o livro, a gente chega lá e lança o livro dentro do transporte. A gente compra, né? Como a gente tem o VAI esse ano, a gente compra esses livros e a gente sempre chama os passageiros para participar. Então o passageiro que vai lá e fala um, que seja um batatinha quando nasce mas ele tá participando, a gente vai e dá um livro desse autor e o autor já autografa na hora pra ele.

\section{Pesquisadora: Ah, que legal!}

Professor: Quando esse autor não está, aí a gente pega alguns livros aí nossos, ou de doações, e, e dá para esses passageiros. Mas é isso, a gente entra que nem vendedor ambulante, a gente ainda num... A gente pensa essa questão de passar o chapéu pra gente recolher dinheiro, né, mas a gente ainda não aplicou isso, a gente aplicou uma ou outra vez, né, mas isso ainda não tem, não tem sido frequente. A gente continua fazendo de graça, mas a gente pensa essa questão por causa de algum um dia todo mundo largar tudo que tá fazendo e viver só disso. Aí vai precisar do chapéu mesmo.

[risos]

Professor: Né? Mas hoje a gente faz de graça, e... Na verdade o pagamento são os aplausos, a interação, né, é... E, e assim, o Poetas Ambulantes é uma coisa que pra mim foi muito revolucionário do ponto de vista de eu tá no sarau, eu tá em ambientes que, assim, o público do sarau são bem parecidos, então a galera que vai à Cooperifa 50, 60\% vai no Sarau do Binho, né, 40 vai no Sobrenome Liberdade, então assim, tá naquele mesmo público que gosta de poesia, alguns curiosos, né? Então tá sempre dentro dessa mesma, né, mesmo grupo. Quando a gente vai pro ônibus, a gente vai pro inesperado, né? 
Que são as pessoas que nem sabem o que que é poesia e a gente coloca aquilo de uma maneira interativa pra elas, né? Então isso foi muito revolucionário pra mim, né? Eu falei: "Gente, a gente tá saindo do ambiente fechado", né? Apesar de ter o espaço pra falar, o ambiente fechado, pra ir pro ambiente público com circulação de pessoas, né? E muito bonito, muito, o alcance disso daí, a gente não tem nem dimensão, sabe? Não dá pra medir, né?

Pesquisadora: É. E... o seu li... esses dois, esse tem editora, né?

Professor: Isso. Esse aqui, ó.

Pesquisadora: Mas, foi uma ação sua?

Professor: Isso. Eu paguei pra fazer.

Pesquisadora: Então, são publicações que você investiu. E esse é independente. Você pensou ele sozinho? O Pétalas e Pedradas, é isso?

Professor: Eu pensei com alguns amigos, né? Eu chamei alguns amigos para participarem do processo...

Pesquisadora: Então você que fez a es... No caso desses livros, você fez a escolha dos textos, que mandou para editora, pensou a capa, tudo foi processo seu.

Professor: É.

\section{Pesquisadora: Com ajuda de algumas pessoas?}

Professor: É. É. Esse daqui foi a editora que propôs a capa. Aliás, eu propus uma ideia, a editora me, me deu a capa.

\section{Pesquisadora: Aham.}

Professor: Esse daqui foi um presente que eu ganhei de aniversário, né? Uma amiga, ela fez, né?

\section{Pesquisadora: A capa?}

Professor: É. Ela me deu de presente de aniversário e na época ela namorava com um amigo meu e esse amigo meu estava escrevendo uma das partes do livro. Ela leu esse, esse livro junto com ele e como ela desenhava, né, inclusive, né? Muito bom...

\section{Pesquisadora: Uhum.}

Professor: No dia do meu aniversário, ela veio com esse desenho e me deu de presente. E na época eu não tinha a capa do livro. Já estava já no, nisso das pessoas revisarem, escrever orelha, prefácio, não tinha capa do livro e eu já estava pensando, putz, como é que eu vou fazer uma capa pra esse livro, né? Eu estava meio perdido, aí ela me deu esse desenho, que ela não deu com a intenção de ser capa, ela me deu porque foi uma ideia que surgiu enquanto ela lia o livro. Aí eu falei: "Poxa vida, meu, um desenho como esse daí, eu acho que eu vou divulgar mais", né? Acabou virando a capa do livro. Né? Então o processo da capa desse livro aqui foi muito mais bonito, né, porque ele foi um presente. Um presente que acabou valorizando um pouco o trabalho dela também, né? E muito mais o meu. Deixou o livro muito bonito, essa capa.

Pesquisadora: É verdade. E... Eu que, queria que, se você puder falar um pouco, é, o que é pra você o guerreiro periférico.

Professor: Guerreiro periférico, apesar da, da linha de escrita hoje ser diferente, desse livro, acho que a essência, ela continua a mesma. Que o guerreiro periférico, a guerreira 
periférica, né? É, é, são os enfrentamentos, né? Porque eu falo que a gente sair de casa e sobreviver é um enfrentamento diário, assim, sabe? Então a partir do momento que a gente sai de casa, às vezes dentro de casa a gente já é alvo, né? Nós somos pessoas públicas, né, somos pessoas com características muito marcantes, né? Tanto físicas, né, o... e... Eu acho que essa questão do guerreiro periférico, ela veio nessa questão do enfrentamento, o título desse livro veio dentro do Mackenzie, que eu tinha um enfrentamento ideológico muito forte lá dentro. Então, é, o guerreiro peri, tipo, eu carrego meus trau... Eu não escondo de ninguém da onde que eu venho, o que eu sou, né? E eu vou pra esse enfrentamento. A gente se transforma, se modifica no meio desses contato, né? Porque o ser humano, a gente vai aprendendo, vai interagindo mas a nossa essência, ela continua a mesma, então, eu encaro o mundo como enfrentamento às vezes, sabe? Sobrevivência, mesmo, então o guerreiro periférico é a, aquele que tá na linha de combate sobrevivendo.

\section{Pesquisadora: E que segue, e que persegue você até agora.}

Professor: Persegue eu até agora. Não deixei de ser o, a, eu falo a escrita mudou um pouco? Mudou. Ainda bem que mudou, né? Mas eu acho que essa essência, eu carrego comigo sabe? Onde que eu vou, eu falo: "Não, eu sou do Jardim Ângela", tal. Talvez a, talvez a minha, a minha escrita hoje não esteja falando tanto do bairro, né? Mas eu sou do Jardim Ângela, foi lá que eu aprendi a escrever. Mesmo que eu não more lá daqui há algum tempo, né? Que eu tenho pretensões de morar em outros lugares, né? Eu vou carregar, eu pretendo carregar isso aí, porque é onde eu nasci, onde eu cresci, onde eu aprendi a ser gente, sabe? E foi dessa raiz aí que eu aprendi a estender as folhas para outros lugares, né? Então é isso, eu vou, eu pretendo continuar a ser, mesmo não dando na periferia da Zona Sul de São Paulo, eu pretendo continuar a ser o guerreiro periférico.

\section{Pesquisadora: Entendi. Professor, o roteiro findou [risos]. Eu queria...}

Professor: Agora eu quero ver pra você escrever isso aí, depois.

\section{Pesquisadora: É. Tem mais alguma coisa que você gostaria de falar? Que não entrou...}

Professor: Deixa eu pensar, aqui. É, cê, cê falou muito da questão do que motiva a escrever que eu acho que é uma coisa bacana de poder falar, do, do público, é... eu queria falar um pouquinho de como isso chega na academia.

\section{Pesquisadora: Diga [risos].}

Professor: Porque é exatamente isso que... Porque assim, é uma coisa que eu tava conversando até com algumas pessoas, assim, como a gente chega na academia e como a academia não valoriza e eu falo isso porque eu já estive dentro da academia, né? A academia trata isso como um tema, vai, "nossa, que legal isso que tá acontecendo", mas num aprofunda e não devolve, sabe? Quando eu falo, a, a gente contribui, né, com, com, com o material, com as coisas, e isso não volta né? Porque eu acho que tinha que ser uma coisa muito mais integrada, sabe? É, a academia, eu acho que ela depende dos acontecimentos sociais pra ela se renovar e a gente também precisa da academia pra repensar várias coisas, né, então, é aquilo que eu falo, eu estive dentro de uma universidade, eu sei exatamente como que é. Eu apresentei um TCC, meu TCC foi sobre literatura marginal dentro da faculdade, foi assim uma novidade pra eles, né, mas ao mesmo tempo eu não sei se isso tá, se isso causou algum impacto lá, pra eles... De repente algum professor começar a trabalhar isso lá dentro, sabe? Ou como pessoas nossas estarem lá também, sabe? Eu, eu me incomodo muito com isso, é uma questão que me incomoda muito por eu já ter estado na academia e ter sempre esse enfrentamento 
também, tipo? Meu... Sabe, não que eu queira ser um pop star da Academia Brasileira de Letras, mas eu acho que a gente tinha que ter mais espaço dentro da academia e a academia tinha que estar também mais presente no cotidiano. Mas é, é um desabafo, é uma inquietação que eu tenho, sabe? Porque é... São mundos que eu frequento, né, tô ali e eu sinto que não há conexão. Não há. Tem, tem alguém, tipo você que faz um trabalho aqui, outra pessoas que faz um trabalho ali mas no, no fim, fica tudo isso muito jogado, sabe, muito espalhado, não tem uma, não tem uma linha de pesquisa, não tem um trabalho maior sobre isso, né? É uma inquietação que eu tenho na verdade.

\section{Pesquisadora: Tem razão.}

Professor: [risos].

\section{Pesquisadora: É. Tem razão.}

Professor: Eu, eu, estive recentemente no Rio de Janeiro, no Morro do Alemão, né? No Morro do Alemão com todas as questões que tem, né? É um lugar que tá em guerra, sempre, né? Eu falo até que é o Jardim Ângela do Rio de Janeiro, que eu conheci uma galera lá que, meu, tem uma relação muito próxima com a academia, tipo da, que era até da Universidade Estadual do Rio. Tipo, da galera da universidade tá na, na quebrada pelo menos uma vez por mês e debater sobre questão ali do cotidiano, sei lá, economia dentro do Alemão, sabe, e gente lá dentro da universidade. Então eu acho que tinha que ter essa aproximação mais, assim, sabe?

\section{Pesquisadora: Essa relação de troca, né?}

Professor: É relação de troca, não de, de, de pegar, estudar sobre aquilo e ficar preso na academia, sabe? Não, trocar, sabe, jogar isso para o mundo, espalhar... Eu acho que a gente também, do lado de cá também tem uma resistência, né? Até porque historicamente várias coisas que a gente fez, a academia se apropriou falando que era dela, né? Muitas coisas. Ser marginal também é uma coisa que a academia gosta de valorizar também mas não com as nossas caras, né? Então tem um processo de resistência do nosso lado também que acho que tem que quebrar. Eu acho que tem que ser aberto nesse sentido. Mas tem o outro lado também, que num volta. Vai e não volta.

\section{Pesquisadora: Vai e não volta. Isso é importante. É importante. É importante pra mim que tô me formando. Né? É uma questão pra pensar, realmente.}

Professor: É, então, eu, eu lembro quando eu apresentei o TCC na faculdade foi uma coisa assim chocante pra várias pessoas, sabe? Inclusive isso, diz, diz... Teve uma outra galera do jornalismo que viu minha apresentação de TCC, fez um documentário sobre o Sérgio Vaz depois, mas eu acho que isso morreu meio, sabe? Não ouvi mais...

Pesquisadora: É um cur... Lá é um curso muito, é, focado nos clássicos e não se discute novas possibilidades de literatura?

Professor: O curso de Letras é isso. Eu não sei se mudou alguma coisa de 2012 pra cá, mas eu acho que não. É um curso pra formar crítico literário que ainda tá preso dentro da literatura consagrada.

\section{Pesquisadora: Uhum.}

Professor: Sabe? Que não chega no contemporâneo, sabe? Não contempla toda a [pausa] complexidade, porque se chega no contemporâneo, chega no contemporâneo que tá na Companhia das Letras. Não no contemporâneo que tá fazendo texto dentro do ônibus ou dentro do sarau.

\section{Pesquisadora: Não no contemporâneo independente, né?}


Professor: É, porque eu acho que isso tem que ser contemplado de alguma forma, porque as pessoas tão consumindo isso daí também. Talvez até mais do que o da acade... Da, da Companhia das Letras, que é um livro que fica lá na Livraria Cultura, tem um público restrito, né? Talvez o do sarau ainda cheguem em mais pessoas, né?

Pesquisadora: É, é pra pensar.

Professor: É muita coisa pra se pensar.

Pesquisadora: É muita coisa [risos]. Professor, eu acho que é isso. Eu ficaria muito mais, eu nem sei que... É muita coisa. Mas é isso. Você quer falar mais alguma coisa [risos]?

Professor: Eu acho que... Eu acho que é só essa questão mesmo, que eu tenho desabafado com algumas pessoas, eu acho importante falar, mas é só mesmo. Agradeço, né, por esse trabalho, né? Que eu acho que é uma linha, é uma linha, é uma linha que as pessoas não, não, não vi ainda as pessoas se preocuparem, né? Os professores que estão dentro desse cenário, né, porque são, professor, ele tá na escola, tá em contato com outras pessoas, né? Então, como é que esses professores absorvem esse ambiente e levam para sala de aula, né, ou como fazem ao contrário, né? Como é que levam a sala de aula para esse ambiente. Mas eu acho a ideia legal.

Pesquisadora: Eu que agradeço a confiança. Porque é uma confiança, né? Empresta o material, né, cede, conversa comigo, agradeço demais, demais, demais mesmo porque sem você e sem todos os outros que tão conversando comigo, eu não teria esse trabalho, né? E... Eu quero deixar registrado meu compromisso [risos] de um retorno, que eu não sei como vai ser exatamente.

Professor: Ah, sim...

Pesquisadora: Mas a gente pode pensar uma forma de, né?

Professor: É, então.

Pesquisadora: É, o texto acadêmico é um texto muito... Duro, acho, né? Ele não é um texto poético, por mais que o material seja, então ele tem toda uma forma aí que a gente tem que seguir, né? Mas eu deixo aqui registrado que a gente vai combinar um retorno, né, não sei de que forma, mas a gente conversa sobre.

Professor: Sim.

Pesquisadora: E obrigada.

Professor: De nada.

Pesquisadora: Mas é muito legal. 


\section{Transcrição da Entrevista com a professora Márcia}

Data da entrevista: 19/01/2018

Local da entrevista: SESC Belenzinho

Duração da entrevista: 2:19:14

Pesquisadora: Você nasceu em Indaiatuba, é isso?

Professora: Isso.

Pesquisadora: Tá, eu vou marcar aqui seu local de nascimento e tem algumas informações que são gerais, de formação e de origem. É... qual sua idade?

Professora: Trinta e oito.

Pesquisadora: Qual é a escolaridade dos seus pais?

Professora: É, meu pai não tem, ele é lavrador, e minha mãe até o quinto ano.

Pesquisadora: Ele nunca foi pra escola?

Professora: Ele chegou a ir, ele disse que foi a noite porque ele trabalhou desde os 7 anos, ele disse que chegou a ir a noite pra aprender a ler, mas, assim, eu até hoje eu não sei se ele sabe realmente ler ou não, porque eu nunca..., assim, eu nunca fiquei...

Pesquisadora: Ah, ele não frequentou, ele não concluiu, né.

Professora: Ele não..., é..., ele dirige, então eu tenho a impressão que ele saiba ler, porque tem as provas para fazer, né, pra passar na carta de motorista, né, mas eu nunca...

\section{Pesquisadora: Sim. E sua mãe?}

Professora: Minha mãe até o quinto ano do Ensino Fundamental, né.

\section{Pesquisadora: Quinto ano.}

Professora: Incompleto também, porque ela não terminou.

Pesquisadora: Não terminou o Fund. II, né.

Professora: Ela até costumava falar que ela até pulava o muro da escola pra não ficar na escola [risos].

Pesquisadora: [risos] Não gostava... E ela tinha um trabalho? Ou ela era do lar?

Professora: Então, ela é aposentada, a minha mãe, porque ela tem transtorno bipolar, assim, bem severo e... ela foi internada várias vezes e aí com dezoito anos ela foi e na época que ela foi internada, ela trabalhava, ela começou a trabalhar com quinze anos, era na... era uma tecelagem, acho que tecia fios de algodão, não sei direito como é, ela falava tecelagem e, aí, como ela foi diversas vezes internada, aí, quando ela tinha uns $23 / 24$, eles aposentaram, por invalidez.

Pesquisadora: Entendi, aí ela não atuou mais. E... você é formada em que curso e em qual instituição? 
Professora: Na UNESP de Assis, no curso de Letras e, depois, eu fiz Pedagogia na Uninove, mais pra..., na verdade eu fiz porque caso eu quisesse prestar pra Direção ou Coordenação, eu teria o curso de Pedagogia que, que é obrigatório pra poder prestar. E depois eu fiz Mestrado em Filosofia.

Pesquisadora: Você fez Letras na UNESP e se formou em que ano?

Professora: 2005.

Pesquisadora: E..., em seguida você fez Pedagogia ou você fez o Mestrado primeiro?

Professora: Primeiro a Pedagogia, mas não foi em seguida, eu não lembro que ano foi pra falar a verdade.

Pesquisadora: Aí você fez a Pedagogia na Uninove, você lembra o ano que você acabou?

Professora: Não...

Pesquisadora: É uma complementação, né?

Professora: É uma complementação, é rapidinho terminar pra quem já tem licenciatura então, eu fiz e, aí, depois eu fiz um Mestrado em Filosofia na Unifesp, aí eu fiz na Unifesp que era mais perto, na verdade eu fiz por ser, que é a Unifesp de Guarulhos que é perto da onde eu moro.

Pesquisadora: Entendi, então fez Mestrado em Filosofia, legal, né! E... em que escola você atua hoje?

Professora: É o nome da escola?

Pesquisadora: É, o nome.

Professora: [risos] Então, eu acabei de me mudar para EMEF Madre Imilda ${ }^{169}$.

Pesquisadora: Madre Imilda, deixa eu marcar aqui.

Professora: É.

Pesquisadora: Esse ano, né, que não começou ainda?

Professora: É, esse ano, eu entrei esse ano, agora eu sou da Madre Imilda. É a terceira escola.

Pesquisadora: Você atua só em uma, né?

Professora: Isso, só em uma.

Pesquisadora: É a terceira escola, antes você atuou em quais?

Professora: É..., Henrique Felipe da Costa, né, EMEF Henrique Felipe da Costa e Antonia e Artur Begbie.

Pesquisadora: Todas na zona Leste?

Professora: Todas na mesma região.

Pesquisadora: Qual é a DRE de lá?

Professora: São Miguel.

${ }^{169}$ EMEF Madre Maria Imilda do Santíssimo Sacramento. 
Pesquisadora: São Miguel, ah, DRE São Miguel. E quanto tempo você tem de magistério?

Professora: Dois mil e seis (2006), ah, já faz dez, onze anos.

Pesquisadora: Dezesseis, dezessete, onze anos, é.

Professora: Onze anos.

Pesquisadora: Onze anos, bastante... Sempre na escola pública?

Professora: Eu cheguei a..., teve uma época que eu fui na particular, mas pouquinho tempo, porque eu não gostei de dar aula na particular.

\section{Pesquisadora: Com a disciplina de Língua Portuguesa?}

Professora: De Língua Portuguesa.

\section{Pesquisadora: Na prefeitura é Língua Portuguesa também que você trabalha?}

Professora: Sim, ano passado eu fiquei na sala de leitura, um ano, mas também acabei saindo por motivos, né, mais burocráticos.

\section{Pesquisadora: É Língua Portuguesa pra Fundamental II e Médio?}

Professora: É Fundamental II e Médio, mas como na prefeitura dificilmente tem Ensino Médio, acho que na DRE São Miguel, se não me engano, são duas escolas só que tem Ensino Médio.

Pesquisadora: Ah, tá.

Professora: E aí quem consegue são as professoras que tem mais tempo de magistério, de concursada, né.

Pesquisadora: Entendi. Então, lá você trabalha com Fund. II, do sexto ao nono ano.

Professora: Isso, eu já trabalhei com EJA também, que nessa escola que eu vou agora que é o Madre Imilda, que eu estou, não tem EJA, mas nas duas anteriores tinham EJA.

Pesquisadora: EJA Fund. II, né, que a rede tem?

Professora: E tem Fund. I também, no EJA também. Porque no ano passado, como eu estava na sala de leitura, eu atuei com o EJA tanto Fund. I quanto Fund. II, porque na sala de leitura, como é uma aula por semana, então você não tem essa distinção, não sei se deveria ter, né, talvez tivesse que ter essa distinção, porque eu achei muito diferente, né, eu tinha nove salas de quinto, ainda que eram quartos e quintos anos, que pra mim foi muito diferente dar aula, eu estava acostumada com Fund. II, então foi bem diferente. Então, eu trabalhei com o EJA que era Fund. I porque eu estava na sala de leitura.

Pesquisadora: Entendi.

Professora: Então, aí, você tem que...

Pesquisadora: Tem que trabalhar com todos.

Professora: Isso, com a escola toda, né. Na minha escola eram duas professoras de sala de leitura, aí, uma ficava de manhã e eu ficava a tarde e algumas aulas a noite.

Pesquisadora: Entendi. E você pode me contar um pouco sobre a sua formação como professora? Como foi, você lembra?

Professora: [risos] Isso que eu ia falar, é diferente, né, como a gente pensa a profissão depois que é professora. Assim, pra começar, acho que um dos motivos, né, eu acho 
engraçado que as vezes você está dando aula e quando você está nervosa os alunos comentam "ah, mas você é professora porque você quer", né, mas aí eu falo, eu costumo comentar com eles, não, não é exatamente porque eu quero, porque aonde eu estava, o mais próximo de eu chegar e ter vida melhor seria sendo professora, né, e aí eu acho que isso mudou um pouco ainda com as políticas públicas, PROUNI, eu acho que deu uma amenizada nisso. Mas quando você queria fazer ensino superior e era de classe muito baixa, ainda mais eu que estava em Indaiatuba que não tinha faculdade, não tinha nenhuma faculdade pública...

\section{Pesquisadora: Pertinho ali, né, na cidade.}

Professora: A mais próxima era a Unicamp, assim mesmo, pra mim... eu não teria nem dinheiro nem pra me locomover, por exemplo, pra ir até lá. E emprego em cidade pequena é muito mais difícil você conseguir. Eu vejo a diferença depois de estar em São Paulo. Em São Paulo é muito frequente você encontrar professor que trabalhava e fazia faculdade, por exemplo, na cidade que era mais do interior é mais difícil de você conseguir emprego, né. Eu tinha feito o técnico em administração e..., assim, eu nem tinha, eu queria fazer faculdade, mas tinha na época Fatec na minha cidade, mas eu não queria nada na área... tecnológica, eu acho que era mais administração, na verdade eu fiz o técnico em administração, porque para mim, também, a melhor escola que tinha era a técnica na minha cidade, era considerada melhor do que a formação normal.

\section{Pesquisadora: Da escola pública?}

Professora: Da escola pública, então, eu acabei prestando o técnico e acabei prestando administração, porque eu tinha algumas opções, ou era administração ou computação que eu também não queria, então, o mais próximo que eu achei de humanas e assim mesmo não era..., tem a parte de humanas, mas não é tanto, era administração. Que aí era eletrônica, mecânica, química então, o que eu achei assim mais fácil fazer foi o técnico em administração. E aí, eu terminei, aí eu pensei em não..., eu demorei pra decidir, porque eu não tinha, eu não sei se quando a gente é do interior a gente tem medo de sair, eu não sei, pelo menos eu era assim, eu tinha muito medo de sair da minha cidade...

Pesquisadora: Não sabe o que vai encontrar, né.

Professora: É, tinha muito medo de sair da minha cidade e aí eu comecei fazer um cursinho comunitário, que era bem longe da minha casa e, aí, eu ganhei a..., eu ganhei a taxa de inscrição pra fazer na UNESP o vestibular e aí eu acabei, na época eu já gostava de escrever e, aí, eu fiquei entre Letras e Psicologia, por que psicologia, eu pensei em fazer porque eu pensei, ah não, eu vou analisar várias pessoas e aí eu consigo compor melhor os personagens e, ao mesmo tempo, eu pensava fazer Letras. Como, assim, a minha mãe tinha muito, tinha o transtorno bipolar e aí eu fiquei com medo de fazer psicologia, que eu achei que seria muito pesado e, aí, eu acabei prestando Letras por causa de literatura mesmo.

\section{Pesquisadora: Entendi. E lá você fez Letras Clássicas?}

Professora: Eu fiz... lá você tinha que, na época, que eu acho que agora mudou, mas na época que eu fiz, você tinha que escolher duas línguas, eu escolhi italiano e francês, aí no terceiro ano, você optava por uma das duas, aí, eu terminei o francês, né, daí deixei o italiano e terminei o francês.

\section{Pesquisadora: Entendi.}

Professora: E, aí, dar aula, na verdade, acaba sendo consequência, né, assim..., porque é muito diferente do que você imagina quando você está na faculdade, porque nem sempre 
dentro da... até..., e eu acho que uma das coisas que é bem frustrante, é em relação à literatura que, por exemplo, você vai ensinar literatura num meio em que a literatura não tem função utilitária nenhuma, é difícil você explicar isso, né! Fazer com que os alunos apreciem a arte e, ao mesmo tempo, você assumir que realmente a arte não precisa ter nenhuma função utilitária, ela não precisa ser nada, então, essa é das frustrações. Então, às vezes, você gosta muito de um conto ou um filme e você quer mostrar e os alunos não conseguem..., até porque é compreensível que, por exemplo, tem alunos que estão numa condição, numa realidade tão... difícil, que é difícil mesmo eles apreciarem, né, então, às vezes eles gostam de coisas que são mais práticas e que tem o resultado imediato, que até às vezes você consegue falar, não, mas se você souber se expressar bem, escrever bem, você vai ter chances maiores, que é uma forma de fazer com que eles consigam apreciar a literatura, mesmo eu não achando que essa é a função principal da literatura, não acho que tem que ter função nenhuma na verdade. É... mas aí você tenta, mas assim mesmo é muito difícil. Pra quem já deu aula sabe que é, né, convencer os alunos é realmente uma tarefa... E aí, tem todo aquele negócio social que você não consegue, várias coisas você... que é a frustração do dia a dia mesmo de dar aula, né, várias coisas que você pensa e você não consegue colocar em prática, né, que às vezes você é tudo dentro da sala de aula menos professora, você vai fazendo outras... mediando...

Pesquisadora: Outras demandas.

Professora: É, mediando conflitos, escutando aluno, tem problema com a mãe, que as vezes teve... choveu muito e a casa dele está alagada, as vezes o pai está desempregado, o irmão está preso, a mãe está presa, ele mora com..., a mãe tá na Bahia, o pai..., sei lá, em algum lugar do Nordeste e ele tá com a..., eu tenho muitos alunos que às vezes eles vivem com pessoas que nem tem parentesco sanguíneo, por exemplo, é uma madrinha, aí, a mãe não podia mais cuidar e entregou pra uma madrinha que também não tem..., você vê que não tem condições também de cuidar. Então, são coisas que é difícil você... e é difícil também você achar que é importante você ensinar alguma coisa para eles de estética, por exemplo, ah, eu vou ensinar estética pra ele, que realmente pra ele, né, não faz muito sentido.

\section{Pesquisadora: É complicado... E pensando nesse contexto, assim, o que te levou a ser professora?}

Professora: [Silêncio]

\section{Pesquisadora: Você já...}

Professora: É..., então, eu..., eu..., eu até não sei, mas, assim, pra ser sincera eu, como eu falei, você tem muitas, muitos sonhos quando você está estudando que você acha que vai ser muito, que vai transformar a vida das pessoas e que na realidade você não transforma muita coisa, né, você vai..., é... [pausa] mas o que me levou..., assim, não sei..., se eu pensar assim, eu não consigo me ver também fazendo nenhuma outra coisa, não que eu ache que é maravilhoso dar aula, não, não acho que é maravilhoso, tenho várias frustrações, mas ainda acho que é melhor do que outras coisas, né, que..., é..., é gratificante às vezes, por exemplo, que nem eu moro, eu dou aula na comunidade que eu moro, então, às vezes é gratificante você ver aquele aluno, principalmente aqueles alunos que você ficava preocupada e pensava, aí meu deus o que será dele, porque ele não faz nada, não sei o que, não consegue se concentrar e aí você vê ele na..., por exemplo, um outro dia eu fui levar meu filho para cortar o cabelo e um dos meninos que eu tinha dado aula estava lá, super feliz, no salão, trabalhando super bem, cortando cabelo, já fazia três anos que ele estava cortando e, um outro, que foi meu aluno também acabou fazendo História e veio conversar comigo, que tinha lido meu livro e não sei o que, então, tem 
umas coisas assim que..., que aí você fala, ah não, até que... que quando você está, você não vê, né, que são pequenas coisas que você vai falando e, as vezes, quando você encontra com esse aluno, ele lembra de alguma coisa que pra você as vezes foi até insignificante o que você falou pra ele, e ajudou ele a pensar em determinadas coisas, então, acaba sendo gratificante a longo prazo, porque a curto prazo é sempre estressante na verdade [risos].

\section{Pesquisadora: E você gosta da profissão, apesar das dificuldades?}

Professora: Então, é que nem eu falei, eu gosto porque eu gosto de mexer, por exemplo, eu gosto de adolescentes, eu gosto de conversar com eles, eu acho gostoso, mas aí tem várias... que também são coisas sociais, estruturais, que não é só do sistema educacional. É isso que eu fico pensando que, as vezes, a gente reclama muito do sistema educacional em si, mas o problema não é o sistema educacional, que nem eu falo, poderia ser uma escola perfeita, com a estrutura perfeita, ele está lá fora, num mundo imperfeito e vai vir pra dentro dessa escola perfeita durante quatro, cinco horas, seis horas e voltar pro mundo dele e depois voltar pra escola, então, não tem como ser fácil, acho que nunca vai ser fácil mesmo que, embora eu ache que realmente teria que mudar muito a valorização, que é obvio, que isso daí todo mundo está cansado, né, a valorização do professor, até valorização, por exemplo, que valorização você tem em fazer mestrado, doutorado em questões de evolução? Pensando até em questões de evolução, não muda quase nada porque se você fizer um doutorado ou se você fizer qualquer cursinho ali, vários cursinhos, você ganha a mesma evolução, né, então não tem..., é... você não é dispensado pra..., que nem eu vivi isso quando fiz o mestrado, tive muitas faltas que eram descontadas do salário, porque eu não poderia sair mais cedo pra fazer porque é mestrado, graduação ainda, né, se você está na graduação, você pode terminar, mas o mestrado ou doutorado... não tem, por exemplo, se você não tiver bolsa, se você estiver numa faculdade que você não tem bolsa, por exemplo, você também não pode ficar sem trabalhar, pedir aquela... porque é sem..., sem vencimentos, né, não tem...

\section{Pesquisadora: $O$ afastamento, né, sem vencimento?}

Professora: É, aí é assim, ou você tem o dinheiro, ou você tem a bolsa, né, quer dizer, você fica meio..., né, você não consegue se aperfeiçoar mesmo. O que eu acho é que é tão estressante que, realmente, você se aperfeiçoa porque você está ali querendo, mas não que acham uma facilidade pra que você faça isso.

\section{Pesquisadora: Uma condição, né?}

Professora: É, eu não acho que..., em nenhum governo, não é nem, não é nem que... o [nome do gestor público] é pior, mas assim, mesmo os... se a gente pensar, mesmo os de esquerda não fizeram nada para auxiliar nesse sentido, que nem tem uma pós que eu estava até esperando, que eu queria fazer o doutorado, só que eu não queria fazer o doutorado, por exemplo, em filosofia, que é o mais próximo que tem que é a UNIFESP. É..., então, pra eu fazer um doutorado, por exemplo em Letras na PUC é dois mil reais, e agora que tem, porque não tinha doutorado, né, em Literatura não tinha na PUC, agora, acho que ano passado que começou. Na USP, você deve saber que é muito difícil, porque você tem que ter o orientador, são poucas vagas, e... que nem na UNESP, onde eu..., eu estudei até tem um professor que me orientaria, mas como que eu vou me deslocar de onde eu estou?

\section{Pesquisadora: Para Assis?}


Professora: Para Assis, tendo que trabalhar todos os dias, porque você não tem, né, você não vai poder parar de trabalhar. Porque até esses dois anos que tem na prefeitura que você pode sair sem receber, é difícil tirar.

\section{Pesquisadora: Ah...}

Professora: É difícil de conseguir até esse que não tem salário, é difícil você conseguir.

\section{Pesquisadora: Que não tem salário... entendi.}

Professora: Ah, que eu ia falar desse..., tem um decreto, acho que chama decreto, não sei se chama exatamente decreto, que o [nome de outro gestor público] que fez, que era uma bolsa mestrado e uma bolsa doutorado para os professores da rede pública. Se você trabalhasse com algo que fosse diretamente relacionado com a sua área, então que nem no meu caso que é Língua Portuguesa, Literatura seria da minha área, então, eu poderia pedir essa bolsa, só que nunca sai, está no papel, existe, mas ninguém sabe como faz, não saiu, não..., você não pode pedir, assim mesmo é baixo, por exemplo, eu acho que de doutorado é 1700, que nem eu falei, na PUC que é um dos poucos...

\section{Pesquisadora: Não paga a mensalidade.}

Professora: Que na PUC é um dos poucos lugares que tem, e acho que..., nem sei se na Mackenzie tem, não, na Mackenzie não tem Literatura, acho que é só é..., em Língua Portuguesa, mas não tem Literatura, acho que é só na PUC mesmo, é dois mil, não chega nem a pagar a mensalidade, mas já ajuda, é óbvio que já... ajudaria.

\section{Pesquisadora: Sim, sim.}

Professora: Ajudaria, mas ninguém sabe, você vai na Diretoria perguntar e, ah, é mesmo, eu sei que tem esse..., mas tipo... E? Como? É..., e aí até tem um..., e que nem..., eu fui esse..., ano passado eu fui pra Alemanha, que eu publiquei um livro e acabou saindo a versão bilíngue e...

\section{Pesquisadora: Ah, que legal.}

Professora: E aí eu pedi, eu sabia que eu tinha direito de um tipo de afastamento e ninguém sabia como fazia para eu ir até Alemanha e fazer o lançamento do livro, e eu não estava pedindo nada. Se você olhar no documento, se é algo que tem a ver com a sua..., com o que você leciona, você pode ganhar até a acomodação, né, a prefeitura entre aspas pode até ajudar com a com acomodação e sei o que. Eu pedi dez dias de afastamento, que era o que eu tinha direito é pedir o afastamento, dez dias, isso tá desde março indo e voltando porque eles consideram que dez dias é muito tempo para eu ir para Alemanha e voltar para lançar um livro, e ter colocado só..., porque eu fui na universidade de lá fazer o lançamento no dia 27. Eles consideram que dez dias é muito, que eu teria que colocar todos os dias, o eu fiz em cada dia que eu estive na Alemanha nesses dez dias. E dias letivos foram cinco, na verdade, que eu perdi, que eu perdi foram cinco dias letivos, o resto era sábado, domingo e feriado, que eu fui no dia 24 e voltei no dia 3 de Maio, fui no 24 de Abril e voltei..., quer dizer, é umas coisas absurdas. Aí vem o próprio..., que aí eu olhei por que que o processo fica indo e voltando, que eu não estou entendendo ainda, porque eu fiz coisas informais lá que não tem porque eu colocar, eu documentar, eu colocar um monte de coisa que não tem. É a mesma coisa aqui, por exemplo, você participa de algum sarau e ninguém vai te dar uma declaração, um documento que você participou de um sarau, por exemplo. Você vai numa livraria, ninguém vai te dar um documento que você foi na livraria lançar um livro, não existe isso. E nem eu, e o pior é assim, nem eu achei que fosse necessário, então eu coloquei o que era o principal, que era o dia 27, eles queriam me é..., me dar cinco injustificadas e, isso, o próprio supervisor de 
escola. Tem um departamento que... que acho que é DINORT ${ }^{170}$, que vê esses casos de afastamento, aí voltou pra a escola e o supervisor falou que eu, é... realmente, a professora..., faltou os dois dias que ela foi pra Alemanha, por causa da viagem que são 17 horas, os dois primeiros, os dois últimos e o dia 27, os outros cinco dias realmente ela não comprovou que estava fazendo alguma coisa. [risos] Mas aí você fica pensando, quer dizer, olha o absurdo! Aí, aí eu tive que mandar várias outras coisas comprovando o que eu estava fazendo, que eu tinha participado de eventos, aí mandei um monte de coisas assim, fotos, e mandei uma declaração até xingando na verdade, porque você vai falar o quê? Que dá, que dá vontade de falar assim, ah desconta os dez dias. Uma vez eu fui também participar em Portugal, mas não era numa publicação, era um evento que tinha em Portugal, e uma pessoa que é até... é um português que vive aqui no Brasil e... e faz sobre, faz várias coisas sobre poesia e não sei o que, e ele me chamou, aí eu fui, só que ninguém sabia me falar, sabia que tinha direito a algum tipo de afastamento, mas não sabia me explicar, nem na escola, nem em lugar nenhum, então, eu acabei indo e fiquei com dez faltas também, porque eu fui e voltei..., quer dizer, é umas coisas que você não tem..., ou seja, eles não consideram, eu falei, o problema é que eles não consideram literatura, porque quando eu fui reclamar na Diretoria de Ensino, o quê que uma das funcionárias, eu não lembro o que ela é, eu não sei se é dirigente, não sei, ela é alguma coisa da Diretoria de Ensino de São Miguel que trata desses assuntos, não sei exatamente o que ela faz, ela falou, "Ah, mas pode ser que tenha... esteja sendo considerado que como você foi lançar o livro, seja algo pessoal, que você foi como algo pessoal." Nossa, algo pessoal, se eu sou de Língua Portuguesa, sou professora de Língua Portuguesa é algo pessoal? É considerado algo pessoal? Fora a portaria que tem lá, tem nesse decreto, tem falando sobre coisas artísticas, está dentro, quer dizer..., mas a própria pessoa que está tratando disso acha que literatura não é algo... tipo, importante.

\section{Pesquisadora: Importante pro professor.}

Professora: Para eles justificar dez dias de...

\section{Pesquisadora: De falta.}

Professora: É, que com alunos seriam cinco dias, que o resto era sábado, domingo e feriado, quer dizer, é umas coisas que você pensa, como que vai valorizar se as próprias estruturas que estão ali não estão a favor da arte também, que a gente costuma muito falar dos alunos, né, ah, os alunos, mas eles já são assim, porque ninguém na verdade que está ali do lado também está dando importância a isso. Não é só o aluno, né, todas as estruturas estão ali falando que não tem realmente importância nenhuma, porque pra alguém que cuida disso aí, me falar que foi algo pessoal e é por isso que eles estão negando... E, ainda, ela ficou brava, porque eu falei, mas como pessoal? Aí, ela saiu e me deixou falando sozinha. Eu falei, nossa!

\section{Pesquisadora: Entendi.}

Professora: Que na cabeça dela, ela estava tentando me explicar.

\section{Pesquisadora: $O$ valor que não existe?}

Professora: É, é, tentando me explicar assim o porquê que não tinha sido aceito o afastamento. E o que eu achei a burrice maior é assim, quer dizer, você tem várias pessoas, você tem uma divisão técnica para fazer isso e, essa divisão técnica, não sabe a distância, porque aí eu fiz até... colei um mapa da Alemanha com os lugares que eu fui, o aeroporto mostrando uma cidade, que a Alemanha não era uma cidade só, não era um bairro, então

${ }^{170}$ DINORT - Divisão de Normatização e Orientação Técnica. 
quer dizer, você vai num lugar, você chega em Frankfurt, eu ia pra Jena que era no interior, não era perto de Frankfurt, aí depois fui fazer em outro, que era em Leipzig, que não era perto também, era uma viagem então, quer dizer, eles consideram muito tempo. $\mathrm{Eu}$ falei, como você vai considerar muito tempo, como se fosse na mesma...

Pesquisadora: Cidade.

Professora: É..., tipo... coisas acho que, absurdas, que você não sente nenhum... é óbvio que eu não faço que... que... que eu nem penso a literatura como algo que tenha necessariamente, esteja ligado ao meu trabalho diretamente, independente de seu ser, se eu fizesse qualquer outra coisa, eu faria literatura do mesmo..., mas como está na mesma área, poderia ter uma valorização maior, né, no seu campo, né.

\section{Pesquisadora: E como que foi o seu curso de graduação lá na Unesp?}

Professora: Você fala...

\section{Pesquisadora: Do ponto de vista da formação, como que foi?}

Professora: Eu acho que foi extremamente bom, mas em relação à licenciatura, então, aí que está, é que se a gente pensar ah, você faz a graducação e você não aprende a dar aula, realmente, se você pensar nas matérias pedagógicas que você tem, elas são muito voltadas para as leis, mas eu lembro que tinha muita... a didática era muito voltada pros PCNs, parte teórica do que é dar aula, você tem todo embasamento teórico, mas obvio que na hora que você chega para dar aula você se sente totalmente perdida, porque você não utiliza a maioria dos conhecimentos mesmo que você tem. Que muita gente fala que você não utiliza, não utiliza porque você não vai ensinar as coisas que você aprendeu, teóricas, vai ensinar de uma outra..., então, nesse sentido, mas não, não acho que teria como ser diferente, assim, ser diferente porque você tem os estágios pra fazer, né, então no estágio, eu acho que você aprende a dar..., a dar aula você aprende no estágio, eu acho que o resto da graduação é a sua formação mesmo que fica ali como embasamento pra dar aula, mas não diretamente, né.

\section{Pesquisadora: Entendi, não tem uma relação direta.}

Professora: É.

Pesquisadora: Tá. $E$ as escolas foram aquelas que você já me contou, né, as que que você lecionou?

Professora: Sim.

\section{Pesquisadora: Quando que você começou a escrever?}

Professora: Eu comecei a escrever eu tinha dezesseis.

\section{Pesquisadora: Dezesseis anos.}

Professora: Então, foi..., por isso que eu falei, foi antes, muito antes de decidir ser professora e, na verdade, até um dos motivos que eu fiz para ser professora, que eu sabia que professora dava aula num período, então, eu sempre pensei em dar aula num período e me dedicar à escrita.

\section{Pesquisadora: Em outro?}

Professora: Em outro. Por isso que eu falei não que isso necessariamente seja..., aconteça, né, que é nem a gente está falando, porque você tem, eu tinha pelo menos essa impressão, ainda as vezes eu tenho essa impressão, de falar ah, não, mas eu não passo tanto tempo na escola e, realmente, assim, contando por semana, assim, as horas, as cinco horas na 
escola, tipo não é tanto tempo, só que às vezes você passa as cinco horas e é tão estressante que quando você chega te sugou todas as energias e que, às vezes, em outro emprego você fique, por exemplo, oito horas e você chegue mais calma do que..., porque dando aula tem dia que você vai e é maior..., que parece também que a aula..., que a aula é uma coisa imprevisível, tem dia que você vai super preparada, super brava e não fala, várias coisas, eu vou ficar com a cara brava aqui que hoje pelo jeito... aí os alunos estão calmos...

\section{Pesquisadora: Tranquilos.}

Professora: Tem dia que você está mais alegre e os alunos estão também muito alegres [risos]. E eu acho que tem todo..., tem todo um jogo cênico, né, que nem eu falo, pra mim é muito difícil dar aula, porque eu acho que a minha cara não ajuda, porque antes, no começo eu achava que era o tamanho, no começo, não, é porque eu sou pequena e, né, acho que é por isso que não tem medo de mim, aí, depois você vai percebendo que não, que tem uns professores enormes, homens também e que os alunos não tem o mínimo medo. Aí o que que a gente, que também eu acho que é um reflexo da nossa sociedade, as pessoas, elas..., elas têm mais medo do que respeito, então, eu sempre costumo falar isso com eles, mas não é porque..., porque, às vezes, eles mesmos falam, principalmente quando dei aula, eu achei engraçado quando dei aula para o Fund. I, e eu lendo a historinha com eles, isso a maior bagunça, eu perguntei, gente mas como que a professora Simone aguenta vocês? Vocês ficam dessa mesma forma com ela? Não é possível! Aí, o menininho, achei tão bonitinho, porque é muito engraçado, ele "não professora, com ela a gente não fica assim, ela é muito brava." [risos] Eu falei, é tão engraçado que os grandes, eles não falam, os maiores, eles já tem um filtro, né, então, quando você pergunta isso, eles "não, a gente é assim com ela também, com todos os professores a gente é assim". Mas você percebe que não, que eles escolhem, então os que eles tem, e eu falo pra eles, eu falo assim, o que eu posso fazer é o mesmo que outro professor pode fazer, ele não pode fazer nada além do que eu posso fazer, então... o por que? E aí eu percebo que também entra muito o negócio do medo, então, o professor que às vezes dá muita convocação, chama a mãe, não sei o que, aí eles ficam um pouco amedrontados e aí pensa duas vezes antes, o que eu acho meio ridículo, porque às vezes você fica pensando assim, quer dizer, eles não estão aprendendo a respeitar mesmo o outro, né, o lugar do outro, quer dizer, está só... tipo, eu estou com medo de talvez acontecer alguma coisa comigo, então eu vou ficar quieto. Mas não por respeito, né, que isso..., e isso é uma coisa que me estressa também dar aula, que às vezes que você tenta não ser estúpida, não ser... com eles e eles acham que você é idiota, porque você está agindo dessa forma. Ah não, não, ela é tonta, então, vamos fazer que ela não..., não acontece nada. Eles não percebem, né, que há um motivo pra você não ser assim, que você acha errado, que..., né.

\section{Pesquisadora: Sim. E que motivos que lhe levaram a escrever, a começar a escrever? Alguém na tua família escrevia, você tinha alguém próximo, como que você descobriu que gostava de escrever?}

Professora: Então, não tinha ninguém que escrevia, mas, assim, minha irmã mais velha, como ela era quatro anos mais velha que eu, ela lia então, às vezes, ela estudava numa escola que pedia para ler alguns livros por bimestre então, às vezes estava ali e eu lia também. Ela morava, na verdade, essa minha irmã mais velha morava com a minha avó, porque minha mãe ficou doente na época que ela nasceu, então final de semana eu ficava lá e, aí, tinha esses livros e eu acabava lendo. Então, eu sempre, sempre gostei de ler, assim, mas, assim, a escrever eu nem lembro, é... uma..., assim, eu acho que uma das coisas que ajudaram de alguma forma também foi a escola, porque como eu escrevia e às vezes os professores elogiavam, não sei o que, você fica com vontade de escrever mais, acho que nesse sentido a escola ajudou, não que eu tivesse uma noção, eu não tinha essa 
noção de, aí, eu quero ser escritora, quando era pequena não tinha nem..., nem essa..., não tinha..., não pensava assim, até quando eu comecei mesmo escrever poemas, não sei o que, com dezesseis anos também não tinha, assim, nada formado que eu queria fazer um livro, não, eu queria escrever quando estava com vontade de escrever, é que depois você vai mudando, acho que você vai ficando mais velha, aí, você já vai mudando, querendo fazer o livro, querendo organizar as escritas, não sei o que, mas no começo...

\section{Pesquisadora: Não.}

Professora: Não, mas eu acho que teve um papel importante nesse sentido e, a minha mãe, embora ela não tivesse também muito estudo, ela lia, às vezes ela lia alguns livros, eu via ela lendo, então, eu acho que isso influenciou, mas a escola também acho que influenciou, porque também tinha, eu lembro que tinha uma professora no quarto ano que ela deixava alguns livros e a gente escolhia o livro que a gente quisesse e, depois, a gente trocava, né. Aí, é... você fosse falar pra um amigo, indicar pra algum amigo esse livro por algum motivo, eu indico pra tal amigo, porque eu acho que ele vai gostar, sei lá, de tal personagem. Então, eu acho que isso também me ajudou a continuar lendo, a biblioteca na minha escola também, tinha uma biblioteca, então, eu ia bastante nessa biblioteca pra pegar os livros, na própria escola que também facilitava, porque não tinha que sair pra...

\section{Pesquisadora: Pra outros lugares.}

Professora: É, pra uma biblioteca pública, por exemplo, era na própria escola.

Pesquisadora: É escola pública?

Professora: Isso. Era numa..., então, tudo isso foi...

Pesquisadora: Entendi. E quando você começou a escrever, você escrevia poesias, você falou, né, adolescente, e você escrevia diários também?

Professora: Diários..., até hoje eu tento escrever diário [risos], toda vez que eu começo a escrever diário, eu fico com aquela impressão, que eu acho que é uma impressão correta, que todo dia eu fiz a mesma coisa [risos], aí vai dando um tédio, nossa, eu só faço a mesma coisa. Mas até hoje eu começo, principalmente entre um livro e outro quando eu sinto que não estou muito inspirada, às vezes eu uso, eu tento escrever diário pra praticar a escrita, no sentido de praticar o ato mesmo de escrever, mas que nem eu falei, mas eu..., eu acabo que nem eu falei, acabo virando semanário mensal. E, aí, eu costumava até fazer no computador, eu tenho alguns arquivos e, também, tem outra coisa, às vezes quando você está fazendo o diário, se você faz o diário no papel, outras pessoas podem ver aquilo, então, eu acho ruim outra..., que é diferente da escrita, né, porque a escrita você quer mostrar, a escrita, sei lá, o romance, o conto..., o poema você quer compartilhar, às vezes, o diário você não quer compartilhar, né, você quer que realmente seja algo seu só, né. Então, eu cheguei a usar, mas é que nem eu falei, eu acabo desistindo no meio do diário, nunca é...

Pesquisadora: Fica lá. E você falou que gosta de ler, né, como que você descobriu o gosto pela literatura? Você consegue pensar, assim, em que momento, se foi esse momento do processo de escolarização, se foi depois.

Professora: Eu acho, é assim, eu lembrando..., eu acho que foi na escolarização, porque eu lembro, assim, o que é mais nítido, assim, a lembrança mais..., que eu lembro que eu tinha, que eu ganhei na escola esse livro que chamava Escola é vida, acho que é $A$ escola é vida, não lembro se era no primeiro ou no segundo ano.

\section{Pesquisadora: Do primário?}


Professora: É, que davam, teve uma época que eles davam os livros, às vezes não, tinha ano que não davam, tinha ano que eles distribuíam esse livro e eu lembro que eu li um... uma música que era do Chico Buarque, que é aquela bem bonitinha que tem..., agora eu esqueci a música, e eu lembro que eu li e gostei muito, eu nem sabia que era uma música, eu lembro que eu lia embaixo e não entendia nada, que tem aquelas referências, né, é por isso que com os alunos eu sempre explico essa referência, porque eu lembro que quando era pequena eu não sabia o que significava. É João, não é João e Maria, agora eu era herói e meu cavalo só falava inglês.

\section{Pesquisadora: Ah, sei.}

Professora: Eu me lembro que eu gostei muito e, nas histórias, eu sempre tinha..., eu costumava olhar o livro e ir olhando as histórias, por isso que eu acho que eu já gostei, eu lembro que eu tinha também um livro, era de provérbios, que eu gostava muito, até pra ensinar, né, a criança a ler. Então, eu acho que a escola, nesse sentido, ajudou muito, porque eu já... e, depois mesmo, que nem eu falei depois essa professora era do quarto ano que deixava..., não que eu me restringisse, por isso que eu não sei quando surgiu pela literatura, eu estou tentando lembrar desde antes, porque depois também na adolescência eu lia literatura, mas eu não lia só literatura, eu lia livros que não tinha nada a ver com literatura, as vezes, que não eram, que eu pegava e eu lia num dia. Que eu acho que é diferente de quando você fica adulto também, que eu não, não procurava uma referência literária, por exemplo, um escritor que é considerado famoso, não, eu lia, eu ia olhando e o que eu achava que era bom eu pegava para ler, não tinha esse critério de ficar...

\section{Pesquisadora: Essa escolha, né.}

Professora: Essa escolha que... que é feita pelo outro na verdade, que a gente tem muito isso, né, na verdade é feita por um... e, no final, é feita pelo capitalismo, porque se a gente pensar nos livros que chegam até... até nós normalmente são, agora não, porque aí eu conheço várias pessoas alternativas, mas no começo sempre chega dessas editoras que são maiores, que são essas que você o tempo inteiro vê e acaba ficando curioso pra ler, mesmo que nenhum amigo tenha te indicado, você vai olhando toda hora, passa e você vê, passa e você vê, você vai ficar, né, curioso pra saber.

\section{Pesquisadora: Interessado, é, entendi. E, hoje, o que você escreve hoje? É poesia, é romance, conto, crônica, se encaixa num gênero ou não? Como é?}

Professora: Então, eu, eu, poemas eu escrevo raramente tanto é que eu não tenho nenhum livro que seja de poemas, esporadicamente eu escrevo poemas, contos eu escrevo até razoavelmente, tenho, eu tenho dois livros que são de contos que são os primeiros, aí, depois eu acabei escrevendo..., aí tem um terceiro que, na verdade, é digital, que ele é... um amigo me convidou pra fazer, então, eu reuni os contos que eu tinha em coletâneas, quando saía em algum lugar e que iam acabar ficando perdidos, porque eu não tinha vontade de publicar o livro de contos de novo. Então, aí, quando ele me falou de publicar, eu falei, ah, eu tenho uns contos esparsos que dá pra eu reunir e não era muito, também não era muita coisa, não era tanta coisa, eu falei, é até melhor, porque o digital é ruim ler, eu acho que é ruim ler coisa muito extensa, porque eu acho cansativo, aliás, até pra conto eu acho meio cansativo, eu acho que... o digital ainda acho que o melhor é o poema pra, não sei, né, são também..., mas eu estou me dedicando mais ao romance, embora eu até escreva, que nem eu falei, eu até escrevo os outros esporadicamente ou, também, quando alguém pede, porque às vezes alguém fala, "ah eu estou fazendo uma antologia de tal coisa, você quer participar?" E, aí, as vezes eu escrevo determinada coisa pra aquela antologia, pra aquela coletânea, mas mais o romance. 


\section{Pesquisadora: $O$ romance e o conto?}

Professora: É.

Pesquisadora: E.... [pausa] como gênero, né. Ah, e sobre quais assuntos que você costuma escrever? Como que você define isso?

Professora: É difícil falar do assunto que você escreve [risos] que vai tendo muito..., é..., mas eu escrevo bastante é... é que é muito mesclado, mas nesses, que nem nesses últimos que eu escrevi, a ideia era fazer uma trilogia que a temática central fosse o corpo, mas o corpo sob todas as formas, assim, então, o fio condutor da trilogia seria o corpo. Mas, eu escrevo muito sobre morte, sexo que acaba entrando, é difícil falar, porque eu acho que é tudo meio intrincado, né, as coisas são todas meio interligadas, mas eu, eu, tenho bastante coisa, às vezes as pessoas olham como se fosse erotismo, mas nem sempre é ou é o erotismo mais macabro, né, não sei [risos]. Mas não é necessariamente, embora eu acho que o erotismo entra também, que nem eu ia falar, eu acho que não tem como você falar, por exemplo, de sexo sem falar de morte, porque eu acho que está ligada a pulsão de vida com a pulsão de morte, não sei. Mas, não tem um tema, mas eu falo que acho que são temas que acabam sempre, que são recorrências sempre, a loucura, também, eu falo bastante, mas aí eu acho que se eu fosse me analisar, talvez, seja até por causa da minha infância, das coisas, então, também é um tema que eu acabo sempre colocando.

Pesquisadora: E como você definiria os seus textos, seus escritos? Olhando assim pra eles você tem..., como que você olha pra eles?

Professora: Nossa, essa é difícil! Mas, em que sentido você fala de definição?

Pesquisadora: Pensando..., pensando no gênero e nesses assuntos que você escolhe.

Professora: [pausa] Não consigo pensar numa definição.

Pesquisadora: Pra você teria uma definição ou não?

Professora: Eu acho difícil falar de definição em literatura, eu nunca consigo, assim...

\section{Pesquisadora: Pensar em uma.}

Professora: Não...

Pesquisadora: Não tem problema. E..., com qual objetivo você escreve? Por que você escreve?

Professora: Olha, se eu pensar..., é que nem eu ia falar, as coisas vão mudando ao longo do tempo e eu, realmente, na verdade, óbvio, que nem eu falei, quando você escreve, você tem a vontade de compartilhar, até pra saber o que o outro está achando da sua escrita, como repercute no outro o que você está escrevendo, mas o meu objetivo principal, eu acho que é sair do tédio, viu, [risos] porque eu me sinto muito mal quando eu não estou escrevendo, eu me sinto inútil quando eu não estou escrevendo, não sei explicar direito, mas se eu não estou escrevendo, eu sinto... tipo... que eu não tenho nenhuma utilidade, eu acho vida muito, assim, tipo, trabalhar, sei lá, dormir, acordar, trabalhar, dormir..., não vejo muito, eu acho que é uma coisa que me dá um animo assim até pra continuar, pra ter, acho que, um objetivo. É porque tem gente, por exemplo, que fala assim, ah, não, vou trocar o carro ano que vem, então vou trabalhar muito esse ano, porque aí ano que vem eu pego um carro modelo sei lá, um outro modelo, não sei o que. Acho que eu vou pensando assim pra ir passando o tempo [risos], quando eu estou escrevendo, eu me sinto mais motivada assim, me dá um ânimo diferente, assim, porque quando eu não estou escrevendo, eu já fico... Nesse sentido, por isso que eu gosto do romance, porque o romance você está sempre meio que acompanhada, porque o conto, o poema, às vezes, 
você faz ali no..., é mais rápido até por causa da extensão mesmo, então você faz e acabou, então dá um sentimento de solidão maior, o romance não, você vai fazendo ali, todo dia você escreve um pouco, mesmo o dia em que você não escreve, você, tipo, senta pra tentar escrever alguma coisa.

Pesquisadora: Entendi. E o que você quer falar aos leitores? Tem uma... assim, quando você escreve, você tem um... uma mensagem aos leitores, você tem algo que você deseja dizer à eles?

Professora: [risos] Eu acho que não é uma mensagem assim, não tem uma mensagem específica pro leitor, mas quando você escreve, como é sempre o desejo de compartilhar, você sempre está criticando alguma coisa, eu acho que sobre qualquer tema que você fala, você sempre acaba entrando numa crítica social ou uma crítica social que seja especificamente humana também, que seja uma crítica sobre alguma característica do homem, ou do homem em geral ou determinado tipo de homem, mas não tenho..., também, tenho uma crítica bastante aos homens, homens mesmo, que é o machismo, isso acaba que, pra quem é mulher escrevendo por mais que, eu não me considero feminista, ah, sou feminista, porque eu não me considero no sentido de não praticar, de não fazer nenhuma ação específica pra isso, mas eu acho que quando a mulher escreve, ela sempre, querendo ou não, ela tem um olhar feminino pro que ela está escrevendo, então ela tem uma..., também ela tem um olhar sobre o homem, um olhar feminino sobre o ato masculino, né, então acho que ela acaba sempre..., também eu acho que não é, não é, que nem eu falei, não me considero e..., literatura, também eu acho estranho essas denominações também, assim, literatura feminina, porque eu acho que coloca tudo em uma caixa, por exemplo, literatura marginal, que eu acho você acaba..., ao invés de você dar destaque pra aquilo, você acaba colocando como por exemplo, a literatura marginal ela é boa, por exemplo, tem um autor destacado que ele é marginal, mas ele não é bom se comparado ao todo, eu acho que às vezes tem essa..., a literatura feminina também, quando você coloca a literatura feminina as pessoas acreditam que às vezes têm uma característica muito dócil, meiga, porque é escrita por uma mulher e eu acho que não é isso também, né, por isso que eu acho meio, quando você compara, como fala? Coloca mesmo em rótulos, né, eu acho que fica meio... Eu acho que é isso.

Pesquisadora: Tá. E você se comunica com os seus leitores? Com quem lê os seus textos, seus livros? Tem contato com eles?

Professora: Tenho, bastante até, que eu acho que é o que mudou bastante na nossa época por causa das redes sociais. Então, os últimos livros eu ia colocando trechos do, ainda faço isso, então, a medida mesmo que eu estou escrevendo, eu vou colocando trechos do que está escrito na internet, no Facebook, então eu acabo usando mesmo como ferramenta literária, na verdade, o meu Facebook é quase todo voltado pra literatura mesmo, pra eventos, pra coisas que eu participo e, aí, eu sempre coloco. E é legal, porque você tem o retorno, então, muita gente que lê ali e depois compra o livro, depois vem pedir o livro, se interessa. Muita gente, também, acaba escrevendo sobre o livro ou algo mais formal, é porque aí, também, tem aquele negócio, muita gente também que eu conheço é leitor e escritor também, né, também tem isso, então ele está lendo, mas também escreve.

\section{Pesquisadora: Em algum momento.}

Professora: É, em algum momento. Então, tem essa devolutiva que eu acho legal. Não que eu vá escrever de acordo com o que ele vai..., com a devolutiva que ele vai me dar, mesmo porque se você for pensar cada um é de um jeito, então um não vai gostar, o outro vai gostar, então não, mas eu acho legal até pra divulgação mesmo da obra, assim, porque aí quando você publica, na verdade, a literatura no Brasil e, principalmente, editoras 
pequenas não é um evento, né, então, por exemplo, eu fico imaginando se eu estivesse longe das redes sociais, qual seria a forma de divulgar? É tem os saraus, os saraus também, que acaba sendo utilizado pra a divulgação dos livros também, mas se fosse pensar, se não tivesse as redes sociais diminuiria muito o alcance, pra você chegar até o leitor seria muito mais difícil, que é diferente, por exemplo, ah, eu saí pela Companhia das Letras, mesmo pela Companhia das Letras na verdade, porque se a gente pensar que eu conheço escritor, que é a Juliana Frank, ela saiu pela Companhia das Letras, por exemplo, mas ela não... tipo, não vendeu grandes, muitos exemplares em quantidade, por que? Porque ela é uma das autoras da Companhia, mas não é a principal, porque tem sempre os principais que eles fazem todo aquele comercial e divulgação, que são os que vendem, os outros ficam ali e vende a mesma coisa que o escritor de editora pequena também, ele não vai..., e que também tudo tem a ver com, se a gente pensa também, tudo tem a ver com o status social, né, porque também... Até pra entrar, por exemplo, na Companhia das Letras não vai ser, eu não acho que tem necessariamente a ver com saber ou não escrever, mais indicação, né, tipo... Não que..., que quem esteja lá seja ruim, não é isso, mas não..., não é bom, porque está lá, né, e, aí, também vale para as premiações, né, que também é tudo..., tudo esquema de mais ou menos...

\section{Pesquisadora: Dos grupos?}

Professora: É.

\section{Pesquisadora: E em relação aos seus leitores ainda, como são as devolutivas? O quê que eles acham dos seus textos, dos seus materiais?}

Professora: Então, eu ia falar, eles gostam muito, porque eu acho que os que não gostam, não tem coragem de falar, né, [risos]. É, porque se a gente pensar que, que na internet é muito isso, né, é... tem até, se a gente pensar nos perfis fakes, o fake é aquele perfil que ele fala o que ele quer, na hora que ele quiser, mas não é necessariamente o que ele tem coragem de falar, né, então, eu acho que a devolutiva é muito boa, mas um dos motivos de ser muito boa é por a pessoa se ela não gostar, eu acho que ela não vai ali tipo..., não, eu não sei falar, porque também poderia ter gente que não gosta e falar de propósito para fazer você se sentir mal, que às vezes na internet também tem isso, mas assim no meu caso não teve ninguém que, o máximo que acontece é que, que nem eu falei, como tem alguns conteúdos que são eróticos, então eu vivo sendo bloqueada, mas aí, eu não sei se, no começo eu acho que eram as pessoas mesmo, por moralismo mesmo, então, eu uso muita imagem, então eu coloco o texto e coloco a imagem também, de fotógrafos na verdade, famosos, mas até antigos, só que pode ser uma foto até 1930, se tiver nu, alguém denuncia que você está usando nudez no Facebook o que é engraçado, né, porque você pensa que a nudez é uma coisa tão..., né, e não necessariamente tudo que, todo nu é erótico também, nem todo nu é erótico, mas não há né essa diferenciação, então, nesse sentido, deve ser os que não gostam e, aí, a maior parte não gosta acho que exatamente por moralismo mesmo, então, nesse sentido não sei, talvez, seja essa devolutiva que você fica..., e aí, mas aí, também, é um mecanismo do próprio Facebook, então por exemplo, as pessoas te denunciam demais, então, o tempo inteiro você é, aí depois vira automático, então por exemplo, se eu colocar qualquer postagem, agora já virou automático e, então, que nem, no começo do ano, como virou o ano e eu pensei, faz tempo que eu não coloco, eu coloquei uma foto e tinha um nu frontal que não era nada, era..., eu não lembro, eu não lembro quem era a fotógrafa que eu coloquei, mas estava até discreto, achei que não fossem bloquear, mas na hora ele bloqueia já, então colocou, ele bloqueou, então, às vezes, eu uso a edição de foto o que fica meio ridículo, porque as vezes você pega, e isso acontece até com pintura, por exemplo, Modigliani que tem a algumas, alguns quadros que tem o nu pintado, ele bloqueia também, porque eu acho que o Facebook ele entra 
num programa, né, não é uma pessoa que... que bloqueia, né, é um programa então, eu acho que vê as formas.

\section{Pesquisadora: A forma padrão, né.}

Professora: E você, acho, que fica também com um código, por exemplo, se você já foi bloqueada muitas vezes, denunciada muitas vezes, você fica, tipo, tachada então, já aconteceu que eu achei até engraçado, que eu coloquei de propósito só pra testar, eu coloquei um manequim nu, era um manequim, mas era manequim, não era, e ele bloqueou da mesma forma, por causa das formas que ele entende que é um nu, mesmo sendo um manequim de loja.

\section{Pesquisadora: Entendi, nem sabia disso.}

Professora: É, é. Então, eu acho que ele vê que tem a forma e se alguém ali denuncia, ele já bloqueia. Se você, que nem eu falei, como eu já fui, aí, eu faço outro perfil então, eu sempre tenho dois perfis e eu tenho a página também, porque muita gente falou, "não, faz a página, é que na página...", é que eu achava que na página soava impessoal, então, eu preferia ter o perfil do que a página, mas aí eu acabei fazendo a página, porque o que acontecia, se eu era bloqueada, só que já aconteceu de eu ser bloqueada nos dois [pausa] e, pra gente é ruim, porque, que nem para mim, o que dá raiva do bloqueio não é porque, ah, eu estou com raiva porque eu sou bloqueada, dá raiva, porque você pensa na hipocrisia, que é uma ferramenta que, né, que é, só que por outro lado, você vai ter que se adaptar e, querendo ou não, quando você coloca..., é que tem todo um esquema, né, no Facebook, então por exemplo, se você coloca uma foto de um nu, que é uma foto que as pessoas podem ser as mais moralistas que sejam, elas são curiosas, né, porque são as fotos que giram mais, então, eu usava até por isso, porque por exemplo, aquele post, ninguém me conhece, aí você vê aquele post ali e vê a foto, ela gira mais, então, na verdade era um...

\section{Pesquisadora: Mecanismo.}

Professora: Mecanismo de marketing pro texto e pra mais leitores, pra mais lugares, né.

\section{Pesquisadora: Entendi.}

Professora: Só que, aí, o pessoal começa, quando tem muita visualização, também começa mais os bloqueios, que as denúncias, né.

\section{Pesquisadora: Ah, as denúncias.}

Professora: E aí você, e é engraçado que quando você entra na página que você paga pra algum..., porque na página aí tem aquele que é patrocinado, não sei se você já reparou que as vezes aparece lá patrocinado, daí, na página, quando você paga um conteúdo, sei lá, dois, três reais pra ele ficar girando pra quinhentas pessoas, que aí têm uma cota lá, tantos reais, tantas pessoas, vai passar para tantas pessoas verem o post, só que se você coloca um post com alguém, com algum tipo de nu, não precisa nem ser nu de..., mas com pouca roupa, ele não, ele não aceita impulsionar. Gente, é muito engraçado que ele coloca e é engraçado a justificativa que ele diz que vai ofender os clientes, porque está com muita exposição de pele. [risos] Porque, aí, você pensa, gente, em pleno século XXI você...

\section{Pesquisadora: Bloquear...}

Professora: Bloquear, e sem contar os outros conteúdos que a gente tem que são altamente, não é nem erótico, é pornográfico mesmo. Se você pensar no funk, o meu filho mesmo que tem onze anos, mas gosta de funk, acho que por causa da batida ele aprendem 
a gostar antes mesmo de saber o que é aquele monte de besteira que eles falam, né, depois que eles descobrem, né, que aí com onze anos ele já sabe o quê que é, mas quer dizer é altamente, né, não é nem... é pornográfico mesmo e, aí, criança acessa ali o conteúdo, você consegue..., as mulheres ali também praticamente sem roupa, não sei o que, aí você bloqueia algo que é de um perfil que é adulto, que são pessoas adultas que estão seguindo..., porque seria diferente, por exemplo, se eles fizessem, o Facebook fizesse um mecanismo pra bloquear pra determinadas pessoas que não querem ver, a pessoa colocaria ali que não quer ver conteúdos e aí bloquearia pra aquela pessoa, aí, tudo bem, é um mecanismo que eu acho válido, porque aí cada um tem, né, quem não quer ver, não vê, né, mas do jeito que eles fazem, tipo...

\section{Pesquisadora: Bloqueia a sua publicação.}

Professora: É, e, assim, sem contar que se você lê, tem lá que você só pode ser bloqueada a sua, se for artístico, algo artístico que nem a fotógrafa, não sei o que, não poderia ser bloqueada, porque é considerado conteúdo artístico, só que eles não fazem essa distinção. Tem lá que é artístico, e que artístico tudo bem, mas quando você coloca...

\section{Pesquisadora: Eles não definem, não filtra?}

Professora: É..., não filtra, que deve ser esse programa que não consegue identificar, né, que é..., o que é uma foto, ou um quadro ou uma tela, que deu até aquela repercussão, né, com aquela tela famosa lá, não sei o nome, $A$ origem.

\section{Pesquisadora: Não vi isso.}

Professora: É, que era do museu, estava exposta e foi bloqueada, tela de vários, centenas de anos e eles bloqueiam, porque entende como pornografia.

Pesquisadora: Como pornografia, entendi. E, qual que é a frequência da sua escrita? E que tempo você destina à escrita no seu contexto de vida diária?

Professora: É..., essa parte que é difícil [risos]. É..., então, quando eu estou que nem, eu quase sempre eu estou escrevendo, porque quando eu termino um romance, eu acabo começando outro até pra não ficar, né, sem fazer nada, então, eu tento separar, por exemplo, mesmo que seja uma hora por dia, fora a leitura, porque aí leitura, leitura eu faço quando dá, né, que é aquele negócio, eu faço à noite, que nem nas férias dá pra ler bastante, porque você não está trabalhando, mas que nem eu falei, no dia de trabalho às vezes você pensa, ah, vou dedicar tantos minutos pra leitura só que, às vezes, de repente, você foi dar aula e tipo..., você volta com uma dor de cabeça imensa e você não consegue ler nada, então, não dá pra ter um..., por mais que você tente colocar uma quantidade de horas pra leitura, não tem... Agora, escrever, mesmo que eu não consiga escrever, às vezes, eu fico uma hora, em média, mesmo que não saia nada, mas ali tentando.

\section{Pesquisadora: Por dia? Todo dia?}

Professora: É, aí que eu ia falar, até essa uma hora dependendo o dia de trabalho também acaba, um dia ou outro você acaba comendo com outras coisas, que daí eu falei, que nem o meu horário do jeito que ficou esse ano, por exemplo, eu vou trabalhar quarenta horas semanais mais ou menos, porque tem o grupo de formação e, então, embora eu trabalhe de manhã, a maioria dos dias eu vou trabalhar uma parte da tarde também, que acaba ficando mais cansativo, porque aí eu vou ter que almoçar na escola, né, porque esse grupo de formação é segunda a quinta, da meio dia a uma e meia.

\section{Pesquisadora: Ah, entendi.}


Professora: Então, acaba comendo o almoço, aí, eu já, né, então dependendo o jeito que fica seu horário, também fica meio... ruim.

\section{Pesquisadora: Ruim, sim.}

Professora: E também esse grupo de formação, por exemplo, teve anos que eu não fiz esse grupo de formação. Por que? Até por causa do tempo mesmo, que é um tempo a menos que você tem também para escrever, é que, aí, entra aquele negócio da desvalorização do professor, porque do jeito que as coisas estão hoje, por exemplo, não, até dá, mas aí, por exemplo, se eu quiser ter um carro mesmo não tem como eu trabalhar trinta horas semanais, por exemplo.

\section{Pesquisadora: Tem que trabalhar mais?}

Professora: É, porque e..., e é o que eu estava até comentando com uma amiga, por exemplo, se você não, eu fico me imaginando, se eu fosse separada por exemplo, não, não é nem separada, por que separado tudo bem que às vezes você tem, mas supondo que fosse mãe solteira, em São Paulo, como que eu viveria com três mil e poucos reais? Se você for ver é pouquíssimo, pra você pagar um aluguel é mais de mil reais numa casa mesmo na... na periferia. Então, supondo que eu não fosse, porque aí se você coloca casada, aí, supõe-se que seu marido vai ajudar a criar o filho, mas supondo que você não tem o vínculo e, sei lá, tem um filho, você não consegue sobreviver com o dinheiro que você ganha se você não cortar um monte de coisa, por isso que entra naquele negócio que fica meio ridículo pedir, tipo, que o professor se... como fala, faça várias coisas, vários cursos para se reciclar, mas não dá essa oportunidade pro professor nem financeiramente, porque não é nem você ficar pedindo curso, porque é meio ridículo também, que tem uma outra coisa que eu acho meio ridícula na prefeitura, ah, curso pro professor, porque tudo é culpa do professor, então, se tal coisa não está certo é porque o professor não é capacitado, tem que capacitar o professor melhor para que funcione a educação. Aí, dão esses cursinhos que, sinceramente, não tem nada de novo, nada de proveitoso e coloca como se fosse pra te capacitar, né, e entra mais como, é..., algo para mostrar, para colocar no portal do que algo que realmente ocorre. Sem contar que mesmo esses que é... é difícil de conseguir, porque às vezes é um professor de cada disciplina da escola que vai fazer esse curso.

\section{Pesquisadora: Ah, é limitado.}

Professora: E muitas vezes, é limitado quando tem dispensa de ponto, e quando não tem dispensa de ponto, às vezes não dá nem para você ir também, dependendo se é contraturno às vezes, por exemplo, é que nem o jeito que ficou meu horário hoje, agora mesmo, por exemplo, se for um curso a tarde, também não dá para eu ir à tarde, porque eu fiquei, acabei ficando nos dois períodos.

\section{Pesquisadora: Nos dois turnos, né.}

Professora: Por mais que seja cinco aulas, a mesma quantidade, né, acabei ficando nos dois que, pra mim, na verdade, ainda não é ruim, porque eu tenho um cargo só, mas aí para quem tem dois cargos já fica...

\section{Pesquisadora: Impossível, né.}

Professora: É, que aí você tem que ver na outra escola se consegue te acomodar naquele horário, entre uma aula e outra, e fica a maior confusão.

Pesquisadora: E como são os seus momentos de escrita? Você escreve em casa geralmente, em outros locais, é... usa música, escreve em silêncio, como é esse 


\section{momento de produzir e com que materiais? Você tem cadernos, você escreve no computador, como que é isso?}

Professora: Então, em casa eu tenho, tipo, é um quartinho mesmo que era a garagem que eu adaptei lá e ficou, tipo, uma biblioteca, que é quase fora de casa que eu uso para escrever, então, aí, eu acendo incenso, coloco a música tipo clássica para ficar mais calmo, pra sentir que estou em outro lugar, mas é sempre em casa mesmo. [risos] Só que, aí, entra a parte que você não é só, né, profissional, aí você é mãe, então, meu filho normalmente, para eu conseguir essa uma hora para eu sair, para eu ficar sozinha, nossa... e ele não é tão pequeno, ele tem onze anos, é o maior xororo para ele me deixar ficar uma hora, que aí entra também, que é uma coisa engraçada, que ele morre de ciúmes da própria escrita, que ele acha que tipo..., que eu gosto mais da literatura do que dele.

\section{Pesquisadora: Não acredito...}

Professora: É, é engraçado, né, que ele fica nesse negócio, "não, você não vai lá, não, não vai, eu não queria que você fosse escritora, não...”. É engraçado que ele fica na... na disputa, então, até esse momento, assim, uma hora às vezes, porque na verdade, às vezes, por exemplo, tem uma hora e de repente você está no meio, porque às vezes você fica uma hora lá e quando chega cinquenta e cinco minutos você tem uma ideia, aí, você acaba ficando mais de uma hora, então, até por causa do meu filho às vezes é difícil, porque às vezes você marca uma hora e quando chega uma hora, eu não estou em casa, lá dentro de novo, ele já vem..., "não, você falou uma hora, então, já acabou seu tempo, volta" [risos]. Então, nesse sentido é difícil, mas eu sempre também, eu não gosto, eu não tenho mania, acho que no começo até escrevia em papel, depois que começou a febre do computador, sempre escrevi direto no computador, porque eu acho mais fácil, acho mais rápido também. Então, se eu tenho uma ideia, eu acho que eu perco menos coisa na hora de transcrever do que se eu tivesse..., eu só uso mesmo, às vezes, papel, assim mesmo acabo usando bloco de notas do celular, por exemplo, tive uma ideia que, sei lá, que depois eu vou desenvolver, aí, eu anoto no bloco de notas e depois eu utilizo.

\section{Pesquisadora: No computador?}

Professora: É, mas é quase sempre no..., eu não tenho muita... muito costume de... de fazer no..., de escrever no papel, no papel às vezes pra revisar, às vezes eu fiz um capítulo, sei lá, eu posso imprimir e, às vezes, eu acrescento alguma coisa ali a lápis, a caneta, assim.

\section{Pesquisadora: Ah, que você imprime pra ler?}

Professora: É.

\section{Pesquisadora: E, assim, quantos romances você tem? Você falou que termina e escreve outro.}

Professora: É, então, mas eu comecei com contos, então, aí, eu tenho dois livros de contos, três se contar aquele edital, né, que é da coletânea, aí, eu tenho esse romance que é Mosaico de rancores que... que é o que foi pra Alemanha, que é a versão bilíngue, mas tem ele...

\section{Pesquisadora: Que foi ano passado que você publicou?}

Professora: É, não, só que foi ano passado na Alemanha, mas na verdade, no Brasil ele foi o primeiro romance que eu escrevi, que foi em 2013 que eu, quer dizer, eu tinha escrito antes, mas a publicação foi em 2013, aqui, e depois eu tenho o segundo que é $A$ Puta, que 
é a parte que eu falei da trilogia, aí, depois de $A$ Puta, O enterro do lobo branco e, agora, eu..., A Casa das Aranhas que seria...

\section{Pesquisadora: Eu estou morrendo de curiosidade, estou aqui pensando [risos], desculpa de atrapalhar, mas eu fiquei muito curiosa.}

Professora: É, eu até trouxe, só não trouxe os primeiros que eu não tenho mesmo mais, eu trouxe o Mosaico, que quando eu fui pra Alemanha eu peguei alguns que, na verdade, lá o editor fez mil exemplares, então assim, eu só não trouxe mais na verdade, porque não tinha lugar na bagagem pra eu trazer, na verdade, né, porque é muita coisa mil na verdade, né. Só que ele fez mil, porque na gráfica de lá compensava fazer mil, por exemplo, se ele fizesse menos saía quase o mesmo preço, um pouquinho mais barato, mas era uma coisa meio que..., insignificante assim a diferença de preço pra fazer mil ou pra fazer duzentos não ia...

\section{Pesquisadora: Mudar tanto.}

Professora: Mudar tanto, então, ele fez...

\section{Pesquisadora: E você lançou em português ou em alemão?}

Professora: Então, ele acabou saindo bilíngue, porque esse eu já tinha lançado em português, em 2013, em 2013 ele já estava lançado em português, aí, ele traduziu, pagou lá uma tradutora aí, ele saiu na versão bilíngue, aí, saiu metade..., porque esse, esse...

\section{Pesquisadora: Ah..., saiu metade português e metade alemão.}

Professora: Na verdade, esse editor é brasileiro, ele me achou na época que eu fazia, quer dizer, eu ainda tenho um blog, mas eu acabo não alimentando, com o negócio do Facebook e da página que é muito mais prático pra publicar, eu acabo não nem colocando mais coisa no blog, mas ele me achou por lá e me convidou pra publicar. É que demorou na verdade, porque ele me convidou foi em 2011 e acabou saindo por causa de várias coisas burocráticas da própria Alemanha mesmo, lá pra..., é... acabou saindo em dois mil, eu nem sei se está marcado 2017 ou 2016, eu acho que foi 2016, no final de 2016, aí, eu fui em 2017 pra lançar oficialmente.

\section{Pesquisadora: Entendi.}

Professora: Mas foi super demorado na verdade.

Pesquisadora: E..., eu ia te perguntar, quanto tempo você leva pra produzir um romance? Tem assim uma ideia, você faz um por ano, como é isso?

Professora: Então, esses eu levei mais ou menos a mesma média, um ano e meio, dois anos para escrever na verdade, porque aí você acaba escrevendo e, aí, você acaba passando também um tempo tentando e fazendo a revisão, não sei o que, e tentando publicar também, porque aí você tenta procurar editora que mesmo as pequenas é muito embaçado pra achar, não é que é embaçado pra você achar, você tem várias editoras pequenas, várias que fazem, mas assim, tem umas que são extrema..., todas são enroladas na verdade, mas tem umas que além de ser enrolada ainda faz umas coisas que você não gosta, assim, do jeito que você não gosta, sei lá, às vezes você não gosta do acabamento do livro, então, acaba que esse processo também demora.

\section{Pesquisadora: De escolha.}

Professora: Porque, as vezes também, você escolhe uma editora aí ela te enrola, tipo, acaba demorando e, aí, você troca, por exemplo, esse... é que não está aqui, $O$ Enterro do Lobo Branco, na verdade, eu ia fazer pela mesma editora do Mosaico e da A Puta, que 
era a Terracota, só que na época que eu ia fazer com ele, ele acabou, ele desfez a sociedade com o sogro dele, ele era junto, ele fazia a editora, mas era ele e o sogro dele, o sogro dele não quis mais fazer literatura, que ele... acho que ele é professor da [nome da universidade privada] e ele achava que não compensava, é porque não compensa mesmo, né, financeiramente óbvio, não compensa, e aí, ele preferiu fazer livros acadêmicos, porque, aí, acho que... óbvio que teria uma saída, porque se ele é um professor, é só ele indicar o livro, né, então, acho que é por isso.

\section{Pesquisadora: Entendi.}

Professora: E, aí, então, também fiquei enrolada com ele, aí, depois ele falou, "olha, desfiz a sociedade, você pode até fazer, mas ele quer que pague, agora a literatura só vai fazer se pagar". Tipo..., aí, eu achei meio assim e falei, ah..., eu não vou pagar para fazer o livro sendo que tem outras editoras, que pagar, você paga de qualquer forma, aí, se você pensar por outro lado, de qualquer forma você paga, porque, por exemplo, você..., você acaba comprando da editora muitos exemplares, eu mesmo compro vários, porque aí eu acabo vendendo pela internet e por que? Não porque eu precisaria fazer isso, porque se você pensar, ah, tem na editora e a pessoa pode ir lá, o leitor, e comprar na editora, mas tem muito leitor que, ah, que quero autografado e, outra coisa, a editora, às vezes, o cara quer comprar e ela demora muito para entregar o livro às vezes, que nem esse último que eu até me arrependi, que eu fiz com a editora Patuá no final, que eu ia fazer com a Terracota, mas eu fiz com a Patuá que é um pouquinho mais conhecida, é pequena, mas assim...

\section{Pesquisadora: Tem um nome já, né, na cidade.}

Professora: É, é, é um pouquinho, só que ele é extremamente enrolado, muito enrolado, em todos os aspectos, tudo bem que é porque ele acaba querendo fazer quase tudo sozinho e..., tipo, quer publicar um monte de gente ao mesmo tempo, mas não tem estrutura pra isso, acaba não tendo estrutura. Então, tem gente que pede, tem gente que vem falar comigo, "olha eu pedi seu livro, nossa, mas já fez três meses, a editora não me mandou", tipo, a pessoa pagou. Então, parece que ele não tem esse controle, tipo de..., então, aí, pra evitar isso, eu prefiro comprar dele, que aí ele faz... óbvio que ele vai fazer um desconto, porque eu sou autora e, aí, eu vendo que eu acho mais..., não é nem que eu acho, que pra mim não compensa mesmo porque eu canso, porque eu tenho que ir lá no correio, você acaba....

\section{Pesquisadora: É um trabalho.}

Professora: É um trabalho, e... embalando, você tem que fazer as embalagens, não sei o que, só que pra divulgar literatura é mais fácil eu fazer isso do que deixar na mão do editor, porque óbvio que se eu deixar na mão de qualquer e não é só ele, eu acho que qualquer dessas editoras pequenas, porque elas publicam muitos títulos só que elas não tem estrutura para absorver esses títulos que elas mesmas, então ela espera que o autor mesmo faça isso, então, ou você faz isso ou você publica e quase ninguém lê.

\section{Pesquisadora: Hum... entendi.}

Professora: Porque a pessoa, tipo, desiste, ela comprou uma vez da editora, você fala, ah, está lá no site, alguém já falou que comprou e não recebeu, que é a maior...

\section{Pesquisadora: Três meses é um tempão, né.}

Professora: Sim, e várias eu vejo, eu já tinha ouvido essa reclamação, mas eu já publiquei com ele meio que sabendo, né, que ia meio que acontecer isso, então, eu já fui meio que, né, já... 


\section{Pesquisadora: Consciente.}

Professora: Consciente, até pra mim. Eu até..., que nem o outro, A Puta, era muito mais fácil eu pedir, mesmo que ele não fizesse divulgação, a Terracota, de nada, só que quando eu pedia exemplar pra ele, ele rapidinho imprimia mais desde que eu comprasse uma determinada quantia, agora esse, às vezes eu, várias vezes eu pedi pra ele e, sabe, demora pra ele reimprimir.

\section{Pesquisadora: Entendi}

Professora: Aí, você chega e esqueceu... é ruim, porque você desanima, porque aí chega uma hora que, tipo, não, não vou nem vender, porque aí você vende e não tem o livro para entregar também.

Pesquisadora: E, assim, quando você..., você faz versões dos textos, dos contos, revisa, muda? Você já faz direto no computador, como que é?

Professora: Então, a maioria eu faço no computador, que nem eu falei de imprimir, mas raramente eu imprimo, às vezes eu imprimo depois de tudo pronto e acabo fazendo esses rascunhos, mas a maioria das vezes é na própria, no próprio ato de escrita, porque às vezes eu escrevo e depois eu volto no mesmo texto no outro dia e..., tipo, mudo, mas não faço, tipo, salvo e faço de novo, não, faço no mesmo, no mesmo arquivo então, essa alteração já não fica, não dá pra saber o que foi alterado, porque eu já faço no próprio...

\section{Pesquisadora: Texto.}

Professora: No próprio texto.

\section{Pesquisadora: Entendi. Fica a versão final, né?}

Professora: É.

Pesquisadora: É..., você tem um processo de definição do tema? Por exemplo, vou pensar em escrever isso agora, né, esse romance com esse tema, como que você pensa os temas do que você produz?

Professora: Então, no início, na verdade, eu não, às vezes nem tenho uma ideia clara do que eu vou escrever, no início, quando eu estou começando escrever, que nem esse $A$ Puta eu comecei a escrever e depois que eu defini que a personagem seria uma puta e não sei o que, uma prostituta, depois que eu vou definindo várias coisas. O segundo que é $O$ enterro do lobo branco, eu já tinha algumas coisas definidas, porque era no sentido de fazer a trilogia, então, eu pensei como seria, na verdade, esse $O$ enterro do lobo branco é um homem que leva a companheira que é um cadáver que, supostamente, ele mesmo matou, e ele sai peregrinando com ela e acontece várias coisas, mas ela está já morta, mas é que aí eu já tinha uma coisa definida por causa do primeiro, que era o tratamento com o corpo, né, como que o corpo...

Pesquisadora: Ah, esse é da trilogia do corpo, né?

Professora: É, então, eu já tinha meio que definido, que nem esse outro também, já tenho meio definido, porque eu tenho que trazer a mesma temática do corpo, da posse, então, mais ou menos...

\section{Pesquisadora: Do corpo feminino?}

Professora: É, que nem eu ia falar, principalmente do corpo feminino.

Pesquisadora: Entendi. 
Professora: Embora, acaba aparecendo os homens de uma outra forma. Esse eu não sei ainda, porque está no começo, mas eu tento trazer da mesma forma o corpo também, continuar com a temática do corpo, mas como está no início, não dá ainda pra saber em que..., à medida que você vai escrevendo também, você vai mudando muita coisa, então, os personagens, que nem às vezes você começa a escrever sobre um personagem que nem é pra ter nenhuma relevância assim na narrativa, às vezes você começa a escrever e ele não vai ter uma, aí, você começa a escrever e você acaba... o personagem que nem era pra ser nada, você acaba gostando e acaba fazendo uma diferença dentro da narrativa. Então, tem umas coisas pré-definidas, né, mas a maioria acho que vai aparecendo no meio da...

\section{Pesquisadora: Do processo da escrita?}

Professora: É, quando você vai...

\section{Pesquisadora: E..., como você concilia as duas atividades de ser professora e ser escritora?}

Professora: É, essa parte é a parte difícil por causa do tempo, porque não é nem a parte de escrever só, porque ainda, que nem eu falei, até essa parte de escrever ainda assim é difícil tempo, porque às vezes você está muito cansada de dar aula mesmo, porque cansa, é algo cansativo, não é algo difícil, eu acho, mas é algo cansativo mesmo, corporal, que as vezes as pessoas falam, "ah, mas acaba com a mente", mas não acaba só com a mente, com o corpo também, porque você fica na sala andando de um lado pro outro, você também está cansada fisicamente, não só mentalmente. Mas, outra coisa que eu acho que dificulta não é essa parte da escrita só, mas às vezes é a parte da divulgação, por que por exemplo, muitas vezes eu tenho um sarau para ir, que é um lugar onde eu vou conhecer pessoas que são escritores e, às vezes, me chamam para alguma outra coisa ou eu vou encontrar um leitor que, então, essas partes que dificulta, na verdade, conciliar, porque por exemplo, que nem ano passado aconteceu muito isso, às vezes eu tinha algum evento literário que alguém me chamava pra participar e era a noite, e a noite eu estava trabalhando, então, eu tinha que faltar nesse dia pra participar. Outra coisa, como eu moro na zona leste que é bem distante às vezes, tudo bem que também acontece sarau, só que às vezes eu sou convidada pra parte que é longe, no centro, nos bairros mais nobres, então eu acabo faltando, não tem como, é difícil você conciliar, você acaba ficando...

\section{Pesquisadora: Numa ou outra.}

Professora: É, algumas coisas você acaba não aceitando e, porque, tipo, não tem como você toda vez também faltar, mas às vezes você acaba, né, deixando de fazer uma das coisas, que não tem como fazer, né.

Pesquisadora: Entendi. E..., ah, isso eu já perguntei, como que você escreve. É...., quando que você começou a publicar seus textos?

Professora: Deixa eu lembrar...

\section{Pesquisadora: $O$ concurso foi o primeiro ou teve outros antes?}

Professora: Ah, não, teve, assim, na época da faculdade... eu estou tentando lembrar aqui se antes..., ah, assim, antes eu já, agora que eu lembrei, em Indaiatuba, quando eu tinha uns dezoito anos eu comecei participar de uma sociedade de escritores [risos], chamava Sociedade de Escritores de Indaiatuba, mas na verdade era uma..., era como se fosse bate papo entre várias pessoas que gostavam de escrever e uma das pessoas que participavam era uma jornalista da Tribuna de Indaiatuba e, aí, eu publiquei, acho, que a primeira vez nessa, nesse jornal. 


\section{Pesquisadora: No jornal, impresso. É um jornal impresso, né?}

Professora: É, impresso, é, é que nem sei se..., não, deve ter ainda que é um jornal bem... bem antigo assim, e aí, depois na..., aí, foi a primeira vez que eu publiquei, mas... porque saiu lá e..., aí, na faculdade eu publiquei nesses fanzines que nas faculdades sempre tem, aí depois, também, participei de, acho que eu participei de dois concursos, não da faculdade, um era da faculdade mesmo, de Letras de Assis e o outro era de uma cidade próxima que era Presidente Venceslau que, aí, eu ganhei um... acho que era segundo lugar ou terceiro, não lembro, que era de contos também, mas era algum lugar. E da faculdade também, era um..., Assis sem palavras, que era como se fosse um microconto, né, miniconto, e aí, eu fui publicando virtualmente, acho que em 2008 que eu comecei a fazer o blog, que eu comecei a publicar com mais frequência que foi quando foi mais ou menos a febre lá dos...

\section{Pesquisadora: Dos blogs.}

Professora: Dos blogs, que também acabou meio que, meio perdido agora também, né, que o Facebook ele acabou... e, aí, eu comecei a publicar em revistas literárias que era..., que aí quando você começa a fazer o blog, também você vai conhecendo várias pessoas e, aí, você vai abrindo e conhecendo outras redes, então, aí, eu fui publicando em revistas, fui enfiando nessas revistas que na época já eram eletrônicas, algumas não, algumas eram também...

\section{Pesquisadora: Impressa.}

Professora: Tinham as impressas também, agora que eu lembrei, tem as impressas também, mas aí, tanto na impressa fui enfiando e, aí, fui e o livro, acho que a primeira vez foi em 2009, que foi quando surgiu a autopublicação, eu não sei se você lembra quando surgiu aquele..., não sei se você conhece que chama Clube de Autores, era um site que você conseguia colocar seu texto, fazer a edição dele e você mesmo publicar.

\section{Pesquisadora: Não. Eu já vi esse selo, não é uma casinha, assim?}

Professora: É, é.

\section{Pesquisadora: Eu já vi esse selo, mas não me lembro do site.}

Professora: É, e aí, você..., você colocava o texto que você quisesse, né, que foi o primeiro de contos Anéis de Saturno, que eu tinha o livro escrito e, aí, eu coloquei no site. Porque nessa época, também, acho 2009, nem tinha essa febre também das pequenas editoras, aí, não era tão barato publicar, que eu lembro que quando eu estava nessa sociedade dos escritores era muito caro publicar ainda e, ainda era, por exemplo, se você quisesse publicar, você tinha quer ter dinheiro e uma quantidade, por exemplo, só publicava se fosse mil cópias, o que deixava muito caro, que ainda não tinha aquela impressão digital, né, que tudo isso facilitou, então, nessa época. Aí, quando surgiu esse Clube de Autores, aí, eu publiquei por aí, porque o que eu fazia, eu publicava e se alguém quisesse eu pegava, mas nesse momento eu nem cheguei a vender, eu entreguei para algumas pessoas que me acompanhava, que lia, que tinha interesse em ler, então, eu publiquei, ah, quero uma cópia, aí, eu ia lá e, tipo, quero uma cópia, e eles entregavam o que era legal. O que era ruim, que por exemplo, se você não sabe nada, que nem eu não sabia de diagramação, óbvio que o livro não sai bonito, sai mal diagramado, porque, na verdade, você coloca lá com a sua diagramação e eles não mudam nada, eles só imprimem, então, se você tem erro de diagramação, o erro vai sair no livro, no livro impresso. Mas, o bom é que você poderia fazer, por exemplo, é fazer uma cópia, que saí caro também, mas na época eu não 
tinha nenhum... não estava fazendo para vender, então foi legal para..., mas às vezes saía trinta e poucos reais o livro, aí, você fazia.

\section{Pesquisadora: Uma cópia?}

Professora: É, até porque era mais fácil você fazer o livro do que você imprimir, é que agora também até isso está mais fácil, né, até a impressora, está tudo mais fácil, né. Já tem impressora que você faz e sai também, gasta menos tinta, é tudo mais fácil, então, mudou muito, que nesse sentido para os autores independentes é muito bom.

\section{Pesquisadora: É.}

Professora: Porque, é... eu acho engraçado que, às vezes, eu escuto esses autores mais velhos falarem, "ah, mas na minha época nunca que eu, eu tenho até vergonha de publicar hoje que eu vendo cem, nem cem exemplares, o maior sacrifício pra vender, na minha época fazia dois mil exemplares e vendia rapidinho", mas só que ele esquece que na época dele também, ele fazia esses dois mil exemplares e a maioria não fazia, tipo, tinha uma editora que escolhia um ou outro que eram os escolhidos mesmo da editora e todo o resto que escrevia não publicava, não conseguia publicar. Se a gente pensar os que publicaram, eles tinham o mínimo de poder aquisitivo para publicar, que é totalmente diferente, é óbvio que ele vendia mais, porque, por exemplo, você pega literatura infanto-juvenil naquela época, por exemplo, ele vai pegar ele, e ele não vai lembrar de autores independentes naquela época, porque quase não tinha, né, tinha um ou outro que era o que também trabalhava já, tinha dinheiro e conseguia juntar o dinheiro para ir numa gráfica e imprimir lá as cópias, a maioria das cópias ia acabar ficando lá, porque não tinha editora, nada, então, quer dizer, era diferente mesmo, mas era só pra alguns. Ele tinha impressão que vendia muito, mas não é que ele vendia muito, ele vendia, porque era só ele. É, tipo, ele e mais alguns, hoje não, como difundiu muito, então, nem todo mundo compra livro, a não ser, tipo [pausa], sim, tem ainda das grandes editoras, porque, por exemplo, se você não tem nenhum contato com editora, com autor independente você vai comprar das grandes editoras que é o que vai aparecer pra você, mas eu falo assim, por exemplo, o rol de amigos que eu tenho ali, eles não compram só de grandes editoras, então, pode sair um livro de um autor que até foi conhecido na década de 80 e 90, de 70 e 60, mas, às vezes, ele não comprou o livro dele, porque ele comprou já cinco de cinco amigos que publicaram ali, né, então acaba dividindo, né.

\section{Pesquisadora: Sim.}

Professora: Por que eu fico pensando isso? É impossível ter mais leitores, que a turma fala, "ah, hoje ninguém lê", mas é impossível que tinha mais leitores antes do que hoje, porque antigamente a turma nem conseguia chegar a ser alfabetizado, que não era escola pra todos, então, quer dizer, não tem como ser..., né, é diferente, porque ele está vendo pelo lado individual dele, então, pra ele realmente, né, às vezes, foi prejudicial. E, se você ver também, tem autor muito mais velho que, também, não, acabou não aderindo aos..., às redes sociais, não sei o que, não..., então, óbvio que ele...

\section{Pesquisadora: Não aparece?}

Professora: É, não aparece, então, se ele esperar a editora por exemplo, não, porque se você for observar as editoras, cada ano ela tem que..., é um que está em cima, né, os outros..., por exemplo, que estava nos anos 80 praticamente nem lembra mais, a não ser que seja um autor que todo ano está lançando, se não...

\section{Pesquisadora: Se não, não...}

Professora: Então, acaba... 
Pesquisadora: Verdade. E teve alguém que incentivou o seu processo de publicação?

Professora: Então, nem sei se alguém incentivou, mas como eu sempre tive, que nem eu falei, com dezoito anos eu entrei nessa, nessa sociedade que a turma era mais velha, então, todo mundo falava, "ah, publica, não sei o que, que também ajuda", só que...

\section{Pesquisadora: Isso foi antes da faculdade, né?}

Professora: Foi antes, só que já era uma cidade pequena. Na faculdade, eu lembro que as minhas amigas na época do blog começou, "não, você tem que fazer o blog, não sei o que, que é legal pra divulgar" e, também, eu acabei conhecendo meu marido na faculdade e ele também escrevia, a gente se conheceu, porque ele escrevia, na verdade, porque a gente escrevia e acabou se conhecendo, então, também isso vai dando um incentivo, um quer e o outro quer também, então, a gente, comecei a publicar nas revistas, na verdade, e aí, fui... e é mais os amigos meus leitores que falam, "ah, não, você tem que publicar, não sei o que, eu quero ler quando estiver pronto", aí, você vai...

\section{Pesquisadora: Vai fazendo.}

Professora: Uma coisa vai levando à outra.

\section{Pesquisadora: Seu blog está ativo?}

Professora: Ele está, é que nem eu falei, ele está ativo, mas tem muita coisa que não está atualizada, porque eu acabo esquecendo de atualizar.

\section{Pesquisadora: E como chama?}

Professora: A vida não vale um conto.

\section{Pesquisadora: $A$ vida não vale um conto?}

Professora: É.

Pesquisadora: Vou olhar então, depois. Aqui não tem, né, a divulgação dele?

Professora: Ah, é, acho que eu nem coloquei.

\section{Pesquisadora: Não.}

Professora: Eu acho que eu já fazia, porque eu comecei, eu acho, em 2008.

Pesquisadora: Eu vou olhar. E, você..., eu queria perguntar como que é feita a divulgação do seu material, porque vai, é... contata editoras independentes, né?

Professora: Sim.

\section{Pesquisadora: E..., você mesmo divulga? Você falou que vai pra saraus para} divulgar? Onde mais você vai? Como que você faz isso?

Professora: É, então, na verdade, a maior, que nem eu falei, a maior fonte de divulgação é o Facebook, ou através do perfil mesmo, pessoal, ou através da página que, aí, tem esses problemas do bloqueio que acaba me, acaba dificultando, porque, às vezes, você quer é..., aconteceu já muitas vezes isso, por exemplo, eu estou bloqueada e alguém me convida pra ir em algum lugar divulgar o livro e eu não consigo responder. Aí, eu tenho que, e às vezes eu tenho a pessoa adicionada num perfil e não tenho no outro, até porque, às vezes, a pessoa nem te..., não vai te adicionar de novo se você já está em algum, né, quer dizer, então, às vezes acaba..., mas, em geral, é em saraus, feira de livros, é... faculdades raramente, quando alguém, quando alguém, é que nem aconteceu, quando conhece você e te chama pra fazer a divulgação, então, que nem no ano passado, tinha uma menina que estava estudando jornalismo na Mackenzie, aí, quando foi a semana das mulheres ela me 
chamou, que eu achei super legal, porque é uma menina super nova e, isso que eu achei legal, que é uma menina nova e ela não se pautou só por, ah, vou chamar só as autores que tem premiação, não, ela chamou diversificado, chamou algumas que tinha premiações até porque é cobrado dela que chame, mas eu achei legal essa visão de chamar autoras independentes também, achei legal e o Wladir Nader que é um autor já bem idoso que ele dá aula na PUC em jornalismo também, ele dá... acho que a disciplina é Jornalismo literário, aí, também na época das mulheres lá, ele me chamou junto com a Márcia Denser que é uma autora mais velha também, então, várias coisinhas, mas que vai..., por exemplo, às vezes eu vou num sarau e acabo conhecendo uma outra pessoa que tem um sarau não sei onde, aí, ele também chama. Agora, o sarau também é uma fonte boa, principalmente, pra essa divulgação.

\section{Pesquisadora: Agora, o sarau, você frequenta algum regularmente ou você vai quando você é convidada? Como é isso?}

Professora: Então, pra falar a verdade, eu acabo indo, até por preguiça mesmo, mais quando eu sou convidada pra participar do sarau, às vezes, tem um que é muito perto da minha casa que é Sarau da Casa Amarela, que ele tem, acho que esse sarau, não sei se o sarau é desde os anos 70, mas o movimento de arte que tem, que o Akira que organiza o sarau, ele faz esse movimento artístico em São Miguel Paulista desde a década de 70.

\section{Pesquisadora: Nossa!}

Professora: Que é no intuito de trazer a arte para as periferias, né, para aquela região, então ali, como ali é perto, às vezes eu vou com mais frequência, que tem até um ambiente meio que, o que eu acho legal desse sarau, por exemplo, esse sarau é... da Casa Amarela, as pessoas que vão ali, são pessoas que vão quase sempre ali, acaba parecendo, toda vez que você vai, você encontra uma ou outra pessoa diferente que, às vezes, é convidado e outras pessoas que vem por causa desse convidado, mas a maioria das pessoas você já viu nos outros dias que você apareceu no sarau. Então, esse eu até vou com mais frequência por causa da proximidade, os outros, na verdade, eu acabo mais indo quando convidam pra... pra participar.

\section{Pesquisadora: E, aí, você leva seu livro, faz conversa, vende?}

Professora: É, quando eu sou convidada para participar, pra venda, pra publicação, aí sim. Às vezes a pessoa te convida só para você..., ah, mas, aí, você pode vender se você quiser, mas ela te convida só para participar, fazer algum tipo de leitura, né, alguma leitura, aí, você escolhe, e... e não é nem que eu goste tanto na verdade, porque eu não gosto tanto de falar em público na verdade, mas se você não vai, que nem eu falei, se você não fala também, não é divulgada a literatura, então, você tem que ir por mais que dê preguiça, porque a maioria das vezes dá preguiça, que às vezes você quer ir pra falar, até para conhecer, trocar, só que entra aquele negócio de São Paulo ser muito grande, travar, então, às vezes, que nem às vezes sai da escola, supondo que nem agora, eu vou ficar esse ano, esse ano eu ainda achei o meu horário bom, porque eu fico com as noites livres, então, assim mesmo, eu saio três e meia, vamos supor, aí você vai chegar em casa e para eu estar aqui quando é convidado é umas oito horas, eu tenho que sair de casa umas seis ou antes, então, acaba dando preguiça, aí você volta já é super tarde então, acaba dando uma preguicinha de ir, né.

Pesquisadora: Sim, é do deslocamento, é grande mesmo.

Professora: É.

Pesquisadora: $O$ que é escrever para você? 
Professora: É, essa entra mais ou menos igual a outra pergunta, que é me manter mesmo..., não é fora das engrenagens, mas também me sentir fora das engrenagens, mas ao mesmo tempo conectada com pessoas que estão pensando parecido comigo esteticamente, né, porque no dia a dia, na verdade, se a gente for analisar, nesse sentido eu acho também que as redes sociais ajudaram muito, porque às vezes você se sentia totalmente deslocada, ah, eu gosto de uma coisa que quase ninguém gosta, que eu não consigo conversar com ninguém sobre isso, todo mundo está agindo e se você falar sobre isso acha que você é louca e, nesse sentido, as redes sociais, que, aí, você tem a impressão que todo mundo gosta, porque quem está ali no seu círculo [risos].

\section{Pesquisadora: São os que gostam.}

Professora: É. E, aí, você..., então, acho que é me sentir fora dessa engrenagem que é meio do capitalismo e consumo, mas ao mesmo tempo conectada com as pessoas, né.

Pesquisadora: E em relação ao Concurso Literário, como que foi a sua participação no concurso? Em quais anos que você participou? Como que você ficou sabendo, como foi sua inscrição, na publicação do resultado, se você consegue me dar um panorama assim?

Professora: Eu só vou lembrar desse daqui que eu não lembro nem o ano.

\section{Pesquisadora: É 2010.}

Professora: Foi o único que eu participei, eu nem sei se continuou tendo, eu sei que eu fiquei muito decepcionada com o jeito, não sei, não sei, me pareceu tudo meio estranho, meio muito..., não sei explicar. É..., uma das coisas também tem que me deixaram meio decepcionada, porque eu lembro que na época teve alguma coisa é.... em homenagem ao, acho que foi o dia do livro, né, que foram distribuídos os livros para os professores que ganharam, não lembro direito como que foi, foi tipo uma recepção e eu lembro que eu falei com o Schneider, que na época era o...

\section{Pesquisadora: Foi o lançamento será?}

Professora: É, acho que foi o lançamento, dever ser, né.

Pesquisadora: Que aí vocês ficaram, recebiam as pessoas e recebiam uma quantidade pra... pra dar pra quem queria e autografar, né?

Professora: Isso, isso.

Pesquisadora: Que eles chamaram como lançamento, né, pelo menos foi essa a informação que eu tive.

Professora: É, acho que foi isso. E eu lembro que eu falei com esse Schneider, eu falei para ele a ideia de fazer uma revista de arte e cultura para os professores que eram, tinham vários professores que escreviam mesmo, que não só literatura, mas das suas áreas, não sei o que, aí, ele falou, "fala com meu assessor", aí, fui lá, falei, mandei e-mail várias vezes e eles nunca nem deram a resposta. [risos] Aí, já fiquei meio..., aí eu nem acompanhei, acabei não acompanhando mais, porque eu achei muito..., tipo, ele fizeram, entra naquele negócio que eu te falei, não há nenhum incentivo para literatura dentro..., eu não acho que há um incentivo para literatura dentro da prefeitura. E, aí, ele faz um concurso, é que aqui, também, esse ano, eu entrei em 2009 na prefeitura, né, então, fazia pouco tempo que eu estava na prefeitura quando lançou, então, eu ainda estava meio que empolgada, mas depois, que nem eu falei, não tem nenhum tipo de incentivo, porque você escreve, você não é incentivada, toda vez você vai para alguma coisa, algum evento de 
literatura, pode ser em faculdade, pode ser em qualquer lugar, você não é dispensado, não sai mais cedo para ir participar, porque é alguma coisa que vale a pena, entendeu?

Pesquisadora: Entendi.

Professora: É nesse sentido que eu meio que... me desmotivei até a participar de outros assim.

\section{Pesquisadora: Dos outros anos?}

Professora: É, eu só participei desse ano mesmo, que eu acho que foi o primeiro.

\section{Pesquisadora: Depois que você viu a condução, aí, você decidiu não...}

Professora: É, eu achei que... que parece que é só para..., que aí entra aquele provérbio, que é só pra inglês ver, porque, aí, eu acho que colocando no portal parece tudo muito... que há um incentivo, mas na verdade não há, não acho que há um incentivo. Tudo bem, foi legal eles terem feito, mas foi só o que eles fizeram, não teve mais nada além, tipo..., que conectou o projeto também, tipo, é um concurso só.

Pesquisadora: Entendi. E..., você teve uma... uma publicação, um texto aceito e um não, né?

Professora: Isso.

Pesquisadora: Nesse mesmo ano, então, você teve uma poesia publicada e um conto que não foi publicado. Como que você viu esse resultado?

Professora: Eu não sei, eu não sei se eu estou certa, a impressão que eu tive é que na poesia tinham menos pessoas e eles precisavam colocar, escolher mais poemas, e tive meio que a impressão que, embora o tema fosse Eu me lembro, que não estava, tipo..., não estava definido que teria que ser uma temática escolar, com tema que..., mas a impressão que me deu até pelos textos, eu lembro que eu li na época, é que se eu falar que eu lembro, eu não lembro, porque faz tempo, eu não lembro exatamente, mas eu achei que a maioria dos textos escolhidos eles tinham... uma temática escolar, eu, eu imagino que... que foi por isso que o outro não foi escolhido, porque não tinha mesmo, tem que o poema também não tem nada, a não ser que fala do Maiakovski, uma da citação do verso, que é o poeta, não sei, mas eu, também, não sei como foi o critério também, eu tive essa impressão ao ler os textos assim que eles tinham escolhido mais os que tinham temática...

\section{Pesquisadora: De escola?}

Professora: É.

\section{Pesquisadora: E que tivessem alguma relação?}

Professora: É.

\section{Pesquisadora: $E$ é isso que te fez não se inscrever para os outros anos? Esse} contexto?

Professora: Também, porque, aí, parece que o professor só está confinado a escrever sobre aquele assunto, nesse sentido também, porque se você falar, o professor escritor, não quer dizer que ele seja escritor de escrita de Literatura Infantil ou que seja escrita sobre a escola, né, que a escrita é algo mais, ainda mais coletivo do que é escola, eu acho. Nesse sentido, também, meio que desanimei, porque eu achei que, que, que sempre que houvesse o concurso haveria essa filtragem de..., desse filtro da temática do professoraluno, dessa relação, mas foi não só por isso, mas foi pelo que eu te falei também, que eu acho que não há mesmo uma política de incentivo à literatura em geral, mesmo tendo, 
que nem eu falei que eu trabalhei na sala de leitura, mesmo dentro da sala de leitura não são renovados os títulos, raramente são renovados os títulos, não são feitos, por exemplo, na sala de leitura mesmo, quando está na sala de leitura, foi pedido palestras com autores, não são feitos, nem para os alunos e nem..., você está na sala de leitura e tem que fazer coisas diferentes, mas não tem nenhuma oferta para você chamar autor, nada.

\section{Pesquisadora: Você tem que fazer por conta própria?}

Professora: Você tem que fazer por conta própria e, tipo, se você chamar alguém é de graça, não tem nem... Que nem, eu saí da sala de leitura até por isso, porque deu o maior... é..., que nem esse que eu te falei, o assistente de diretor, ele começou a me perseguir por causa disso, que eu tinha feito um..., organizado um sarau para ser feito na sala de leitura e tinha chamado vários autores que viriam de graça, lógico que eu tive que ficar pedindo e..., porque ele falou que no mínimo ia, não, você pode chamar e a gente vai buscar o autor. Aí, perto do dia, ele não queria deixar eu fazer no pátio, não queria nem buscar os autores na estação Itaquera, que era o mínimo, porque tinha autor que morava super longe, é... vários empecilhos, coisas burocráticas e já não estava ajudando em nada, na verdade, que nem eu falei, que não tinha nenhuma verba específica para isso, ia fazer tipo um, né, com a bondade dos outros na verdade, né. É..., então, quer dizer, tem toda uma estrutura que aparece no portal, que parece que é muito, mas no fim quem sempre faz é os professores, de acordo com o que eles conseguem. Então, tem muito professor que eu via mesmo em sala de leitura que às vezes chamava, que nem, eu lembro que eu participei uma vez de um..., um professor que eu até conheço que me chamou pro EJA, pra falar do livro, depois que eu..., que era na feira de São Miguel, na feira do livro de São Miguel e, como ele era da sala de leitura e tinha dentro das escolas, as escolas podiam participar, ele me chamou para falar, mas é sem ganhar nada então, é sempre assim, o professor que chama, o professor que organiza e quem leva a glória é, tipo, a prefeitura, é quem está ali, né, que parece que ajudou a acontecer alguma coisa. É nesse sentido que eu acho meio irritante, né.

\section{Pesquisadora: Entendi.}

Professora: De que, tipo, não há um incentivo real, né, porque que nem esse mesmo foi em 2010, a gente está em 2017, eu não acho que, o quê que ele fez a mais além do..., a não ser que fez e eu não sei, mas do concurso? Não teve nenhuma..., por exemplo, teve o concurso, mas não teve por exemplo, que nem essa ideia de fazer uma revista voltado pra..., pra artes em geral, eu nem tinha falado de literatura, mas de artes mesmo, até coisas de artigos científicos, que tem vários professores que estão na rede e estudam ainda, ou mestrado, ou doutorado, ou especialização, ou que escreve mesmo e gosta de escrever, daí, eu conheço vários, eu conheço vários da prefeitura que são mesmo escritores, que livros e não sei o que, mas não foi feito nada e nem dá o mínimo, que nem eu falei, não dá nem o mínimo, tipo, eu vou sair e fazer uma publicação no exterior e eles... eles querem te dar falta? Nos dias que você estava lá, porque acham, consideram que aquilo ali é muito você ter ido, que você está indo pra se divertir, sendo que não teve nenhum tipo de..., é...., não deram dinheiro para a passagem, nada, e acham muito de dar cinco dias, dia letivo, de afastamento de dia letivo, sei lá.

[Pausa]

Pesquisadora: Eu estou pensando, porque a partir do que você me diz, as minhas perguntas mudam um pouco, porque, assim, é..., eu queria entender um qual é a impressão e a participação de quem participou do concurso, né, [pausa]. Qual que era a sua expectativa dele? Por que você decidiu participar? 
Professora: Então, na verdade, eu participei mesmo, porque qualquer coisa que tem de literatura, na época, eu era..., hoje eu não participo de concursos até, porque eu..., aí, tem toda uma questão que nem eu falei, que eu acho que tem muita sacanagem, acho que não... não é lícito. Nesse caso, como é até um concurso menor, eu acho que é lícito, não acho que houve, por exemplo, ah, tal professor foi, porque conhece alguém e por isso que está lá na, não, isso não, mas que nem eu falei, acho que não teve mesmo nenhuma..., não aconteceu nada e eu achei que acontecesse, achei que esse seria o primeiro passo para uma valorização do professor escritor, por exemplo, do professor que escrevesse, que fosse..., mas não houve, que nem eu falei, não houve, até para você mesmo fazer qualquer tipo de curso você não tem nenhuma..., é..., não te dão..., não te ajudam...

\section{Pesquisadora: Incentivam}

Professora: Não te incentivam, nada, é nesse sentido.

Pesquisadora: Entendi. E, teve uma importância para você a participação, uma relevância nessa primeira edição que você participou?

Professora: Então, no momento sim, que nem eu falei, porque no momento também eu via toda a estrutura da prefeitura de uma outra forma, porque fazia pouco tempo que eu estava na rede, né, então, nesse sentido sim, mesmo porque que nem eu falei, na época eu achei que realmente fosse só o início de uma mudança de visão sobre a escrita, sobre a literatura, que houvesse outras coisas para incentivar a literatura, até, não só em relação, lógico que tem algumas coisas para incentivar o aluno, mas falta os professores mesmo, não só dos alunos, os professores também.

Pesquisadora: Então, no momento sim. E como foi... [pausa], qual que é a sua impressão da leitura do livro publicado? Você acha que teve muitos leitores? Você acha que ele teve um..., muitos leitores assim, professores leitores, alunos leitores? Você tem essa..., você teve uma devolutiva de quem leu o seu texto e o de colegas?

Professora: Isso eu acho que não tive muito de colegas que tenham..., eu acho que ficou exemplar na escola, mas não lembro de ninguém, tem aquele negócio de, ah, que legal você saiu, mas não uma devolutiva assim, está difícil falar se os professores leram ou se utilizaram com os alunos, eu não..., eu realmente não...

\section{Pesquisadora: Aonde você está tem o livro?}

Professora: Não mais.

\section{Pesquisadora: Não tem?}

Professora: Aí, que está, não vi mais assim.

Pesquisadora: Ah... não viu, tá. Então, nem na sala de leitura que você trabalhou não tinha?

Professora: Não, não estava lá pelo menos, não sei se estava em algum lugar ali que você não vê e que, às vezes, pelo menos nessa escola tinha até bastante livros, porque professor também, bastante professor doou, não sei o que, é..., mas não me lembro de ter visto, não sei se foi, porque eu não lembro assim, porque eu não olhei no livro de..., na época que eu estava na sala de leitura, nem lembrei disso, de olhar, porque por exemplo, tem o livro de tombos para ver se ele foi mesmo para a escola, né, mas, aí, tem também o negócio que sala de leitura os livros tem uma perda, tem uma perda de exemplares, então, eu mesmo..., eu lembro que na época, na escola em que eu estava, eu deixei até porque eu tinha ganhado alguns exemplares, eu lembro que eu deixei na sala de leitura, mas também, né, mas também nem sei se ficou lá, não sei... 
Pesquisadora: É..., ia perguntar, não sei se acho que já..., talvez seja a mesma resposta, mas eu vou fazer a pergunta assim mesmo. Para você professora, como que você explica ou percebe atitude da prefeitura em promover esse concurso?

Professora: [risos] É, isso que eu ia falar, acaba sendo a mesma, que parece que não tem uma..., ele acaba ficando algo solto, não tem todo um projeto em cima, né, da escrita, da valorização da escrita mesmo do professor, não há, porque para começar, para você valorizar algo, você tem que..., tá, vamos falar que, talvez, os vinte por cento de desconto que eles dão lá do cartão educador, que é uma coisa que tinha, tiraram e agora colocaram de novo, né, que se você, e eu acho que é pouco vinte por cento, mas já é algum tipo de incentivo, mas se pensar, é... acaba ficando um incentivo solto, por exemplo, pelo o que eu te falei também, se você quer fazer um doutorado, você não tem nenhuma bolsa, não tem como sair, se você quer fazer num outro lugar, você não tem como..., né, então, acaba ficando algo solto mesmo. E como se fosse algo para quem já é também, não que só escritor, quem é, e se considera escritor participe do concurso, mas meio que, para mim parece prêmio de consolação, ah, vou né, já que você é professor e escreve vou colocar você, sabe, num livro, para você se sentir importante, alguém importante dentro da educação, para mim dá meio que essa impressão.

Pesquisadora: Entendi. E pensando no seu material, esses, esses textos você escreveu, você já os tinha ou você escreveu para o concurso?

Professora: Eu já, eu não lembro o conto, o conto eu, eu não sei se escrevi pro concurso, não lembro mesmo, porque eu não lembro qual é, então eu preciso lembrar. O poema eu já tinha e enviei, agora o conto, eu acho que eu escrevi quando saiu o concurso, eu fiquei pensando o tema, é, mas eu lembro que não era nada, não me lembro de ter alguma relação com escola, é que eu não consigo mesmo, faz tempinho e eu não consigo lembrar, eu estava tentando lembrar.

\section{Pesquisadora: Você tem ele ainda?}

Professora: Eu devo ter, até em alguma coletânea, eu devo ter algum é que eu não lembro qual é pra...

\section{Pesquisadora: Você pode ter publicado em outro lugar.}

Professora: É, posso ter publicado depois, mas eu não lembro mesmo.

\section{Pesquisadora: Eu vou olhar o título e eu te mando.}

Professora: Ah, tá, que talvez pelo título eu lembre.

Pesquisadora: E..., bom, em relação às outras publicações eu já perguntei. Em relação às publicações digitais, né, é que na verdade você coloca trechos ou o blog, também, eu queria saber se você pode falar que textos que você seleciona, né, ou que trechos você escolhe para publicar nesses espaços? $\mathbf{E}$ por que a escolha de publicar nesses ambientes digitais?

Professora: Aí, muda, porque assim, até pelas plataformas também, porque se pensar no blog, eu não tinha uma seleção do que publicar no blog, porque normalmente o pessoal também que lia os blogs não se importavam com o tamanho da publicação, então, às vezes, eram textos um pouco mais longos e o pessoal lia assim mesmo e, você, também ia na página daquela pessoa, daquele leitor, e lia o deles também, trocava, né, inclusive eu conheço pessoas que eram dessa época de dois mil e..., e que eu continuei acompanhando e a pessoa continuou me acompanhando até hoje. É..., com a revista também, as digitais também, não tem uma seleção do que publicar também, porque aí 
depende do que é pedido, às vezes é pedido um texto mais longo, às vezes um texto mais curto. Agora, no Facebook sim, tem a seleção, porque o Facebook você sabe que as pessoas estão ali a passagem e, eu mesmo, muitas vezes eu posto o que eu tenho, um trecho e, às vezes, eu nem vou olhar a publicação do outro, curtir o que o outro..., porque as vezes eu estou sem tempo e..., as vezes, nem dá tempo de eu ler as mensagens, só vou pra..., então, normalmente eu escolho trechos muito curtos, até dos romances que também acaba acontecendo isso, as vezes eu posto muito trechos que são mais eróticos por que? Porque sei que ali vai ter uma visualização maior e vai divulgar melhor aquela obra, mesmo que aquela obra não seja erótica, querendo ou não a pessoa vai ficar mais curiosa, então, aí, seria uma estratégia meio de marketing, que eu acho que era diferente do blog que não precisava disso, que o Facebook você está mesmo a passagem, né, então você bate o olho e você, comigo pelo menos acontece, eu acho que, mas acho que todo mundo acontece que é, então, às vezes a imagem te prende mais a atenção do que o texto ou, às vezes, você olha a imagem, então, eu seleciono muito também as imagens, então, sempre tento colocar das fotógrafas que eu considero melhor, os quadros e as telas que eu considero melhor, não sei o que, porque eu acho que se a pessoa bateu o olho e gostou da imagem, ela fica curiosa pra acessar o conteúdo do..., e é óbvio que, assim, pode ter, que nem eu falo, porque eu até entro bastante em discussão com meu marido sobre isso, né, "ah, mas eu postei o texto e não sei o que e ninguém leu, ninguém...", eu falei, ué, mas você postou o texto inteiro no Facebook, ninguém vai ler, porque ninguém lê o texto inteiro no Facebook, então, tipo, são estratégias, então se você colocar esse trecho pode ser um... e, também, pode ser terrível aquele trecho, nem é o, às vezes nem é o, às vezes acontece muito isso, às vezes nem é o trecho que você gosta mais e você coloca e a pessoa destaca aquele trecho que você mesmo não gostou, pega de outro lugar, do seu livro e coloca aquele trecho que não é o que você gosta e a pessoa gostou, então, eu acho que o trecho curto funciona mais no Facebook pra divulgação. E foto, querendo ou não, então, por exemplo, às vezes você para um evento, que nem eu falei, também não interessa se no evento tinha cinco pessoas ou mil, depende da foto, de como você editar essa foto [risos], eu sempre falo, porque às vezes você, parece tudo tão glamoroso, que você olha, nossa, tinha tanta gente, não sei o que, mas onde você está, não tem ninguém, nossa, ninguém liga pra literatura. E, realmente, no Facebook tem uma outra dimensão, né, é porque, aí, você faz a edição, coloca aquela foto que tem mais gente, que está o livro, não sei o que, então, eu acho que tudo é uma questão de edição, pelo menos no Facebook é só você editar que... [risos].

\section{Pesquisadora: Fica ótimo. E o que significa escrever literatura nos dias de hoje?}

Professora: Eu vou pensar se é só nos dias de hoje, né, é, porque se a gente..., eu ia falar assim, é..., é gratificante como algo pessoal pra mim que nem eu falei, porque eu tenho, eu me sinto mal se eu não estou escrevendo, mas não que acham uma grande... que seja algo glamoroso escrever, porque não é, porque quase ninguém lê, se a gente que está num lugar que até..., que nem, eu que sou professora de Língua Portuguesa vejo isso diariamente, de cada trinta e cinco alunos, quantos leem efetivamente, tem uma prática de leitura? Eu pego o Fundamental II, então, supondo que eles tenham começado lá no Fundamental I, quantos permaneceram? Porque também acontece isso, né, muitos tem essa prática no... até o quarto, quinto ano e acabam perdendo essa prática, eles não continuam, o que é engraçado e, a escrita eu acho a mesma coisa, às vezes eu pego alunos, por exemplo, de sexto ano que escrevem muito melhor do que aluno de nono ano, porque é nesse tempo, meio tempo, que é pouco, ele perdeu o interesse pela leitura e pela escrita, ele vê várias outras coisas que são mais interessantes e, se a gente pensar, a leitura também é algo que requer mais tempo, porque é o tempo, na verdade, não é que, não é mais tempo 
em extensão, né, que por exemplo, você leva uma hora e meia pra ver um filme, uma hora e meia você lê várias páginas, mas assistir um filme não requer sua atenção total, às vezes o livro, dependendo o livro, ele requer sua atenção total, você não consegue ler um livro e fazer outras coisas ao mesmo tempo, então, você tem que ter um tempo de repouso e eu acho que atualmente a gente não tem esse tempo de repouso, eu acho que nesse sentido é diferente, eu acho que antigamente não tinha tanta gente alfabetizada, porque a escola era excludente, então até gente alfabetizada era menos do que tem hoje, só que ao mesmo tempo as pessoas tinham menos é... diversão, no sentido de ter televisão, cinema, é... jogos, internet, redes sociais que..., assim, eu estou pensando por mim também, que eu não sou nem tão velha, eu acho que eu não sou tão velha [risos], é..., na minha época não tinha muito, por exemplo, você estava lá à tarde, sem fazer nada, eu ia ler, não tinha, tipo, o Facebook, porque até eu mesmo perco tempo, eu acho, às vezes, tem esse tempo que eu perco mesmo que é com as divulgações, mas às vezes eu perco tempo, tipo..., só lá pra ficar olhando assim, estou com preguiça e fico lá, perco o maior tempo. Na nossa época, na sua não sei, quantos anos você tem?

\section{Pesquisadora: Trinta e quatro.}

Professora: É, você é mais nova, mas ainda assim...

\section{Pesquisadora: É a mesma geração.}

Professora: É..., então não tinha muito com o que você perder tempo, ou era brincar ou era..., então, eu acho que tinha um tempo maior para a literatura, um espaço maior assim, e agora as pessoas estão entediadas, as crianças mesmo, as crianças, os adolescentes estão entediados, aí que nem, uma coisa que eu acho que a literatura perde muito é para as séries de TV, porque eu via, principalmente com Netflix, porque eu vejo os adolescentes amarem, isso o que eu acho engraçado, que eu falo para eles, que eles falam que ler é chato, eu falo, gente, vocês falam que ler é chato, mas vocês assistem filme, vocês assistem novela, vocês ficam milhares de horas para terminar de ver uma série de televisão, que é uma história, que a base dela, na verdade, é um roteiro, que é escrito. É, tudo bem que, aí, se você, que aí entra aquele negócio de você, que a gente tem essa preguiça mesmo, que ali já está, né, na tela e você não precisa ficar lendo e..., que eu acho que é isso que a literatura perde muito, e nem acho que é porque não tem uma educação, lógico que faz diferença é... tanto a educação, o sistema educacional quanto o sistema social faz diferença, mas não é só isso também, também é todo, se for ver, é todo o sistema inteiro, né, que é, que nos condiciona a fazer coisas que sejam mais agradáveis, né.

Quem entra até o negócio da literatura que as pessoas quando a literatura é um pouco mais difícil, é..., entra até aquele conceito também de literatura que entrou muito em voga de literatura mediana, que é a literatura que, tipo, qualquer um consegue ler e a literatura um pouco mais difícil...

\section{Pesquisadora: Mais elaborada?}

Professora: É, é chata, mas não é que é chata, ela vai demandar um tempo maior de entendimento do que uma coisa que você lê ali e imediatamente você entende, né, então, eu acho que tudo isso acaba prejudicando, né, então, né, acaba..., fazer literatura, acho que atualmente é muito mais difícil nesse sentido.

\section{Pesquisadora: Por conta desses aspectos. Você acha que ser professora interfere na sua obra literária? Se sim, de que forma? E se não, por que não interfere?}

Professora: Então, é uma pergunta... difícil, porque eu acho que tudo interfere, no fato de você escrever e até no que você escreve, mesmo que não seja de forma direta, mas se 
você lembrar, por exemplo, eu estou lembrando de uma menina, é..., uma menina gêmeas que..., Argentina, que começou a estudar na escola, duas meninas Argentinas, elas não tinham mais sotaque, nada, fazia um tempo que elas estavam aqui, mas uma chamava Augustina e eu achei muito legal o nome, então eu coloquei numa das personagens do livro o nome dela, então, tipo, querendo ou não acaba interferindo, mas que nem eu falei, às vezes não é diretamente, mas às vezes, já aconteceu também, por exemplo, de eu estar escrevendo um conto e estar conversando com um aluno e ele falar alguma coisa ali, uma expressão, que eu achei muito legal por exemplo, e utilizar no conto ou no livro e, às vezes, não é nada espetacular, uma coisa às vezes até besta assim, que não é nada didático, nada, mas é uma coisa que te inspirou e, aí, você acabou utilizando, então, eu acho que sempre interfere. E eu tenho muita vontade também, eu escrevi um conto que era infantojuvenil e eu tenho vontade de estender para..., é..., para um livro infanto-juvenil, e acaba interferindo a escola, porque às vezes eu tenho essa vontade até por dar aula que, aí, você escuta umas coisas engraçadas e vê umas atitudes dos adolescentes engraçadas que dá vontade assim, né, embora não seja mesmo minha área, mas tenho vontade, só que, aí, eu teria que ter também um tempo para, porque é muito diferente também a escrita infantojuvenil da literatura adulta, né, tem todo um..., eu acho muito difícil escrever de uma forma que fique, tipo, interessante, que fica interessante para o adolescente e..., porque, às vezes, quando você escreve literatura, tudo, você vai perdendo esse, né, saber o que é tonto, o que é..., então, às vezes, eu tenho um pouco dessa vontade de escrever, mas nunca, nunca realizei.

\section{Pesquisadora: Nunca investiu nisso.}

Professora: Não, não. Talvez um dia assim, quando eu estiver...

\section{Pesquisadora: E você acha que ser escritora interfere no seu trabalho como professora?}

Professora: Aí, eu já acho que interfere, porque com certeza eu pego muito mais no pé em relação à leitura, até por gostar muito de leitura, então, eu acabo sempre, sempre indo para esse campo, então, acabo sempre falando muito sobre isso e, até, sobre tudo, nem só sobre..., é..., sobre literatura, mas sobre tudo o que envolve a literatura, todos os aspectos, desde escrever até publicar, tudo o que há por trás das grandes editoras, que também há uma mistificação por parte dos alunos, por exemplo, é..., eu acho engraçado que às vezes você começa a falar com os alunos e eles tem a impressão que não tem escritor brasileiro vivo, por exemplo, né, e..., mas, gente, por que vocês acham isso? Ou que só tem escritor bom americano, porque, aí, ele fez um monte de séries de livros, né. E séries que já é para vender muito, já foi feito para vender muito, que sai junto com filme e não sei o que, aí, eles tem a impressão que não tem muitos escritores bons brasileiros, então, eles falam isso, às vezes, quando você pergunta, quando você está começando e você pergunta isso, eles falam, "não, mas eu acho que não é conhecido, porque não é bom". Aí, tem todo esse...

\section{Pesquisadora: Ah..., toda essa discussão.}

Professora: Aí, você tem que entrar com toda essa desconstrução, né, não é porque está sendo anunciado que é bom, né, é considerado bom exatamente porque está sendo exaustivamente anunciado, né, e acho que nesse sentido interfere bastante, você vai querer o tempo inteiro ficar, até porque você pensa, eles querendo ou não, eles são os leitores de amanhã, pois o leitor pequenininho que há ali, um dia ele vai ler literatura até pelo que eu te falei, junta os alunos que são dois, que aliás, eles estão agora com vinte, vinte e um por aí, que eu dei aula para eles, eles estavam no nono ano e, depois de muito tempo, ele lembrava, eu achei engraçado que ele lembrava, que quando saiu o livro A Puta, ele 
comprou, não sei o que, falou que leu e não sei o que, e comentou sobre o livro, falou que comentou com esse outro aluno, que eu lembrava deles bem, que eram alunos até participativos, e ele falou, "ah, você foi influenciada pelo Gabriel Garcia Marquez? Que eu lembro que um dia na aula você estava com o livro Memórias das minhas putas tristes." Quer dizer, eu achei tão engraçado, porque quer dizer, eu estava com o livro que eu nem, e eu lembro que ele, depois que ele me falou isso que eu lembrei que ele tinha me perguntado por causa o nome, eu acho, do livro, né.

Pesquisadora: É, pode ser.

Professora: E é engraçado que depois de vários anos eles lembrou daquilo...

\section{Pesquisadora: Da situação, do livro, da relação...}

Professora: Do livro que eu estava lendo e não sei o que, eu achei legal, eu falei, querendo ou não você acaba influenciando pra que eles leiam que, às vezes, você encontra eles e eles falam, "ah, eu lembro que você estava lendo, que você estava com o livro na mão", então, quer dizer, querendo ou não eles estão ali observando a sua atitude também, né, por mais que você acha que não, né, que a gente acha que não tem a mínima importância mesmo o que a gente fala, não sei o que, então, você sempre está influenciando o outro, né.

Pesquisadora: É. E você não escreve sobre..., não é sobre, mas assim, a escola tematiza seus escritos de algum modo?

Professora: Não.

Pesquisadora: Não.

Professora: Eu não lembro se tem algum, acho que não tem nenhum...

\section{Pesquisadora: Nenhum?}

Professora: Ah, é, tem, que nem eu falei tem um conto só, que é um conto infantil que foi até um amigo meu que escreve mesmo, que é da prefeitura, ele escreve mesmo literatura infanto-juvenil, ele tem dois livros infanto-juvenis e ele tinha uma revista, aí, ele me convidou para escrever um conto infantil, aí, eu acabei escrevendo por causa dele e, aí, o tema, não é o tema, é a história de uma menina que gosta de um menino, mas isso acontece na escola e tem um pano de fundo, né.

Pesquisadora: Ah, é um pano de fundo.

Professora: Mas, a maioria absoluta não.

Pesquisadora: Não. E você pode falar um pouco mais, porque algumas coisas você já disse, sobre as suas opções de leitura? O quê você gosta de ler? O quê você lê? Que gêneros? Autores?

Professora: É assim, muito variado, pensa, muito variado mesmo, porque é praticamente a literatura, hoje eu leio muito mais literatura do que, por exemplo, ensaio, teoria literária, mas leio também, teoria literária leio, e..., mas eu lia mais outros tipos de livro, hoje eu acabo lendo muito mais da minha área, mas literatura, eu leio literatura brasileira, literatura russa eu leio bastante, deixa eu ver..., italiana, italiana é o Pirandello que eu gosto, mas também..., e acabo lendo muito autores independentes, até porque eu conheço e são meus amigos e acabo lendo, ou porque me pedem para ler ou porque eu fico curiosa ou porque eu vou no lançamento e pego o livro e acabo também lendo bastante literatura, mas é bem diversificado. E gênero também é bem..., bem diversificado, que nem eu falei, que nem você perguntou dos diários, agora eu estou lendo, eu estou lendo dois, eu 
comprei faz pouquinho tempo os diários da Sylvia Plath, eu conheço a obra dela assim, mas tem uns poemas que eu gosto, li o..., não cheguei nem no fim, o romance, e aí, eu comprei o diário que eu estou até gostando bastante. E o livro, o romance, eu não gostei tanto, não achei tão bom e, então, eu leio assim bem diversificado, não tem nada assim, até em gêneros, acho, talvez, o gênero que eu menos leio, acho que é crônicas, assim. Agora, contos e romance e poesia eu sempre leio, poesia eu gosto muito, só acho assim que às é difícil achar um... um poeta que a totalidade da obra seja boa, às vezes ele tem muitos poemas que seja bons, mas quando você lê..., eu ainda acho que de todos o Carlos Drummond ainda é, eu acho, mesmo que um monte de gente fale que alguns estrangeiros são maravilhosos, mas ainda acho que na totalidade, o Drummond consegue ser melhor, não que ele tenha só, só, só poemas bons, mas eu acho que ele tem uma quantidade enorme de poemas bons, tem outros que eu gosto, mas, assim, pensando na quantidade, eu ainda acho que ele é o...

\section{Pesquisadora: Melhor, assim, para você.}

Professora: É, assim, pensando na quantidade, porque, assim, se eu pensar num poema, tem vários que eu..., eu gosto do Umberto Elter que é português, que tem vários bons, mas eu penso na quantidade que o Carlos Drummond tem de bons, eu acho o Drummond melhor.

\section{Pesquisadora: Entendi. E o que significa para você, Márcia, escrever literatura?}

Professora: Eu acho que é me manter viva, é que nem eu falei, acho que tira um pouco do tédio e me..., faz com que eu sinta que existe algum sentido, né, é assim, para eu me sentir mesmo que a minha existência tem alguma singularidade, porque se eu pensar assim parece que não tem nenhuma importância, se não pensar em relação à escrita, eu não me acho diferente em nada que faria uma grande diferença em nada, assim, tipo, eu não dou aula melhor que ninguém, eu não cozinho melhor que ninguém, e cozinhar piorou [risos], aí, escrever me dá essa sensação de que eu consigo ser diferente, me ponho numa posição..., não é de diferença, mas de ver mesmo um sentido para a vida que eu acho que assim, sem a literatura, às vezes eu fico pensando, quando eu não estou escrevendo, eu paro muito para pensar nisso, que eu me sinto assim, quando eu não estou escrevendo, eu sinto que a vida é mais chata, assim, quando eu não estou escrevendo, eu não consigo...

Pesquisadora: Entendi. Bom, o roteiro é esse, eu acabei. Tem alguma coisa que você gostaria de falar que não entrou como pergunta?

Professora: Não, acho que...

Pesquisadora: É isso?

Professora: É.

Pesquisadora: Agradeço a paciência, a atenção, por responder tudo. Obrigada.

Professora: Eu que agradeço. 


\section{PRODUÇÕES LITERÁRIAS DE PROFESSORES COLETADAS NA PESQUISA}

Essa lista de materiais literários foram coletados durante a pesquisa de campo, mas devido ao quantitativo recolhido, não foram analisados nesta pesquisa. Apesar disso, consideramos fundamental deixar registrado todos os textos e livros de literatura identificados no percurso investigativo.

- BARBIERI, Márcia. Tô cansada. In: TARTARINI, André (Org.) Cada um por si e Deus contra todos: Cabeça Dinossauro, o livro. Rio de Janeiro: Tinta Negra, 2016, p. 132-148.

- BARBIERI, Márcia. A Puta. São Paulo: Terracota Editora, 2014.

- BARBIERI, Márcia. Anéis de Saturno: contos circenses. Clube de Autores, [s. d.].

- BARBIERI, Márcia. Encarnación. In: MELO, Rodrigo. (org.) Casa de Orates: contos sobre loucura. Itabuna, BA: Mondrongo, 2016, p. 29-31.

- BARBIERI, Márcia. Mosaico de Rancores. São Paulo: Terracota Editora, 2013. (edição bilíngue, português e alemão).

- BARBIERI, Márcia. O enterro do lobo branco. São Paulo: Patuá, 2017.

- BARBIERI, Márcia. Memórias de antigos vitrais. Texto inscrito no Concurso Literário Valeu, Professor que não foi publicado.

- BARBIERI, Márcia. Afeto. Texto inscrito no Concurso Literário Valeu, Professor que não foi publicado.

- CIRÍACO, Rodrigo. 100 Mágoas. São Paulo: Edições Um por Todos, 2011.

- CIRÍACO, Rodrigo. Te pego lá fora. São Paulo.

- COSTA, Arlete Mendes. Poesia?! Poesia inscrita no Concurso Literário Valeu, Professor que não foi publicada.

- GUACCALUZ, Daniel Lopes. No céu com diamantes. São Paulo: Alink Editora, 2017.

- $\quad$ KAWAMURA, Eduardo. Poemas Dispersos. São Paulo: edição do autor, 2018.

- LOPES, Daniel. Derrota. In: MELO, Rodrigo. (org.) Casa de Orates: contos sobre loucura. Itabuna, BA: Mondrongo, 2016, p. 53-64.

- LOPES, Daniel. Luto. In: LOPES, Daniel; BARBIERI, Márcia. (orgs.) O outro lado da notícia. São Paulo: Alink Editora, 2016, p. 7-11.

- LOPES, Daniel. Por enquanto. Poesia inscrita no Concurso Literário Valeu, Professor que não foi publicada.

- MARTINS, Esther M. F. Uma história improvável. Texto inscrito no Concurso Literário Valeu, Professor que não foi publicado. 
- MARTINS, Esther M. F. Cenário. Texto inscrito no Concurso Literário Valeu, Professor que não foi publicado.

- MATSUDA, Osvaldo. Chuveirinho. São Paulo: edição do autor, 2017.

- MATSUDA, Osvaldo. Ecologicamente ilhamos. Peruíbe, SP: Editora Inteligência, 2011.

- $\quad$ MATSUDA, Osvaldo. FP ou PF e PF, São Paulo: edição do autor, 2018

- $\quad$ MATSUDA, Osvaldo. FP ou PF, São Paulo: edição do autor, 2018.

- MATSUDA, Osvaldo. Geane. Peruíbe, SP: Editora Inteligência, 2012.

- MATSUDA, Osvaldo. Noite Anã. São Paulo: edição do autor, 2016

- MATSUDA, Osvaldo. O nascido da Virgem. São Paulo: edição do autor, 2017.

- MOITINHO, Janaína. Agrade Ser. . In: Slam do Grito. Marginais Plácidos 2015. São Paulo: Gráfica Pigma, 2016, p. 182.

- MOITINHO, Janaína. Cuidado: fraude. In: O casulo 12. Desobediência. São Paulo: PROAC, [s.d.], p. 31. (folheto)

- MOITINHO, Janaína. Rita. In: Revista do SESC. [s.d.] Disponível em: www.sescsp.org.br

- MOITINHO, Janaína. Destino. In: Revista Transvista. [s.d.], p. 42. (revista eletrônica).

- MOITINHO, Janaína. [poesia sem título]. In: Revista Transvista. [s.d.], p. 64. (revista eletrônica).

- MOITINHO, Janaína. Cidreira. In: Revista Transvista. [s.d.], p. 40. (revista eletrônica).

- MOITINHO, Janaína. Cachaça. In: Revista Transvista. [s.d.], p. 61. (revista eletrônica).

- MOTA, Dinha Maria Nilda de C. Zero a zero: 15 poemas contra o genocídio da população negra. São Paulo: Edições Me Parió Revolução, 2015.

- MOTA, Maria Nilda de Carvalho. Onde Escondemos o Ouro. São Paulo: Edições Me Parió Revolução, 2017.

- NOGUEIRA, Jamir. Luas, lutas e literaturas. In: Poetas do Tietê. Vol.2, 2017, p. 45.

- NOGUEIRA, Jamir. Esbórnia Herzegovina. In: BENITES, C. E. et. al. (Org.) SAMPOESIA: São Paulo Mostra Internacional de Poesia. São Paulo: Editora Catrumano, 2014, p. 29.

- NOGUEIRA, Jamir. Curitiba. In: BARBOSA, J. et. al. (Org.) 28․ Salão Nacional de Poesia Psiu Poético. São Paulo: Editora Catrumano, 2014, p. 34. 
- NOGUEIRA, Jamir. Boca voraz, garra feroz. In: BARBOSA, J. et. al. (Org.) $28^{\circ}$. Salão Nacional de Poesia Psiu Poético. São Paulo: Editora Catrumano, 2014, p. $35-36$.

- OliVEIRA, Vandeí. LGBT e o direito aos afetos. In: SACOLINHA. (Org.) Fanzine Vasto. Suzano, 2017, p. 66-67.

- REGINA (nome fictício). Solidão. Poesia inscrita no Concurso Literário Valeu, Professor que não foi publicada.

- RODRIGUEZ, Márcia Glória. A cadelinha lambada. São Paulo: Ícone, 1997.

- RODRIGUEZ, Márcia Glória. No céu dos cachorrinhos. São Paulo: Ícone, 1997.

- RODRIGUEZ, Márcia Glória. O tempo não pára. São Paulo: Ícone, 1997.

- RODRIGUEZ, Márcia Glória. Os catadores de papel. São Paulo: Ícone, 1997.

- RODRIGUEZ, Márcia Glória. Quando o amor acontece? São Paulo: Ícone, 1997.

- RODRIGUEZ, Márcia Glória. Um gnomo no meu jardim. São Paulo: Ícone, 1997.

- SANTANA, Jefferson. Rimar amor com vida. In: Slam do Grito. Marginais Plácidos 2015. São Paulo: Gráfica Pigma, 2016, p. 75-76.

- SANTOS, Michele. Excertos duma peça suja. In: RUSHE, Ana. et. al. (orgs). Golpe: antologia-manifesto. São Paulo: Nosotros Editorial, 2016, p. 292-294.

- SANTOS, Michele. Arrocha. In: Raimundo: revista da nova literatura brasileira. Disponível em: www.revistaraimundo.com.br, 2016.

- VIRGINIA (nome fictício). Ser mulher e mãe. In: Blog Palavras, palavrinhas e palavrões. 2017.

- VIRGINIA (nome fictício). Palavrinhas para uma criança que vai nascer. In: Blog Palavras, palavrinhas e palavrões.

- VIRGINIA (nome fictício). Sarau do Parque Pinheirinho D’água. In: Blog Palavras, palavrinhas e palavrões. 2015.

- VIRGINIA (nome fictício). Benedeti e Galeano. In: Blog Palavras, palavrinhas e palavrões. 2015.

- VIRGINIA (nome fictício). Sobre viagens, liberdade e gravidez. In: Blog Palavras, palavrinhas e palavrões. 2015.

- VIRGINIA (nome fictício). Baú de recordações. In: Blog Palavras, palavrinhas e palavrões. 2015. 